KaRine DaUfenbach

A modernidade em
Hans Broos 

Karine Daufenbach

\section{A MODERNIDADE EM Hans BroOs}

Tese apresentada à Faculdade de Arquitetura e Urbanismo da Universidade de São Paulo para obtenção do título de Doutor em Arquitetura e Urbanismo.

Orientador: Prof. Dr. Paulo Júlio Valentino Bruna 
AUTORIZO A REPRODUÇÃO E DIVULGAÇÃO TOTAL OU PARCIAL DESTE TRABALHO, POR QUALQUER MEIO CONVENCIONAL OU ELETRÔNICO, PARA FINS DE ESTUDO E PESQUISA, DESDE QUE CITADA A FONTE.

Assinatura:

E-mail: kdaufenbach@yahoo.com.br

Ficha catalográfica preparada pela Seção de Tratamento da Informação do Serviço de Biblioteca - EESC/USP

Daufenbach, Karine
A modernidade em Hans Broos / Karine Daufenbach.
-- São Paulo, 2011.
271 p. : il.
Tese (Doutorado - Área de Concentração: História
e Fundamentos da Arquitetura e do Urbanismo) -
FAUUSP.
Orientador: Paulo Júlio Valentino Bruna.
1. Arquitetura moderna (Alemanha ; Brasil). 2. Broos,
Hans, 1921-. I. Título.
CDU 72.036


A Hans Broos

À minha família:

Meus pais Daniel e Maria Luiza, meus irmãos Luciano e Gustavo, e meu amigo Sebastião 



\section{AgRADECIMENTOS}

Agradeço a Paulo Bruna, meu orientador, pela confiança depositada e pelo apoio ao longo de todas as etapas deste estudo. Ao co-orientador Johann Josef Böker, pela oportunidade de pesquisa no SAAI da Universidade de Karlsruhe, Alemanha. Neste instituto, pude contar com o inestimável auxílio de Birgit Nelissen.

Agradeço imensamente minha professora de alemão Janete Weirich, pela dedicação e bom humor com que me auxiliou na compreensão deste belo, mas difícil idioma.

Aos meus amigos Claudia, Marcelo e Kátia, agradeço a presença constante. Também a Thiago Romano Mondini de Souza, Clarice Gislaine Lorenzetti e Tiago Tamanini Junior pelas ajudas de última hora.

A todos os Arquivos Históricos alemães e brasileiros consultados, assim como ao CREA-SC, agradeço pela gentileza com que atenderam minhas solicitações.

Aos profissionais e proprietários que permitiram a visita às obras, que são inúmeras, e impede aqui a citação nominal; seja nas obras de Egon Eiermann, Friedrich Wilhelm Kraemer, Hans Broos, e em tantas outras que se fizeram necessárias, estendo aqui a todos meus sinceros agradecimentos.

Este trabalho contou com o apoio da FAPESP (Fundação de Amparo à Pesquisa do Estado de São Paulo) e CAPES (Coordenação de Aperfeiçoamento de Pessoal de Nível Superior) para a pesquisa no exterior. 



\section{RESUMO}

"A Modernidade em Hans Broos" é um estudo que parte da obra alemã e brasileira do arquiteto Hans Broos (1921), compreendida entre fins da década de 1940 e os anos 1970. O cenário alemão pós-guerra torna-se contexto chave, onde o arquiteto reúne densa formação teórica e prática, e experiências que conformarão o cerne de seu fazer arquitetônico. À formação ampla e diversificada junta-se o desejo de contextualizar suas propostas no ambiente brasileiro, quando aqui chega no início da década de 1950. Este encontro inicial com a arquitetura da Escola Carioca resultará especialmente fértil, maduro e complexo quando o arquiteto assimila os pressupostos gerais do Brutalismo Paulista, que se mesclam às referências que o mantém atrelado à experiência alemã. O objetivo da tese é demonstrar o quanto sua arquitetura brutalista mantém-se afinada aos pressupostos de sua formação, seja pela via teórica e indireta, seja pelo exemplo direto do trabalho do mestre Egon Eiermann. A partir de referências múltiplas, também sua obra ajudará a compor o cenário multifário do Brutalismo Paulista nos anos 1960 e 1970. 



\section{ABSTRACT}

"Modernity in Hans Broos" is a study developed from the analysis of the german and brazilian works by architect Hans Broos, between the late 1940s and the 1970s. The post-war german situation is the key context, in which the architect gathers a dense theorical and practical background, and experiences that will form the core of his architectural practice. To this broad and diverse background, he adds the desire of contextualizing his work to the brazilian environment, when arriving here in the early 1950s. This primary encounter with the brazilian architecture of the Carioca School will prove specially fertile, mature and complex when the architect assimilates the main concepts of the Paulista Brutalism, which are bound to the references he attains to his german experience. The focus of the thesis is to show in what dimension his brutalist architecture is aligned to his background's concepts, wether by the theoric and indirect way, or by the direct example of the works of master Egon Eiermann. From multiple references, Hans Broos's work will also cope with the multifaceted scenario of 1960s and 1970s Paulista Brutalism. 



\section{SUMÁRIO}

$\begin{array}{ll}\text { INTRODUÇÃO } & 15\end{array}$

CAPÍtUlO 1 - O ENCONTRO COM A ARQUITETURA BRASILEIRA 19

Um outro recomeço: a "Germânica” Blumenau 21

A NOVA ARQUITETURA BRASILEIRA $\quad 52$

CAPÍtulo 2 - ReVEndo ANTECEDENTES: os AnOS 1930

ARQUITETURA ALEMÃ NOS ANOS 1930

ARQUITETURA EM CRISE

Capitulo 3 - Alemanha Pós-Segunda Guerra 107

RECOMEÇO OU CONTINUIDADE? $\quad 109$

$\begin{array}{ll}\text { UM RECOMEÇO POSSÍveL } & 127\end{array}$

REFERÊNCIAS ALEMÃS 144

Capítulo 4 - O brutalismo em Hans Broos $\quad 189$

O BRUTALISMO 191

UM BRUTALISMO E MUITAS REFERÊNCIAS $\quad 209$

CONSIDERAÇÕES FINAIS $\quad 259$

$\begin{array}{ll}\text { REFERÊNCIAS } & 261\end{array}$

$\begin{array}{ll}\text { FONTE DAS ILUSTRAÇõES } & 269\end{array}$ 



\section{INTRODUÇão}

Ao longo de alguns anos de estudo, a obra arquitetônica de Hans Broos (GrossLomnitz, Eslováquia, 1921) tem se mostrado de particular interesse e fonte inesgotável de inspiração. De tal maneira, que a pesquisa iniciada no mestrado em 2004 pela Universidade Federal do Rio de Janeiro ganha continuidade como tema do doutorado. O olhar que inicialmente ficou restrito às obras brasileiras, com poucas e superficiais, por vezes, equivocadas informações sobre a obra alemã, pode ser aqui ampliado e aprofundado. Esta aproximação revelou, porém, muito mais que uma interessante obra, não sem tempo, merecedora de reconhecimento, mas um fio condutor que nos leva a cenários e personagens até então desconhecidos.

Formado pela Technische Hochschule Carolo-Wilhelmina $\mathrm{zu}$ Braunschweig (hoje Technische Universität) em 1947, Broos reúne uma sólida formação teórica e prática, que teve início na cidade de Praga durante o conflito mundial e se consolidou nos anos posteriores com dois grandes nomes da arquitetura alemã pós-guerra: Friedrich Wilhelm Kraemer (1907-1990) e Egon Eiermann (19041970). Ao lado de seu professor Kraemer, Broos colaborou em diversos projetos, também depois de formado, entre novos e principalmente, de reconstrução de edifícios e conjuntos urbanos na arrasada cidade de Braunschweig. Já com Egon Eiermann, então em plena ascensão profissional, professor da Universidade de Karlsruhe a partir de 1947, Broos colabora em projetos de maior porte, cuja influência em seu trabalho é notável.

O ano de 1952 parece ser um ano decisivo para o arquiteto. Nele Broos dá início aos preparativos para deixar o país, assim como fizeram outros arquitetos que também haviam escolhido o Brasil para viver. Mas ao contrário deles, que emigram em sua maioria no imediato pós-guerra, Broos aqui chega em 1953, nos tempos do "milagre" econômico alemão. Sua saída do país não está relacionada, portanto, às agruras de meados dos anos 1940. Broos desfrutava de boas oportunidades de trabalho ao lado de Kraemer e Eiermann, e já dava início a uma - já visível - prolífera carreira como autônomo.

Tampouco o Brasil foi o único destino imaginado ou perseguido pelo arquiteto. Durante aquele mesmo ano Broos troca inúmeras cartas com escritórios de 
vários países, entre eles Estados Unidos, Canadá, Inglaterra, África do Sul, e países latino-americanos - como México, Venezuela e Argentina. Todas as respostas, quando vinham, eram negativas. Parece ter sido mais um conjunto de coincidências do que uma decidida vontade, o fato de Broos ter optado pelo Brasil - através de um contato em comum com a família Hering de Blumenau. Broos foi assim recepcionado fortuitamente na família que seria sua maior cliente, e para quem construiria obras desde seus primeiros anos até sua última grande obra, a Indústria Têxtil Hering do Nordeste.

Entretanto, são várias as referências ao Brasil como "terra da salvação" em seus escritos; notadamente uma salvação não material, mas espiritual, em que o arquiteto deseja se afastar do combalido ambiente europeu e da constante ameaça da guerra, como eram sentidos os anos da chamada "Guerra Fria".

O Brasil representava um campo ilimitado de trabalho e criatividade. Era a imagem da liberdade projetual e de um mundo a ser construído, contraposta à noção de limitação projetual em um ambiente a ser reconstruído: "não queria mais só olhar para o passado, mas para o futuro". O encantamento com o solo e a arquitetura brasileira pode ser visto nas obras dos primeiros anos no Brasil, em que o arquiteto procura claramente uma aproximação com a arquitetura da Escola Carioca, ao mesmo tempo em que suas referências alemãs seguem presentes. Entretanto, este encontro com a arquitetura brasileira, que inicialmente se reflete na posição de um "aprendiz" (especialmente no fim dos anos 1950) se revelará especialmente fértil nos anos 1960 e 1970, quando o arquiteto assimila os pressupostos gerais do Brutalismo Paulista. Referências já presentes em sua própria obra são catalisadas no meio paulista, e mesclam-se às referências alemãs, em especial de seu mestre Eiermann. Da posição de aprendiz Broos passa a contribuir de modo resoluto e particular dentro do cenário brasileiro, notadamente, da arquitetura do Brutalismo Paulista, à época, tendência já firmada em São Paulo. A partir de referências múltiplas, também sua obra ajudará a compor o cenário multifário do Brutalismo Paulista nos anos 1960 e 1970, que possui referências e praticantes muito mais diversos do que tem noticiado a historiografia recente.

\section{ESTRUTURA DA TESE}

O trabalho se concentra no estudo da obra alemã e brasileira de Hans Broos, desde o período de sua formação, no fim dos anos 1940 até os anos 1970.

No Primeiro Capítulo é analisado o encontro de sua arquitetura com o ambiente brasileiro, em que é notável o desejo de contextualização das propostas, ao mesmo tempo em que elementos já existentes em sua arquitetura seguem bastante presentes. 
No Segundo Capítulo, faz-se uma revisão dos fatos que antecedem o contexto pós-guerra alemão, notadamente, o período 1930-1945 que revela intricadas relações, que atuarão de forma decisiva no período que lhe é posterior. A ele conecta-se irremediavelmente os anos pós-1945, contexto chave da tese, tema do Terceiro Capítulo. Nele o arquiteto reúne experiências que irão balizar sua prática projetual, mesmo quando no ambiente brasileiro, e que se fará notar em sua obra madura de fins dos anos 1960 e 1970.

São nestes anos que a arquitetura de Hans Broos aproxima-se dos pressupostos do Brutalismo Paulista, e revela, mais do nunca, a presença de elementos conceituais e formais de sua experiência alemã. Estas relações serão analisadas no Quarto e último Capítulo, em que se pretende demonstrar, o quanto sua arquitetura brutalista está atrelada ao período de sua formação, em especial, do mestre Eiermann; e analisar, de que maneira estas referências são retomadas e reelaboradas em sua obra. 



\section{Capítulo 1 \\ 0 encontro com a arquitetura brasileira}





\section{UM OUTRO RECOMEÇO: A “GERMÂNICA” BLUMENAU}

A pequena e distante Blumenau, em Santa Catarina, representou para Hans Broos um outro recomeço: o brasileiro, distante de suas raízes, e com novo caminho profissional a trilhar; facilitado, porém, pelo idioma comum e pelos costumes mantidos e a intensa troca cultural com o país de origem da ex-colônia Dr. Blumenau. ${ }^{1}$

Cidade com espetacular desenvolvimento econômico e de intensa vida cultural, a arquitetura moderna era vista ainda apenas em jornais e revistas. Apesar de contar entre os seus o engenheiro civil Emílio Baumgart, reconhecido como um dos pioneiros no Brasil na técnica do concreto armado, ${ }^{2}$ a arquitetura moderna passava ao largo. Apesar das construções em estilo germânico nesta época não serem mais predominantes, ${ }^{3}$ na cidade dos anos 1950 , que contava à época menos de cinquenta mil habitantes, ${ }^{4}$ predominava construções de um pavimento e a característica provinciana típica de uma cidade do interior.

Em janeiro de 1953, entretanto, encontram-se na cidade dois jovens arquitetos no início de suas carreiras, que já trilhavam de forma segura o caminho do moderno. Quando Broos aqui chega, em janeiro de 1953, também visita pela primeira vez a cidade Gottfried Böhm (1920), ${ }^{5}$ que acertava os últimos detalhes para dar início ao importante e esperado novo projeto da Igreja Matriz da cidade (1953-1958). Em um local em que os laços culturais com o país de origem estavam ainda fortemente amarrados - arquitetos alemães eram muito bem recebidos, como o provam Böhm e mais tarde Broos - Broos encontrou aqui muita abertura para seu trabalho, como mostra o volume de projetos que datam desde os primeiros anos de sua carreira brasileira.

Chegados pai efilho, Dominikus Böhm(1880-1955) eGottfried Böhm, respectivamente, o projeto teria sido confiado a ambos, ${ }^{6}$ inclusive por indicação papal, ${ }^{7}$ devido, certamente, à tradição de gerações em construção de igrejas católicas a que estavam ligados. A esta época, Dominikus Böhm era um arquiteto de renome em seu país, provinha de uma família de arquitetos e construtores de longa tradição em construção religiosa, tradição na qual Gottfried dava seus primeiros passos, e se mostraria profissional de reconhecido talento.

Lançada a pedra fundamental da Igreja Matriz em maio de 1953, Gottfried Böhm viria ao Brasil ainda por algumas vezes, seja por causa deste edifício, ou pela construção de

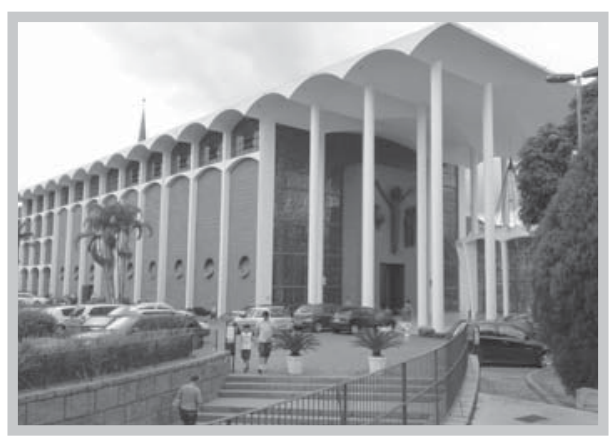

Fig. 1 - Gottfried Böhm. Igreja Matriz. Blumenau. 1953-1958.

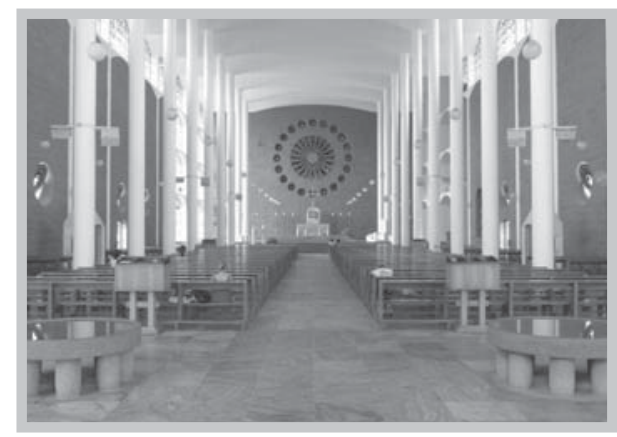

Fig. 2 - Gottfried Böhm. Igreja Matriz. Blumenau. 1953-1958. 
uma nova Igreja na vizinha Brusque, iniciada dois anos mais tarde. A igreja de Blumenau seria também o primeiro de alguns projetos que o arquiteto alemão realizaria no país. Além daquele de Brusque, também para as cidades catarinenses de Joinville e Tubarão, mas que não saíram do papel.

Também seria uma igreja a primeira obra realizada por Broos no Brasil, um pequeno edifício para a comunidade evangélica local. Ao contrário da Igreja Matriz que não dispunha de grande orçamento, ${ }^{8}$ mas que, mesmo assim, fora executada em concreto armado, com finos materiais de acabamento - mármore, entre outros, conforme manda a regra -, o projeto para a comunidade evangélica deveria ter dimensões bem mais modestas.

Dadas as condições bastante diferentes que cercaram os projetos, os resultados arquitetônicos foram igualmente diversos, baseado também, naturalmente, nas concepções arquitetônicas totalmente opostas representadas por seus autores.

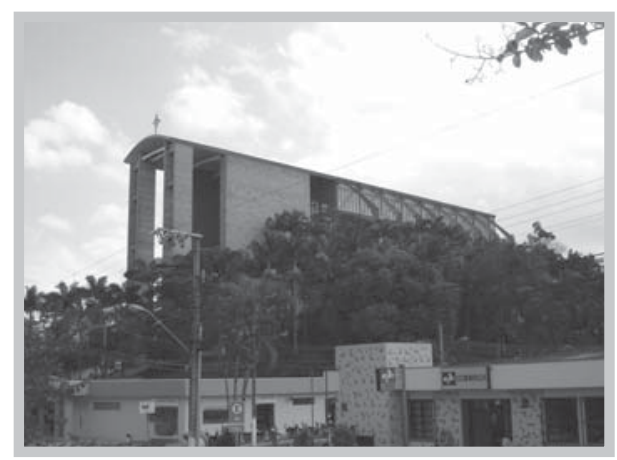

Fig. 3 - Gottfried Böhm. Igreja São Luis Gonzaga. Brusque. 1955-1962.

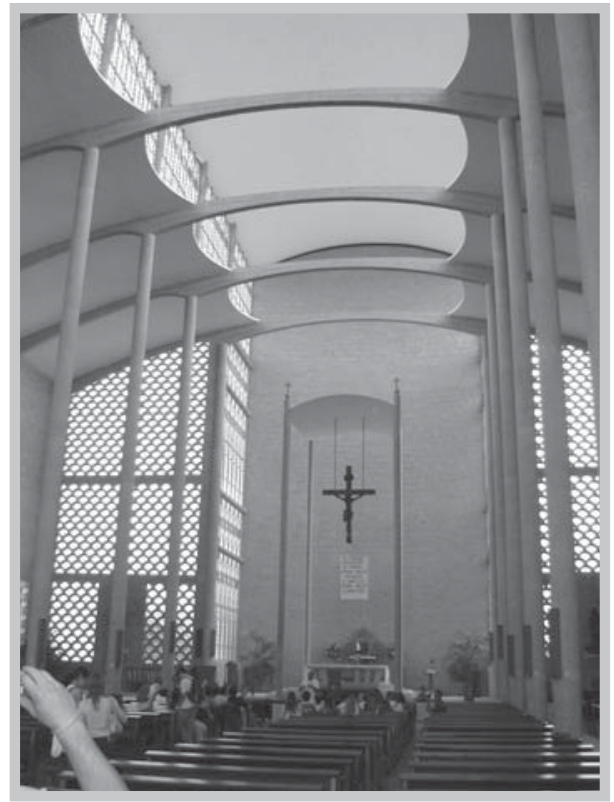

Fig. 4 - Gottfried Böhm. Igreja São Luis Gonzaga. Brusque. 1955-1962.
Gottfried Böhm, arquiteto moderno, representante de uma linha com fortes traços expressionistas, com obras nos anos de 1960 como a Prefeitura de Bergisch Gladbach-Bensberg (1963-1969) e a Igreja em Neviges (1963-1972), defendia desde seus primeiros projetos uma liberdade formal como poucos em seu país. Seu pai, Dominikus Böhm, apesar de não se alinhar irrestritamente ao moderno dos anos 1920 - e talvez, por isso mesmo, não ser tão reconhecido pela historiografia da arquitetura - construía a partir de tecnologia moderna, voltando-se mais para o então expressionismo recente, com traços goticizantes e para uma noção de massa construída, que muito o aproxima de um Hans Poelzig. De seu pai, Gottfried Böhm herdou o gosto pelas linhas sinuosas e expressivas, tetos facetados e a estrutura marcante em alusões góticas que dramatizam o espaço interno e o transforma num jogo cênico de luz e sombra.

Em ambos os projetos, de Blumenau e de Brusque, é notável a influência da obra perretiana, com tetos abobadados, a concepção basilical e a demarcação pontual dos pilares internos. Ainda que os projetos sejam atribuídos a Gottfried, admite-se que Dominikus tenha tido participação fundamental na elaboração dos projetos, até mesmo no de Brusque, cujo início da construção se deu poucos meses antes de seu falecimento. 
Em Blumenau, a veia perretiana é mais notável; o arquiteto concebe a igreja segundo a tradição basilical de três naves e tetos levemente abobadados em concreto armado, com a série de pilares pontuais que delimitam a nave principal, concebida originalmente em concreto aparente. E a torre sineira, construída posteriormente e afastada da igreja, em conjunto com a escadaria principal de acesso, constitui um belo marco urbano da cidade. Já em Brusque, a Igreja São Luis Gonzaga (1955-1962) parte de referências semelhantes, mescla novos elementos que a tornam num dos edifícios mais belos do estado. Como em Blumenau, também aqui a torre sineira torna-se mais que um simples adendo ao volume principal. Porém ela é construída junto à igreja, sob a mesma cobertura, mas destacada dela. Se aqui o arquiteto revisita novamente a matriz perretiana, lança mão, entretanto, de elementos expressionistas que ganham corpo em suas alusões góticas de arcobotantes e contrafortes concebidos em concreto armado e com fechamento em vidro, utilizando ainda pedra e elementos vazados; um edifício imponente e monumental que se sobressai na paisagem.

Muito embora as contribuições de Gottfried e Dominikus Böhm sejam de peso, desconhecidos, entretanto, do público especializado e carentes do devido estudo e reconhecimento, elas permanecem ações pontuais de uma arquitetura de primeira grandeza. No caso de Broos, seus projetos ajudaram a moldar a face da moderna Blumenau nos poucos anos em que o arquiteto lá permaneceu e também nos anos seguintes, já que nunca desataria os laços com a cidade, mesmo quando estabelecido em São Paulo. Lado a lado com as construções antigas e em estilo germânico, Broos propõe sua arquitetura de convicção moderna, sem concessões regionalistas, como a Casa Comercial Peiter (1956-1959), edifício com estrutura em concreto armado que repete a solução corbusiana Domino, ${ }^{9}$ ladeada por prédios históricos. O edifício do Grande Hotel Blumenau (1960) foi certamente o que mais deu a cara da "modernização" da cidade. Construído em pleno centro histórico como o edifício mais alto da cidade, junto às construções de no máximo quatro pavimentos, constituise num marco da modernidade, disputando força com a torre da Igreja Matriz. Mas certamente foi nos arredores da cidade, que o arquiteto teve suas contribuições de maior interesse, que ajudariam a compor a bela paisagem fabril dos arredores da cidade. ${ }^{10}$

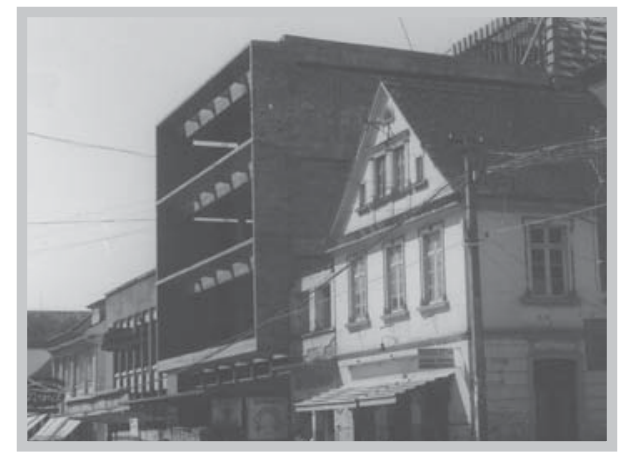

Fig. 5 - Hans Broos. Casa Comercial Peiter. Blumenau. 1956-1959.

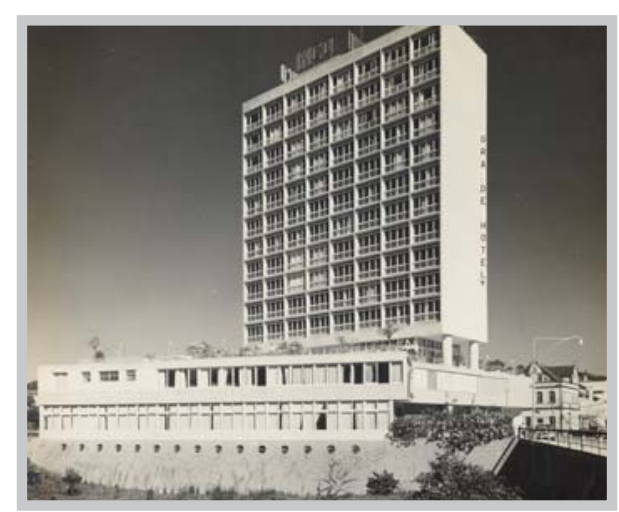

Fig. 6 - Hans Broos. Grande Hotel Blumenau. Blumenau. 1960. 


\section{AS PRIMEIRAS OBRAS}

Ao contrário do projeto da igreja Matriz de Blumenau, as condições que deram origem ao projeto da Igreja Evangélica de Itoupava Seca (1953-1955), bairro ao norte da zona central da cidade, lançavam-lhe pressupostos muito mais modestos e restringentes.

Nada que apresentasse, porém, um empecilho ao arquiteto. Ao contrário do que se pensa, arquitetos como Broos que, por um lado, saíram de um país com material e tecnologia de ponta - devida à situação favorável esboçada já no início dos anos 1950 - e estavam habituados a construir em concreto armado e estrutura metálica, haviam acabado de sair de uma situação iníqua, em que era preciso lidar com condições muito adversas. Além das experiências do pós-guerra, tinham a seu favor a tradição do conhecimento prático baseado no trabalho artesanal típico da cultura alemã.

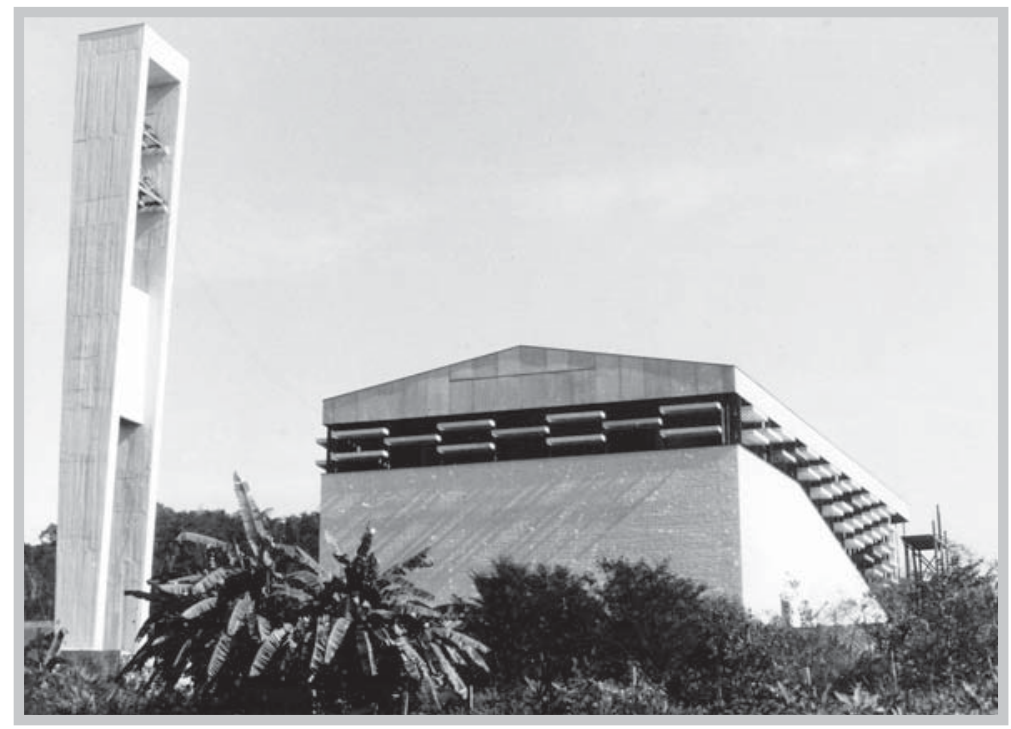

Fig. 7 - Hans Broos. Igreja de Itoupava Seca. Blumenau. 1953-1955.

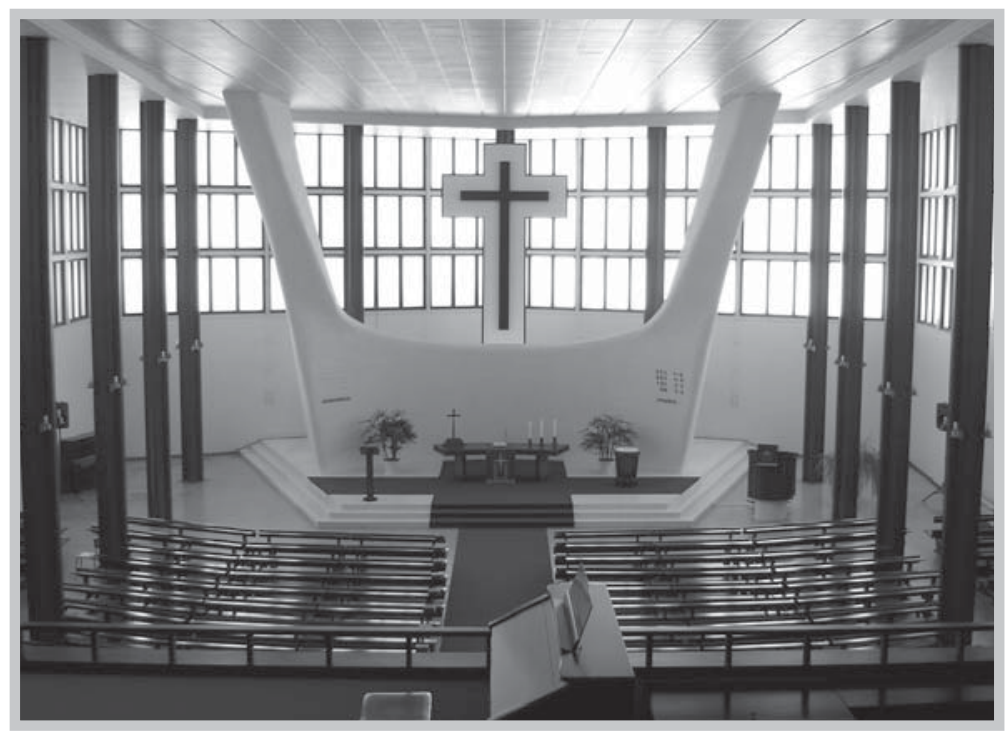

Fig. 8 - Hans Broos. Igreja de Itoupava Seca. Blumenau. 1953-1955.
Com a Igreja de Itoupava Seca, o arquiteto deve buscar o conhecimento adquirido nos primeiros anos pós-guerra, onde os trabalhos simples e artesanais predominavam e retoma as experiências das obras emergenciais executadas no ano de $1946^{11}$ e seus conhecimentos práticos de pedreiro e marceneiro, exigidos dos estudantes nos cursos de arquitetura. Uma realidade que mostra que desde muito cedo o aspecto pragmático e a intimidade com o ofício eram, para Broos e sua geração, tão ou mais importantes que o aspecto teórico na formação profissional.

Sérias limitações financeiras impeliram o arquiteto a buscar nos materiais locais e nas soluções simples a resolução do problema, e o arquiteto mostra que sabe se adaptar muito bem ao novo contexto e às condições restritivas 
do projeto. Apesar de ser amplamente utilizado no país, e o próprio símbolo da moderna arquitetura brasileira, o concreto armado ainda era artigo de luxo em algumas regiões do país. O arquiteto dá preferência então ao uso da madeira, material abundante na região, naturalmente mais acessível. A madeira é utilizada em sua função estrutural e nas aberturas que cercam todo o volume próximas à cobertura, em diferentes alturas. A faixa inferior das paredes é executada em alvenaria, mas que não possui papel estrutural; este é sobretudo legado à madeira e ao concreto armado - que se limita a quatro pontos de apoio nas extremidades da planta retangular. $\mathrm{O}$

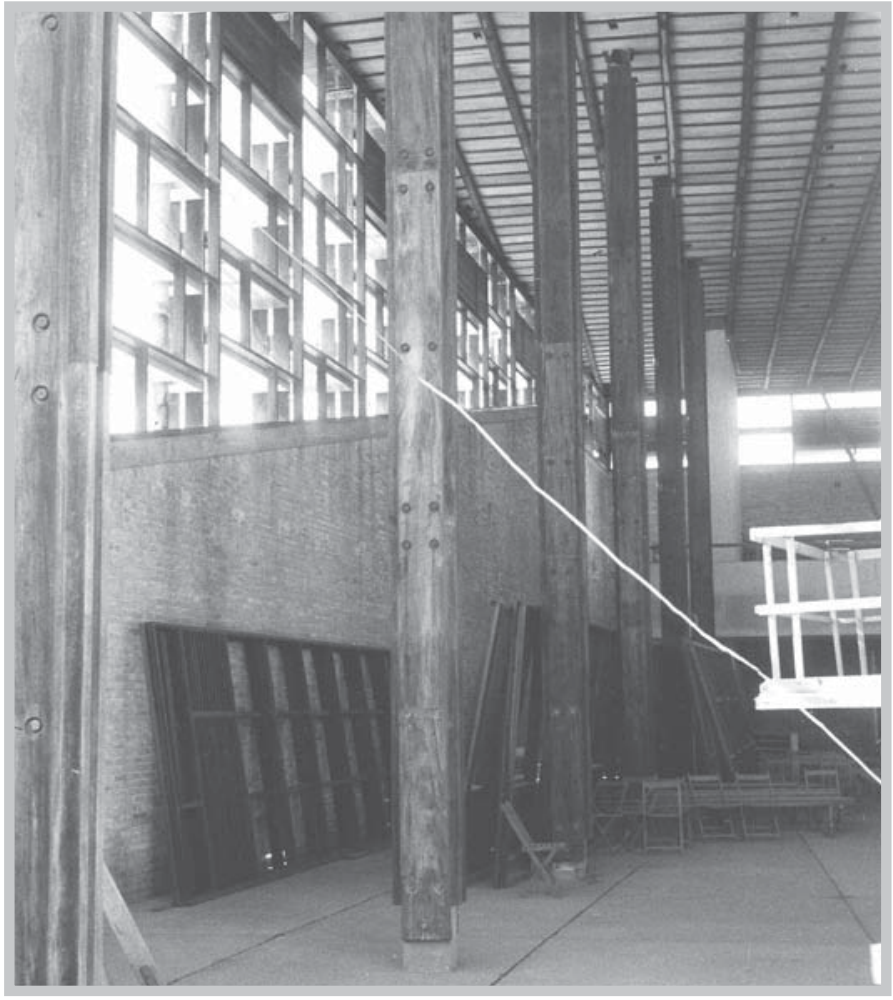

Fig. 9 - Hans Broos. Igreja de Itoupava Seca. Blumenau. 1953-1955. suporte em concreto armado do mezanino - duas paredes paralelas às paredes externas próximas à entrada - serve como estrutura parcial do volume ao prolongar-se até o forro. Na extremidade oposta, junto ao altar, o arquiteto utiliza novamente o concreto armado, mas não como um simples ponto de apoio. Usa a oportunidade para conceber um volume que dá fechamento e envolve o altar; suas formas contorcidas e originalmente em concreto aparente, com veio expressionista - que o aproxima timidamente da obra de Brusque de Böhm - contrasta com o sóbrio interior, composta tão delicadamente pelos longilíneos apoios em madeira.

O volume e os materiais simples desta igreja se traduzem em um interior acolhedor, em que o esmero do detalhe e o desenho dos elementos sobressaemse. Broos explorou a madeira para fins múltiplos, em suas qualidades estruturais, funcionais e expressivas. Os pilares pontuais, em alusão à matriz perretiana, demarcam uma pretensa nave central (que inexiste, devido ao teto plano), distinguindo a área de assentos da circulação perimetral. Do mesmo material que surgem os delgados pilares cruciformes, também são feitos o principal motivo do projeto - o brise-soleil que protegem as aberturas. Através de uma moldura retangular com cinco travessas intermediárias, toda a abertura do edifício é preenchida com brises que intercalam-se na fachada, em seu jogo de luz e sombra. O volume simples e despretensioso ganha movimento, leveza, uma graciosidade escandinava fundamentada na simplicidade quase artesanal do 
prédio, uma funcionalidade sachlich moderada pelo calor da madeira e reboco fino das paredes, pelo qual podemos ver o desenho do tijolo, admirá-lo em seu caráter rústico e natural, como nas primeiras casas de Eiermann dos anos 1930. ${ }^{12}$ Em sua primeira obra no Brasil, Broos traz fortes referências de sua terra natal. A simplicidade e o caráter despretensioso da arquitetura nórdica, que tanto impregnaram (ou, ainda impregnam) seus mestres Kraemer, Eiermann e os colegas alemães, em maior ou menor grau, acham aqui sua versão brasileira em madeira, tijolo, e concreto armado.

Em seu interior o prédio é banhado por intensa luminosidade, refletida pelo brisesoleil e que ganha formas e cores múltiplas, e faz seu sóbrio interior animar-se pelo jogo de luz. Broos reformula o célebre projeto de Auguste Perret para a Catedral de Notre Dame de Raincy (1922-1923) com seus jogos de vidros e cores, luzes

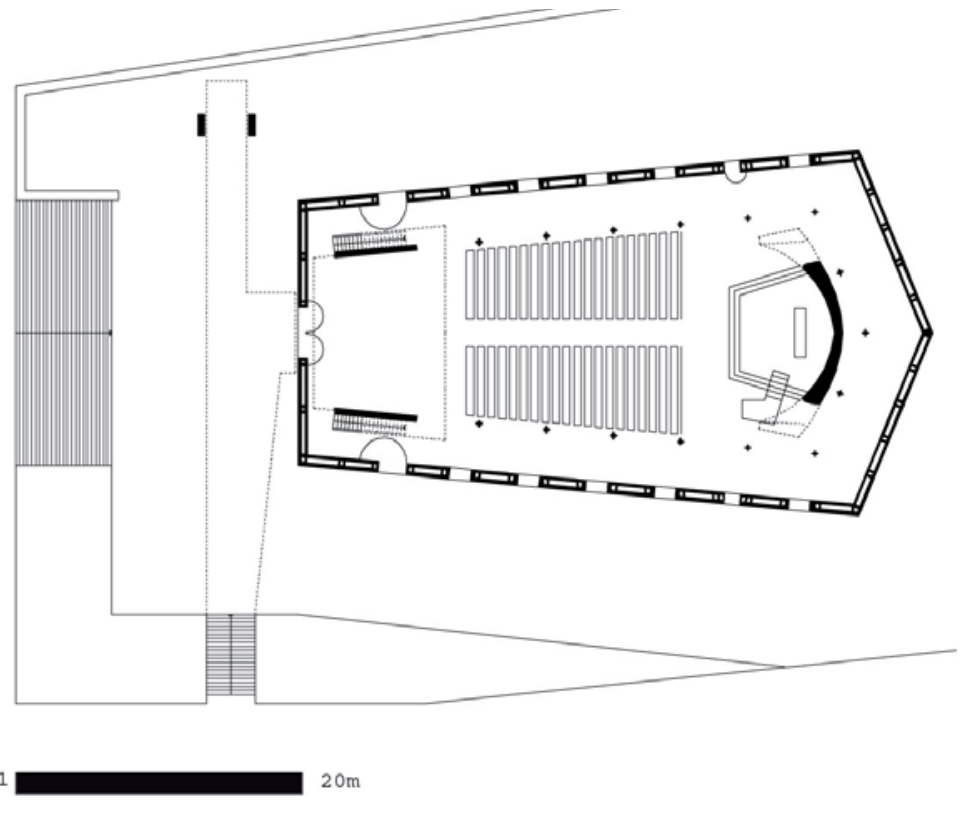

Fig. 10 - Igreja de Itoupava Seca. Planta baixa.

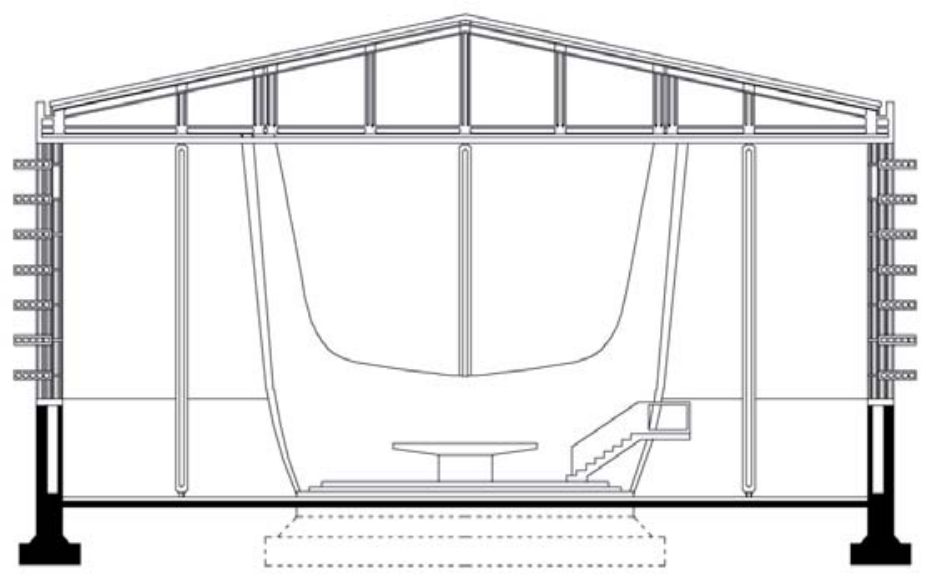

Fig. 11 - Igreja de Itoupava Seca. Corte transversal. que banham o interior do edifício, um projeto dos mais influentes e revisitados do século $\mathrm{XX}$, que pode ser encontrado também na obra de Eiermann, tanto na simples Matthäuskirche como na monumental Gedächtniskirche, de alguns anos mais tarde.

Para o Campanário, executado poucos anos depois, o arquiteto busca referência na Igreja da Pampulha inaugurada dez anos antes. O formato trapezoidal, que confere certo movimento à pequena igreja, aliada à marquise de ligação entre esta e o campanário, com pilotis metálicos, lembram a solução de Niemeyer com seus delgados pilotis arqueados. E assim como Itoupava revela esta tímida, quase despercebida assimilação de elementos da arquitetura brasileira, num projeto do mesmo ano, esta influência se revela muito mais fortemente. $\mathrm{O}$ arquiteto parece de fato, sair do mundo alemão e 
mergulhar no ambiente brasileiro, buscando novas referências para seu trabalho.

No projeto para a Escola Primária Barão do Rio Branco (1954) o arquiteto parte de uma composição que possui forte apelo junto à moderna arquitetura brasileira: o bloco único sobre pilotis, e o entrecruzamento de volumes. Broos sai do bloco único de suas obras anteriores e experimenta maior liberdade que se traduz em um projeto multidirecional e que pretende propiciar novas experiências espaciais. De uma maneira interessante, propõe uma via interna à escola, por baixo do volume sobre pilotis.

Aqui também se revela pela primeira vez uma característica de suas obras que Broos iria utilizar em vários de seus projetos: a forma límpida de sua arquitetura e suas superfícies lisas em contraste com a superfície rugosa da pedra, que empresta sua textura e coloração ao projeto "puro" que se revelará cada vez mais marcante, na medida em que seus projetos ganham características "desmaterializadas". O arquiteto procura o contraponto do objeto puro, leve, quase transcendente, na materialidade e rusticidade da pedra. Neste projeto utiliza a pedra como fechamento lateral no bloco superior e no inferior, como fechamento do volume que se projeta em primeiro plano, que contém o auditório e recebe formato arredondado.

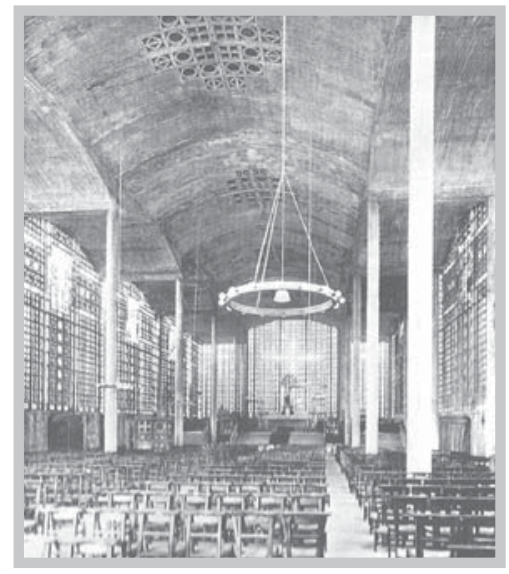

Fig. 12 - Auguste Perret. Catedral de Notre Dame de Raincy. 1922-1923.

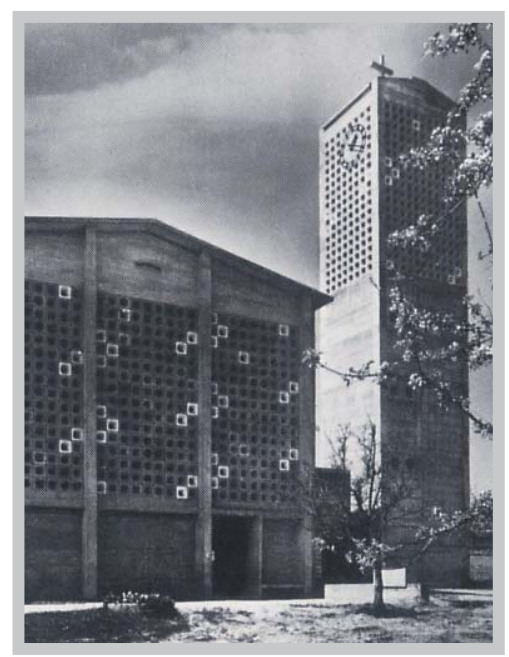

Fig. 13 - Egon Eiermann. Matthäuskirche. Pforzheim. 1952-1956.

É justamente após o período em que Broos passa no Rio de Janeiro ${ }^{13}$ que esta posturaé mais acentuada, como mostram os projetos da Residência Ellinger (1958), do Internato de Ibirama (1959) e da Residência Carlos Curt Zadrozny (1960). Característica marcante da arquitetura brasileira, o uso de elementos naturais no projeto, ou o contraste do objeto arquitetônico quase imaterial com elementos "tectônicos" isolados, se mostrava uma característica marcante na obra de arquitetos como Lucio Costa, Francisco Bolonha, Sergio Bernardes e do escritório MMM Roberto. À época do projeto da escola, estava em construção um projeto que, ao que tudo indica, teria causado grande

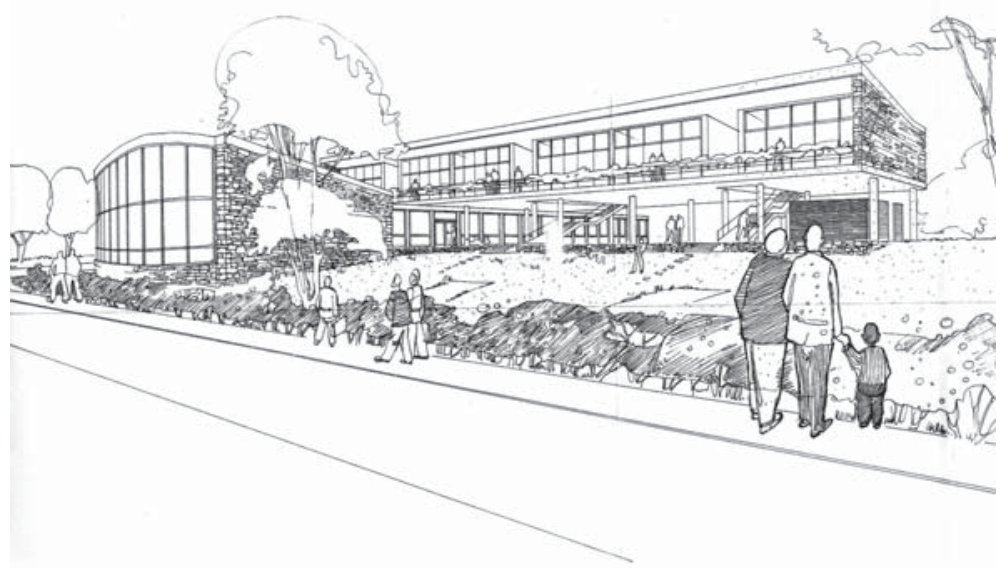

Fig. 14 - Hans Broos. Escola Primária Barão do Rio Branco. Projeto. Blumenau. 1954. 
admiração em Broos. O Pavilhão Lowndes (1953-1954) do escritório MMM Roberto, uma estrutura modular com cinco pórticos transversais de cantaria, que suportam quatro elementos de vidro, unindo de modo surpreendente técnicas

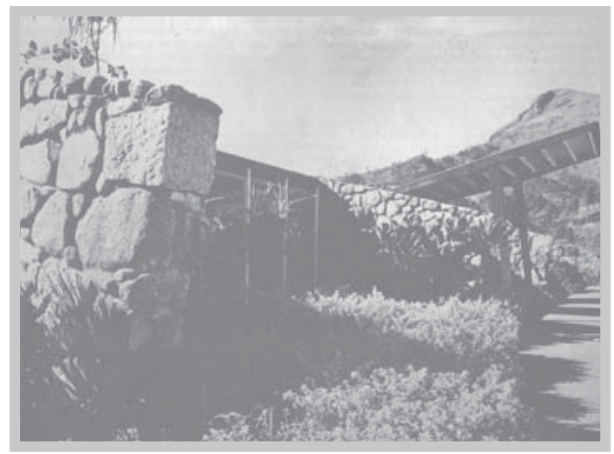

Fig. 15 - M.M.M. Roberto. Pavilhão Lowndes. Petrópolis. 1953-1954.

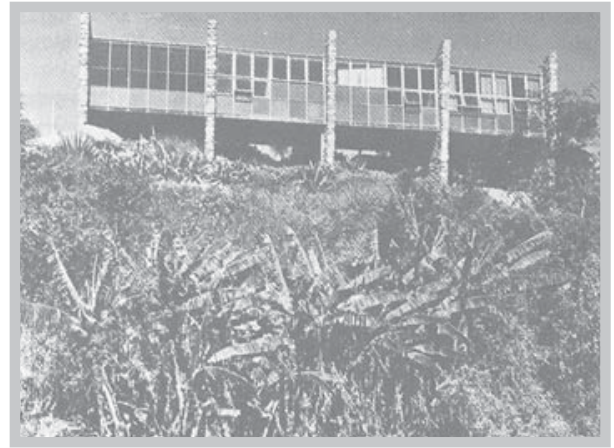

Fig. 16 - M.M.M. Roberto. Pavilhão Lowndes. Petrópolis. 1953-1954. contemporâneas e material local. Talvez como nenhuma outra, esta obra marca a diferença entre elementos naturais e artificiais, entre a expressividade e rusticidade da pedra e a neutralidade do vidro - recurso pouco visto na arquitetura alemã neste período, onde predominam materiais como ferro, vidro e concreto armado e o jogo formal e o uso de texturas é, de modo geral, pouco explorado. ${ }^{14}$

Broos provavelmente só teria conhecimento deste edifício no ano seguinte à sua execução, quando de sua publicação em algumas das revistas especializadas ${ }^{15}$ e, então, pessoalmente, durante sua estada na então capital federal. Os registros da obra, feitos por Broos e mantidos até hoje em seu escritório, sugerem seu caráter "exemplar" para o arquiteto, e a admiração que teria causado. Não apenas pelo fato de serem raros os registros de obras de outros autores armazenadas ou expostas no escritório do arquiteto, ${ }^{16}$ mas principalmente, pelo efeito que esta obra, e talvez tantas outras similares, causou em seu trabalho, que pode ser verificada pela pronta inserção deste material nas várias oportunidades que o arquiteto encontrou para propô-lo - ora exacerbando o contraste da pedra com materiais e proposições formais límpidas, ora utilizando-o como parte de uma composição densa e pesada.

Deste último modo o arquiteto concebe sua segunda obra construída no Brasil, a Residência Wittich Paul Hering (1955), utilizando a pedra em parte da estrutura portante, e também como elemento formal, que contribui para a noção de volume denso e massivo que a casa encerra. Como em Itoupava, também aqui Broos lança mão de diferentes técnicas e materiais e mostra, mais uma vez, sua habilidade em lidar com uma produção arquitetônica quase artesanal ou pelo menos, baseado em materiais e técnicas mais simples e rudimentares do que aqueles que utilizava em suas últimas obras alemãs.

$\mathrm{O}$ arquiteto incorpora neste projeto, pela primeira vez, a pedra como estrutura portante, combinada ao uso do concreto armado; também utiliza paredes de alvenaria estrutural revestidas com reboco rústico e madeira como estrutura da cobertura. Ao invés de ver isso uma regressão (como a ideia poderia sugerir) das 
liçõesquetiveracomEgonEiermann - um amante da precisão e da "limpeza" construtiva do aço, para quem a construtividade e o correto emprego dos materiais deveriam ser espelhados objetivamente na estética do edifício - Broos via nisso, antes, uma oportunidade de conferir, através de materiais naturais como a pedra, uma expressividade natural em seus projetos, que ao objeto límpido e quase imaterial (no caso, em trabalhos futuros) contrapõe uma materialidade pulsante, inexistente em seu projeto da casa $\mathrm{Abel}^{17}$ ou nas obras de Eiermann. Além disso, a própria obra de Eiermann - um arquiteto que reivindica processos construtivosmodernos-deixaclara a persistência no uso de técnicas tradicionais, como no edifício de Blumberg ou na Residência do Arquiteto em Baden-Baden. ${ }^{18}$ Claro que, por um lado, as obras de Kraemer seguem, ao menos inicialmente, uma linha mais tradicional que se revela também no uso de materiais tradicionais como a pedra e a madeira; entretanto, as casas de Broos nada possuem de "tradicional” em sua concepção, e o uso que faz de determinados materiais convencionais não podem ser vistos como possíveis "influências" do tempo alemão, e sim, a uma judiciosa noção dos materiais de que dispõe, e a decidida vontade de valer-se deles como elementos estéticos.

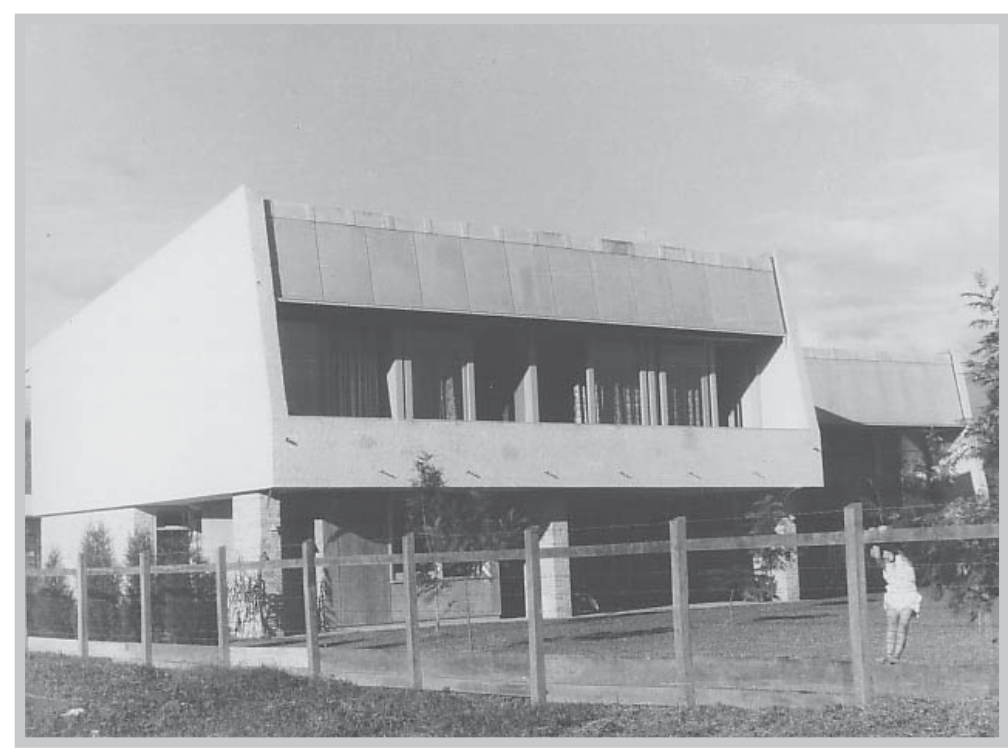

Fig. 17 - Hans Broos. Residência Wittich Paul Hering. Blumenau. 1955.

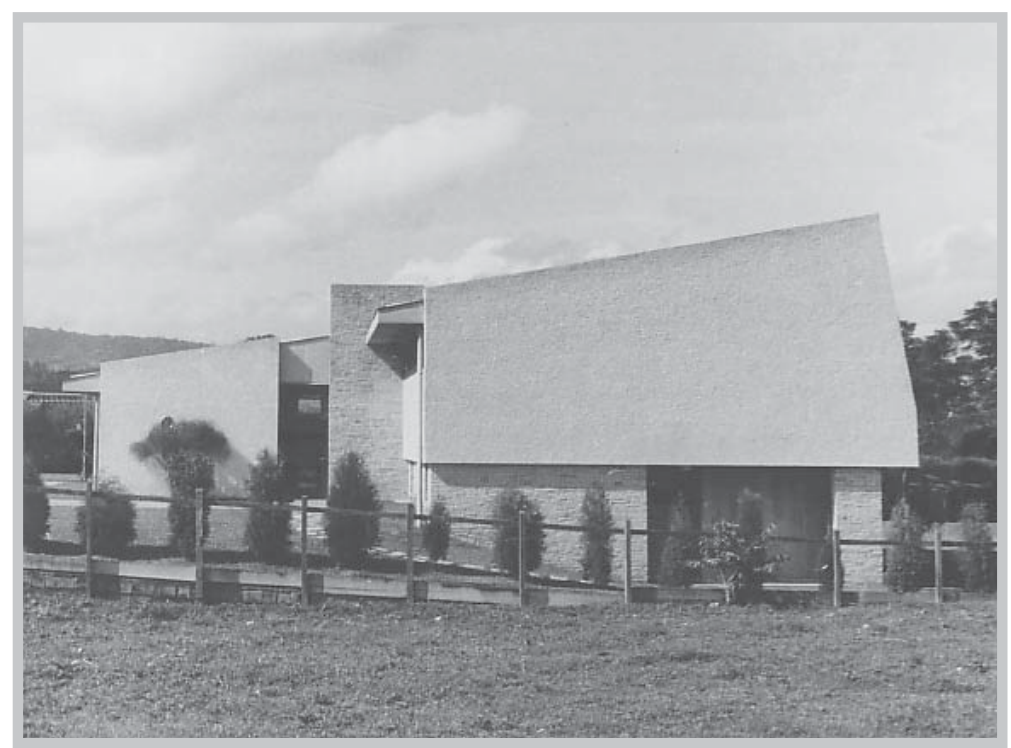

Fig. 18 - Hans Broos. Residência Wittich Paul Hering. Blumenau. 1955.

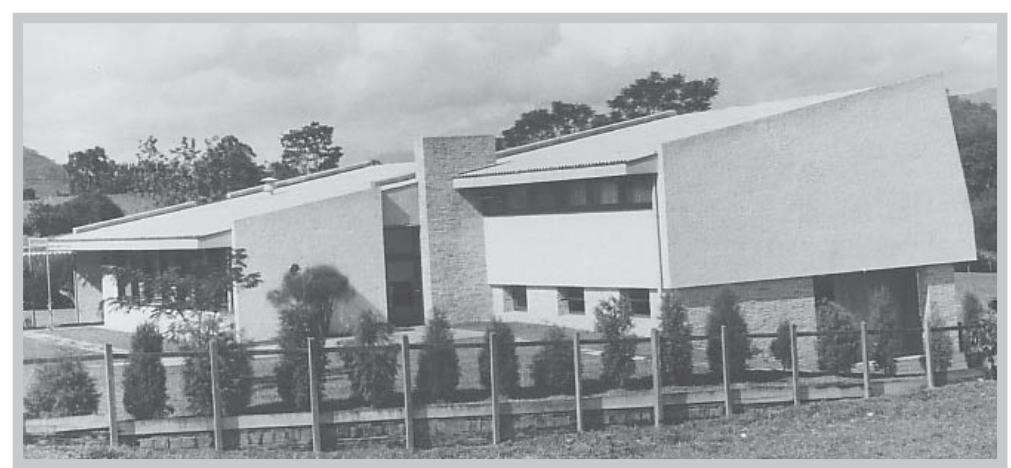

Fig. 19 - Hans Broos. Residência Wittich Paul Hering. Blumenau. 1955. 
Mas, se por um lado, Broos, através do uso da pedra e de técnicas tradicionais, revela que está se integrando de modo sensato e decidido ao novo ambiente, mostra, por outro lado, o quão próximo suas opções projetuais ainda estão de sua arquitetura européia. Nisto, tanto a residência Wittich Paul Hering quanto a Igreja de Itoupava dão mostras claras, ainda que reelaboradas e reinventadas em solo brasileiro.

Na casa Wittich Paul Hering, Broos parte da mesma concepção volumétrica que deu origem à Residência Gustav Abel em Gernsbach (1951-1952), só que agora, reelaborada em sua estrutura. O equilíbrio, a leveza e a clareza construtiva da casa em Gernsbach cedem ao vigor do concreto armado e a pedra, e dão lugar a uma nova estética na Residência Wittich Paul Hering. É particularmente interessante observar, como o arquiteto, partindo da mesma tipologia de sua casa alemã, mas utilizando-se de outros meios, alcança resultados formais tão diversos. $\mathrm{O}$ resultado é a noção de volume denso, pesado e massivo, que segue basicamente a mesma volumetria da primeira obra (só que duplicados os volumes), com a ampla abertura horizontal, fechado nas laterais e que se eleva gradativamente e sugere a ideia de movimento. Enquanto que na obra alemã a precisão construtiva dá a tônica do projeto, onde são diferenciados os elementos estruturais daqueles formais, em Blumenau o arquiteto procura uma síntese formal dos elementos constitutivos, e da noção de "partes" de um todo, tem-se a noção de bloco, de um todo indivisível.
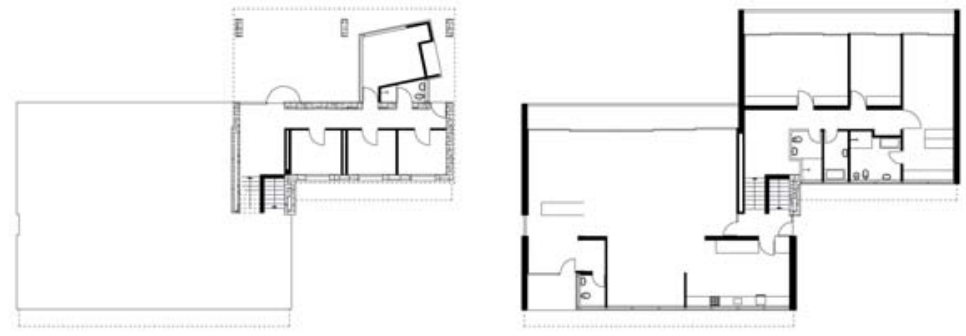

Fig. 20 - Residência Wittich Paul Hering. Planta baixa subsolo e pavimento térreo.

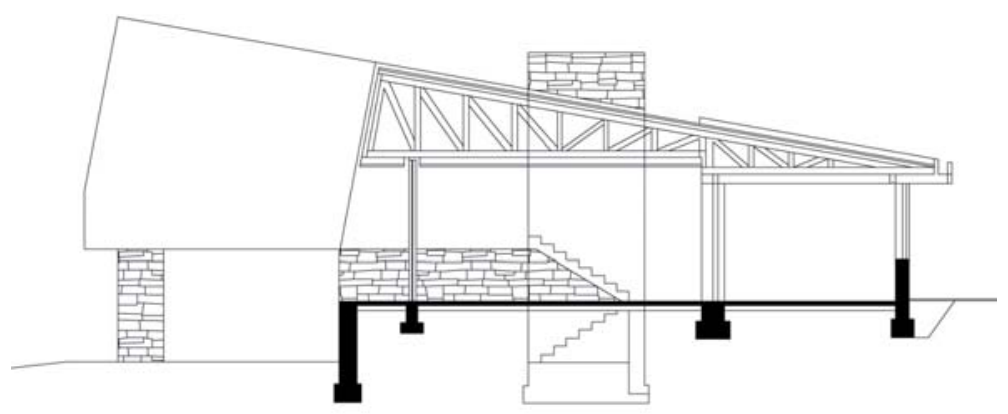

Fig. 21 - Residência Wittich Paul Hering. Corte transversal.
A casa em Gernsbach, ${ }^{19}$ sua primeira e única obra como autônomo na Alemanha, revela, por sua vez, a influência da obra eiermanniana,em especial da Fábrica de Blumberg. ${ }^{20}$ Primeiro projeto em que trabalhou ao lado do grande arquiteto alemão, por sua experiência, Broos foi designado chefe da equipe de projeto e ocasionalmente, coordenou também os trabalhos in loco como mestre de obras. Considerada uma das mais importantes obras do arquiteto alemão e prestigiada como uma arquitetura renovadora no pós-guerra, esta obra foi, sem dúvida, a que mais impregnou 
Broos e a que mais lhe serviu de inspiração para projetos futuros. Tal influência já pode ser vista na Casa Abel, concebida imediatamente após as conclusões dos trabalhos em Blumberg, como atividade paralela ao escritório.

Do mesmo modo que em Blumberg, a Residência Abel expõe de modo claro a construtividade da obra, evidenciandoosmateriaisutilizados e a modulação que dá origem à forma, diferenciando seus aspectos construtivos e formais. Também como em Blumberg, Broos utiliza tecnologia mista - para o subsolo semi-enterrado concreto armado; blocos de concreto estrutural revestidos com pastilhas cerâmicas nas paredes externas, enquanto que a cobertura tem sua estrutura em perfis metálicos tipo I apoiada nas paredes maciças centrais e nos esbeltos pilares metálicos da

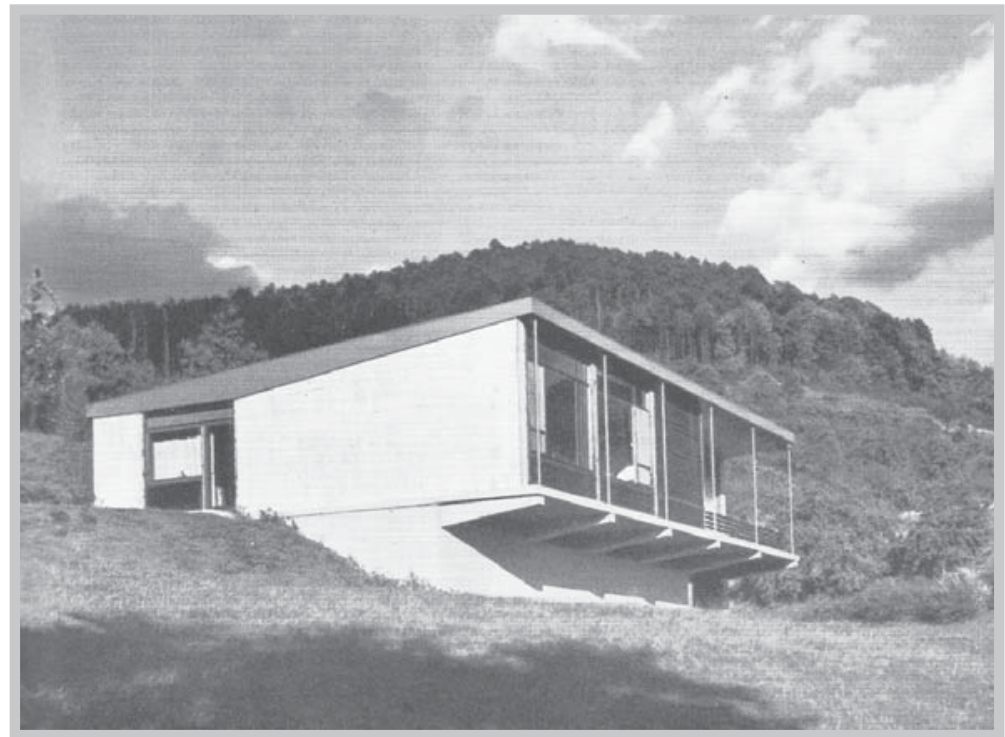

Fig. 22 - Hans Broos. Residência Gustav Abel. Gernsbach (Alemanha). 1955.

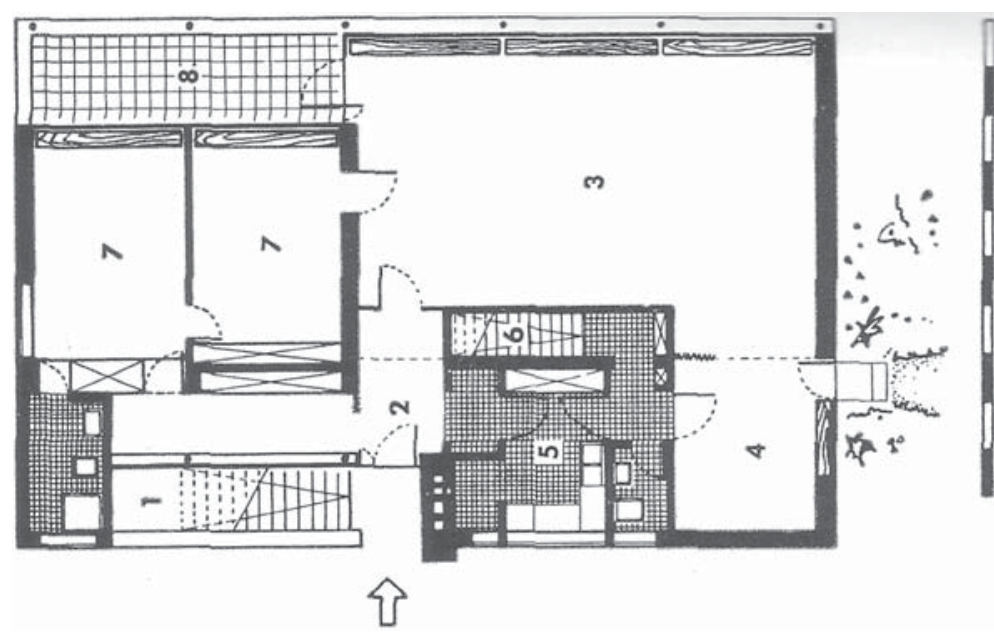

Fig. 23 - Residência Gustav Abel. Planta baixa pavimento térreo. fachada principal.

Relativamente enxuta em suas dimensões, a casa tem na planta-baixa uma divisão espacial que servirá de origem a outros projetos, inclusive à Residência W.P. Hering: os dormitórios, dispostos de maneira transversal à fachada principal (que não é necessariamente a fachada "pública") expõem sua divisão interna na fachada, conferindo a esta a noção de ordem e divisibilidade espacial; além da organização funcional semelhante área social e serviços separada da área íntima (no caso da Residência Hering dispostas em volumes distintos). A casa, concisa e clara em sua forma, se assenta sobre uma vasta paisagem montanhosa, que tem a sua frente o vale da cidade visto através das amplas vidraças da sala de estar. Em sua forma simples reúne uma variedade cromática e de materiais surpreendente, com as persianas externas em

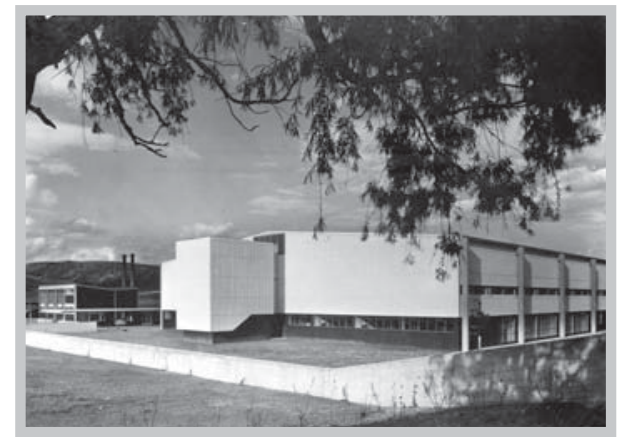

Fig. 24 - Egon Eiermann. Indústria Têxtil. Blumberg. 1949-1951. 
madeira natural, pastilhas cerâmicas amarelo-acinzentadas, e as peças metálicas em azul claro (à exemplo das obras de Eiermann).

Na casa em Gernsbach, mesmo fazendo uso de técnicas mistas, algumas delas tradicionais como a alvenaria estrutural, predominam a precisão construtiva e a limpeza formal. Por exemplo, as vigas que suportam o primeiro pavimento, transversais ao bloco, são demarcadas e deixadas visíveis em sua dimensão e formato, algo que não ocorre em Blumenau. A elas são alinhadas a divisão longitudinal do volume, que fazem predominar a noção de ordem e divisibilidade. Vigas, paredes, laje do pavimento são distinguidas e, especialmente esta última, percebida em ínfima espessura, bem como a estrutura da cobertura, que também se diferencia das paredes laterais. Vigas e estrutura da cobertura afunilam-se em suas extremidades, explicitando em seu desenho o correto dimensionamento conforme leis da estática, e também concorrem para a noção de leveza.

Já na casa W.P. Hering é operado o oposto: ao invés da diferenciação entre vigas e laje do pavimento e materiais de fechamento, temos a concepção de um todo indivisível. A espessura da laje é incorporada ao guarda-corpo da sacada dos dormitórios, que se liga à parede lateral formando um bloco, onde são irreconhecíveis seus limites e os diferentes materiais utilizados. Também aqui não é reconhecível a estrutura da cobertura, tampouco o telhado propriamente dito, encoberto pela platibanda nas fachadas frontal e laterais. Apenas na fachada de fundos (que na verdade é a fachada da rua) o telhado pode ser avistado.

Em Gernsbach, a noção de vazio conferida pelas aberturas surge da estruturação e da divisibilidade do volume - linhas horizontais do pavimento e da cobertura, e linhas verticais da divisão das aberturas e guias das lamelas; enquanto em Blumenau temos a noção de bloco, e o recuo das aberturas de vidro faz com que a diferença entre cheio e vazio seja mais pronunciada, e assim a noção de vazio vem da idéia de retirada do cheio. Ou seja, enquanto em Gernsbach o vazio é "construído", obtido através da ordenação dos elementos arquitetônicos, em Blumenau o vazio surge como escavado do cheio, um vazio que é esculpido na massa. Assim, temos a noção de "bloco", que antes de diferenciar seus elementos constitutivos, engloba-os, os oculta e forja numa mesma unidade, que encerra a noção de uma arquitetura com forte veio expressionista, ainda que diferenciada de sua essência e sem esta proposição. Nas duas casas temos a noção de movimento do volume, sugerida pela linha ascendente da cobertura e reiterada pelo vazio do subsolo. No caso da Residência Abel, esta noção é sugerida pelo recuo deste pavimento e pelo balanço parcial do volume. Já na casa W.P. Hering, sobre pilotis, identificamos o subsolo (semi-aberto) como um grande vazio, pela sombra que ali se projeta, mesmo quando ali se encontre um volume fechado. ${ }^{21}$ 


\section{UM PRINCÍPIO E SUAS VARIAÇÕES}

O volume denso e pesado da casa W.P.Hering, com sua propensão ao movimento e volumetria definida pelas paredes laterais e linhas horizontais do pavimento e da cobertura, com seu grande rasgo horizontal - que tem sua origem na casa Abel - seria o motivo de outras pesquisas do arquiteto para a concepção de projetos residenciais, que encontra, em termos gerais, também na mesma disposição da planta o motivo gerador do espaço. Entretanto, nas próximas proposições, o arquiteto as faz assimilando novos aspectos: o uso da cobertura em borboleta e a incorporação do pátio dentro da planta, que acarreta a separação mais distinta daquela organização espacial anteriormente citada, mas agora modificada - área social e íntima em um bloco, separado do outro bloco reservado para a área de serviços.

A Residência Carlos Renaux (1955) pode ser considerada um misto entre a casa Abel e a casa Hering. Partindo da tipologia que dera origem à casa Abel, o arquiteto assimila também as modificações introduzidas no projeto da casa Hering. O projeto desenvolve-se basicamente de modo similar à casa Hering: uso da pedra, mas agora fartamente, em paredes e muros laterais, assim como na base da casa, ${ }^{22}$ paredes laterais em alvenaria estrutural, em formato trapezoidal que perpassam a cobertura, e até mesmo, no detalhe da porta lateral, representada como um rasgo ou uma quebra na linha de continuidade da parede. Também aqui o arquiteto confere a mesma noção de movimento do volume já presente nas duas casas anteriores. Mas, surpreendentemente, nesta casa o arquiteto revisita valores de seu projeto alemão, como que novamente reformulando seus elementos projetuais (a casa Hering é uma reformulação de seu trabalho; a Renaux é novamente uma reformulação das experiências

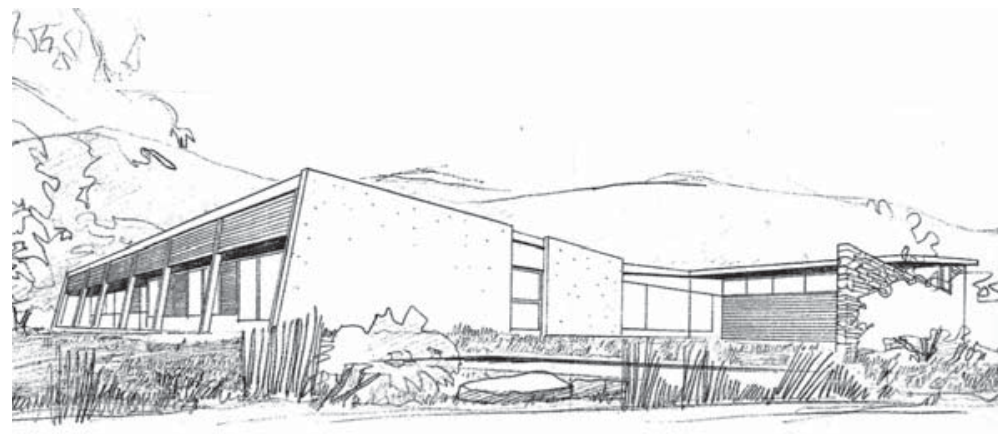

Fig. 25 - Hans Broos. Residência Carlos Renaux. Projeto. Brusque. 1955. anteriores).

Tal como a Residência Abel, aqui a casa ganha contornos e elementos mais delicados que os vistos na casa Hering, e também aqui, Broos diferencia os elementos estruturais daqueles de vedação, e enriquece o projeto através de novos elementos e diversidade de materiais. A exemplo da casa alemã, o projeto para a Residência Renaux recebe lamelas externas de madeira - aqui elas são fixas, a exemplo de brises fixos - mas concebidas em superfície inclinada e com a fachada recuada, como propôs o arquiteto para a da casa de Blumenau. 


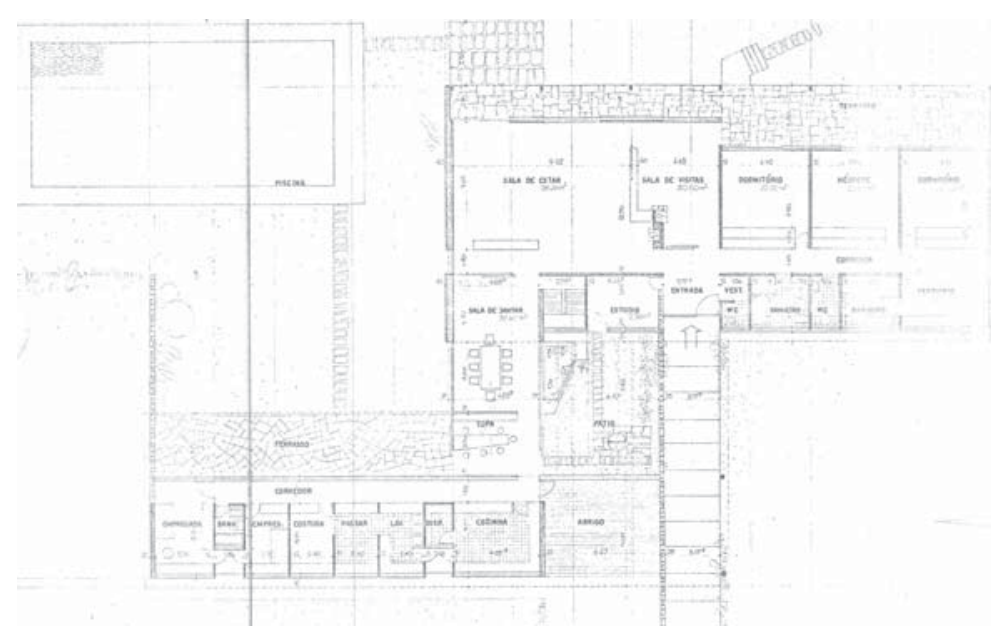

Fig. 26 - Residência Carlos Renaux. Planta baixa.
Formalmente, a casa assemelhase profundamente à Residência Abel, entretanto sua materialidade e construtividade só pode se comparada ao projeto posterior brasileiro. Broos reformula novamente seu trabalho e faz da casa Abel em Gernsbach mas também da casa Hering em Blumenau - um objeto de reflexão e pesquisa, como um princípio formal, para os próximos projetos.

$\mathrm{Na}$ casa Renaux o arquiteto procura um retorno à leveza, integridade e ordem presentes na casa Abel, mas a ela incorpora as conquistas feitas no seu projeto posterior brasileiro: a materialidade e a expressividade dos materiais, que possui uma ordenação como princípio formal (como na casa Abel), mas que não predomina sobre a volumetria, e onde a materialidade impõe-se sobre a individualização dos elementos.

$\mathrm{O}$ arquiteto faz dos muros de pedra elementos ordenadores e definidores de ambientes. O muro da entrada distingue os diferentes acessos de pedestres e de carro e reserva o pátio interno dos olhares alheios. O segundo muro, paralelo àquele, dá privacidade ao terraço e à sala de jantar/ copa, espaço concebido com grandes aberturas de vidro. Aqui como nos demais projetos residenciais, o arquiteto concebe as paredes laterais vedadas quase que totalmente, deixando as aberturas voltadas para duas direções - tímidas aberturas voltadas para a rua e amplas aberturas voltadas para o lado oposto, que correspondem geralmente ao setor social e íntimo da casa.

Esta concepção tem sua origem na residência Abel, através da formulação do objeto arquitetônico autônomo e preciso em sua volumetria. Noção que é transposta na casa Hering e também aqui, embora na concepção de uma moradia térrea, com dimensões maiores e planta deslocada e alongada, tal noção seja mais difícil de reconhecer, embora ela persista.

Broos sai da forma prismática e fechada de sua primeira residência e a expande com o projeto da casa Renaux. Há uma expansão da planta baixa, maior articulação do que aquelas apenas sugeridas na casa Hering, que também persegue uma maior articulação, embora ainda não renuncie à forma fechada. 
Ao mesmo tempo que este projeto marca um retorno a certos elementos e características de sua casa alemã, assim como as suas reformulações da casa W.P. Hering, busca, de forma bastante determinada, assimilar algumas características que se podem dizer arraigadas dentro da arquitetura moderna brasileira. Além da maior articulação da planta baixa, da incorporação do pátio, e do uso do brise (que surge diretamente do uso que fez das lamelas na casa de Gernsbach), o arquiteto incorpora a cobertura em borboleta, amplamente utilizada na arquitetura brasileira nestes anos, que não se origina nesta Escola (Carioca), mas certamente encontrou aqui, seu local de florescimento. ${ }^{23}$

O motivo maior desta articulação é a incorporação do pátio interno, que além de conferir maior intimidade aos ambientes - ao voltá-los para dentro da casa trouxe uma maior distinção no zoneamento funcional, diferenciando claramente os setores íntimo e social do setor de serviços - ao contrário de antes, quando o setor íntimo tendia a um maior isolamento -, embora a mesma concepção geral da planta-baixa das casas anteriores permaneça. $O$ pátio interno, motivo fartamente usado pelos arquitetos brasileiros a esta época, mostra-se especialmente bom recurso para terrenos exíguos, em lotes urbanos, onde a casa se volta para dentro do lote, permitindo o contato com a natureza e garantindo a privacidade dos moradores. ${ }^{24}$ Não parece ser este o caso. Embora no projeto não estejam marcados os limites do terreno, o projeto de $822 \mathrm{~m}^{2}$ deixa claro que a inserção do pátio não se deve à exigüidade do terreno, e sim, às novas pesquisas do arquiteto.

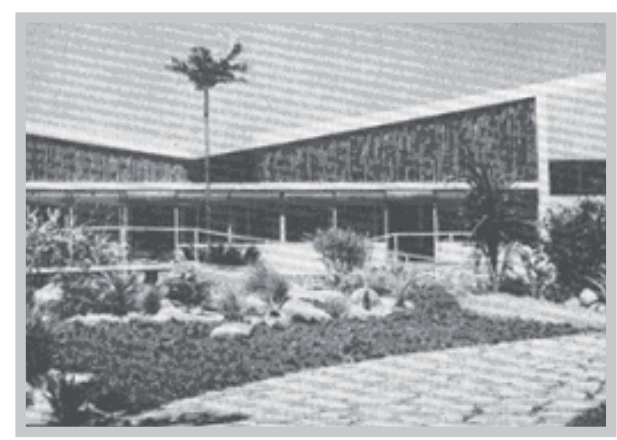

Fig. 27 - Oscar Niemeyer. Casa Kubitschek na Pampulha. Belo Horizonte. 1943.

A exemplo da Casa Renaux, os próximos projetos residenciais parecem avanços de uma pesquisa formal e espacial incessante, baseado nos modelos iniciais e assimilados elementos da arquitetura moderna brasileira. No projeto para a Residência Augusto Reichow (1958) Broos parte novamente do modelo da casa Hering - uma caixa bem definida sobre pilotis, com paredes trapezoidais onde o guarda-corpo incorpora a laje do pavimento numa única superfície, e fechamento dos quartos recuado em relação à fachada. A noção de movimento continua: bloco sobre pilotis, cobertura em "V" e paredes, tanto da fachada principal como de "fundos" inclinadas (formando ângulo oblíquo com a laje do pavimento). Os pilares em pedra daquela são trocados por pilotis mais esbeltos, deixando a aplicação da pedra restrita a três paredes laterais do térreo e à lareira.

Só que aqui, ao partir da mesma volumetria da casa Hering, Broos assimila suas últimas conquistas - o pátio e a cobertura em borboleta, e também a concepção da planta-baixa em alas, além de utilizar elementos vazados de concreto, alguns 
deles com vidros coloridos, dispostos na parede externa da sala de jantar. Os brises ganham formas maiores, como venezianas basculantes, mas que seguem os mesmos princípios das casas anteriores.

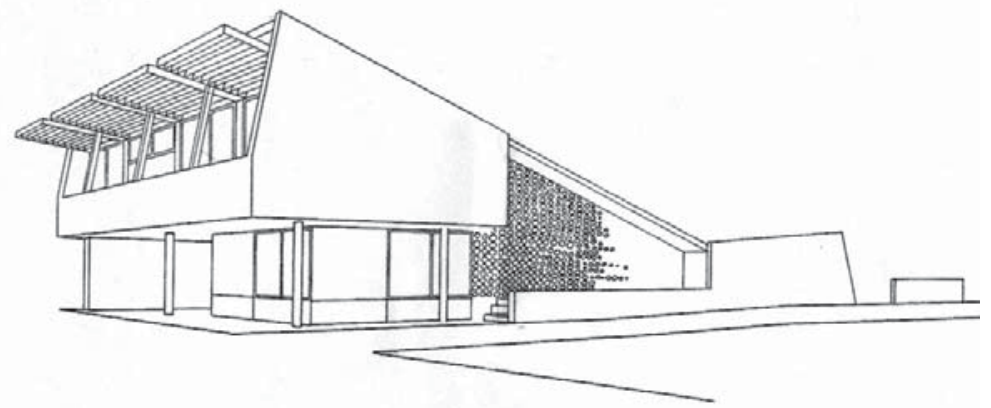

Fig. 28 - Hans Broos. Residência Augusto Reichow. Projeto. Cabeçudas. 1958.

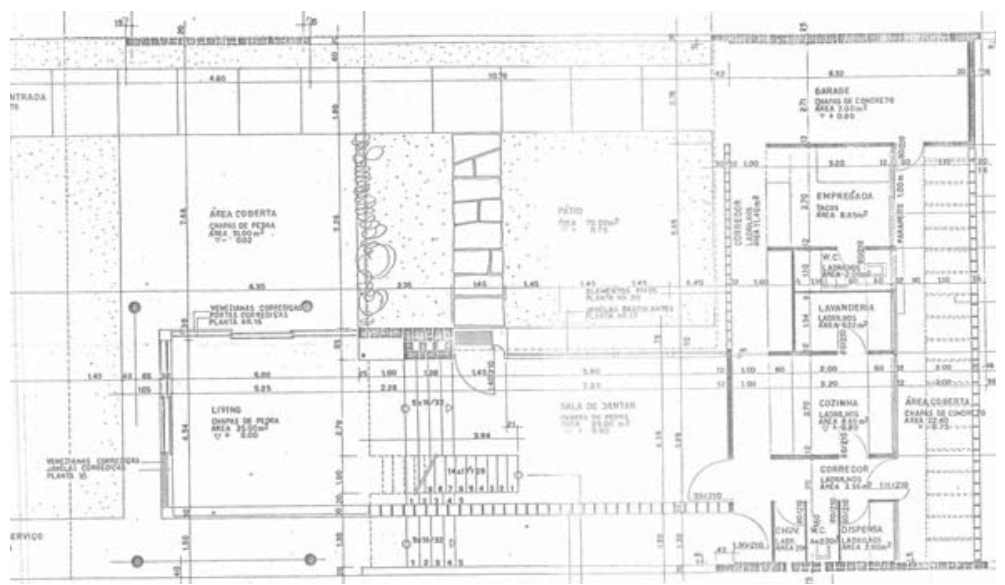

Fig. 29 - Residência Augusto Reichow. Planta baixa.
Aqui temos uma planta em "L", que segue a mesma disposição da casa Renaux: separação entre os setores social e íntimo no bloco de dois pavimentos e de serviços no bloco térreo, com a sala de jantar atuando como ambiente de transição entre a área social e de serviço e ladeando o pátio interno. Para esta casa de praia, com terreno de dimensões modestas $\left(435 \mathrm{~m}^{2}\right)$, a solução em "L" com pátio semi-aberto parece ser o melhor recurso para gerar privacidade e maior diversidade espacial. Interessante notar que a disposição dos setores não seguem uma regra conforme a orientação solar, por exemplo. Nota-se que me muitas casas da arquitetura moderna deixa-se o setor de serviços e sanitários voltados a oeste, enquanto os outros setores desfrutam de insolação mais branda. Em Broos esta setorização, assim como a vedação das paredes laterais segue, em geral outra lógica - a de voltar os setores social e íntimo para o interior do terreno, deixando o setor de serviço voltado para a rua. Lógica que, entretanto, não se impõe como regra; dependendo do lote e da vista, também é subvertida, naturalmente.

A casa de Gernsbach transforma-se em fonte de inesgotável pesquisa para os projetos residenciais, que predominam nesta época frente aos demais programas; e uma vez mais a primeira casa do arquiteto surge como exemplo, agora para a Residência Alfredo Zinkhahn (1958). Broos parte da mesma volumetria da casa Abel, com a noção de movimento sugerida pela cobertura ascendente, a projeção da sacada em balanço, a noção de volume autônomo, parcialmente sobre pilotis, com aberturas tímidas na fachada posterior e amplas aberturas na fachada frontal e paredes laterais vedadas. Externaliza parcialmente na fachada sua organização interna, através da divisão dos dormitórios e das aberturas da área social. Além disso, Broos concebe a residência Zinkhahn com a mesma diferenciação dos 
elementos vistos na casa Abel: desenho nítido da "moldura" da casa, composta pela linha contínua entre laje do pavimento e paredes laterais, e a moldura do telhado ganha dimensões mais sutis, ao contrário da generosa platibanda da residência Hering.

Mas ao contrário da casa de Gernsbach, que tem seu subsolo em concreto armado rebocado, fazendo reconhecer a ligação da casa com sua base, neste projeto Broos diferencia terminantemente o "fato bruto" e natural daquele "espiritualizado" em formas puras e racionais. Broos concebe o subsolo semi-enterrado, todo ele em pedra como uma continuação do solo e diferenciado, portanto, do fato arquitetônico. A casa parece então um objeto puro, um prisma de formas precisas que pousa sobre o elemento rústico, mas não faz parte dele, e se libera gradativamente do

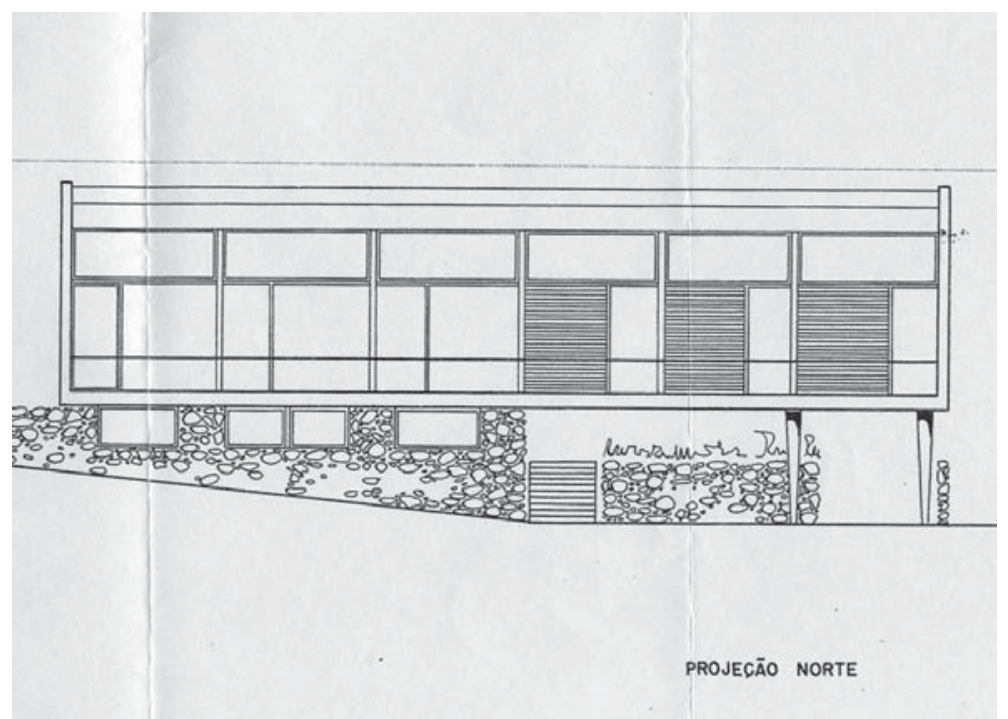

Fig. 30 - Hans Broos. Residência Alfredo Zinkhahn. Projeto. Blumenau. 1958.

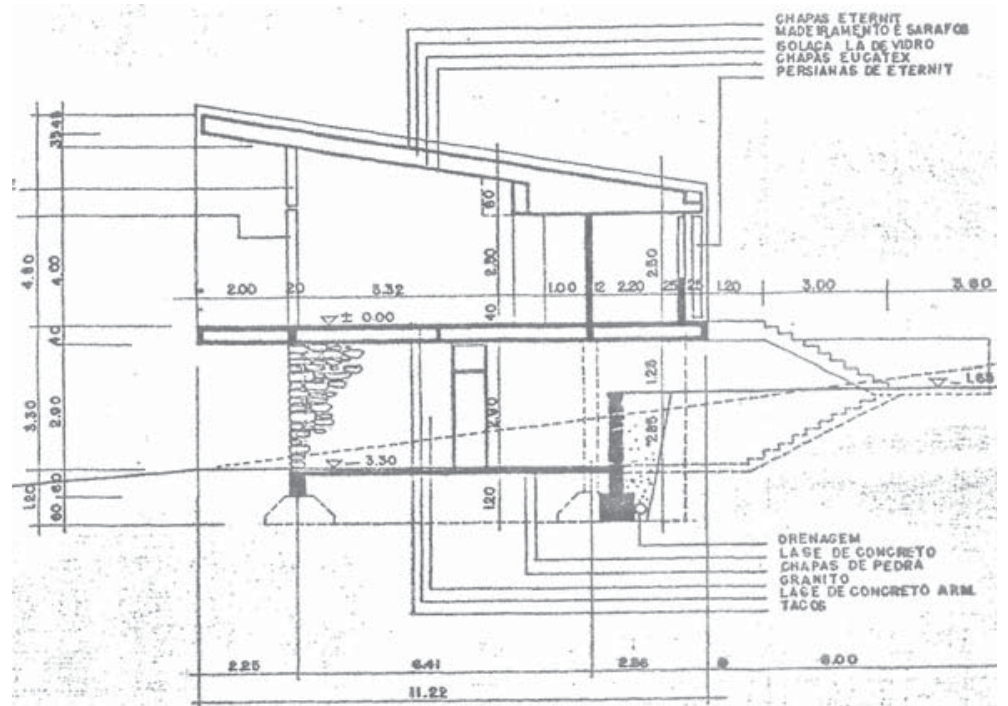

Fig. 31 - Residência Alfredo Zinkhahn. Corte transversal. solo na outra extremidade sobre pilotis.

\section{A PROCURA PELA PUREZA FORMAL}

Os projetos dos anos de 1957 e 1958, que se confundem com a estadia de Broos na então capital federal e os anos imediatamente posteriores, mostram a procura pela pureza formal, um constante exercício de limpidez no desenho e maior precisão construtiva. $\mathrm{O}$ arquiteto começa a diferenciar mais a pedra como elemento de base do objeto arquitetônico, parcialmente sobre pilotis, que assume um tom mais "artificial" e elaborado, com linhas mais puras e desenho mais nítido, que se diferencia do fato bruto e da matéria natural. A pedra dá o tom da porção telúrica, ligada ao assentamento, que faz a transição entre o solo e o fato “espiritualizado". 


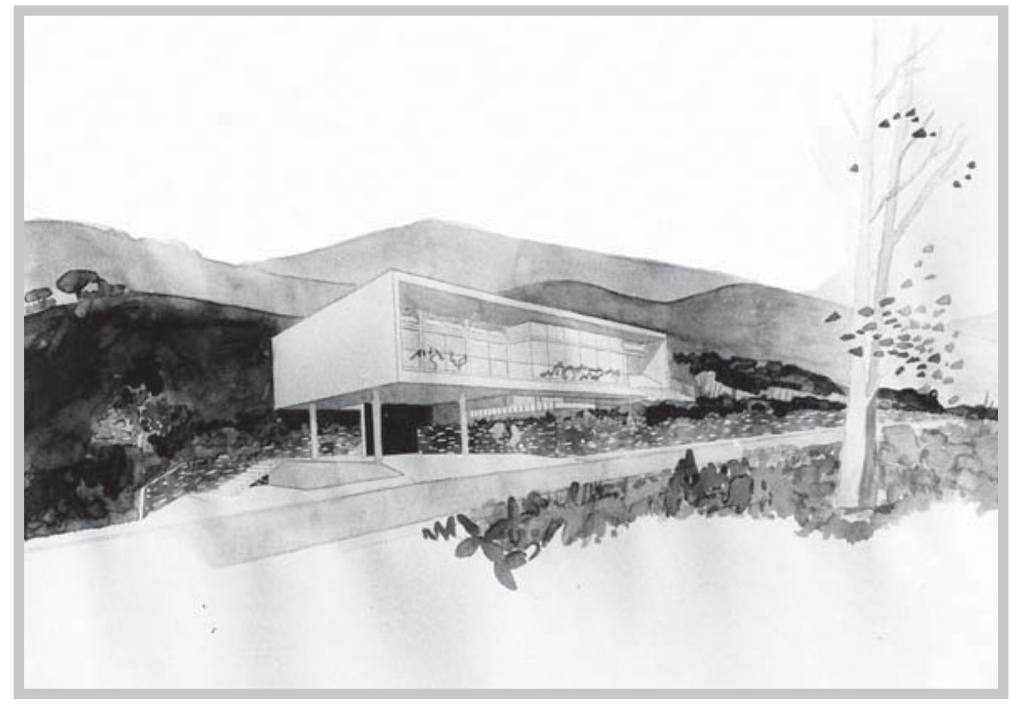

Fig. 32 - Hans Broos. Residência Ellinger. Projeto. Blumenau. 1958.

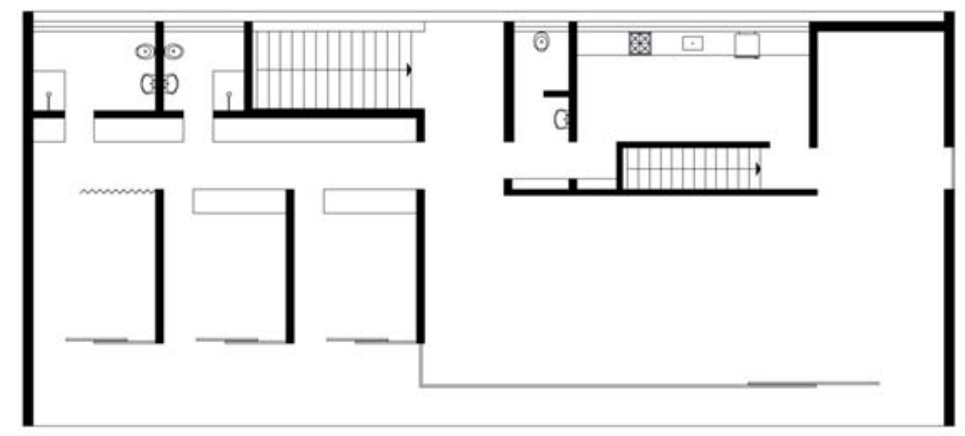

Fig. 33 - Residência Ellinger. Planta baixa.

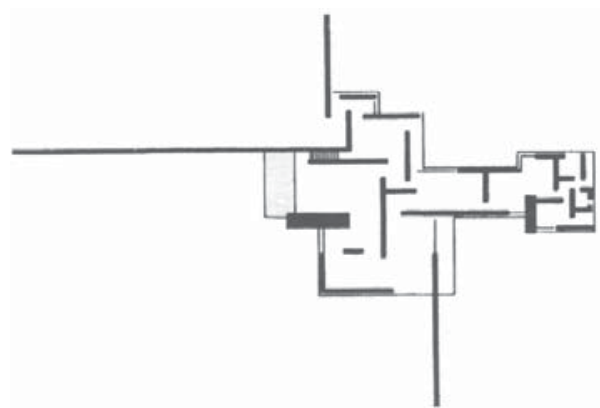

Fig. 34 - Mies van der Rohe. Casa de campo. 19231924. Planta baixa.

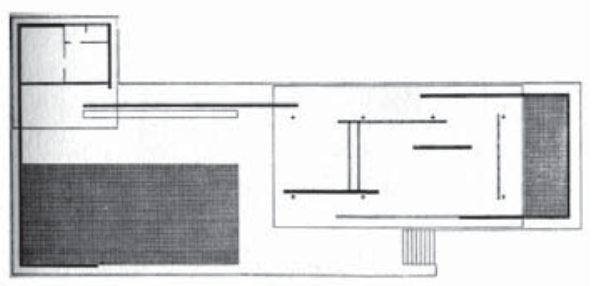

Fig. 35 - Mies van der Rohe. Pavilhão Alemão para a Exposição de Barcelona. 1929. Planta baixa.
Broos contrapõe ao objeto arquitetônico quase desmaterializado, composto com um mínimo de traços, a materialidade da pedra, com sua genuína expressividade, presente $\mathrm{m}$ quase todos os seus projetos desta época. $\mathrm{O}$ arquiteto projeta uma envolvente, onde torna nítido o desenho da caixa paredes laterais, cobertura e laje do pavimento - unidos em um único traço. Nestes anos seus projetos revelam uma procura obsessiva pela abstração do desenho, que se revela basicamente no desenho estrutural da caixa sobre pilotis e nos fechamentos de vidro.

O projeto para a Residência Ellinger (1958) revela de forma mais notável tais proposições. Revela também uma pesquisa espacial próxima à arquitetura de Mies van der Rohe, composta pelo desenho elementar que surge em planos paralelos e transversais que delimitam espaços internos, sem que muitas vezes se interceptem, como em seus projetos para a Casa de Campo (1923-1924) e para o Pavilhão Alemão para a Expo Mundial de Barcelona (1929). Tanto os dormitórios quanto as salas recebem fechamento total de vidro, então percebemos a fachada frontal apenas como vidro envolto por uma fina casca estrutural. Uma vez mais, a planta equivale de modo muito similar à planta da casa Abel; e é por esta razão que esta última torna-se tão interessante do ponto de vista formal e espacial: a casa de Gernsbach é reformulada inúmeras vezes; perdura a mesma concepção da planta-baixa e da volumetria, e ganha conotações bastante distintas entre si, que lhe confere o status de tipo formal, que quase sempre prevalece nas proposições do arquiteto. 
Na Residência Ellinger, em nome da pureza formal, Broos troca a noção de movimento que a cobertura ascendente encerrava pela cobertura plana. Também a pureza e a limpeza formal reclamam nova estrutura portante: aqui pela primeira vez toda a estrutura surge em concreto armado, inclusive a cobertura, algo que a Casa Peiter, projeto do mesmo ano, também traz. Deste modo, Broos abandona a platibanda em seus projetos, que tinha por finalidade conferir um caráter puro à volumetria da casa, dissimulando a estrutura tradicional do telhado.

A casa Zinkhahn pode ser considerada um ponto de transição para esta "fase" mais purista do arquiteto; ainda que tenha claras aproximações com suas predecessoras - como a cobertura inclinada - se apresenta como objeto autônomo sobre pedra e pilotis, ou seja, se "desloca" do chão. Mas ao mesmo tempo, de uma forma ampla e genérica, o desenho da caixa com fachada frontal recuada começa com a casa W.P. Hering, ainda que a "caixa" aqui deva ser relativizada, pois não é mais que a aparência externa, já que sua construtividade revela um processo artesanal, distante, portanto, da precisão construtiva das últimas obras.

A mesma concepção geral da casa Ellinger pode ser vista nos projetos para o Internato de Ibirama (1959) e no Edifício Condomínio Cabeçudas (1959). Nestes exemplos não construídos, o projeto é reduzido às suas estruturas elementares, a forma se confunde com a própria estrutura. A composição segue bastante semelhante: pilotis no térreo ou primeiros pavimentos, e volumetria marcada pelo desenho nítido da caixa, que surge como corpo principal, até mesmo para projetos de dimensões maiores como estes. $\mathrm{O}$ arquiteto persegue o máximo de pureza numa construção geométrica rigorosa, se desfaz da massa, rumo a uma estrutura cada vez mais leve e imaterial, onde os

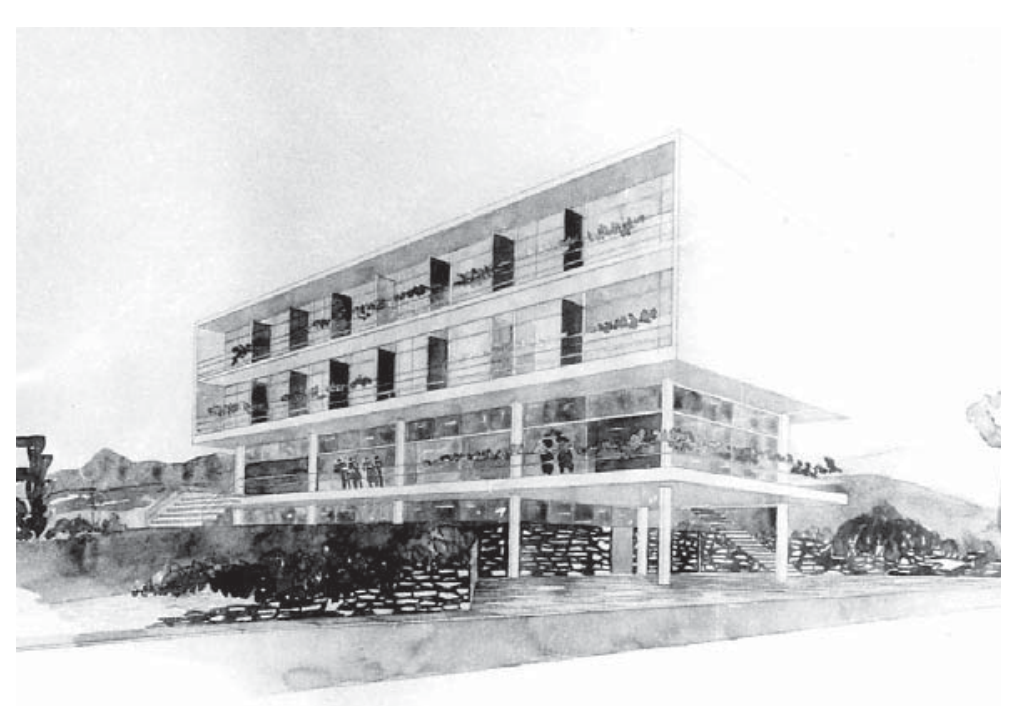

Fig. 36 - Hans Broos. Internato de Ibirama. Projeto. Ibirama. 1959.

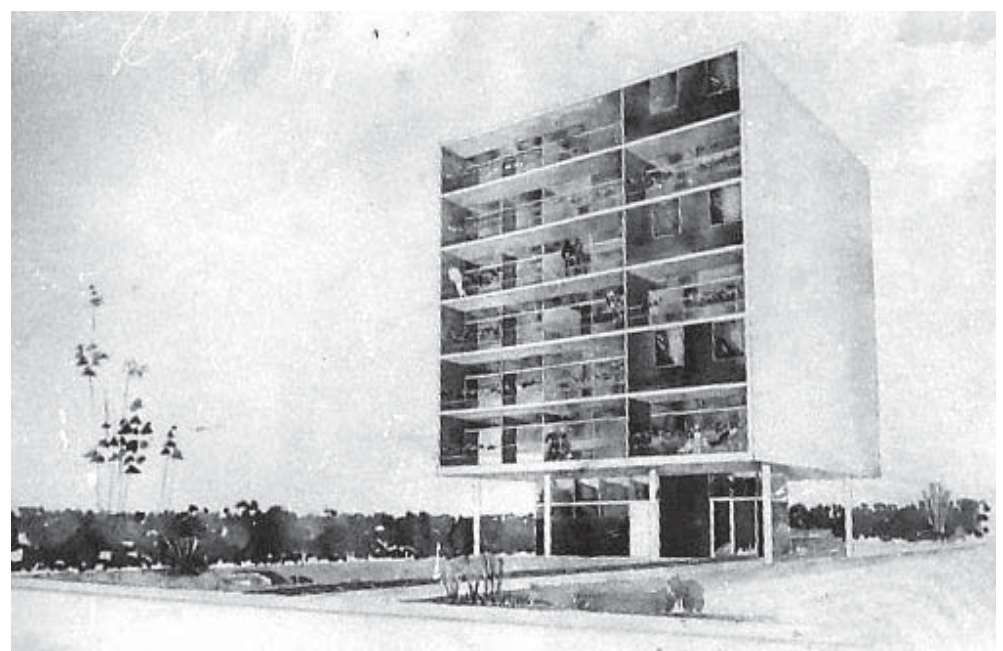

Fig. 37 - Hans Broos. Edifício Condomínio Cabeçudas. Projeto. Cabeçudas. 1958. 
fechamentos de vidro parecem não impor limites ao espaço. No Internato de Ibirama, o arquiteto procura a mesma relação de contraste entre o edifício e seu entorno; busca contrapor ao objeto prismático a organicidade natural da pedra, na forma de muros e taludes.

\section{AproximaÇão com a Escola CARIOCA}

Entre os anos de 1956 e 1957 Broos está envolvido com os trabalhos da revalidação de seu diploma na então Universidade do Brasil, no Rio de Janeiro. Mais precisamente o último ano foi dedicado à concepção do que seria sua tese de revalidação: "Edificações Açorianas em Santa Catarina.", como já mencionado. $\mathrm{O}$ arquiteto percorre várias regiões do Estado para o levantamento de obras históricas, da casa açoriana, existente principalmente no litoral, mas também em algumas regiões interioranas. $\mathrm{O}$ arquiteto pode, deste modo, obter um profundo conhecimento acerca da história e da cultura do seu estado, principalmente no que se refere à arquitetura e à evolução dos modos de morar. Mas seus trabalhos destes anos mostram que seu interesse e conhecimento cultural e histórico não se reflete, de modo algum, em concessões regionalistas em sua arquitetura; ao contrário.

Quando o arquiteto coloca: "não existem critérios universais, somente regionais e humanos", ${ }^{25}$ não pode ser entendido que sua arquitetura se volte ao regional ou faça uso de traços arquitetônicos históricos. Sua arquitetura tende ao local visando satisfazer ao contexto construído, aos materiais disponíveis e ao clima; e ao universal, tendo em vista os pressupostos funcionais e estruturais a que submete todos os seus projetos, baseados na racionalidade como capacidade de resposta a toda e qualquer situação. Broos constrói para Blumenau, São Paulo ou Florianópolis arquiteturas que não se distinguem na essência. Seu credo na validade das formas modernas está tão arraigada em seu pensamento quanto o está a necessidade de adequar esta linguagem ao urbano e ao patrimônio como mostram algumas das propostas destes anos.

É justamente neste curto, inspirador e produtivo tempo de convívio direto com as obras da Escola Carioca, de que o arquiteto nunca negou sua admiração, é que surgem os projetos mais próximos à esta Escola (alguns deles os mais puristas da obra do arquiteto, que somente irá se repetir na Igreja de São Bonifácio ${ }^{26}$ ). Para o projeto da Biblioteca Pública e Arquivo Dr. Blumenau (1957), localizado numa área histórica da cidade e ladeado por dois exemplares da típica arquitetura germânica, Broos propõe um projeto que revela claras influências da Escola Carioca, com elementos típicos como pilotis, brises, fachadas com fechamentos diversos e, sobretudo, a busca de leveza e equilíbrio, que se traduziu também 
pela busca de uma pureza e abstração formal, como as últimas obras aqui relatadas: "o que me fascinava não era a forma, mas a filosofia que havia por trás dela”. ${ }^{27}$ Entretanto, é notável que também a forma o encantou e influenciou seus projetos.

São dos anos 1957/1958 as obras que mais se assemelham à arquitetura carioca. Os projetos do arquiteto ganham traços leves e buscam a diferenciação formal e volumétrica, e se diferem significativamente de sua obra inicial, como demonstram os projetos para a Biblioteca Dr. Blumenau e o edifício da Assembléia Legislativa de Santa Catarina, ambos de 1957.

Tendo em vista o programa consideravelmente extenso da Biblioteca Dr. Blumenau, com setores admi-

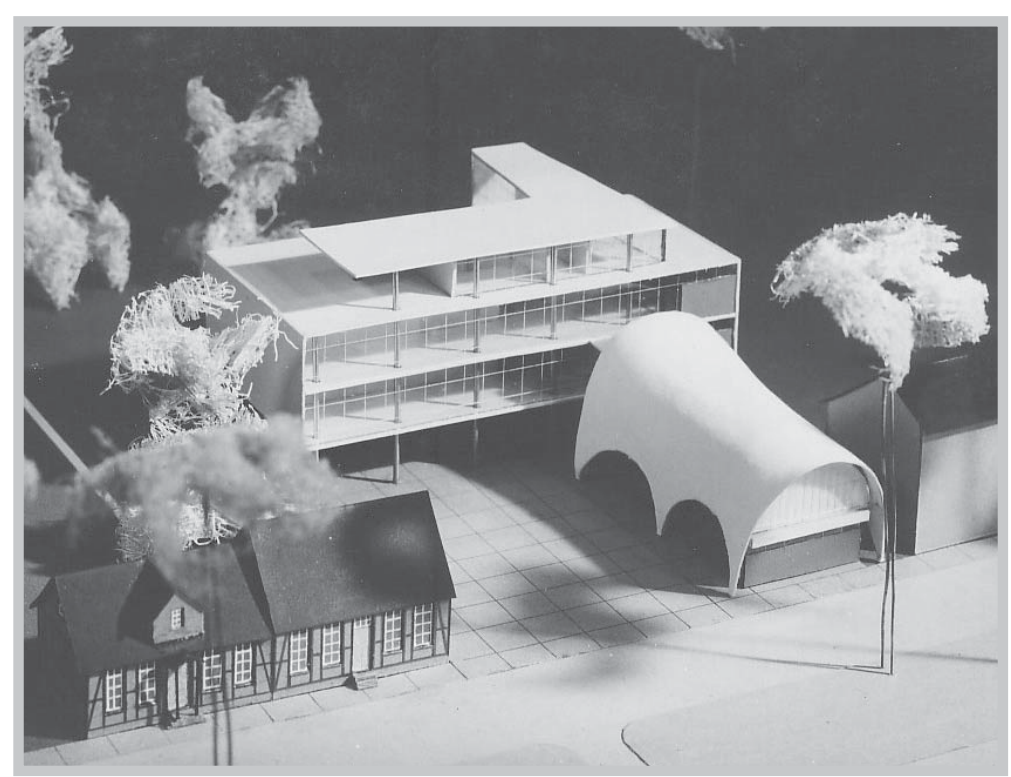

Fig. 38 - Hans Broos. Biblioteca Pública e Arquivo Dr. Blumenau. Projeto. Blumenau. 1957. nistrativos e de arquivamento de documentos, e a escala significativamente maior dos dois novos prédios em relação ao entorno, o arquiteto propõe o recuo do edifício de maior dimensão. Forma-se então um pátio entre as antigas construções e as novas, e em continuidade com o passeio. O prédio menor, que se adequa aos prédios do entorno, surge junto ao passeio, posicionado transversalmente, num sentido de ligação entre a rua com seus modelos típicos, e o

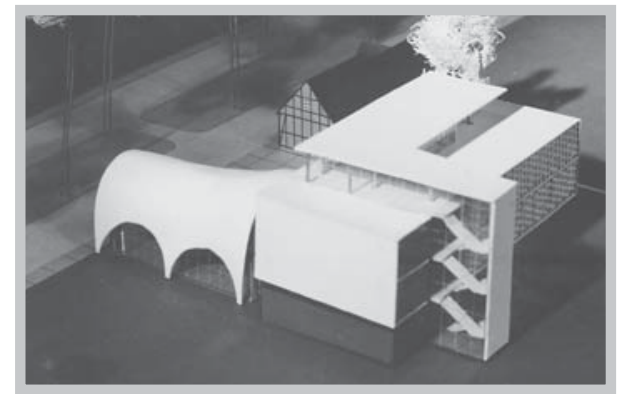

Fig. 39 - Hans Broos. Biblioteca Pública e Arquivo Dr. Blumenau. Projeto. Blumenau. 1957. novo complexo dentro da quadra.

No edifício menor o arquiteto faz uma explícita referência às cascas estruturais tão utilizadas na arquitetura brasileira - como na Igreja da Pampulha - na qual a estrutura de concreto armado muito fina e visualmente muito leve, parece mal tocar o chão. Através dos recortes circulares tem-se fechamento em vidro das laterais. Já o prédio de trás, que se posiciona transversalmente àquele, parte de uma concepção bastante diversa do primeiro. Enquanto neste o cheio predomina sobre o vazio, naquele é o vidro que toma a maior parte da superfície; enquanto no primeiro a forma orgânica domina a concepção - talvez a única concessão que o arquiteto tenha feito a esta noção compositiva - no segundo o arquiteto parte da forma ortogonal e do mesmo rigor formal que dera origem aos últimos 
projetos. Mais uma vez o Broos parte de um cubo sobre pilotis, com fachadas laterais vedadas. Enquanto a fachada frontal ostenta quase total transparência, a fachada posterior é diferenciada através do uso de elementos vazados. A forma cúbica tem seu rigor quebrado através da cobertura com planta em " $\mathrm{L}$ " sobre o terraço, que dá origem ao volume da escadaria nos fundos do prédio.

Seus projetos destes anos ostentam uma forma cada vez mais límpida, busca na tecnologia do concreto uma estética mais apurada. O que antes possuía um caráter puro, mas que inegavelmente exigia esforços de "vestidura" para dar um caráter de coisa "limpa" e dissimular o caráter artesanal de sua construção, agora a arquitetura realmente revela com precisão sua construção.

Os elementos construtivos são empregados com exatidão e o arquiteto revisita alguns dos "pontos" corbusianos da arquitetura moderna, como já havia feito na Casa Peiter que, embora não seguidos à risca pela arquitetura brasileira - que talvez dentre a "família" moderna foi uma das que mais se permitiu reflexões com a história e a cultura local - os cinco pontos de Corbusier foi uma questão importante, ainda que mais inicialmente, mas constantemente revisitada pelos arquitetos. Aqui Broos faz uso de pilotis, estrutura independente, fachada recuada independente, aberturas que tomam todo o pavimento, e terraço (não o jardim) coberto. Podemos ver que Broos assimila inegavelmente muitos elementos da nova arquitetura brasileira, além do volume parabolóide - a referencia mais literal até aqui - a diferenciação de fachadas - uma em vidro outra com elementos de vedação contra o sol - além do volume cristalino da escadaria e seu fechamento em continuação à cobertura do terraço, que rompe com o volume rígido. De certa forma, tais aspectos colocam-se dentro do processo de articulação da planta, inserção de elementos vazados e da cobertura tipo borboleta que vinham mostrando seus projetos residenciais.

No mesmo ano Broos daria novamente claras mostras de sua aproximação formal com a Escola Carioca. No projeto para o concurso do edifício da Assembléia Legislativa de Santa Catarina (1957) o arquiteto projeta o seu primeiro edifício em alturas, e o concebe tendo a sua frente os princípios gerais daquela escola. $\mathrm{O}$ arquiteto o concebe em dois volumes - uma torre com os escritórios e gabinetes e um mais baixo para as sessões plenárias e auditório. Os edifícios localizam-se em uma esquina, mas o arquiteto não tira proveito desta situação e os dispõe lateralmente à rua. O edifício menor volta-se para uma praça e procura aproximarse do gabarito das edificações vizinhas, ainda que as ultrapasse significativamente. Já o edifício em alturas é colocado para trás deste, junto à uma pequena Igreja, com a qual perfaz uma espécie de átrio elevado em seu segundo pavimento, na 
mesma altura do acesso à igreja, porem sem conectar-se a ela. Interessante que o prédio sobre pilotis deixa o térreo livre, e permite a conexão entre a igreja e a rua voltada para a praça, ou seja, não pretende "isolar" fisicamente o pequeno edifício religioso, mais do que o edifício em altura já o faz visualmente.

O volume menor se faz imponente frente aos prédios vizinhos, e aqui o arquiteto revisita a sua tão cara noção de movimento, que tanto caracterizou suas primeiras casas. A ideia da "caixa" ganha um aspecto bastante pesado e massivo, apesar dos quatro pavimentos translúcidos da fachada frontal. Já o edifício maior ostenta uma leveza que o difere do anterior e se apresenta como um típico edifício da escola Carioca: bloco de nove pavimentos sobre dois pavimentos de pilotis, somados a um elemento

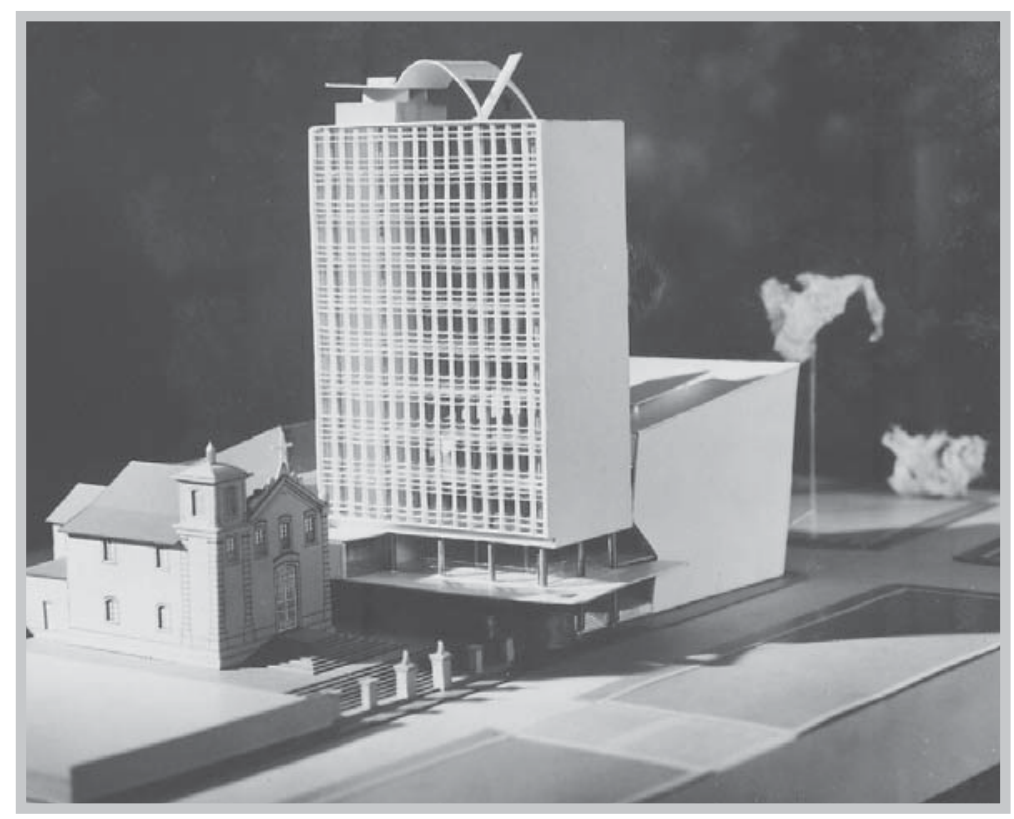

Fig. 40 - Hans Broos. Edifício da Assembléia Legislativa de Santa Catarina. (Concurso). Florianópolis. 1957. escultural no terraço, uma já quase "tradição" iniciada desde o edifício do Ministério da Educação e Saúde (MES). A torre apresenta-se com duas fachadas diferentes - uma com vidro e a outra com uma trama de elementos horizontais e verticais para vedação solar.

O motivo da caixa, que tanto anima os projetos do arquiteto, aqui não parece ter favorecido a relação do prédio com a esquina. Para a rua da igreja, os blocos são colocados lateralmente e não parecem assumir nenhuma relação mais direta. Tampouco teve êxito a brusca relação da torre com a pequena igreja, apesar da tentativa do "átrio", ou mesmo a relação entre os dois novos volumes. No edifício em altura, o volume que surge escultural na cobertura é o arremate da torre de serviço que perpassa todos os andares e inclui a caixa do elevador. Este e outros detalhes do conjunto proposto demonstram, principalmente no desenho da torre, uma filiação tão incondicional aos (velhos) valores da arquitetura moderna brasileira que, de início, um encontro frutífero com sua arquitetura alemã e a saudável mescla de valores aparentemente opostos, transforma sua arquitetura quase em "lugar comum".

Esta "fase" do arquiteto, de muita produção mas pouca construção, deixou raros exemplares, nenhum da "fase" mais purista. Somente alguns ligados à escola 
Carioca foram construídos, como a Casa Peiter (1956-1959), a Residência Carlos Curt Zadrozny ${ }^{28}$ e a Prefeitura de Rio do Sul, construída com várias modificações, alterando completamente a proposta do arquiteto.

No projeto da Prefeitura de Rio do Sul (1958-1960) $)^{29}$ Broos persegue o ideal de leveza, a diferenciação formal e dos fechamentos, mas de uma forma muito mais madura e sem referências literais, que o assemelha ao projeto do Internato de Ibirama. Naquele edifício cada setor do vasto programa ganha formas individualizadas. O bloco principal sobre pilotis abriga as salas da administração municipal, o bloco horizontal do segundo pavimento, as salas de juizado e promotoria, salas de audiência, cartório e biblioteca e o volume térreo de dois pavimentos, câmara de vereadores e salas de Júri, além das duas torres de escadaria que se projetam nos fundo do prédio.

$\mathrm{Na}$ fachada principal todos os detalhes endossam a noção de leveza: o bloco horizontal do segundo pavimento, quase "suspenso" sobre pilotis, que se projeta além dos limites frontais da torre, distingui-se sutilmente desta pelos mesmos pilotis. No último pavimento a cobertura parcialmente vazada também desfaz

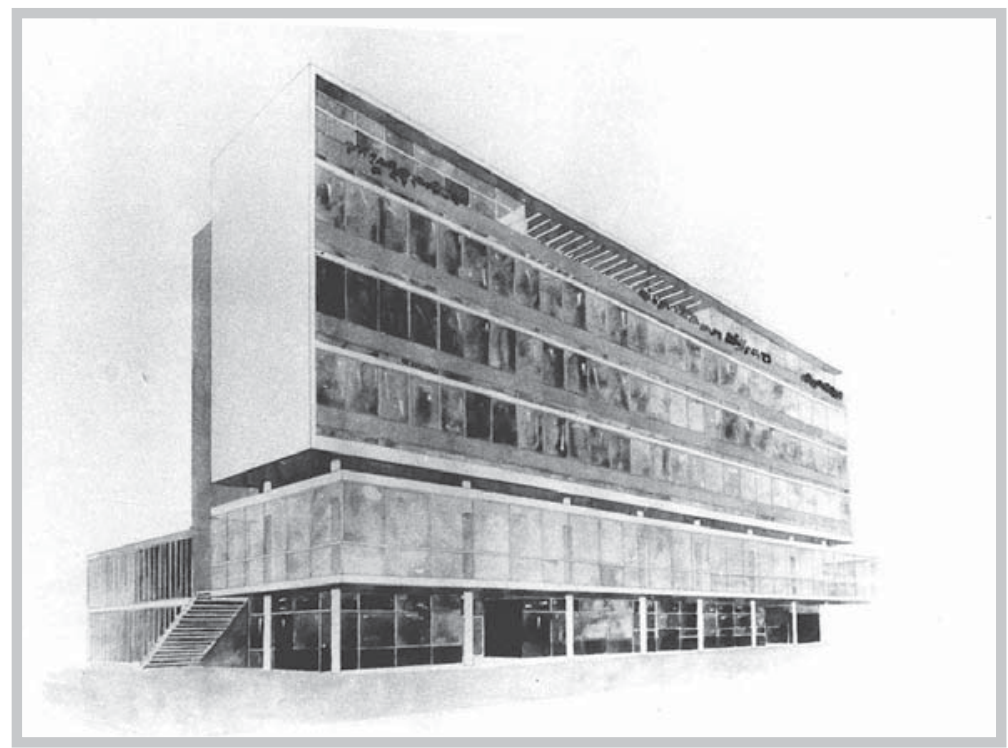

Fig. 41 - Hans Broos. Prefeitura de Rio do Sul. 1958-1960. a noção de bloco fechado. E é claro a, a presença massiva de vidro como fechamento, faz do prédio um elemento quase cristalino. $\mathrm{Na}$ fachada oposta o arquiteto utiliza brises verticais como recurso para a diferenciação formal. Em oposição a esta fachada opaca, as torres envidraçadas deixam antever as delicadas estruturas de circulação.

Do cubo fechado e do volume autônomo o arquiteto parte para a procura de maior diferenciação

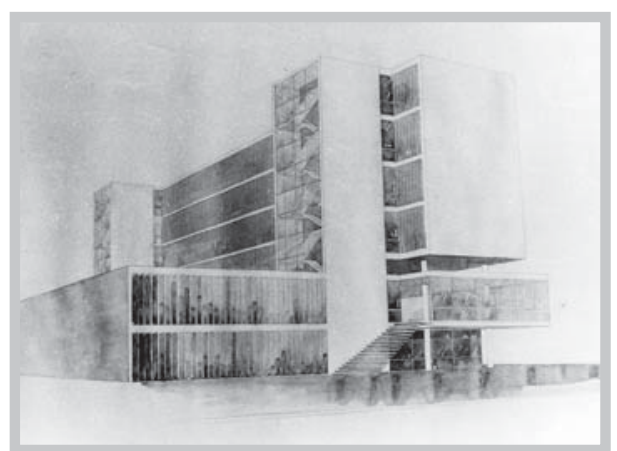

Fig. 42 - Hans Broos. Prefeitura de Rio do Sul. 19581960. formal, composição volumétrica, tendo em vista maior riqueza espacial, movimento e liberdade projetual; noções que geraram novas concepções formais para o desenvolvimento do projeto residencial.

Na residência Carlos Curt Zadrozny (1958-1961) o arquiteto se desfaz do volume puro e autônomo, fechado, rumo a uma forma mais aberta e expansiva, composta em alas. $\mathrm{O}$ desenho da caixa se desfaz ou, ao menos, não 
é nitidamente perceptível. Ao invés disso, o arquiteto prefere o projeto em extensão, alongado, com planta em "L", mas que faz uso de algumas conquistas dos projetos não realizados dos últimos anos, como a fachada que se conserva em sua unidade estética e tende a se desvencilhar do chão (como nas residências Zinkhahn e Ellinger), e a casa, alva e pura em sua forma, se diferencia dos muros de pedra que recortam o terreno.

$\mathrm{O}$ arquiteto revisita aqui elementos por ele já incorporados em outros projetos, mas numa estética totalmente nova. Também a Casa Renaux possuía a cobertura borboleta, e principalmente, o pátio interno e a expansão da planta baixa, mas ligava-se sobretudo à estética das primeiras casas, como a Abel e sobretudo a W.P. Hering. Da experiência da aproximação com a Escola Carioca fica a leveza desta casa, sua parede lateral e cobertura vazadas e a sensação de se deslocar do solo. Mas apesar da pureza formal que predomina através das perfeitas junções entre os elementos formais e construtivos, como a laje do pavimento, as paredes externas e as estruturas da cobertura - o resultado estético não é tão puro e preciso quanto o projeto da Casa

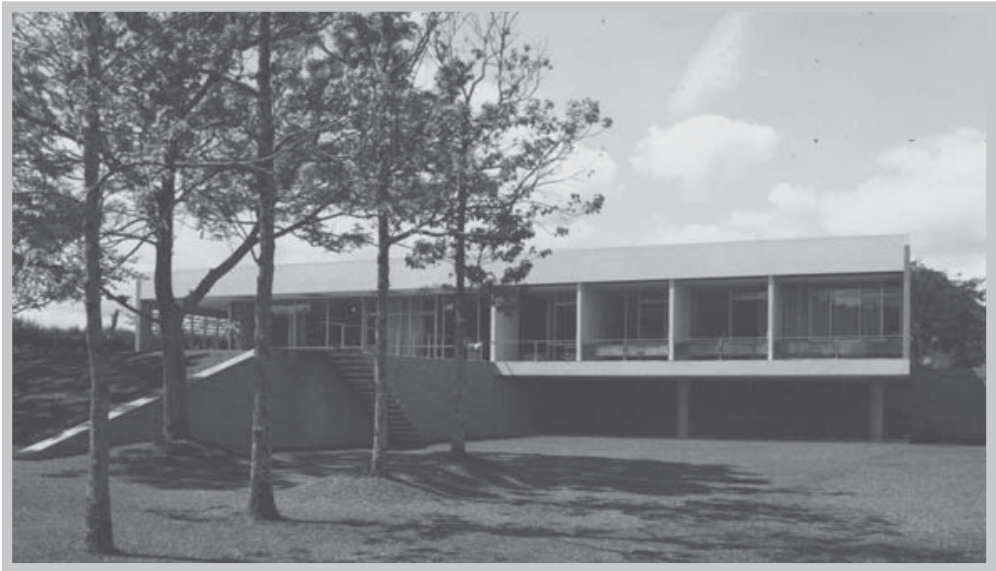

Fig. 43 - Hans Broos. Residência Carlos Curt Zadrozny. Blumenau. 1958-1961.

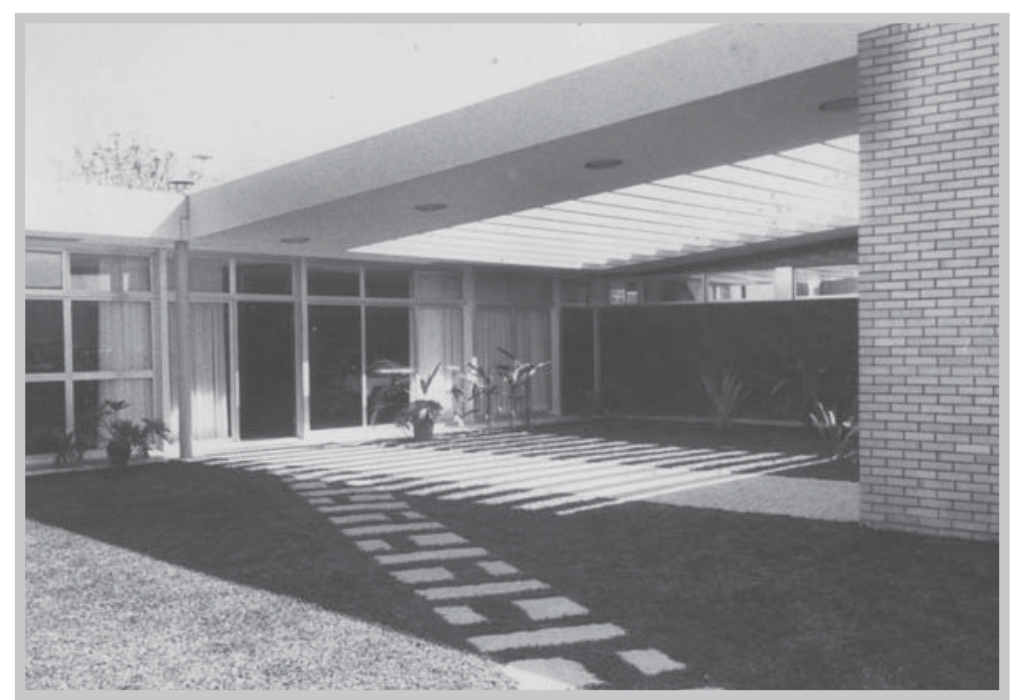

Fig. 44 - Hans Broos. Residência Carlos Curt Zadrozny. Blumenau. 1958-1961.

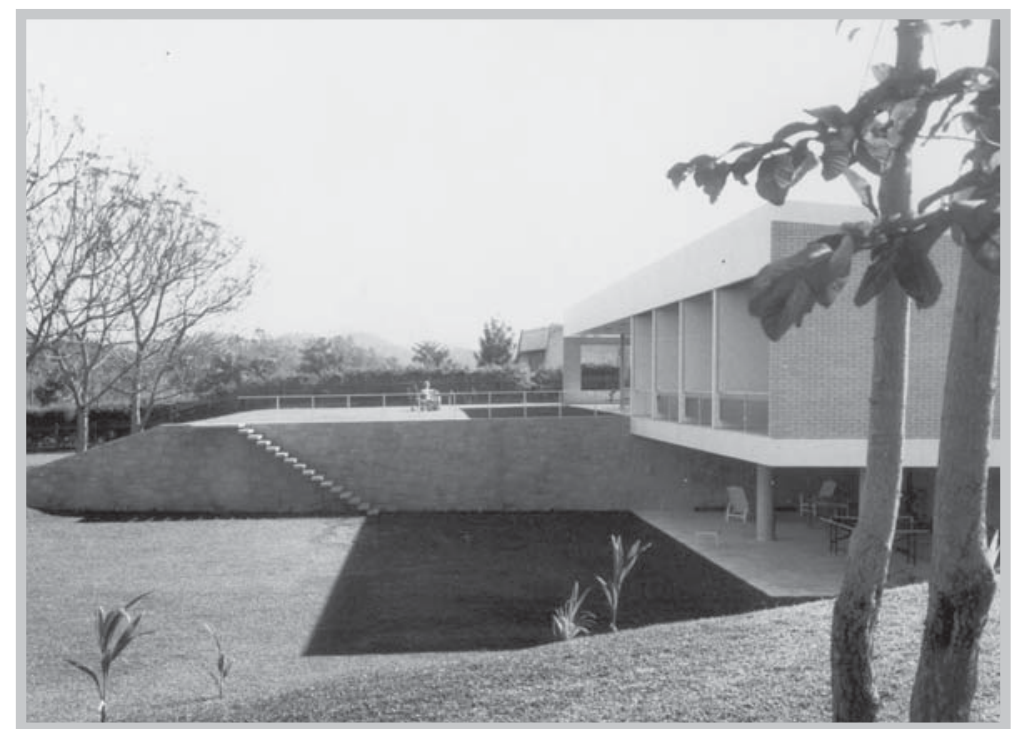

Fig. 45 - Hans Broos. Residência Carlos Curt Zadrozny. Blumenau. 1958-1961. Ellinger, por exemplo.

Aqui Broos incorpora novamente a cobertura tipo borboleta, e novamente faz uso da platibanda para esconder a estrutura do telhado. O "grafismo" dos projetos 
anteriores, puristas, encontram aqui sua versão construída, onde fica clara a diferença entre a proposição e as possibilidades de realização. Mesmo assim, nestes "exercícios" puristas e da Escola Carioca, Broos gera uma arquitetura mais leve e expansiva, que muito se diferencia das primeiras obras construídas. Vizinhas, podemos verificar as nítidas diferenças entre as Casas W.P. Hering e Carlos Curt Zadrozny, construídas com aproximadamente cinco anos de diferença. Construída em concreto armado - o que permitiu também esta estética mais "apurada" - a casa Zadrozny ainda traz muito, porém, da construção convencional, como paredes portantes de alvenaria e parte da cobertura com estrutura em madeira (enquanto a outra, da garagem com as pérgulas, foi realizada em concreto armado).

Neste projeto, apesar do arquiteto incorporar sua já tradicional cobertura borboleta - colocada transversalmente à fachada principal - ela não modifica substancialmente o projeto como o observamos, como ocorre na residência Reichow por exemplo. Na fachada principal predomina o volume horizontalizante, que remete aos recentes projetos do arquiteto não construídos.

Aqui também Broos repete soluções bastante experimentadas, por um lado, mas as renova, por outro. Em todos os projetos residenciais anteriores, vimos que principalmente a disposições dos dormitórios e as também as divisões das

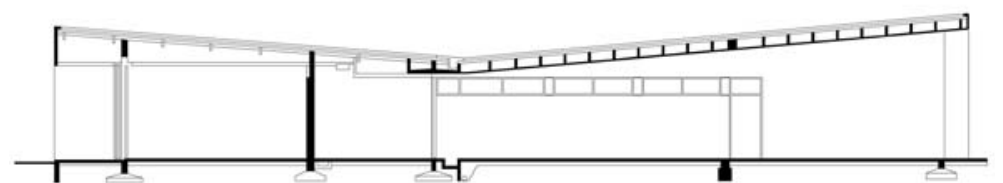

Fig. 46 - Residência Carlos Curt Zadrozny. Corte Iongitudinal.

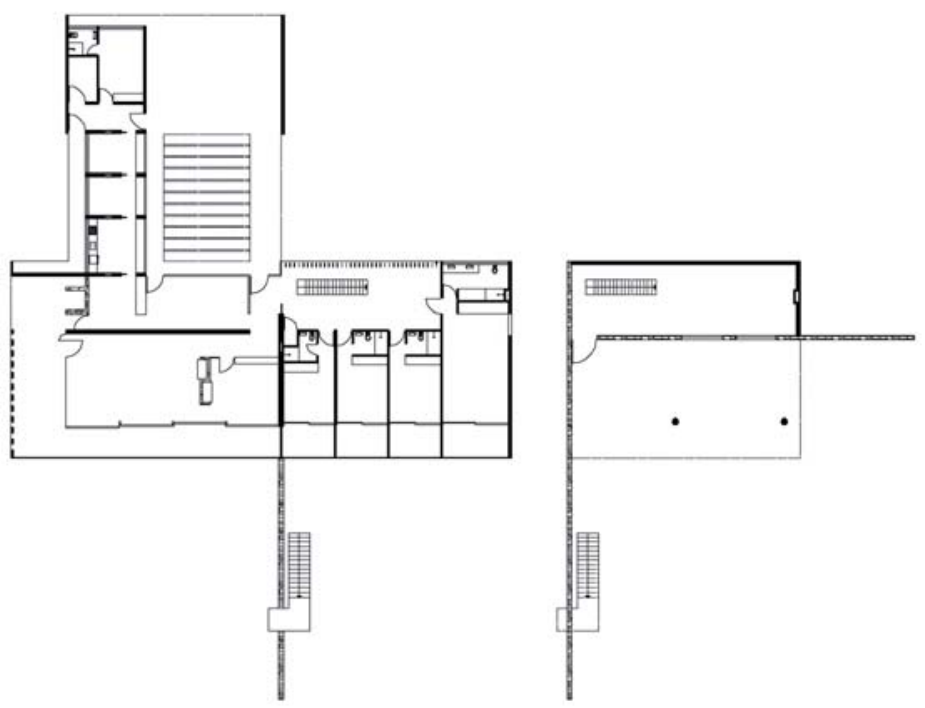

Fig. 47 - Residência Carlos Curt Zadrozny. Planta baixa pavimento térreo e subsolo. salas geravam certa ordenação na fachada; esta era o espelho da estrutura interna, exemplificada, na maior parte das vezes, apenas pela divisão das aberturas e/ou lamelas, brises e também das guias fixas das lamelas. Na Casa Zadrozny Broos estende a divisão interna até a fachada principal, e o que temos é uma noção de ordem e regularidade nunca vistos, quase "clássica".

Como nos projetos mais "puristas" também aqui a pedra é deixada somente como embasamento, enquanto o objeto arquitetônico se diferencia e se conserva em sua autonomia e pureza formal; o fato "artístico" é separado do fato natural. Mas vemos que todo 
o terreno é ordenado e trabalhado em conjunto com a casa e para este fim específico. Não podemos falar aqui em uma natureza intocada e de um objeto que se contrapõe a ela. Broos trabalha arquitetura e natureza para que juntos resultem num ambiente adequado para determinado fim, o que se repetirá em projetos posteriores.

Broos procura a variação de materiais e tonalidades como antes, mas de uma maneira muito mais sutil. A pedra surge somente no embasamento e em elementos como lareiras; nas paredes laterais, onde em muitos projetos o arquiteto optou por utilizar a pesada e expressiva pedra, usa agora o tijolo aparente, material mais leve e esteticamente neutro, e deixa assim seus projetos com caráter mais unitário, onde busca ressaltar a leveza do objeto e diferenciá-lo de qualquer característica telúrica.

$\mathrm{Na}$ fachada principal o arquiteto trabalha com grandes recuos do espaço interno, para evitar a incidência direta do sol poente e ao mesmo tempo, garantir a vista para o jardim e para o rio. Este recurso confere profundidade à fachada e contraste entre áreas sombreadas e iluminadas. Tal solução, aliada à sombra que se projeta no andar de pilotis faz com que a casa se "solte" do chão, e somente as principais linhas compositivas sejam ressaltadas. A casa então surge como um prisma horizontal onde registramos apenas seus delicados perfis verticais e os horizontais.

O mesmo sentido horizontalizante do volume, que predomina nas últimas proposições e, sobretudo na residência Zadrozny, também é verificado na Residência Eduard Zipser (1959-1960) em Florianópolis. O arquiteto projeta em extensão, utilizando toda a largura do terreno e dispõe a casa

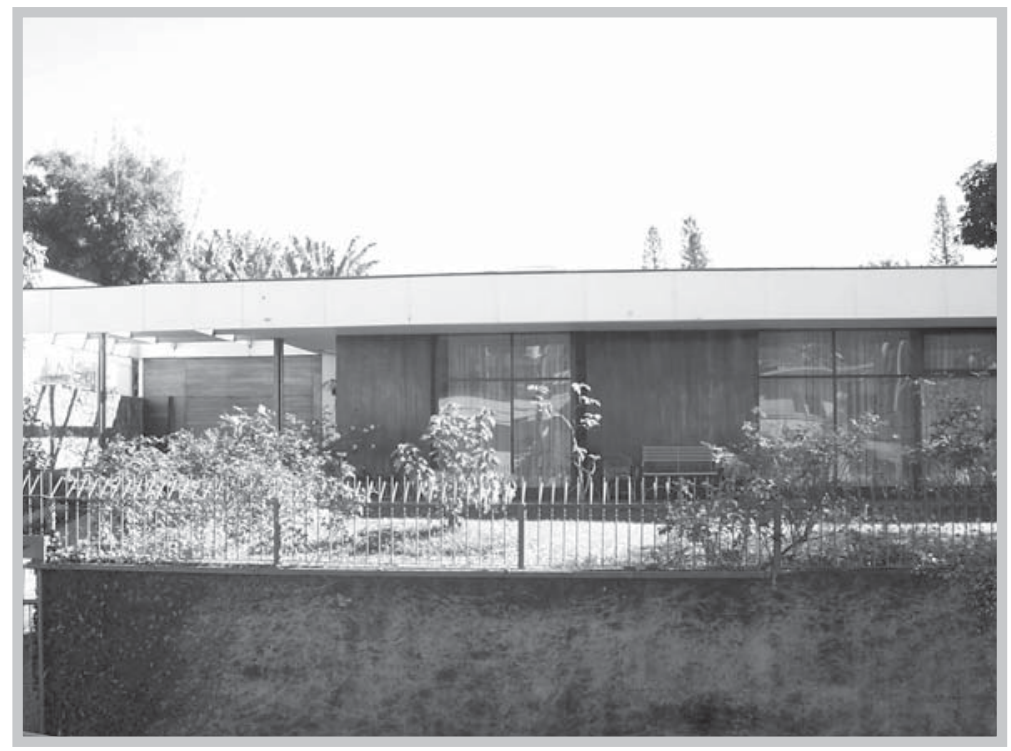

Fig. 48 - Hans Broos. Residência Eduard Zipser. Florianópolis. 1959-1960.

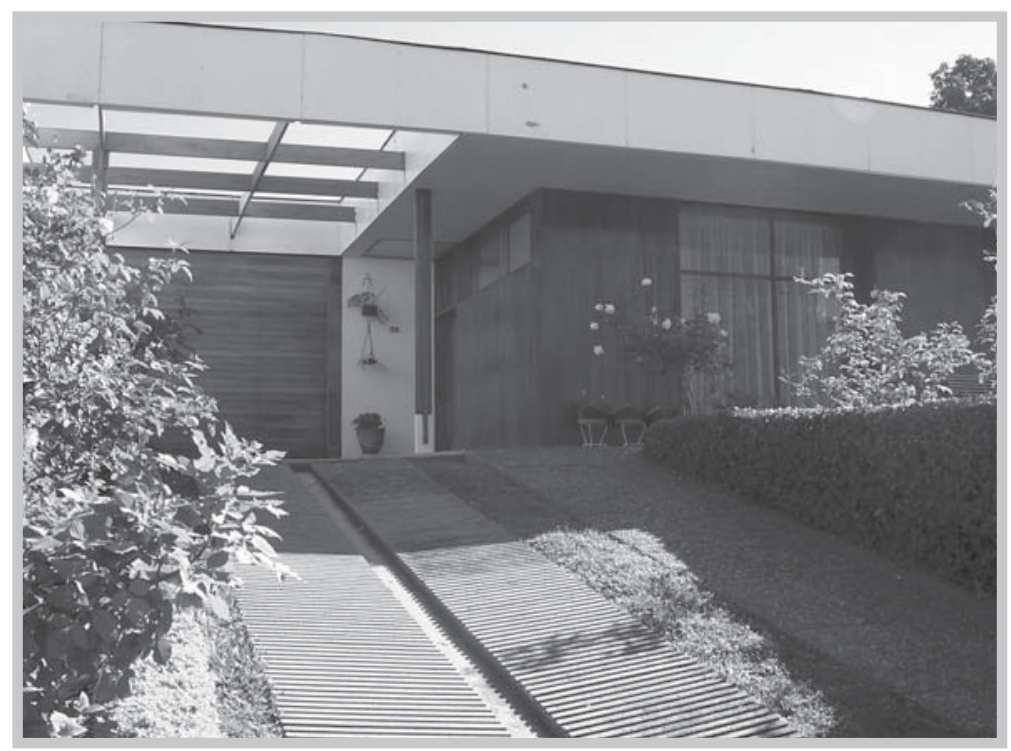

Fig. 49 - Hans Broos. Residência Eduard Zipser. Florianópolis. 1959-1960. 
longitudinalmente a ele, recuando-o significativamente da rua. Assim como na residência Zadrozny, casa e terreno são concebidos juntos, fazem parte do mesmo ato construtivo; também aqui o terreno é "moldado" para servir à casa da maneira mais adequada possível.

O terreno encontra-se em uma plataforma levemente elevada da rua com uma ampla testada. Broos propõe a volumetria tipo pavilhão, horizontal e rente ao chão, com sua ampla cobertura que abraça toda a extensão do terreno, disposta sobre o "pódio" miesiano. A generosa platibanda metálica branca, em franco contraste com a madeira utilizada no revestimento e nas aberturas, parece planar e, juntos, cobertura e terreno, são realçados e se reforçam mutuamente em sua horizontalidade e linearidade.

A expansão da planta baixa realizada com o projeto da residência Zadrozny, através da planta em "L", é proposta aqui através da cobertura; a casa, mais

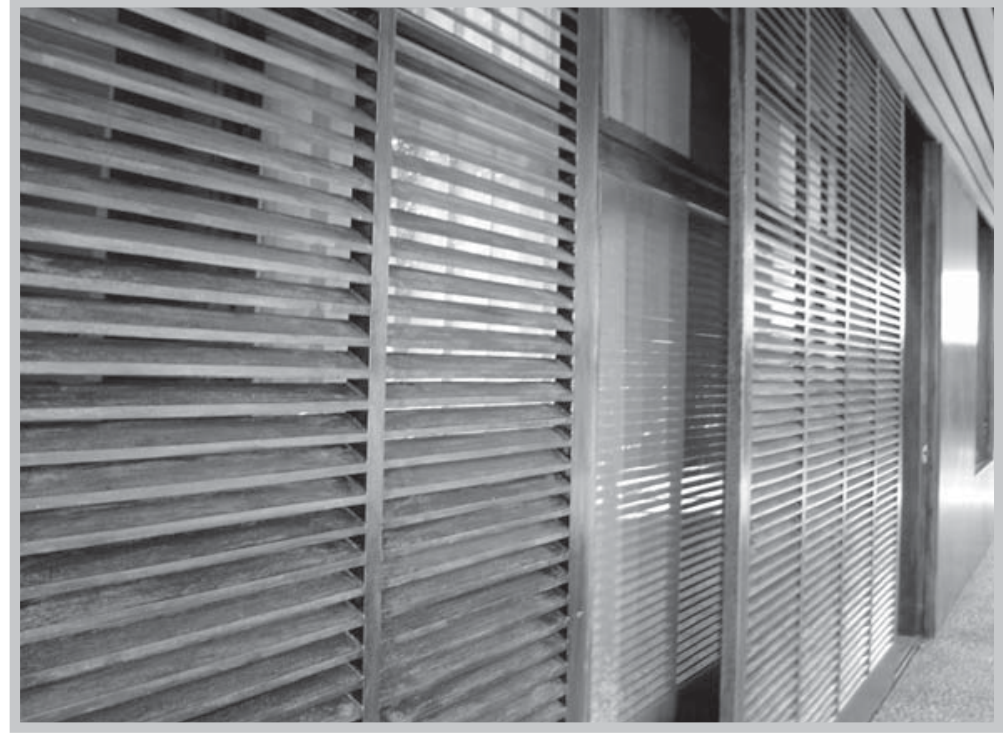

Fig. 50 - Hans Broos. Residência Eduard Zipser. Florianópolis. 1959-1960.

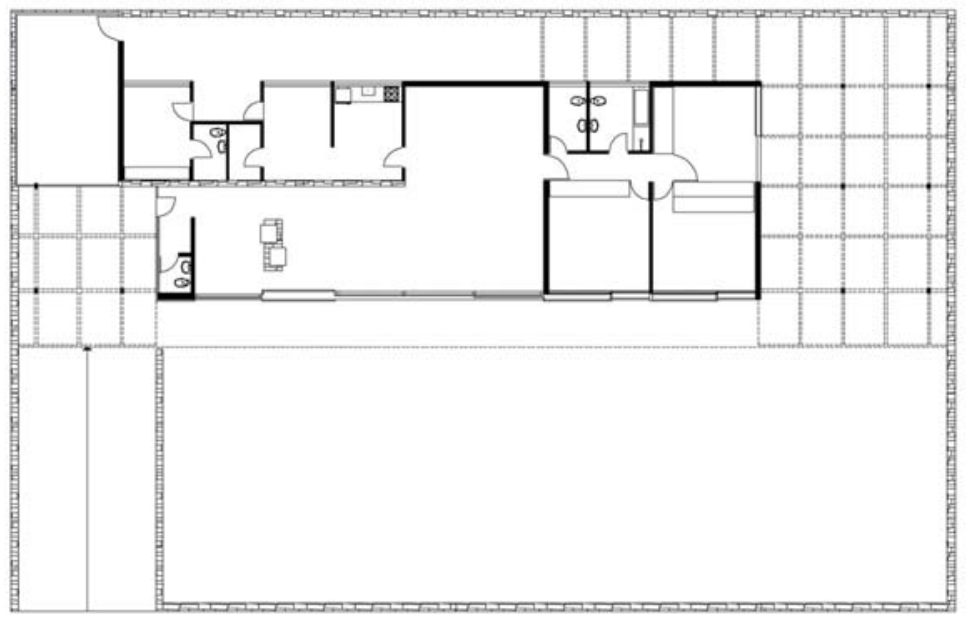

Fig. 51 - Residência Eduard Zipser. Planta baixa. compacta e solta no lote - exceto pela garagem, que se alinha ao limite sul - incorpora os recuos laterais do terreno por meio de pérgulas, estendendo a cobertura até os limites laterais e explorando sua horizontalidade e enfocando a continuidade espacial através da cobertura. Continuidade espacial que se faz também através das amplas aberturas da fachada principal com o jardim que, por estar elevado da rua, é incorporado ao espaço privado da casa. $\mathrm{O}$ jardim ganha status de coisa construída, também é elemento projetual, e jamais espaço residual.

Para proteger a fachada voltada a oeste, Broos a dota de amplas venezianas, e faz reviver, de um modocontemporâneo, umelemento da tradição residencial brasileira de longa data. A delicadeza deste fechamento e a reversibilidade que 
conferem à fachada dão à casa grande particularidade. Também a variedade de materiais empregados e o esmero nos detalhes chamam a atenção.

Aqui, o arquiteto parece reencontrar o trabalho artesanal de sua primeira obra no Brasil. A madeira domina como material utilizado como estrutura e revestimento de grande parte das superfícies da casa, que ainda conta com fundações em concreto e paredes de alvenaria estrutural. As paredes com aberturas em madeira possuem várias camadas: paredes interna e externa, folhas de vidro e a veneziana. Os pilares cruciformes, como em Itoupava Seca, sustentam o pergolado metálico. Além disso, temos a pedra nos muros e em paredes internas da casa. $\mathrm{O}$ arquiteto faz um sublime jogo de materiais, e brinca com suas qualidades táteis e ópticas numa solução única de formas, cores, materiais e texturas diversas. 


\section{NotAS}

1 A cidade foi fundada como colônia privada do imigrante Dr. Hermann Bruno Otto Blumenau em 1850.

2 Engenheiro Civil formado pela Escola Politécnica do Rio de Janeiro, considerado "pai do concreto armado no Brasil", foi o engenheiro calculista do prédio do MES, que trazia inovações técnicas e estruturais em sua construção. Atuava no Rio de Janeiro. Cf. Segawa, Hugo. Arquiteturas no Brasil 1900-1990. São Paulo: Edusp, 1997, p. 91; Ministério, da participação de Baumgart à revelação de Niemeyer. Projeto, n. 102, ago. 1987, 158-160.

3 Algo porém que seria em breve revertido. No ano de 1972 foi criada uma lei que concedia benefícios tributários àqueles que construíssem suas casas nos modelos germânicos enxaimel ou estilo "Chalé dos Alpes" no perímetro urbano. Foi dada seqüência a esta lei na administração seguinte de 1977, tornando a cidade repleta de pastiches históricos. Entretanto é notável a forte identidade urbana, sobretudo na área central da cidade, seja pelos poucos originais ainda preservados ou pelas cópias destes. Cf. Kormann, Edith. Blumenau: arte, cultura e as histórias de sua gente (1850-1985). (Edição da Autora) Vol. IV, 1996, p. 107-108.

4 Em 1950 eram quarenta e oito mil habitantes, destes, metade concentrados na cidade. http://www.blumenau.sc.gov.br/downloads/seplan/relatorio_pmb_censo_2010.pdf

5 Arquiteto alemão laureado com o Prêmio Pritzker em 1986.

6 O projeto teria sido de autoria de ambos, pelo menos até a morte de Dominikus em 1955. Gottfried Böhm, formado em 1947 em Munique, trabalhou no escritório do pai entre 1947 e 1950 e 1952 e 1955, portanto, à época do projeto e início da construção. Após 1955 Gottfried Böhm assume o escritório paterno.

7 Cf. Matriz de São Paulo Apóstolo: Blumenau, Santa Catarina, Brasil. Blumenau: [s. n.], 1963.

8 Um projeto anterior ao de Böhm teria sido recusado pelo alto valor da obra. Cf. Kormann, Edith, op. cit. p. 101.

9 Um dos raros exemplos em que o arquiteto parte desta solução estrutural.

10 Projetos que serão vistos no Capítulo 4.

11 Entre agosto de 1945 até o início das aulas em Braunschweig em fevereiro de 1946, Broos havia acumulado certa experiência prática na pequena cidade de Bad Oldesloe, no norte do país. Entre os trabalhos executados, como colaborador do arquiteto Helmut Schmersahl (mas segundo este, sob total responsabilidade de Broos), estariam: reparação de casas e edifícios danificados, construção de moinho e alojamentos provisórios, entre outros. A partir daí, Broos daria seqüência aos estudos interrompidos pela guerra. (Documento particular de Hans Broos.)

12 Que serão analisadas no Capítulo 3.

13 Em 1956, por conta da necessidade da revalidação de seu diploma de "engenheiroarquiteto", de que resulta o estudo "Casas antigas no litoral de Santa Catarina", de 1957, no qual Broos faz um levantamento da arquitetura da imigração açoriana neste estado. Foi publicado em 2002 sob o título "Construções antigas em Santa Catarina. Até a revalidação do diploma suas obras eram assinadas pelo engenheiro civil de Blumenau Otto Hupfeld, responsável pelos cálculos estruturais de quase todos os projetos e formaria, em 1968, com Broos a "Hans Broos Sociedade Civil Ltda" em São Paulo.

14 Exceto nos edifícios religiosos, onde, como veremos, os arquitetos empregam o material dos antigos edifícios destruídos, em geral, a pedra, com sentido simbólico.

15 Revista Módulo n. 1, março, 1955 e Habitat n. 22, maio-jun. 1955.

16 Desativado desde 2005, porém conservado com projetos originais até o momento.

17 Único projeto alemão de Hans Broos como autônomo. Será visto a seguir.

18 Aliás, a arquitetura moderna teve seu pensamento construído no apelo tecnológico, baseado em técnicas e materiais industriais inovadores e numa estética que seria resultante destas condições. Entretanto, na prática, grande parte das edificações construídas sob a insígnia do "moderno" revela que tal formulação não passou de mera ficção. 
19 Localizada a poucos quilômetros de Karlsruhe, sofreu grande resistência junto aos órgãos legais para a aprovação do projeto "moderno demais", e revela a insistente resistência a este tipo de arquitetura mesmo nestes anos. Nos anos seguintes à sua construção, a casa desfrutou de certa repercussão junto à imprensa do país. Foi destaque na Revista Baukunst und Werkform, importante publicação simpática à Arquitetura Moderna, e surgiu anos mais tarde também no livro Neue Deutsche Architektur que retrata a Arquitetura Moderna alemã em seus últimos dez anos. Cf. Wohnhaus in Gernsbach bei Baden-Baden. Baukunst und Werkform, n. 1, 1953, p. 31-36; Hoffmann, Hubert. Neue Deutsche Architektur. Stuttgart: Verlag Gerd Hatje, 1956.

20 Este projeto será analisado mais demoradamente no Capítulo 3.

21 Interessantemente, o arquiteto utiliza o subsolo em pilotis para agir com liberdade na concepção deste volume, não se fixando aos limites ortogonais que regem a planta. Através do seu revestimento em cor escura - ao que tudo indica madeira pintada, sem nenhuma referência, porém, na planta-baixa original e irreconhecível na casa, já profundamente modificada - nosso olhar quase não registra este volume e, desta maneira, identificamos o subsolo como um grande vazio.

22 Fica difícil dizer, porém, se a fundação é de pedra, devido à insuficiência de plantas e detalhamento; provavelmente de concreto armado a exemplo da Casa W.P. Hering.

23 Seu precedente formal é a Casa Errazuriz (1930) de Le Corbusier. Marcel Breuer utilizou a cobertura tipo borboleta em diversos projetos dos anos 1940. No Brasil, Niemeyer a utilizou no projeto do Iate Clube da Pampulha em 1942 e na Residência Kubitschek em 1943, que se tornou um modelo empregado amplamente por outros arquitetos, tamanho fascínio que exerceu na época. Cf. Bruand, Yves. Arquitetura Contemporânea no Brasil. 4. ed. São Paulo: Perspectiva, 2002, p. 112.

24 Bons exemplos são as casas de Rino Levi, em especial a Residência Castor Delgado Perez (1958-1959).

25 Hans Broos. Texto particular do arquiteto, s/d.

26 Será analisada no Capítulo 4.

27 Hans Broos, sobre a Arquitetura Moderna Brasileira. In: Wolf, José. Escritório Hans Broos. $A U$ n. 50, out./nov., 1993, p. 93.

28 Entre pequenas alterações e placas publicitárias a Casa Peiter ainda se mantém no centro de Blumenau, enquanto o segundo não resistiu às especulações imobiliárias e foi demolida para dar lugar a um posto de gasolina.

29 Justamente pelo fato de ter sido construído com muitas alterações, será analisado aqui o projeto original proposto. 


\section{A NOVA ARQUITETURA BRASILEIRA}

Diferentemente do panorama europeu pós-guerra, onde predominava um ambiente de animosidade, desconfiança, paralisação e sem rumo certo e seguro a seguir, o cenário brasileiro surgia em plena ascendência e efervescência cultural, fixado num grupo já relativamente grande - ou, que ao menos, já alcançava todo o território nacional - que guardava pretensa coesão em suas propostas. Enquanto na Europa há uma "redescoberta" do moderno - ou seja, ter-se-ia que aprender ou reaprender a ser moderno, ${ }^{1}$ estando as novas gerações numa desconfortável e imprecisa situação de reconhecimento, e as gerações mais velhas incumbidas de dar continuidade a uma frágil "tradição" - no Brasil vive-se o entusiasmo de uma recente e valorizada já denominada "tradição moderna", noção que os textos de Lucio Costa tentam precocemente incumbir.

Finda a Segunda Guerra, esta nova arquitetura brasileira ainda não podia ser dada como hegemônica no contexto nacional, pois que seguiam concomitantemente a ela arquitetos filiados à tradição, ou ligados a posturas mais conservadoras. ${ }^{2}$ Mas sua rápida consagração tanto nacional quanto internacionalmente, lhe garantiu o status de dominância e a condição de dignitário de certa autoridade - não apenas referente aos novos edifícios, como em relação ao patrimônio construído - que fizeram com que localmente os arquitetos também a admitissem como tal e se convertessem à "causa" moderna.

\section{A FORMAÇÃO DE UMA MODERNIDADE}

Os anos 1930 e 1940 representam anos de significativas mudanças em todos os aspectos - políticos, social e cultural - aqui vale dizer, arquitetônicos. Sai-se dos anos 1920, onde irrupções intempestivas e afrontas juvenis - nem sempre levadas a sério - configuraram ações isoladas que deveriam mostrar uma nova ordem e um novo jeito de viver - e assiste-se nos anos 1930 e 1940, gradativamente, ao irrompimento de um movimento muito mais generalizado e maduro, defendido por vários arquitetos e amparado pelo Estado. Tal situação, a que já se podia chamar de "tradição", desfrutará precocemente de reconhecimento e sucesso internacional, o que lhe realimenta e dá créditos ao nível local para reforçar e ampliar seu poder operativo de modo quase inquestionável.

Enquanto no plano internacional (europeu) o problema do patrimônio histórico será uma questão amplamente e forçosamente abraçada pela Arquitetura Moderna somente no segundo pós-guerra, aqui a preocupação já nasce com ela; ou melhor, com ela surge a autoridade de operar sobre o futuro e o passado. ${ }^{3}$ Ao mesmo tempo que se nutre deliberadamente de fontes internacionais, corbusianas em 
particular, de forma resoluta e não negando certa subserviência inicial, procura no reencontro com o passado achar a sua modernidade, e conquistar o que era original e próprio da cultura brasileira. No aparente paradoxo de tentar encontrar no passado uma modernidade mais profunda e fugir de uma possível gratuidade formalística, almeja a conquista da propalada "identidade nacional".

Enquanto no ambiente europeu da década de 1920 o passado sinalizava um fardo, uma barreira a ser transposta, e qualquer resquício de história considerado delito, que justamente negava uma atitude mais francamente moderna e original, o reencontro com o passado ocorrerá somente no pós-guerra, mas com características outras. Senão por necessidades psicológicas e por um entendimento mais profundo das questões humanas, quando não por coação (em geral da sociedade "conservadora"), mas jamais estimulados pela recuperação de elementos tradicionais ou pela busca do particular para legitimar o universal.

Em muitos aspectos vale dizer que a Arquitetura Moderna brasileira tomou a dianteira nos discursos que ganhariam corpo somente a partir da Segunda Guerra Mundial. Entre eles, a questão da monumentalidade, da saída do racionalismo ortodoxo, a recuperação de elementos tradicionais da arquitetura como forma de contribuição local e original. E, talvez o menos lembrado deles, a convivência da nova arquitetura com a antiga, seja pela via teórica e formulação de uma conduta operativa (através do IPHAN com Lucio Costa), seja pela via prática, com o exemplo do Hotel de Ouro Preto de Niemeyer. ${ }^{4}$

A consolidação do moderno se dá no pós-guerra; há uma profunda intenção internacionalizante de inserir o país na rota da cultura global e afirmar-se culturalmente - e fazer ombrear sua produção com países exportadores da vanguarda - e se fazer notar em outras partes do mundo. No pós-guerra são inúmeras as mostras e exposições da arte e arquitetura moderna brasileira em países europeus. ${ }^{5}$ Deixar o passado colonial e agrário para trás, afirmarse perante os países de "cultura", superar o atraso (que sempre esteve mais na estética preconizada por esta arquitetura do que nela mesma) e a dependência cultural, fazia parte do projeto moderno nacional, no qual a arquitetura possuía especial papel.

\section{AS PRIMEIRAS MANIFESTAÇÕES}

Atribui-se à Semana de Arte Moderna de 1922, marco e início do movimento cultural modernista em São Paulo - fato isolado, de transgressão e culto a determinadas personalidades, com repercussões quase insignificantes para a arquitetura, mas que, todavia, se configurou num primeiro ato, com o mérito 
de abrir caminhos para renovações mais densas. Em 1925 são publicados dois textos $^{6}$ na imprensa diária por dois arquitetos formados na Itália: Rino Levi e o russo Gregori Warchavchik que, apesar de causar certa celeuma na categoria profissional (principalmente o texto de Warchavchik), não impuseram à prática corrente da construção qualquer modificação imediata. Já próximo ao final dos anos 1920 começa a se condensar em São Paulo, um pequeno grupo de arquitetos - imigrantes ou que voltaram de seus estudos no exterior - e que formarão a vanguarda arquitetônica da "primeira hora".

Também à Warchavchik é atribuída a primeira manifestação construída da nova arquitetura; ${ }^{7}$ sua própria residência à Rua Santa Cruz em 1927. Uma solução artificiosa, porém, que escamoteava seu caráter artesanal sobre uma pretensa imagem de modernidade - entre elas a técnica construtiva, o telhado que se supunha plano, entre outros - e acabou por comprometer e contradizer os enunciados de dois anos antes, que pregavam a verdade na arquitetura e a necessidade de sua produção em série. Entretanto, a casa tem o mérito de se tornar um marco para o desenvolvimentos futuros da nova arquitetura. Dadas as dificuldades materiais e técnicas, as inovações introduzidas por Warchavchik limitaram-se ao plano estético, contradizendo o teor racionalista e tecnológico que, supostamente, era o aspecto prioritário no moderno (sendo que a estética deveria ser o reflexo direto dos novos materiais e técnicas empregadas, portanto, uma consequência e não causa primeira). Excetuando-se o primeiro projeto, as demais casas construídas em seguida pelo arquiteto assimilam-se muito à frieza e ao rigor formal de um Gropius dos anos 1920, com aspecto rude e agressivo, que serviu mais a um irrompimento para abrir caminhos do que para fazer escola.

O surgimento e ascensão da arquitetura moderna no Brasil (e na América do Sul) como ato declarado, é simultâneo ao seu processo de queda na Europa. Enquanto lá a arquitetura moderna encaminhava-se para um formalismo prescritivo e já era alvo de ataques da burguesia conservadora e mesmo de arquitetos que viam nela a "ditadura" da cobertura plana, ${ }^{8}$ no Brasil ela dava seus primeiros passos. Passos insipientes é verdade, que tiveram início em São Paulo, antes de se "transladar" ao Rio de Janeiro e lá encontrar seu lugar de florescimento alguns anos mais tarde.

Enquanto no Rio de Janeiro a história da arquitetura moderna se confunde com fatos isolados e a presença de alguns poucos personagens na mobilização de forças que permitiu seu rápido impulso na década de 1930, em São Paulo, seu desenvolvimento parece ter sido mais natural e de base, fruto de uma determinada relação de trabalho e visão do projeto. 
Aliada à formação ligada às engenharias, também a prática profissional em São Paulo caracterizava-se por uma significativa prática no canteiro de obras em que se mesclavam a atividade de arquiteto e engenheiro civil. $\mathrm{O}$ perfil do arquiteto em São Paulo estava muito mais vinculado ao do construtor, ligado, antes por um empirismo que advinha da prática construtiva do que da tradição artística BeauxArts que predominava no meio carioca, distante das questões mais práticas e comerciais da construção. Até a década de 1950 o mercado era dominado pelas construtoras, exigindo dos arquitetos o conhecimento prático da profissão.

Enquanto no Rio de Janeiro os arquitetos trabalhavam associados aos engenheiros sem acumular as atribuições de projeto e execução, "em São Paulo até a década de 1940 a arquitetura era um produto dos canteiros de obras, resultado de um racionalismo empírico desenvolvido através da acumulação sistemática de experiências. A proximidade dos nossos engenheiros-arquitetos com os canteiros de obras e o vínculo com a totalidade do empreendimento constituíam a principal fonte de aproximação dos nossos profissionais às idéias modernas."

$\mathrm{Na}$ então capital federal, a partir da interferência de Lucio Costa na Escola Nacional de Belas Artes em 1930-1931 e sua frustrada tentativa de reforma no ensino, é possível identificar a criação de um meio mais consistente e profícuo para a germinação das novas ideias, que resultou na alteração do campo de discussão e da produção da arquitetura. É impensável, contudo, desvincular o rápido impulso que tomaram as novas ideias da arquitetura - e o caráter progressista identificado com ela - do momento político, cultural e social que se vivia no país e da noção de caráter renovador e modernizador da Era Vargas. Ideias renovadoras encontraram aqui o lugar propício para seu florescimento, e a nova arquitetura emprestaria sua face à modernização das estruturas governamentais e sociais e a um país que se urbanizava rapidamente.

Com base nos princípios corbusianos, os arquitetos cariocas, restritos a um reduzido círculo, souberam desenvolver uma linguagem com forte apelo local, em que se sobressaem a procura pela leveza formal, a recusa da "ditadura" do ângulo reto ${ }^{10}$ e a forte vinculação ao clima e materiais e tradições construtivas locais, o que fez alguns críticos internacionais a considerarem uma das mais férteis produções modernas, juntamente com a produção finlandesa, centrada na figura de Alvar Aalto. ${ }^{11}$

Entretanto, a história da arquitetura moderna Brasileira parece sempre ser contada a partir de determinados fatos (como a construção do Ministério da Educação e Saúde - MES, no Rio de Janeiro) e seletos autores que deram a "guinada" em nossa história cultural e comandaram a decisiva transformação; ou uma história 
contata a partir de ilustres figuras, como o próprio Warchavchik, Le Corbusier, e sua vinda ao Brasil, Lucio Costa e Niemeyer e alguns outros que, mais a sombra dos célebres mestres, as vezes perdem-se pelo caminho. Não que isso seja surpresa ou fato raro dentro da historiografia do Movimento Moderno, como podemos fazer paralelo com os acontecimentos europeus. ${ }^{12}$ A necessária revisão dos fatos, como bem coloca Hugo Segawa em "Arquiteturas no Brasil", ${ }^{13}$ nos certifica de um movimento muito mais amplo, de modo algum uníssono, que não tem posto único no Rio de Janeiro; privilegiado, sim, e nos demonstra a existência de outras manifestações que auxiliaram para que o Movimento Moderno tomasse as proporções que tomou.

Segawa, e também Carlos Lemos, ${ }^{14}$ recuperam obras em todo o país que demonstram iniciativas isoladas ao longo da década de 1920 e em início de 1930 que ainda não contam com o devido reconhecimento, mas que certamente autorizaram a favorável situação dos anos 1930 para o florescimento daquela arquitetura. Ambas as abordagens destacam o que já havia de "moderno" no Brasil anterior à "modernidade programática" (nos dizeres de Segawa) ainda que sob roupagens históricas; ou seja, uma modernidade baseada na prática corrente da construção no país. Na segunda metade da década de 1930, dez anos após a publicação dos primeiros escritos modernos na imprensa brasileira, tendências alinhadas ao pensamento moderno (ou pelo menos não acadêmicas) já estavam plenamente assimiladas. Vários acontecimentos dão conta das experiências já em andamento, anteriores ou concomitantes ao concurso e construção do MES (1936-1943), ${ }^{15}$ que já geravam certo meio propício, uma insipiente "tradição" moderna, tanto no setor público - como no exemplo de Luiz Nunes na Prefeitura de Recife em 1935-1936; Affonso Eduardo Reidy na Prefeitura da Capital Federal a partir de 1932 - e também em concursos - Álvaro Vital Brazil e Adhemar Marinho ganham o concurso em 1936 para o edifício Esther (1936-1938) em São Paulo, ano em que os irmãos Marcelo e Milton Roberto vencem o concurso para a sede da ABI no Rio de Janeiro; em 1937 estes últimos vencem o concurso para o Aeroporto Santos Dumont e Attílio Correa Lima para a Estação de Hidroaviões no Rio de Janeiro.

Em parte devido ao apoio governamental, em parte ao processo de mudança social e cultural que se processava no país, e a decidida vontade de renovação artística e cultural (como a Semana de 1922 deixou clara) assiste-se, nos anos 1930 a uma rápida ascensão da arquitetura moderna que desmentem o pioneirismo atribuído ao MES e relativizam sua centralidade na história da Arquitetura Moderna brasileira. 


\section{BRASIL: ANOS 1950}

Seria apenas no imediato pós-guerra, com a criação do MASP em 1947 por Assis Chateaubriand, empresário do ramo das comunicações, e do MAM-SP em 1948, pela família Matarazzo, de cujo núcleo seria formado, pouco depois, a Bienal de Artes de São Paulo - instituições que rapidamente encontram renome internacional - que São Paulo se consolidaria como liderança nacional no âmbito da cultura, posto até então ocupado pelo Rio de Janeiro. O entusiasmo que circundava o meio cultural estava estreitamente ligado a pujança econômica da cidade, ambiciosa por alçar-se à liderança em matéria artística equivalente ao posto assumido no campo industrial.

São Paulo revelou-se solo fértil para a fermentação das transformações que eram lançadas. A progressiva concentração de riquezas da próspera burguesia local e a complexa constituição social - fluxos migratórios internos, com um já extenso proletariado nacional e de estrangeiros, e um novo mercado, composto em parte de imigrantes, nutrido nos quadros de um forte empresariado, comprometido com as transformações em curso - liga-se a uma cultura cada vez mais urbana, além da acelerada urbanização e industrialização que lhe permitiu elevar-se ao posto de metrópole.

Broos aqui chega num momento de fermentação cultural para a arte e arquitetura brasileira, com a consolidação dos museus, Bienais e os eventos que marcaram as comemorações do IV Centenário. O país passava por uma fase de otimismo e aspiração à modernidade, identificada na idéia de progresso. Na Europa tratava-se de (re)construir um continente em ruínas; aqui, de construir a própria modernidade, livre do fardo do passado, que agora, contraditoriamente e mais do que nunca, reclamava reexame por parte dos arquitetos europeus. Há que se admitir, a ideia de um país a construir, pleno de riquezas naturais e vivendo transformações de vulto era, no mínimo, sedutora. Completa a imaginação do imigrante recém chegado a construção de Brasília nos anos imediatamente posteriores. Durante os anos da construção da futura capital federal, na incrível marca de três anos, o arquiteto registra pessoalmente as construções provisórias, os trabalhadores e o surgimento de alguns edifícios no grande canteiro de obras do planalto central.

A Bienal de Arquitetura nasce como equivalente à de Artes também em 1951 e a visita de nomes consagrados da arte e da arquitetura passa a ser algo cada vez mais frequente. Durante as primeiras Bienais visitam o Brasil arquitetos, críticos e historiadores internacionais, da alçada de Le Corbusier, Walter Gropius, Mies van der Rohe, Alvar Aalto, José Luis Sert, Ernesto Rogers, Philip Johnson, Max 
Bill, Bruno Zevi, que por aqui passavam com membros do Júri ou participantes de eventos, ou ainda, como agraciados com o que já era retratado como o "Nobel" da arquitetura. ${ }^{16}$ Ao lado de outros eventos, principalmente entre 1951 e 1954 - ano que marca as comemorações do IV Centenário da cidade - São Paulo transforma-se em palco das principais discussões acerca da arquitetura da Escola Carioca, que polemizam sobre os rumos tomados por esta arquitetura, com questões que gravitam, sobretudo em torno da obra de Oscar Niemeyer.

Também durante os anos 1950 entre as polêmicas do figurativismo e abstracionismo encontra lugar nos espaços de arte da cidade o movimento concretista com calorosos debates e ruidosos manifestos. E a seguir, os embates entre concretistas e neoconcretistas, as novas vanguardas brasileiras, amadurecem o debate artístico no país, acirrando novamente as posições entre paulistas e cariocas, só que tendo desta vez os cariocas no "contra-fluxo". A Bienal transformou-se em local privilegiado de discussão das novas propostas. A arte abstrata, incompreendida pela maior parte dos artistas e críticos brasileiros, encontrará nos espaços dos MAM-SP seu lugar de promoção e, sobretudo, nas Bienais, cuja primeira edição coroou Max Bill e sua "Unidade Tripartida” com o Primeiro Prêmio Internacional, e consagraria definitivamente o abstracionismo na segunda edição, com salas especiais a Paul Klee, Alexander Calder e Piet Mondrian.

Todos estes acontecimentos tornam São Paulo epicentro das mudanças culturais no país nos anos 1950, e sela o seu destino de metrópole moderna - principalmente com os festejos de 1954 - que só perderia parte do foco, e ao mesmo tempo encontraria o ápice da ideia moderna, a poucos anos dali, quando os refletores voltam-se à construção de Brasília.

De fato, os anos 1950 tornam-se anos fecundos de reflexões e revisões, com a politização do meio artístico, debates entre realismo versus abstracionismo, redemocratização do país, e de transformações nas linguagens: nas artes visuais e poesia e, também, na arquitetura. Parte destas reflexões se voltaria diretamente à arquitetura brasileira na forma de ácidas críticas. A despeito do tom ufanista que cercava a produção brasileira, bem como sua precoce consagração internacional, sua aparente aceitação hegemônica não escondia senão, a partir dos anos 1950, fortes críticas, tanto nacionais quanto estrangeiras. Desde 1950, através da revista Habitat, Lina Bo Bardi começa a realizar uma ainda suave, mas potente crítica à arquitetura brasileira. ${ }^{17} \mathrm{~A}$ mais contundente, notória e indigesta delas coube sem dúvida, a Max Bill, arquiteto, escultor e designer suíço, ex-aluno da Bauhaus, idealizador da Escola de Ulm, considerada a mais bem sucedida escola 
de design planejada nos moldes da Bauhaus. Entre excessos e ataques verbais ao "barroquismo" e à "perigosa tendência acadêmica" que, segundo ele, rondava a arquitetura moderna da Escola Carioca, Bill, em um tom didático, alertava os brasileiros sobre a falta do - muitas vezes reiterado - conteúdo social das obras. O que inicialmente fora considerado uma liberdade projetual e enriquecimento do vocabulário moderno, através principalmente da saída da ortodoxia moderna foi, aos poucos, julgado irracionalidade e gratuidade formal, ou como despeja Bill, o "supra-sumo da anarquia na construção." ${ }^{18}$ De certa forma suas críticas encontram ressonância no nascente movimento concretista local, cujo manifesto de 1952 possui temas que correspondem ao seu credo, como a função social da arte. De modo geral, seu "apelo" nada amigável, endossado pelas críticas já presentes no meio nacional e mesclados ao quadro de instabilidade ideológica que se formava nesta época (que acertaria em cheio a arquitetura), adiantaria em alguns anos certa guinada teórico-conceitual dentro da arquitetura moderna brasileira. 


\section{Notas}

1 Moderno enquanto estilo, haja vista que as bases filosóficas e doutrinárias do moderno enquanto causa já haviam sido solinhadas havia tempo. O assunto será retomado e analisado nos Capítulos 2 e 3.

2 A este propósito, interessante consultar a revista Acrópole onde, ao contrário da Habitat e Módulo, dominam arquiteturas tradicionais. Seria a equivalente da Baumeister alemã, em que vemos o outro lado da moeda.

3 Cf. Cavalcanti, Lauro. Moderno e Brasileiro. A história de uma nova linguagem na arquitetura (1930-1960). Rio de Janeiro: Jorge Zahar Ed., 2006.

4 Ainda que esta última questão tenha ficado mais no plano teórico, e o exemplo do Hotel de Ouro Preto seja questionável.

5 Por exemplo, a Exposição "Brasil constróe" (sic), iniciada no MAM-RJ em 1952, que circulou por várias capitais européias: Londres e Stuttgart em 1953, Lisboa, Viena, Roma, Madri, Barcelona e Oviedo na Espanha, e Zurique (1955) e, como relata o artigo, seria ainda exibida em Düsseldorf (Alemanha) Estocolmo e Oslo. A Exposição "Brasil constróe", em Zurique, Suíça. Habitat, n. 21, 1955 p.6.

6 "Arquitetura e a Estética das Cidades" de Rino Levi e "Acerca da Arquitetura Moderna" de Warchavchik, este publicado meses antes sob o título "Futurismo" no jornal da colônia italiana paulistana "Il Piccolo".

7 A despeito do tom nacionalista que cercava a renovação da arquitetura brasileira, tanto no movimento neocolonial quanto da arquitetura moderna, esta foi introduzida, ou ao menos é atribuída sua introdução, a um imigrante, e não menos, que sua origem (da arquitetura moderna) é estrangeira.

8 Como veremos no Capítulo 2.

9 Camargo, Mônica Junqueira de. Princípios de Arquitetura Moderna na obra de Oswaldo Arthur Bratke. Tese de Doutorado. São Paulo: FAU-USP, 2000, p. 52.

10 Que chegará, segundo alguns críticos, a extremos formalísticos e a certa irracionalidade projetual. Cf., por exemplo: Bill, Max. O arquiteto, a arquitetura e a sociedade. In: Xavier, Alberto (org.). Depoimento de uma Geração. Arquitetura Moderna Brasileira. São Paulo: Cosac \& Naify, 2003, p. 158-163. Palestra realizada em 1953 na FAUUSP e publicada na Revista Habitat n.14, fev. 1954.

11 Como ofazSiegfried Giedion. Cf. Giedion, Siegfried. O Brasil e a arquitetura contemporânea, 1954. In: Xavier, Alberto (org.). Depoimento de uma Geração. Op.cit., p. 155-158.

12 Mais precisamente, a arquitetura alemã dos anos 1920 e 1930. Cf. Capítulo 2.

13 Cf. Segawa. Hugo. Modernidade Pragmática. In: Segawa, Hugo. Arquiteturas no Brasil. Op. cit. p. 53-76.

14 Lemos, Carlos A. C. Arquitetura Contemporânea. In: Zanini, Walter (org.). História Geral da Arte no Brasil. Vol. II. São Paulo: Instituto Walther Moreira Salles/ Fundação Djalma Guimarães, 1983, p. 823- 865.

15 O concurso data de 1935. Após sua anulação, Lucio Costa é chamado pelo ministro Gustavo Capanema para encabeçar o grupo de trabalho que, sob a consultoria de Le Corbusier, daria origem ao projeto final.

16 Le Corbusier obteve o Prêmio Internacional na primeira Bienal (1951), Gropius da segunda edição (1953).

17 Cf., por exemplo, o artigo "Bela Criança". Habitat n. 2, p. 3.

18 Bill, Max. O arquiteto, a arquitetura e a sociedade. In: Xavier, Alberto (org.). Depoimento de uma Geração. Arquitetura Moderna Brasileira. Op. cit., p. 161. 


\section{Capítulo 2 \\ Revendo antecedentes: os anos 1930}





\section{ARQUiTETURA ALEMÃ NOS ANOS 1930}

Ao contrário do que geralmente se reporta, o flagelo dos arquitetos alemães, modernos ou não, não teria iniciado apenas em 30 de janeiro de 1933 com a ascensão do Partido Nazista ao poder. Mais do que por razões políticas, a primeira grande "dispersão" dos arquitetos deu-se por razões econômicas, quando se faziam sentir os primeiros reflexos da crise financeira que se seguiu à quebra da Bolsa de Nova Iorque em 1929. A isto, seguiu-se a primeira onda de emigração dos arquitetos alemães, que foram procurar meios de sobrevivência em lugares distantes de sua terra natal.

Os tempos de paz e prosperidade haviam durado poucos anos na República de Weimar. A crise que afetou os Estados Unidos em outubro de 1929 teria resultados diretos na economia alemã, que vinha obtendo ajuda financeira daquele país através do Plano Dawes, que respaldou a construção de muitos Siedlungen a partir de 1925. O mercado de construção civil foi diretamente afetado, e os planos de construção de novas habitações banidos. De 311.000 habitações construídas no ano de 1930, somente 141.000 foram levadas a cabo em $1932 .{ }^{1}$ Com o fim da ajuda financeira externa e a falência dos bancos, estados e cidades não conseguiam mais dinheiro para obras públicas. Muitos foram também os escritórios que fecharam as portas ou, ao menos, tiveram seus números reduzidos.

A estes fatos junta-se a fulminante ascensão do Partido Nazista nestes anos que, naturalmente, não pode ser desconsiderada. A cada dia o partido conquistava mais espaço no poder político do país, e nas eleições de 1930 já havia colocado correligionários nos postos de comando de vários municípios, como o exemplo de Dessau, que resultou na saída de Hannes Meyer da direção da Bauhaus. ${ }^{2}$ Aqui também já teria início a perseguição dos arquitetos modernos, tidos "comunistas", que se intensificou com a chegada de Hitler ao poder.

\section{ARQUITETOS MIGRANTES}

Quando Ernst May deixa seu cargo de Secretário de Planejamento de Frankfurt e aceita a proposta do Governo soviético (e deixa o cargo puramente por razões econômicas, uma vez que o Partido Democrático Alemão continuaria no poder municipal até 1933) mais de mil arquitetos candidataram-se para acompanhá-lo neste empreendimento. Para estes arquitetos, principalmente os de orientação política de esquerda, a União Soviética representava neste momento uma terra de esperança, um caminho aberto a inúmeras oportunidades, e o único país do mundo capaz de fazer florescer uma nova sociedade. E as tarefas impressionavam pela grandiosidade e complexidade, vislumbradas a partir do lançamento do 
primeiro Plano Quinquenal em 1928. A famosa Brigada May contou com um grupo de vinte pessoas, responsáveis pela construção de habitações e planejamento de cidades; mas não era a única. Outras duas "brigadas" formaram-se sob o comando dos arquitetos Hannes Meyer e Kurt Meyer.

A Turquia foi também um dos países que serviram de abrigo a muitos arquitetos alemães, como Martin Wagner, antes de sua definitiva instalação nos Estados Unidos. Diretor de Planejamento Urbano da Grande Berlim entre os anos de 1926 e 1933, Wagner construiu, ao lado de Bruno Taut, os famosos Siedlungen nos arredores de Berlim. Já Taut realizou na Turquia seus últimos trabalhos, como Diretor do Departamento de arquitetura da Academia de Belas Artes de Istambul e chefe do escritório de arquitetura no Ministério de Cultura antes de sua prematura morte em 1938. Lá também encontraram trabalho arquitetos como Hermann Jansen, ocupado desde 1927 com o planejamento da nova capital Ankara, além do mestre Hans Poelzig; mas sua morte em 1936 abreviou outros possíveis trabalhos.

Para arquitetos de origem judia, a emigração foi, naturalmente, a única saída. Mendelsohn previu acertadamente o destino do país sob o governo NacionalSocialista e emigra, poucos dias antes da chegada de Hitler ao poder, para a Inglaterra e daí para a Palestina. Em Jerusalém, Mendelsohn obteve relativo sucesso profissional, diferentemente de alguns de seus colegas emigrados. Lá contou com o apoio de um antigo mecenas que também havia se estabelecido na Palestina - Salman Schocken, para quem ele havia construído as famosas Lojas Schocken na Alemanha. Também construiu a residência para o futuro primeiro presidente israelense Chaim Weizmann. Com a preocupação de que os exércitos alemães no norte da África pudessem também alcançar a Palestina, segue Mendelsohn em 1941 para os Estados Unidos.

A onda emigratória de judeus para a então Palestina, a partir de 1933, levou aproximadamente 250 mil pessoas a deixarem o país, dentre estes aproximadamente cem arquitetos, ${ }^{3}$ entre eles grandes artistas judeu-alemães ou atuantes na Alemanha, como o especialista em teatro Oskar Kaufmann e os arquitetos Adolf Rading (que não era judeu, mas casado com esposa judia), Alexander Klein (que desenvolveu o método de investigação sistemática para planta baixa nos anos 1920, principalmente para pequenas moradias) e Harry Rosenthal. Muitos deles, recém saídos das escolas de arquitetura alemãs, dentre elas a Bauhaus, iniciaram suas carreiras em Israel. Da atividade concentrada destes arquitetos formaram-se redutos da arquitetura moderna no país, como as cidades de Haifa e Tel-Aviv (conhecida como The White City), que mesclam em 
sua paisagem a linguagem moderna com usos e tradições locais. Dentre aqueles estão Arieh Sharon, formado na Bauhaus em 1929 e atuante em Berlim até 1931, e Richard Kauffmann.

Os Estados Unidos pareciam ser o terreno mais propício para o desenvolvimento da nova arquitetura. Aos vienenses já emigrados Richard Neutra e Rudolph Schindler, juntaram-se cérebros dos mais criativos como Walter Gropius, Mies van der Rohe, Marcel Breuer, Konrad Wachsmann e Erich Mendelsohn. Mas um personagem em especial parecia exercer atração sobre os arquitetos: Frank Lloyd Wright, que depois de desacreditado por seus colegas europeus nos anos 1920, tem novamente as atenções voltadas para si a partir de suas realizações da década seguinte.

Walter Gropius, depois de sua permanência por três anos na Inglaterra, em 1937 aceita o convite da Universidade de Harvard e torna-se diretor do Departamento de Arquitetura até 1952. Em 1945, ao lado de jovens arquitetos, funda o escritório The Architects' Collaborative (TAC). O mesmo caminho seguiu Marcel Breuer, ex-aluno e ex-professor da Bauhaus, que desde a sua chegada aos Estados Unidos, em 1937, mantém até 1941, uma próxima parceria de trabalho com Gropius. A partir de então realiza inúmeros projetos residenciais e grandes projetos internacionais (como o prédio da UNESCO em Paris) sob o nome Marcel Breuer \& Associates.

Mies van der Rohe abre seu escritório de arquitetura em Chicago, para onde emigra em 1938. Neste ano torna-se Diretor do curso de Arquitetura do Illinois Institute of Technology (então Armour Institute), onde também Ludwig Hilberseimer, Walter Peterhans e Josef Albers, todos ex-professores da Bauhaus, assumem seus postos de docência. Além disso, foram muitos os arquitetos professores desta escola, que fizeram parte da vanguarda artística e arquitetônica alemã, que também encontraram nos Estados Unidos seu destino final: Wassily Kandinsky, Lyonel Feininger e Lasló-Moholy Nagy, que dirigiu a "New Bauhaus" em Chicago e fundou sua própria escola, a “School of Design” em 1938.

Desta verdadeira "diáspora" dos arquitetos modernos alemães nos anos 1930, foram realmente poucos os que retornaram ao país após a Segunda Guerra. Ernst May regressa em 1953, Paul Bonatz (que emigrou para a Turquia em 1943) um ano depois, Richard Paulick (desde 1933 na China), retorna em 1950 e dirige-se à zona soviética. Em seus destinos, muitos não encontraram senão um local de exílio, com poucas ofertas de trabalho e escassas encomendas, sem que pudessem continuar de forma frutífera o que vinham colocando em prática desde início dos anos 1920. Bruno Taut é exemplo disto. Depois de suas grandes realizações em 
Magdeburg e em Berlim, como Diretor de Planejamento da cidade e arquiteto da GEHAG (uma cooperativa de habitação), respectivamente, Taut amarga poucos trabalhos em sua rápida passagem pela URSS e pelo Japão antes de sua ida à Turquia.

Como lembra Pehnt, é instigante pensar em como teriam se comportado estes arquitetos emigrados na Alemanha pós-1945. No encontro com outras culturas durante o exílio dos anos 1930 e 1940, em que se fizeram produtivos, muitos demonstram conquistas relevantes em seu trabalho, como o próprio Gropius, desde suas primeiras realizações na América. Muitos voltariam a construir no país, outros esperariam em vão por uma chance. ${ }^{4}$

\section{ArQuitetura e Política nos anos 1930}

Mesmo depois da ascensão do Nazismo, a situação política não parecia ser um empecilho à permanência de alguns arquitetos modernos na Alemanha; o que os afugentava era, sobretudo, a desoladora perspectiva de trabalho. Quando ainda estava em Londres, antes, portanto de sua definitiva ida para a América, Gropius deixou em aberto a possibilidade de um retorno, e regressou a Berlim muitas vezes em meados dos anos 1930 para tratar da questão. ${ }^{5}$

Também para Mies a situação política não representou obstáculo a sua permanência no país. Somente quando seus ganhos sobre as patentes de mobiliário desapareceram e encomendas maiores escassearam, a situação lhe pareceu insustentável. ${ }^{6}$ Sua indiferença política surpreendeu até mesmo seus colegas berlinenses, quando o arquiteto assina em 1934 o embaraçoso Aufruf der Kulturschaffenden:? "Acreditamos neste Führer, que satisfez nosso mais profundo desejo por harmonia," ${ }^{8}$ mesmo após a perseguição e o fechamento da Bauhaus sob sua direção, a pretexto de uma "busca domiciliar" sob a alegação de existência de material ilegal (leia-se comunista) no prédio. $^{9}$

Já são bem conhecidas as relações que alguns dos arquitetos da nova arquitetura alemã mantiveram ou tentaram manter com o Regime, ${ }^{10}$ como os casos clássicos de Mies van der Rohe e Walter Gropius. Através de seus principais expoentes, a arquitetura moderna - apartidária que era, assim apresentada, ao menos, por seus principais representantes, apesar de sua inegável proximidade com os ideais socializantes de esquerda - tentou inculcar ao novo Regime, que ela mesma se prestaria ao papel de elite que conduziria o país neste novo momento político, social e cultural que se antevia. Guiados pelo exemplo italiano, reiterava-se que também na Alemanha à vanguarda moderna caberia o lugar de comando dos rumos culturais do novo Estado. Arquitetos como Tessenow, Poelzig e Mies eram 
comparados aos Futuristas e a Marinetti: "Estes artistas (Nolde, Klee, Tessenow, Poelzig, Mies) e nenhum outro são os representantes do Fascismo na arte."11

Theodor Fischer, considerado um dos grandes construtores alemães, ele mesmo nenhum vanguardista, também se esforçou em convencer o Regime acerca da legitimidade desta arquitetura. Em um corajoso discurso em novembro de 1933 em frente à Kampfbund für deutsche Kultur, ${ }^{12}$ Fischer empenhou-se para deixar claro que a nova arquitetura seria o único estilo verdadeiramente alemão, e portanto, nacional, ao contrário dos estilos precedentes - Gótico, Renascentista, Barroco - todos eles tomados de empréstimo de culturas alheias. Com a Neues Bauen, seria a primeira vez, na História da Arquitetura, que se havia conseguido um estilo genuinamente local: "espírito alemão, convertendo-se em forma pelo trabalho alemão, é arte alemã", ${ }^{13}$ e esforça-se em deixar claro seu caráter inegavelmente nacional: "a ideia de renovação é alemã, e não internacional."14

Esforço inútil e argumentação difícil de ser levada adiante, quando há pouco mais de um ano tivera lugar no Museum of Modern Art (MoMA) de Nova Iorque a Exposição International Style, onde figuravam os principais expoentes da Arquitetura Moderna alemã sob a incômoda tarja da internacionalidade. ${ }^{15}$

A mudança de discurso que se opera neste tempo fica nítida ao lembrarmos que, para as vanguardas, a internacionalidade era um adjetivo visto com muita euforia; engenheiros e arquitetos sentiam-se conectados através da ideia de uma internacionalidade sugerida pelas novas possibilidades técnicas da construção, que ultrapassavam limites nacionais: "a forma construtiva não conhece pátria; ela é internacional e expressão de índole construtiva internacional. Internacionalidade é uma qualidade de nossa época" proclama Hannes Meyer. ${ }^{16}$ O mesmo Gropius, que em 1925 falava de uma unidade no caráter construtivo moderno que extrapola fronteiras, ${ }^{17}$ vai defender anos mais tarde junto à elite do Partido Nazista, assim como o fizeram outros colegas, o caráter nacional da arquitetura moderna: "podemos hoje, pois, inequivocamente demonstrar, que a 'Neues Bauen' é, no essencial, um bem do espírito alemão". ${ }^{18}$

Entretanto, as disputas internas pelo comando do setor cultural dentro do Regime, que também ocupou os arquitetos tradicionalistas, num momento em que os parâmetros culturais dentro do novo Estado ainda não haviam sido totalmente esclarecidos, duraram pouco tempo. Em breve ficaria claro que, nem uma, nem outra, se prestaria a representar o grande império de mil anos ideado por Hitler. A visão de mundo "romântica" e débil da arquitetura tradicionalista não serviria para tamanha tarefa, tampouco a nova arquitetura, sinônimo da insegurança de sua época: "no primitivo culto cubista dadaísta esta insegurança encontrou 
por fim, a única expressão adequada [...]." ${ }^{19}$ Somente uma arquitetura grandiosa, monumental, poderia fazer frente a um Estado de ambições globais; e Hitler chega até mesmo a comparar-se aos Gregos e Romanos, e tira daí o exemplo glorioso para seu pretenso império, "já que é melhor imitar algo bom, a criar um novo ruim." ${ }^{20}$ Para a nova arquitetura, o recado já estava dado.

\section{A SOBREVIVÊNCIA DA ARQUITETURA MODERNA}

Mesmo a perseguição e condenação da Arquitetura Moderna, "bolchevique", "comunista", "árabe" ou tantos outros termos com os quais era combatida, não significou seu total banimento na Alemanha pós-1933. Se por um lado ela foi severamente combatida como uma cultura "não alemã", por outro, ela sobreviveu, de forma "velada" na linguagem de alguns arquitetos modernos, mas também, como parte do sistema.

A noção de interregno na história da Arquitetura Moderna alemã destes anos não é somente contraditória aos fatos, como também contesta a ideia de "exílio" interno de alguns arquitetos, ${ }^{21}$ e a noção de uma suposta "resistência" daqueles que continuaram a construir "moderno" naqueles tempos.

Mais que um ato heróico de seus autores, perseverar ou não no moderno dependia da disposição de funcionários locais, responsáveis pela supervisão e fiscalização do setor da construção civil. Ficava a cargo das municipalidades, decidir sobre eventuais danos à "Cultura de Construção Alemã" (Lei de 1934) ou se a "Expressão de Caráter Decente da Construção" (Decreto sobre a forma de construção de 1936) estivesse em perigo, ${ }^{22}$ e tanto se poderia encontrar funcionários mais rigorosos, quanto alguns mais benevolentes, ou até mesmo simpáticos à arquitetura moderna. ${ }^{23} \mathrm{Em}$ alguns setores, como nas residências unifamiliares, a arquitetura moderna era tolerada, noutras ocasiões, necessária e bem-vinda, como no caso da indústria.

É claro que os próprios arquitetos estavam cientes nas suas escolhas, de que não deveriam ousar demasiadamente, e utilizar, de uma só vez, todo o repertório formal moderno. Ao invés de coberturas planas, telhados inclinados com telhas, cimento amianto, uso de uma, duas ou mais superfícies inclinadas; ao invés de longas aberturas envidraçadas, aberturas menores e mais convencionais. Mesmo assim, muitas casas mantêm-se de um modo decididamente contemporâneo, que nega o Heimatstil (estilo regional) da arquitetura residencial da época. Além disso, permanecem em seu sentido de volume puro e autônomo. Muitas são as casas escondidas no jardim, longe dos olhares vigilantes dos guardiões da “cultura da construção alemã". Ou então, casas posicionadas lateralmente à rua, 
mostrando a fachada mais convencional, como a Residência Bolle (1934-1936) de Egon Eiermann.

Frequentemente o que vemos é um misto de adequação e contumácia, que colabora para a formação de um moderno moderado, mas uma linguagem que segue sendo individualizada, e nega a ideia de Gleichschaltung ${ }^{24}$ cultural. Dentro deste comportamento, arquitetos modernos aprenderam a utilizar uma linguagem muito mais diversa do que na década precedente, que teve que se adaptar às circunstâncias, e que resultou num modo muito mais flexível e menos dogmático de lidar com a arquitetura.

Hans Scharoun é um exemplo disto. $\mathrm{O}$ arquiteto teve que renunciar à linguagem marcante de formas orgânicas de sua arquitetura, e utilizar uma linguagem muito mais convencional - ao menos em sua aparência externa - mas que não deixa dúvida de sua filiação, principalmente no que diz respeito à planta baixa. Durante este período, o arquiteto, que não obteve grande número de encomendas, construiu cerca de treze residências, e deteve-se de tal maneira na compreensão da planta baixa, que é possível notar uma significativa evolução em sua obra pós-guerra.

Também a Casa Ziegler (1936) de Hugo Häring é exemplo de uma arquitetura que se reveste num caráter mais convencional sem, no entanto, deixar de ser contemporânea. $\mathrm{O}$ arquiteto continua a desfazer a rigidez dos volumes, através da concepção de ângulos oblíquos, que segundo ele, proporcionam maior aproveitamento do espaço. Entretanto, aquele momento cultural na Alemanha foi mais impiedoso com o defensor da "Arquitetura Orgânica" (ou Organicista, como ele defendia). Häring teve que esperar quatorze anos desde sua Casa Ziegler para

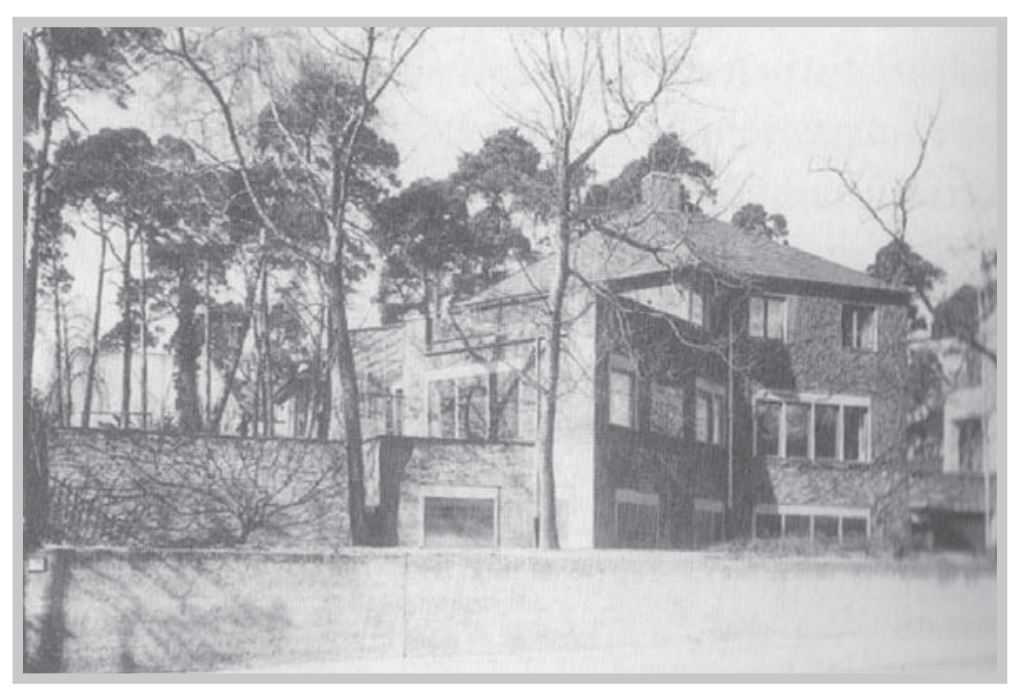

Fig. 1 - Hugo Häring. Casa Ziegler. Berlim. 1936.

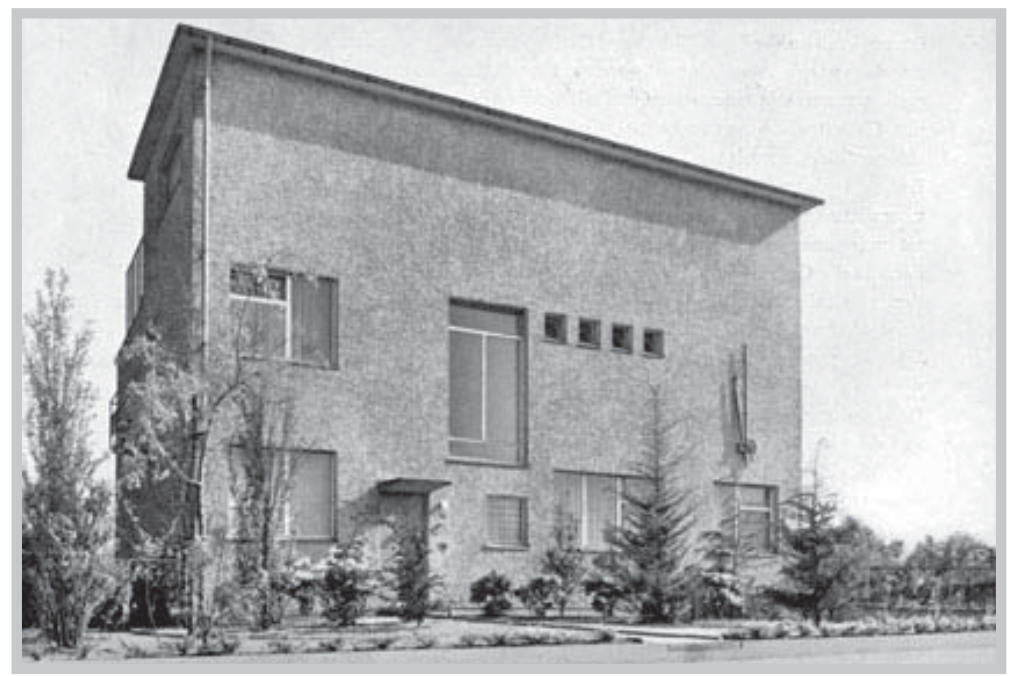

Fig. 2 - Residência Enkling de Rudolf Schwarz. Duisburg.1934-1937. 
novamente construir, ${ }^{25}$ período no qual ficou à frente de sua Escola de Artes e Artesanato "Kunst und Werk" comprada por ele em 1935.

Ludwig Hilberseimer, Bernhard Pfau, Sep Ruf e Egon Eiermann são alguns dos arquitetos que também construíram casas modernas durante estes anos. Mas nem todas tinham o objetivo de passar despercebidas ou de adotar formas mais tradicionais. Algumas surgem marcantes, quase em tom provocativo. É o caso da Residência Enkling de Rudolf Schwarz (1934-1937) que com sua imensa fronte, aspecto sisudo e disposição incomum das aberturas, lembra algumas das casas projetadas por Adolf Loos.

Eiermann surge como um arquiteto que desfrutou de relativa comodidade nestes duros anos. Não somente construiu significativo número de residências, como firmou-se um arquiteto industrial a partir de meados dos anos 1930, algo essencial para garantir os meios de sobrevivência, numa época em que as encomendas particulares começam a se tornar escassas. Além disso, o arquiteto pode construir dentro de sua linguagem arquitetônica e preservar sua linguagem moderna ao longo destes anos, e aqui iniciam alguns desenvolvimentos que irão se estender por sua carreira pós-guerra.

\section{As Casas de Egon Eiermann}

Nos anos 1930 Eiermann projetou casas nos arredores de Berlim que, a um primeiro momento, apresentam-se de um modo bastante convencional. Adaptamse aos requerimentos da "boa construção" da época: renunciam à cobertura plana e às grandes aberturas de vidro, optando por telhados inclinados e aberturas moderadas. Mas esta adequação não é senão mais aparente do que real: os telhados são apenas levemente inclinados e as aberturas negam displicentemente qualquer noção de simetria. E, mais importante que isso, o modo como são inseridas e se relacionam com o exterior é totalmente diverso do esperado. Nestas casas Eiermann cria um sentido de ligação entre o interior e exterior que será preservado em sua obra pós-guerra, e que pode ser lido, em alguns casos, na "dissolução da fachada", presente em projetos de diversos programas.

Características de sua fase berlinense, as Residências Bolle (1934-1936), Dienstbach (1936), Matthies (1937) e Steingroever (1937) guardam muitas semelhanças na sua volumetria, nos materiais empregados e no resultado estético alcançado; exemplos de uma arquitetura que também é "sentida" em sua construção e nos materiais. Principalmente as três primeiras são casas bastante compactas e com uma volumetria extremamente simples, dotadas de uma naturalidade e graciosidade que as tornam especialmente interessantes. 
As casas parecem tentar conservar em seu interior o mesmo sentido de natureza intocada que é preservada no exterior. O piso externo, de pedra, com recorte irregular, avança pelo interior das casas, até mesmo pelas áreas sociais, sem que os elementos construídos constituam uma barreira ou um limite. Na casa Steingroever, a escada e a meia-parede, feitas em granito com acabamento bruto, fazem referência a uma natureza arcaica que foi trazida para o interior da casa.

O espaço construído também é espaço natural. O arquiteto cria a união entre interior e exterior que não é somente visível, ela é também vivenciada. $\mathrm{Na}$ casa Bolle, o jardim de inverno, que delimita a sala de jantar, também contribui para a sensação de uma natureza presente no espaço de convivência.

As casas também buscam um maior diálogo com o jardim através da volumetria, ao se desfazerem do bloco único e criarem alas em formato "S", "L" ou " $T$ ”, que podem ser simplesmente a prolongação de um setor da casa. Procuram desta forma, se decompor em partes e tentam criar maiores oportunidades de relacionamento entre interiorexterior. Mas a casa continua sendo um objeto totalmente autônomo; ela se conserva distinta do meio onde surge.

$\mathrm{O}$ arquiteto também utiliza elementos naturais e vazados como fechamento e limite entre ambientes, perfazendo no interior da casa a mesma comunicação que realiza entre interior-exterior. $\mathrm{Na}$ Casa Bolle, os três ambientes que compõem o setor social são colocados em um único espaço, e o arquiteto os separa apenas visualmente com uma estante de metal e vidro e uma lareira, mas os mantém inteiramente comunicáveis.

O aspecto de naturalidade destas casas também é corroborado pelos materiais utilizados e pelo modo como são empregados. Em todas elas, o arquiteto parte de materiais convencionais e os usa de um modo inesperado, como as pedras utilizadas na cobertura e no piso, com corte irregular, ou então,

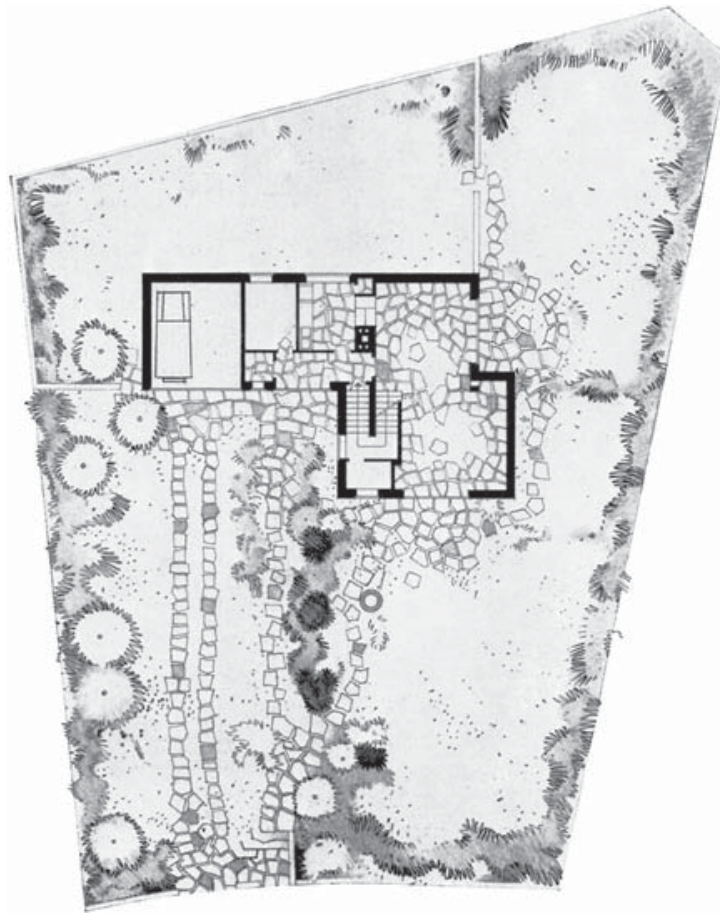

Fig. 3 - Egon Eiermann. Residência Dienstbach. Berlim. 1936.

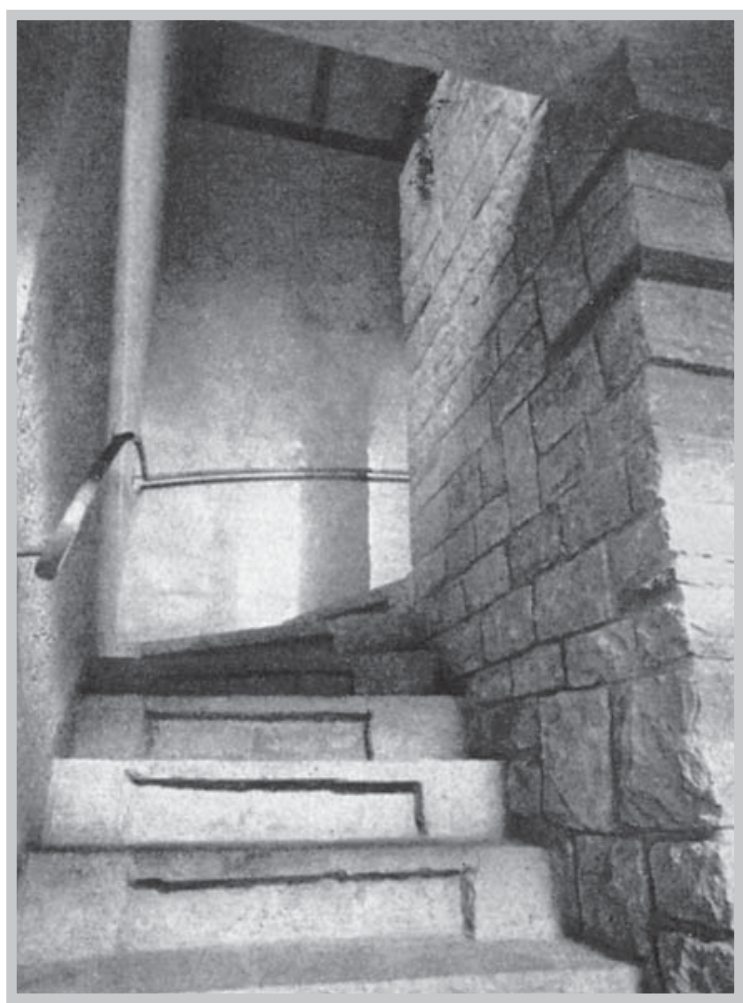

Fig. 4 - Egon Eiermann. Residência Steingroever. Berlim.1937. 
o aspecto rugoso das paredes, feitas com tijolos de barro cobertos com uma fina camada de reboco. Assim também se apresentam as paredes internas das casas, deixadas, por vezes, sem revestimento.

A admiração do arquiteto pelo rústico e pelo simples encontra nestas casas um dos melhores exemplos. Na Casa Dienstbach, o arquiteto chega até mesmo a colocar ratã natural como preenchimento da porta da garagem, por entre a estrutura de madeira. Aquele material será fartamente utilizado em seus projetos de mobiliário a partir de final dos anos 1940, que aliam um desenho acolhedor com a utilização de materiais naturais.

O caráter rústico das casas Bolle e Dienstbach é ainda mais acentuado nas superfícies da Casa Matthies. Nas casas anteriores reconhecíamos a construção da parede, através da superfície irregular mostrada com o fino reboco; na Casa Matthies o arquiteto intensifica seu caráter rugoso e sem muitos cuidados, ao não retirar os excessos das juntas entre os tijolos. Os excessos são incorporados

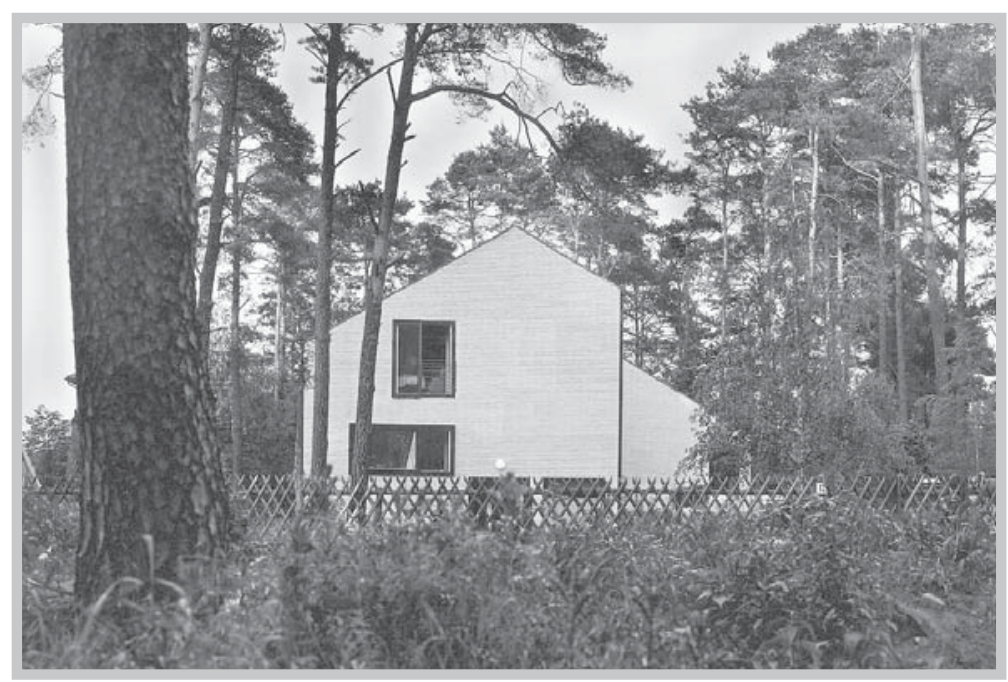

Fig. 5 - Egon Eiermann. Residência Bolle. Berlim. 1934-1936.

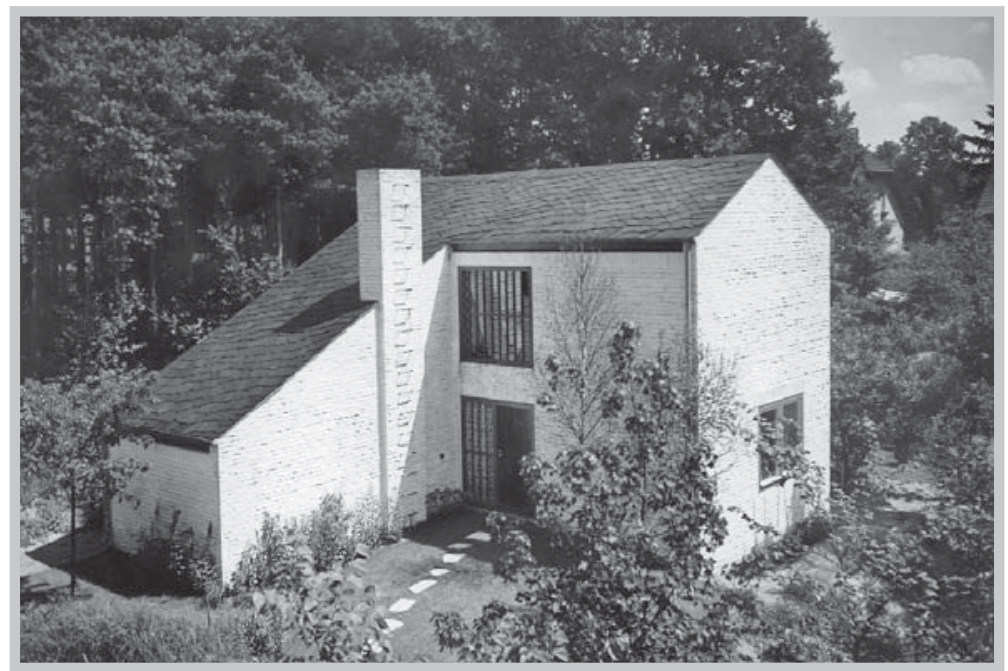

Fig. 6 - Egon Eiermann. Residência Matthies. Berlim. 1937. à parede, como parte dela. De maneira geral, o arquiteto mostrouse sempre um adepto incondicional das superfícies rugosas e do caráter rústico da construção, que concilia com a concepção de volumes mais puros. É o que mostram algumas de suas obras do pós-guerra como as igrejas Matthäuskirche e a KaiserWilhelm-Gedächtniskirche.

Ao mesmo tempo que evitam uma linguagem provocativa, estas pequenas casas nos arredores de Berlim são decididamente contemporâneas, esecolocam nasantípodas da arquitetura "regionalista" de arquitetoscomoPaulSchmitthenner ou Paul Schultze-Naumburg. Do mesmo modo, são impensáveis em relação à estética preconizada pela Bauhaus, sua superfície lisa e homogênea, sua cobertura plana e sua pureza volumétrica irretocável. 
Estas casas representam senão uma congruência na obra de Eiermann: a busca por uma linguagem moderna, mas que amplia o rol de materiais e formas, e sai do moderno estrito que já caracterizava as realizações do final dos anos 1920 . Mostram um tipo de orientação projetual que não é resultado apenas da vigilância oficial no Terceiro Reich. Sua casa Hesse, construída pouco antes do fatídico ano de 1933, já demonstra a linguagem flexível e descontraída, que busca nos materiais tradicionais "humanizar" a arquitetura. O arquiteto segue suas convicções, formuladas desde sua época como aluno de Hans Poelzig, ${ }^{26}$ e mostra em que termos sua obra se filia à arquitetura moderna.

Embora tais características sejam também próprias da casa Steingroever, esta se revela uma obra de transição em relação ao modo como se relaciona com o exterior. Neste ponto diferencia-se das precedentes e liga-se às casas "Haus der Dame" (Projeto, 1937) e Vollberg (1939-1942).

A Residência Steingroever possui um programa muito mais vasto que as anteriores; sua planta, em “T”, possui dois pavimentos em sua maior ala; entre duas destas alas, o arquiteto faz um pátio aterrado, no nível do segundo andar, para o qual volta as aberturas das áreas social e íntima, que lhe são adjacentes. Também antes, as casas tinham esta franca conexão com o espaço externo, mas pareciam

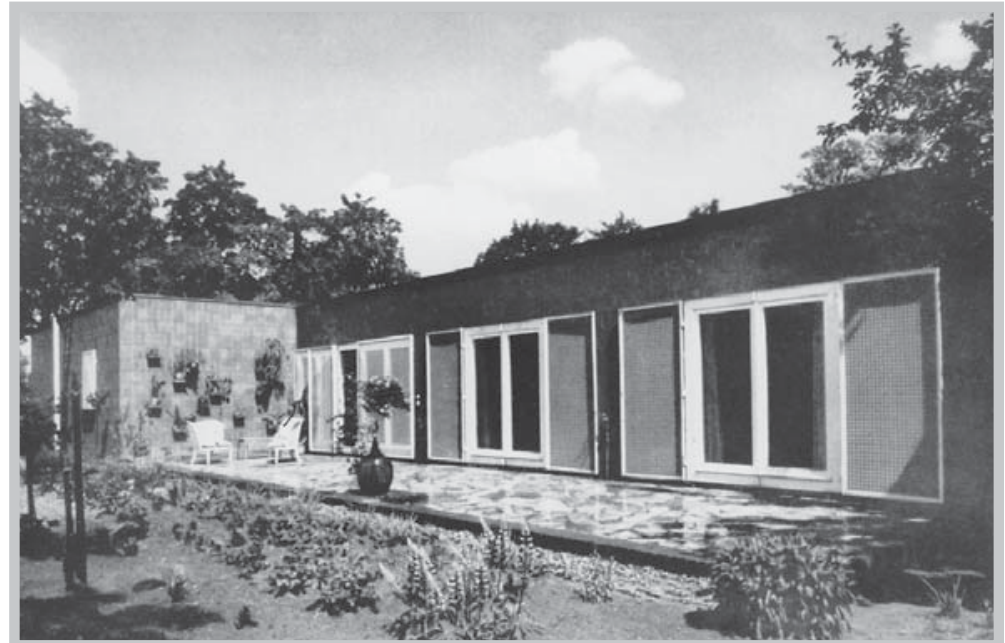

Fig. 7 - Egon Eiermann. Residência Hesse. Berlim. 1931-1933.

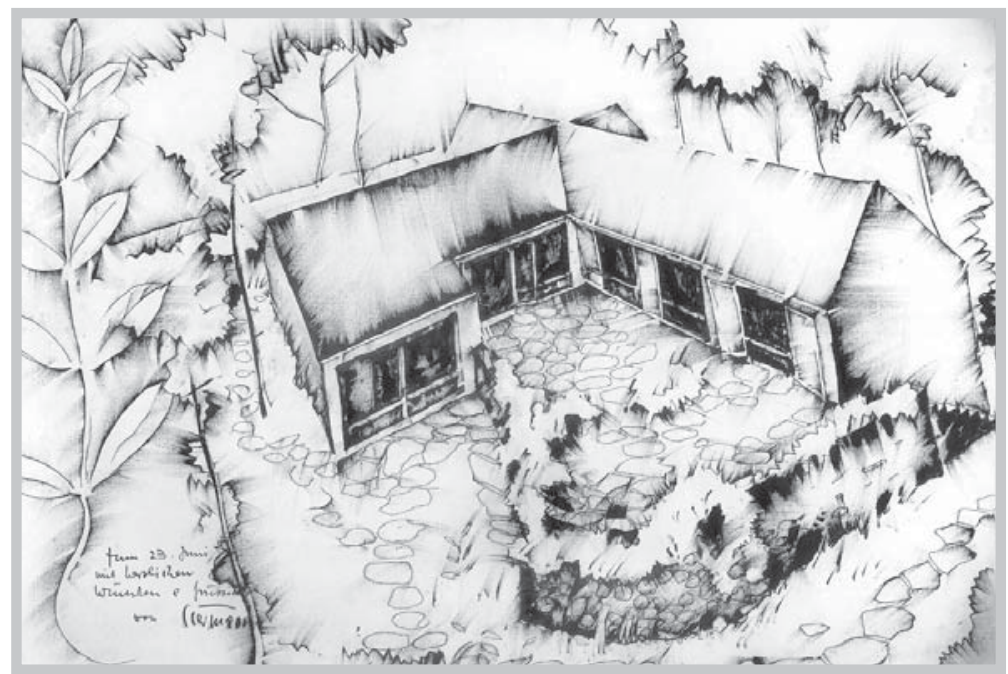

Fig. 8 - Egon Eiermann. Residência Steingroever. Berlim. 1937. Perspectiva do arquiteto.

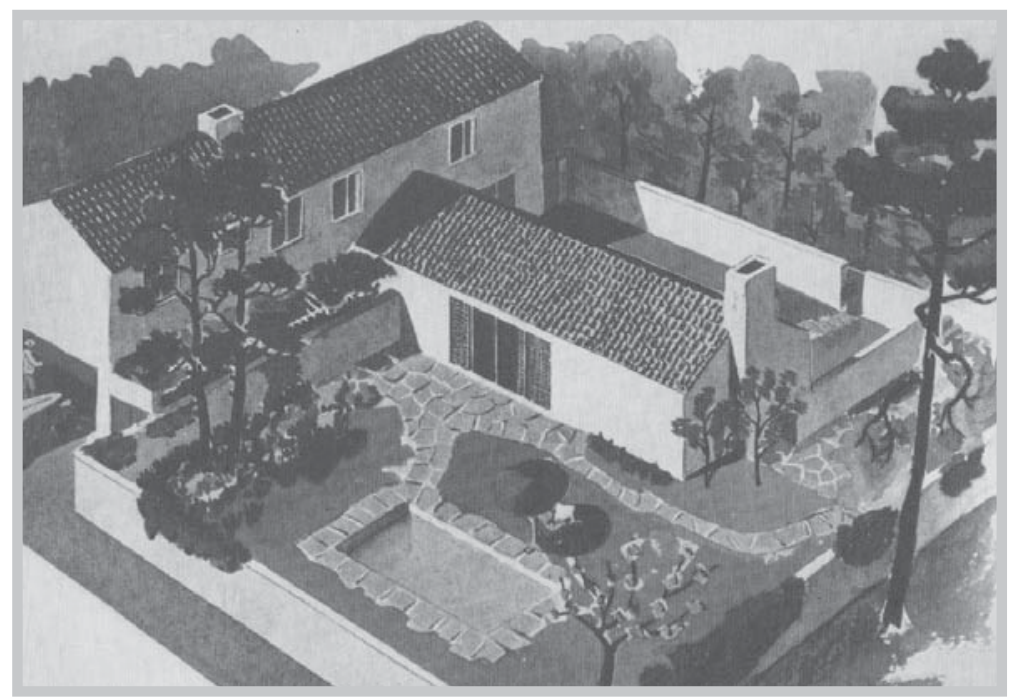

Fig. 9 - Egon Eiermann. Haus der Dame. Projeto. 1937. 
ser simplesmente inseridas naquele espaço, sem o perturbar. Aqui o arquiteto delimita o jardim, a casa cria um novo espaço, não se limita apenas a inserir-se num ambiente, transforma-o. Aqui o arquiteto também "cria" o espaço natural.

Gradativamente as casas passam a ser mais expansivas e a delimitar o jardim, através do uso de alas e muros, agregando de forma mais incisiva o espaço externo para junto do espaço de convivência. As casas tendem a fundir-se com a natureza e deixam de lado o caráter "autônomo" das primeiras obras. Inicialmente, elas tendem a se inserirem no ambiente natural, sem o modificar; depois passam a "criar" um espaço para si e a delimitar com maior nitidez o espaço externo, transformando-o também em espaço habitável.

Assim ocorre no projeto fictício da casa "Haus der Dame" (1937), solicitada pela Revista “DieDame”. Oarquiteto partedesoluções bastantepróximasaodesenvolvido para a casa Steingroever, mas vai além disso. Aqui Eiermann materializa a idéia de um "voltar-se para dentro" levando em consideração todo o terreno, quando

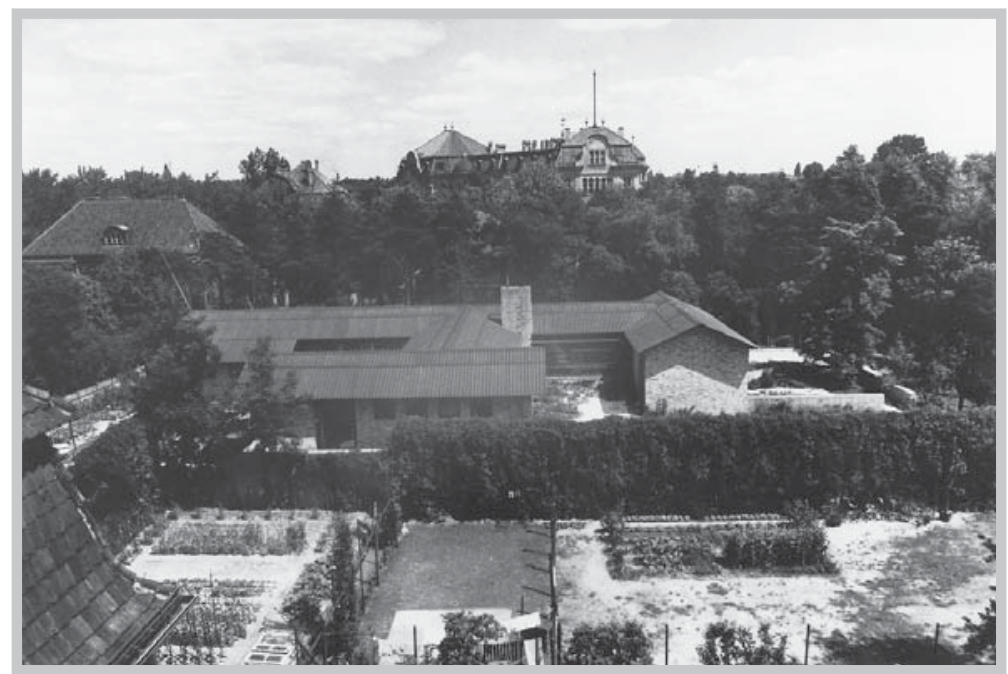

Fig. 10 - Egon Eiermann. Residência Vollberg. Berlim. 1939-1942.

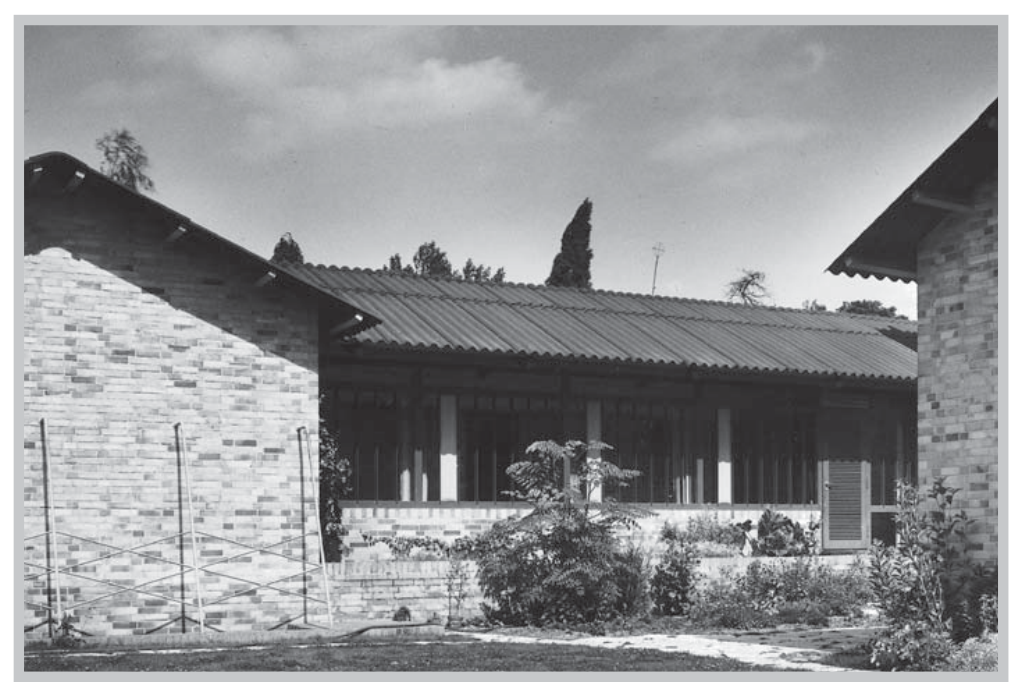

Fig. 11 - Egon Eiermann. Residência Vollberg. Berlim. 1939-1942. $\mathrm{o}$ arquiteto ergue muros e pretende que todo o espaço seja habitável. Da mesma forma que antes, $\mathrm{o}$ arquiteto delimita o espaço natural, e pretende ampliar o espaço social da casa. É a simultaneidade no projeto da casa e do jardim: o arquiteto os projeta de maneira simultânea e indissociável. Ao contrário daqui, na casa Vollberg (1939-1942) que dispunha de um amplo terreno, a necessidade não era tornar todo ele habitável, mas criar áreas de intimidade e convivência para seus moradores. A solução adotada foi a concepção em várias alas e a delimitação do jardim através de muros baixos, que criam espaços mais reservados e jardins integrados aos ambientes adjacentes. Esta casa, em sua concepção "aberta”, "espalhada" no terreno, se coloca contrária às primeiras casas, mas expõe o desejo sempre presente de unir o interior 
da casa com o exterior imediato. A concepção em alas foi o modo encontrado pelo arquiteto para lidar com um vasto programa, e ao mesmo tempo, proporcionar o contato direto com a natureza e locais de maior privacidade.

Nos três primeiros exemplos a casa ainda é um objeto fechado e compacto, um ponto central a partir do qual irradiam-se as relações com o exterior, onde o piso contínuo tem especial importância. Os volumes conservam-sefundamentalmente autônomos, nos quais a composição em alas é apenas ensaiada. Já nas demais, as formas adotadas são, ao contrário, mais expansivas, para justamente captar o espaço ao redor trazendo-o para seu domínio.

\section{O ARQUITETO INDUSTRIAL EIERMANN}

Antes mesmo da guerra Egon Eiermann fizera-se conhecer por um arquiteto industrial e já desfrutava de certa notoriedade. Até meados dos anos 1930 o arquiteto havia se detido basicamente na construção de residências unifamiliares, em concursos, além da participação na organização da controversa exposição Gebt mir vier Jahre Zeit de 1937, exposição-propaganda do Governo Nazista - a exemplo dos colegas Gropius e Mies, que em 1934 haviam participado da grande exposição “Deutsches Volk, Deutsche Arbeit” organizada pelo DAF ${ }^{27}$ em comemoração ao dia do trabalhador. Com a iminência da guerra e as escassas encomendas particulares, aproximar-se da construção de indústrias parece o único meio de garantir maior segurança financeira nesta época. É o que procura fazer Eiermann desde meados dos anos 1930, sem, no entanto, obter sucesso. ${ }^{28}$

Quando do anúncio, em outubro de 1936, do Vierjahresplan ${ }^{29}$ pelo governo, deuse início a uma intensa construção de indústrias de matéria-prima e armamento no país. A este tempo os planos da guerra já estavam delineados, e a grande preparação para a guerra começava. Refugiar-se na construção de indústrias, ou em qualquer outro setor de interesse do governo, além de garantir meios de sobrevivência, era a oportunidade de trocar o papel de soldado pelo de arquiteto: "Como soldado, não preciso me alistar, ao menos não por agora, já que estamos ocupamos com algumas construções, cuja realização é seguramente tão importante quanto minha utilização como guerreiro. Eu sempre estive mais propenso à construção de indústria e acho nela, no que diz respeito à nossa profissão, a única verdadeira satisfação." ${ }^{30}$

A partir do projeto da Indústria DEGEA-AG (1938) em Berlim, Eiermann ingressa no ímpeto de construção industrial que tomou conta do país. E a situação, apesar da iminência do caos, parecia confortante: "a aproximação dos arquitetos liberais com a construção de indústrias do 'Plano de Quatro Anos', tanto quanto sei e 


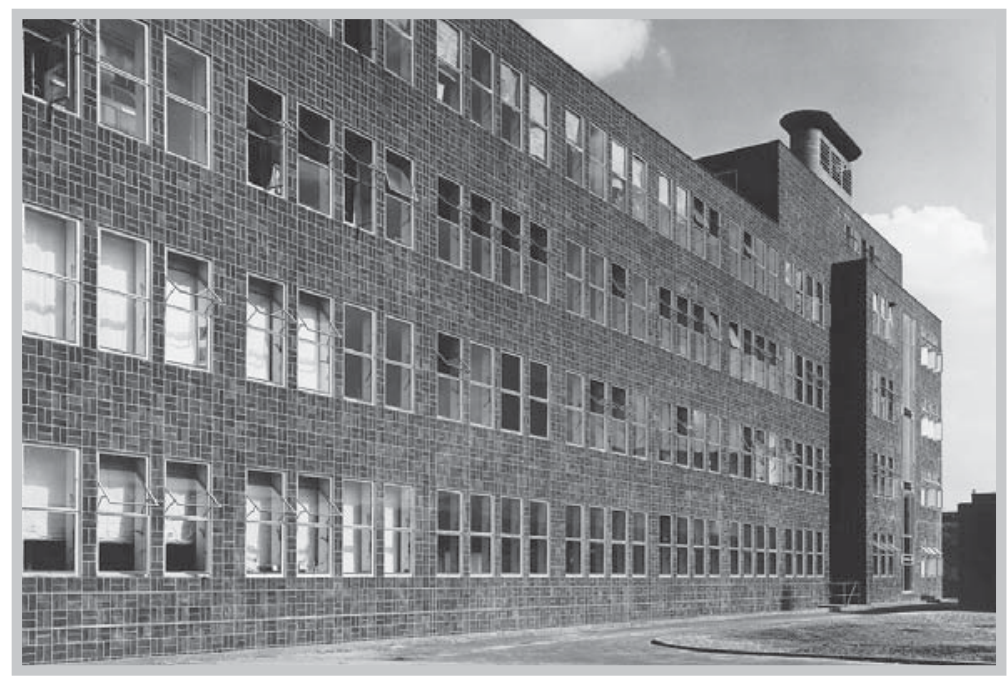

Fig. 12 - Egon Eiermann. Indústria DEGEA-AG-Auergesellschaft. Berlim. 1938.

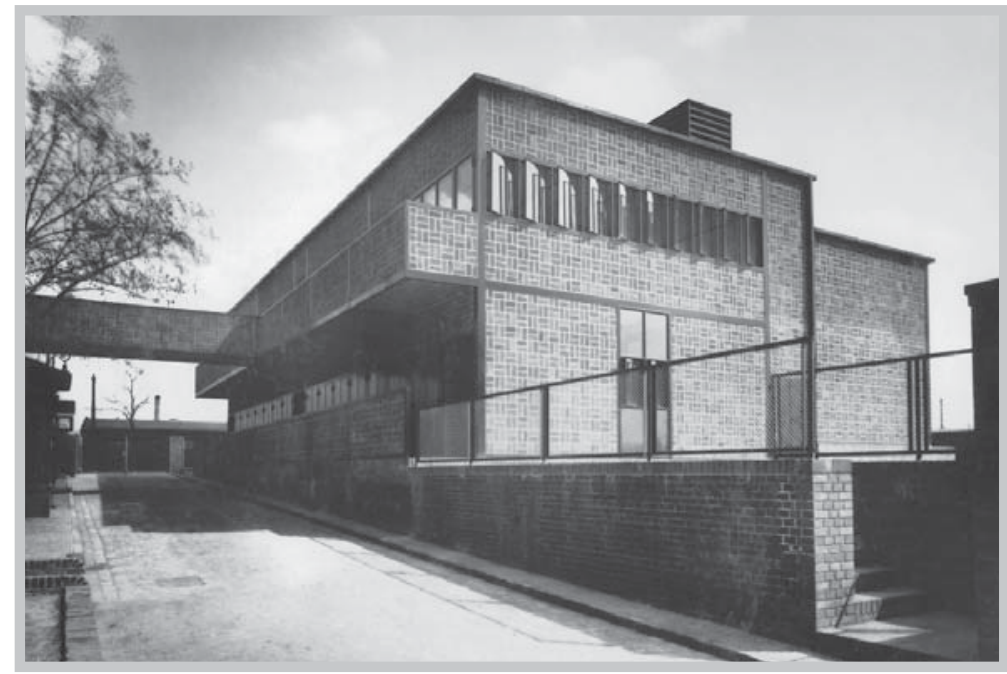

Fig. 13 - Egon Eiermann. Berliner Elektrizitätswerk AG (BEWAG). Berlim. 1929-1930.

ouço, é absolutamente animadora. Muitos arquitetos estão neste momento assoberbados com tais encomendas." 31

À medida que os anos avançam Eiermann torna-se mais ocupado com a construção industrial, sendo sua principal encomenda a fonte de renda a partir de 1940 até o final da guerra. Em seu primeiro projeto desta nova fase que se iniciava, Eiermann deparou-se com uma situação inusitada. A área destinada à construção da DEGEA-AG situava-se dentro dos limites do Eixo Norte-Sul de Berlim - uma grande esplanada que fazia parte do plano de remodelação da cidade, planejada pelo arquiteto do "Führer" Albert Speer. Em vista disso o projeto teve que contar com a permissão do antigo colega de estudo da Technische Hochschule Berlin-Charlottemburg, que havia se tornado arquiteto inspetor geral de Berlim em 1937. Depois de muita negociação e objeções feitas por Speer e a insistência de Eiermann para levar adiante suas proposições, a construção somente pode ser realizada por se tratar de obra em caráter provisório. Mesmo assim Eiermann deixa clara sua insatisfação em relação ao resultado obtido; a obra seria "algo Speer e algo Eiermann. E algo enfadonho. Mas razoavelmente inequívoco, e eu espero, comparada com outras, que sob a influência de Speer surgiram, ainda bastante bela". ${ }^{32}$

Embora seja perceptível certa noção de estagnação, pela rigidez do volume e ordenação repetitiva das aberturas - sem se saber, no entanto, até que ponto influenciou o exame oficial - o prédio, ainda assim, dá mostras claras do desenho funcional e da racionalidade construtiva que o motivaram. Além disso, traz alguns pontos dignos de nota, como o grande pano de vidro da escadaria e a torre de ventilação e o abrigo destinado à queima de carvão deixados em concreto aparente. 
Por um lado, esta rigidez formal e noção de estaticidade em muito contradizem a primeira obra do arquiteto, quando recém formado, também uma indústria a Subestação de transformação do Berliner Elektrizitätswerk AG (BEWAG) em Berlim (1929-1930). Trata-se de um pequeno edifício, que se adequa à escala dos antigos prédios fabris existentes no local, e que deles se diferencia, pela forma pura e austera, alinhamentos precisos e poucas aberturas. Ao mesmo tempo procura uma movimentação e diferenciação formal não vista em seu projeto da DEGEA. $\mathrm{O}$ arquiteto utiliza aqui melhor distribuição de massas e recursos como balcões e a passarela elevada, que faz a ligação com um dos prédios antigos e conferem dinamismo ao bloco.

Contudo, a mesma rigidez formal e o sentido de estagnação da DEGEA se faz notar também no Edifício Administrativo da Indústria Märkischer Metallbau (1939-1941), projeto posterior àquele. A rigorosa e elementar disposição das janelas acaba por criar o mesmo sentimento de "enfadonho" da DEGEA, não fosse o uso de um recurso bastante utilizado pelo arquiteto em obras posteriores: o terraço com cobertura recuada, leve e delgada. Uma solução que conferiu movimento, leveza e diferenciação formal onde havia estaticidade e monotonia.

Esta cobertura, utilizada principalmente em blocos menores, com volumes rígidos e pesados, foi usada pela primeira vez em um projeto de intervenção em uma fábrica existente, a Total-Werke Foerstner \& Co. (1938-1939). Aqui Eiermann utiliza sabiamente a cobertura plana como arremate do novo setor, construído em continuidade ao antigo prédio e sobre o embasamento já existente. $\mathrm{O}$ arquiteto toma por base a dimensão dos pavimentos do prédio existente e os prolonga, aumentando o pédireito do último pavimento e dotando-o de amplas aberturas.

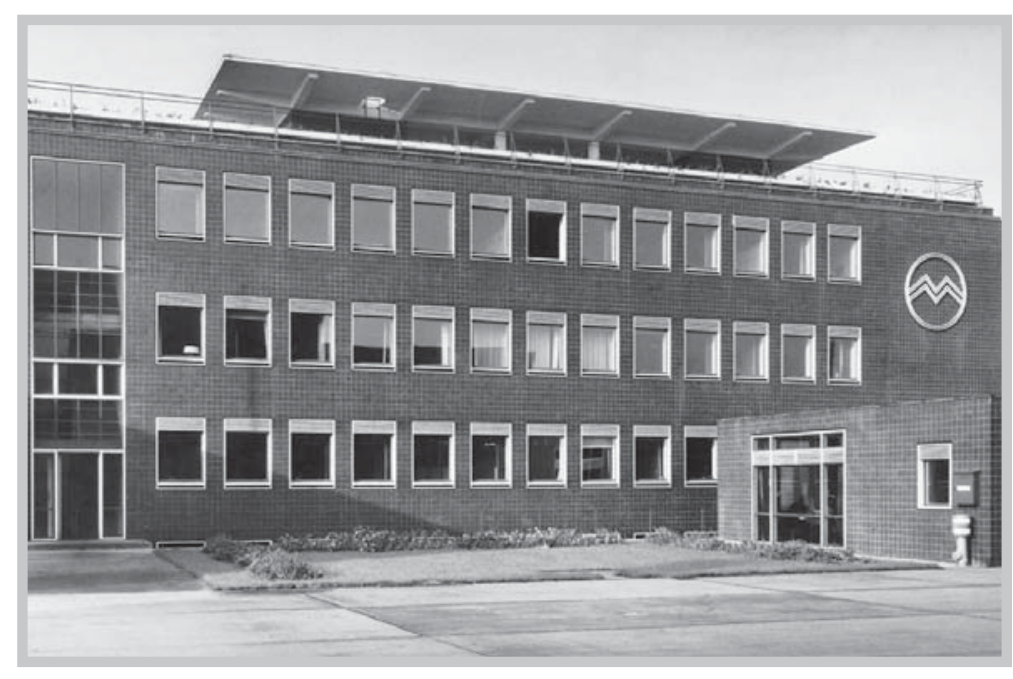

Fig. 14 - Egon Eiermann. Märkischer Metallbau. Edificio Administrativo. Oranienburg. 1939-1941.

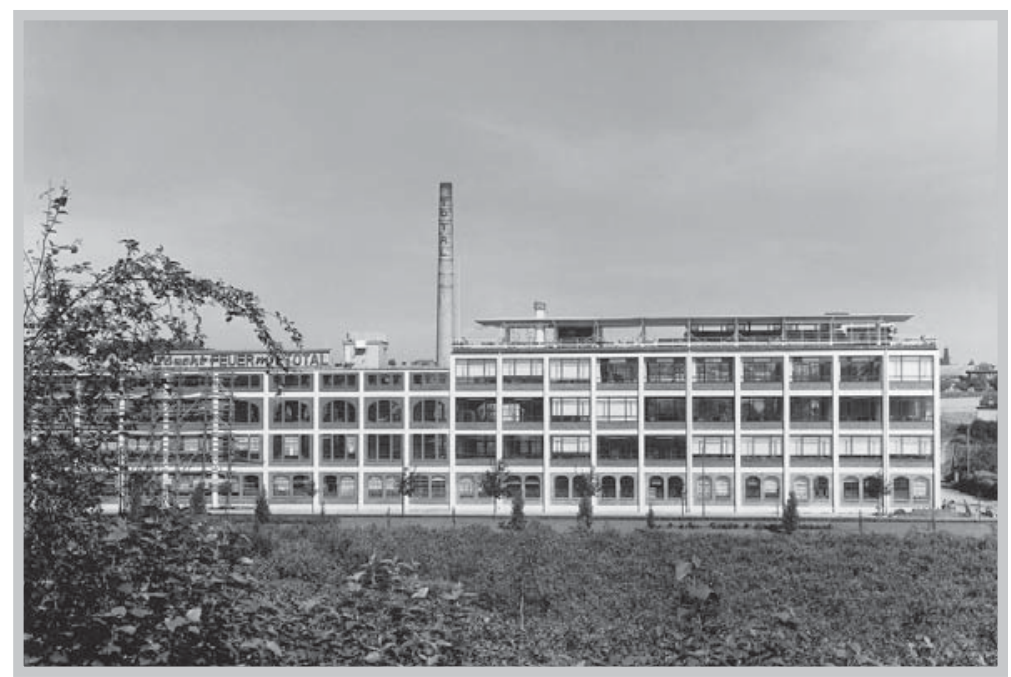

Fig. 15 - Egon Eiermann. Total-Werke Foerstner \& Co. Apolda. 1938-1939. 


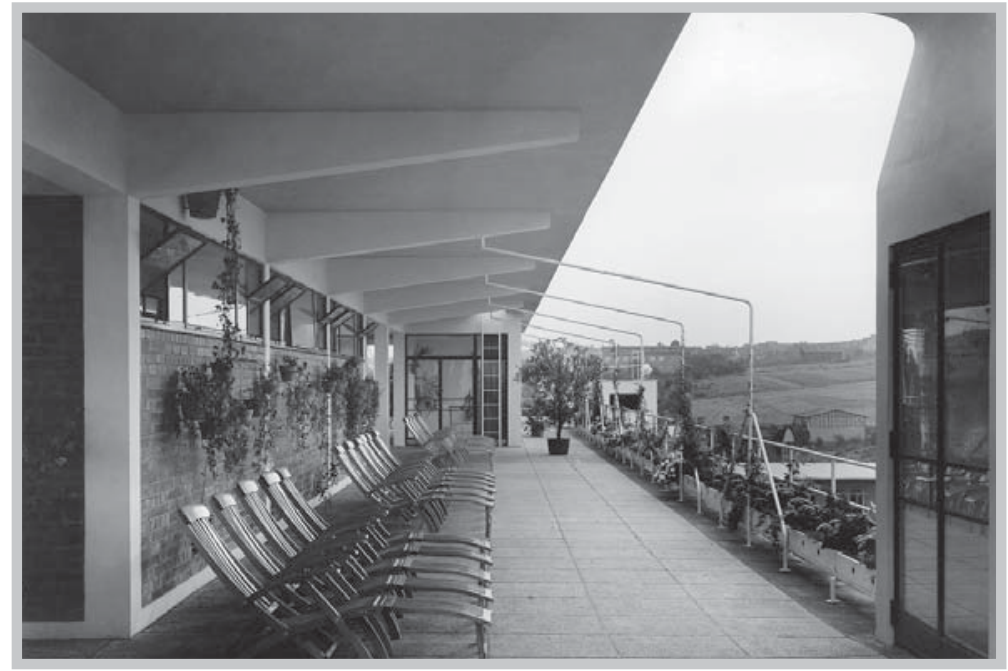

Fig. 16 - Egon Eiermann. Total-Werke Foerstner \& Co. Apolda. 1938-1939.

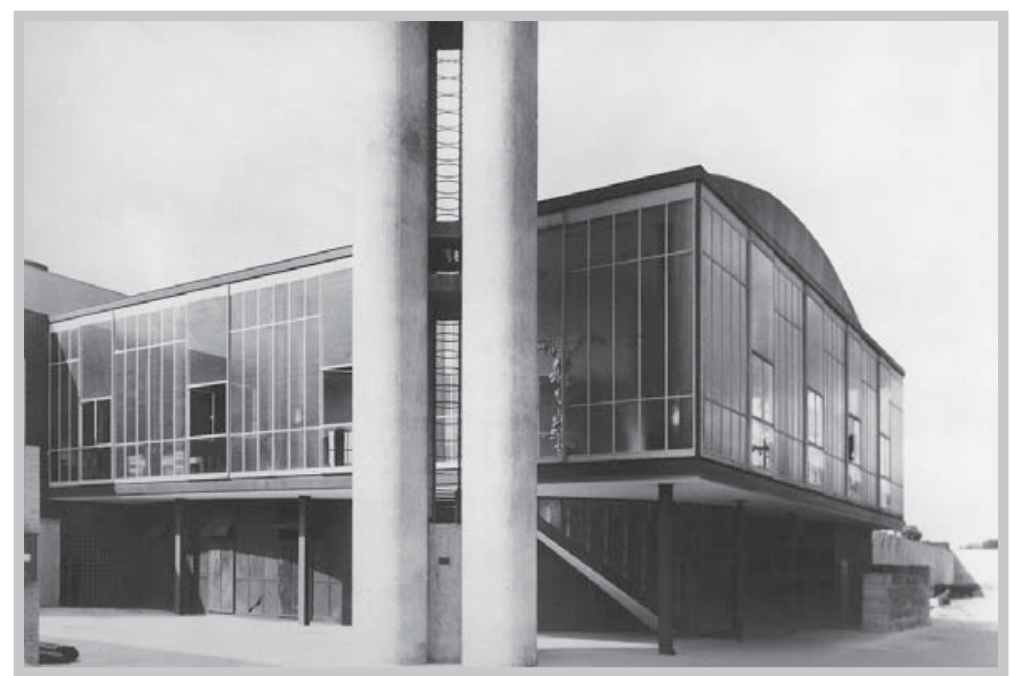

Fig. 17 - Egon Eiermann. Märkischer Metallbau. Refeitório e Casa de Caldeiras. Oranienburg. 1939-1941.
$\mathrm{O}$ ponto de união entre o antigo e o novo setor é o realce da estrutura dos prédios. $\mathrm{O}$ arquiteto destaca as linhas de composição, pintandoas de branco, e diferencia, desta maneira, a delgada estrutura de concreto armado que dá forma ao novo prédio -reveladas pelas amplas aberturas - das espessas paredes de alvenaria estrutural do antigo bloco. No novo prédio, o maior interesse recai na cobertura sobre o terraço, com seus esbeltos perfis metálicos - detalhes sutis, como parapeitos e apoios verticais para trepadeiras - que agem como um conjunto diáfano que dá acabamento ao bloco. E pensar que foi possível construir a cobertura plana nestes anos!

Como já mencionado, construir moderno não exigiu nenhum ato de heroísmo dos arquitetos. Até mesmo dentro de alguns órgãos oficiais do governo tinha lugar a Arquitetura Moderna, como é o caso do Departamento do Schönheit der Arbeit. Caso contrário, estes e outros exemplos não seriam possíveis, num tempo que nenhum projeto era encarado como encomenda particular, e nada escapava do exame crítico do Estado. Entre amenizações e pequenas adaptações, a Arquitetura Moderna não somente sobreviveu nestes anos, como gerou exemplares que podem ser confundidos até mesmo com as realizações dos áureos anos 1920.

Um destes exemplos é o prédio do refeitório da Indústria Märkischer Metallbau. O pequeno edifício surge cristalino, com fechamento diáfano, em uma construção precisa e esbelta em estrutura metálica. Localizada no subsolo, a Casa de Caldeiras eleva-se até a altura do térreo, com volume arredondado e fechamento em vidro. Também merece destaque neste projeto as quatro chaminés de concreto da fábrica, isoladas e reunidas de forma concêntrica, dispostas ao lado do refeitório. Eiermann, aqui como em outros projetos, aproveita estes elementos basicamente 
funcionais e os transforma em elementos compositivos, atuando como um ponto de referência e uma dominante do local.

Entretanto, não são apenas encomendas de indústrias que chegam às mãos do arquiteto. Com o avanço da guerra, surgem projetos de alojamentos provisórios, acampamentos militares e de equipamentos de auxílio, e alguns mais ambiciosos, como o planejamento de uma cidade, como parte do projeto de uma oficina para reparação de aviões. ${ }^{33} \mathrm{O}$ arquiteto vê seu campo de trabalho ampliar-se ainda mais, ao receber encomendas de equipamentos industriais para várias cidades do país e até mesmo nas regiões anexadas a leste e, em troca, ganhava proteção política para si e para seus colaboradores. ${ }^{34}$

Exilar-se na construção industrial foi, indubitavelmente, mais um ato de sobrevivência que de coragem nestes anos. Entretanto, se esta indústria servia ou não à guerra e suas atrocidades, não é questionado. Conscientes ou não de tal controvérsia, os arquitetos que tomaram parte da construção industrial do país parecem querer obliterar as conseqüências práticas deste tipo de atitude durante o período nazista.

Fato é que, a partir de sua breve carreira em Berlim, Eiermann passa a desfrutar de uma relativa e flagrante notoriedade na profissão. $\mathrm{O}$ então jovem e relativamente desconhecido arquiteto conhece um impulso em sua carreira que lhe valeu convites para diversas universidades e o projetou como um arquiteto industrial no pós-guerra. São vários os projetos industriais que datam dos primeiros anos pósguerra, entre elas a Fábrica Têxtil de Blumberg (1949-1951), um marco na carreira do arquiteto. Já em 1947 Eiermann assume a cadeira de "Grandes Projetos" na Universidade Técnica de Karlsruhe. Nesta cidade, daria continuidade à já bemsucedida carreira, se tornaria um aclamado professor e um dos grandes nomes da arquitetura no país, com obras marco para a então jovem República Federal Alemã.

\section{"REFÚGIO" MODERNO: A CONSTRUÇÃO INDUSTRIAL}

A construção de indústrias valeu como "exílio" interno para os arquitetos modernos que permaneceram na Alemanha na década de 1930. Foi ali onde a Arquitetura Moderna teria sido preservada, defendida da contaminação histórica e monumental que afetava a arquitetura oficial do Terceiro Reich: "[...] se faz também necessário abrir-lhes os olhos (às novas gerações) para algumas realizações, que em nosso próprio país 'à parte a celeuma da arquitetura do III Reich' surgiram, obras, nas quais o pensamento da nova arquitetura permaneceu vivo e continuou seu desenvolvimento." 35 
Esse ato de coragem e de resistência de arquitetos que não teriam se curvado ao sistema e se deixado vencer pelas agruras dos tempos, é agora motivo de orgulho. A arquitetura industrial praticada durante os anos 1930 é vista como o fio tênue que liga a Arquitetura Moderna dos anos 1920 com o futuro de grandes construções que se tinha pela frente: "Que um pequeno número de arquitetos fiéis aos princípios encontraram no caminho da indústria uma saída e um refúgio, torna possível à construção alemã novamente encontrar-se para a construção do mundo que restou com mãos não totalmente vazias." ${ }^{36}$

E assim, em meio à auto-bajulação e dissimulação, foi dedicado à construção industrial dos anos 1930 o primeiro número da Revista Baukunst und Werkform, partidária da Arquitetura Moderna e seu principal veículo local de divulgação, editada entre 1947 e 1962. Entre seus colaboradores estavam grandes nomes como Otto Bartning, Hugo Häring, Rudolf Schwarz, Rudolf Lodders e Egon Eiermann, que contavam entre aqueles que permaneceram "fiéis" à Arquitetura Moderna, e que dispunham, eles mesmos, dos melhores exemplos da arquitetura moderna industrial realizada nos anos 1930 ou mesmo antes. Sem obras a mostrar do país destruído, a revista volta-se, então, à construção industrial realizada naqueles anos, venerada como um ato heróico de resistência no célebre artigo Zuflucht im Industriebau. ${ }^{37}$

Apesar do tom reinante de heroísmo e bravura que tenta insuflar, Rudolf Lodders, ele mesmo um grande arquiteto industrial daqueles anos, faz um retrato da época em tom melancólico, querendo explicar o que parecia ser inexplicável. Mas em meio ao turbilhão de acontecimentos e à ameaça do assombroso porvir, só um caminho parecia certo e seguro - a construção industrial: "em toda essa agitação (do início dos anos 30) ao mesmo tempo agonizante e desesperadora, refletíamos acerca de uma alternativa. Então iniciou-se uma verdadeira vida nômade, e finalmente mergulhamos lá, onde Hitler havia deixado uma válvula de escape: na construção da indústria “. ${ }^{8}$

A arquitetura moderna teria sido ali preservada em sua essência, no que era mais caro aos arquitetos modernos: funcionalidade, racionalidade, economia de custos e meios, motivo que parecia suficientemente digno para livrá-los de qualquer questionamento. Tanto mais quanto se antevia as novas tarefas que se teria pela frente. Aqueles mesmos princípios guardados tão zelosamente encontrariam, enfim, uma nova e grande missão dignificadora: definir os rumos da reconstrução alemã: "em todas as outras áreas da reconstrução, do planejamento urbano aos mínimos detalhes de uma casa, admitimos como forma natural, o que, a partir da construção industrial, se mostrou imprescindível logro e lúcido conhecimento, 
como um verdadeiro e encorajador rasgo de luz na escuridão, que vamos ao encontro." 39

Mas a "válvula de escape" a que se refere Lodders não era sem razão. A construção da indústria não estava no foco das atenções do Regime, que se voltavam às construções oficiais e do partido, ou que estivessem em pontos estratégicos. Esta situação acabou deixando o caminho mais livre, sem tantos obstáculos para a construção industrial, que merecia importância apenas quando servia de propaganda ao Estado. Certamente o projeto da indústria DEGEA de Egon Eiermann não teria enfrentado problemas caso não estivesse localizado em uma área de tanta representatividade para o governo.

A partir do "Plano de Quatro Anos" de 1936, a indústria alemã deveria se equipar com um parque eficiente. Para isso, não somente eram necessárias, como bemvindas, modernas indústrias que fossem construídas com modernos métodos. Neste setor, a construção de uma arquitetura "moderna" - ou como preferir, algo que primasse pela funcionalidade, racionalização de custo e meios, utilização de pré-fabricação e por uma expressão estética objetiva, clara e racional - era vista como intrínseca.

Como lembra Pehnt, a construção de indústrias requer industrialização dos meios. Uma de suas exigências mais recorrentes é a de produção flexível. Grandes pavilhões com número reduzido de apoios e espaços livres para o fácil remanejamento dos equipamentos torna-se condição básica, e para o aumento ou remodelação do pavilhão, partes padronizadas pré-fabricadas tornam o trabalho ainda mais prático. Na Alemanha do período da guerra, o risco de uma parte de uma indústria ser atingida por bombardeios aéreos tornava esta necessidade ainda mais premente. ${ }^{40}$

E disso até os nazistas estavam convencidos. Sabiam que a indústria, onde projetavam a ideia de um país competente e produtivo - o que é reforçado pela apologia da própria imprensa contemporânea aos fatos ${ }^{41}$ - deveria espelhar esta eficiência. E tiravam proveito disso. Da ideia de eficiência, produtividade, alto desempenho, sugeridos pelos modernos prédios, faziam o outro lado da propaganda do sistema - baseada, por um lado, na arquitetura de estilo de "preservação do regional" (Heimatschutzstil, que se colocava na arquitetura tradicional, de casas unifamiliares em um ambiente idílico cercado por natureza, totalmente contrário, portanto, à construção de habitações em massa da República de Weimar); e por outro lado, na formulação de uma imagem de um Estado que se queria forte, eficiente e de grande competência técnica. 


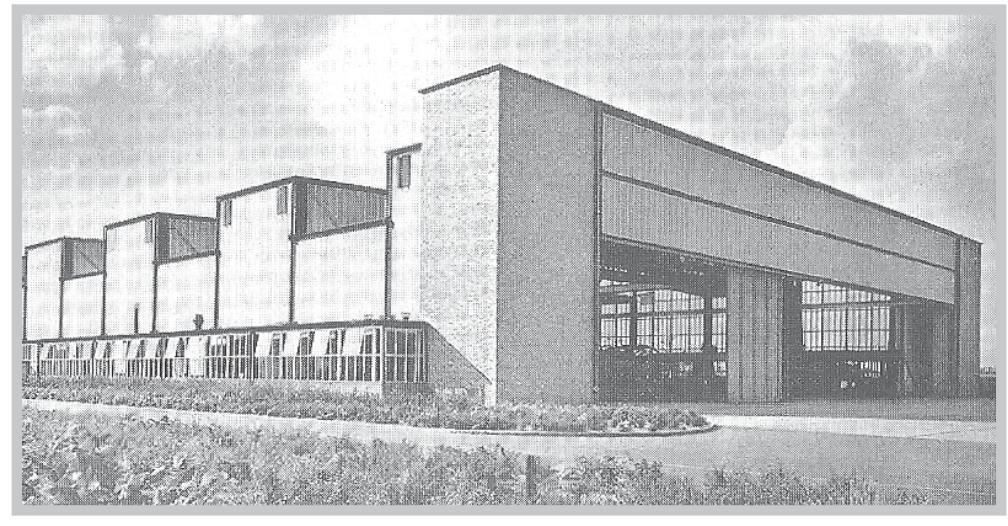

Fig. 18 - Herbert Rimpl, Josef Bernard. Heinkel-Flugzeugwerke. Oranienburg. 1936 1938.

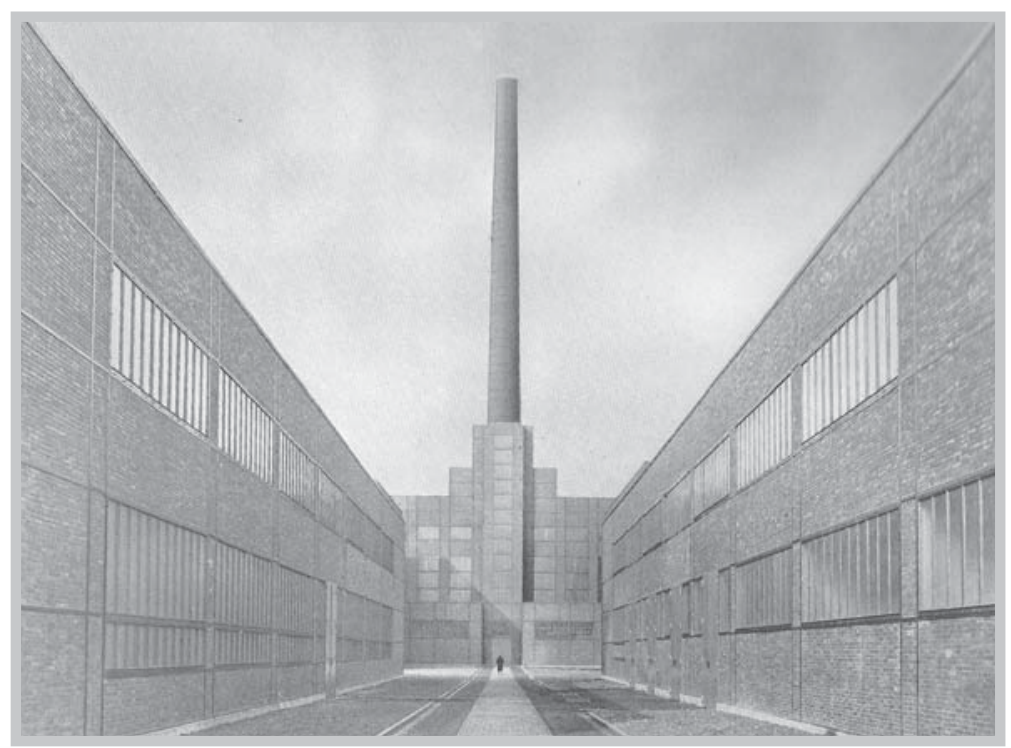

Fig. 19 - Fritz Schupp, Martin Kremmer. Parque Industrial na Westfália.

O Estado Nazista não teria sido, portanto, um bloco hermético, como sugere a noção de um Estado totalitário. Sob seu vasto manto encontraram abrigo não somente as construções monumentais de grande representatividade política e a arquitetura tradicional pequenoburguesa, mas o moderno nas indústrias, e também o enxaimel, usado nas "Casas da Juventude Hitlerista" pelo arquiteto Hanns Dustmann. E aqui, um paralelo pode ser encontrado com o Brasil dos anos 1930, tanto no que se refere à ideia de um Estado supostamente monolítico - que abrigou construções tão diversas, do ponto de vista estilístico, quanto os Ministérios da Educação e Saúde (1936-1943), da Fazenda (19361943) e do Trabalho (1936-1938), todos localizados na Esplanada do Castelo, próximos uns aos outros ${ }^{42}$ - quanto ao impulso concedido à Arquitetura Moderna brasileira, onde a plena aceitação de seus pressupostos e sua rápida ascensão é explicada, em grande parte, pelo financiamento do Estado ditatorial de Getulio Vargas. Associação entre arquitetura e Estado, que também será acolhida como oportuna pela crítica, embora não sem certo embaraço. ${ }^{43}$

Hitler mesmo aponta para esta coexistência (pacífica) de múltiplos estilos dentro de seu suposto império: "para os locais de trabalho cabem luz, ar e racionalidade, de uma prefeitura exijo decoro, e de uma casa, proteção, que me prepara para a inclemência da luta pela vida”. ${ }^{44} \mathrm{E}$ formula tal pensamento utilizando palavras reivindicadas como invenção moderna - luz, ar e racionalidade - ou que, ao menos, pertenceriam "por direito" aos arquitetos modernos. Para se ter ideia, algo tão impensável como a Fagus-Werke de Gropius, símbolo do virtuosismo moderno do segundo decênio do século XX, chegou a ser mostrada, ao lado de outras fábricas dos anos 1930, como exemplo de empresa-modelo nacionalsocialista! ${ }^{45}$ 
A continuidade da Arquitetura Moderna durante os anos 1930 não se deu, portanto, sem o consentimento do Regime e, ao contrário, não exigiu nenhum ato heróico de seus militantes como alguns arquitetos insistiam em retratar. ${ }^{46}$ E, sobretudo na construção industrial, foi possível uma continuidade da "tradição" moderna (se assim pode ser chamada), desde os tempos dos pioneiros e que iria alcançar

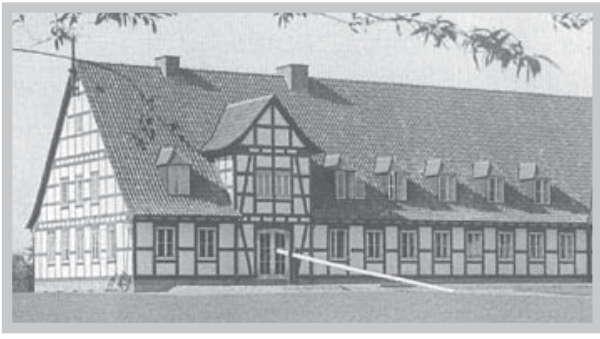

Fig. 20 - Hanns Dustmann. Hitler-jugend-Heim Hermann Göring. Melle, Niedersachsen. 1937-1938. o país em reconstrução a partir de 1945.

Entretanto, nesta Alemanha dos anos 1930 não havia mais lugar para a Arquitetura Moderna como ela fora concebida, socializante, igualitária, revolucionária. $\mathrm{O}$ que foi praticado durante o Estado Nazista foi uma arquitetura desprovida de seu estímulo inicial, que foi conservada, sobretudo em seus parâmetros formais e em suas qualidades técnicas e construtivas. E podemos afirmar, foi também assim que se deu a continuidade da arquitetura no pós-guerra; uma arquitetura já apartada de seu teor revolucionário, que já havia perdido há tempos a sua pretensa unidade, e talvez por isso, já desacreditada, ela mesma, de seu caráter uníssono, teve, no pós-guerra, uma multiplicidade de propostas maior ainda que nos anos 1920.

Estes arquitetos fiéis aos princípios, que buscaram asilo na construção de indústrias, orgulham-se em dizer que ali se achou uma lacuna. Mas para que e a quem serviram estas pérolas da Arquitetura Moderna? Os porquês da história são veladamente colocados de lado. Alfons Leitl, editor da revista Baukunst und Werkform, parecia observar os fatos, em que ele mesmo participou, de maneira mais realista: "Nós todos, ou a maioria de nós, não somos nenhum herói, ou apenas de uma forma muito parcial. Caso contrário, não estaríamos mais aqui. Todos nós nos metemos em algum lugar e trabalhamos também. $\mathrm{O}$ trabalho que tínhamos a realizar, fizemos em uma Alemanha coordenada, em postos de trabalho coordenados. Se projetamos construções para a indústria, conjuntos de moradia rurais, abrigos para trabalhadores, barracas, construções militares ou pontes - sentamos todos no mesmo barco marrom." ${ }^{\text {47 }}$

Foi na construção voltada para a guerra, que se formaram inúmeros jovens arquitetos alemães, e onde também encontraram trabalho arquitetos modernos, entre eles ex-alunos da Bauhaus e arquitetos que regressavam das expedições à URSS que, caso contrário, não encontrariam trabalho na Alemanha dos anos 1930. Além disso, o trabalho para a construção industrial, tão importante quanto o combate, significava para estes jovens, a segurança de não ser chamado ao front. 
Com a ausência dos mestres modernos, que ao longo da década de 1930 haviam deixado a Alemanha, a reconstrução após o conflito mundial ficou, sobretudo, nas mãos desta geração mais jovem (alguns arquitetos com obras desde os anos 1920, mas que até então haviam permanecido mais à sombra do "Star team"), mas não tão inexperiente assim: nos setores de construção do Governo, no escritório de Herbert Rimpl ${ }^{48}$ - escritório encarregado das atividades ligadas à construção do Reichswerke Hermann Göring, ${ }^{49}$ e que chegou a ter cerca de 700 colaboradores -, na Organisation Todt ${ }^{50}$ e no Atelier de Albert Speer, formaria-se a geração de arquitetos que entraria em ação a partir de 1945 e comandaria a reconstrução do país.

Esta sobrevivência da Arquitetura Moderna durante os anos 1930 também endossa parte da crítica posterior feita ao Movimento Moderno: o demasiado apartidarismo de seus sequazes. O engajamento de certos arquitetos modernos na propaganda nazista, bem como o serviço prestado por estes arquitetos para o regime, ainda que de uma forma indireta e sob a ótica da pretensa resistência, mostram que nesta época a Arquitetura Moderna já havia perdido sua força combativa e não representava mais antagonismo às forças majoritárias. Atitude que se mostrará muito mais claramente no pós-guerra, quando esta arquitetura empresta sua feição cristalina aos arranha-céus de grandes bancos e corporações e se torna a própria marca do capitalismo nos anos 1950 e 1960. 


\section{Notas}

1 Pehnt, Wolfgang. Deutsche Architektur seit 1900.2. ed. Ludwigsburg/ München: Wüstenrot Stiftung/ Deutsche Verlags-Anstalt, 2006, p. 187.

2 Hannes Meyer havia substituído Walter Gropius na direção daquela escola em 1928, seguido por Mies van der Rohe em 1930.

3 Warhaffig, Myra. Sie legten den Grundstein. Leben und wirken deutschsprachiger jüdischer Architekten in Palästina 1918-1948. Tübingen, 1996, p. 18. apud: Pehnt, Wofgang. Deutsche Architektur seit 1900. op. cit. p. 236.

4 Como Adolf Rading e Hannes Meyer. Cf. Pehnt, Wolfgang. Deutsche Architektur seit 1900. op.cit. p. 244.

5 Nerdinger, Winfried (org.). Bauhaus-Moderne im Nationalsozialismus. München: Prestel, 1993. p. 157.

6 Pehnt, Wolfgang. Deutsche Architektur seit 1900. op. cit. p. 239.

7 Apelo dos Produtores de Cultura.

8 Pehnt, Wolfgang. Deutsche Architektur seit 1900. op. cit. p. 197.

9 Haussuchung in Bauhaus Steglitz. In: Teut, Anna. Architektur im Dritten Reich 1933-1945. Frankfurt/ Berlin: Verlag Ullstein, 1967, p. 138.

10 Cf. entre outros, Anna Teut. Architektur im Dritten Reich. op.cit. e Barbara Miller-Lane. Architecture and Politics in Germany 1918-1945. Cambridge: Harvard University Press, 1968.

11 Werner, Bruno E. Der Aufstieg der Kunst. (Maio 1933). In: Teut, Anna. Architektur im Dritten Reich 1933-1945. op. cit., p. 147.

12 Liga de Combate pela Cultura Alemã, órgão Nacional-Socialista.

13 Fischer, Theodor. Vermächtnis an die Jugend. Palestra em novembro 1933, Augsburg. In: Teut. Anna. Architektur im Dritten Reich 1933-1945. op. cit., p. 155.

14 Idem, ibidem.

15 Como lembra Pehnt, a questão da internacionalidade atribuída à arquitetura moderna foi uma constante crítica dos defensores do Regionalismo. Paradoxalmente, à época das construções e planos megalomaníacos do Regime em estilo neoclássico, verifica-se paralelos em outros países, como nos Estados Unidos, Inglaterra, e até na arqui-inimiga URSS. Cf. Pehnt, Wolfgang. Die Manipulation des Menschen. Albert Speer im Gespräch. In: Pehnt, Wolfgang. Die Erfindung der Geschichte. Aufsätze und Gespräche zur Architektur unseres Jahrhunderts. München: Prestel, 1989, p. 132.

16 Pehnt, Wolfgang. Esperanto oder Dialekt. Internationalität im modernen Bauen. In: Pehnt, Wolfgang. Die Erfindung der Geschichte. Aufsätze und Gespräche zur Architektur unseres Jahrhunderts. Op.cit., p. 144.

17 Idem, ibidem.

18 Idem, p. 146.

19 Hitler, Adolf. Discurso no Encontro do Partido em setembro 1933, Nuremberg. In: Teut. Anna. Architektur im Dritten Reich 1933-1945. op. cit., p. 91. O Discurso no Encontro do Partido em Nuremberg foi o primeiro dos chamados Discursos Culturais de Hitler. Tornou-se notório por ser a primeira vez que coloca publicamente suas opiniões acerca da arquitetura e da cultura em geral depois de sua nomeação como chanceler.

20 Idem. Ibidem.

21 Scharoun teria construído Siedlungen em Berlim e Bremerhaven durante os anos 1930, que contrariam a imagem do mestre sem trabalho e em "emigração" interna. Cf. Pehnt, Wolfgang. Op. cit. p. 218.

22 Pehnt, Wolfgang. Deutsche Architektur seit 1900. op. cit. p. 216.

23 Este é o caso do Departamento Schönheit der Arbeit, responsável pela construção dos equipamentos industriais do Terceiro Reich. Cf. Sonja Hildebrand. "Ich weiß nicht wirklicht warum, ich so eine traurige Berühmtheit bin.” Egon Eiermann in Berlin: Grundlagen 
der Nachkriegskarriere. In: Jaeggi, Annemarie (org.). Egon Eiermann (1904-1970): die Kontinuität der Moderne. Ostfildern-Ruit: Hatje Cantz Verlag, 2004, p. 30-39.

24 Gleischschaltung, termo que provém da eletrônica, pode ser traduzido como sincronização ou uniformização. No Terceiro Reich foi utilizado como um termo que remete à pretendida unidade central, tanto política quanto cultural.

25 Hugo Häring só construiria duas casas depois da guerra, as casas Schmitz em Biberach an der Riß (1949-1950).

26 Refiro-me ao Grupo „Junger Architekten“ (jovens arquitetos) de que Eiermann fez parte. Será tratado adiante.

27 Deutsche Arbeitsfront - Frente de Trabalho Alemã.

28 Sonja Hildebrand. "Ich weiß nicht wirklicht warum, ich so eine traurige Berühmtheit bin." Egon Eiermann in Berlin - Grundlagen der Nachkriegskarriere. In: Jaeggi, Annemarie (org.). Egon Eiermann (1904-1970): die Kontinuität der Moderne. Ostfildern-Ruit: Hatje Cantz Verlag, 2004, p. 34.

29 Ou Plano de Quatro Anos. Plano do Governo Nazista que previa o fortalecimento econômico do país e a construção de equipamentos industriais de armamento e de matéria prima voltados para a guerra.

30 Egon Eiermann para Fritz Janecke. 07/08/40. Propriedade de Andreas Janecke. Malmö (Suécia). apud: Hildebrand, Sonja. Op. cit. p. 35.

31 Egon Eiermann para Landesleiter Berlin der Reichskammer der bildenden Künste. 11/08/1937. Bundesarchiv Berlin. apud: Hildebrand, Sonja. Op. Cit. p. 34

32 Egon Eiermann para Fritz Janecke. 20/12/1937. Propriedade de Andreas Janecke. Malmö (Suécia). apud: Hildebrand, Sonja. Op. cit. p. 35.

33 Albert Speer, arquiteto, ex-colega de Eiermann, Ministro de Armamento do Governo alemão a partir de 1939, teria ajudado seus amigos e ex-colegas dos tempos de estudante nos difíceis anos da guerra. Segundo Speer, a Eiermann ele teria dado um projeto de hospitais provisórios (como provavelmente o Hospital destruído pela guerra de Beelitz-Heilstätten, 1943-1944). Pehnt, Wolfgang. Die Manipulation des Menschen. Albert Speer im Gespräch. In: Pehnt, Wolfgang. Die Erfindung der Geschichte. Aufsätze und Gespräche zur Architektur unseres Jahrhunderts. op. cit., p. 135.

34 Hildebrand, Sonja. Op. cit. p. 37.

35 Alfons Leitl: Anmerkungen zur Zeit (Anmerkungen zu den Bildern dieses Heftes). Baukunst und Werkform, 1947, n. 1, ano 1, p.14.

36 Idem, ibidem. Grifo nosso.

37 Lodders, Rudolf. Zuflucht im Industriebau. Baukunst und Werkform, 1947, n. 1, ano 1, p. 37-44.

38 Idem. p. 39

39 Idem, p. 42.

40 Pehnt, Wolfgang. Deutsche Architektur seit 1900. 2. ed. Ludwigsburg/ München: Wüstenrot Stiftung/ Deutsche Verlags-Anstalt, 2006, p. 221.

41 Cf. por exemplo: Troost, Gerdy. Das Bauen im neuen Reich. Bayreuth: Gauverlag Bayerische Ostmark, 1938.

42 Cf. Cavalcanti, Lauro. Moderno e Brasileiro. A história de uma nova linguagem na arquitetura (1930-1960). Rio de Janeiro: Jorge Zahar Ed., 2006.

43 Isso é especialmente verificado no texto de Mário Pedrosa: "Os novos construtores utilizaram-se do poder de ação dos ditadores para por em prática suas ideias. Souberam fazer compreender então tudo o que pensavam e sonhavam realizar. A ditadura lhes ofereceu esta possibilidade, mas resultou daí uma contradição, ainda não totalmente superada, entre os ideais democráticos e sociais implícitos na nova arquitetura, entre seus princípios racionais e funcionalistas e as preocupações de autopropaganda, de exibição de força, o gosto do suntuoso e da riqueza para impressionar os responsáveis pela ditadura, simbolizada, talvez então, pelo 'brio' às vezes excessivo e as formas gratuitas que se tornaram moda." Mário Pedrosa. Arquitetura Moderna no Brasil. In: Xavier, Alberto (org.). Depoimento de uma Geração. Arquitetura Moderna Brasileira. São Paulo: Cosac \& Naify, 2003, p. 100-101.Texto 
introdutório à exposição Arquitetura Brasileira Contemporânea, Museu de Arte Moderna de Paris, 1953.

44 Speer, Albert. Spandauer Tagebücher. Frankfurt, 1975, p. 262. apud: Pehnt, Wolfgang. Deutsche Architektur seit 1900. op. cit. p. 222.

45 Pehnt, Wolfgang. Deutsche Architektur seit 1900. op. cit. p. 222.

46 Mais surpreendente ainda, parece ser o fato de que, ainda hoje, arquitetos como Eiermann, que mergulharam na construção industrial como um ato de sobrevivência, serem louvados pela crítica por não terem se submetidos ao tom reinante do gosto nazista, como fica claro na colocação de Gerhard Kabierske: o arquiteto teria obtido sucesso como arquiteto autônomo durante os anos do Nacional socialismo "quase sem reverência ao gosto oficial", ou então, que suas obras seriam "menos resignadas”.Kabierske, Gerhard. Egon Eiermann als Lehrer. In: Jaeggi, Annemarie (org.). Egon Eiermann (1904-1970): die Kontinuität der Moderne. op. cit, p. 40- 41.

47 Leitl, Alfons. Anmerkungen zur Zeit. Baukunst und Werkform n. 1, ano 2, 1949, p. 3. O termo Gleischschaltung, traduzida aqui por coordenação, é um termo que provém da eletrônica e significa coordenação, sincronização, e também uniformização. No Terceiro Reich foi utilizada para remeter à pretendida unidade central, tanto política quanto cultural.

A cor marrom faz alusão ao Nazismo; era a cor utilizada pelo partido, inclusive em seu uniforme.

48 Herbert Rimpl foi colaborador bastante próximo de Mies van der Rohe entre final dos anos 1920 e início dos 1930.

49 Hermann Göring foi um militar alemão e uma das principais figuras dentro do III Reich. O Reichswerke Hermann Göring, um consórcio industrial de siderurgia e para exploração de minério, diversificou-se mais tarde na indústria militar e desenvolveu-se como um gigante estatal.

50 Fundada por Fritz Todt em 1938, Ministro de Armamento e Produção de Guerra durante o III Reich, a Organização Todt era responsável pela construção de infraestruturas militares. Uma de suas maiores obras foi a Muralha do Atlântico. 


\section{ARQUITETURA EM CRISE}

No final dos anos 1920, a Arquitetura Moderna não desfrutava de modo algum de uma pretendida unanimidade, como conhecidos historiadores tentaram inculcar, ${ }^{1}$ nem nunca deixou de ser apenas uma minoria (pelo menos até o final da Segunda Guerra) de esquerda (teoricamente), combativa, corporativa e muito, muito panfletária. Atitude que talvez ajude a explicar a rápida projeção desta arquitetura, apesar de ser restrita a um pequeno círculo de arquitetos.

Nestes anos a Arquitetura Moderna já gozava de grande notoriedade e ganhava imensa projeção junto à imprensa a partir de algumas de suas últimas realizações. Entretanto, era difícil fazer um balanço do real alcance e avanço daquela arquitetura e, até que ponto havia de fato conquistado seu espaço na sociedade.

Os arquitetos modernos mostravam-se incansáveis defensores de sua causa promoviam encontros, palestras, exposições, publicações, e organizavam-se em agremiações, desde menores como Der Ring, Der Blaue Reiter, até a maior delas, o CIAM (Congresso Internacional de Arquitetura Moderna), fundado em $1928 \mathrm{e}$ que mostra o alcance internacional daquela arquitetura. Apesar de suas grandes diferenças internas, de posturas, estilos, visão social e política, externamente ela guardava uma pretensa coesão, se assumia em "bloco", como melhor demonstra o CIAM.

As conquistas dos últimos anos haviam sido muitas e, algumas, de grande envergadura: a concepção do internacional e aclamado Siedlung Weissenhof em 1927,2 a representação oficial do país na Exposição Mundial de Barcelona em 1929 (com o célebre pavilhão de Mies van der Rohe), ou então na representação do Deutscher Werkbund na Exposição da Société des Artistes Décorateurs em Paris em 1930. A contar com algumas publicações da época, a arquitetura moderna já havia dominado todos os setores da construção; a vida e o mundo eram modernos.

Mas ao mesmo tempo em que colecionavam importantes conquistas, viam-se, mais do que nunca, cercados pelos crescentes contra-ataques da ala conservadora, que utilizava-se dos mesmos meios dos modernos: reuniam-se em agremiações, até mesmo internacionais, promoviam contra-demonstrações à la Weissenhof e publicavam livros e manifestos. E mais importante que isto, a Arquitetura Moderna já começava nestes anos a colecionar críticas internas, que acenavam para a inadequação de algumas propostas e para sua possível estagnação em dogmas, como melhor demonstra o projeto do Siedlung Dammerstock em Karlsruhe. 


\section{GRUPO JUNGER ARCHITEKTEN}

Não eram poucos os que acreditavam que os trompetes que entoavam $A$ Vitória do Novo Estilo de Construção ${ }^{3}$ haviam sido enunciados cedo demais. Vozes críticas surgiam até mesmo das gerações mais jovens de arquitetos, de quem se espera maior deslumbramento frente à nova "era técnica" que se anunciava. Até mesmo ali, a nova arquitetura já encontrava contestadores, que imaginavam e queriam que o futuro tivesse outro aspecto que aquele imaginado por Walter Gropius. ${ }^{4}$

Estes arquitetos, reunidos no grupo Junger Architekten, ${ }^{5}$ eram em sua maioria alunos de Hans Poelzig na Universidade de Berlim-Charlottenburg. Entre eles, estavam o próprio Julius Posener e Egon Eiermann, colegas de estudo. Posener diz que, naquela época - meados dos anos 1920 - esses jovens arquitetos tinham outra visão do que havia ocorrido e ao que hoje é apresentado: "Algo assim é mostrado: Bauhaus e Werkbund conduziram a renovação da arquitetura; uma nova arquitetura, que nós ainda hoje, depois de mais de cinquenta anos, admiramos, estava naquele instante se impondo, então abrem-se as cortinas." E questiona: "Foi totalmente assim? Nós naquele tempo jovens tínhamos outra coisa na lembrança?"6

O que condenavam era este certo diletantismo, toda a teoria por trás da Arquitetura Moderna que era, para eles, em último caso, somente pretexto para uma nova forma; contestavam "nem tanto, seu funcionalismo que não funcionava. Mais ainda que ele era um pretexto [...] um pretexto para uma nova forma. Nem tanto, que os novos edifícios eram comumentemente mal construídos. Isso foi o ponto principal da crítica nazista; e ela não era injustificada. Nossa crítica ia adiante, era mais geral. Nós achávamos que não se pode confundir impunemente a Arquitetura com Técnica, Sociologia, Higiene, Biologia e disciplinas similares não arquitetônicas". ' E continua, que viam em todo lugar problemas mal colocados e respostas que não os convenciam porque os resultados eram tão semelhantes, pareciam compromissados com um conceito formal tão forte, "que o problema colocado seria apenas e novamente 'pretexto"'.

Esses jovens assumiam uma posição crítica e contestadora frente à arquitetura da época; a aceitação cega e acrítica de todos os seus pressupostos parecia inaceitável. Contestavam a doutrina e a propaganda, a balbúrdia que cercava o Movimento, segundo eles, um exagero; opinião que muitos arquitetos compartilhavam. Achavam que todo este panfletismo e teorização eram apenas um meio de vencer o abismo que se fez entre o costume e então propalada "era técnica". E contradizem os arquitetos que achavam que poderiam encontrar tão prematuramente a forma característica desta "era técnica"; eles estariam enganados ao pensarem que já teriam encontrado esta forma: “foi rápido demais". ${ }^{9}$ E Posener completa que, neste 
desejo, esses arquitetos teriam abandonado o trabalho manual do arquiteto: "nós éramos da opinião, que os costumes mereçam observação do arquiteto. Nós nos voltávamos para Heinrich Tessenow, que sabia mais como as pequenas pessoas deveriam viver - e como elas queriam viver - do que vinte Arquitetos-sociólogos de 'meia tigela"'. ${ }^{10} \mathrm{E}$ consideravam que o arquiteto deveria, em primeiro lugar, conhecer o processo e as condições da construção - que julgavam ser ainda de trabalho manual - e pensar em todas as particularidades de uma obra: janela, degraus, corrimão, exigência que estariam, segundo Posener, presentes na obra do colega Eiermann. Em outras palavras, reivindicavam uma casa e não uma máquina de morar, ou então como Posener salienta em artigo homônimo, uma cadeira e não uma máquina de sentar. ${ }^{11}$

\section{CONTRA MANIFESTOS}

Assim também pensavam arquitetos tradicionalistas como Paul Bonatz, Bestelmeyer, Paul Schmitthenner e Paul Schultze-Naumburg, que fundam, com

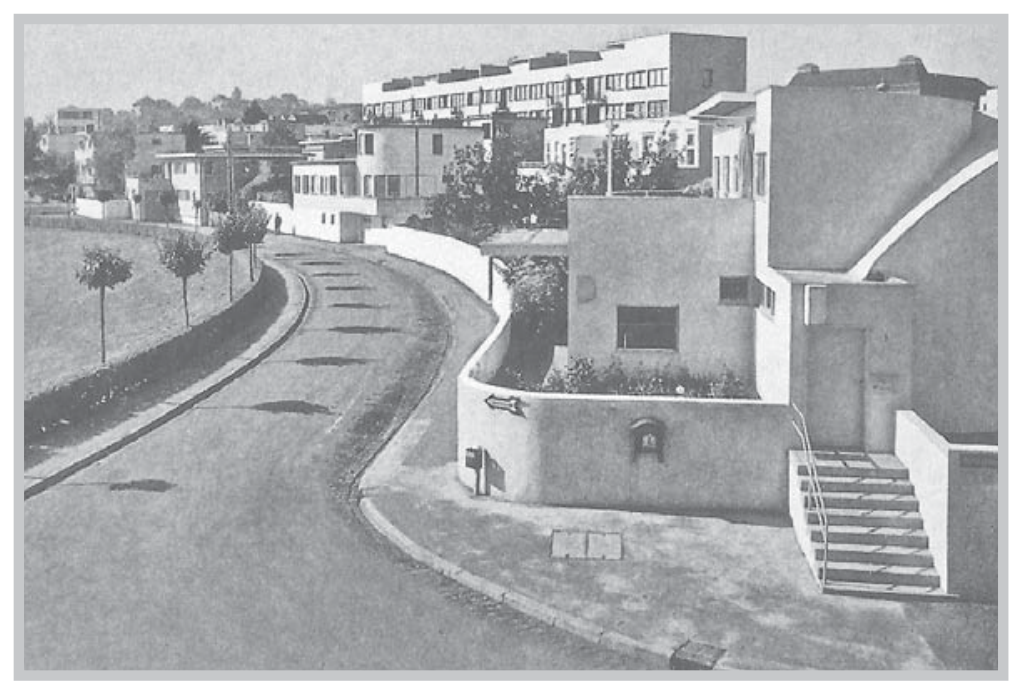

Fig. 1 - Mies ban der Rohe (coordenação). Siedlung Weissenhof (1927). Stuttgart. Cartão postal de 1930

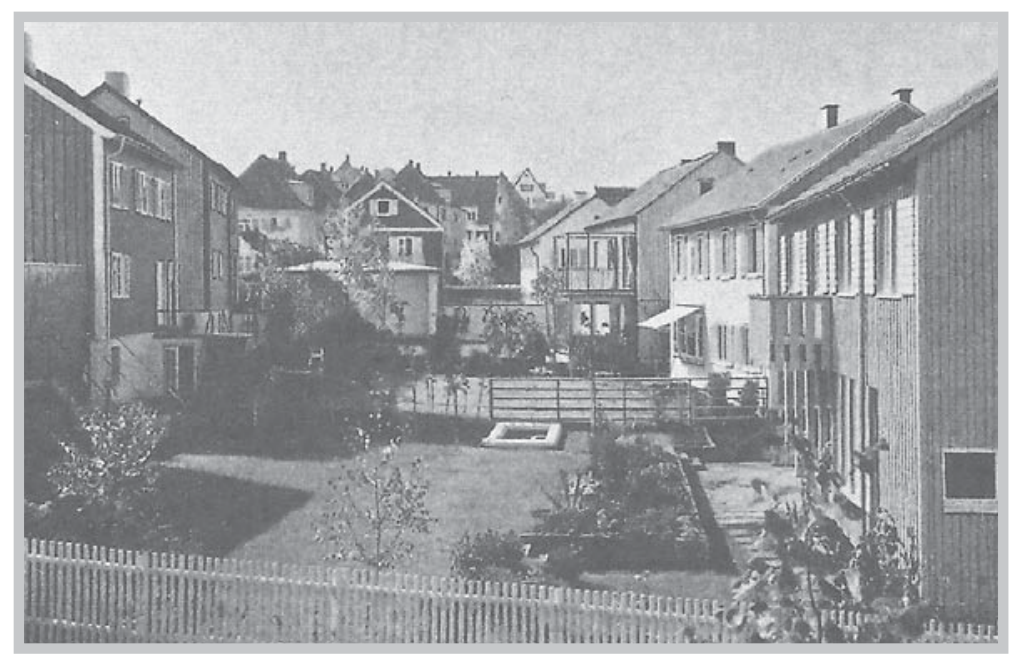

Fig. 2 - Paul Schmitthenner (coordenação). Siedlung Kochenhof. Stuttgart. 1928-1933. outros colegas, em junho de 1928 (no mesmo período, aliás, em que arquitetos do CIAM reuniam-se no Castelo de La Sarraz, na Suíça) o grupo Der Block - em alusão e oposição ao vanguardista Der Ring. Através de seu manifesto publicado, afirmam-se "ligados à sua concepção de cultura”, ideia que conferia a expressão em suas obras. E apesar de acreditarem numa própria expressão da arquitetura daquele tempo, consideram a "concepção de vida do próprio povo e da natureza do país", sem negligenciar o que já fora herdado e o que já havido sido alcançado. Por fim, em um recado mais direto aos modernos, estes arquitetos refutariam "uma publicidade demasiada precipitada por uma produção de acordo com a moda, que põem em risco um desenvolvimento saudável."12 
A sua "ligação à cultura" seria exemplificada poucos anos mais tarde no Siedlung Kochenhof (1928-1933) em Stuttgart, um contra manifesto ao vizinho e ilustre Siedlung Weissenhof (1927). Sob a coordenação de Schmitthenner, à experimentação e ao caráter de novidadedesteécontrapostaànoção de moradia tradicional, construída com a velha e conhecida madeira. À internacionalidade do Weissenhof é contraposta o projeto somente a partir de arquitetos locais; às novas formas de morar, casas e plantas baixas tradicionais; à disposição irregular do planejamento urbano, a composição mais retilínea e habitual. Se no Weissenhof a única prescrição foi a construção de coberturas planas, no outro, foram os telhados com 35 graus de inclinação.

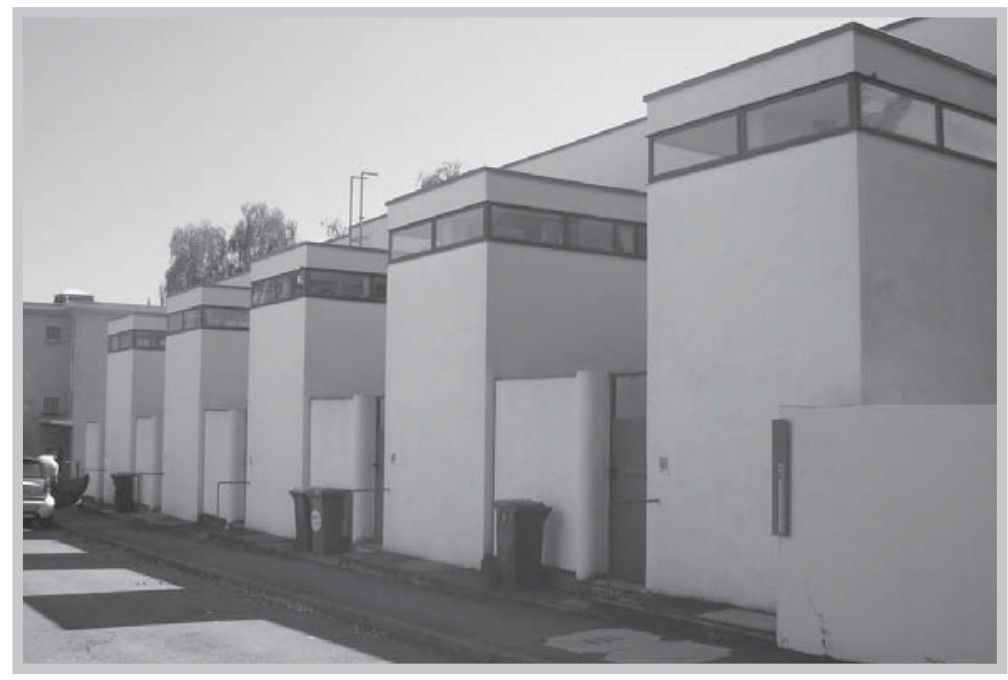

Fig. 3 - J. J. Pieter Oud. Casas em fita no Siedlung Weissenhof. Stuttgart. 1927.

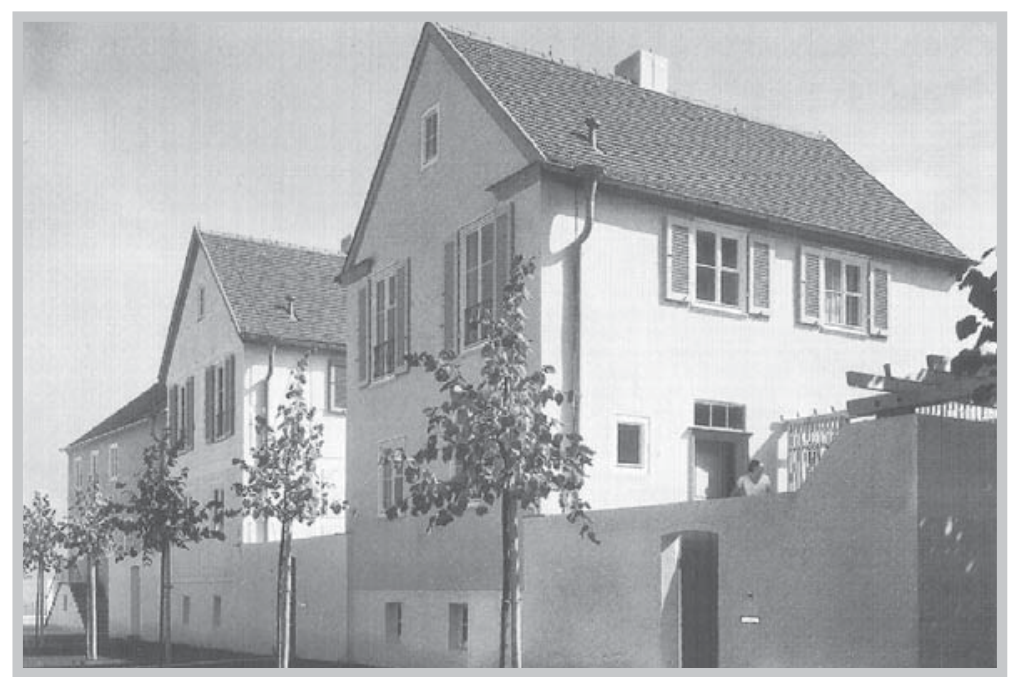

Fig. 4 - Paul Schmitthenner. Casas no Siedlung Kochenhof. Stuttgart. 1933.

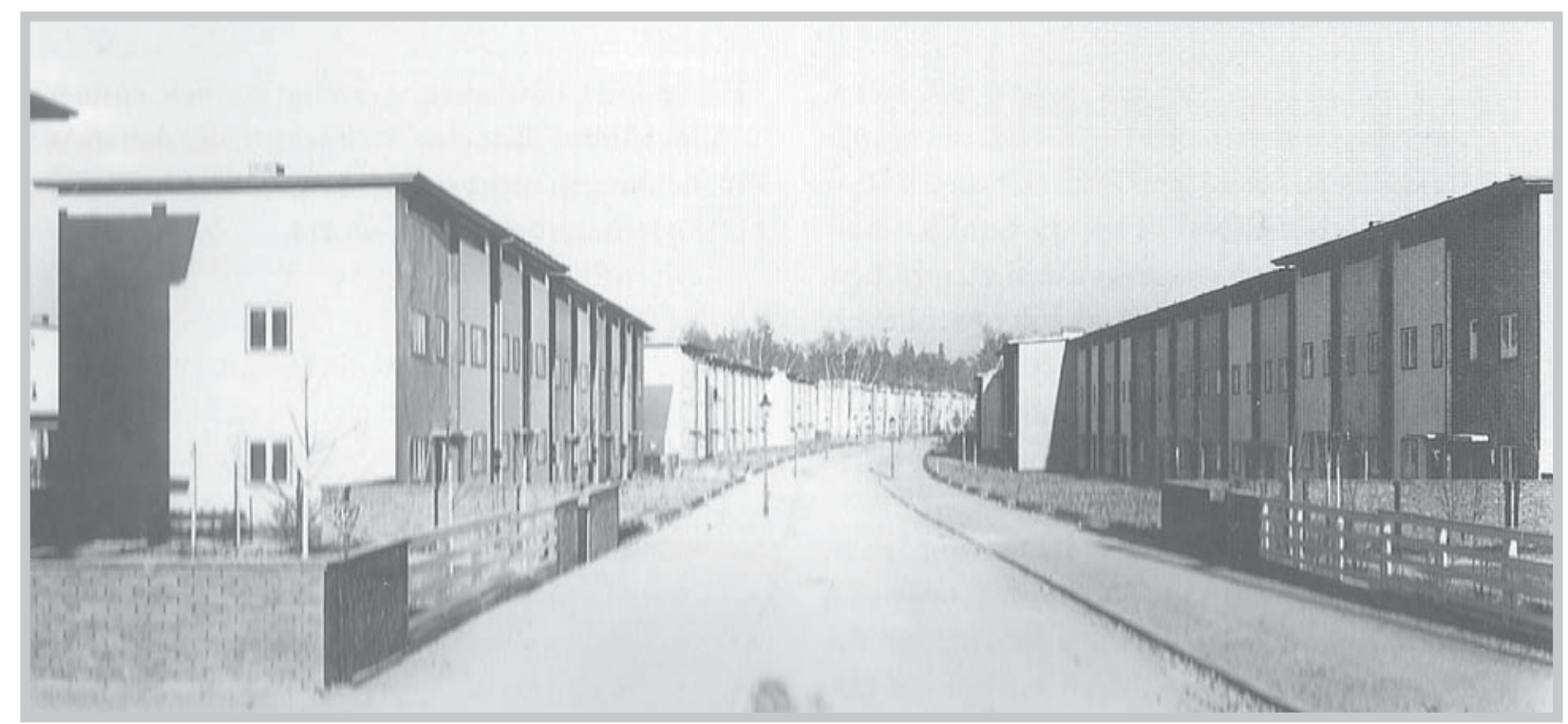

Fig. 5 - Bruno Taut, Martin Wagner. Siedlung "Onkle Tom“. Berlim. 1926-1931. 


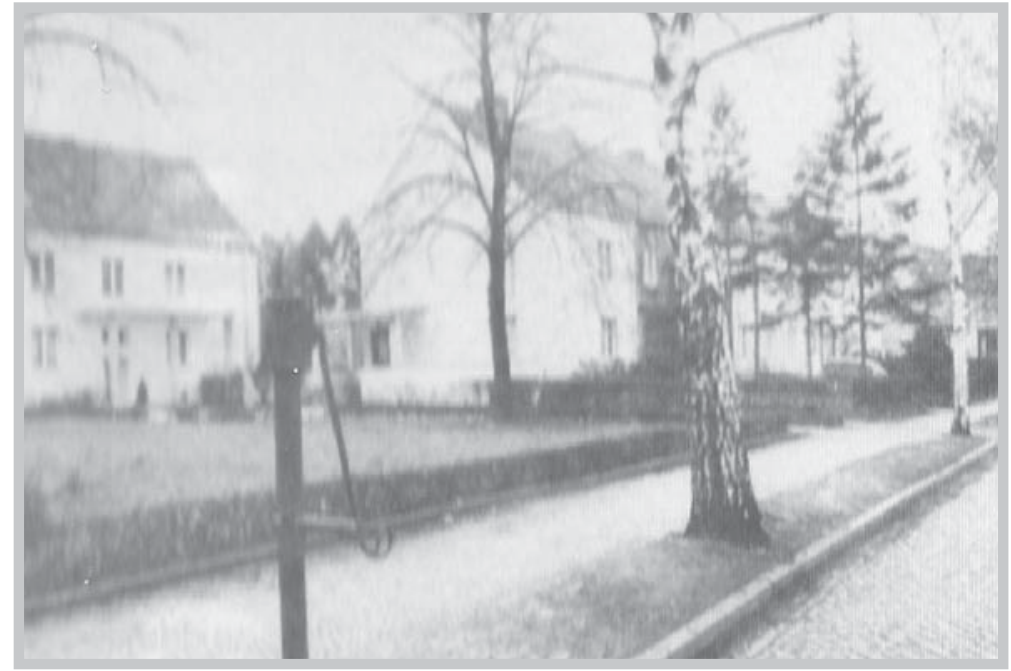

Fig. 6 - Heinrich Tessenow (coordenação). Siedlung Am Fischtal. Berlim. 1927-1929.

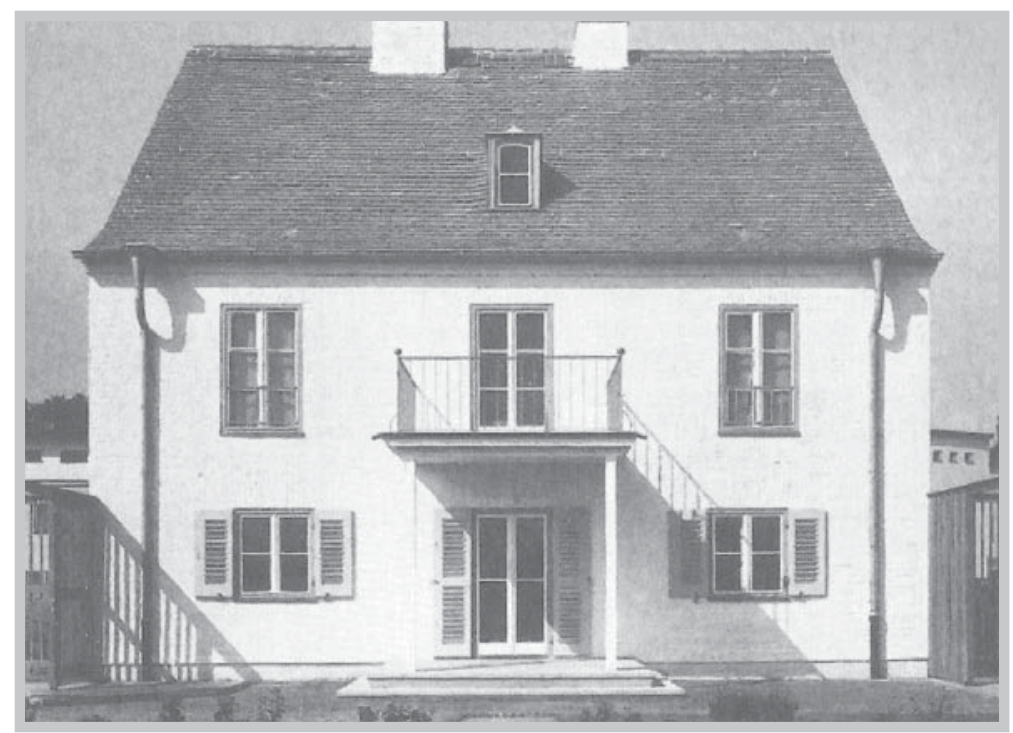

Fig. 7 - Paul Schmitthenner. Residência no Siedlung Am Fischtal. Berlim. 1928-1929.

O Siedlung Kochenhof foi saudado na imprensa como contra modelo ao Weissenhof, considerado, inclusive no exterior, como uma amostra implementada pelo novo governo no país ${ }^{13}$ - noção errônea, pois que ele já vinha sendo planejado há alguns anos, entre vários contratempos que atrasaram sua construção. Certamente o novo governo deu o aval que faltava para a sua realização.

Situação idêntica havia ocorrido poucos anos antes em Berlim. O Siedlung Am Fischtal (1927-29) foi construído como uma clara afronta ao Siedlung "Onkle Tom" (1926-1931) de Bruno Taut; e isso já em 1927. A reação ao moderno teria começado, portanto, bem antes do que se imagina ou noticia. Construído junto a um bairro de classe média, o conjunto habitacional para operários não era ali bem-vindo. Como contraponto foi construído as suas margens o Siedlung Am Fischtal com seus pronunciados telhados inclinados, que deveriam obstruir a visão para o infame conjunto de tetos planos de Taut. E ali não construíram somente "ferozes" opositores do moderno como Schmitthenner, mas também Tessenow, Paul Mebes, Alexander Klein e Hans Poelzig.

\section{O Tradicional e o Monumental}

Ainda em seu artigo, Posener coloca que não sabiam ao certo se esta arquitetura mais tradicional era um avanço ou um retrocesso. ${ }^{14}$ Mas hoje percebem que também ela teria aberto caminho para o Terceiro Reich - apesar de Klein, Tessenow e Poelzig estarem entre os arquitetos que ali construíram - pois também essa arquitetura figuraria nos almanaques do Terceiro Reich, como exemplo de arquitetura que resgataria a "verdadeira" cultura alemã. Quando o Nazismo 
chega ao poder, faz também sua esta arquitetura tradicional de arquitetos que não comungavam, necessariamente, dos ideais do partido.

Alguns destes arquitetos tidos como Tradicionalistas (a exceção de Klein e Poelzig neste caso) seriam absorvidos pelo Regime, na representação oficial das pequenas obras, ${ }^{15}$ e encontrariam trabalho durante os anos 1930.

Grosso modo, podemos diferenciar três grupos de arquitetos e estilos arquitetônicos que coexistiam na Alemanha em fins dos anos 1920: no "pelotão" da frente dois grupos - os combatentes (e agora, mais do que nunca, combatidos) pioneiros da Arquitetura Moderna: Walter Gropius, Mies van der Rohe, Ernst May, Adolf Meyer e seus colegas, que conseguiam neste momento grandes realizações, como o internacional Weissenhofsiedlung, e a representação nacional na Exposição Mundial de Barcelona; os arquitetos do Heimatschutzstil, ${ }^{16}$ agora igualmente combativos, mobilizavam-se contra a "desmoralização" e contra uma cultura não alemã; também pode ser chamados Nacionalistas, pois partem de pressupostos tradicionalistas mas são ferozes defensores de uma cultura alemã como Paul Schmitthenner e Paul Schultze-Naumburg. Entre estes dois grupos, figuram arquitetos tradicionalistas como Heinrich Tessenow e Paul Bonatz, que prezam por uma arquitetura mais limpa e clara, também nas obras monumentais, sem tanto saudosismo como um Schmitthenner; mas o cultivo de uma estética pequeno-burguesa, com grandes planos de telhado, volumetria típica, afora a adoração pelo trabalho manual, os deixavam nas antípodas dos modernos. ${ }^{17}$

Nas contra demonstrações, como no Siedlung Kochenhof e Am Fischtal, encontramos arquitetos tanto do segundo, quanto do terceiro grupo. Posener coloca que viam nisso o embate dos "avós" contra os "pais" da Arquitetura Moderna: os "avós" defrontavam-se com a nova arquitetura de maneira céptica, assim como eram cépticos em relação à "nova-velha" arquitetura, que recentemente surgia, e em relação a um Schmitthenner" ${ }^{18} \mathrm{E}$ os jovens arquitetos estavam mais para o lado dos avós do que dos pais do moderno, na defesa de um Poelzig e não de um Mies.

Posener diz que graças a Poelzig eles também mantiveram este cepticismo em relação à nova arquitetura e um grande cepticismo em relação à obra Nazi. E achavam o "front" falso: tanto Bauhaus quanto Schmitthenner. Queriam uma nova arquitetura e tanto a Bauhaus quanto Schmitthenner lhes pareciam enganosos; estavam à procura de um "terceiro caminho."19 $\mathrm{E}$ aponta para a arquitetura escandinava, que nos anos 1930 desenvolveu uma arte do espaço e dos móveis que se pode chamar de um terceiro caminho" ${ }^{20}$ ou que, ao menos, aponta para uma outra direção. 
De qualquer forma, é interessante notar que muitos dos arquitetos modernos saíram dos bancos escolares onde estes arquitetos "tradicionalistas" lecionavam e não de escolas modernas como a Bauhaus. Quem, como estudante, quisesse trilhar um caminho sólido e seguro, e assegurar a escolha da formação "correta", tomava o rumo para escolas como a Technische Hochschule de Stuttgart ou a de Weimar, onde Paul Schultze-Naumburg lecionava, ${ }^{21}$ bem como para Berlin-Charlottenburg, onde Tessenow tinha grande reputação. De todos os centros de formação de arquitetos, os dois primeiros eram os que concentravam o maior número de estudantes em 1939. ${ }^{22}$ Theodor Fischer, considerado um dos grandes construtores alemães, cujas obras não figuram nos quadros do moderno, ajudou a formar toda uma geração de arquitetos, nas escolas de Stuttgart e Munique: Dominikus Böhm, Hugo Häring, Ernst May, Erich Mendelsohn, J.J. Pieder Oud, Wilhelm Riphahn, Bruno Taut são alguns dos arquitetos que passaram por suas mãos. ${ }^{23}$

Nas principais escolas de arquitetura do país eram estas figuras mais "conservadoras" que dominavam. Theodor Fischer e German Bestelmeyer

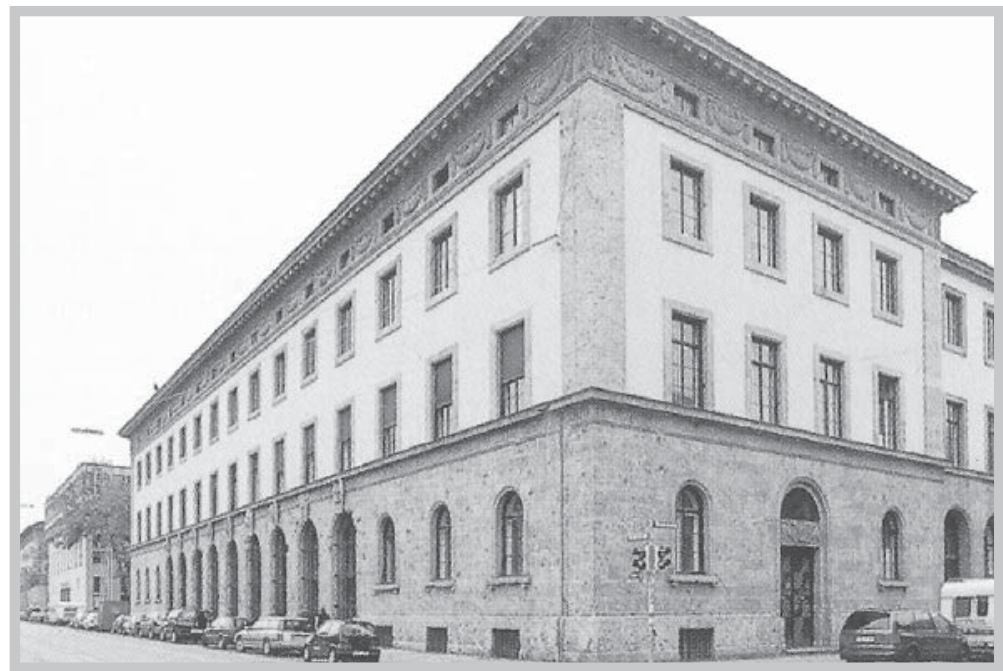

Fig. 8 - German Bestelmeyer. Ampliação da Universidade Técnica de Munique. 1926.

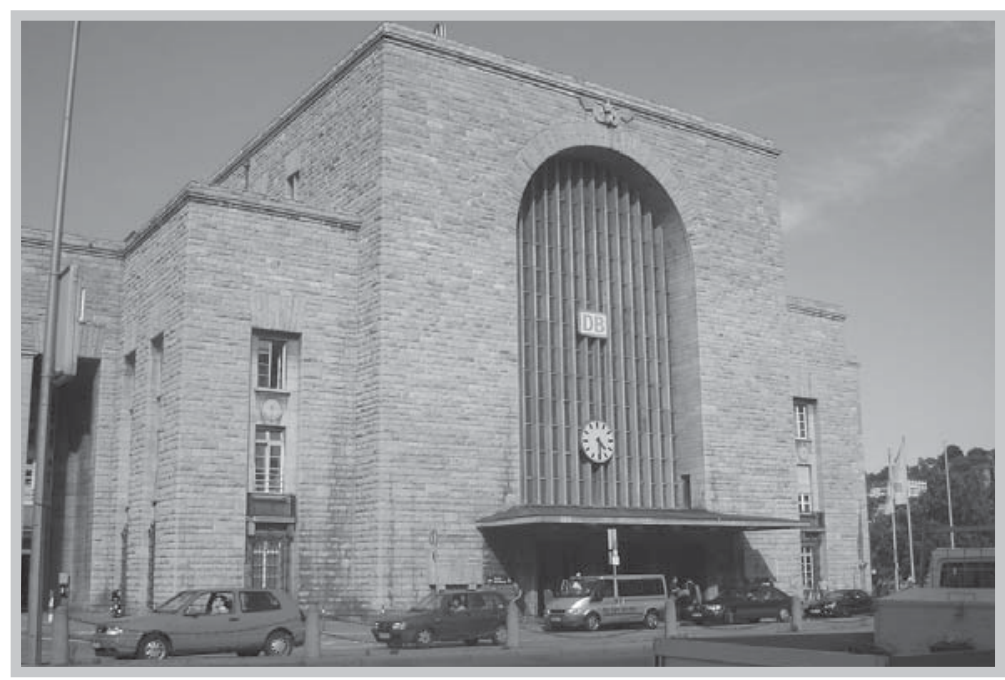

Fig. 9 - Paul Bonatz. Estação Central. Stuttgart. 1913-1927. eram influentes professores na Universidade Técnica de Munique e igualmente influentes arquitetos na Bavária, não somente por suas obras, mas também por seus escritos. Paul Bonatz e Paul Schmitthenner eram as principais figuras em Stuttgart, assim como Hans Poelzig (talvez o mais moderno dentre estes) e Heinrich Tessenow dominavam em BerlinCharlottenburg. Estas duas últimas escolas formavam mais arquitetos do que Walter Gropius e seus sucessores Hannes Meyer e Mies van der Rohe na pequena Bauhaus, que contava anualmente no máximo 200 alunos e, entre 1919-1933 somara algo em torno de 1200 a 1300 alunos. ${ }^{24}$ Além disso, havia figuras muito atuantes como Fritz Höger, que dominava no norte do país, e Fritz Schumacher, arquiteto-chefe em Hamburgo. 
Tais nomes fazem parte de uma geração de notórios arquitetos e construtores que não se lançaram às cegas em direção à Neues Bauen, que se mantinham mais reservados em suas escolhas e buscavam inspiração na tradição, no contexto, e seguiam uma linha mais autônoma em seu trabalho. Acreditavam mais em sua própria experiência tanto quanto ainda no trabalho manual, e conferiam avanços em suas obras sem deixar de prestar atenção nos hábitos e costumes das pessoas, para quem o mundo desejado pelas vanguardas ainda era um mundo estranho. Exemplo desta liberdade projetual que reivindicavam para si, é o fato de Poelzig ter construído tanto no Siedlung Weissenhof, como no seu oponente Kochenhof.

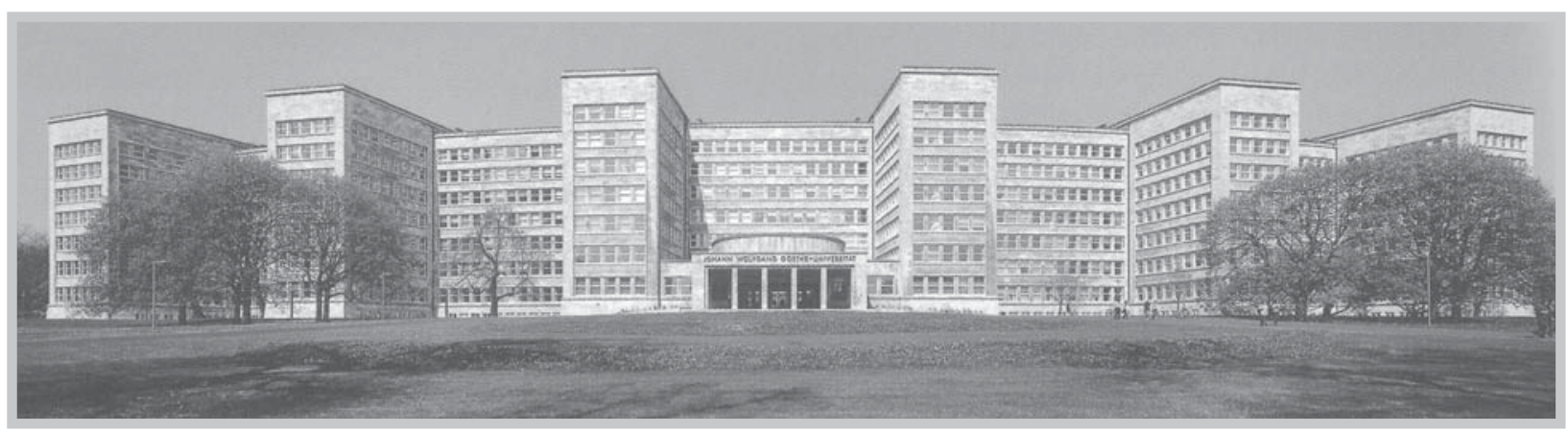

Fig. 10 - Hans Poelzig. Edifício Administrativo da IG-Farben. Frankfurt. 1928-1932.

O tom principal de algumas obras é dado pela monumentalidade e a massa construída de um modo objetivo (sachlich), claro, límpido e funcional. Hans Poelzig tem uma obra genial que é definida dentro destes termos. Mesclando obras que vão do Expressionismo à Neue Sachlichkeit (assim entendidos pelo menos na época), para Poelzig arquitetura é massa construída, é força e pujança plástica surgida do arranjamento das massas. Em seu colossal projeto para o Edifício Administrativo da IG-Farben (1928-32) em Frankfurt - um edifício levemente arredondado e dentado com $250 \mathrm{~m}$ de comprimento, construído em estrutura metálica - prevalece o desejo pela representatividade, traduzida em uma monumentalidade imponente.

Nãoque esta arquitetura monumentale, porvezes, mais tradicional, tivesse sidobanida anteriormente; ao contrário, ela sempre sobreviveu. Desde a unificação do Império em 1871 até a Primeira Guerra, o que se via era a monumentalidade Guilhermina, assim como nos primeiros anos do século XX uma monumentalidade classicizante, da qual a Fábrica de Turbinas da AEG de Behrens é exemplo. A partir de meados dos anos 1920 ela ressurge mais "moderna", adotando contornos mais limpos e claros, mas utilizando-se ainda de alguns critérios clássicos de composição como a simetria. Alguns arquitetos ainda se permitiam adornos, como entablamentos horizontais, decorações aplicadas junto aos acessos principais, esculturas e fontes, revestidas em pedras e mármores. É o moderno com reservas, que não se lança cegamente aos 


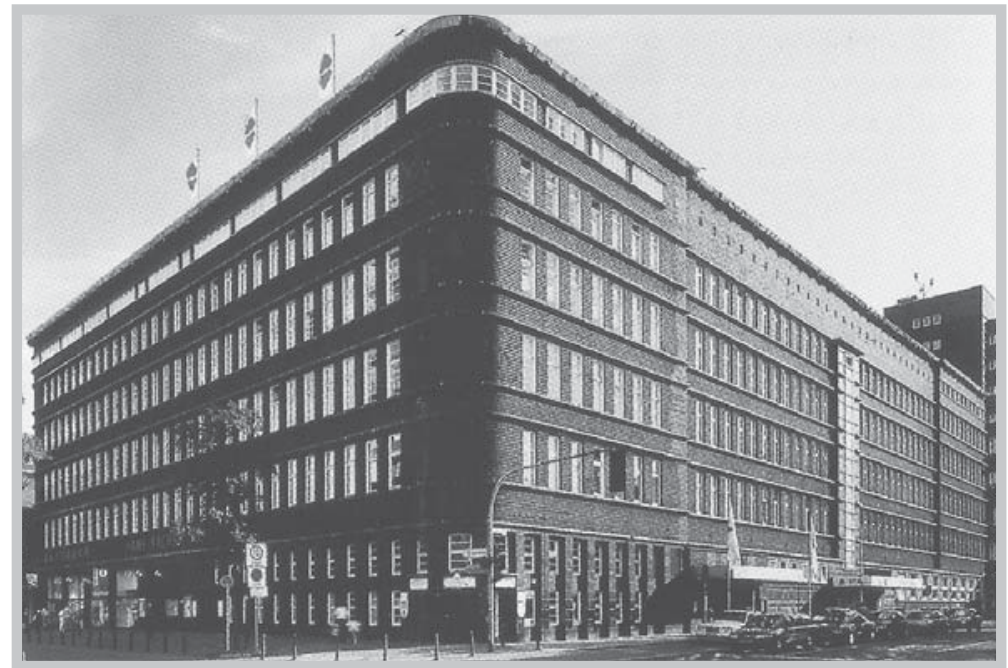

Fig. 11 - Alfred Fischer. Hans-Schachs-haus. Gelsenkirchen. 1924-1927.

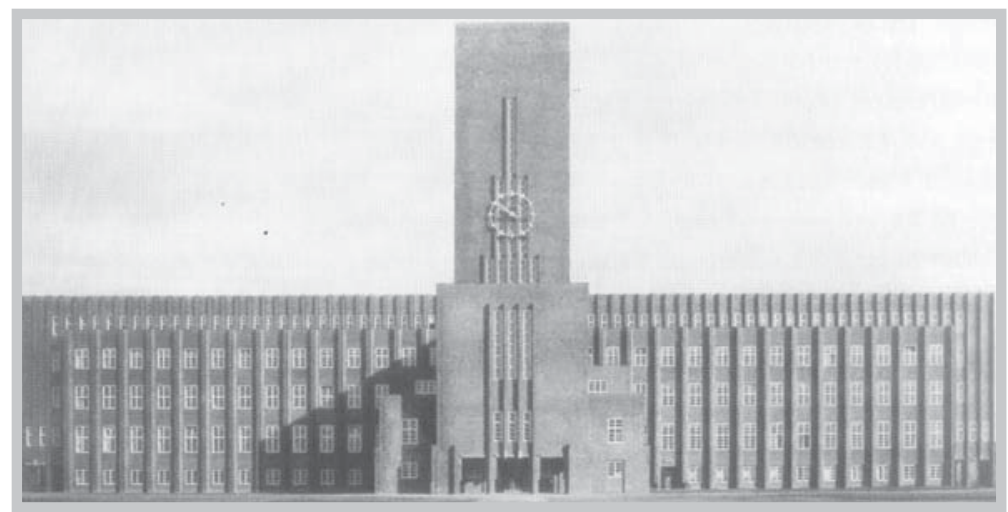

Fig. 12 - Fritz Höger. Prefeitura. Wilhelmshaven-Rüstringen. 1927-1929. pressupostos vanguardistas, mas que é conscientemente e deliberadamente contemporâneo. Esta monumentalidade também era vista nas grandes indústrias, que não economizavam nos recursos modernos: disposição racional dos setores, flexibilidade dosespaços, uso de estrutura metálica desmontável. Também nas construções de infraestrutura como torres de caixa d'água, subestações elétricas, obras em represas, o que também se via era o desejo de unir uma construção técnica e claramente funcional à noção de "composição" arquitetônica.

Entretanto, ahistoriografia "oficial” do Movimento Moderno, limitouse a retratar obras monumentais e com alusão ao clássico, como a Fábrica de Turbinas da AEG de Behrens, somente como uma "preparação" para o triunfo moderno, e não vistas dentro de uma tradição construtiva, autônoma dentro da arquitetura, que existiu antes e continuou existindo, apesar dos modernos (para então voltar à cena nos anos 1930). A Fábrica de Behrens é muitas vezes retratada como uma obra "ainda" não moderna, que peca pela alusão clássica e pelos lapsos conservadores, ainda mais quando comparada à obra de dois anos mais tarde do antigo aprendiz Gropius, a Fagus Werke, arquitetura revolucionária para sua época. ${ }^{25}$

\section{FRAGILIDADES INTERNAS}

Com vozes críticas advindas dos opositores, os arquitetos modernos já estavam bastante familiarizados, o que faz parte da rotina de um movimento combativo ao atentar contra a ordem firmada. O problema é quando estas mesmas vozes críticas começam a surgir dentre seus próprios simpatizantes. O Siedlung Dammerstock (1928-1929) em Karlsruhe se constituiu em um dos principais deflagradores de críticas dentro do Movimento Moderno. Com planejamento de Walter Gropius - que havia deixado há pouco tempo a direção da Bauhaus - e 
Otto Haesler, Dammerstock se traduz em um esquema rigoroso de habitações em linhas paralelas entre si, dispostas na direção norte-sul, com parte noturna voltada a leste e diurna a oeste. Também aqui alguns itens foram prescritos para os arquitetos que assumiram os projetos: coberturas planas, formato das janelas, e a utilização de reboco liso nas fachadas.

Dammerstock foi calorosamente discutido junto à imprensa na época de sua construção. E suscitou inúmeras controvérsias, como as que levanta Adolf Behne, um dos principais teóricos alemães acerca da Neues Bauen, que denominou a demasiada rigidez do conjunto e das habitações, onde tudo parece ser prescrito, de Wohndiät (Dieta da moradia), na qual o "homem acaba [...] se tornando um conceito, um personagem." $26 \mathrm{E}$ diz, ironicamente: "o homem deve, ao menos junto aos arquitetos sensatos, a leste ir para a cama, a oeste comer e responder as cartas da mãe, e a moradia é assim tão organizada, que ele não pode fazer absolutamente nada diferente."27

O princípio da igualdade a todo custo, o que a construção em fita se propõe - mesma distância entre os edifícios, de modo que a todos os moradores correspondam frações iguais de ar, luz, vegetação, enfim, o princípio da democracia expresso na construção - estava "se tornando um dogma, um formalismo que se alastra sob a máscara da ciência." ${ }^{28} \mathrm{E}$ sua crítica vai ao encontro do que já contestavam os Junger Architekten: "O arquiteto é hoje, mais higienista do que o Higienista, mais sociólogo, que o Sociólogo, mais estatístico que o Estatístico e mais biólogo que o Biólogo. Ele esquece frequentemente, porém, que higiene, estatística, biologia e sociologia somente tem valor, quando eles não devoram o espaço de morar..." 29

O exaltado mundo da técnica e da racionalidade, que se espelhava na máquina, em aviões

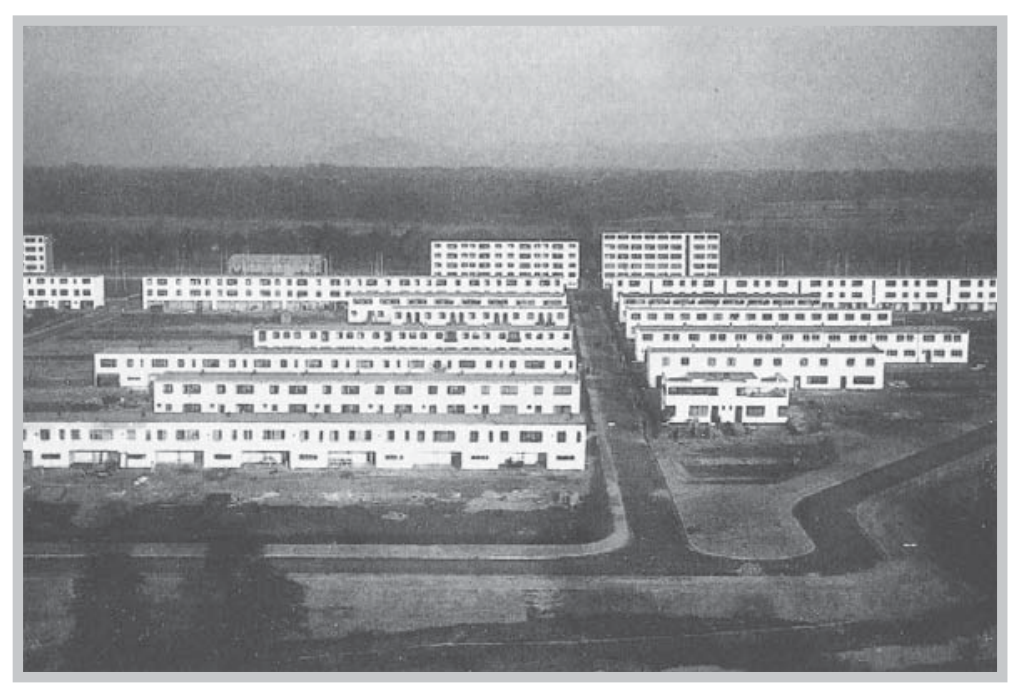

Fig. 13 - Walter Gropius, Otto Haesler (Planejamento). Siedlung Dammerstock. Karlsruhe. 1928-1929.

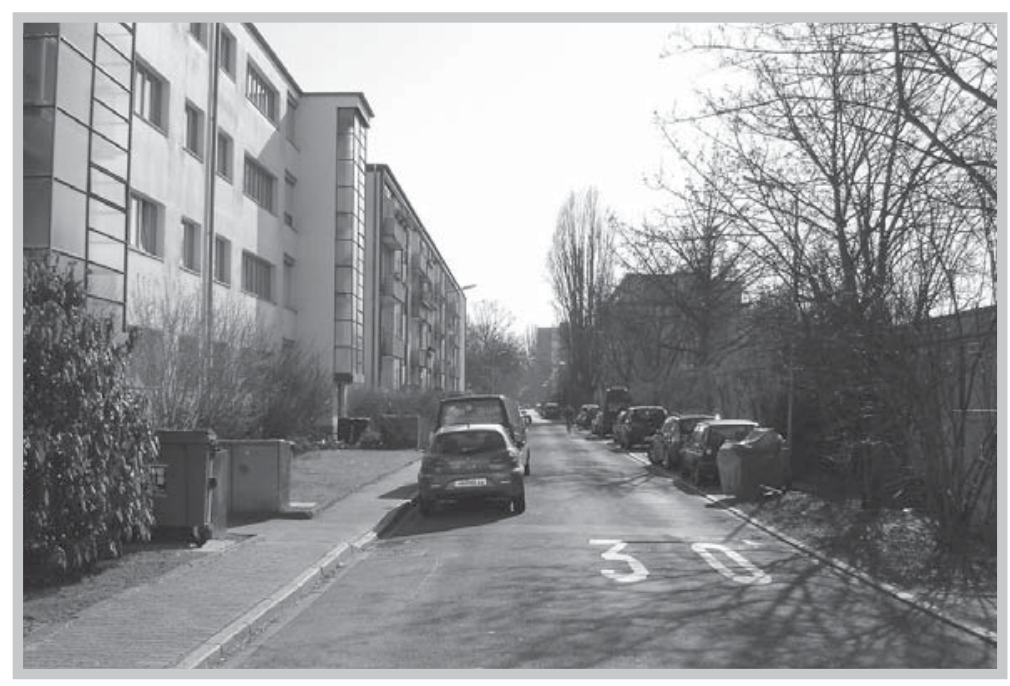

Fig. 14 - Walter Gropius, Otto Haesler (Planejamento). Siedlung Dammerstock. Karlsruhe. 1928-1929. 
e em automóveis, parecia estar perdendo sua força motivadora e o espírito revolucionário para entrar em outro - de amarras. Como ressalta Pehnt, o que críticos como Adolf Behne e também Alexander Schwab temiam, era a prematura estagnação da Arquitetura Moderna em dogmas: "Aqui é provavelmente o ponto, a partir do qual se deve explicar a resistência de outros setores, agora também da massa trabalhadora contra a Arquitetura Moderna. [...] Resistência [...] surge a partir de um desejo inconsciente por uma racionalidade completa, que conheça, reconheça e satisfaça também as necessidades sociais e espirituais." ${ }^{30}$

Também Mies van der Rohe, através de sua proposta para a Deutsche Bauausstellung de 1931, manifestava a cristalização de alguns ideais que se mostravam inaceitáveis para o momento. Nesta exposição, em que o foco era a construção e organização de pequenas habitações, Mies propõe uma casa com pátio - uma aproximação conceitual e estética ao seu projeto para a Exposição Mundial de Barcelona de dois anos antes -, um modelo luxuoso que claramente se afastava do proposto, e com o agravante da crise econômica que fazia cada vez mais drásticas consequências no país. Aos protestos da direita conservadora, que já eram fartos neste período, juntavam-se agora os de arquitetos de esquerda, que se organizam na exposição Proletarische Bauausstellung, que teve lugar em Berlim no mesmo ano.

Mas se questionamentos acerca dos ideais sociais da nova arquitetura sempre estiveram presentes, começam a surgir também questionamentos de origem mais prática, quando os custos das experiências construtivas começaram a aparecer. Principalmente no campo de construção de habitação, os arquitetos modernos estavam sempre dispostos a testarem novos materiais e técnicas construtivas ainda não avaliadas, desde que custos de construção fossem reduzidos.

Tal postura foi politicamente legitimada, quando, em junho de 1927 entra em vigor uma lei que sustentava financeiramente conjuntos habitacionais experimentais, com vistas à sua melhoria e redução de custos. Algumas semanas mais tarde, seria formada a "Sociedade de Pesquisa pela Economia na Construção Civil e Habitação", a RfG, ${ }^{31}$ que iria então sustentar empreendimentos de "alto risco". Entre eles, o próprio Dammerstock, Dessau-Törten, e Weissenhof, mas também inúmeros projetos que não contavam entre os vanguardistas.

Coberturas planas mal construídas e de pouca espessura, problemas com o aquecimento devido às grandes superfícies envidraçadas e uso de vidro simples, isolamento escasso e juntas de dilatação esquecidas, figuravam entre os problemas mais recorrentes. Mas foram os adversários da nova arquitetura que se aproveitavam dessas situações mal sucedidas, e se dedicavam a registrar com afinco cada problema encontrado. Em 1931 foi lançado a Brochura "Pecados Construtivos e Desperdício de Dinheiro na Construção" de Curt R. Vincents, distribuído gratuitamente a 
escritórios, repartições públicas, construtoras e arquitetos, até para a Suíça, e que chegou à nona edição. ${ }^{32}$ Também a crítica nazista iria basear-se largamente nestes fatos, e iria procurar moldar a visão das novas gerações sobre a Arquitetura Moderna apoiando-se, sobretudo, nestas questões. ${ }^{33}$

Nenhum outro item da Neues Bauen foi tão controverso e discutido como a cobertura plana. Em inúmeras publicações da época discutia-se suas vantagens e desvantagens econômicas, construtivas, funcionais. Muthesius parece apreender o real motivo das discussões: "todas estas coisas não tem nada a ver com racionalização, nem com economia, tampouco com necessidade construtiva. Trata-se apenas de problemas formais", ${ }^{34}$ referindo-se ao Weissenhofsiedlung, que para ele, era exemplo de como a nova forma soava "tirana" sobre seus representantes. Sua colocação é importante também na medida em que deixa claro que críticas não provinham apenas daqueles que viam ali o aviltamento de toda cultura e tradição da habitação, mas de um entusiasta defensor da estandardização e normatização dos produtos industriais.

\section{TEMPO DE MUDANÇAS}

Nos últimos anos da República de Weimar o período de agitação e confronto estava aberto. Em um tempo de muita diversidade de pensamento, crise econômica e disputa política, também a arquitetura não ficou ilesa: "São passados os anos, nos quais as atividades simultâneas de temperamentos tão diferentes como Gropius, Kreis, Poelzig ou Tessenow eram vistos pelos observadores bem intencionados como uma disputa frutífera [...]."35

No fim dos anos 1920 Paul Schmitthenner torna-se um dos mais influentes protagonistas de uma organizada e sistemática contra-reação ao Movimento Moderno que tem vez na Alemanha. Em seu livro Das Deutsche Wohnhaus formula o que seria para ele uma arquitetura humana, baseada na tradição, oposta à frieza da Arquitetura Moderna. Contra as palavras de ordem modernistas, formula também as suas: "quente" contra a frieza moderna, individualidade contra a massificação e por fim, a noção de cultura contra a de civilização. Esta seria representada pelo insensível moderno, enquanto aquela, pela Tradição: "de um lado: entendimento calculado, máquina, massa, coletivismo, do outro: sentimento, vida de 'sangue quente', homem, personalidade. A marcha triunfal da técnica ameaça esmagar completamente os campos da Humanidade." 36

O combate e as ofensivas à Arte e à Arquitetura Moderna foram intensificados através da iniciativa política do Partido Nazista. A partir de 1929 formam-se vários grupos no país para atuar nas diversas áreas da cultura e da arte. ${ }^{37}$ Camuflados como independentes politicamente, e apoiados fortemente na propaganda, estes 
grupos atuavam na defesa da tradição e da "cultura alemã" e no combate à "cultura de Weimar". O Kampfbund für deutsche Kultur (KfdK), ${ }^{38}$ fundado em 1928, seria um dos grupos mais influentes, e contaria com representações em várias cidades alemãs. Em apenas dois anos de atividade já havia conseguido até mesmo organização internacional, e contava em 01.01 .1933 seis mil membros divididos em 240 grupos. ${ }^{39}$

Multiplicavam-se nestes anos as ofensivas e as manifestações contra a Arquitetura Moderna. Críticas eram cada vez mais ácidas, e surgiam desde objeções fundamentadas até reações mais agressivas e insultos, em que a nova arquitetura se torna símbolo de um progresso não desejado e algo virulento dentro da sociedade, chegando ao auge com as publicações de caráter racista e preconceituoso de Paul Schultze-Naumburg.

Em Kunst und Rasse (1928) Schultze-Naumburg desenvolve sua tese entre palavras como "degeneração" e "seleção". Liga as atuais tendências da Arte Moderna à sua polêmica tese racista, e antecipa, na teoria o que seriam os campos de concentração e extermínio de anos mais tarde, ao reclamar pela "higiene da raça através de seleção e acasalamento dos mais aptos, saudáveis, bonitos e do extermínio dos incapazes, doentes e feios." ${ }^{\prime 40}$ Àquele binômio se ligaria imediatamente a Arte Moderna, como forma de manifestação "degenerada" e que, portanto, deveria ser eliminada. E para não restar qualquer dúvida quanto à origem repugnante desta arte inculta $\mathrm{e}$ enferma, o autor coloca em seu livro, lado a lado, telas e gravuras modernistas com figuras de pessoas com debilidade física e mental e tenta distinguir, deste modo, o que é bonito e certo, e o que é feio e errado; o culto do inculto.

Assim como as vanguardas após a Revolução de 1918 anunciaram o fim de um tempo e início de outro, os opositores do moderno, já em 1930, indicavam o fim de uma época. Wendepunkt in der moderner Architektur era o tema de uma palestra que Schmitthenner havia proferido na Technische Hochschule BerlimCharlottenburg, que pregava a vitória sobre o novo estilo dos modernistas. ${ }^{41}$

A ênfase de Schmitthenner - bem como a de toda a arquitetura conservadora na arquitetura ligada ao contexto, encontraria ressonância não somente nas altas esferas ou junto aos mais velhos, mas também junto às gerações mais jovens: "Dever-se-ia estar presente e ver com próprios olhos, como a juventude estava presente em ambas as palestras que Paul Schmitthenner proferiu [...], então se sabe que a palavra sobre um ponto de mudança na arte da construção não é nenhuma parola", ${ }^{42}$ informa o jornal Baukultur, órgão veiculador das ideias do Der Block. O que de fato, não deve ter sido difícil, tendo em vista o conservadorismo predominante e a grande abertura que as ideias do partido nazista encontravam 
nas universidades alemãs, seja entre professores ou estudantes. ${ }^{43} \mathrm{E}$ afirma categoricamente: “a nova geração de arquitetos está farto do método sem alma da arquitetura moderna [...]."34

A ambiguidade da época é mostrada pelos próprios eventos que tem lugar na Alemanha: enquanto que em Berlim e em Weimar Schmitthenner proferia a já citada palestra Wendepunkt in der Modernen Architektur (Ponto de Mudança na Arquitetura Moderna) onde decretava o fim de uma época, Mies e seus colegas organizavam a exposição Die Neue Zeit (O Novo Tempo), planejada para 1932 (mas banida em virtude da crise financeira de 1929) como uma exposição internacional em comemoração aos 25 anos de fundação do Deutscher Werkbund em Colônia, cidade que houvera acolhido a exposição equivalente em $1914 .{ }^{45}$

Por fim vale lembrar um último e talvez mais abrangente aspecto da crise da arquitetura por volta de 1930. Em um tempo de transição, dilacerado entre a crise econômica e política, as disputas internas pelo poder e a consolidação do novo regime crescia o desejo, não por uma nova forma de vida, mas por uma forma de vida segura e por um regresso a um passado onde o mundo ainda estava confortavelmente em ordem.

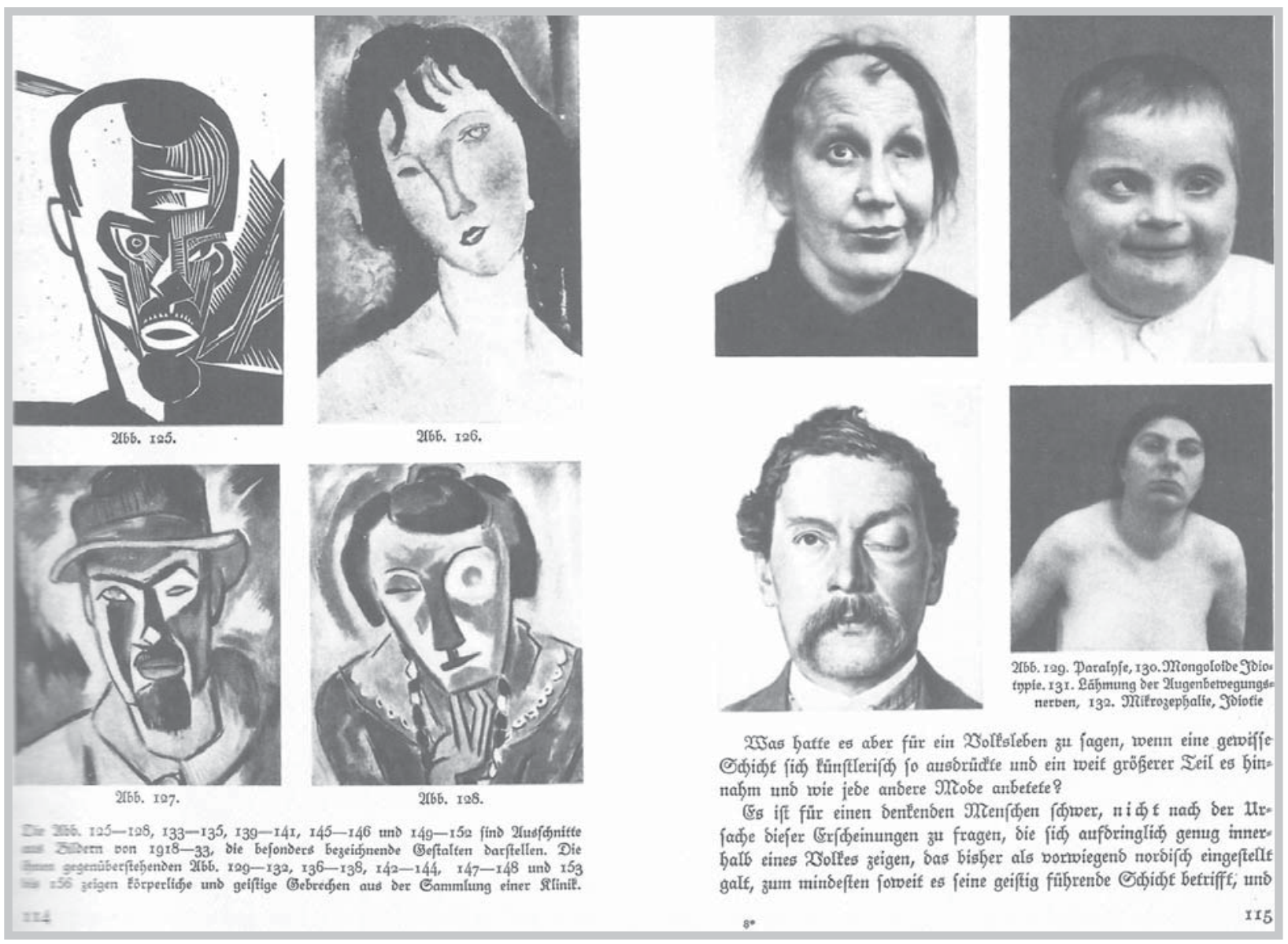

Fig. 15 - Paul Schultze-Naumburg. Kunst und Rasse. Publicação. 1928. 
Desde a Revolução de 1918, em que a burguesia viu seu espaço de influência ser drasticamente reduzido e onde o mundo de privilégios havia, pelo menos, parcialmente, acabado, tanto a burguesia como a pequena burguesia - que viam com incerteza, insegurança e insatisfação o futuro -, aspiravam a um mundo que pudesse restabelecer a ordem das coisas. A democracia, o liberalismo e também as prerrogativas da Arquitetura Moderna - internacionalidade, universalidade, coletividade - eram vistam por alguns como apenas um período de transição, até que a ordem fosse novamente restaurada. ${ }^{46}$

O mesmo desejo por uma "nova ordem" que se fazia premente, principalmente junto às novas gerações e aos artistas e intelectuais finda a Primeira Guerra, se renova cerca de uma década mais tarde, só que do lado aposto, do lado de quem via nessa "nova ordem" uma falta de ordem.

Por volta do ano de 1930, o fim da Kulturbolchevismus ${ }^{47}$ torna-se promessa de campanha em quase todas as eleições municipais e nacionais. E arquitetos de renome como Schmitthenner, Schultze-Naumburg e German Bestelmeyer apoiavam o ponto de vista do partido, ${ }^{48}$ enquanto muitos outros recebiam com entusiasmo a subida do Nacional-Socialismo ao poder, visto como uma força política que novamente proveria encomendas e meios de subsistência; encomendas, que agora, não mais proviriam de particulares, mas seriam resultado de uma situação legitimada dentro de um Estado forte. ${ }^{49}$ E não sem razão: em 1929 o Estado financiava cerca de um terço do volume construído no país; em 1934 esta proporção era de dois terços, e em 1938 já representava $80 \% .^{50}$

Com a chegada de Hitler ao poder, foram providenciadas medidas imediatas que tiraram os arquitetos modernos das posições de destaque. Já em 1928 o Partido Nazista havia nomeado Paul Schultze-Naumburg diretor da antiga Bauhaus de Weimar. Através da "Gesetz zur Wiederherstellung des Berufsbeamtentums" de 7 de abril de 1933, se consolidaria a "varredura" de arquitetos, diretores de planejamento municipais, professores e artistas modernos de seus postos de trabalho. Esta lei permitiu a demissão por motivos raciais ou políticos de figuras como Bruno Taut, Martin Wagner, Hans Scharoun, Werner Rading, Ludwig Hilberseimer, Richard Döcker, Walter Rietzler, Bruno Paul, Wassily Kandinky, Oskar Schlemmer, Hans Poelzig, Carl Hofer, Georg Muche, Bernhard Weiß, Clemens Holzmeister entre outros. E também os prefeitos Konrad Adenauer de Colônia, Fritz Hesse de Dessau e Emil Landmann de Frankfurt, todos por "inadmissível suposto favorecimento de determinado grupo de arquitetos ou devido a experimentos construtivos não permitidos." ${ }^{51}$

A Arquitetura Moderna parecia estar perdendo território e a pretensa primazia, que de fato, nunca lhe pertenceu. Apesar do esforço constante em propalar seus 
ideais e construí-los como manifestos visíveis, aquela arquitetura não desfrutou da unanimidade que tentou outorgar a si, nem mesmo nos áureos tempos da República de Weimar, onde contava com o apoio de algumas municipalidades, como as acima citadas, para executar os programas de habitação do Governo. O grande programa de construção de habitações iniciado por volta de 1924, ao contrário do que somos levados a crer, teria sido concedido apenas a uma pequena parcela dos arquitetos declarados modernos. ${ }^{52}$ Mas como lembra Miller-Lane, eram justamente esses projetos que mais saltavam às vistas em jornais e revistas, realçados junto ao público com frases de efeito como "Das neue Frankfurt", "Das neue Berlin", "Das neue Deutschland”, e reforçados pelas exposições intituladas "Wie Wohnen", "Das neue Wohnen" (que assumiam sempre um caráter didático e exemplar). Entretanto, para os arquitetos envolvidos nestes projetos, a construção de habitação em massa e, até mesmo a construção da Neues Bauen, "continuava a pertencer a um programa utópico mais abrangente." ${ }^{53}$

Posener finaliza seu artigo dizendo que mudanças estavam acontecendo naquele tempo, ainda que nunca houvesse uma Arquitetura-Nazi e um Estado-Nazi. E que nem os arquitetos modernos teriam ficado imunes. A própria obra de Gropius é testemunha desta mudança dos tempos que parecia pairar no ar. Sua casa em Lincoln, Massachusetts (1937-1938), construída logo após sua emigração para os Estados Unidos, diverge substancialmente de sua obra precedente. Esta ideia ratifica o que Gropius diria anos mais tarde no Encontro de Arquitetos em Hanover, por ocasião da Exposição Constructa, em 1951: "na vida, principalmente na América, ele teria vivenciado tantas coisas, que se chocariam com seus antigos princípios. Assim teria ele no início acreditado, se poderia conseguir uma forma internacional. Ele teria vivenciado ao longo de sua vida, que isso seria um equívoco. Toda construção deve ser elaborada a partir do contexto, da paisagem, do povo, dos costumes, etc, e só assim é natural, que a construção admita muitas formas diferentes." ${ }^{54}$

De fato, a subida do Nacional-Socialismo ao poder em 1933 parece ter antecipado uma marcha já em andamento. A julgar pelas evidências, a crise na Arquitetura Moderna, ou a propalada "Crise do Racionalismo" dos anos 1940 e 1950, teria lugar muito antes na história da arquitetura. 


\section{Notas}

1 Como Sifried Giedion ou Bruno Zevi.

2 Neste aparente sucesso pode ainda ser contabilizado o "efeito cascata" provocado pelo Weissenhofsiedlung: seu exemplo foi multiplicado em outros países europeus, através de exposições dos Werkbund locais: em Brno (1928), Breslau (1929, onde Scharoun constrói o conhecido edifício de habitações em alas com planta em S), Praga (1932), Neubühl, próximo a Zurique (1932) e Viena (1932), que assim como seu precursor, visavam a experimentos habitacionais e urbanos para um "morar moderno".

3 Walter Curt Behrens. Der Sieg des Neues Baustils. 1927, com o Siedlung Weissenhof estampado na capa.

4 Posener, Julius. Die Krise in der Architektur um 1930. In: Wingler, Hans M. (org). 100 Jahre Walter Gropius. Schließung des Bauhauses 1933. Simpósio. Berlim, 28.03.1983, p. 7

5 Jovens Arquitetos. Grupo fundado em 1926 por estudantes, em sua maioria alunos de Poelzig, como Eierman, Posener, Fritz Janecke - amigo próximo de Eiermann e seu sócio no início dos anos 1930 - Richard Paulick, entre outros. Em 1931 chegou a contar 26 integrantes.

6 Posener, Julius. Op. cit. p. 7

7 Idem, p. 8.

8 Idem. Ibidem.

9 Idem, p. 9

10 Idem. Ibidem.

11 „Stuhl oder Sitzmachine“. Vossiche Zeitung. Berlin, 9/6/1932. Entretanto, a obra dos integrantes do Junger Architekten iria deixar claro que, apesar das duras críticas ao moderno, isso não significa sua renúncia a esta corrente, como a própria obra de Eiermann mostra. Estes jovens apenas sinalizam seu distanciamento em relação ao formalismo abstrato da corrente principal e buscam repensar a arquitetura, mas desde um ponto de vista moderno.

12 Der Block (Manifest). In: Teut, Anna. Op. cit. p. 29. Originalmente publicado na revista Baukunst, 1928, München, p. 128.

13 Durth, Werner; Sigel, Paul. Baukultur. Spiegel gesellschaftlichen Wandels. Berlim: Jovis, 2009, p. 258.

14 Posener. Op. cit. p. 10. Isso vem ao encontro de uma interessante passagem em uma aula da disciplina "Teoria da Arquitetura Moderna" com o Professor Werner Sewing, durante meu estágio de doutorado na Alemanha. Segundo Sewing, em uma palestra proferida pelo mesmo Julius Posener nos anos 1970, este teria dito que ele e sua geração não suportavam mais aquelas "caixas" brancas da arquitetura moderna - pois não tinham bom acabamento, nem profundidade, e os aspectos construtivos eram péssimos. Em 1933, teriam ficado entusiasmados com o novo regime, na esperança de que a arquitetura de Hitler fosse melhor que aquilo. A platéia teria ficado chocada com tal declaração, ainda mais, por Posener ser judeu. Aula em 4.02.2009. Karlsruhe.

15 Já que nas obras maiores ou de grande representatividade seria a monumentalidade neoclássica o estilo escolhido.

16 Pode ser traduzido como estilo de defesa do regional.

17 Toda simplificação deste tipo é perigosa e incorre no erro de anular a variedade de manifestações arquitetônicas existentes, o que é justamente, um tipo de abordagem aqui criticado e manifestadamente repudiado. O crítico alemão Gerhard Fehl sugere que dos anos 1930 aos 1950 tenha-se seis tipos ideais de estilos arquitetônicos. Entretanto, a título de exemplo, e para uma breve explanação que se achou necessária, coloco estas três diferenciações, que são as mais notáveis, sem adentrar nos pormenores. Cf. Fehl, Gerhard. Die Moderne unterm Hakenkreuz. Ein Versuch, die Rolle funktionalistischer Architektur im Dritten Reich zu klären. In: Frank, Hartmut (org.). Faschistische Architekturen: Planen und Bauten in Europa 1930 bis 1945. Hamburg: Christians, 1985. 
A diferenciação aqui proposta entre grupos de arquitetos e não entre estilos arquitetônicos é, pois, proposital: no final dos anos 1920, com a crise econômica, é acirrada a divisão entre os arquitetos; a luta por encomendas e, principalmente, por esferas de influência torna-se uma luta política. Cf. Durth, Werner. Deutsche Architekten. Biografische Verflechtungen 1900-1970. Stuttgart/ Zurique: Karl Krämer Verlag, 2001, p. 55.

Posener. Op.cit. p. 10.

19 Idem. p. 12

20 Idem. Ibidem.

21 Voigt, Wolfgang. Die Stuttgarter Schule und die Alltagsarchitektur des Dritten Reiches. In: Frank, Hartmut (org.). Faschistische Architekturen: Planen und Bauten in Europa 1930 bis 1945. op. cit., p. 234.

22 Nonn, Friedrich. Die Kulturarbeiten Schultze-Naumburgs. Zu seinem 70. Geburtstag am 10. Juni 1939. In: Zentralblatt der Bauverwaltung 59, 1939, p. 633-639, apud: Voigt, Wolfgang. Die Stuttgarter Schule und die Alltagsarchitektur des Dritten Reiches, op. Cit, p. 234.

23 Pehnt, Wolfgang. Deutsche Architektur seit 1900. op. cit.p. 120.

24 Pehnt, Wolfgang. Deutsche Architektur seit 1900.2. ed. Ludwigsburg/ München: Wüstenrot Stiftung/ Deutsche Verlags-Anstalt, 2006, p.124.

25 Ainda que a imagem da Fagus seja muito mais avançada do que sua efetiva construção. Segundo Pehnt, a fachada em vidro não é curtain wall, ao contrário do que retratam inúmeros livros, já que os perfis metálicos desenvolvem função estrutural também. E o detalhe construtivo que causou furor à época - o canto envidraçado sem apoio - repetido no bloco das oficinas da Bauhaus de Dessau, foi conseguido não sem esforço dos arquitetos: Gropius e Meyer previram na cobertura das esquinas do prédio vigas metálicas em cruz invertidas, posicionadas diagonalmente à esquina de vidro, que suportam então a carga ali existente. Pehnt, Wolfgang. Deutsche Architektur seit 1900. op. cit., p. 83.

26 Behne. Adolf. Dammerstock. In: Die Neue Sammlung, Staaliches Museum für angewandte Kunst (org.). Zwischen Kunst und Industrie. Der Deutsche Werkbund. München, 1975, p. 264. Originalmente publicado em: Die Form, n. 6, 1930.

27 Idem. Ibidem.

28 Behne. Adolf. Dammerstock. Op. cit. p. 264.

29 Idem. Ibidem.

30 Sigrist, Albert (pseudônimo de Alexander Schwab). Das Buch vom Bauen. Berlin, 1930. apud: Pehnt, Wolfgang. Deutsche Architektur seit 1900. 2. ed. Ludwigsburg/ München: Wüstenrot Stiftung/ Deutsche Verlags-Anstalt, 2006, p.180.

31 Reichsforschungsgesellschaft für Wirtschaftlichkeit im Bau- und Wohnungswesen. Entre os membros estavam Walter Gropius, Ernst May, Bruno e Max Taut e Otto Bartning.

32 Bausünden und Baugeldverschwendung. Teut, Anna, op. cit. p. 55.

33 Esta questão fica bastante clara nas entrevistas que realizei na Alemanha com ex-colegas de Hans Broos. Quando pergunto a Wolfgang Bley e Klaus Zimmermann, arquitetos que iniciaram os estudos antes da guerra e imediatamente após, respectivamente, sobre o que sabiam em sua época de estudantes sobre a Bauhaus e a nova arquitetura, respondem que quase nada, a não ser que eram edifícios extremamente mal construídos.

34 Hermann Muthesius, apud: Pfister, Rudolf. Das Programm und die neue Ideologie. In: Teut, Anna, op. cit. p. 25.

35 Pehnt, Wolfgang. Deutsche Architektur seit 1900. op.cit. p.188

36 Schmitthenner, Paul. Das deutsche Wohnhaus. Stuttgart, 1932, p. 8. apud: Pehnt, Wolfgang. op.cit. p. 188.

37 Durth, Werner; Sigel, Paul. Baukultur. Spiegel gesellschaftlichen Wandels. Berlim: Jovis, 2009, p. 252.

38 Liga de Combate pela Cultura alemã.

39 Durth, Werner; Sigel, Paul. Baukultur. Spiegel gesellschaftlichen Wandels. Op. cit., p. 253. 
40 Schultze-Naumburg, Paul. Kunst und Rasse. München, 1928. apud: Durth, Werner; Sigel, Paul. Baukultur. Spiegel gesellschaftlichen Wandels. Op. cit.. p. 251

41 Durth, Werner; Sigel, Paul. Baukultur. Spiegel gesellschaftlichen Wandels. Op. cit. p. 254

42 Baukultur. 14.02.1931.

43 Cf. Dupeux Louis. Historia cultural da Alemanha 1919-1960. Rio de Janeiro: Civilização Brasileira, 1992.

44 Baukultur. 14.02.1931.

45 Onde estavam presentes a célebre Fábrica Modelo de Gropius e Adolf Meyer e o Pavilhão de Vidro de Bruno Taut.

46 Durth, Werner; Sigel, Paul. Baukultur. Spiegel gesellschaftlichen Wandels. Op. cit. p. 260

47 Ou "Cultura bolchevique" uma das tantas denominações para a Arte e Arquitetura Modernas e a Cultura de Weimar.

48 Miller-Lane, Barbara. Die Moderne und die Politik in Deutschland zwischen 1919 und 1945. In: Lampugnani, Vittorio M.; Schneider, Romana (org.). Moderne Architektur in Deutschland 1900 bis 1950: Expressionismus und Neue Sachlichkeit. Stuttgart: Verlag Gerd Hatje, 1994, p. 240

49 Durth, Werner. Deutsche Architekten. Eine Biographische Verflechtungen 1900-1970. Stuttgart/ Zurique: Karl Krämer Verlag, 2001, p. 86.

50 Idem, p. 91.

51 Teut, Anna. Op. cit. p. 67.

52 Possivelmente 5\%, de acordo com Adelheid von Saldern. apud: Miller-Lane. Op. cit. p. 227.

53 Miller-Lane, Barbara. Op. cit. p. 227.

54 Wolters, Rudolf. Relato de Walter Gropius no Encontro de Arquitetos em Hanover em 3.07.1951. In: Durth, Werner. Deutsche Architekten. Biografische Verflechtungen 1900-1970. Stuttgart/ Zurique: Karl Krämer Verlag, 2001, p. 323.

Ao ampliarmos esta visão para o caso não estritamente alemão, veremos que a colocação ainda é válida. Também a obra de Le Corbusier já dava claros sinais desta mudança dos tempos. Já é conhecida sua obra do fim dos anos 1920 e início de 1930, em que o arquiteto faz uso de materiais e técnicas tradicionais, como a Casa de Mandrot, 1929-1932, colocando em questão a primazia absoluta das técnicas modernas. Estas casas geram um tom embrutecido como uma antevisão do que seria sua obra pós-guerra. 
Capitulo 3

Alemanha Pós-Segunda Guerra 



\section{RECOMEÇO OU CONTINUIDADE?}

Em maio de 1945 segue-se definitivamente a capitulação da Alemanha. O país é um território em e de ruínas. À destruição e falta de condições materiais essenciais de sobrevivência, segue-se também o drama e o débito moral com o reconhecimento das atrocidades cometidas durante o domínio nazista.

Desde meados de 1943, os bombardeios aéreos nas cidades alemãs haviam crescido bruscamente; desde meados de 1944, os equipamentos de produção de guerra tinham sido severamente atingidos. Ainda assim, a arquitetura ocuparia o Führer até os últimos meses do conflito. E da mesma forma, continuaria a ocupar arquitetos. Enquanto bombardeios aéreos faziam milhares de vítimas e soldados continuavam no front um embate que já parecia perdido, os planos de reconstrução de muitas cidades alemãs prosseguiam. Ainda no início de 1945, os planos das cidades de Linz, Hamburgo, Berlim, entre outras, iam adiante, e preparavam as condições do novo recomeço.

Dos trabalhos dos anos durante a guerra, principalmente dos envolvidos com os planos de reconstrução, se formaria um círculo bastante próximo de arquitetos e planejadores, que permaneceria tecendo relações, ativos e influentes nos anos após a guerra.

\section{Mostras DA DESTRUiÇÃo}

Em 1948 o diretor italiano Roberto Rossellini lança o filme "Alemanha Ano Zero". Rodado em Berlim um ano antes, em meio às ruínas da cidade gravemente atingida, o filme nos dá a noção da devastação e do drama vivido. As cidades são montanhas de entulhos. O montante dos escombros é avaliado em 400 milhões de metros cúbicos, o que significa uma muralha de dois metros de largura por sete de altura ao redor do país. ${ }^{1}$ Os trabalhos de remoção duraram anos. Algumas cidades somente se veriam livres deles na década seguinte.

Um cartão postal com foto de 1952 da cidade de Dresden, uma das últimas cidades atingidas pelos bombardeios, ilustra o trabalho realizado. Homens que fazem o trabalho braçal de remoção dos escombros parecem desaparecer em meio à pilha de restos da destruição. Muitas pessoas estiveram envolvidas nesta tarefa, como ficaram conhecidas as Frauentrümmern (mulheres dos destroços). Os materiais reutilizáveis são selecionados, limpos e colocados em outra pilha. Ladeando os escombros, o singelo trilho dos vagões encarregados da remoção dos destroços. Ao fundo vemos as ruínas da Frauenkirche, um dos tantos edifícios históricos da cidade que não resistiram. Reinaugurada há poucos anos, ${ }^{2}$ a igreja foi reconstruída 
em sua forma original, em parte, a partir dos próprios materiais; um trabalho minucioso que envolveu uma grande equipe de trabalho. Dresden, conhecida como uma das mais belas cidades barrocas da Europa, teve cerca de $40 \%$ de suas habitações destruídas; dados ainda maiores em relação aos bens culturais.

As destruições causadas pela guerra concentraram-se essencialmente nas maiores cidades e mais densamente construídas; as que tiveram mais perdas humanas também. Na então Alemanha ocidental, cerca de um quarto de toda habitação foi aniquilada, números ainda maiores em relação a edifícios públicos e equipamentos industriais. Cidades como Dessau, Kassel, Koblenz, Mainz, tiveram quase 75\% de suas habitações destruídas. ${ }^{3}$ Em outras, este número chega a $80 \% .{ }^{4}$ Ao já imenso número de desalojados, somam-se novos milhões de fugitivos das antigas áreas colonizadas a leste.

A situação da moradia era ainda mais grave na parte ocidental do país. Por um lado, esta região foi a mais suscetível às tropas inimigas, e a que mais sofreu, portanto, com os ataques aéreos; por outro, a partir da reforma monetária no verão de 1948, em que era notável uma significativa melhora no nível de vida da parte oeste alemã, deu-se de forma mais intensa a onda de imigração do leste para oeste.

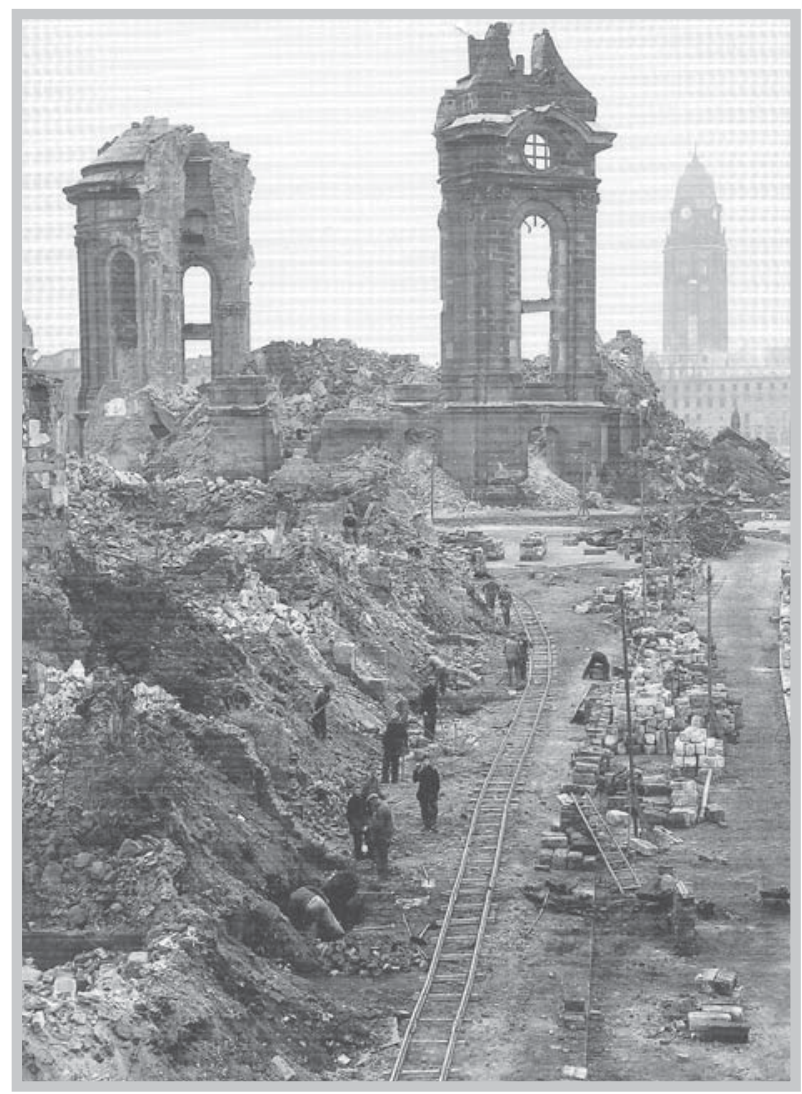

Fig. 1 - Dresden. Cartão Postal com foto de 1952.
A crise da habitação era, em realidade, uma situação que se arrastava por anos e havia começado antes mesmo da Primeira Guerra Mundial. Nos poucos anos de atividade intensa da República de Weimar, de 1925 até os reflexos da crise econômica de 1929, os números não foram suficientes para por fim à situação. Também o Governo Nazista não chegou a uma quantia expressiva de construções, que nem nos melhores anos alcançaram os números do período anterior. Em toda a era Hitler chegou-se a 1,7 milhão entre novas moradias e renovações (o que representa um quarto do que foi destruído na guerra).

Por muito tempo, a Alemanha foi um país itinerante, que viveu anos de deslocamento e rearranjamento de sua população. Grandes cidades de outrora haviam se tornado excampos de batalha quase desabitados. A cidade 
de Colônia, por exemplo, que contava 750.000 habitantes antes da guerra, possuía em 1945 apenas 40.000 e levaria até 1958 para que o antigo número de sua população fosse atingido. Os refugiados vindos do leste europeu procuravam um novo lar. Aos poucos, também os combatentes de guerra voltam para casa.

\section{O CONTEXTO DO RECOMEÇO}

Nesta Alemanha pós-1945, o ambiente era bastante diverso daquele dos anos 1920. Assumia novas formas e um novo caráter. No ano de 1918, sobre o caos econômico, político e social da guerra perdida, nascia o desejo de uma profunda mudança. A guerra não havia somente acabado com a monarquia, não era somente político o seu resultado, era também moral e principalmente espiritual - uma nova civilização estava no porvir, uma democracia em seu sentido mais profundo. Então temos o Expressionismo (que mesmo tendo iniciado antes da guerra, encontra no contexto pós-guerra o seu lugar de florescimento), que a partir da arte e do nascimento de um ideal comum aspira sobrepujar o caos instalado e deseja um "renascimento ideal", nas palavras de Argan. ${ }^{5}$

Vozes revolucionárias não encontravam mais ressonância na Alemanha do pósguerra. Nada de grandes aspirações, nada de idealismo; a "Catedral do Futuro"6 não encontra aqui sua equivalente. Antes de vozes revolucionárias, se faziam sentir esperanças mais discretas, menos idealizadas: "somente com esforços concentrados, somente com o trabalho coletivo e oficinas coletivas, pode ter êxito a construção. Pelo espírito de sacrifício, chamamos a todos aqueles com boa disposição" lê-se no documento que marca a nova fundação do Deutscher Werkbund em janeiro de 1947. Como afirma Pehnt, o que chama a atenção nos documentos dos primeiros anos após a guerra é a ausência de precisão e o exagero em formulações cuidadosas e sublimes. ${ }^{8}$ Os documentos se dividem entre aqueles que tentam buscar uma explicação ou sentido para o caos vivido, e aqueles que tentam justificar caminhos tomados, mas no geral, são ricos em imprecisões e ideias vagas. E, igualmente, antes da construção de um ideal comum - o que a "Catedral do Futuro" sugere - era necessário resolver as diferenças internas, de arquitetos separados por desavenças políticas, tornadas explícitas durante o período nazista e, que agora, expunham claras cisões. Divergências que dizem respeito até mesmo aos arquitetos emigrados e aqueles que permaneceram no país.

Talvez uma das primeiras mostras destes conflitos internos seria protagonizada por Gropius, em sua visita ao país em 1947, e Karl Bonatz, irmão de Paul Bonatz, que trabalhou em Berlim durante o III Reich junto ao Inspetor-Chefe Albert Speer como responsável pela construção de abrigos militares. Gropius, que 
neste mesmo ano havia se tornado Conselheiro do Governo Militar NorteAmericano na Alemanha concedeu inúmeras entrevistas durante sua estadia em Berlim e proferiu uma aguardada palestra, recebida com grande entusiasmo pelo público. ${ }^{9}$ Além de uma retrospectiva sobre sua carreira e seus últimos trabalhos nos Estados Unidos, Gropius também se voltou para a realidade alemã e estimulou seus colegas a desenvolverem seus trabalhos de modo "atual" e a planejar "sem levar em consideração a presente pobreza da Alemanha". ${ }^{10} \mathrm{E}$ completou: "planejamento urbano dura centenas de anos, para que se falhe em qualquer comedimento."11

Esta observação de Gropius, entre outras, foi recebida como uma afronta por Karl Bonatz, que deferiu a seguinte crítica, publicada no mesmo número da Revista Neue Bauwelt: "não se pode esperar de um modo justo, que um homem recém chegado dos Estados Unidos, (país) relativamente intocado pela guerra e suas consequências, que em poucos dias apreenda a situação e o ambiente na Alemanha e que imediatamente nos dê uma receita útil nas mãos segundo a qual devemos proceder." ${ }^{\prime 2}$ E a crítica continua com uma observação que é direcionada para outros que, como Gropius, haviam emigrado nos anos 1930: "Somente aquele que aqui anteriormente vivenciou e assistiu à Alemanha imediatamente após o colapso do Regime de Hitler, pode julgar quais enormes realizações [...] serão consumadas." ${ }^{13}$ E completa: "Aqui em Berlim não somos iludidos, somos realistas, sensatos, que querem se livrar do 'atoleiro' com luta sem descanso, persistente, sob circunstâncias difíceis e frequentemente, com meios mínimos, mais do que com ideias geniais [...]"14

Mais do que estigmatizar os arquitetos emigrados e nutrir uma desconfiança em relação à legitimidade e oportunidade da contribuição destes na reconstrução do país, Bonatz lança luz a uma cisão ainda maior e de longa data. O recado aqui fica claro, Bonatz não somente repudia as observações de Gropius como todos os arquitetos modernos; as "ideias geniais" ligam-se diretamente aos arquitetos modernos de antes de 1933 à Bauhaus e a toda e qualquer ideia de inovação. É sinalizada, de forma contundente, uma renovada situação em que "de um lado antigos membros do (Deutscher) Werkbund e da Bauhaus novamente se relacionam com seu contexto em grande parte rompido em 1933, enquanto estão de outro lado 'realistas sensatos', que com sucesso arranjaram-se nas circunstâncias pós 1933 no Regime de Hitler."15

Ficava clara a cisão, não somente entre uma situação já existente, que remonta ao fim dos anos 1920, mas uma diferenciação entre aqueles que se engajaram no regime e encontraram trabalho (indiferentemente se integrantes do Partido ou não) e aqueles que se mantiveram distantes ou "fiéis" à Arquitetura Moderna 
(alguns deles fiéis à Arquitetura Moderna mas não tão distantes assim do regime, como vimos, ${ }^{16} \mathrm{e}$ nem com pouco trabalho), entre eles, exemplos como Hans Scharoun e Richard Döcker, que passaram os anos do regime amargando poucas encomendas, sobretudo o segundo.

O "ajuste de contas" estava apenas começando. Muitos arquitetos bem sucedidos durante o Regime Nazista voltaram a exercer tranquilamente seus postos de docência ou obtiveram cargos nos órgãos de planejamento, outros prosseguiram como profissionais autônomos. A

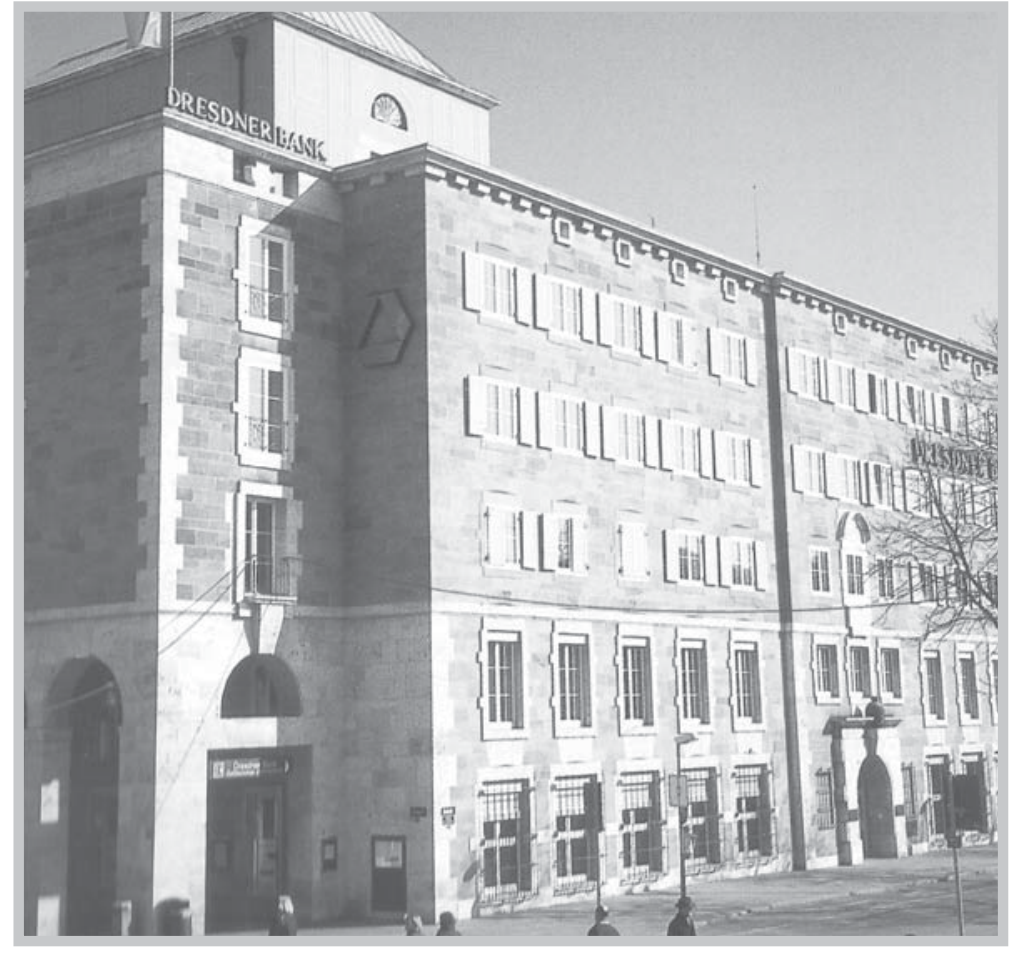

Fig. 2 - Paul Schmitthenner. Dresdner Bank. Stuttgart. 1949-1955. maioria passava despercebida. Mas há casos polêmicos que despertaram a ira dos colegas, como o "Caso Schmitthenner" que chegou a ser chamado à Universidade de Stuttgart para assumir o antigo posto. Devido à pressão e ao repúdio exercido pelos colegas, seguiu-se de imediato sua aposentadoria. Como profissional autônomo realizou ainda algumas obras de caráter tradicionalista.

\section{5: ANO ZERO?}

Por isso mesmo, antes de uma total ruptura, predominou continuidade no ambiente pós-1945, pelo menos no que tange ao corpo de profissionais e até mesmo ao tipo de planejamento urbano exercido até então. A evidência do que foi praticado no segundo pós-guerra leva-nos a refutar a tão propagada ideia de "hora zero" como acena o título do filme do conhecido diretor italiano. A ideia de "ano zero" ou "hora zero" e sua alusão a um suposto desmantelamento das práticas e convicções existentes e a um renascimento total é, de fato completamente errônea. São muitos os casos em que a carreira de arquitetos bem sucedidos durante o Regime Nazista segue no pós-guerra de maneira ilesa, como atestam os casos de Friedrich Tamms, Rudolf Hillebrecht, Hans Bernhard Reichow, Hanns Dustmann, Konstanty Gutschow, Rudolf Wolters, entre outros, além de Karl Bonatz, que sucedera Hans Scharoun como Secretário de Urbanismo de Berlim em 1946 e após a divisão da cidade tornou-se Diretor de Planejamento na parte ocidental. 
Muitos foram os escritórios de planejamento do governo ou os escritórios particulares que interromperam suas atividades por apenas alguns dias. Helmut Hentrich e seu sócio Hans Heuser, que haviam trabalhado com encomendas da Organização Todt ${ }^{17}$ para a remodelação de Hamburgo, interromperam suas tarefas por apenas duas semanas e, então, seguiram adiante. ${ }^{18} \mathrm{O}$ escritório, que depois passa a ser Helmut \& Petschnigg, se transformaria em um dos maiores e mais bem sucedidos dos anos 1950 e 1960 do país.

De fato, estes e outros arquitetos, que haviam trabalhado no setor de "Reconstrução de Cidades Destruídas pela Guerra", chefiado por Albert Speer, haviam adquirido uma vantagem de experiência junto a atividades que seriam muito válidas nos anos pós-guerra: "eliminação de escombros, abrigos, construção racionalizada de habitação voltada ao futuro, neste caso, sem um planejamento urbano demasiado atencioso."19

Muitas foram as cidades, entre elas Berlim, Düsseldorf, Hanover, Munique, Nuremberg, que tiveram seus Escritórios de Planejamento chefiados pelos mesmos arquitetos, ou seus colaboradores, dos tempos anteriores a 1945 . Em outras situações, estes, mesmos não estando em postos de comando, continuariam a exercer influência decisiva e a definir as diretivas do planejamento pós-guerra, como membros de júris em concursos. ${ }^{20}$ Mas não eram somente os profissionais que continuavam ativos; também perduravam projetos do tempo nazista. Para muitos arquitetos, também soluções propostas para aquela época pareciam conservar sua validade. Projetos monumentais daquele tempo chegavam a ser descaradamente apresentados como novos; outros, levemente modificados e propostos. $^{21}$

Friedrich Tamms foi um destes casos, em que a carreira de antes e após a guerra prosseguiu de forma surpreendentemente intocada. Encarregado a partir de 1938 do novo planejamento de Berlim, e com atividades na Organização Todt e no setor de Reconstrução do Terceiro Reich, Tamms foi nomeado em 1948 Diretor de Planejamento de Düsseldorf e exerceria influência por mais de vinte anos no planejamento daquela cidade. Sob o comando de Tamms, é proposto o plano para a reconstrução e remodelação da cidade. Nele são planejadas amplas avenidas que rasgam a cidade, e seguem diretamente para o núcleo urbano antigo. São previstas, inclusive, estradas com dois andares. Ao contrário, eram os arquitetos de fato modernos, que se autodenominavam "Architektenring," em alusão ao grupo dos anos 1920 Der Ring que, em sua contra proposta, apresentam um planejamento com diferenciação e hierarquia de ruas, as quais formam círculos e meio-círculos concêntricos, e preservam o centro histórico do grande fluxo 
de veículos, e, ainda, com ruas para pedestres. As avenidas largas, de percursos mais retilíneos, o uso de transporte individual com arrojados edifícios, valem a Düsseldorf, nos anos 1950, o título de uma das cidades mais progressistas do país, ${ }^{22}$ sob a direção de Tamms.

Assim também seguiram os projetos de reconstrução de outras cidades, sustentados por arquitetos com farta experiência neste setor, provenientes do Terceiro Reich. Estes projetos simplificadores, e que reservavam pouca atenção ao ambiente construído, tidos como os mais arrojados e "modernos", revelam sua inegável proximidade e filiação com a postura adotada no Regime Nazista. Isso leva Pehnt a considerar, também a partir de outros motivos, que a influência da Carta de Atenas - numa Alemanha que, a partir de 1933, é fechada para as influências externas e onde revistas internacionais não circulavam - é exagerada junto à crítica especializada. ${ }^{23}$
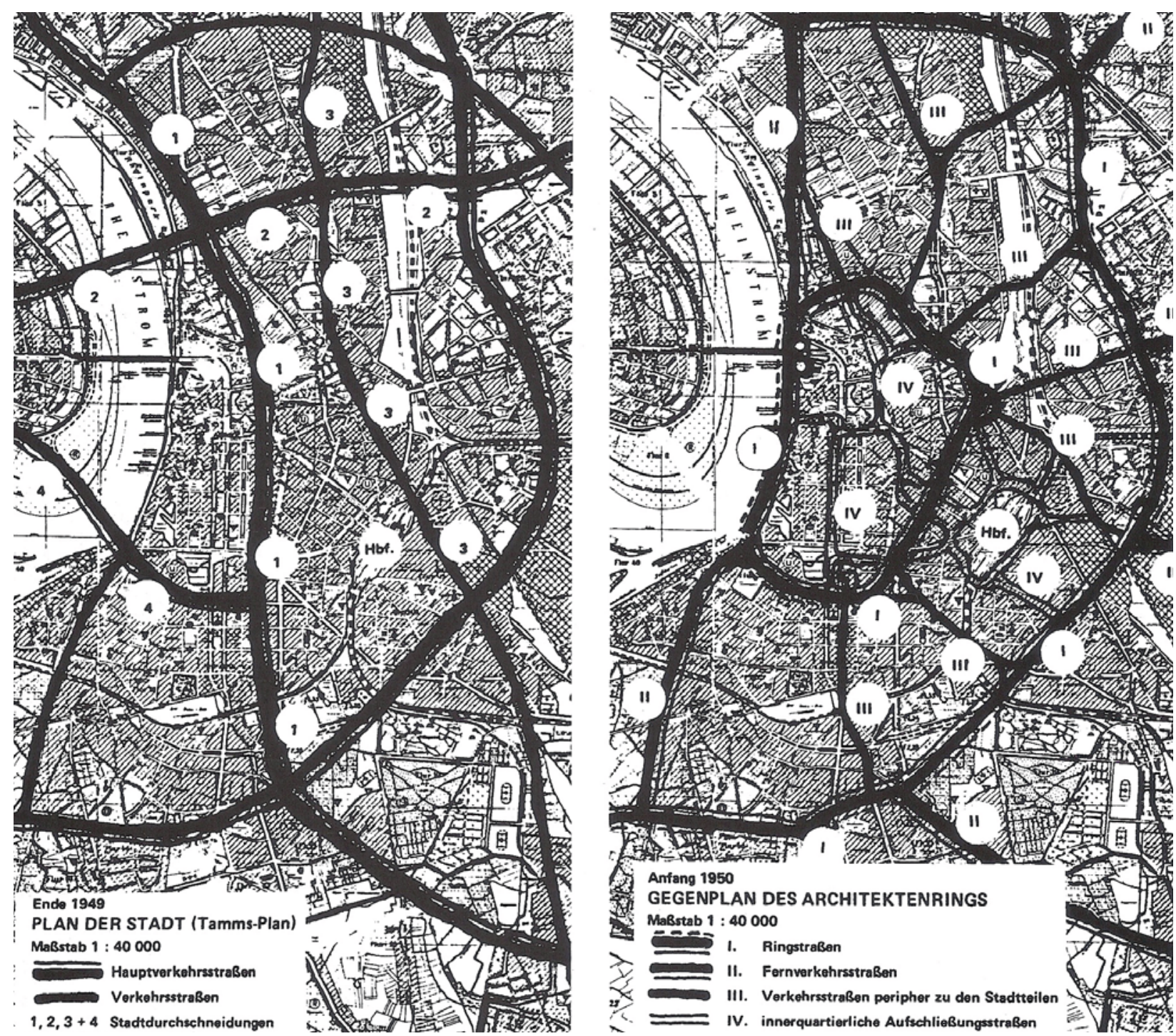

Fig. 3 - Plano para remodelação de Düsseldorf. À esquerda o plano de Friedrich Tamms (1949). À direita a contra-proposta do Architektenring (1950). 
A Carta teria sido introduzida no conhecimento dos arquitetos alemães apenas a partir de $1945,{ }^{24}$ dois anos após sua publicação. O autor coloca que a principal questão tratada pela Carta de Atenas - a especialização da cidade e sua separação em partes - não deve ser superestimada. Um dos motivos refere-se ao fato de que desde tempos anteriores a 1933 alguns planejadores e teóricos enfocam a separação de funções da cidade; nisso a Carta de Atenas não seria de modo algum revolucionária. Outra questão é que desde o tempo nazista, a descentralização das construções era vista como a melhor medida de segurança contra ataques aéreos, e o mesmo pensamento prosseguiu nos anos posteriores, em meio à Guerra Fria. ${ }^{25}$ Tal pensamento, que surgia velado nos projetos urbanos do pósguerra, fora oficialmente colocado como diretiva para a formulação de planos urbanísticos em $1938 .^{26}$

Também o fato de que a Carta promove a Circulação a um dos itens essenciais de que é composta uma cidade, ao lado do Trabalho, Habitação e Lazer, ao invés de ser apenas um meio de comunicação que serve aos demais, não é nenhuma surpresa, já que o automóvel vinha sendo objeto de culto há décadas. Mas até que ponto esta postura simplificadora é fruto do próprio contexto histórico ou do pensamento moderno (ou ambas, já que este também é fruto de seu tempo) é uma questão que ultrapassa o problema aqui proposto. É interessante notar, porém, que a Carta de Atenas e a tão discutida “Tabula Rasa”, podem não ser consequências apenas do pensamento moderno, como a crítica dos anos 1960 tão ferozmente lhe outorgou. Podem ser sim, frutos de uma época de pensamento. Não raramente, a teoria é que acompanha o que emerge na prática.

Isso fica claro ao se analisar projetos urbanos feitos pelos escritórios municipais comandados por arquitetos e planejadores vindos do período Nazista. A mesma monumentalidade exigida e aspirada pelo Regime é colocada em prática no pósguerra por estes mesmos planejadores, tendo em comum as amplas avenidas que rasgam a cidade, sem demasiada atenção aos estragos feitos. Só que agora, ao invés dos grandes eixos triunfais e dos prédios imponentes num estilo neoclássico, são propostos igualmente grandes eixos, não mais destinados à representatividade do Estado ou às demonstrações públicas, mas com ousados edifícios em altura, com sua estética limpa e cristalina.

No pós-guerra a arquitetura moderna não possuía mais o inimigo comum a ser combatido - o academicismo. Ou melhor, ele ainda sobrevivia, porém mais como um símbolo reacionário de um passado não tão distante, que contava agora com certo repúdio não só da classe moderna, mas em parte da sociedade (principalmente imprensa diária e especializada), e os arquitetos que a ele ainda 
se filiavam tratavam rapidamente de mudar deliberadamente sua estética como prova de sua "limpeza" política. No pós-guerra, a arquitetura moderna valeu como "desnazificação", e ganhou adeptos que não se filiavam tanto assim às suas propostas sociais $\mathrm{e}$ reformadoras (já caducas, é verdade), mas que se mostraram rapidamente familiarizados com suas premissas formais, tornando fácil a conversão de escritórios tradicionais para "causa" moderna. A arquitetura do Movimento Moderno talvez não tenha se tornado tão predominante quanto sugerem alguns críticos, mas seguramente torna-se soberana em certos meios; em muitos casos, mais por uma necessidade conjuntural que por uma filiação ético-moral.

Escritórios que até bem pouco tempo construíam nos moldes da estética tradicional e corpulenta do Terceiro Reich, demonstram que aprenderam rapidamente a linguagem do moderno. No início dos anos 1950, Helmut Hentrich e Hans Heuser, provenientes do Terceiro Reich e acostumados à arquitetura imponente, constroem o Edifício Administrativo da Victoria Versicherung (1951), em que ainda é visível o gosto pelo peso, a noção de simetria e de massa. Alguns anos depois, o mesmo Hentrich, junto de seu novo sócio Hubert Petschnigg entram subitamente e definitivamente na bandeira do moderno. Com o DreiScheibenhaus para Phoenix-Rheinrohr (1957-1960) exaltam precisão, leveza e transparência; edifício que se tornou um dos ícones da arquitetura pós-guerra na Alemanha ocidental.

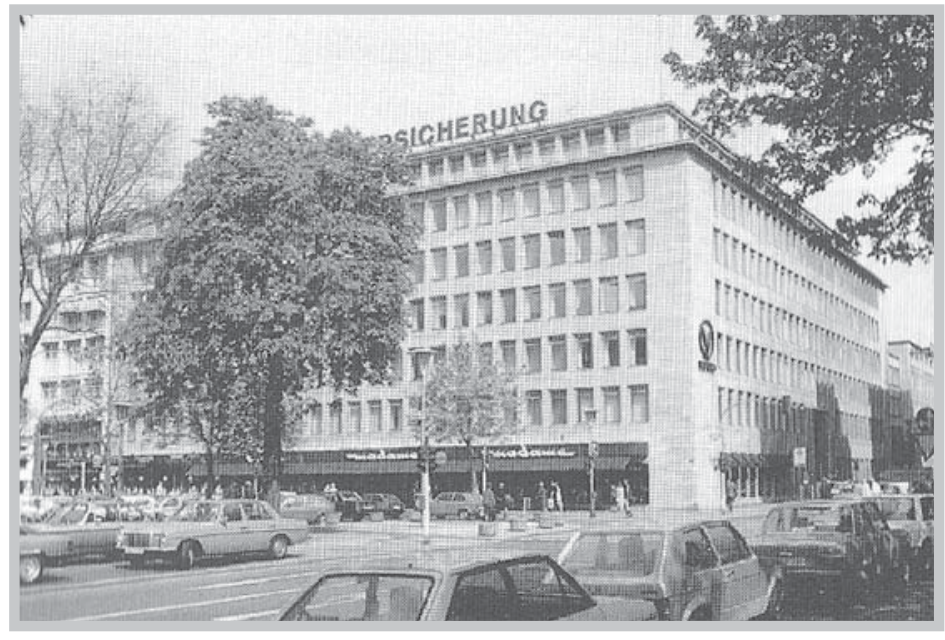

Fig. 4 - Helmut Hentrich, Hans Heuser. Edifício Administrativo da Victoria Versicherung. Düsseldorf. 1951.

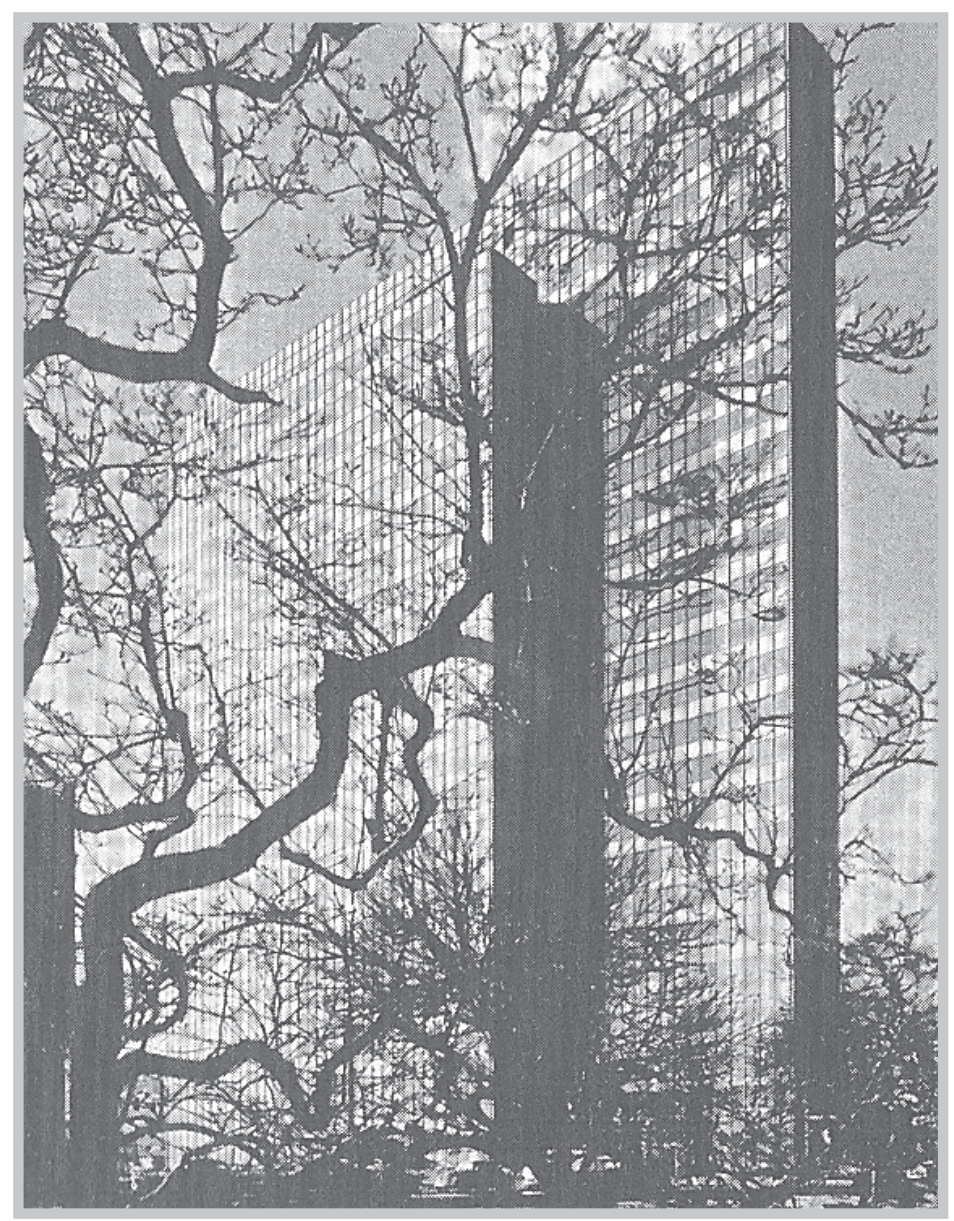

Fig. 5 - Helmut Hentrich, Hubert Petschnigg. Edifício Phoenix-Rheinrohr. Düsseldorf. 1957-1960. 


\section{RECONSTRUIR OU CONSTRUIR NOVO}

Para os arquitetos que contavam entre os modernos, a posição sobre este tema era bastante clara e defendida ardentemente, até mesmo para construções consideradas das mais valiosas, cultural e historicamente. Otto Bartning é categórico: "Reconstruir? Tecnicamente, financeiramente não é possível, digo a vocês; o que digo? - psicologicamente impossível!", ${ }^{27}$ ou então Ernst May: "riscamos uma clara linha sobre o passado e seu inglório passado". ${ }^{28}$

Tal é também a clareza de pensamento que pode ser lido no Stimmen zum Neuaufbau. Ein Aufruf: Grundsätzliche Forderungen que não deixa dúvidas quanto ao comportamento proposto para a reconstrução. No documento-convocatória que marca a nova fundação do Deutscher Werkbund, os trinta e oito arquitetos que o assinam, entre eles Egon Eiermann, Richard Döcker e Max Taut, lançam cinco pontos que devem ser observados na reconstrução do país, entre eles, que “o patrimônio destruído não deve ser reconstruído em caráter histórico, novas tarefas só poderão surgir em novas formas". ${ }^{29} \mathrm{E}$ completam, que para construção de habitação, bem como para prédios públicos, móveis e utensílios "buscamos, ao invés de super-especialização ou de formas emergenciais rudimentares, a (forma) simples e válida. Pois que somente a (forma) válida-simples é multiplamente utilizável." ${ }^{\text {30 }}$

Mas esta radicalização não foi seguida à risca, ao contrário; muitos prédios foram reconstruídos em seus modelos históricos, não sem antes serem precedidos por intenso debate e polêmicas. Nos primeiros anos após a guerra, o destino de algumas edificações, ou então, o que deveria acontecer com as ruínas, era calorosamente discutido na imprensa. Já em 1945 as primeiras medidas de segurança foram tomadas para salvar prédios históricos considerados mais importantes. Em outros casos, em especial na zona soviética, alguns edifícios precisariam esperar décadas para serem reconstruídos. Os trabalhos para reconstrução da Frauenkirche em Dresden, por exemplo, somente teriam início após a reunificação do país.

Mas alguns edifícios, principalmente aqueles de grande valor cultural, foram reconstruídos no imediato pós-guerra, seguindo integralmente ou parcialmente, o modelo histórico precedente. Um destes prédios foi a Paulskirche (1789-1833, reconstrução 1946-1948), igreja que sediou a primeira reunião do Parlamento Nacional Alemão em 1848, após a unificação do país, e também a casa onde nasceu o escritor Goethe, ambas na cidade de Frankfurt. A primeira contou com uma reconstrução em breve tempo. Já em 1948 tinham lugar as comemorações de sua reinauguração, combinadas com as do centenário da unificação do país. $O$ edifício foi erguido basicamente em sua forma original, com algumas pequenas 
alterações. Já a casa de Goethe (1754, reconstrução 1947-1951) contou com um projeto tão fiel quanto possível ao original. Postura esta que desagradou a muitos, suscitando inclusive questões morais referentes ao tema da reconstrução. A destruição da casa do escritor não seria ela mesma parte da história? Ao se tentar reconstruir fielmente um edifício não se tentaria camuflar os acontecimentos? Em ambos os casos, os argumentos não foram levados em consideração.

Uma terceira alternativa parecia ser aquela em que a ruína é preservada como um memorial e completada por edifícios em linguagem contemporânea. Um exemplo desta postura é o projeto para a Gedächtniskirche em Berlim (19571963) de Egon Eiermann (mas é preciso ser dito, não a partir de um modelo proposto pelo arquiteto). No ano de 1956 foi lançado um concurso fechado para a reconstrução da igreja, que deixava em aberto a manutenção ou não da antiga torre. A igreja em estilo neo-românico, construída entre 1891 e 1895 por Franz Schwechten em memória ao imperador Guilherme I, não possuía grande valor arquitetônico. $\mathrm{O}$ arquiteto previu

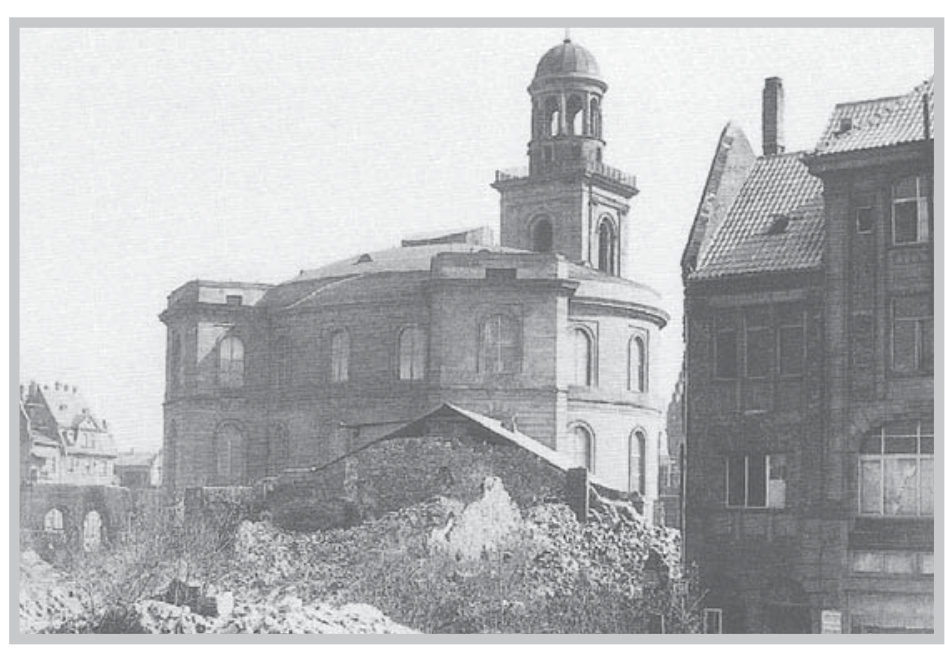

Fig. 6 - Eugen Blanck, Gottlob Schaupp, Rudolf Schwarz, Johannes Krahn. Projeto de Reconstrução da Paulskirche. Frankfurt. 1946-1948.

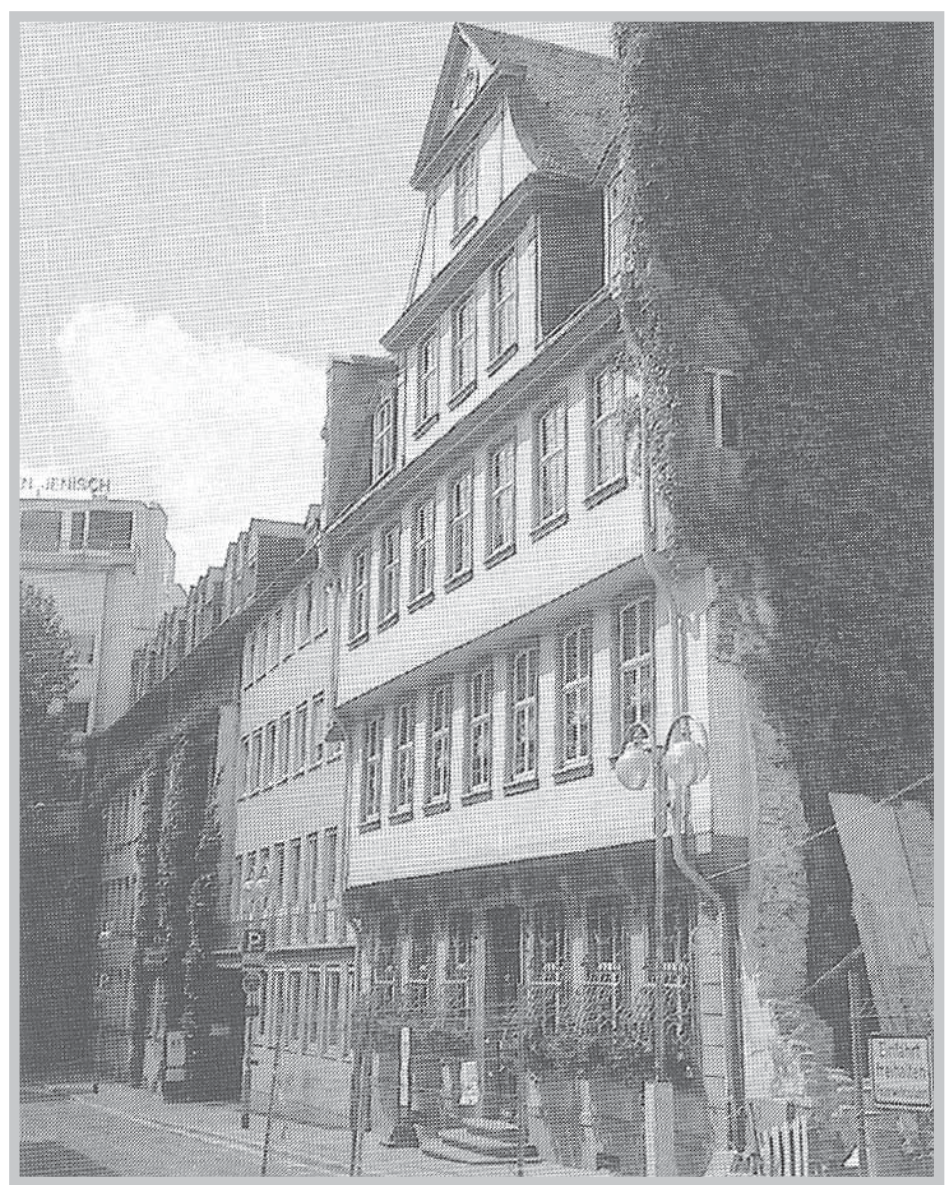

Fig. 7 - Theodor Kellner. Projeto de Reconstrução da Casa Goethe. Frankfurt. 19471951. sua demolição nas duas etapas que precederam a proposta final.

Para uma posição tão decidida quanto à dos modernos, geralmente a população não estava preparada. Protestos populares e na imprensa seguiram-se, exigindo que a torre fosse preservada como "coração" da cidade. Por uma iniciativa da imprensa local, um abaixo-assinado colheu em poucos dias 46.000 assinaturas, 


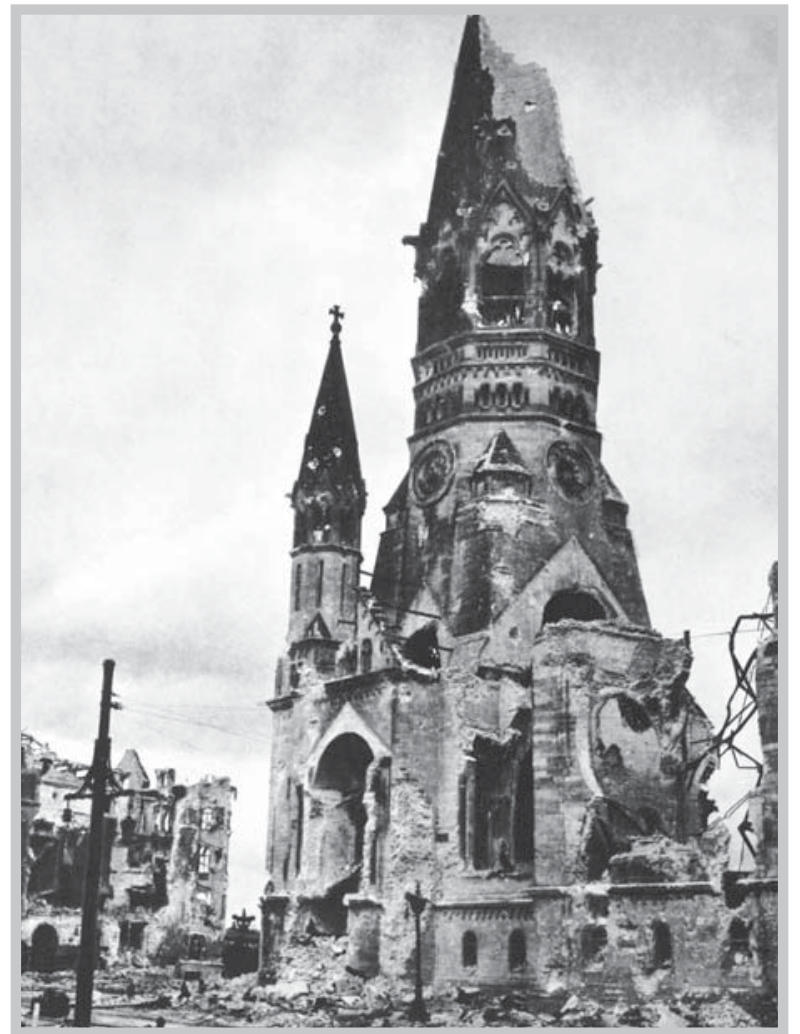

Fig. 8 - Franz Schwechten. Kaiser-Wilhelm-Gedächtniskirche. Berlim. 1891-1895.

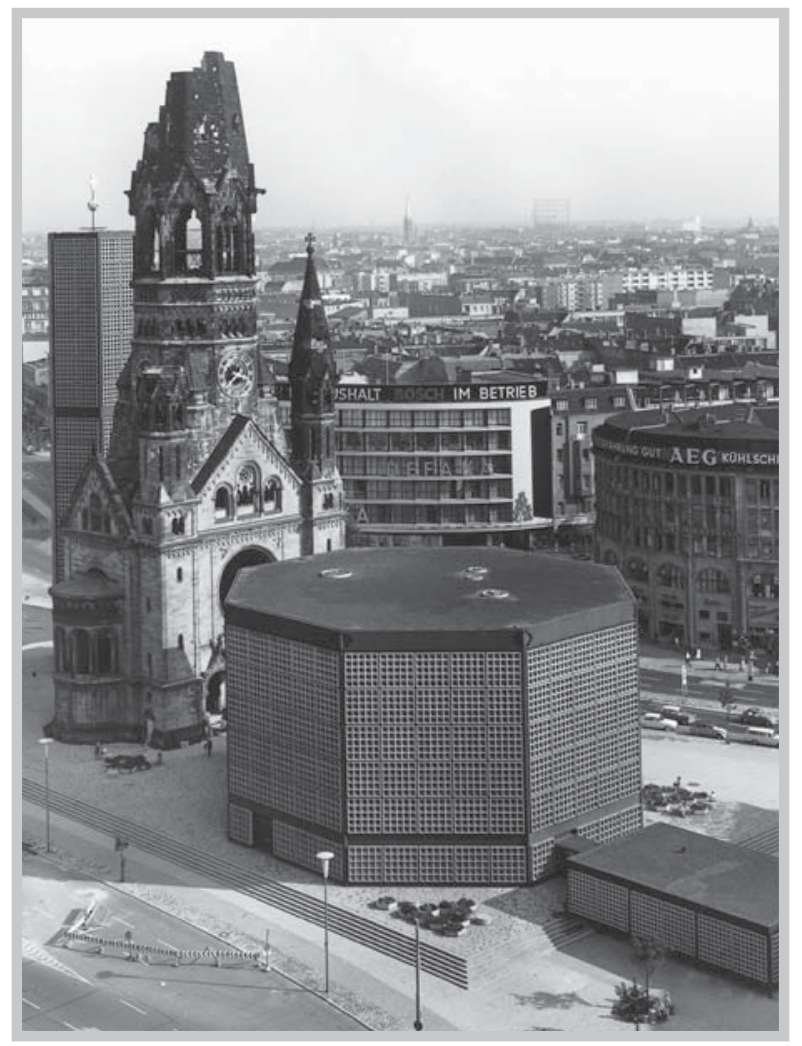

Fig. 9 - Egon Eiermann. Novo projeto da Kaiser-WilhelmGedächtniskirche. Berlim. 1957-1963. que reivindicavam a permanência da "mais bela ruína da cidade."31 Só então Eiermann, que já havia vencido o concurso, viu-se compelido a incorporar a velha torre em seu projeto. Também nos dois projetos anteriores ele havia previsto as partes da igreja - nave, torre, capela - como elementos separados, desfazendo a noção de massa construída e prevendo o preenchimento do vazio que se formou. Tal proposta mostrouse uma boa solução urbana, que desfaz a noção de espaço ilhado, presente no projeto original.

Este comportamento que perfaz o "diálogo" entre as ruínas e os novos edifícios foi uma postura bastante utilizada, e que gerou interessantes projetos, como St. Alban em Colônia e a Igreja St. Nicolai em Hamburgo, esta, que também teve sua torre neogótica preservada dos bombardeios. Como se verifica, ao contrário do que tenta estabelecer o apelo do Deutscher Werkbund, não havia no país uma postura única e legitimada, sobre como lidar com o que sobrou da destruição; tampouco uma resolução sobre o que fazer com os edifícios mais e os menos importantes. A questão sobre o que salvar e o que demolir ficava muitas vezes a cargo das autoridades locais. Em muitos edifícios, em que uma recuperação ainda seria possível, optou-se pela demolição. Vinham ao encontro desta iniciativa "as estatísticas de risco e a Higiene Sanitária, que por fim, tinham os argumentos mais fortes. Ao lado estava sempre o convencimento de planejadores, que somente uma retirada completa dos escombros permitiria uma efetiva nova construção". ${ }^{32}$ Esta foi a prática predominante no planejamento exercido no país em fins dos anos 1940. 


\section{Estratégias do Planejamento}

$\mathrm{Na}$ falta de materiais de construção, de máquinas e condições financeiras, o recurso inicial para reduzir o déficit habitacional foi a improvisação. Em meio à utilização de casas parcialmente destruídas e barracos improvisados, muitos arquitetos se voltam para um material que havia em abundância: a terra. Tanto na zona oriental quanto na ocidental a construção com argila foi difundida e amplamente promovida. Os periódicos especializados ilustravam maneiras de se construir com materiais naturais, a fabricação de tijolos a partir da argila, e a construção com coberturas de palha. No imediato pós-guerra, foram muitos os Siedlungen assim construídos, da maneira mais acessível e rápida possível.

Mas ao mesmo tempo em que a época pedia soluções urgentes e medidas sensatas para lidar com necessidades essenciais, não faltavam projetos que voassem alto. Da destruição era, sim, possível, a chance necessária para planejar uma cidade melhor, com mais luz, ar, espaço, maior liberdade, e no caso de Berlim, que ostentara o título de "maior cidade de casernas de aluguel do mundo," 33 a possibilidade de deixar no passado esta realidade: "Disso surge uma chance única para a reforma da moradia, para uma liquidação da malfadada herança do século XIX..."34

Muitos arquitetos viam na destruição causada pela guerra, a oportunidade de um efetivo e completo planejamento. Na cidade mais espalhada, em meio à luz e ao verde, deveria acontecer uma nova vida. Em muitos casos, os planejadores previam a mais completa transformação urbana. Nos primeiros anos não faltavam projetos de edifícios em altura em meio a parques, ou ao menos, campos gramados; as ruas-corredores eram suprimidas e, em seu lugar, projetadas autoestradas para um fluxo de automóveis que ainda não era previsto. Tais soluções se estendiam até mesmo para cidades como Dresden e Nuremberg, onde os edifícios históricos são relegados a um papel secundário.

Hans Hopp, em seu projeto urbano para Dresden de 1945, reservava aos edifícios históricos tão somente uma estreita faixa junto ao rio que corta a cidade. $\mathrm{O}$ restante dela deveria ser preenchida por edifícios em altura em forma de cruz à Corbusier.

Mas talvez nenhum outro projeto do imediato pós-guerra tenha sido tão radical quanto o de Hans Scharoun para Berlim, quando estava no comando do Escritório de Planejamento da cidade. Mostrado na exposição Berlin plant em agosto de 1946, o Kollektivplan (Planejamento Coletivo, em oposição à feição individual da era nazista) mostra o que

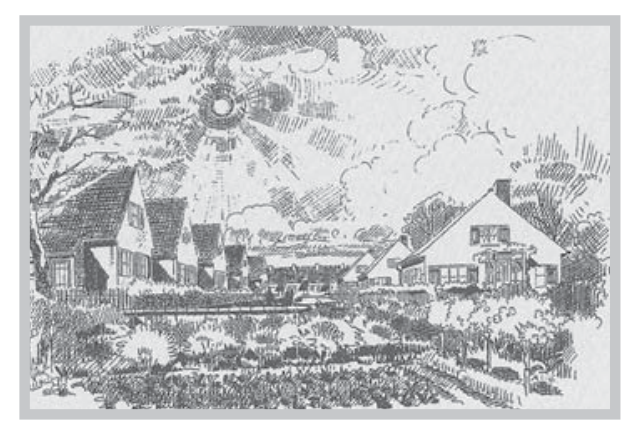

Fig. 10 - Max Taut. A cidade do futuro. Publicação. 1946. 

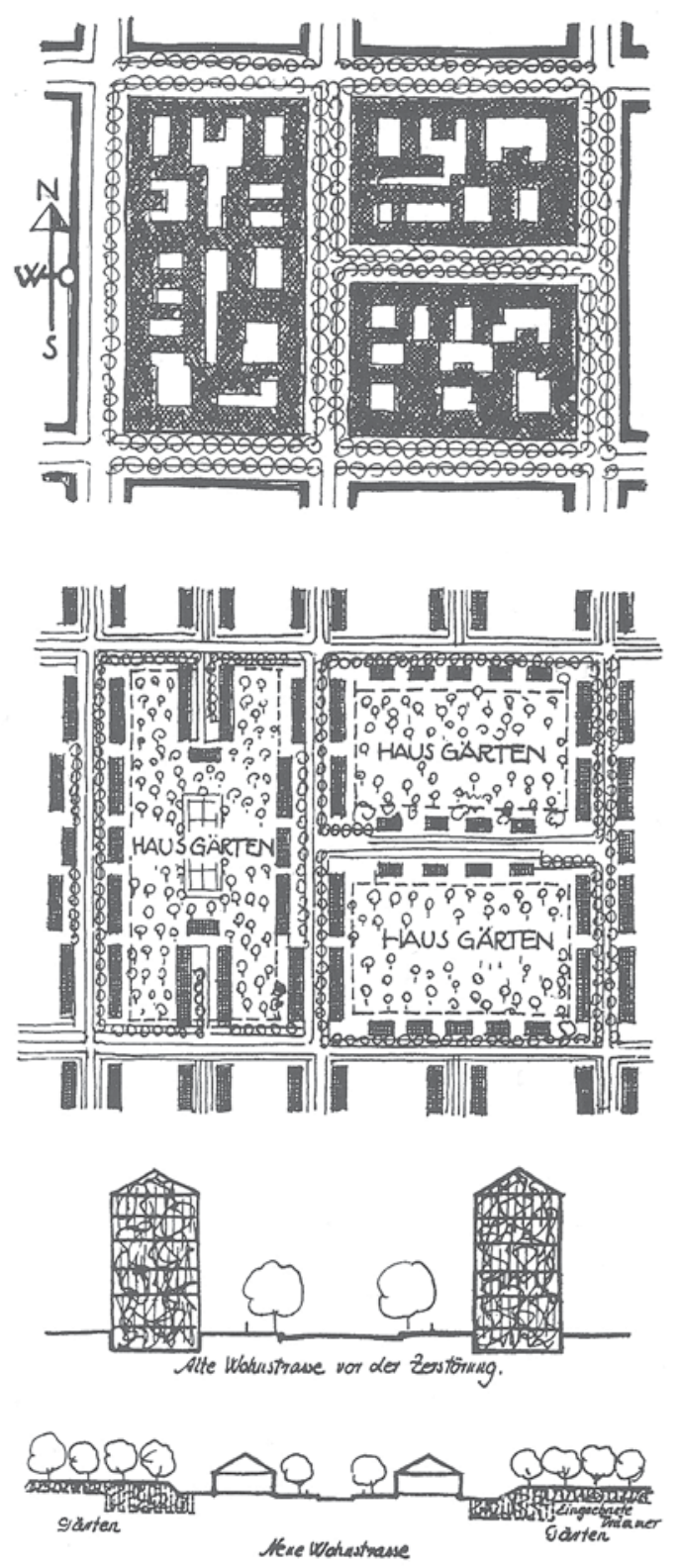

Fig. 11 - Max Taut. Transformação de uma rua residencial. Publicação. 1946.

provavelmente nenhum berlinês ainda havia se dado conta: que a cidade, que se desenvolve ao longo do rio Spree, é originalmente um vale. O projeto tenta conciliar a noção de cidade com a de paisagem natural, que pode ser abrangida com um golpe de vista. Scharoun e sua equipe prevêem sua completa modificação. Da antiga Berlim, densamente construída, passam para o conceito de uma cidade aberta e de espaço natural, que se deita sobre o vale do rio onde originalmente se instalou: "O 'Stadtlandschaft' (ou paisagem urbana) é um princípio formal para o planejador, que domina sobre os grandes conjuntos habitacionais. Através dele é possível dividir em partes o ilimitado, imensurável em algo abrangível e moderado, e ordenar estas partes de tal forma, como interagem floresta, campo, montanha e lago em uma bela paisagem." ${ }^{35}$ Scharoun chega até mesmo a mudar a localização das ruas, ignorando toda a infra-estrutura, tanto subterrânea quanto de superfície, numa cidade que contava com bondes e até mesmo metrô, além de túneis. Nesta paisagem urbana, seriam propostos, ao invés de eixos ortogonais, traçados orgânicos, que seguem curvas e respeitam o traçado natural do lugar, formando espaços naturais. Toda uma hierarquia de ruas e caminhos é prevista, que substituem cruzamentos e interseções. Também foi este princípio de planejamento que utilizou Rudolf Schwarz para seu projeto para a cidade de Colônia em 1950. Entretanto, no caso de Scharoun, as vias retilíneas que sobressaem no projeto, servem ao trânsito rápido, e como em outras propostas da época, as artérias da cidade assumem muitas vezes um papel importante, preponderante até.

O tema Stadtlandschaft ou de uma "paisagem urbana", tem uma longa tradição. Já nos anos 1930 durante o Regime Nazista havia teóricos trabalhando com este conceito, que teria sido cunhado ainda antes, em 1930. ${ }^{36}$ Mas há que se ter em vista que esta ideia é a própria noção que estava presente nas formulações de Ebenezer Howard ou Parker \& Unwin nas Cidades-Jardins. Também tem lugar nas novas formulações o conceito de Nachbarschaft (seu equivalente inglês Neighbouhood unit - unidade de vizinhança), que formam as hierarquias do conjunto e dão lugar a um planejamento urbano orgânico. 


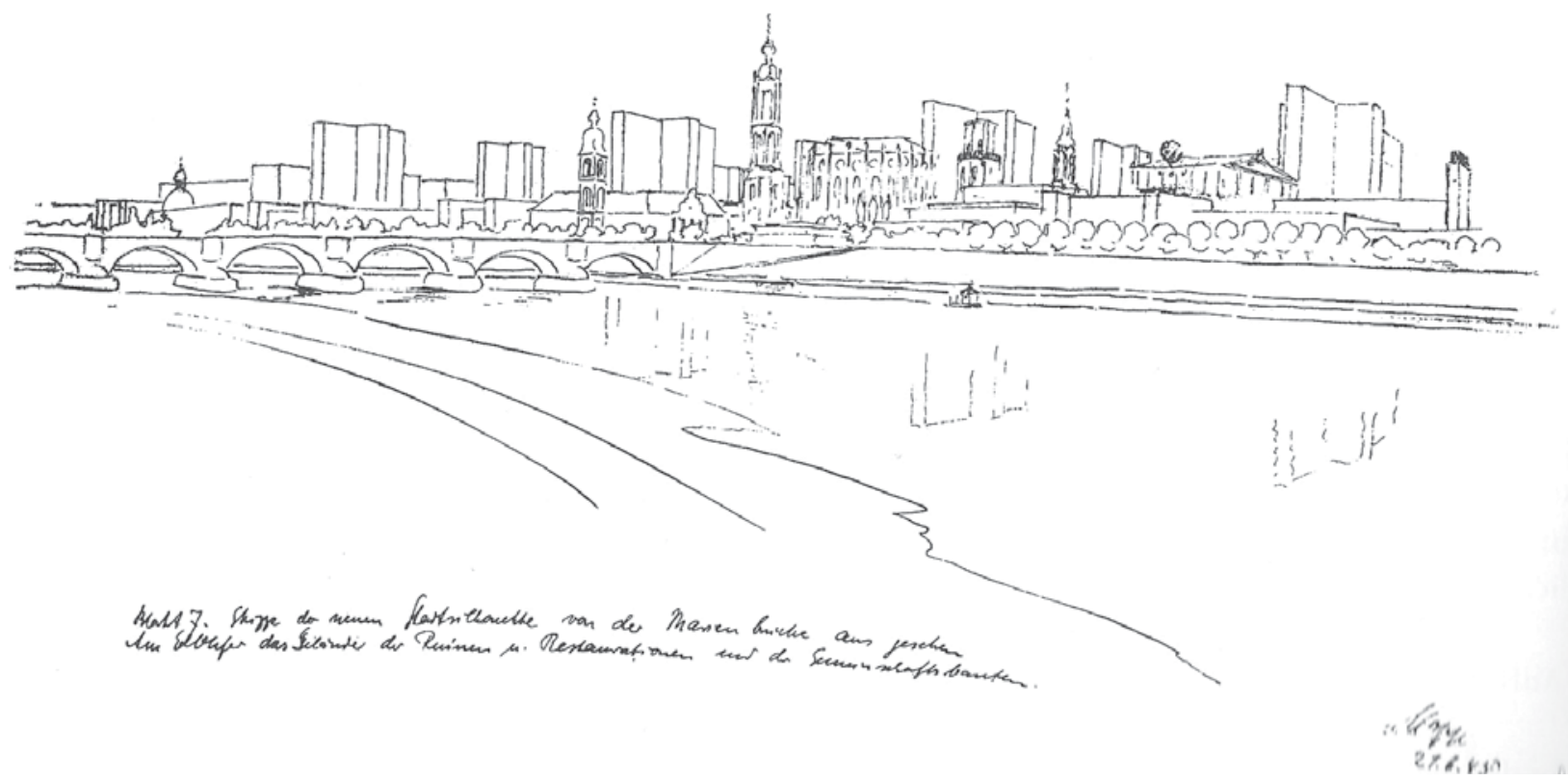

Fig. 12 - Hans Hopp. Plano de Reconstrução para Dresden. Projeto. 1945.

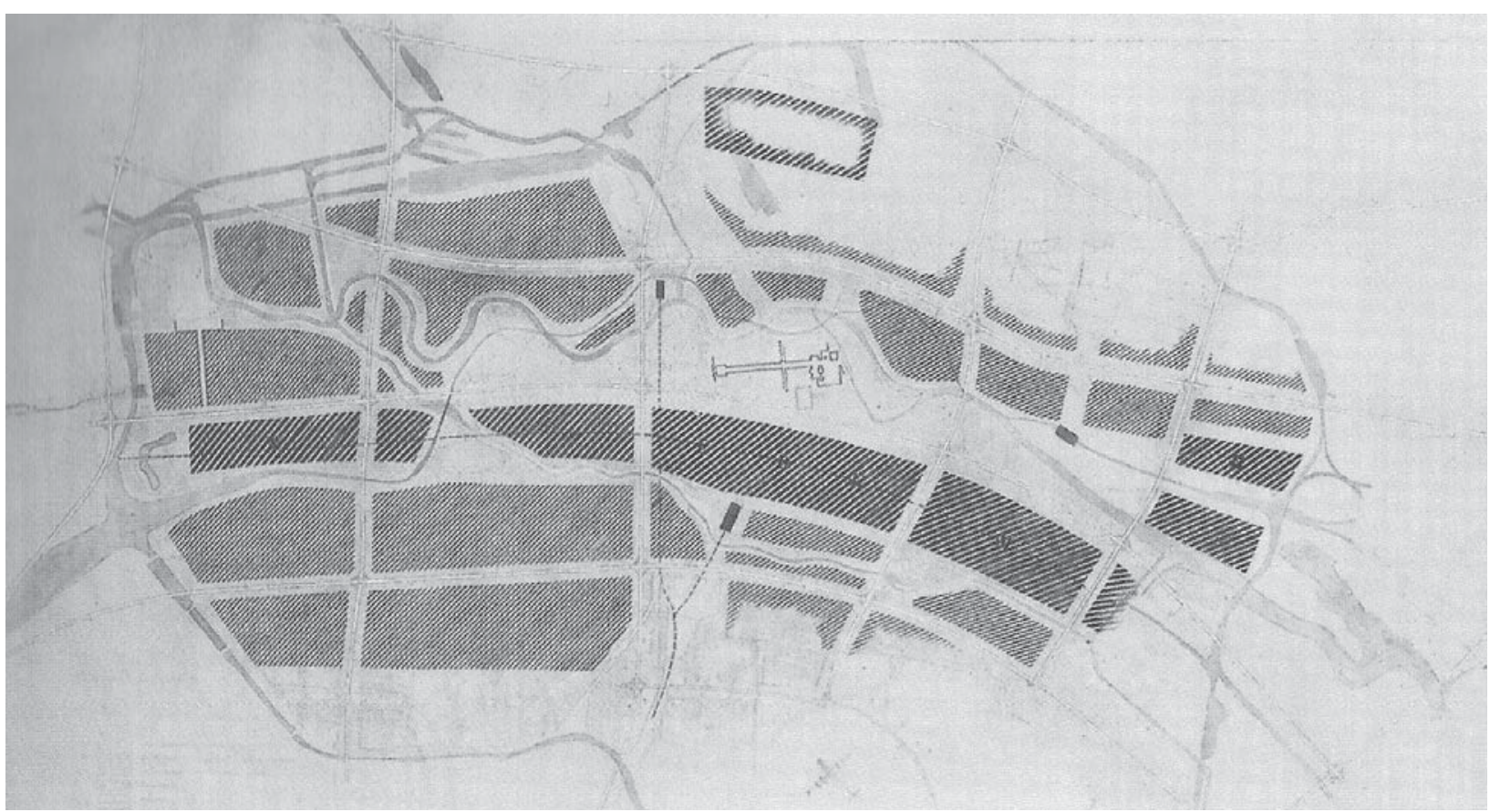

Fig. 13 - Hans Scharoun. Kollektivplan. Projeto. Berlim. 1946.

Mas tamanha radicalidade ficou mesmo reservada às pranchetas de desenho. $\mathrm{Na}$ realidade, este radicalismo figura entre as exceções do que foi posto em prática, como o caso de Grindelhochhäuser em Hamburgo (1946-1956) com seus doze edifícios em meio a uma paisagem límpida, ilhados no contexto da cidade. Tanto posições ultra-modernas quanto as demasiadamente conservadoras foram negadas na Alemanha em reconstrução. Posições extremistas de radicalismo, por um lado, e conservadorismo por outro, foram denegadas em favor de uma posição intermediária, conciliadora entre um respeito ao passado e uma decidida vontade de melhorar o futuro. ${ }^{37}$ Ao lado do projeto de avenidas que rasgavam as cidades e lhes valiam o título de "modernas," também eram previstos ruas reservadas aos 


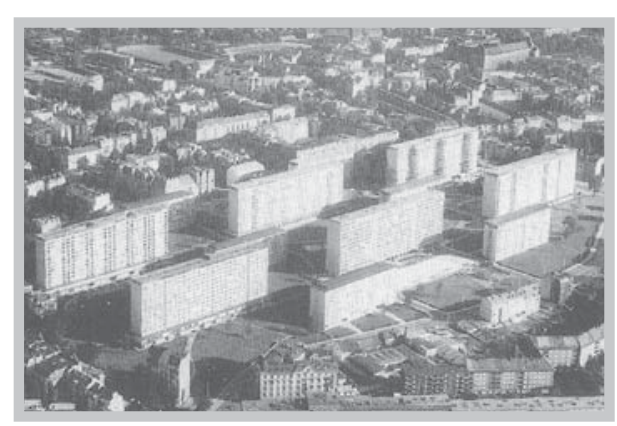

Fig. 14 - Bernhard Hermkes, Rudolf Jäger, Rudolf Lodder e outros. Grindelhochhäuser. Hamburgo. 1946-1956

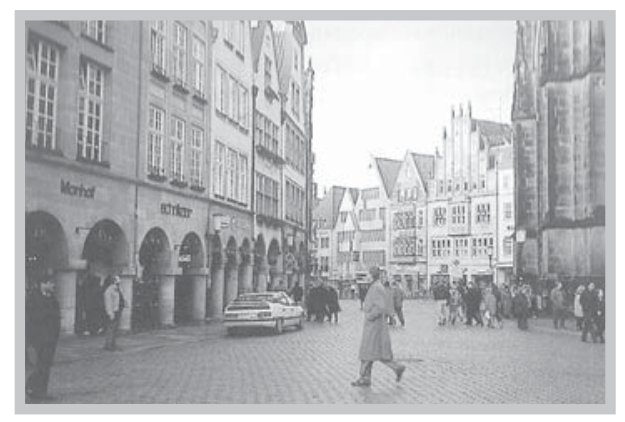

Fig. 15 - Escritório de Planejamento Urbano. Mercado Principal. Münster. 1945-1952. pedestres, que tinham seu exemplo no conhecido projeto de Lijnbaan em Roterdã (1949-1955).

Defato,oqueamaioriadaspropostasdeplanejamentourbano tinha em comum, fossem elas para grandes bairros com edifícios em altura, ou pequenas habitações unifamiliares, era a forma aberta de projeto, descongestionada. Mas também não faltaram exemplos de cidades que, sentindo-se muito ligadas às suas tradições, optaram pela reconstituição de seus antigos espaços - como a praça do mercado, o centro histórico ou as ruas mais importantes - que, muitas vezes, formavam “ilhas” de tradição em cidades modernas. Freiburg, Münster, Nuremberg e Munique contam entre estas. Não que esta postura também não tenha gerado exemplos desastrosos, como o "fachadismo" de Münster, onde foram desenhados alguns modelos padronizados de fachadas, aplicadas de forma alternada na praça principal da cidade. Para a visão da época, este tipo de planejamento que procurava preservar o traçado das ruas e a essência das construções - ainda que gerando modelos questionáveis - valiam como reacionários, presos ao antigo sistema. Já aqueles que reorganizavam radicalmente, foram atribuídos ao novo, aberto ao futuro, não observado, como lembra Pehnt que, neste caso, "a maioria de seus protagonistas provinham da Tecnocracia Nacional-Socialista." 38 


\section{Notas}

1 Pehnt, Wolfgang. Deutsche Architektur seit 1900. 2. ed. Ludwigsburg/ München: Wüstenrot Stiftung/ Deutsche Verlags-Anstalt, 2006, p. 247.

2 Reinaugurada em 30 de outubro de 2005.

3 Pehnt, Wolfgang. Deutsche Architektur seit 1900. Op. cit. p. 247.

4 Neundörfer, Ludwig. Inventur des Zusammenbruchs. Baukunst und Werkform, n.1, 1947, p. 21.

5 Argan, Giulio Carlo. Arte Moderna. São Paulo: Companhia das Letras, 1992.

6 Em alusão à Bauhaus, como Gropius a denomina no manifesto que marca sua fundação em 1919.

7 Ein Aufruf: Grundsätzliche Forderungen. Publicado diversas vezes entre eles em: Baukunst und Werkform, no 1, 1947, p. 29.

8 Pehnt, Wolfgang. Deutsche Architektur seit 1900. Op. cit. p. 250.

9 Durth, Werner; Sigel, Paul. Baukultur. Spiegel gesellschaftlichen Wandels. Berlim: Jovis, 2009, p. 401.

10 Rudolf Weilbier. Es kam und sprach Walther Gropius(sic). Neue Bauwelt, n. 35, 1947, p. 549.

11 Idem. Ibidem.

12 Karl Bonatz. Anmerkungen zu den Presseinterviews und zu seinem Vortrag im TitaniaPalast am 22.August 1947. Neue Bauwelt n. 35, 1947, p. 550.

13 Idem. Ibidem. Grifo no original.

14 Idem. Ibidem.

15 Durth, Werner; Sigel, Paul. Op. cit. p. 402.

16 Ver Capítulo 2.

17 Fundada por Fritz Todt em 1938, Ministro de Armamento e Produção de Guerra durante o III Reich, a Organização Todt era responsável pela construção de infraestruturas militares.

18 Pehnt, Wolfgang. Deutsche Architektur seit 1900. Op. cit. p. 251.

19 Idem. ibidem.

20 Durth, Werner. Deutsche Architekten. Biografische Verflechtungen 1900-1970. Stuttgart/ Zurique: Karl Krämer Verlag, 2001, p. 237.

21 Pehnt, Wolfgang. Deutsche Architektur seit 1900. Op. cit., p. 252.

22 Idem.p. 254.

23 Idem. p. 275.

24 A Carta de Atenas surgiu em 1933 durante o IV CIAM e foi publicada em 1943 por Le Corbusier.

25 De fato, nos anos pós-guerra, grande parte dos alemães acreditava na possibilidade de uma nova guerra mundial; em 1951 quase metade da população considerava possível o estourar de uma guerra ainda naquele ano. Noelle, Elisabeth; Neumann, Erich Peter. The Germans: Public Opinion Polls 1947-1966. Wesport: Greenwood Press, 1981, p. 604.

26 Durth, Werner. Deutsche Architekten. Biografische Verflechtungen 1900-1970,op. cit. p. 216.

27 Otto Bartning. Ketzerische gedanken am Rande der Trümmerhaufen. In: Frankfurter Hefte 1, 1946, p. 46. Grifo no original.

28 Ernst May zum Frankfurter Wiederaufbau. Ein Gespräch mit dem Stadtplaner. In: Frankfurter Rundschau, 19.2.1949. apud: Pehnt, Wolfgang. Deutsche Architektur seit 1900 op. cit. p. 258

29 Stimmen zum Neuaufbau. Ein Aufruf: Grundsätzliche Forderungen. Baukunst und Werkform. $\mathrm{n}^{\circ} 1,1947$, p. 29

30 Idem. Ibidem. 
31 Kabierske, Gerhard. Kaiser-Wilhelm-Gedächtniskirche. In: Jaeggi, Annemarie (org.). Egon Eiermann (1904-1970): die Kontinuität der Moderne. Ostfildern-Ruit: Hatje Cantz Verlag, 2004, p.173.

32 Pehnt, Wolfgang. Deutsche Architektur seit 1900. Op. cit. p. 257.

33 Hegemann, Werner. Das steinerne Berlin. Geschichte der größte Mietskasernstadt der Welt. 1930.

34 Neundörfer, Ludwig. Inventur des Zusammenbruchs. Baukunst und Werkform, n.1, 1947, p. 21.

35 Hans Scharoun. Zur Ausstellung Berlin-plant. Neue Bauwelt. n. 10, 02.09.1946, p. 3.

36 Pelo historiador de arte Siefried Passarge em seu livro Stadtlandschaften de Erde. Hamburg, 1930.

37 Pehnt, Wolfgang. Deutsche Architektur seit 1900. Op. cit. p. 278.

38 Pehnt, Wolfgang. Deutsche Architektur seit 1900. Op. cit. p. 276. 


\section{UM RECOMEÇO POSSÍVEL}

Passados os primeiros anos após a guerra, em que predominava o cenário de entulhos e construções provisórias, ${ }^{1}$ e questões sobre como agir com os edifícios históricos e planos (por vezes utópicos e ultrarradicais) de reconstrução das cidades dominavam os debates, volta-se agora a face ao futuro, só que de uma maneira mais pragmática.

Após a reforma monetária no verão de 1948 e as vultosas somas advindas do plano Marshall, ${ }^{2}$ tem início na Alemanha em 1948 uma torrente de concursos, que inaugurará, de fato, a grande fase de reconstrução no país. Desde a reforma monetária era notável uma significativa melhora no nível de vida da parte oeste em comparação ao leste alemão, ${ }^{3}$ corroborado pelo plano econômico norteamericano, que deu a partida inicial para o "Milagre Econômico" da parte ocidental do país. No plano Marshall os créditos financeiros também eram enviados para a construção civil, destinados à construção de conjuntos habitacionais e também a um programa especial de habitação para refugiados. Indiretamente todo o processo de reconstrução beneficiou-se da retomada econômica que o plano ajudou a proporcionar. Essencial foi também seu efeito político, pois que sinalizava a futura união das três zonas ocidentais e o surgimento, em 1949, da República Federal Alemã.

São inúmeros os concursos lançados simultaneamente e por todo o país em 1948, em um momento, de forma mais local, para gradativamente tomar proporções internacionais. Agora sim os arquitetos não mais poderiam lamentar a ausência de trabalho que sinalizara os anos precedentes; ao contrário, há casos de escritórios que abrem filiais em outras cidades do país. Os concursos são marcados pelos mais diversos programas; desde a menor escala até grandes proporções; desde reconstruções de edifícios considerados importantes, edificações isoladas até remodelações e reconstruções de sítios históricos e porções da cidade.

\section{ALÉM DAS FRONTEIRAS}

Mas nesta retomada da construção, para onde se orientar? De fato, os jovens arquitetos alemães formados em fins de 1930 ou nos anos imediatamente posteriores à Segunda Guerra encontravam-se, como não seria diferente, em uma posição imprecisa: ao retrocederem o olhar, avistavam um passado do qual queriam se livrar, como tudo o que ele sinalizava, evidentemente também sua arquitetura oficial; ao seu redor, não mais que escombros, construções provisórias e barracos; a sua frente um futuro incerto. Os arquitetos que pudessem servir de exemplo a esta nova geração e conduzir os rumos do desenvolvimento do país, 
haviam emigrado em sua maioria, ${ }^{4}$ e os poucos que regressaram, o fizeram alguns anos mais tarde. ${ }^{5} \mathrm{~A}$ isto juntam-se os anos de auto-isolamento que o país se impôs e a censura de imprensa quase perfeita durante os anos do Regime Nazista, ${ }^{6}$ que não permitiam o "olhar" para fora, e assim, os desenvolvimentos por que passava a arquitetura moderna em outros países passaram despercebidos. ${ }^{7}$

Não que não houvesse arquitetos capacitados e, tampouco, sem experiência. Ao contrário; para os que permaneceram no país durante os anos 1930, não lhes faltavam a experiência, as ligações e a influência nas esferas de poder, que sobreviveram ao jugo da guerra, tampouco a capacitação necessária para comandar os desenvolvimentos do país, tanto que os legitimou a assumir, de pronto, os principais postos junto aos escritórios de planejamento municipais das principais cidades alemãs. Possivelmente a pior situação restou para esta nova geração, como no caso de Hans Broos, que não tinham a experiência necessária para nela se apoiar, tampouco exemplos domésticos recentes e "dignos" de emulação.

O “isolamento" dos jovens estudantes no imediato era ainda maior tendo em vista que, além do "sufocamento" dos anos do regime nazista, grande parte dos estudantes era egressa dos campos de batalha, ${ }^{8}$ alheios ao desenvolvimento internacional da arquitetura e quando muito, informavam-se através de revistas como "Die Kunst im Deutscher Reich"."

Além disso, os mestres que haviam emigrado não voltaram a construir tão cedo no país. Mies só voltou a construir anos mais tarde a National Galerie de Berlim (1962-1968) com a qual encerraria sua obra em sua terra natal, apesar dos muitos projetos que recebera e que não foram levados adiante. ${ }^{10}$ Walter Gropius, apesar de ser Conselheiro do Governo Militar Norte-Americano no país desde 1947, igualmente só receberia encomendas anos mais tarde com o edifício de oito andares para o Interbau (1957), os edifícios de produção da fábrica de porcelana Rosenthal \& Thomas em Selb/ Amberg, e mais tarde com a encomenda do edifício para a Bauhaus-Archiv (1964,1976-79) que o arquiteto não viu realizado, e do Siedlung Neuköll (1962-1975) em Berlim, posteriormente denominado Gropiusstadt (Cidade Gropius).

Passados alguns anos, esta nova geração vai procurar exemplos para espelhar sua própria obra: voltam-se para arquitetos "de casa" e encontram Egon Eiermann que inicia sua obra pós-guerra com a fantástica Indústria Têxtil de Blumberg; além de Rudolf Schwarz, Otto Bartning, e o mestre Hans Scharoun. Voltam-se também às revistas internacionais e encantam-se com a precisão e ousadia de Mies, e suas obras posteriores como o Seagram (1954-1957) de Nova Iorque, com 
a Unidade de Habitação de Marselha e Ronchamp de Corbusier, bem como com as propostas de Gropius e Frank Lloyd Wright.

Os primeiros exemplos vinham de fora: a vizinha Suíça e os países escandinavos serviam como um exemplo próximo de uma arquitetura "possível". O futuro estava a um olhar: "após anos de estrangulação olhamos novamente sobre as fronteiras e saudamos alegres o encontro com as realizações alcançadas no exterior em todas as áreas da forma do espaço e de equipamento."11

As revistas da época estampam frequentemente projetos da vizinha Suíça e dos Países Escandinavos. Não somente as publicações (livros, revistas) documentavam fartamente a arquitetura desenvolvida nestes países, como ela também chegava aos alemães através de inúmeras exposições. ${ }^{12}$ Os principais destinos de excursões de arquitetura ou de professores com alunos eram Suíça, Suécia, Dinamarca e Holanda. O que os encantava na produção destes países, que permaneceram neutros durante a Segunda Guerra, era a jovialidade e o pragmatismo desta arquitetura, que não havia conhecido o dogmatismo em que resvalara a arquitetura moderna alemã no final da década de 1920. Em relação à produção suíça, eram admiradas "a consistência, integridade, e renúncia a padrões da moda"13 das obras mais recentes; era como se a nova arquitetura, que em seus anos de florescimento tivesse passado despercebida pelo país vizinho, lá tivesse sido conservada e agora, aos arquitetos alemães, lhes era dada a chance de apoderar-se novamente do que, de fato, sempre lhe pertenceu. ${ }^{14}$

A Dinamarca tornou-se outra referência, identificada na obra de Erik Gunnar Asplund e principalmente do jovem arquiteto Arne Jacobsen, que aliava a arquitetura do chamado Estilo Internacional com sutilezas locais, qualidade nos detalhes e materiais tradicionais. Contato que se fez primeiramente através das inúmeras publicações, para lá seguiram muitas excursões de estudo a partir dos anos 1950. Como um Estado que se baseava em grande parte em intervenções estatais, a Suécia também foi um exemplo tomado pelos arquitetos alemães. A política habitacional levada a cabo desde 1932 pelo governo local estabelecia vultosos empreendimentos regidos sob normatização e racionalização, que serviam como bons exemplos de urbanidade, como mostram exemplos nos arredores de Estocolmo como Vällingby (1952-1957), que em sua forma e, principalmente, no uso de coberturas, registram aspectos da arquitetura tradicional, além da procura de diferenciação formal entre os edifícios.

São em geral países que tiveram uma postura mais resguardada em relação à arquitetura moderna, que nos anos 1920, tivera uma ressonância bastante moderada sobre a produção local. E justamente nos anos 1930, quando parte 


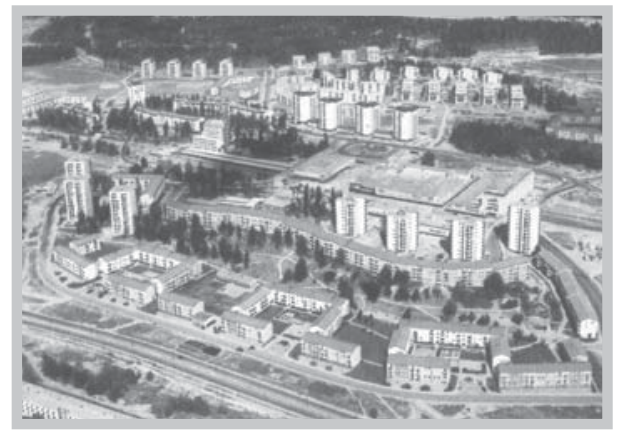

Fig. 1 -Sven Backström, Leif Reinius e outros. Divisão de Planejamento Urbano. Vällingby-Estocolmo. 1952-1957. da Europa cai sob o domínio do Fascismo e, tem início, em geral, as reações ao moderno, começa a ganhar impulso nestes países - Escandinávia, Suíça, Holanda a Arquitetura Moderna, através de uma lenta e gradual evolução, em conjunto com as qualidades artesanais próprias destes países. E é para lá que se voltarão, depois da Segunda Guerra, olhares atentos para uma espécie de "reaprendizado", e esta arquitetura sensível e "natural" servirá de exemplo e fascinará arquitetos, tanto das novas gerações quanto os mais experientes. No pós-guerra, a arquitetura escandinava representa um caminho seguro ou, no dizer de Julius Posener, um "terceiro caminho", aqui ainda válido, pois medeia entre modernidade e tradição, uma modernidade mais segura e firme do que aquela ideologicamente programática dos anos 1920.

Mas no rol das arquiteturas e países que encontravam lugar no seio do debate arquitetônico alemão pós-guerra, a Arquitetura Moderna Brasileira não parecia estar tão entronizada. Ao contrário do que se pensa, e a despeito de sua ampla divulgação no exterior e do reconhecimento internacional que já desfrutava nesta época, a arquitetura brasileira obtinha pouca, quase nenhuma apreciação da imprensa local. A um primeiro momento, as revistas voltam-se para problemas locais da reconstrução, com poucas aberturas a obras e arquitetos estrangeiros, privilegiada, como dito, a ligação que mantinham com os países do norte. A partir dos anos 1950 tem-se, de fato, uma maior abertura para outros países, com uma participação brasileira muito pequena, vista mais como uma situação distante e peculiar do que um exemplo admissível e passível de emulação. ${ }^{15}$

Mesmo uma revista simpática a arquitetura moderna como a Baukunst und Werkform não reproduzia reportagens de peso sobre a arquitetura brasileira em suas páginas; nada que possa ser comparado ao fascínio exercido pela arquitetura escandinava sobre os profissionais e a imprensa locais. As notícias sobre o que aqui se produzia eram, antes, de segunda mão, por intermédio de revistas internacionais, principalmente a francesa L'Architecture d'aujourd'hui, que no imediato pós-guerra publicou alguns números dedicados ao Brasil. ${ }^{16} \mathrm{~A}$ este propósito, os arquitetos entrevistados na Alemanha, quando questionados sobre seus conhecimentos à época, sobre arquitetura brasileira, respondiam em uníssono: "arquitetura brasileira...não, não conhecíamos muito..."17

Além disso, a célebre publicação Brazil Builds de $1943,{ }^{18}$ que teve origem na exposição homônima, foi publicada em meio ao conflito mundial e, portanto, de efeito quase nulo em território germânico. Tal situação obriga-nos a relativizar 
seu alcance, ao menos no tocante a estes países no ano de seu lançamento e anos imediatamente posteriores. Finda a guerra, o contato com a arquitetura moderna brasileira viria algum tempo depois - como para Hans Broos, Victor Reif e Adolf Franz Heep - mais provavelmente através de publicações internacionais, como L'Architecture d'aujourd'hui e sua edição especial de 1947 sobre a arquitetura brasileira.

\section{REDESCOBRINDO A HISTÓRIA}

O isolamento de vários anos sob o regime nazista e através da guerra obrigou principalmente os jovens arquitetos a obter estímulos fora das fronteiras do país. Mas mesmo para os mais experientes, viagens e excursões ao exterior valiam como "cursos de aperfeiçoamento" em matéria de arquitetura, e foram muitas as excursões que professores faziam com seus alunos, ou viagens de estudo que arquitetos empreendiam; em cada zona de domínio do território alemão era procurado que os profissionais fossem colher estas experiências no país de origem.

Os Estados Unidos eram, sem dúvida, um dos países que maior fascínio exercia sobre os arquitetos locais; fascínio porém, de longa data, pelo menos desde o início do século - seus arranha-céus, cidades voltadas para o uso do carro e o modo de vida norte-americano, com suas facilidades diárias: lojas de auto-atendimento, televisão nas casas, além das novas relações no mercado da construção civil, que cedia cada vez mais lugar para as corporações e construtores em detrimento do trabalho isolado do arquiteto, como relata impressionado Eiermann, após sua primeira viagem em $1950 .{ }^{19}$ Com a emigração dos mestres modernos Mies, Gropius, Breuer, Wachsmann, além daqueles há mais tempo emigrados Richard Neutra e Schindler, o país parecia o verdadeiro reduto do futuro. Além disso, o escritório SOM e, é claro, Frank Lloyd Wright, que já havia sido largamente divulgado na Europa desde 1910. Especialmente suas obras dos anos 1930 Casa da Cascata em Bear Run, Pensilvânia, Fábrica Johnson \& Son em Racine, Wisconsin e suas Usonia-House, diz Pehnt, pertencem ao museu imaginário dos arquitetos pós-segunda guerra. ${ }^{20} \mathrm{E}$ sem dúvida, a modo de grand finale, o Museu Guggenheim de Nova York inaugurado em 1959, mas em elaboração desde 1943. Além disso, eram muitas as exposições sobre a arquitetura norte-americana: "Amerikanische Architektur seit 1947", "So wohnt Amerika" onde a atração principal eram as casas de Wright.

São nestes primeiros anos do pós-guerra que capítulos da história da Arquitetura Moderna começam a se descortinar para a nova geração. Segundo Justus Herrenberger ${ }^{21}$ são nestes anos que eles reconhecem de fato o que foi a Bauhaus; 


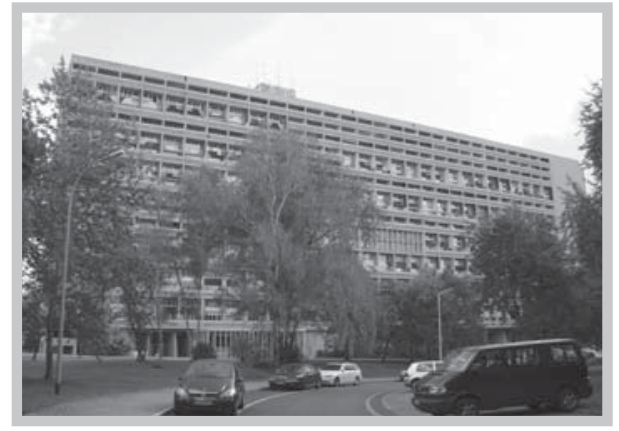

Fig. 2 - Le Corbusier. Unidade de Habitação. Berlim. 1956-1958.

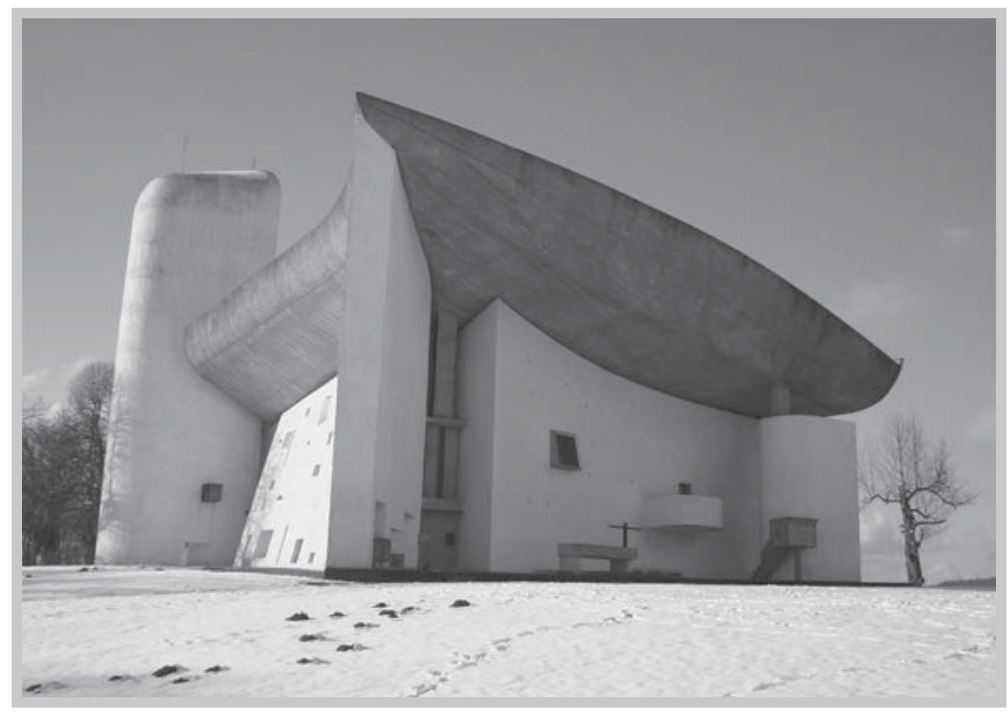

Fig. 3 - Le Corbusier. Capela Notre-Dame-du-Haut. Ronchamp. 1950-1955. ligadas à escola. ${ }^{22}$

não que antes não soubessem, conheciam a Bauhaus ou alguns lances da história da arquitetura moderna; mas segundo a ótica nazista, que enfocava os erros construtivos e as inadequações climáticas dos edifícios modernos. Já em 1946, teve lugar a Exposição "Bauhaus-Dessau" que mostrava trabalhos, projetos e publicações dos personagens

Imediatamente após 1945 são publicados na Alemanha os planos urbanísticos de Le Corbusier, enriquecidos com as propostas para a América do Sul e Norte da África. Com a Unidade de Habitação (1946-1952) em Marselha, Corbusier concretiza o projeto de um novo modelo de habitação urbana que causaria imensa influência na arquitetura mundial. Uma década mais tarde Berlim receberia também o seu exemplar da Unité, construído por

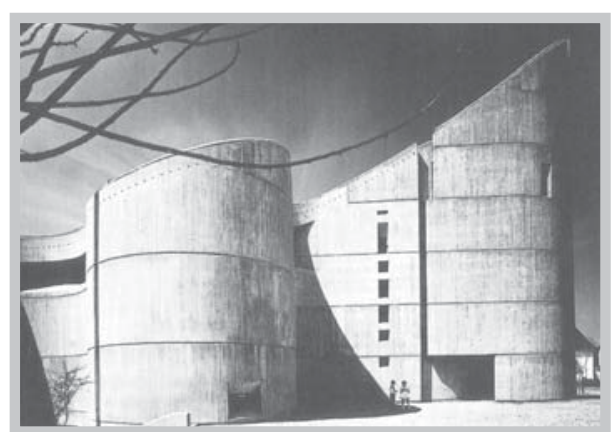

Fig. 4 - Joachim e Margot Schürmann. Igreja Pio X. Neuß, Alemanha. 1965 ocasião da Interbau (1956-1958), porém não na área da exposição, e com diversas modificações no projeto. ${ }^{23}$

Mas talvez nenhuma obra provocou tanta polêmica (e talvez nenhuma outra influenciou tanto) como a Capela de Ronchamp (1950-1955), que surpreende a todos com seu aspecto maciço e sua forma livre, e despertou críticas elogiosas tanto quanto polêmicas. Suas espessas paredes (principalmente a do lado sul com suas aberturas que dramatizam a luz), a cobertura curva em concreto aparente que pressiona o espaço interno, causaram sensação na época. Depois dela, muitas igrejas queriam ser Ronchamp; muitos projetos começam a ganhar formas arredondadas com tetos curvos e entradas quase sempre camufladas, ou apenas insinuadas, mas não escancaradas. Com esta obra, Corbusier anuncia uma saída triunfal do modernismo ortodoxo e a inclusão da história e da liberdade criativa, e chega mesmo a renegar sua obra pregressa; renuncia a uma arquitetura fria e, sobretudo, ao dogma da verdade construtiva. Algo que Eiermann não poupou de suas críticas: "Uma parede não deve ser mais grossa do que suas necessidades técnicas e outras mais exigem [...], e 
nem um centímetro mais grossa." ${ }^{24}$ E completa: "Na arquitetura, quando vocês a tomam por séria, vocês não podem fazer coisas, onde vocês simulem algo." ${ }^{25}$ Para Eiermann, Ronchamp era uma "escultura adentrável”, comparável à Estátua da Liberdade em Nova York; pertencia ao mundo da escultura, não ao da arquitetura. E retrucava os estudantes, fascinados pela obra. ${ }^{26}$

\section{A FÁbRica De BLumberg}

No final dos anos 1940, a construção da Indústria Têxtil de Blumberg (1949$1951)^{27}$ de Egon Eiermann causou um imenso impacto junto a esta nova geração, ${ }^{28}$ e se mostrou como uma surpreendente manifestação de um modo de fazer o moderno que abria amplas possibilidades, desenhada com simplicidade e sem se prender a fórmulas, que foi recebida com grande entusiasmo e levou legiões de arquitetos a esta pequena cidade no sul da Alemanha.

Assim como fizeram Peter Behrens e Walter Gropius no início do século XX, também Egon Eiermann, no pós-guerra, renova a linguagem arquitetônica através da construção de uma fábrica, unindo a um só tempo, simplicidade, diferenciação formal e uma elegante Sachlichkeit, que transformou esta fábrica num marco da arquitetura pós-guerra alemã e da obra do arquiteto. ${ }^{29}$

Egon Eiermann aprendera a utilizar a linguagem moderna de um modo amplo e variado para poder construir "moderno" durante o Terceiro Reich, assim como também o fizeram arquitetos como Hans Scharoun e Hugo Häring. Das casas simples e naturais dos anos 1930 surge uma linguagem flexível, que faz uso alternativo de materiais convencionais e descobre um modo não dogmático de ser moderno e de lidar com a arquitetura, que se conservou na sua obra pós-guerra.

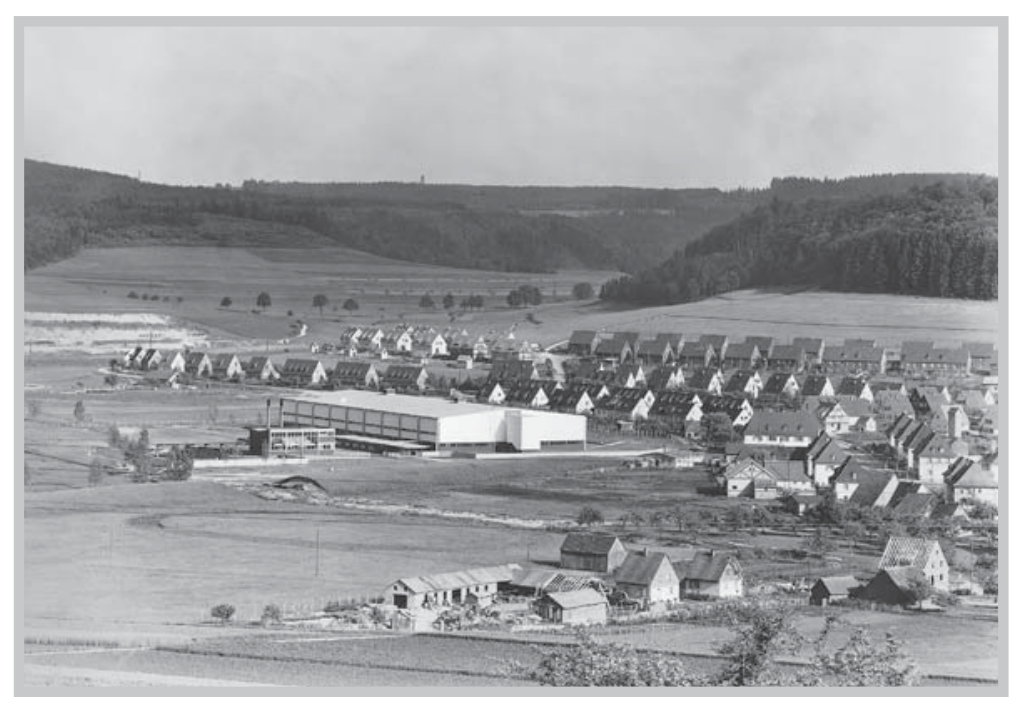

Fig. 5 - Egon Eiermann. Indústria Têxtil Blumberg. Blumberg. 1949-1951.

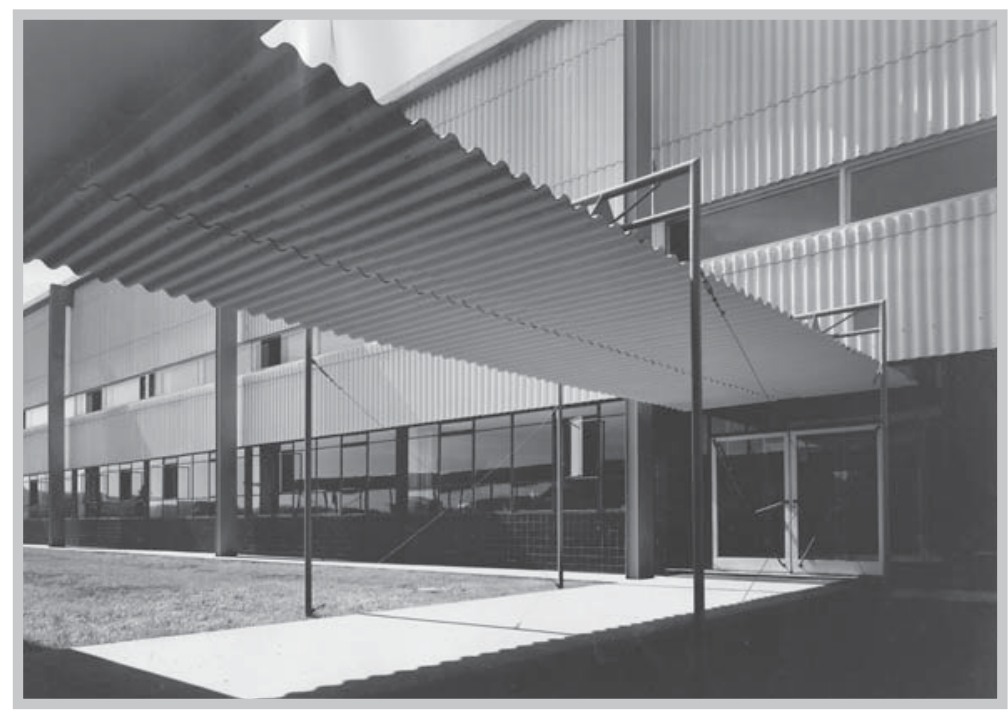

Fig. 6 - Egon Eiermann. Indústria Têxtil Blumberg. Blumberg. 1949-1951. 


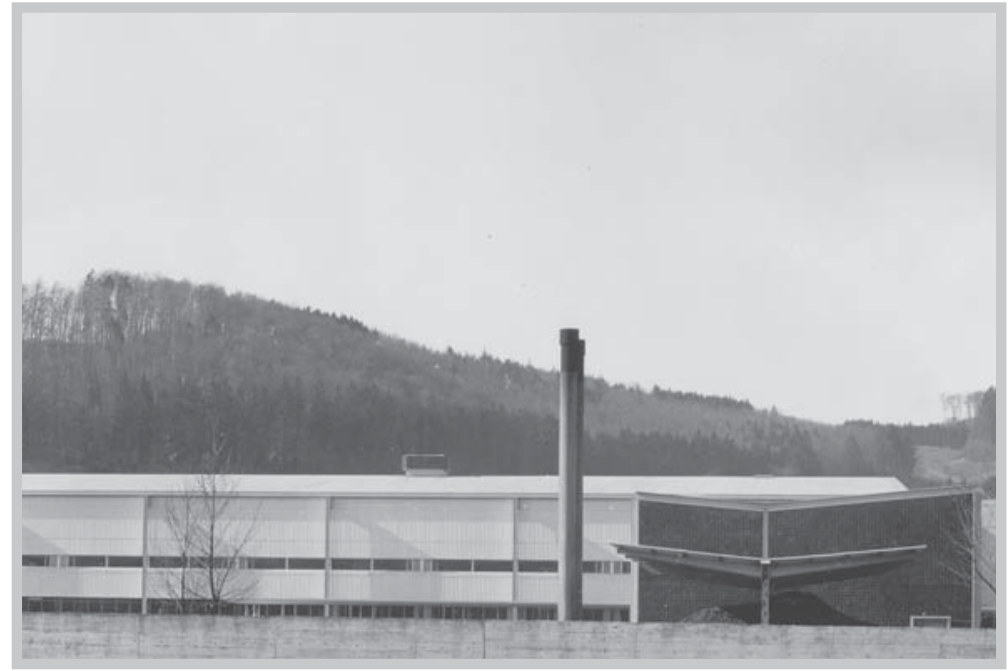

Fig. 7 - Egon Eiermann. Indústria Têxtil Blumberg. Blumberg. 1949-1951.

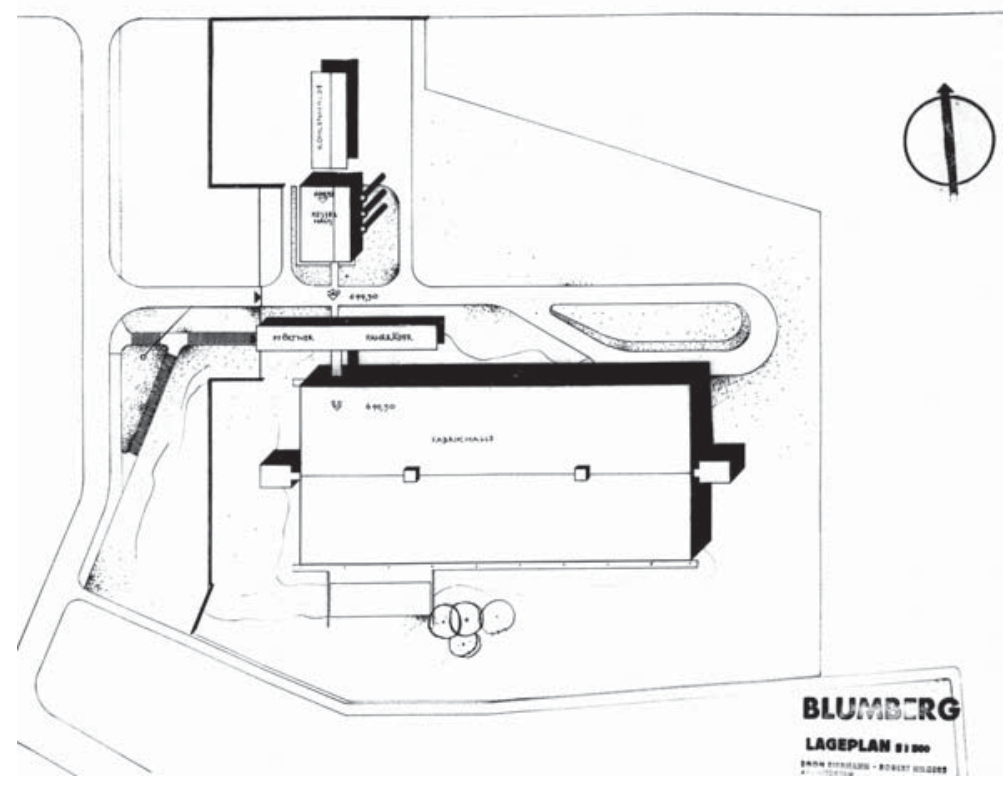

Fig. 8 - Indústria Têxtil Blumberg. Implantação.
A precisão construtiva e a verdade formal eram suas máximas, e $\mathrm{o}$ arquiteto procura tornar tais princípios visíveis em seus projetos. Assim Eiermann concebe esta fábrica, explorando seu valor estético puramente de sua funcionalidade e de sua construtividade, e que impressiona tambémpelassoluções originaisque emprega, como as chapas onduladas de fibrocimento na fachada, tendo em vista necessidades funcionais, e a recusa dos sheds na cobertura em favor de um telhado levemente inclinado, o que a faz adequar-se com naturalidade ao contexto, e assumir até mesmo, um caráter convencional, em meio às casinhas do entorno.

À construção industrial sempre coube um importante, senão primordial papel dentro do Movimento Moderno. Se por um lado, o projeto habitacional solicitouintensa pesquisa projetual e também foi campo de experimentação construtiva e, por certo, ocupou a maior parte das discussões arquitetônicas no entre guerras, por outro, foi reservado à indústria o lugar da modernidade por excelência, depositária de verdadeiras inovações técnicas e estéticas. A importância do projeto de Blumberg, assim como de outras indústrias do pós-guerra, vem a confirmar a primazia da arquitetura industrial no Movimento Moderno alemão: Para ela se voltaram os melhores arquitetos alemães desde o início do século: Peter Behrens, Hans Poelzig, Walter Gropius, Hermann Muthesius, que não queriam deixar tamanha tarefa somente nas mãos dos engenheiros; na Alemanha Nazista, representou uma espécie de "porto-seguro" para os sequazes do moderno, e agora, no pósguerra, representa, mais do que uma renovação formal, o reerguimento, em amplo sentido, da nação. 
Mas afinal, o que esta obra traz de grande novidade? Realmente nenhuma. Ou melhor, quase nenhuma. A um olhar mais atento, suas formas revelam significados profundos. Sua maior e melhor novidade é exatamente a sua não transgressão, o seu não comportar-se como um protesto construído ou um templo do trabalho. Sua novidade está em utilizar materiais convencionais de um modo inesperado, além de diferenciar de maneira exata, clara e límpida, estrutura, construção e materiais. Se por um lado esta fábrica se opõe totalmente à noção de "Tempo do Trabalho", como a fábrica AEG de Behrens corporifica, por outro lado, se distancia também da fábrica-modelo, ícone de novas técnicas e materiais como a FagusWerk de Gropius, ou tantos outros exemplos de monoblocos de curtain-wall que sublinham o caráter puro e cristalino do edifício. ${ }^{30}$ Blumberg, mais que trazer inovações tecnológicas, impressiona pelas soluções inteligentes que emprega, mesmo fazendo uso de tecnologias tradicionais. O galpão fabril utiliza tecnologia mista: em sua base, estrutura de concreto pré-fabricado com fechamento em alvenaria e aberturas de vidro; no piso superior, estrutura metálica nos apoios e na estrutura da cobertura.

Financiada pelo Plano Marshall, ${ }^{31}$ a construção da fábrica teve delidar coma pressão por prazos bastante exíguos do financiamento e os duros invernos do sul do país, que limitavam o andamento dos trabalhos; e a isso se deve também as soluções construtivas e tecnológicas adotadas. Iniciada a obra no outono de 1949, com fundação e estrutura do pavimento inferior em concreto armado, devido ao rigoroso inverno sulista e ao escasso cronograma, optou-se então pela construção do pavimento superior através de uma solução mais rápida e livre das sujeições climáticas. Foi executado então em estrutura metálica, com apenas dois apoios internos e centrais, e apoios nas extremidades lançados para fora do prédio, com fundações próprias. $\mathrm{Ou}$ seja, uma estrutura superior com total autonomia em relação ao térreo, que em parte nele se apóia e, em parte se apóia no exterior, lançando visíveis, para fora do prédio, apoios metálicos em azul claro - dois elementos perfil I com bases contrapostas, formando um $\mathrm{H}$ com vão intermediário, cujo nicho posterior incorpora os dutos de água pluvial

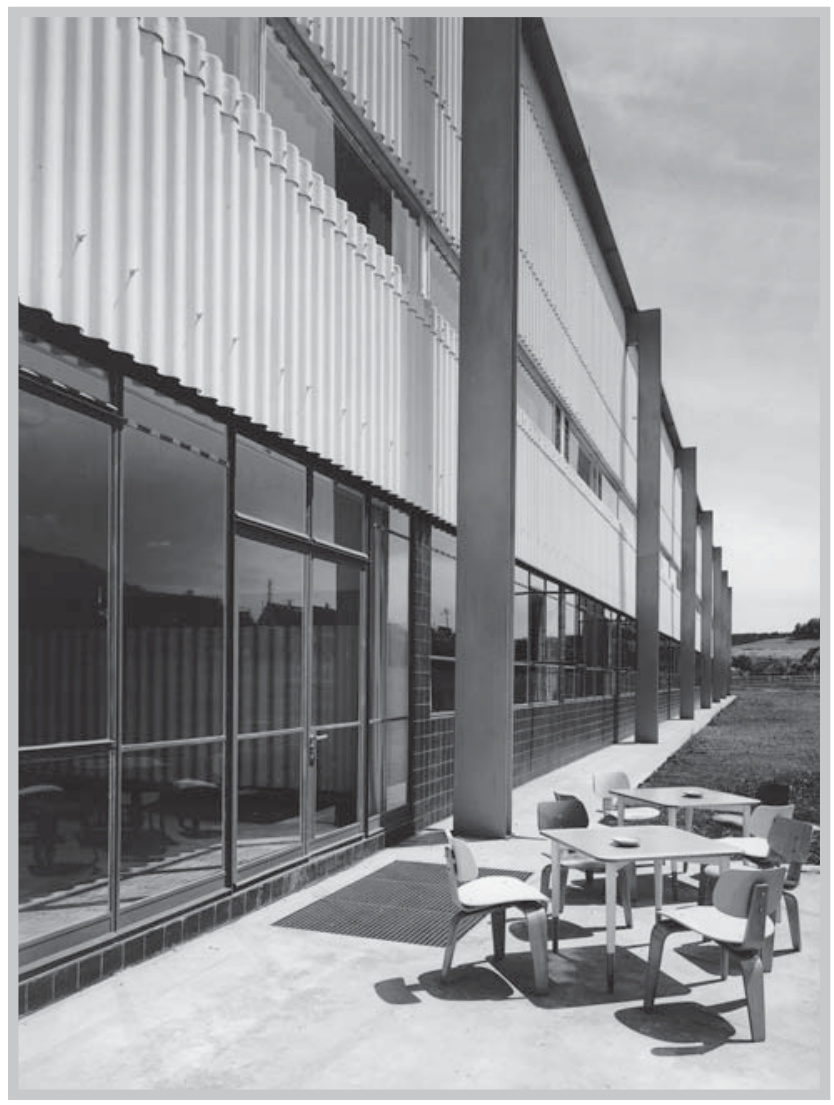

Fig. 9 - Egon Eiermann. Indústria Têxtil Blumberg. Blumberg. 19491951. 
- na altura total do prédio e ao longo de toda a fachada. No pavimento inferior, o programa - escritórios, serviços de expedição e apoio, e refeitório - adequa-se bem aos inúmeros pilares que resultaram da solução estrutural convencional. Já no pavimento superior, impuseram-se outras necessidades: propiciar ao ambiente um espaço flexível, com vãos maiores que permitissem remanejamentos internos, o que somente seria possível com uma tecnologia mais avançada. Resolvida a estrutura, o pavimento superior, que abriga a produção têxtil propriamente dita, necessitava de acuradas e precisas soluções para seus fechamentos.

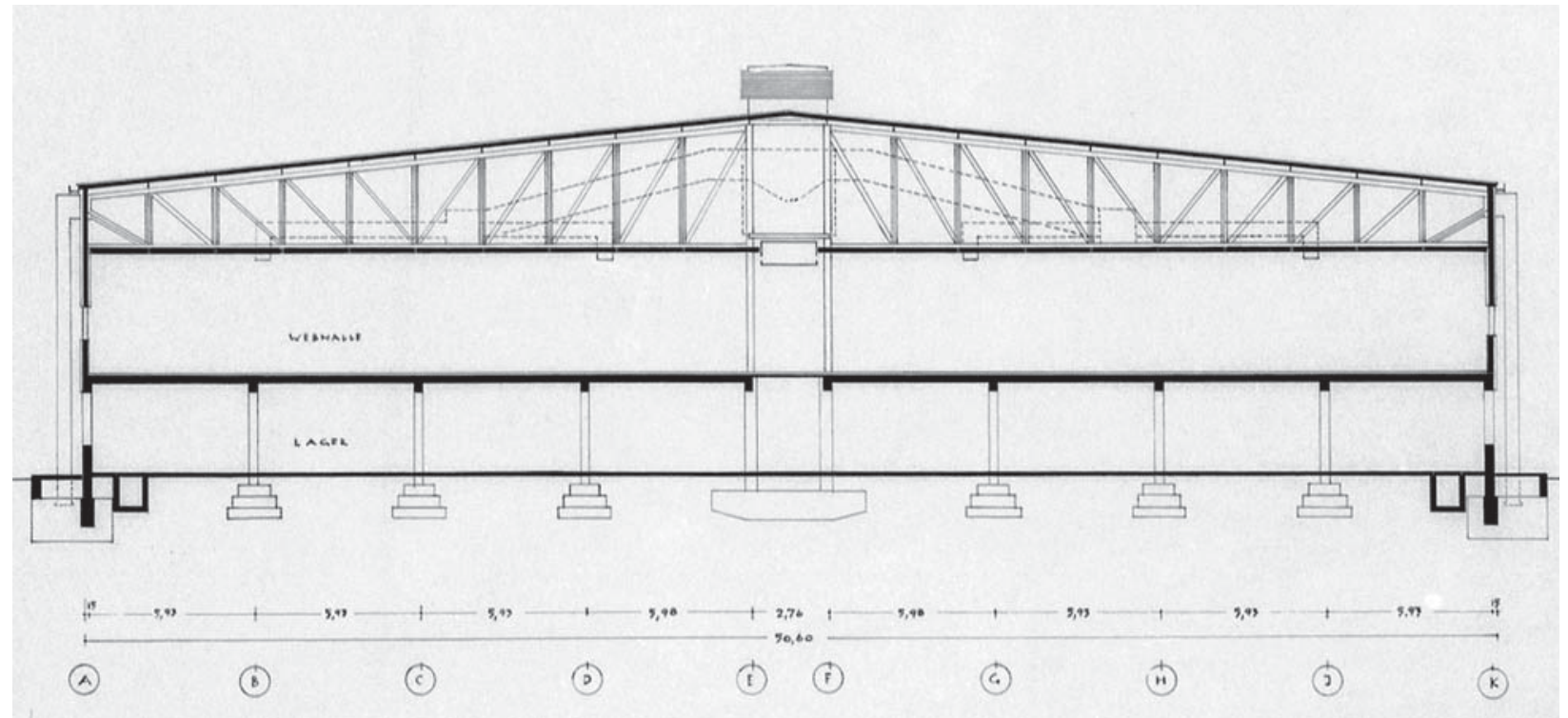

Fig. 10 - Indústria Têxtil Blumberg. Corte Transversal.

Em 1950 Eiermann, a convite do governo militar norte-americano, empreende sua primeira viagem aos Estados Unidos especialmente por ocasião da construção desta fábrica, e fica impressionado com as "dunkle Fabriken" (ou fábricas escuras, pois não partiam da premissa da solução em sheds da cobertura, mas do pressuposto do uso da iluminação artificial). A partir desta viagem, o arquiteto propõe então uma nova solução para a cobertura: recusa tanto os telhados com altos índices de inclinação, como as coberturas em sheds, solução mais comumente empregada em fábricas, que visam iluminação e ventilação naturais. Tendo em vista o rigoroso inverno nesta região e a neve que se acumula por semanas nos pontos de junção dos sheds, tornando-o uma solução inadequada, portanto, o arquiteto planeja o telhado levemente inclinado, com uso permanente de iluminação artificial. Os rasgos nas janelas, ao contrário do que se possa pensar, não correspondem a uma pretendida iluminação natural no interior do edifício; com elas, pretende-se garantir ao operário o constante contato visual com o exterior. Porém, o maior desafio, agora sem a ventilação pela cobertura, estava em vencer a grande umidade relativa do ar interno, necessária ao processamento da malha. Eiermann resolveu o problema através de paredes constituídas por 
várias camadas com diversos materiais que exercem funções distintas, que internamente deveriam absorver a umidade, e externamente proteger-se da chuva. $\mathrm{Na}$ face interna a parede leva uma camada de concreto poroso; ao centro, uma camada de cortiça, entre outros acabamentos, revestida externamente com placas de fibrocimento onduladas, material originalmente empregado como cobertura, e até então nunca havia sido utilizado como revestimento de fachada. Solução puramente funcional e, que se mostrou tão óbvia quanto inusitada, repetida inúmeras vezes em outros projetos industriais pelo país.

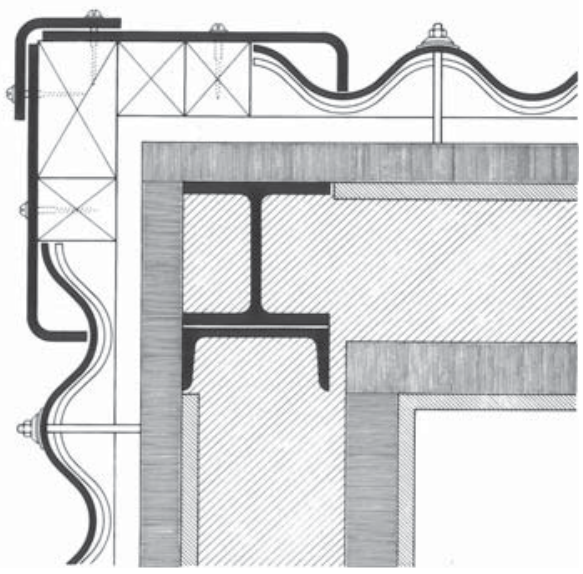

Fig. 11 - Indústria Têxtil Blumberg. Detalhe em planta do canto do pavillhão principal.

O edifício reproduz em sua fachada a racionalidade da estrutura, e fundamenta sua estética a partir da própria funcionalidade e construtividade. Características que impressionaram a nova geração pela simplicidade e franqueza com que expõe seus elementos constituintes. Ao deixar o pavimento superior em sua cor natural e distinguir o revestimento dos dois pavimentos, o arquiteto diferencia suas distintas essências construtivas e funcionais. Ao revestir o térreo, inclusive da caixa da escadaria, com pastilhas cerâmicas pretas, o arquiteto confere uma surpreendente leveza e elegância ao edifício, desfazendo a noção de bloco monolítico e arraigado ao chão. Noção corroborada pelas colunas soltas do edifício que, além disso, equilibram, com a proposta de uma divisão vertical, o volume horizontalizante de $112 \mathrm{~m}$ de comprimento. Além disso, o conjunto fabril é composto por volumes separados e individualizados - pavilhão principal, as caixas das escadarias, o acesso principal coberto, portaria, casa de caldeiras - tudo isso contribui para a dissolução do volume, algo mais coincidente com a escala do entorno e para evitar a formação de um volume único, grandioso e inflexível.

Dividido em três blocos principais - casa de caldeiras, portaria e galpão fabril - a cada volume é reservada autonomia volumétrica, e também, em relação aos materiais e tecnologia construtiva. Apesar da volumetria simples do bloco principal e seu aspecto mais tectônico, a casa de caldeiras, revela uma concisão formal e aspecto cristalino que deixa antever as caldeiras em seu interior, e em tudo

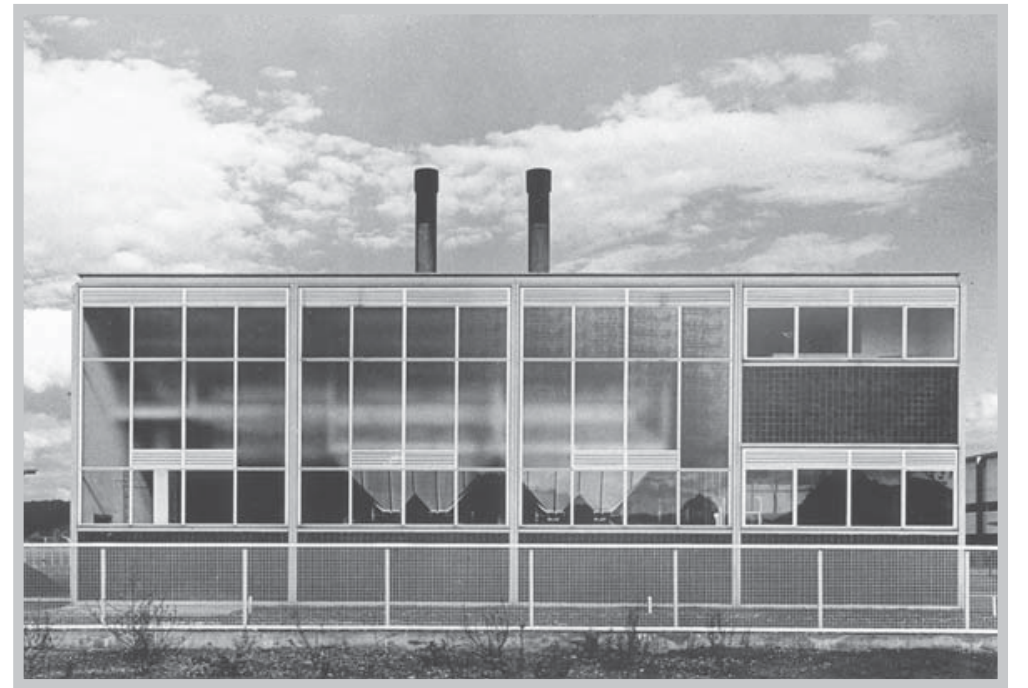

Fig. 12 - Egon Eiermann. Indústria Têxtil Blumberg. Casa de Caldeiras. Blumberg. 19491951. 
deve ao edifício do refeitório e casa de caldeiras da Märkisches Metallbau, obra dos anos 1930 do arquiteto. ${ }^{32}$

A simplicidade do bloco principal e o modo despretensioso como utiliza os materiais, ligam esta fábrica, uma de suas primeiras no pós-guerra, irremediavelmente a sua produção dos anos 1930, comparável à liberdade projetual e originalidade das casas berlinenses. Por outro lado, este edifício também revela de uma forma bastante nítida, embriões de sua arquitetura que se desenvolverão e ganharão soluções exemplares ao longo de sua carreira, como veremos nas próximas obras.

\section{ESPAÇOS SACRAIS}

O tema igreja ocupou insistentemente a prancheta dos arquitetos no pós-guerra. Se nos anos 1920 a construção dos Siedlungen foi a grande marca da arquitetura, que deixou registros em todos os livros que abordem aquele momento, o período entre os anos 1950 e início dos 1970 transformou-se em um tempo de construção religiosa na Republica Federal Alemã. Apenas com um breve olhar sobre as revistas de época, tem-se noção da impressionante quantidade de projetos, acompanhados por artigos que justificam sua posição nos novos tempos e a evolução formal ao longo dos anos. ${ }^{33}$ Esta hiperatividade construtiva liga-se a princípios alimentados há décadas pelo movimento litúrgico - que culminaram no II Concílio Vaticano entre 1962 e 1965, que propunha a modernização da igreja católica - cujo andamento foi acompanhado por simpatia também pelas igrejas evangélicas. "Participação ativa dos fiéis", como preconiza o artigo 123-124 da Constituição Litúrgica, ${ }^{34}$ direciona para a colocação de todos os elementos litúrgicos unidos em um mesmo espaço, e tanto as igrejas católicas quanto protestantes procuram uma maior proximidade com o altar. Grandes espaços são trocados por menores e mais acolhedores; a orientação longitudinal e cruciforme, por plantas mais centralizadas.

Dos anos iniciais do pós-guerra, onde tem lugar um programa de construção emergencial de igrejas, a partir de formas e materiais simples, avança-se ao longo dos anos 1950 para um caráter cada vez mais escultural e simbólico dos projetos, com uso do concreto armado. Inspirados pelo exemplo de Ronchamp, os arquitetos buscam formas esculturais que dramatizam o espaço a partir do uso da luz, e encontram também nos restos da destruição - no começo por força das circunstâncias - material com forte apelo simbólico. Otto Bartning e Rudolf Schwarz foram dois grandes nomes na construção religiosa pós-guerra, de igrejas protestantes e católicas, respectivamente. Além é claro, dos arquitetos Dominikus Böhm e Gottfried Böhm, pai e filho, descendentes de uma família de arquitetos 
e construtores de longa tradição na construção de igrejas, inclusive com exemplares realizados no sul do Brasil. ${ }^{35}$

Otto Bartning colocou em prática, a partir de 1946, um vasto programa de construção emergencial de igrejas desenvolvido pelo arquiteto, que gerou a construção da surpreendente marca de 43 exemplares. A partir do uso de materiais simples como a madeira e restos dos entulhos, como a pedra, o arquiteto concebeu belíssimos exemplares que combinam a simplicidade da planta, com elaboradas estruturas aparentes da cobertura, muitas vezes estruturas treliçadas, ou superfícies facetadas, num misto de austeridade e aconchego.

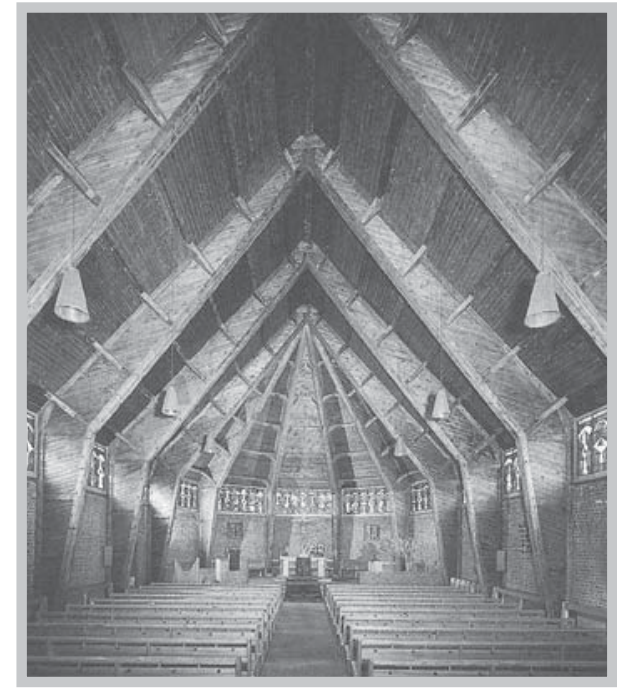

Fig. 13 - Otto Bartning. Auferstehungskirche. Pforzheim. 1948-1951.

Rudolf Schwarz em seu projeto de St. Anna em Düren (1951-1956), com suas formas geométricas e duras - um grande retângulo com muros de pedra que cerram o ambiente - em nada lembra a Basílica Gótica anterior destruída pela guerra. Aqui o arquiteto toma de empréstimo os restos da pedra vermelha que compunham a antiga basílica como se os fizessem "reviver" em uma nova forma, em

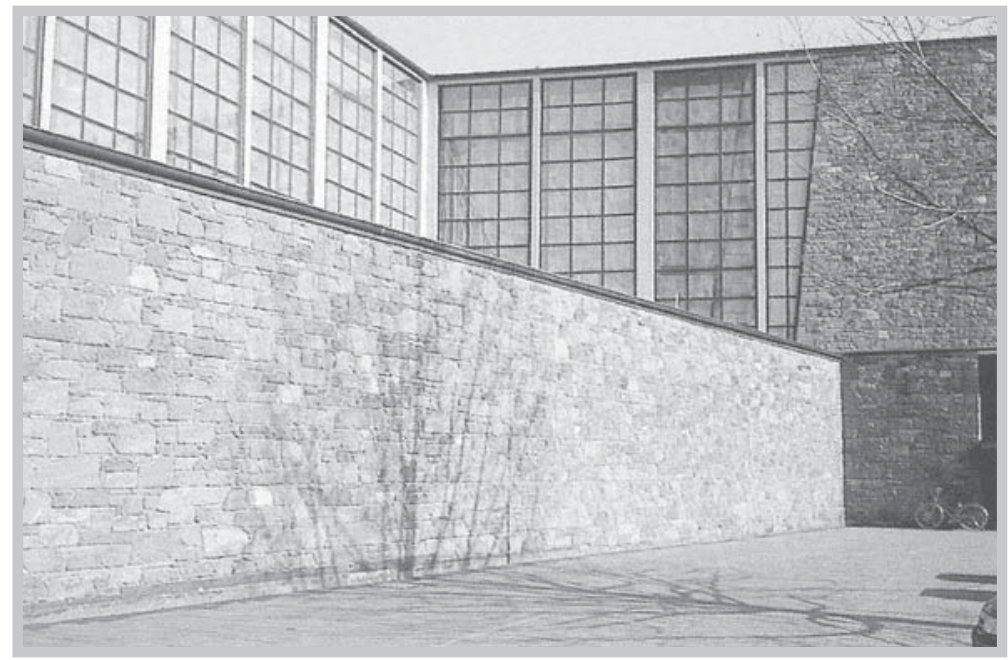

Fig. 14 - Rudolf Schwarz. Igreja St. Anna. Düren. 1951-1956. contraste com o vidro, material cristalino e contemporâneo, utilizado em uma das laterais. Os materiais advindos da destruição são utilizados de uma forma simbólica, como um elemento vivo que pudesse guardar um pouco da história a ser contada, e assim são concebidos os muros irregulares de texturas diversas com pedras de coloração e tamanhos diferentes. Essa simplicidade e escassez dos meios dignificaria ainda mais a obra, tendo em vista que muitos destes projetos já acontecem nos anos do "milagre econômico" e não mais nos anos de penúria onde tudo faltava.

É também através de meios e formas simples, neste caso ditado pelos limitados recursos de que dispunha a comunidade eclesiástica, que Egon Eiermann concebe o projeto da Matthäuskirche (1952-1956) em Pforzheim, louvado junto à crítica, e que mereceu até mesmo a ilustre visita do emigrado Mies van der Rohe. Eiermann parte de soluções bastante modestas: volumetria extremamente simples e espaço único que congrega todas as ações litúrgicas, com cobertura 


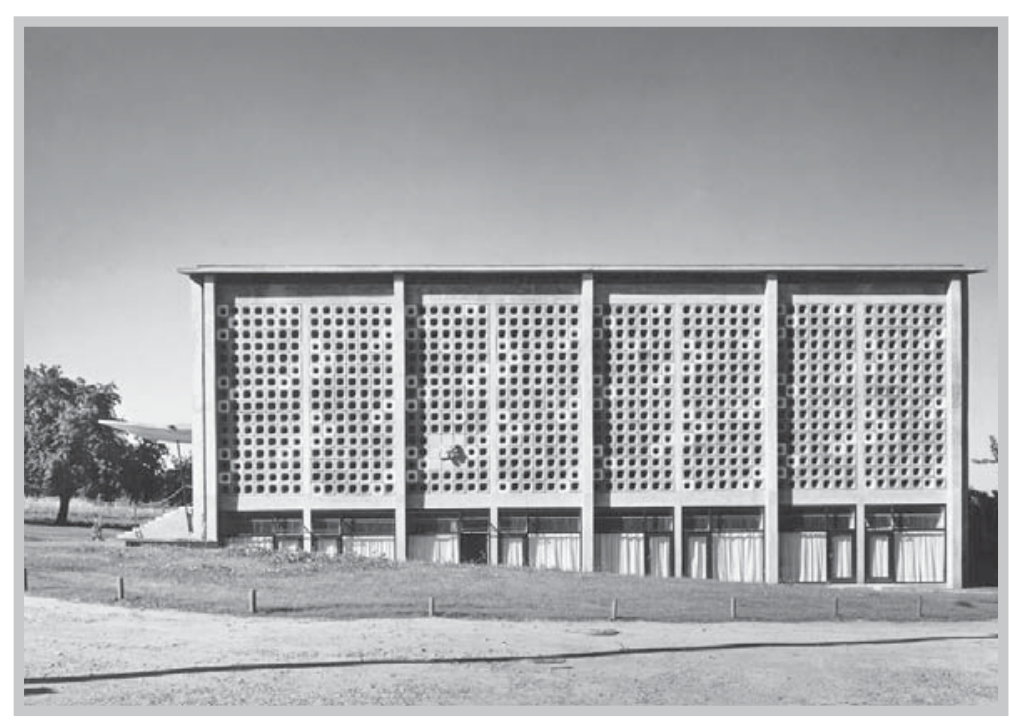

Fig. 15 - Egon Eiermann. Matthäuskirche. Pforzheim. 1952-1956.

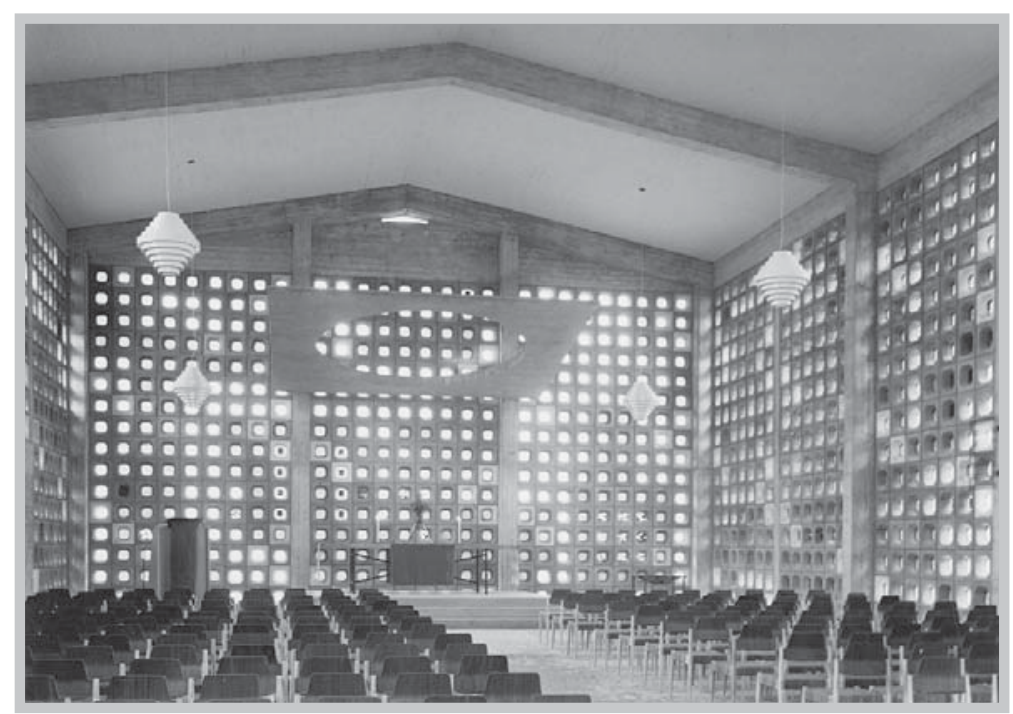

Fig. 16 - Egon Eiermann. Matthäuskirche. Pforzheim. 1952-1956.

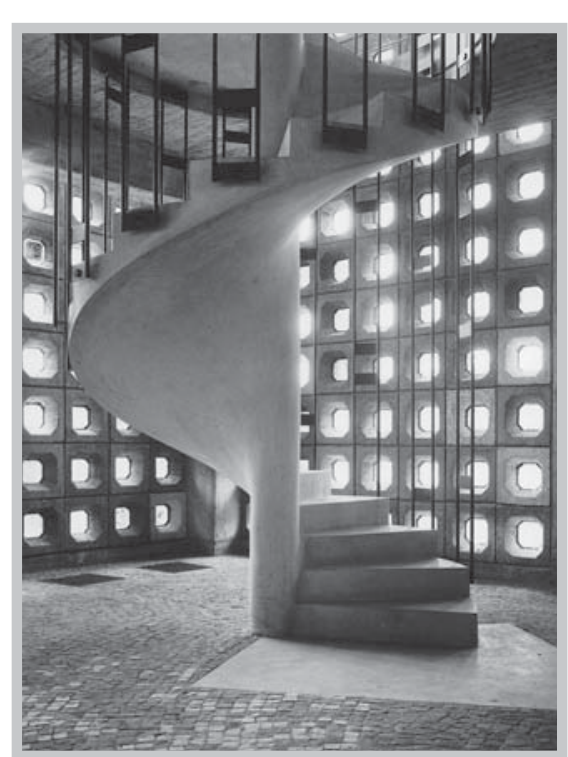

Fig. 17 - Egon Eiermann. Matthäuskirche. Pforzheim. 1952-1956. levemente inclinada em duas águas com chapas onduladas de fibrocimento, com estrutura em concreto armado pré-fabricado deixado aparente e fechamentos em cerâmica, levemente recuados da estrutura. Uma pequena escadaria sob a cobertura, ambas em concreto aparente, marcam o acesso centralizado. O subsolo, parcialmente enterrado, que abriga espaços para uso da comunidade, ganha fechamentos de vidro e se diferencia do espaço sacral.

A surpresa fica por conta do fechamento. Concebido de uma forma igualmente simples, é feito a partir de pequenos blocos cerâmicos vazados, a partir de material dos escombros recolhidos da cidade amplamente atingida na guerra. Cada elemento vazado, concebido individualmente, ganha uma coloração sutilmente diversa entre o vermelho-tijolo e o branco, e recebe preenchimento de vidros coloridos. O ambiente adquire assim uma iluminação ampla e homogênea filtrada pelo vidro que reflete seus vários tons. À noite, em contrapartida, a pequena igreja torna-se um pequeno ponto iluminado na paisagem que irradia luz desde seu interior.

Tudo revela um tom cuidadoso dos detalhes, inclusive o altar, o púlpito e a bela pia batismal que também são de autoria do arquiteto. $\mathrm{O}$ piso recebe um tratamento rústico, feito a partir de mosaico português em tons neutros e variados; assim também é todo o edifício, que assume um aspecto rude pelos materiais crus que utiliza e ao mesmo sublime, pela iluminação e sutil coloração em seu interior. 
Até mesmo aqui, na arquitetura religiosa - em que parece predominar certo comportamento estabelecido, onde até mesmo arquitetos considerados "racionais" permitem-se "licenças" formais - uma linguagem bastante reduzida e racionalmente justificada rege a concepção; o arquiteto não procura diferenciála volumetricamente de um galpão fabril ou uma casa comercial por algum tipo de espetáculo formal. "No fundo, a construção de igrejas é uma questão muito objetiva (sachlich), na qual a sequência das atividades litúrgicas e seus pressupostos espaciais e funcionais devem ser corretamente aplicados na edificação"36 escreve Eiermann nos anos 1960. E no mesmo ano, justamente contrariando as tendências formais da década, que encontram talvez seu maior representante em Gottfried Böhm com suas formas "maneiristas", o arquiteto, por ocasião do projeto da Igreja de Dachau, expõe sua reprovação: "o autor condena o constante jogo com novas formas, que por fim, degenera-se em puro sensacionalismo." ${ }^{37}$ 


\section{Notas}

1 A presença de entulhos perdurou, de fato, até início dos anos 1950. Já as edificações provisórias eram gradativamente trocadas por outras, mas muitas delas perduraram por longos anos, e chegaram mesmo a ganhar status de definitivas. Cf. Pehnt, Wolfgang. German Architecture 1960-1970. Praeger Publishers: New York, Washington, 1970.

2 Plano do Governo norte-americano de ajuda financeira para a reconstrução de alguns países europeus, tendo como principal destino França, Reino Unido, Itália, e Alemanha Ocidental. É anunciado nos Estados Unidos em 5 de junho de 1947 e entrou em vigor no ano seguinte até 1951.

3 O que intensificará ainda mais a imigração do leste para as zonas a oeste do país.

4 Como Walter Gropius, Mies van der Rohe, Erich Mendelsohn, Konrad Wachsmann, Marcel Breuer, que haviam emigrado, diretamente, ou por outros países, para os Estados Unidos. Cf. Capítulo 2.

5 Ernst May regressa em 1953, Paul Bonatz, arquiteto da linha conservadora, mas de grande renome, regressa um ano mais tarde. Cf. Capítulo 2.

6 Boyken, Immo. Die Architektur Eiermanns aus der Zeit nach dem Zweiten Weltkrieg. In: Schirmer, Wulf (org.). Egon Eiermann 1904-1970: Bauten und Projekte. Stuttgart: Deutsche Verlags-Anstalt, 1984, p. 59.

7 Excetuando-se, naturalmente, os desenvolvimentos da arquitetura moderna alemã que tiveram lugar mesmo durante o Regime Nazista. Cf. Capítulo 2.

8 As universidades davam preferência de matrícula aos ex-combatentes; isso justifica, em parte, a elevada faixa etária dos estudantes. Segundo uma estatística nas universidades da zona britânica (que inclui a Universidade de Braunschweig), no semestre de verão de 1946, demonstra que mais da metade dos estudantes estavam entre a faixa etária de 25 e 29 anos e mais. Cf. Schmedding, Anne. Lehre in Braunschweig. In: Wilhelm, Karin; Gisbertz, Olaf; Klingenberg-Jessen, Detlef (et. al.). Gesetz und Freiheit: der Architekt Friedrich Wilhelm Kraemer (1907-1990). Berlin: Jovis, 2007, nota de rodapé 14, p. 109. Ainda segundo a autora, Justus Herrenberger disse que o conhecimento do grau militar das colegas tinha certa importância entre os estudantes: foi constatado, segundo estatísticas neste mesmo semestre, que 380 dos 916 estudantes de arquitetura possuíam o grau militar destacado - oficial, oficial reserva e suboficial - e que era um percentual significativamente alto comparado a outros cursos. Idem, nota de rodapé 19, p. 109.

9 "A Arte no Império Alemão".

10 Mies também teria sido convidado a construir edifício para a Interbau de 1957, convite que foi renegado pelo arquiteto.

11 August Hoff. Vorwort. In: Neues wohnen. Werkbund-Ausstellung Deuschte architektur seit 1945. Köln, 1949. p.16. apud: Pehnt, Wolfgang. Deutsche Architektur seit 1900. 2. ed. Ludwigsburg/ München: Wüstenrot Stiftung/ Deutsche Verlags-Anstalt, 2006, p. 279.

12 Que já ocorriam desde os anos 1920, como a exposição de arquitetura Dinamarquesa que teve lugar em Berlim em 1926, e exerciam forte desde então, forte influência local.

13 Pehnt, Wolfgang. Deutsche Architektur seit 1900. op. cit., p. 279. Não por acaso, ao mesmo tempo em que a Arquitetura Moderna Brasileira despertava encantamento, arrancava ácidas críticas dos arquitetos, críticos e historiadores europeus, quando era, justamente, estes aspectos que os encantavam: pragmatismo, a simplicidade, a integridade, onde as formas brasileiras surgiam como gratuitas, apesar de ser igualmente admirado seu "frescor" e a renovação formal que traziam em seu bojo. Ainda mais, em se tratando de Max Bill, cujo projeto da Escola de Ulm (1953-1955), de sua autoria, uma edifício em forma de cubos e prismas com terraços, em concreto aparente e madeira ao natural, é tomado como exemplo da solidez e do pragmatismo suíço.

14 Idem, ibidem.

15 É verificável, no entanto, o fascínio exercido pelo projeto da igreja da Pampulha, que influenciou inúmeros projetos, nenhum de grande interesse, mas que podem ser verificados nas revistas especializadas da época. Apesar das intensas pesquisas com cascas estruturais 
na Alemanha, mesmo nos anos 1930 sob os auspícios nazistas, é inegável a influência do mestre brasileiro naqueles projetos.

16 Edições n. 12, 1947 e n. 42-43, 1952, por exemplo.

17 Arquitetos ex-colegas de Broos, também formados no imediato pós-guerra: Wolfgang Bley, Klaus Zimmermann, Peter Dresel e Justus Herrenberger.

18 Exposição e livro que mostram a tradicional e a nova arquitetura brasileira, organizada pelo arquiteto Philip Goodwin e o fotógrafo G.E Kidder Smith, com patrocínio do governo norte-americano, vinculada à "política de boa vizinhança" desenvolvida pelo presidente Franklin Roosevelt para a conquista estratégica de aliados no conflito mundial.

19 Pehnt, Wolfgang. Deutsche Architektur seit 1900 op. cit., p. 283.

20 Idem, ibidem.

21 Em entrevista à autora.

22 Cf. Baumeister, Heft 2, 1947, não é precisado as cidades por onde passaria a exposição.

23 A "rua comercial" inexiste aqui, assim como o terraço com equipamentos. Também não era permitida legalmente a construção dos cômodos de apenas 2,26m de pé-direito.

24 Eiermann, Egon. Transcrição de uma aula em 1963. In: Clemens, Kieser. Egon Eiermann: Zwei Wohnhäuser in Baden-Baden. Ein Stück Deutsche Architekturgeschichte. Karlsruhe, 2002, p. 19.

25 Idem, ibidem.

26 Como fica claro na mesma transcrição acima citada.

27 Laureada como o Prêmio Hugo Häring em 1969.

28 Segundo Broos, "não haviam arquitetos para se espelhar na Alemanha" nestes anos, como foi exposto acima; a mesma colocação foi feita por alguns dos arquitetos alemães entrevistados, reiterando o grande impacto desta obra sobre os arquitetos e estudantes na época de sua construção.

29 Mas certamente não desfrutou da fama internacional da AEG e da Fábrica Fagus; sequer é mencionada em livros brasileiros.

30 Como mencionado no Capítulo 2, o fechamento de vidro da Fagus Werke não seria curtainwall.

31 O Plano possuía especial interesse na recuperação econômica de cidades e regiões debilitadas economicamente através da construção de indústrias. Este era o caso da cidade de Blumberg, situada numa área de mineração falida depois da guerra.

32 Ver Capítulo 2.

33 Por exemplo na revista Baukunst und Werkform destes anos.

34 Pehnt, Wolfgang. Deutsche Architektur seit 1900. op. cit., p. 306.

35 Como visto no Capítulo 1.

36 Eiermann, Egon. Carta a Else Hinsch, Frankfurt, 21.9.1964, apud: Boyken, Immo. Die Architektur Eiermanns aus der Zeit nach dem Zweiten Weltkrieg. In: Schirmer, Wulf (org.). Egon Eiermann 1904-1970: Bauten und Projekte. Stuttgart: Deutsche Verlags-Anstalt, 1984, p. 63.

37 Justificativa de projeto para o concurso da Igreja evangélica no antigo campo de concentração de Dachau, 1964. 


\section{REFERÊNCIAS ALEMÃS}

\section{O ARQUITETO EIERMANN}

Com inúmeros artigos, livros, escritos elogiosos e apaixonados, que não deixam de ser cansativos e repetitivos ou exagerados, com as famosas frases do arquiteto, geralmente curtas e incisivas, citadas à exaustão, a obra de Egon Eiermann parece ser do tipo que não há nada mais a ser dito. Até mesmo a proposição deste estudo parece ser algo banal na Alemanha (ou que não mereça demasiada atenção); Broos, que não é conhecido por lá (e tampouco o é no Brasil), torna-se tão somente mais um Eiermann-Schüler (discípulo de Eiermann) entre os inúmeros que existiram e que eventualmente formem uma Eiermann-Schule (Escola Eiermanniana).

Sendo um dos arquitetos mais conhecidos e divulgados do século XX em território alemão, e um dos principais da segunda geração de modernos, a onipresença de Eiermann em livros de história (alemães) sobre a arquitetura do século passado deve-se não somente a quantidade e à qualidade arquitetônica de suas obras. Suas obras ajudaram a compor o cenário alemão pós-guerra, com obras paradigmáticas, que ajudam a contar trechos de uma história de reconstrução e reerguimento, como a Tecelagem Blumberg e o Pavilhão Alemão da Exposição Mundial de Bruxelas. Como poucos arquitetos em seu país, Eiermann desenvolveu sua obra arquitetônica desde os anos 1930 cuja surpreendente evolução, baseada em determinados pontos notáveis, atravessa os anos 1930 e 1940 e pode ser sentida em sua obra pós-guerra. Conta-se ainda a significativa influência na formação das novas gerações de arquitetos. Professor carismático, ainda hoje, passados mais de quarenta anos de seu falecimento e mais de sessenta anos de sua primeira turma, parece ainda manter fortes e vivas as lembranças na mente de seus alunos.

A existência ou não de uma Eiermann-Schule continua sendo, até hoje, assunto polêmico entre críticos, ex-alunos e colaboradores do arquiteto. Ele nunca teria ensinado um estilo de projeto e, sim um método projetual, dizem os que refutam a idéia; e sim, haveria uma escola, pela inegável influência que Eiermann exerceu e os inúmeros discípulos que formou, embora o próprio arquiteto contestasse esta idéia. Entre as características principais desta possível Escola estariam a precisão técnica, a clareza construtiva e formal, e a expressão técnica do edifício extraída de suas soluções estruturais, construtivas e funcionais. Como coloca Wolfgang Bley, ex-aluno e colaborador de Eiermann, os alunos de Karlsruhe eram conhecidos por saber fazer. ${ }^{1}$

Entretanto, se houve ou não uma Escola de Eiermann, se Hans Broos faz parte dela, excede os objetivos do estudo aqui proposto, tampouco esta questão nos parece 
merecer maiores delongas. Em relação a isso, o crítico da arquitetura Wolfgang Pehnt faz uma importante distinção (que extrapola a mera constatação da existência ou não da referida Escola, e que antes nos dá uma interessante visão de dois pólos dentro da arquitetura alemã de meados do século passado), ao diferenciar entre uma Eiermann-Schule e uma Scharoun-Schule. Pehnt escreve que uma de suas primeiras tarefas como editor, no início dos anos 1960, foi organizar um dicionário popular sobre a arquitetura moderna internacional, ${ }^{2}$ e coube à ele selecionar e escrever sobre dois representantes da Segunda Geração de arquitetos modernos alemães, ou seja: mais novos que Gropius, Mies e Mendelsohn, e mais velhos que Oswald Matthias Ungers, por exemplo. Decidiu-se então por Egon Eiermann e Hans Scharoun: "eles me pareciam as figuras mais fortes no panorama alemão dos anos de $1960 \mathrm{e}$, além disso, como arquitetos, incorporavam possibilidades opostas em relação ao projeto". ${ }^{3}$ E nos revela o porque: "Eiermann, a quem a clareza e a nitidez da forma e a elegância da solução está presente no coração, Scharoun, examina cada tarefa de tal forma, como se ela lhe fosse apresentada pela primeira vez." ${ }^{3}$ Pehnt diz que esta formulação lhe é ainda hoje plausível: "A mbos os arquitetos, Eiermann em Karlsruhe e Scharoun em Berlim, eram professores carismáticos, que podiam inspirar seus alunos e colaboradores. Seus ensinamentos e suas obras exemplares construídas foram tão intensamente tomadas e trabalhadas que tornam a Eiermann-Schule e a Scharoun-Schule dois pólos de abordagens e modos de trabalhar." "Em Karlsruhe foi ensinado a arte do ajuste, em Berlim o ajuste da arte. Para o realista Eiermann, eram a construção, o material, a função, a economia, que justificavam a forma em seu discurso, para o vitalista Scharoun, eram torrentes vitais, aspiração à forma, o existencial e o essencial. Para Eiermann dever-se-ia poder basear as decisões com argumentos, para Scharoun ativar a força do espírito criador.”'

Ao contrário de seu colega Scharoun ou do "organicista" Hugo Häring, Eiermann recusava a individualidade e a excepcionalidade da obra pela validade e aplicabilidade das soluções; o "novo" não lhe parecia necessário, quando se podia partir de soluções legítimas e comprovadamente válidas, afinal "nós estamos aqui para fazer sempre coisas novas, ou estamos aqui para melhorar as coisas que já existem?"7 E nesta postura, se aproxima de Mies van der Rohe, que tendia à repetição de uma solução considerada ideal e universal, a fazer de cada obra um experimento.

No ateliê de Eiermann dominava a Ratio e a eloquência; ${ }^{8}$ o arquiteto procura no aspecto construtivo, na correta construção e na estrutura, a justificativa formal de sua obra: "Nós não somos pintores. Nós não somos escultores. Somos arquitetos" dizia aos alunos. Precisão, clareza de pensamento e a negação do gesto arquitetônico eram sentenças prontamente identificadas por seus pupilos. 
Eiermann tinha uma atitude bastante informal com seus alunos, que carinhosamente o chamavam simplesmente Egon, algo significativo num país cujas formalidades de tratamento são algo bastante importante. Raramente preparava as aulas que iria lecionar, quase sempre de improviso e ligadas a um problema concreto, geralmente relacionadas à alguma obra que estava projetando ou executando no momento. Eiermann era um dos poucos professores que também construíam, e trazia problemas práticos de sua rotina do escritório para serem resolvidos em sala de aula. Esta aproximação com a realidade junto aos estudantes - aliada ao desejo por novas construções, alimentado após os anos de sufocamento político - fazia com que os alunos se identificassem muito com o jovem professor. Já no final da década de 1940, pouco tempo após sua chegada à Universidade de Karlsruhe, o crescente número de projetos de seu escritório particular faria com que o endereço de seu escritório se confundisse com sua sala no departamento de arquitetura. Até 1970 ainda era possível ver parte dos projetos de seu escritório na universidade. ${ }^{10}$

As aulas, que segundo o plano de estudos, eram dirigidas a apenas duas turmas, logo estariam abarrotadas de alunos, com quase todos os estudantes do curso, atraídos por aquela figura radiante, como seus alunos o retratam. Seu jeito espontâneo e carismático, sua linguagem cotidiana e ativa linguagem corporal o afastavam do estereótipo clássico de professor, e logo transformaria as aulas em uma espécie de "espetáculo", apoiado no talento teatral e de desenho do mestre."1 Em poucos anos o arquiteto construiria uma reputação que lhe valeram nos anos 1950 e 1960 convites para outras universidades alemãs e estrangeiras.

O afluxo de estudantes para Karlsruhe era bastante grande, e a maioria deles dirigia-se para as aulas de Eiermann. Entre 1950 e 1960 o arquiteto contabilizava uma média de vinte e oito formandos sob sua orientação, sobrecarga que fazia parte das queixas do arquiteto. Entretanto, segundo Kabierske, as aulas geralmente ficavam aos cuidados de um assistente formado. ${ }^{12}$

De 1947 a 1955 Egon Eiermann foi a principal figura dentro do curso de arquitetura da Universidade de Karlsruhe, época em que recebe muitas encomendas e vê seu nome se projetar no cenário nacional e internacional. Seu renome logo se confundiria com a própria escola, que mais e mais estaria centrada na figura do arquiteto e com ele se identificaria. Em breve, a escola seria "uma, senão $a$ instituição de ensino dominante para arquitetos na República Alemã." ${ }^{13}$ Externamente, a escola conservaria uma visão de homogeneidade; o corpo docente - Otto Haupt, Heinrich Muller, Otto Ernst Schweizer e agora Egon Eiermann - correspondiam a uma visão uníssona, direcionada ao ensino dentro da concepção da arquitetura moderna, ao contrário da polarização de 
convicções que tinha lugar em Stuttgart, entre figuras como Paul Schmitthenner e Richard Döcker. No final dos anos 1950 veio uma fase de grandes projetos, que projetou de forma incontestável e definitivamente seu nome no cenário nacional e internacional, com obras ambiciosas como o Pavilhão Alemão na Exposição Mundial de Bruxelas de 1958 (1956-1958), a Versandhaus Neckermann (19581961), a Embaixada Alemã em Washington (1958-1964) e um dos projetos mais celebrados, a Kaiser-Wilhelm-Gedächtniskirche (1957-1963) em Berlim.

\section{A OBRA DE EIERMANN No PÓS-GUERRA}

Podemos ver na Matthäuskirche um modelo para os exemplos futuros de igrejas do arquiteto: volume simples, renúncia de qualquer efeito em favor de uma forma clara, que por si só, e complementada pelos materiais, deve conferir o tom sublime que uma igreja requer. Para o arquiteto, a forma é apenas o meio, o lugar de reunião onde se dará a celebração comum. Para o projeto do concurso da KaiserWilhelm-Gedächtniskirche, a forma, igualmente simples, é justificada não como a falta de imaginação ou expressão do fastidioso e, sim, como "expressão da compreensão mútua de todas as pessoas, portanto, não da individualidade, senão da validade universal. Ela é, ademais, alheia à moda e atemporal. A construção é somente o envoltório para um acontecimento na alma." 14

$\mathrm{Na}$ Matthäuskirche o arquiteto constrói um simples cubo com suas "paredes de luz" como fechamento homogêneo, que tampouco diferencia o fechamento do altar - demarcado apenas por uma pequena plataforma elevada de três degraus e um cobertura vazada e atirantada em concreto aparente-epropõeo espaço único. Tal "pavilhão" homogêneo também é o pressuposto formal para seu mais importante edifício religioso, a Gedächtniskirche, de cinco anos mais tarde. Tanto aqui, quanto (e pela primeira vez) no pequeno edifício de Pforzheim, o arquiteto utiliza um motivo que se repetiria diversas vezes em sua carreira, inspirado na releitura perretiana da influente Notre Dame de Raincy (1922-1923) e suas paredes vazadas por onde a luz filtrada perpassa todo o ambiente.

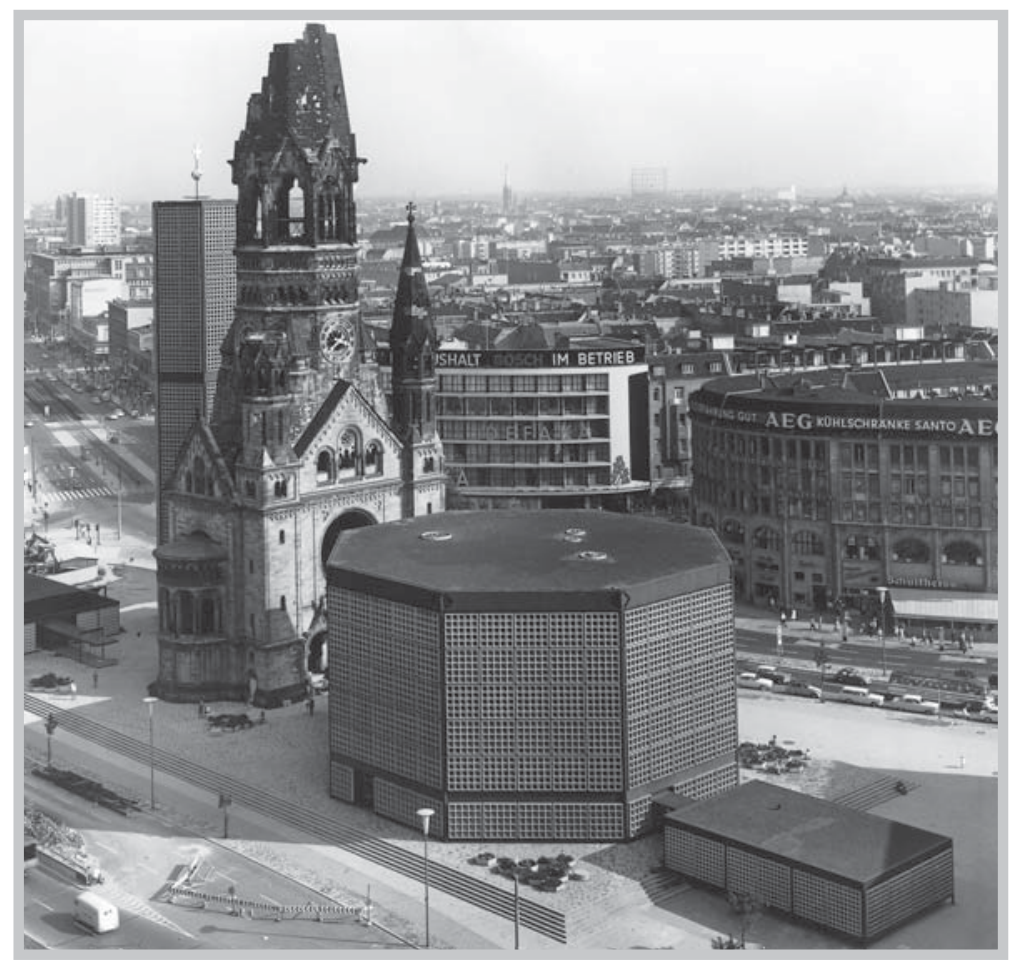

Fig. 1 - Egon Eiermann. Kaiser-Wilhelm-Gedächtniskirche. Berlim. 1957-1963 
O motivo do "favo" - a parede com elementos vazados - que confere uma luz homogênea e indireta com as nuances diversas da coloração do vidro, será repetido em diversos projetos, como o religioso - reconstrução da igreja de Karlsruhe (1954) e para a pequena igreja em Dachau (1964), não realizados - mas não somente. A mesma proposição é a solução sugerida para uma das alternativas do Teatro do Estado de Baden (Badisches Staatstheater, concurso 1959-1960), e sua derivação encontra lugar em projetos para Lojas de Departamentos, como a Warenhaus Horten (1958-1962) cuja aproximação em relação ao uso do "favo" à Gedächtniskirche é notável, e sua antecessora, a Warenhaus Merkur (1951-1960), um exemplo, digamos, não tão bem sucedido dentro da carreira do arquiteto. ${ }^{15}$

Na Gedächtniskirche, que pode ser considerado uma evolução da Matthäuskirche em maior escala, o projeto já é concebido em aço, material “aristocrático" por natureza. No volume octogonal da igreja de Berlim, Eiermann concebe uma

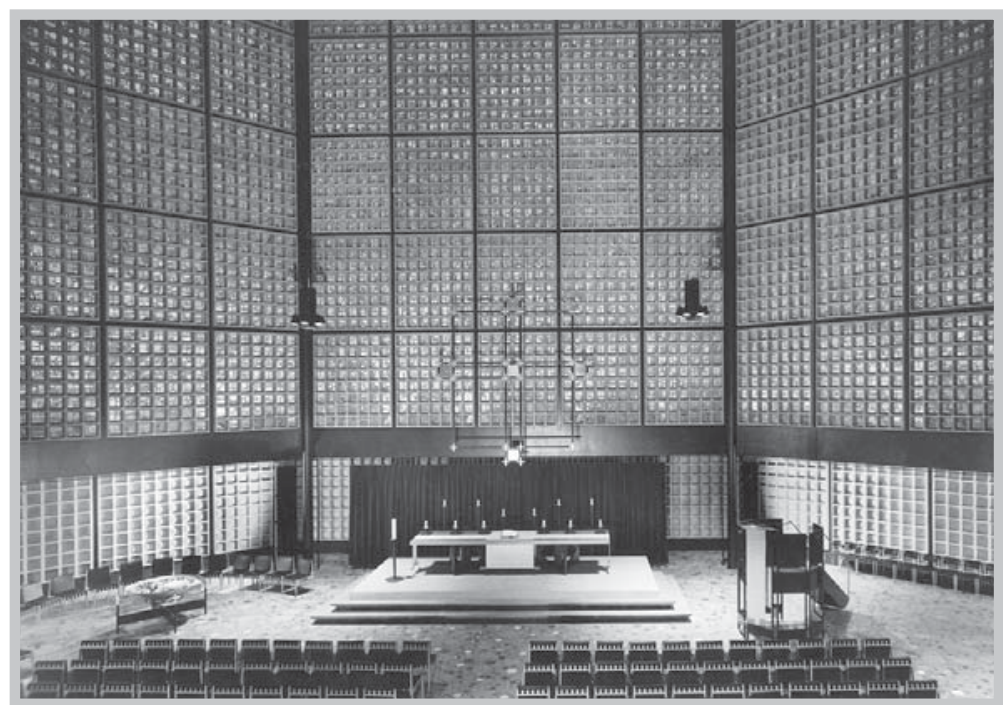

Fig. 2 - Egon Eiermann. Kaiser-Wilhelm-Gedächtniskirche. Berlim. 1957-1963

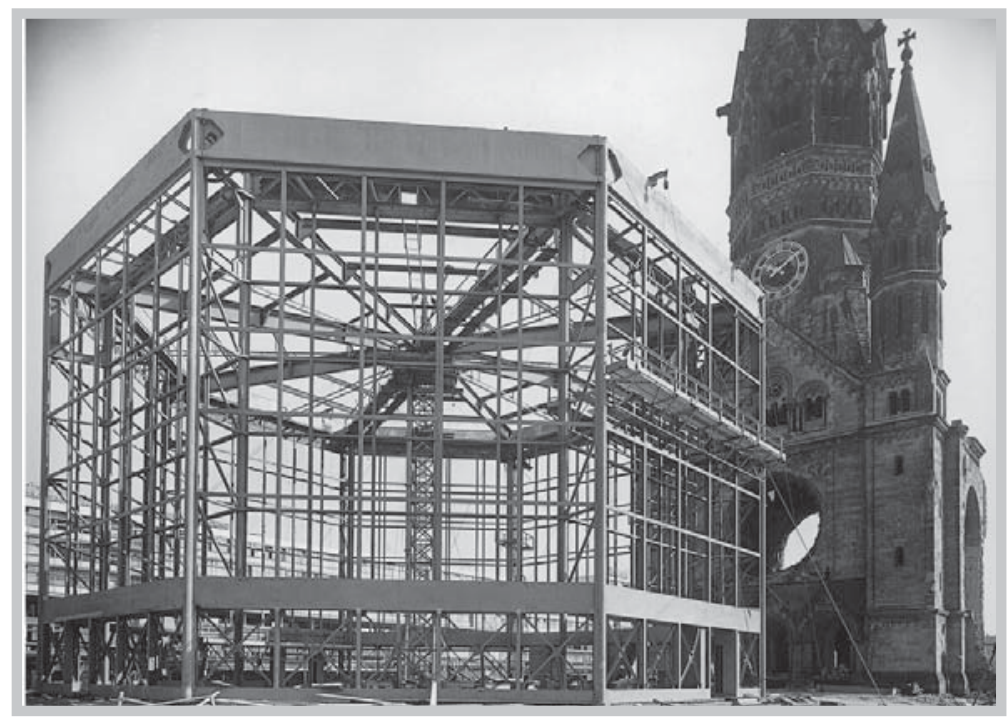

Fig. 3 - Egon Eiermann. Kaiser-Wilhelm-Gedächtniskirche. Berlim. 1957-1963 estrutura metálica dupla, deixado um vão interno de $2,20 \mathrm{~m}$, segundo $\mathrm{o}$ arquiteto, para reduzir o ruído do intenso trânsito local. Tanto a estrutura interna quanto a externa recebem o preenchimento em painéis pré-fabricados de concreto aparente com a estrutura em "favo", assim como fará na obra posterior de Dachau. Mas aqui o fechamento recebe um tratamento muito mais elaborado. Partindo de uma estrutura de concreto armado em grelha de aproximadamente $2,80 \times 2,80 \mathrm{~m}$, a composição com fechamento de vidro foi concebido em conjunto com ovitralista francês Gabriel Loire, que, a partir de restos de vidro encontrados no lugar da destruição, elaborou os pequenos vitrais que compõem o "favo" em uma luz azul predominante, mesclada com vermelho, dourado e verde, que revestem a igreja, a torre e a capela. 
A partir do concurso para a Gedächtniskirche inaugura-se uma grande fase, com obras de peso na carreira do arquiteto, que constrói simultaneamente esta igreja em Berlim, a Neckermann (1958-1961), o Pavilhão de Bruxelas (1956-1958) e a Embaixada Alemã em Washington (1958-1964), entre outras. Pelo menos os dois últimos guardam uma proximidade formal muito grande com a primeira. A estrutura metálica determina precisamente a volumetria destes projetos e se sobressai no conjunto, principalmente no Pavilhão e na Embaixada, que recebem fechamento de vidro e ostentam a característica leveza dos projetos do arquiteto, com o uso dos vários "aparatos" superpostos à fachada, como os delicados perfis metálicos que tendem a diluí-la e a torná-la incorpórea.

Interessante notar que os primeiros projetos da Gedächtniskirche, iniciados em 1956, diferiam substancialmente da proposta executada. Como já dissemos, o arquiteto previu a demolição da antiga torre, tanto na primeira quanto na segunda etapa do concurso (na primeira etapa apresentou um projeto com duas variantes, na segunda, um projeto que modifica levemente a primeira opção da etapa anterior, e por fim, a proposta final, que se difere de todas as outras).

$\mathrm{Na}$ etapa inicial, a primeira alternativa de projeto apresentada pelo arquiteto e sua equipe sugere um volume bastante simples - talvez até mesmo demasiadamente vulgar para tal empreendimento - que guarda profunda proximidade com a Matthäuskirche, tanto pela volumetria quanto pelo fechamento, mas em escala maior e com duas torres (sineira e com relógio), construída sobre uma plataforma de exagerada altura (cerca de quatro metros). Contrapondo o volume convencional desta, a segunda variante surge com um caráter arrojado, com cinco volumes circulares, entre eles a torre, todos interligados por passarelas. Na segunda etapa do concurso, para qual somente três participantes foram selecionados, Eiermann volta a sua primeira alternativa, com volume de cobertura de duas águas, com algumas ligeiras modificações, a principal delas, a diminuição da altura da plataforma.

Vencido o projeto, protestos da imprensa e da população contestavam a demolição da "mais bela ruína da cidade" proposta pelo arquiteto em todas as etapas do concurso. Só então o arquiteto viu-se impelido a incorporar a velha torre e reelaborar totalmente o projeto, agora sim, definitivo, e ao que parece, para melhor. Ainda assim o arquiteto contestava a ideia: "A torre reina tão massiva e central, que todo acréscimo de uma igreja neste lugar, produziria algo fora de equilíbrio." ${ }^{16}$ o arquiteto troca então

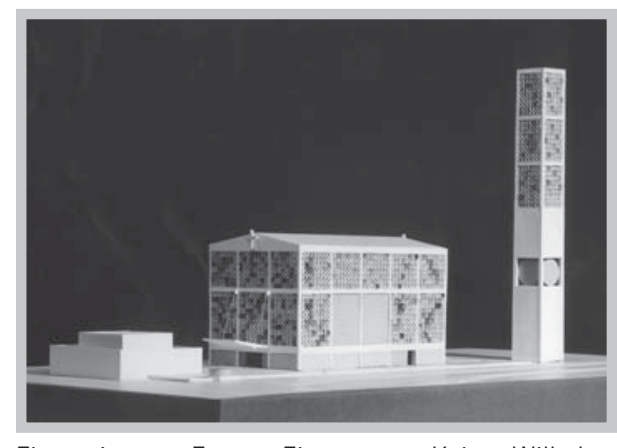

Fig. 4 - Egon Eiermann. Kaiser-WilhelmGedächtniskirche. Projeto proposto para a segunda etapa do concurso. 1956. 
a concepção longitudinal da proposta vencedora, por um volume octogonal, acompanhado de volumes menores em formas puras e suas derivações, em que contrasta radicalmente os novos volumes da antiga torre em estilo neo-românico deixada em seu aspecto ruinoso. De todas as soluções, o projeto executado é indubitavelmente o mais maduro, com os volumes arranjados da maneira mais interessante e, também do ponto de vista urbano, a proposta mais conciliadora.

Em todas as propostas as partes da igreja surgem como volumes autônomos - o edifício principal, com nave, altar e coro; a capela, a sacristia e a torre (quando não duas torres) - que se mantiveram na proposta final do projeto. Ao concebê-los como elementos isolados, o arquiteto idealiza um novo espaço urbano, incluindo a torre como um dos elementos do espaço. Através da plataforma retangular de seis degraus, sob o qual se localiza o novo conjunto formado, Eiermann conecta as diversas partes da igreja, e as promove a um novo espaço urbano. Neste projeto a relação entre os novos edifícios e a antiga torre se faz pela distância entre os prédios. A interdependência dos novos prédios (isolados mas interdependentes) é estendida à antiga torre apenas visualmente, colocada como figura, elemento sem função dentro do novo conjunto urbano. Pensada como elemento simbólico - por si só, função bastante digna e legítima - e justificada moralmente pelo arquiteto, ${ }^{17}$ a torre acabou por se tornar uma figura alegórica, que une o velho e o novo numa pitoresca composição.

Aqui todos os novos edifícios recebem o mesmo tratamento, seguindo uma composição que propõe homogeneidade: formas básicas, com estrutura metálica aparente que define a volumetria, e fechamento com "favos" em concreto armado aparente preenchidos com vidros coloridos. A estrutura dupla dos favos, que absorve os ruídos externos e também filtra a luz solar, reflete de modo homogêneo as cores dos vidros para o interior do edifício. À noite, projetores de luz existentes neste vão da estrutura, garantem a iluminação homogênea do interior, e a torna também, a exemplo da Matthäuskirche, um ponto de luz no exterior.

Afora as questões extra-disciplinares que a arquitetura suscita, voltemos às questões mais estritamente formais da obra de Eiermann. Interessante notar que, ao tempo da concepção do projeto definitivo da Gedächtniskirche, que tanto difere das propostas anteriores - em sua volumetria, exceto pelo tipo de fechamento e sua concepção em elementos isolados - o arquiteto estava envolvido em outro projeto, que guarda proximidades formais com a igreja de Berlim. Feito em parceria com Sep Ruf (1908-1982), o Pavilhão de Exposições de Bruxelas revela que a parceria com o ex-companheiro "mestre do minimalismo" foi muito profícua, e não em vão, os trabalhos posteriores de Eiermann revelam a mesma 
essencialidade e leveza das formas baseadas em sua estrutura modular, como a posterior Embaixada de Washington e mesmo a Gedächtniskirche, apesar da notável leveza dos demais projetos não estar aqui presente. Com escritório em Munique, Sep Ruf se destacou em obras como a Residência do Chanceler em Bonn (1960-1964), Academia de Artes Plásticas de Nuremberg (1950-1954), pelo caráter leve, uso de muito vidro e esbeltos apoios metálicos.

O Pavilhão incorpora a noção de arquitetura efêmera tãovaticinada por Eiermann, sinônimo de leveza, transparência e elegância nos detalhes, uma arquitetura que preza pela essencialidade de formas e paleta mínima de materiais. Em meio ao verde, onde nenhuma árvore poderia ser retirada, os arquitetos partem para uma concepção flexível, a partir de oito volumes prismáticos de tamanhos variados que se ajustam ao terreno sinuoso, conectados por passarelas entre si e acessados por uma elegante ponte desde a área comum da feira. O prolongamento das lajes dos pavimentos para além dos fechamentos de vidro, os elementos esbeltos de que é composta a fachada em suas várias "camadas", a diluem

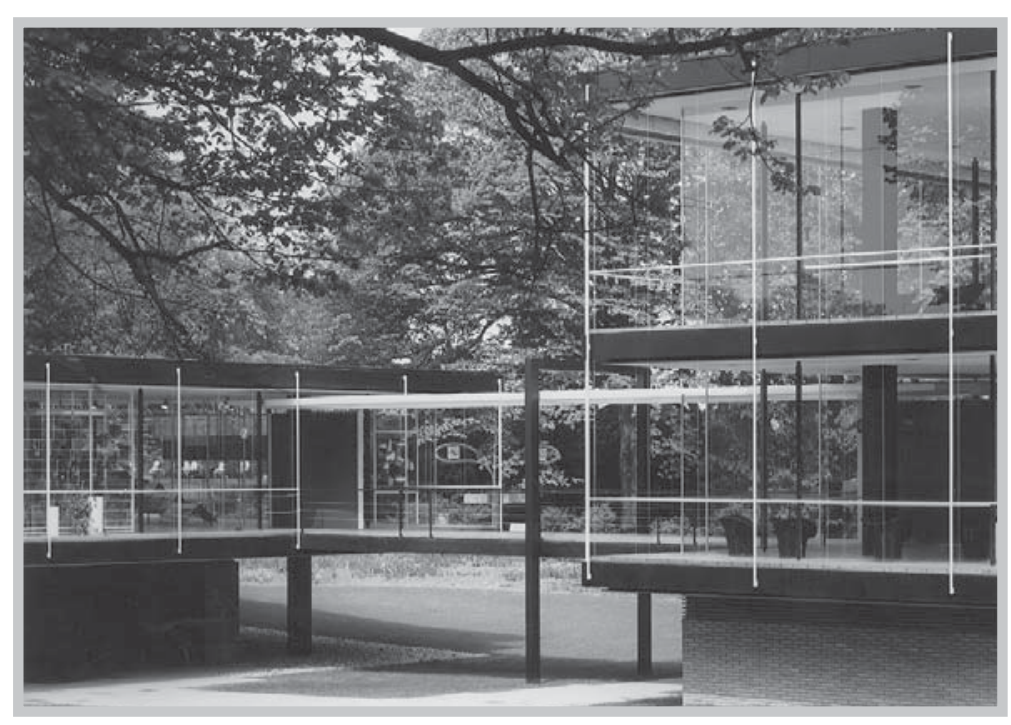

Fig. 5 - Egon Eiermann, Sep Ruf. Pavilhão Alemão para a Exposição Mundial de Bruxelas. 1956-1958.

e a tornam difusa, sem um limite reconhecível, que amplia ainda mais a sensação de uma arquitetura permeável, em franca conexão com o exterior.

Trinta anos separam este Pavilhão daquele de Mies para a Exposição Mundial de Barcelona, então a única oportunidade de mostrar a Alemanha de Weimar internacionalmente, através de uma concepção espacial:

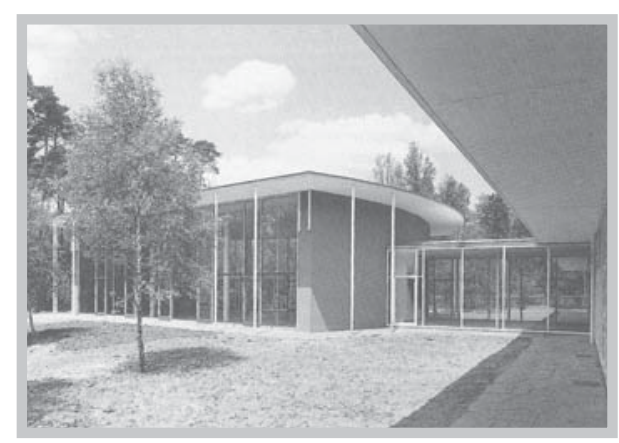

Fig. 6 - Sep Ruf. Academia de Artes Plásticas. Nuremberg. 1950-1954.

"Não queremos nada mais que clareza,simplicidadeehonestidade" acentuou o comissário-geral da representação alemã de então. ${ }^{18}$ Apartado da noção epicurista do pavilhão miesiano, com o pavilhão de Bruxelas, o país intenciona mostrar seu brilho renovado em

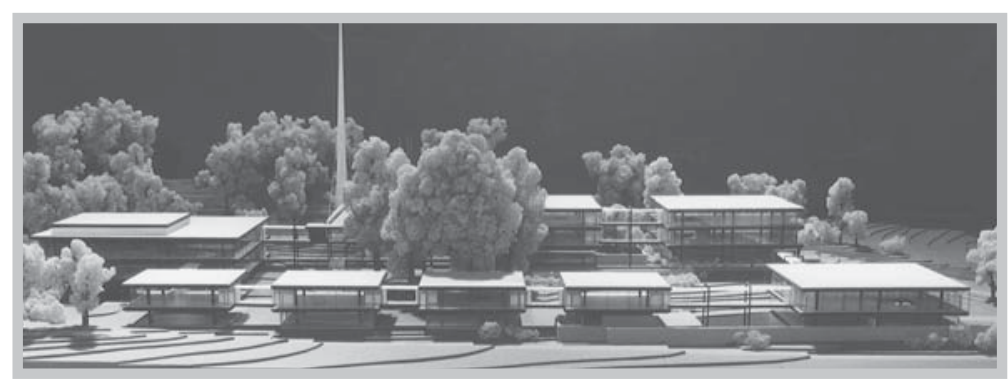

Fig. 7 - Egon Eiermann, Sep Ruf. Pavilhão para a Exposição Mundial de Bruxelas. Maquete do conjunto. 


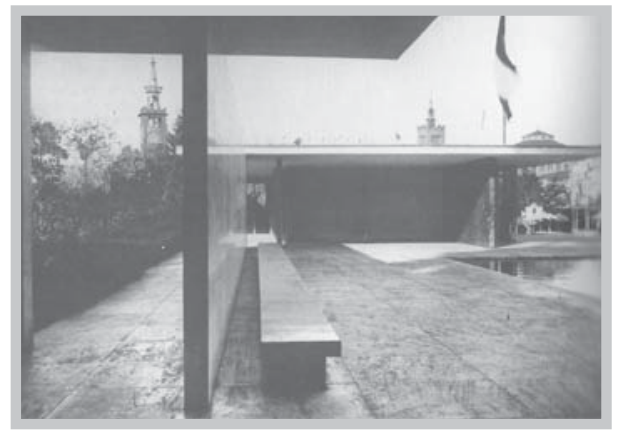

Fig. 8 - Mies van der Rohe. Pavilhão Alemão para Exposição Mundial de Barcelona. 1929.

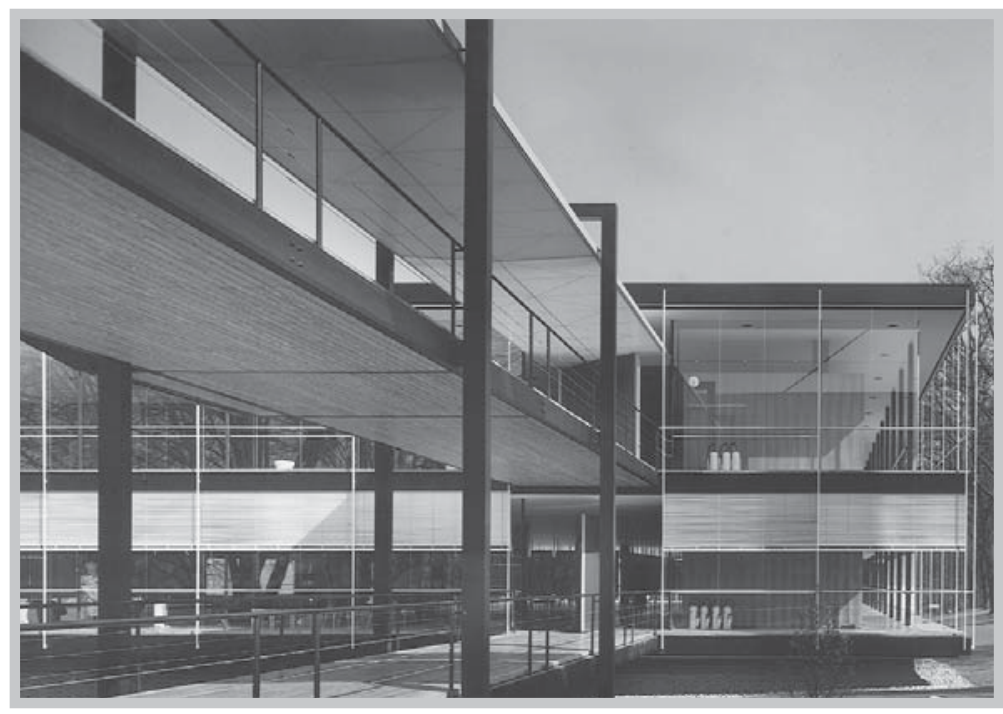

Fig. 9 - Egon Eiermann, Sep Ruf. Pavilhão Alemão para a Exposição Mundial de Bruxelas. 1956-1958. do "milagre".

sua igualmente primeira apresentação internacional pósguerra e, fazer desta arquitetura, sua imagem e semelhança: aberta, transparente, democrática; o orgulho da nação reerguida e renovada. Saudado como "moderado"19 pela imprensa local, o pavilhão manteve-se distante de qualquer intemperança motivada pela pujança econômica dos tempos

Assim o pavilhão se define pela discrição e essencialidade de suas formas, materiais e cores: formas puras, estrutura metálica em preto, vidro, guias e corrimãos metálicos em branco, forros e pisos em madeira natural e alvenaria na base. Assim também pode ser descrito sua construção e detalhamento; tudo concorre à leveza, ao imaterial, à negação de esforços e dos esforços estáticos. Ponte, passarelas, pavilhões, apoios e vigas, pórticos, e paramentos parecem se tocar minimamente numa composição filigranar e concisa. As passarelas de ligação avançam por entre os edifícios, mas não os tocam; os pilares metálicos internos recebem acabamentos pontiagudos em suas extremidades que parecem mal tocar as superfícies; nas passarelas, a cobertura é ligada à estrutura porticada apenas pelos conectores! Já dizia Eiermann: “o detalhe é a única nobreza”. Aqui todo o edifício assume a estética do "Noli me tangere", ${ }^{20}$ uma forma de conceber a arquitetura que não dizia somente respeito à obra eiermanniana.

O ideal de leveza, transparência, agilidade formal foi perseguido pela arquitetura dos anos 1950 e início dos 1960, que animava ainda obras em todo o planeta, apesar de já encontrar claro contraponto na tendência brutalista nascente. $O$ Escritório SOM, Eero Saarinen, Arne Jacobsen eram partidários internacionais desta tendência, com algumas obras que podiam ser vistas na Alemanha, como os Consulados norte-americanos construídos pelo escritório SOM. Eiermann, Kraemer, Sep Ruf, Paul Schneider-Esleben, o Escritório Hentrich \& Pettschnig contavam entre os principais representantes locais desta tendência, que tinha no Lever House (1950-1952) do SOM ou no Seagram Building (1954-1958) de Mies van der Rohe exemplos brilhantes. 
A influência especialmente da obra de Arne Jacobsen sobre Eiermann é marcante em algumas obras destes anos. A forma clara e concisa, a elegância "fria" e austeridade da Prefeitura de Rødovre (1955) encontram paralelo em obras como o Edifício Administrativo da Essener Steinkohlenbergwerke AG em Essen (1956-1960). Neles, o edifício é disposto em blocos distintos conectados por passarelas sempre transparentes, que nunca alcançam a altura dos blocos vizinhos e se diferenciam como elemento autônomo.

Apesar da realidade caótica que algumas cidades ainda viviam, os anos 1950 são lembrados como anos do "milagre econômico", onde a produção de bens de consumo e de investimentos alcança números surpreendentes, assim como a exportação, e parte desta arquitetura leve, com maior diferenciação formal que aquela dos anos 1920 com estrutura de esqueleto metálico ou concreto armado, expondo no térreo os pilares, marquises, terraços cobertos são parte do otimismo e confiança que marcaram estes anos. No seu interior os edifícios conhecem também criatividade sem limites no que concerne à forma e também aos materiais; interiores exuberantes com paredes onduladas, escadas em múltiplos desenhos, pisos e paredes com mosaico; ostentam a prosperidade, o desejo pelo bem estar, e deixam para trás os penosos anos do imediato pós-guerra. ${ }^{21}$

O tipo "pavilhão" corresponde aos anseios da época: arquitetura leve, de caráter temporário que pressupõe movimento. Há nele algo de efêmero; além da noção de leveza que encerram, deixam-se facilmente desmontar. Em tempos de mobilidade, a ideia de uma arquitetura

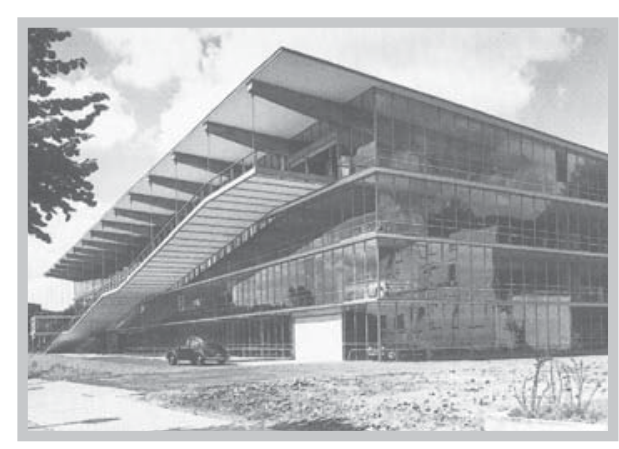

Fig. 10 - Paul Schneider-Esleben. Edifício de Garagens. Düsseldorf. 1949-1951.

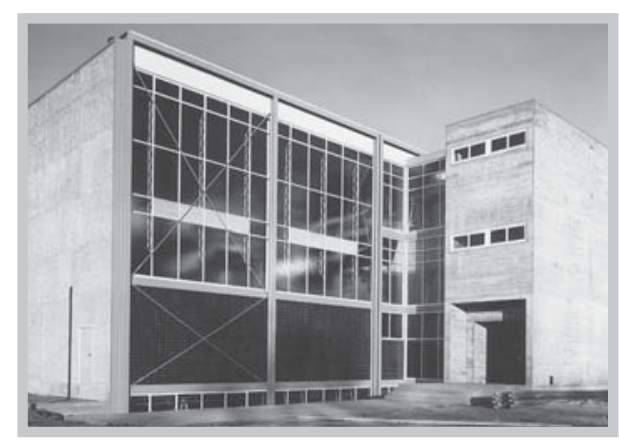

Fig. 11 - Egon Eiermann. Usina Experimental da Universidade de Karlsruhe. 1951-1956

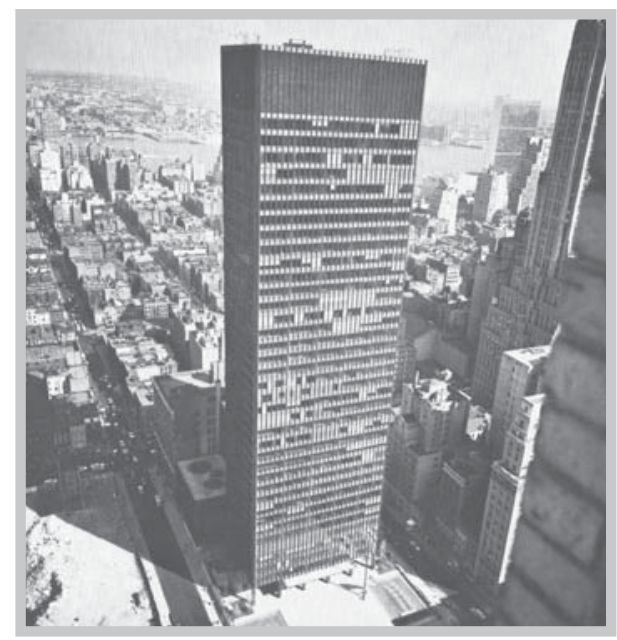

Fig. 12 - Mies van der Rohe. Seagram Building. Nova York. 1954-1958. eternamente durável lhe parecia absurda: "O problema do desmonte é, hoje, muitas vezes mais importante do que o da construção. Visto sob este aspecto [...] temo muito, portanto, pelo concreto armado, que somente pode ser explodido, e advogo pelos materiais que podem ser novamente isolados, pela madeira, ferro ou aço, que se pode montar e são novamente desmontáveis.”22 A arquitetura deveria existir enquanto tivesse utilidade, ou seja, ter um prazo de vida útil, como carros e eletrodomésticos. Este era um dos motivos pelo qual o arquiteto era um incorrigível apreciador do aço, material "aristocrático", que permite ser montado e desmontado, e novamente utilizado. Ademais, já traz sua própria forma, e exige conhecimentos específicos no seu trato; não se deixa moldar como o concreto. ${ }^{23}$ 


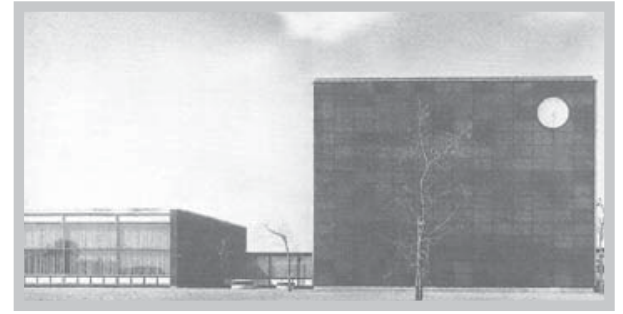

Fig. 13 - Arne Jacobsen. Prefeitura de Rødovre. 1955.

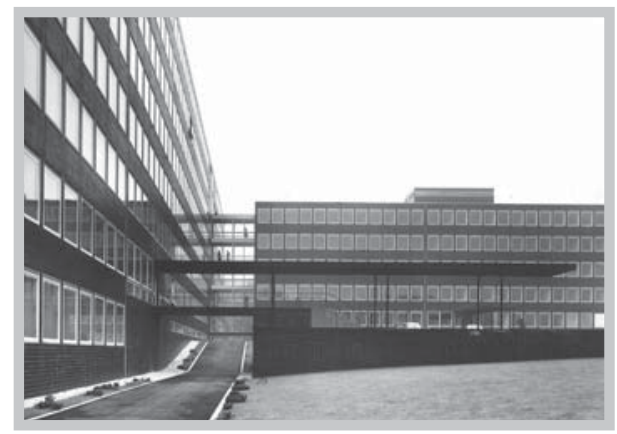

Fig. 14 - Egon Eiermann. Edifício Administrativo da Essener Steinkohlenbergwerke AG. Essen. 19561960.

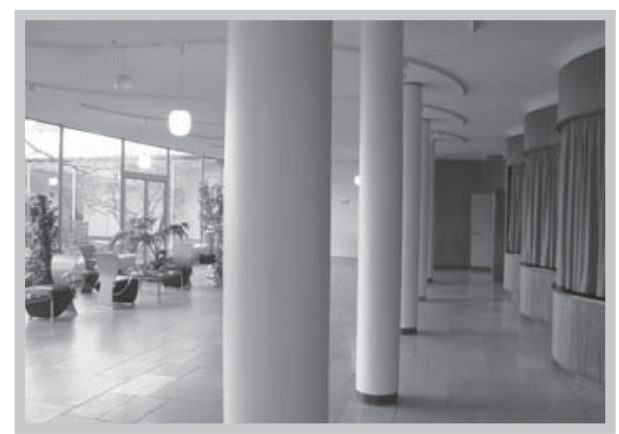

Fig. 15 - Friedrich Wilhelm Kraemer, Gerd Lichtenhahn, Dieter Oesterlen. Rádio NWDR. Hanover. 1948-1951.
O motivo pavilhonar se repete constantemente na arquitetura de Egon Eiermann, não somente através de estruturas metálicas, mas também em concreto, como nas soluções mais simples, a exemplo da Matthäuskirche. Nesta igreja como na Gedächtniskirche, vimos que o tipo pavilhonar se presta a um papel simbólico também. Na sua simplicidade e pureza volumétrica encerraria quase que a noção primitiva do templo, apenas um singelo envoltório para o Geschehen im Geiste. Em sua base porém, está sua qualidade estritamente funcional, que se presta a atender programas díspares como igrejas, indústrias - como Blumberg -, Rádio de Stuttgart, Usina Experimental da Universidade de Karlsruhe (que teve a colaboração de Broos na fase de projeto), escritórios da IBM, os dois edifícios mais baixos da Olivetti, e a ampliação da Universidade de Saarbrücken (1951-1952), neste especialmente, onde se nota claramente a influência do pensamento miesiano. Antes, a estrutura do pavilhão, que tem seu antecedente em Blumberg, não ficava claramente demarcada ou visível, como na Rádio de Stuttgart. Em Saarbrücken, porém, o pavilhão do Auditório Máximo recebe todo ele, ao seu redor, fechamento em vidro, como um prisma cristalino, com estrutura em pórtico, colunas internas ao volume (devido à projeção, para as laterais, do espaço interno) e grelha estrutural transversal em negativo - que recebe revestimento externo, entretanto, e não é visível do exterior. Como em Mies, todos os ambientes compartilham do grande espaço conformado pela estrutura única: o auditório principal, dois auditórios menores, salas de apoio, concebidos livremente dentro do grande vão, como espaços autônomos formal e estruturalmente.

A demonstração mais cabal deste pensamento surge com um concurso de meados dos anos 1960, para a construção de uma nova área central para a cidade de Castrop-Rouxel (1965-1966), para a qual era prevista a construção de centros de cultura e administrativos, setor de saúde, pavilhão de esportes e edifício de usos múltiplos.

Eiermann propõe uma grande grelha pergolada como estrutura básica, a partir da qual seriam edificados os pavilhões "genéricos" em diferentes tamanhos e formatos, que por sua vez, abrigam edifícios em seu interior, soltos, com estrutura autônoma, a serem concebidos de acordo com as funções específicas. 
Talvez pela primeira vez, Eiermann parte, não do edifício isolado, mas de um edifício-cidade, um centro urbano construído, que é, a um só tempo, edifício e paisagem, solução bastante recorrente nos anos 1960 . A estrutura é lançada: por entre ela, os pavilhões são acomodados e interconectados pelo pergolado, e praças abertas são previstas entre eles. Os pavilhões guardam uma grande homogeneidade formal; são tão somente envoltórios estruturais

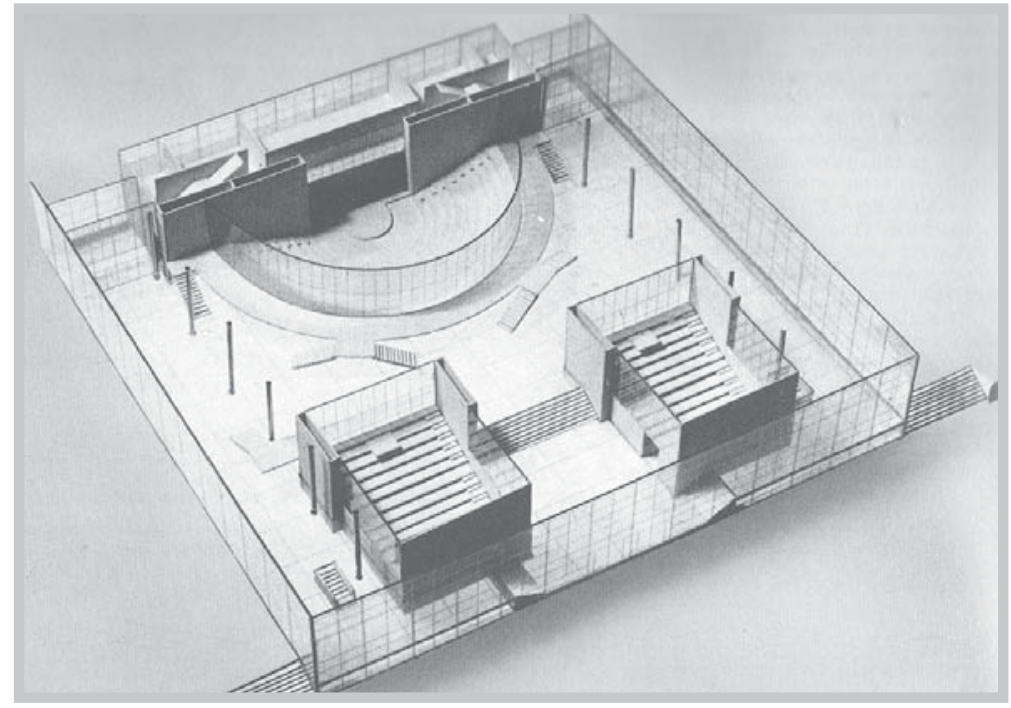

Fig. 16 - Egon Eiermann. Universidade de Saarbrücken. 1951-1952. que corporificam o desejo por soluções versáteis e com aplicabilidade infinita. Demonstração do espaço universal e flexível miesiano, que na sua pretensa validade universal, engloba toda e qualquer função.

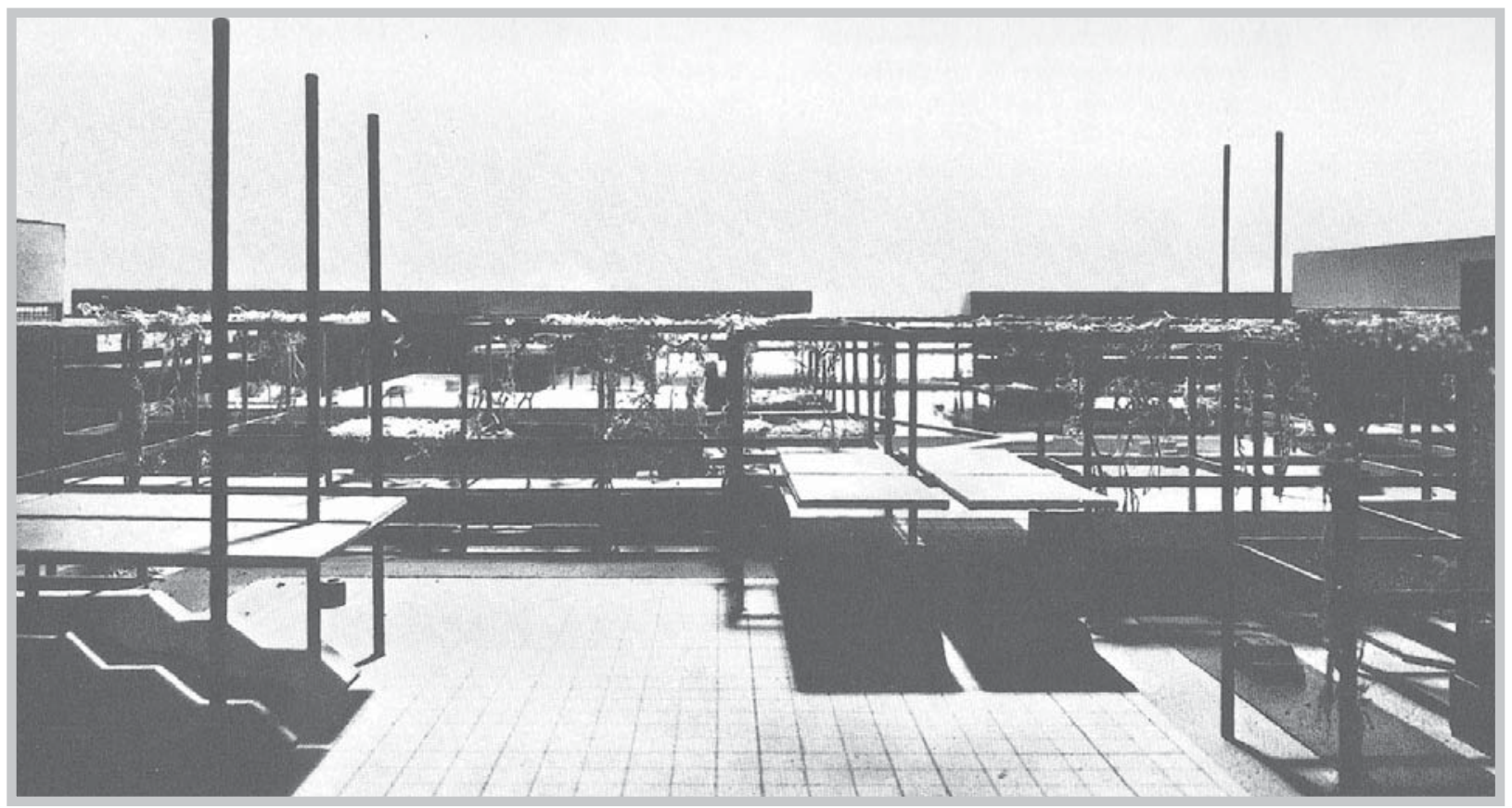

Fig. 17 - Egon Eiermann. Novo centro de Castrop-Rouxel. 1965-1966.

É com o mesmo ideal de leveza, transparência e agilidade nas formas que Eiermann dá vida a outro edifício de representação internacional - a Embaixada Alemã em Washington (1958-1964) - elaborada imediatamente após o sucesso do Pavilhão de Bruxelas, e dá mostras do reconhecimento profissional que alcança em seu país.

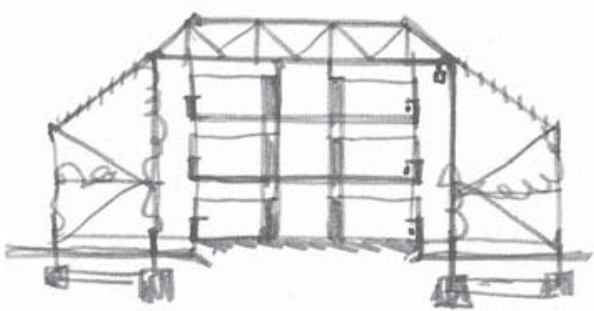

Fig. 18 - Egon Eiermann. Novo centro de CastropRouxel. Desenho dos pavilhões. 1965-1966. Pensado originalmente para ser um projeto assinado pelos 


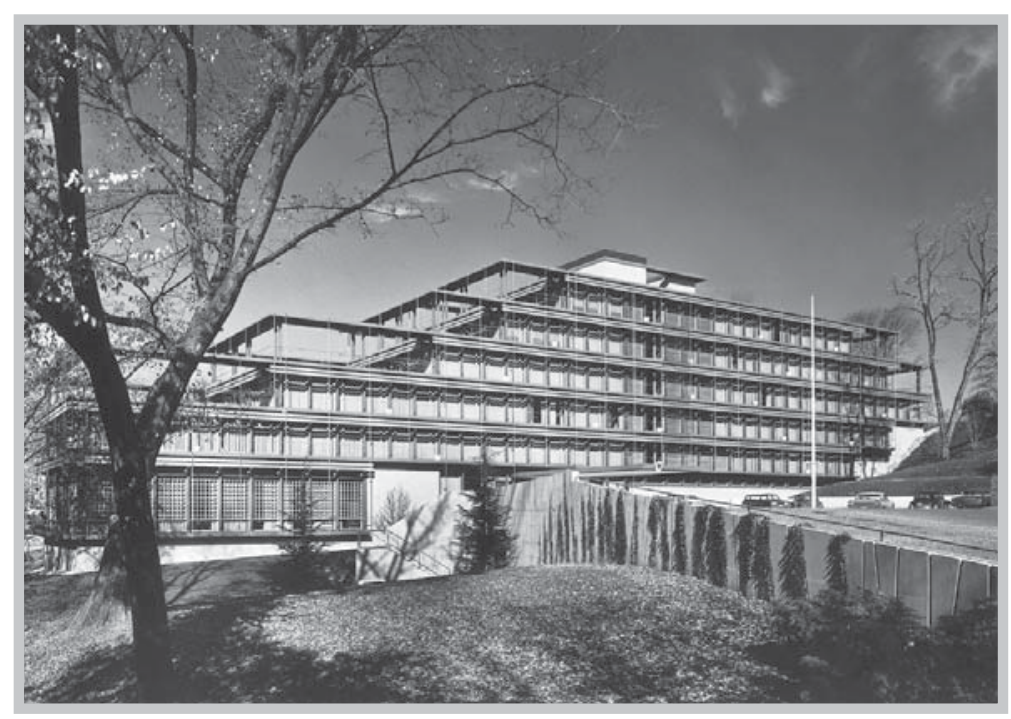

Fig. 19 - Egon Eiermann. Embaixada Alemã. Washington. 1958-1964.

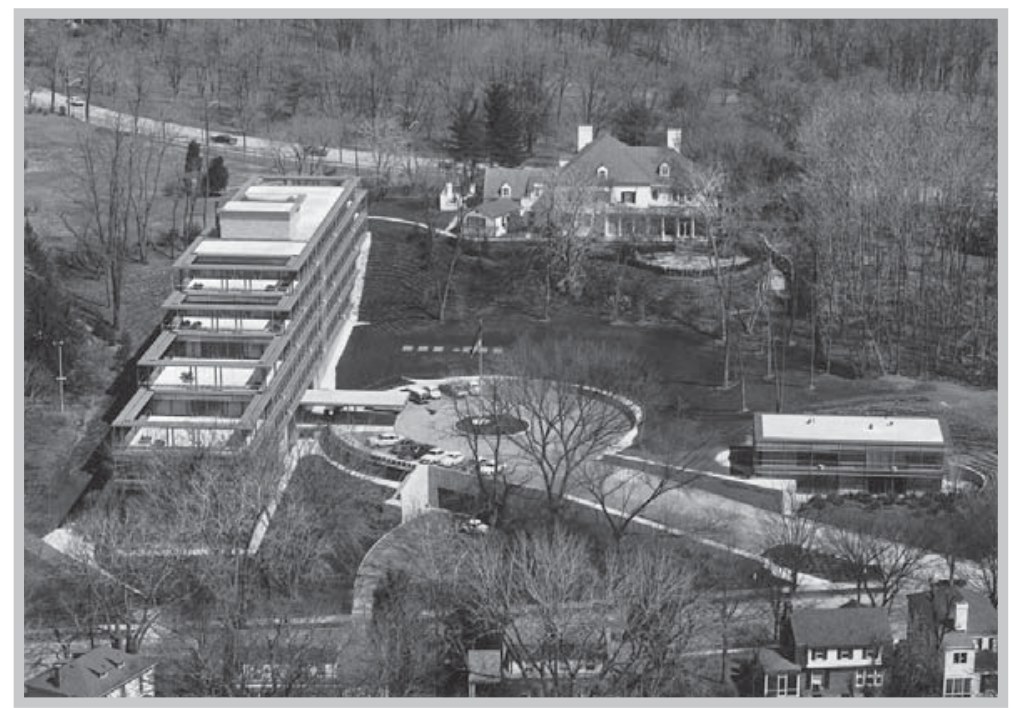

Fig. 20 - Egon Eiermann. Embaixada Alemã. Washington. 1958-1964.

dois maiores arquitetos alemães na América, Walter Gropius e Mies van der Rohe, Eiermann seria responsável apenas pela adequação do plano ao sítio, ${ }^{24}$ situação inusual que $\mathrm{o}$ arquiteto soube contornar com bons argumentos pessoais e técnicos. $^{25}$

Eiermann recorre aos mesmos elementos da arquitetura do Pavilhão: volumetria definida pela estrutura metálica, fechamentos em vidro e uma profusão de elementos metálicos apostos à fachada guias verticais e corrimãos - que a tornam leve e difusa, com seus limites já bastante diluídos.

O projeto se assemelha a lâminas horizontais sobrepostas, deslocadas entre uma extremidade e outra, onde, através da estrutura, que avança e se solta do edifício assim como faz em Blumberg, porém, de modo distinto - surgem terraços e espaços vazios que complementam e equilibram a massa, num jogo de escalonamento que liberta a arquitetura da forma compacta e rígida que lhe dá origem, e o aproxima do "maravilhoso projeto" para o concurso da Casa da Amizade (Haus der Freundschaft, 1916) em Constantinopla, de seu mestre Poelzig, que o arquiteto nunca ocultara, o havia fascinado em sua juventude. ${ }^{26}$

Decisivo para tal estruturação da Embaixada foi o acentuado declive do terreno, onde o arquiteto busca adequar a escala do edifício à escala do contexto; tanto numa extremidade quanto na outra, o edifício assume o sítio e o entorno construído. Ou seja, uma mostra de uma arquitetura "local", embora os materiais "universais" que utiliza. Concebido em plenos anos 1960, quando vertentes da arquitetura reagem ao moderno ortodoxo e às formas pré-concebidas e propõe um novo olhar à cidade e materiais "tectônicos", Eiermann demonstra que mesmo uma forma arrojada com ângulos retos e também o aço lhe permitia encontrar formas que se adequassem ao lugar e a uma situação específica. 
Com o edifício da Embaixada Alemã em Washington Eiermann finalmente realiza um motivo que sempre permeou suas criações, desde os anos 1930 (como o Prédio da Justiça em Berlim, 1930 que revela também uma monumentalidade inusual em sua obra): o edifício escalonado, que surge com mais intensidade nas propostas dos anos 1960, mas que até então nunca fora levado adiante.

Tema recorrente em sua obra, o tema do escalonamento permeava suas criações em propostas alternativas como artifício utilizado para romper com a altura e o impacto da escala dos edifícios, mas que raramente chegava a ser apresentado como proposta final.

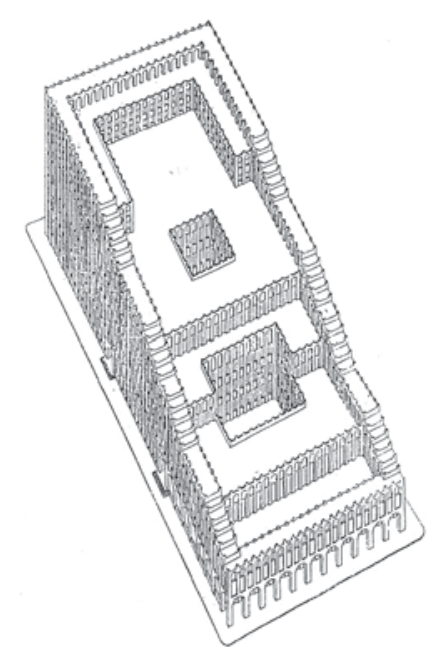

Fig. 21 - Hans Poelzig. Haus der Freundschaft. Constantinopla. 1916.

São exemplos desta composição escalonar: uma proposta alternativa para o projeto construído doEdifício Administrativo da Hochtief AG em Frankfurt (1966-1968), o projeto para a Prefeitura de Essen (1963), e uma alternativa de projeto para o edifício do Parlamento Alemão em Bonn (1965-1969).

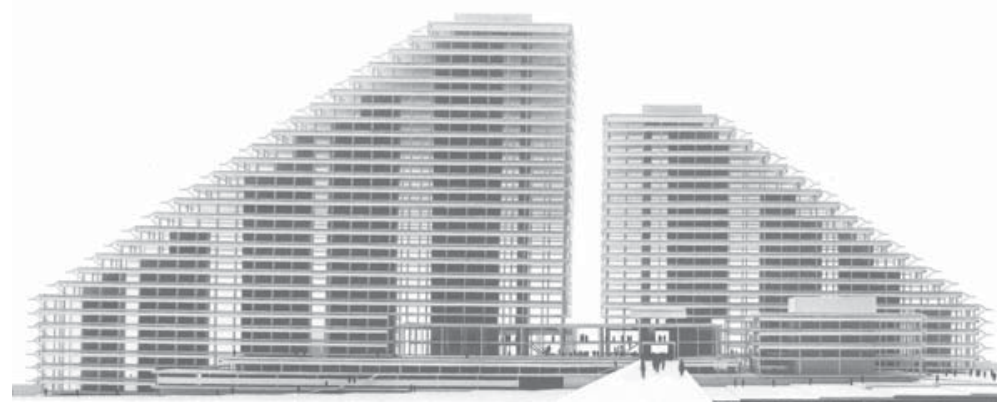

Fig. 22 - Egon Eiermann. Prefeitura de Essen. 1963.

Uma destas propostas mais interessantes trata-se de uma das alternativas para o projeto para a Rádio Emissora de Stuttgart, vencido em concurso em 1948, que ocupou por anos o escritório. O projeto contou com a participação de Hans Broos, mas acabou sendo abandonado em virtude do surgimento da televisão, que demandava novas disposições e equipamentos. Programa extenso - que compreendia o complexo da rádio emissora, setor administrativo, salas de concertos, restaurante e café, além de uma série de salas de

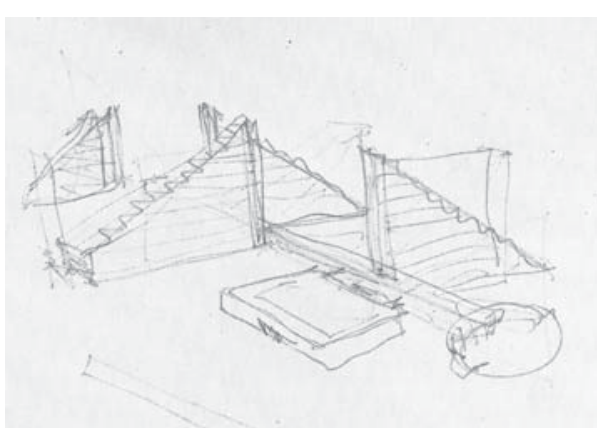

Fig. 23 - Egon Eiermann. Edifício do Parlamento Alemão. Alternativa de projeto. Bonn. apoio e uma oficina - que seria disposto em pelo menos três grandes edifícios. $\mathrm{O}$ projeto deveria conjugar ainda uma antiga casa existente no terreno, a ser usada como uma das salas de concertos. Em uma das alternativas, o escalonamento foi utilizado para agrupar o vasto programa e amenizar o volume construído, ao mesmo tempo em que se adequava ao sítio levemente em declive, utilizando também terraços internos, mas de modo diverso, a exemplo da Embaixada.

Afora a questão do escalonamento, esta proposta é interessante na medida em que deixa clara a atitude de projeto de seu autor. Como já nos esclarecera Pehnt, Eiermann se coloca nas antípodas de Scharoun. Podemos ter uma noção mais 


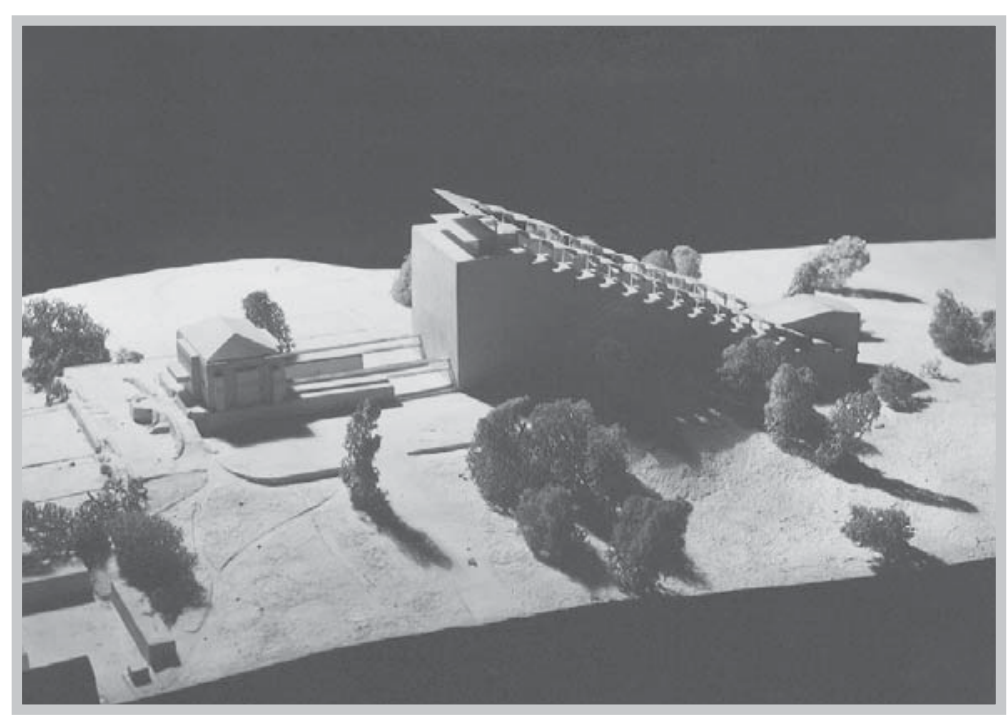

Fig. 24 - Egon Eiermann. Rádio Emissora. Alternativa de projeto para concurso. Stuttgart. 1948

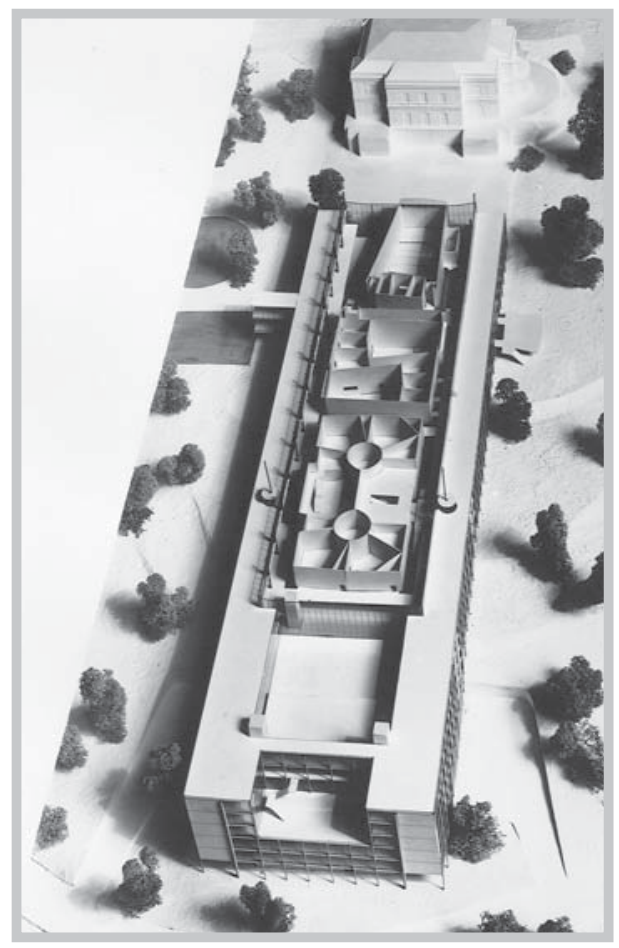

Fig. 25 - Egon Eiermann. Rádio Emissora. Proposta final. Stuttgart. 1949-1951.

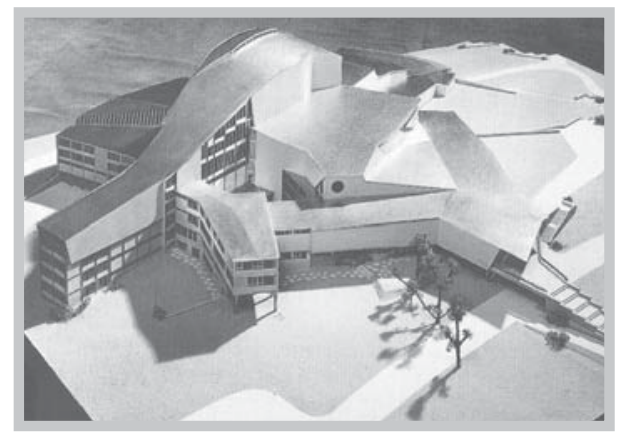

Fig. 26 - Hans Scharoun, Hermann Mattern. Teatro de Kassel. 1952. clara desta colocação a partir da análise da planta-baixa da Rádio de Stuttgart. Em seu interior, são inúmeras as salas de teste de voz, de emissão, gravação, reunidas em dois núcleos principais centralizados no prédio; salas que admitem certa forma orgânica, dispostas num espaço restrito que permite múltiplos acessos e interconexões. Eiermann agrupa todo este conjunto em uma forma externa rígida, uma planta retangular que "amarra" qualquer "desvio" formal e não revela seu interior. Ao contrário, se pensarmos em Scharoun, que utiliza a estrutura espacial interna para chegar à forma final, o arquiteto certamente teria feito desta organicidade motivo para uma forma orgânica total, a exemplo do projeto para o Teatro de Kassel (1952, com a colaboração de Hermann Mattern), ${ }^{27}$ que neste aspecto, é ainda mais revelador que a célebre e posterior Filarmônica de Berlim (1956, 1960-1963).

Também a partir do exemplo da Rádio de Stuttgart e de tantos mais - Blumberg, Gedächtniskirche - é possível verificar uma importante noção de composição da arquitetura do Eiermann - a composição a partir da adição. $\mathrm{O}$ arquiteto projeto quase sempre a partir de volumes puros (círculo, retângulo) e suas derivações (hexágono, octógono), justapondo-as para obter diferenciação formal, ou conectando-as através de passarelas. Na Rádio de Stuttgart isso fica claro na medida em que o arquiteto divide, em todas as suas propostas para este projeto, os diferentes programas em volumes isolados e diferenciados. Mais que o princípio compositivo da adição, podemos falar em uma individualização dos elementos de composição, que pode ser volumétrica, programática, funcional, estrutural, e se revela até nos detalhes, como os componentes de um corrimão de escada. 
No Siedlung de Hettingen (19461947) tem início o princípio de lançar a estrutura para fora do prédio, que resultará em último e mais significativo estágio, nas passarelas externas, que não são mais estruturais, mais guardam

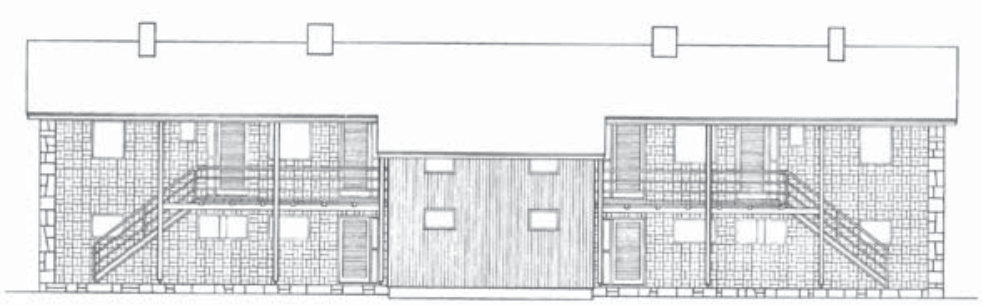

Fig. 27 - Egon Eiermann. Siedlung de Hettingen. 1946-1947. motivos funcionais (e estéticos). ${ }^{28}$ Veremos que a partir desta obra, passando por Blumberg até a Olivetti, tem-se a evolução do princípio de individualizar os elementos, torná-los visíveis e legíveis, individualizados em seu caráter material, funcional e estrutural - como os pilares exteriorizados de Blumberg, as passarelas externas dos edifícios, ou os pequenos elementos que formam um corrimão, por exemplo. Num corrimão, diferencia o conector entre a escada e a haste vertical, esta do apoio, e este da barra longitudinal. Até elementos retos e curvos são diferenciados em cor e/ou material.

A isto junta-se a estética do "não-me-toque" desenvolvida pelo arquiteto desde final dos anos 1930 com a Fábrica em Apolda, e com mais intensidade nos anos 1950 - elementos como marquises não chegam a tocar a cobertura vizinha, mantém-se distanciados e deixam clara sua independência formal e estrutural. Isso é levado ao máximo rigor no Pavilhão de Bruxelas onde, como vimos, os apoios metálicos são unidos às passarelas apenas pelos ínfimos conectores.

Em Blumberg os edifícios são individualizados - casa de caldeiras, a portaria e o pavilhão de produção - e diferenciados em sua forma e materiais. Além disso, é procurado que a cada função distinta corresponda a uma diferenciação de fechamentos e revestimentos. O pavilhão, por sua vez, já diferenciado em sua estrutura (base de concreto armado e pavimento superior de estrutura metálica) recebe fechamento diferente que expõe sua natureza construtiva e funcional diversa. Em uma perspectiva maior, o mesmo princípio é adotado na diferenciação programática/funcional, ao diferenciar em blocos distintos, distintas funções - como o restaurante, edifício de escritórios e passarela de ligação no Edifício Administrativo em Krefeld - e culmina em última análise na individualização de setores de um mesmo edifício: na Gedächtniskirche, o arquiteto "desmonta", destrinça o programa como que em peças, utilizando o espaço urbano como elemento unificador.

Voltemos agora novamente ao motivo "favo", amplamente utilizado pelo arquiteto, não somente em proposições religiosas; ele pode ser encontrado em dois projetos para

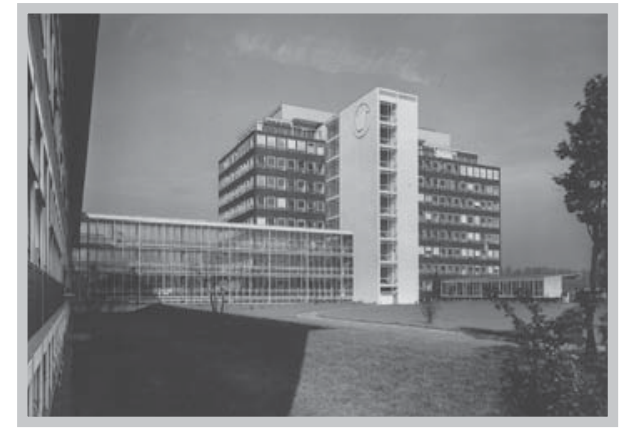

Fig. 28 - Egon Eiermann. Edifício Administrativo Vereinigten Seidenwebereien. Krefeld. 1950-1956. 


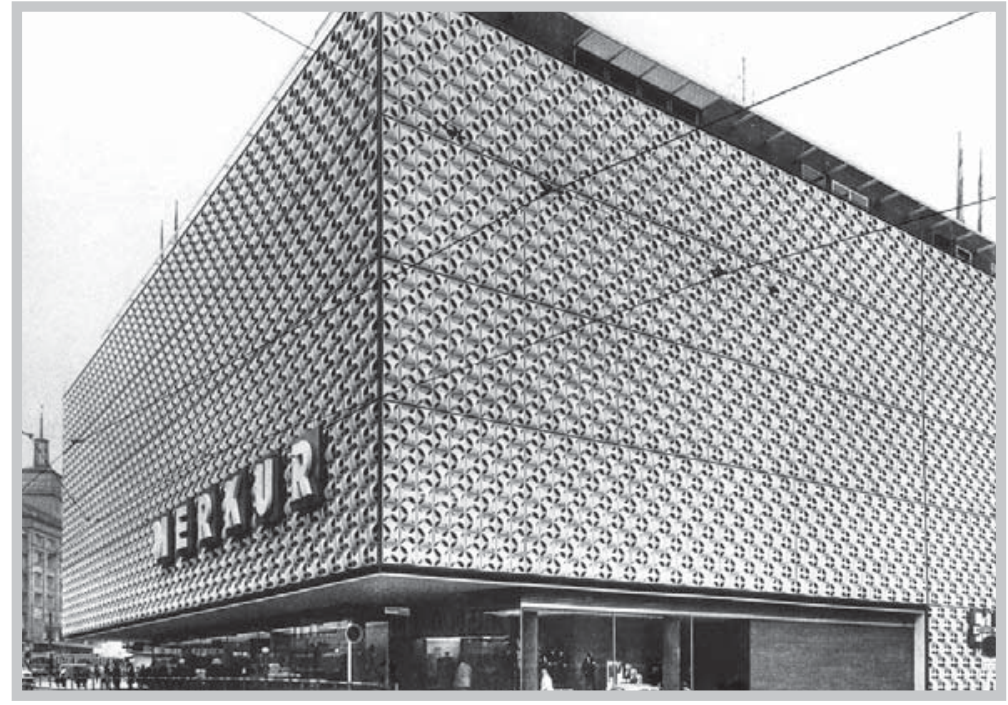

Fig. 29 - Egon Eiermann. Casa de Departamentos Merkur. Stuttgart. 1951-1960.

Lojas de Departamentos e, um deles, merece ser brevemente analisado. $\mathrm{O}$ primeiro destes projetos suscitou muita polêmica no início dos anos 1950, por duas razões - a primeira pelas circunstancias em que ocorreu, mas também pelo resultado arquitetônico questionável da proposta. A Casa de Departamentos Merkur em Stuttgart (1951-1960) foi construída no lugar onde havia a legendária Casa Schocken (1926-1928) de

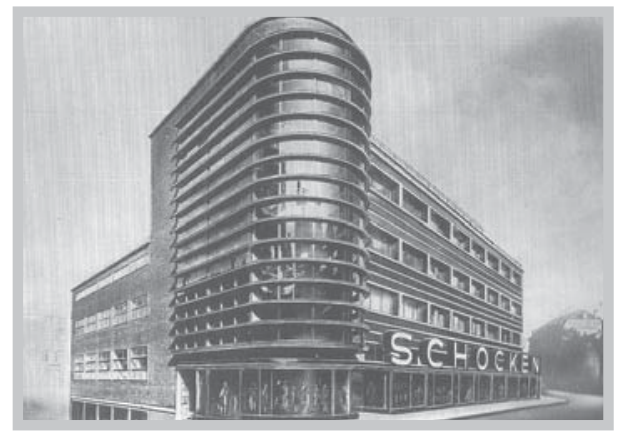

Fig. 30 - Erich Mendelsohn. Casa Schocken. Stuttgart. 1926-1928
Erich Mendelsohn. A antiga loja se mostrava insuficiente para atender a uma grande casa de departamentos, o que sugeria sua demolição, preservando, porém, o famoso meio círculo que abrigava a escada. Devido ao baixo pé-direito da escadaria - que inviabilizaria a conexão com o novo bloco - optou-se finalmente pela demolição total do prédio. A ameaça de demolição suscitou um debate intenso em toda a imprensa, vinham cartas de vários países e de dentro da Alemanha exigindo a manutenção do prédio e por fim uma carta dos Estados Unidos da viúva de Mendelsohn. A pressão foi tamanha que, segundo Eiermann, não lhe restava outra alternativa a não ser renunciar ao projeto, pois "as acusações que a mim chegam do país e do exterior, lançam suspeitas sobre uma postura oportunista, que para mim, não é possível suportar." ${ }^{29}$ Depois de tantos embates e discussões em que o arquiteto se viu envolvido, o antigo edifício, um dos marcos da Arquitetura Expressionista dos anos 1920, veio finalmente abaixo. Finda a polêmica sobre a demolição, as discussões que cercavam o projetam não parariam por aí.

Para a elaboração da nova proposta a substituir o antigo Edifício Schocken, arquiteto e proprietário, ${ }^{30}$ baseando-se em justificativas estritamente funcionais, como a liberdade para mudanças de layout, e mudanças internas (aberturas e equipamentos), sem que isso acarretasse alterações na fachada, decidem-se pelo completo fechamento (opaco) do edifício, à maneira de uma segunda fachada, uma casca exterior homogênea que permitisse liberdade de remanejamentos e alterações na construção.

A exemplo da Matthäuskirche, Eiermann utiliza novamente a fachada em "favo", mas com novo desenho, tridimensional e entrelaçado; mais complexo e 
ao mesmo tempo, prosaico. Aqui esses elementos cerâmicos de $60 \times 60 \mathrm{~cm}$ criam um envoltório que torna o edifício homogêneo e irreconhecível sua estrutura e construtividade, e contrariam a lição do próprio arquiteto: a honestidade e a "verdade" construtiva. Tanto na Matthäuskirche e no projeto posterior da Gedächtniskirche estes elementos vazados eram colocados como fechamento por entre a estrutura, que ficava visível; aqui ele a dissimula. O edifício, homogêneo, todo ele cerrado, ganha a noção de bloco pesado e hermético, apartado de seu entorno, negando qualquer visualidade interna e noção de proporção. O edifício torna-se um objeto, uma fachada-ornamento e marca para a empresa que, bastante sugestiva, virou moda dentro da concepção das grandes lojas pelo país, inclusive na zona oriental. "E para isso teve que sucumbir a obra anterior de Mendelsohn?” Pergunta sarcástico, Pehnt. ${ }^{31}$

Afora a infamante afronta a uma das obras-primas de Mendelsohn, ${ }^{32}$ à concepção das Casas de Departamento de Eiermann cabe a origem de um importante elemento dentro de sua arquitetura. Por vezes já citadas aqui, voltemo-nos mais atentamente sobre as "passarelas externas" que se tornará um marco em sua obra, independentemente do programa.

Segundo o arquiteto, a passarela externa reúne as funções de facilitar a limpeza externa das janelas, dispensando os andaimes em edifícios mais altos; proteção à incidência solar; como rota de fuga e, ainda, como contraventamento. Nos edifícios de fins dos anos 1950 e anos 1960 foi uma solução fartamente utilizada, que virou uma marca projetual do arquiteto e ela mesma gerava o caráter da obra, conferindo leveza e movimento aos edifícios.

A passarela externa, como será utilizada posteriormente, surge pela primeira vez na Warenhaus Merkur em Reutlingen, (1952-1953), mas como um prolongamento, em concreto armado, do piso dos pavimentos, contraposto aos finos perfis metálicos do guarda-corpo e das guias verticais onde são fixadas as persianas. Neste caso a passarela externa serve principalmente como proteção solar e para limpeza externa das aberturas, e as outras funções remetidas às qualidades desta solução, foram sendo "anexadas" ao longo dos anos pelo arquiteto.

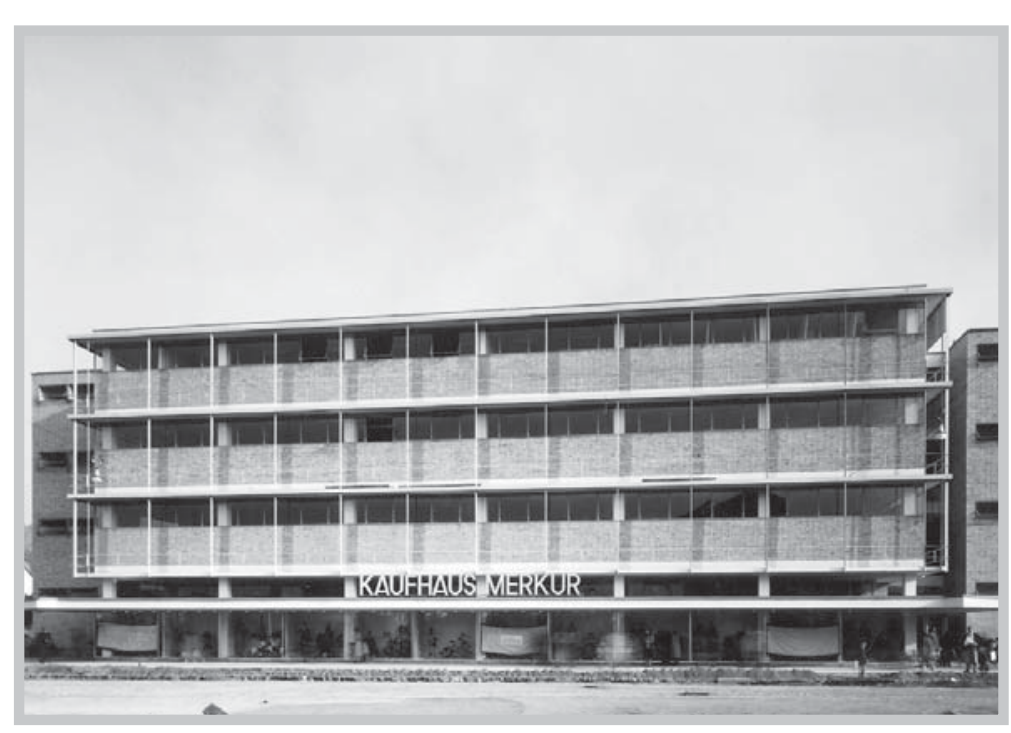

Fig. 31 - Egon Eiermann. Warenhaus Merkur. Reutlingen. 1952-1953. 
Também se pode ler nesta solução das passarelas, a mesma atitude projetual de Eiermann já vista em projetos anteriores: jogar a estrutura e qualquer aparato

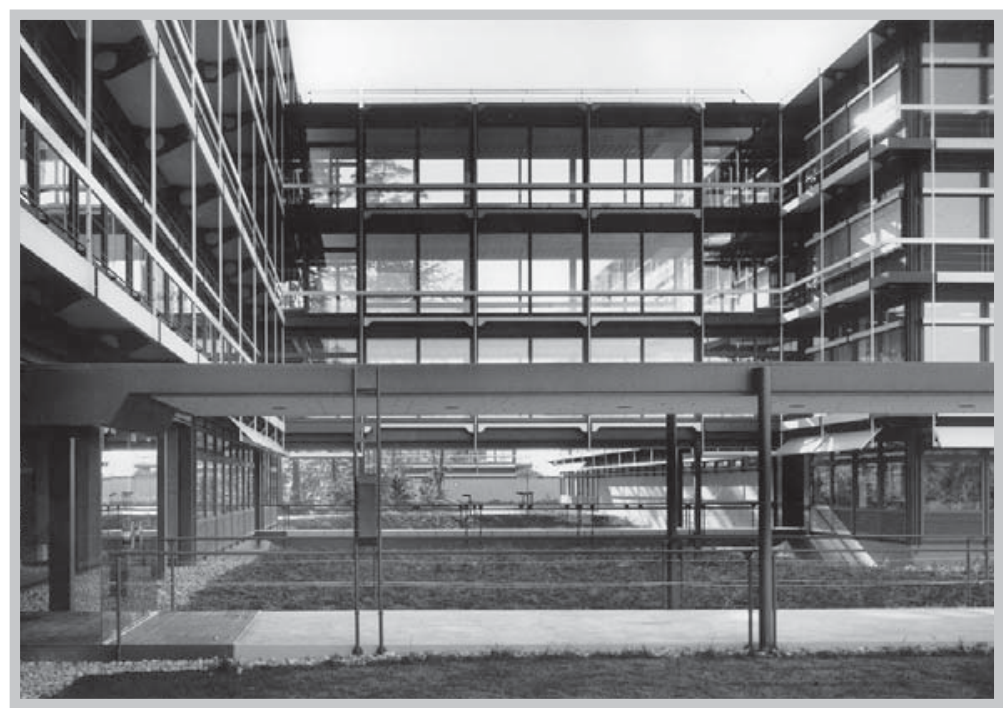

Fig. 32 - Egon Eiermann. Edifícios de Escritórios IBM. Stuttgart. 1967-1972.

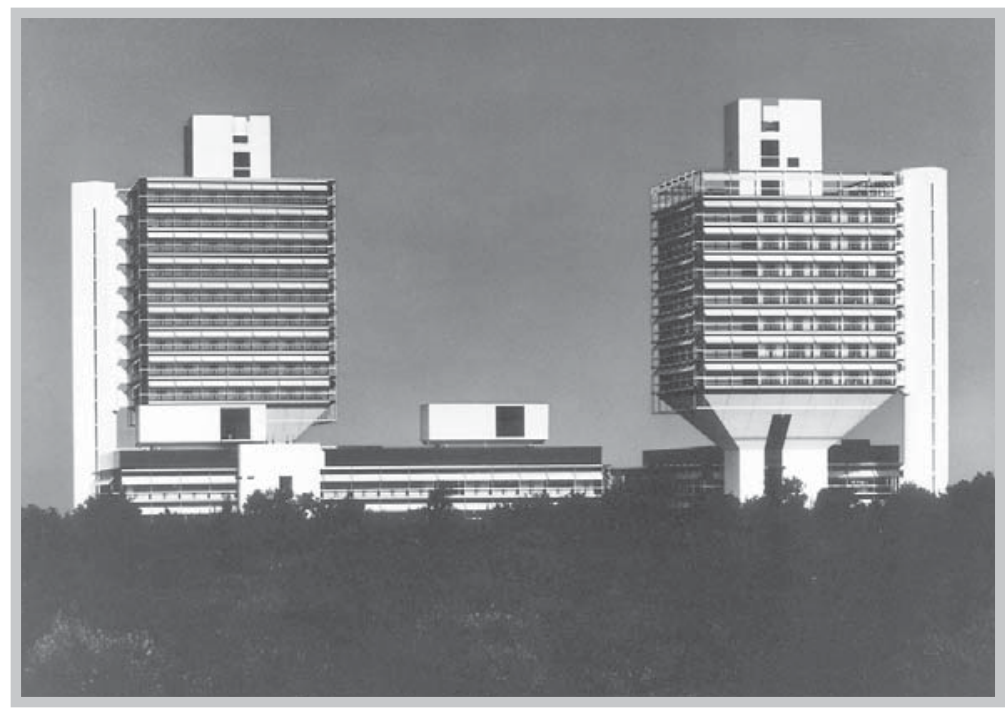

Fig. 33 - Egon Eiermann. Edifícios para Olivetti. Frankfurt. 1968-1972. para fora do prédio; o edifício é quase sempre concebido como uma estrutura límpida, em uma forma pura e essencial; além disso, faz parte de sua postura, deixar os elementos estruturais, construtivos e funcionais, bem como todo e qualquer "aparato" externalizados, bem como individualizar as partes de que é composto o edifício e de torná-las legíveis, atuando na composição plástica do prédio (postura que não pode ser lida como "didática", mas formal, que vê na técnica, nos matérias e na "correta" construção a única justificativa para a forma arquitetônica).

No Pavilhão de Bruxelas o arquiteto faz uso pela segunda vez desta solução, mas aqui embora seja o mesmo princípio, ela surge bastante diversa.

Em Reutlingen, apesar de ser uma continuidade do piso, a passarela diferenciava-se claramente do corpo principal, auxiliada pela cor e

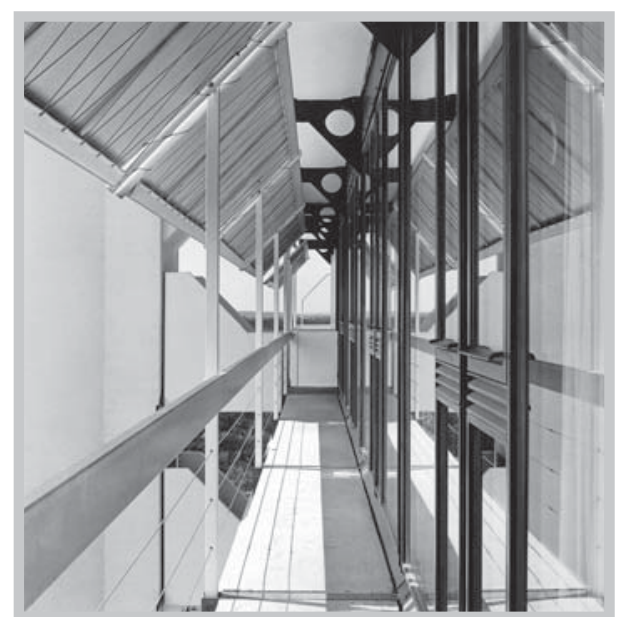

Fig. 34 - Egon Eiermann. Edifícios para Olivetti. Detalhe da passarela externa. Frankfurt. 1968-1972. material distintos. Já no Pavilhão ela surge visivelmente como continuidade, sem uma clara separação com o edifício, a não ser o vidro que o envolve. É neste edifício que a passarela assume seu caráter principal que é a fachada em camadas, que será, em última instância, a melhor consequência das passarelas externas, que será o grande interesse em edifícios como da IBM de Stuttgart. Nestes exemplos, pergunta-se: onde acaba o edifício? No vidro - que é seu fechamento propriamente dito, ou nos delgados perfis metálicos que recobrem toda a fachada formando uma espécie de revestimento diáfano, e que servem como guias para as 
persianas que, quando fechadas, formam um novo envoltório e mudam completamente o edifício, e apesar da forma rígida, consegue ao mesmo tempo metamorfosear-se.

Com efeito, a concepção da passarela externa leva a duas concepções distintas - uma delas é a dissolução da fachada como este belo exemplo do Pavilhão de Bruxelas; a outra é a existência da passarela propriamente dita, como

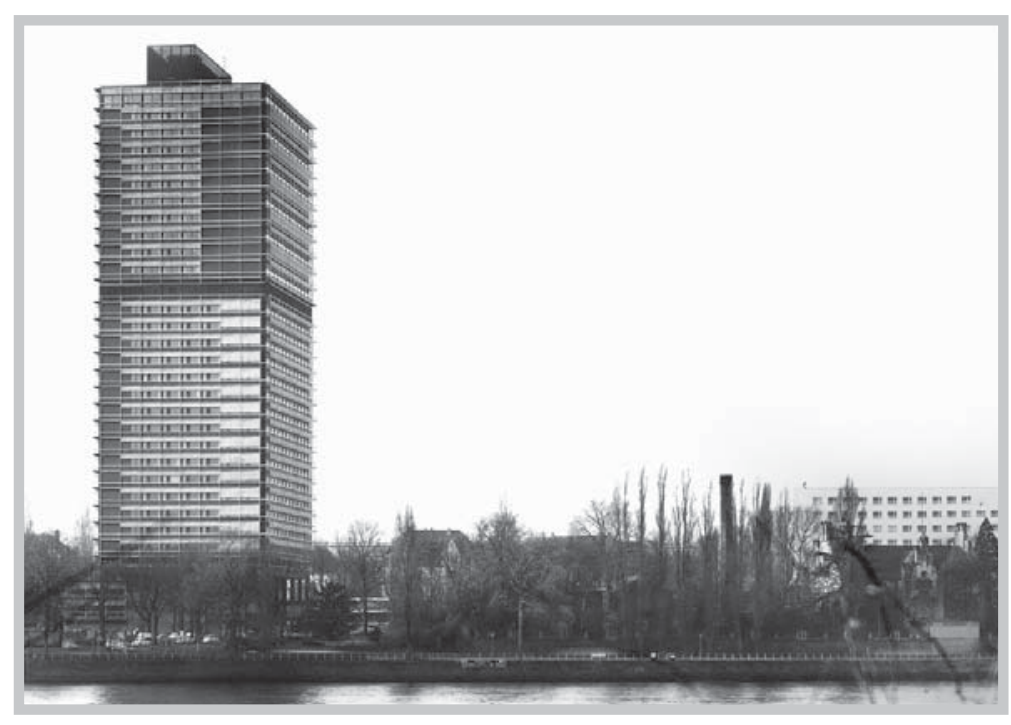

Fig. 35 - Egon Eiermann. Edifício do Parlamento Alemão. Bonn. 1965-1969. algo aposto, como na IBM e na Olivetti, que tanto atua na noção de "dissolução" da fachada, como na primeira, quanto no seu oposto, o de "acumular" fachadas, como os exemplos da Olivetti e do prédio do Parlamento Alemão em Bonn. Dois fatores contribuem para isso. A escala dos prédios e o fato de que as passarelas possuem nestes casos muita informação.

\section{CONSIDERAÇÕES}

Sem dúvida, faz parte deste estudo, de forma inevitável, até mesmo porque uma contribuição necessária e bem-vinda, a apresentação da obra de Egon Eiermann (bem como a obra de Kraemer, analisada posteriormente) que, de forma surpreendente, porém não inexplicável, é quase totalmente desconhecida entre nós, o que é mais espantoso ainda, quando se compara a importância deste arquiteto em sua terra natal. Importância que se mostra nos inúmeros artigos, livros e periódicos (principalmente alemães, mas não somente) que relatam não apenas sua obra, mas também a personalidade carismática e cativante (de cujas famosas frases não fugimos aqui, até porque, para dar ao leitor uma ideia do interessante pensamento deste arquiteto). Enfim, um arquiteto que provoca comentários e críticas apaixonadas, muitas vezes exageradas e unívocas no sentido que seguidamente não concorrem para uma crítica ampla, ou um olhar desapaixonado e, geralmente, evitam um confrontamento com aspectos questionáveis em sua obra. Uma solução projetual, ou melhor, uma boa solução, comporta olhares críticos multifacetados, dependendo do ponto de vista do observador e das variáveis levadas em conta, sendo que, tanto maior é a riqueza da solução adotada, quanto maior serão as possibilidades abertas à crítica. 
Exemplos não faltam: as passarelas externas, assim como enunciadas pelo arquiteto, são quase sempre, com raras exceções, expostas por suas qualidades funcionais; ou então, a repetição impensada pela crítica, de que a disposição dos edifícios da Olivetti e sua solução em "cálice" - o princípio do edifício-árvore wrightiano - foi uma solução impelida pelo vasto programa em exíguo terreno, e não uma escolha estética de seu autor. Discursos reproduzidos pela crítica que, assim como o discurso do arquiteto, justificava a própria obra como resultado unívoco entre estrutura, forma e construção, numa relação quase exata, sem laivos de arbitrariedade. Sendo uma disciplina mediante arte e técnica, a arquitetura incluirá, conscientemente ou não, assumidamente ou não, mas sempre necessariamente, alto grau de juízo de gosto.

Pode-se dizer que as passarelas externas ${ }^{33}$ "diluem" as fachadas, as fazem em camadas, desfazem o bloco monolítico, torna-o visivelmente leve, com movimento e que contribuem na apreensão da escala. Já num outro olhar, pode-se inferir que esta solução nega a estrutura do edifício e que, apesar de inegavelmente conferir leveza e movimento à fachada, não deixa de ser um envoltório homogêneo que dissimula o seu interior - principalmente na escala do edifício em alturas, pela repetição que assume. Deste ponto de vista seria algo comparável às curtain-walls; uma pele que nega as relações e estrutura internas do edifício, tão anônima em sua totalidade quanto as insípidas fachadas de vidro do chamado International Style, atualizados, porém, em uma versão que ganha tridimensionalidade.

Inegavelmente, as passarelas externas conferem leveza e movimento à obra. Embora o sentido aqui de leveza, seja bem diferente daquela admitida nas obras de um Mies ou Gropius. Eiermannn geralmente parte de um corpo "convencional", e o "reveste" com as passarelas, um envoltório filigranar sobreposto ao edifício, que confere o sentido de leveza pelos perfis delicados de seus elementos e tende ao desmantelamento do corpo cúbico que lhe serve de hospedeiro.

Eiermann sempre os justificou com argumentos puramente funcionais, que chegam até mesmo a soar convincentes. Entretanto, eles servem muito mais a uma eventual noção de harmonia e a propugnada questão da "verdade construtiva" e sua conseqüente legibilidade externa. No campo estritamente funcional, sua argumentação não parece proceder. E mais que isso: ela vai mesmo contra a maior lição que o arquiteto sempre se impôs e tentou justificar a própria obra: a "verdade" construtiva. Antes de expor a estrutura e a construtividade do edifício e torná-las legíveis, como premissa de sua linguagem compositiva, a passarela externa as dissimula, e coloca toda e qualquer diferenciação formal do edifício sob o vasto e homogêneo manto das passarelas que o circunda. No 
edifício da Olivetti, elas se encontram nas quatro fachadas, algo seguramente não necessário, pelo menos no que diz respeito ao brises - até porque, num país em que a luminosidade no inverno é drasticamente reduzida, brises fixos são até mesmo contra-indicados. Isso confirmaria a noção da arquitetura de Eiermann pensada enquanto objeto, autônomo, e não um elemento multifacetado com fachadas diferenciadas. Além disso, elas são realmente necessárias nos blocos mais baixos? Como proteção solar, sim, mas quanto aos outros elementos, soam exagerados. As passarelas externas assumem característica de solução fechada, aplicada em bloco, independentemente da real necessidade ou adequação de todos os elementos que a compõem. Ainda neste exemplo, contraria a noção de funcionalidade do arquiteto, o fato dos dois edifícios em alturas serem projetados idênticos para programas tão díspares: um destinado a escritórios, e o outro, a um hotel para hóspedes da firma. Também no edifício do Parlamento Alemão em Bonn, as passarelas não se encaixam no discurso estritamente funcional e estrutural. Do $19^{\circ}$ ao $28^{\circ}$ pavimento, por exemplo, há salas de pé-direito duplo, ocultadas na fachada. Aqui também as passarelas ao mesmo tempo em que conferem escala e ritmo (que nesta escala, entretanto, perde seu efeito, e mais se confundem a uma grelha externa) ocultam a natureza interna do edifício.

Entretanto, tais observações, que poderiam ser estendidas para outras obras e outros elementos de sua arquitetura, só vem a colaborar com a ideia de quão ampla, sugestiva e de grande interesse é o trabalho deste arquiteto, e que comporta vários olhares, justamente pela qualidade que encerra. 


\section{Notas}

1 Em entrevista à autora.

2 Hatje, Gerd (org.). Knaurs Lexikon der Modernen Architektur. München, Zürich: Droemersche Verlagsanstalt, 1963.

3 Pehnt, Wolfgang. Sechs Gründe, Eiermanns Werk zu lieben. Und einer, es nicht zu tun. In: Jaeggi, Annemarie (org.). Egon Eiermann (1904-1970): die Kontinuität der Moderne. Ostfildern-Ruit: Hatje Cantz Verlag, p. 17.

4 Idem, ibidem.

5 Idem, ibidem.

$6 \quad$ Idem, p. 17-18.

7 Egon Eiermann. Extraído de uma aula no semestre de inverno 1963/1964. apud: Boyken, Immo; Büchener, Rudolf (et.al). Egon Eiermann 1904-1970: Bauten und Projekte. Stuttgart: Deutsche Verlags-Anstalt, 1984, p. 66

8 Pehnt, Wolfgang. Sechs Gründe, Eiermanns Werk zu lieben. Und einer, es nicht zu tun. op. cit. p. 18.

9 Eiermann, Egon. Transcrição de uma aula em 1963. In: Clemens, Kieser. Egon Eiermann: Zwei Wohnhäuser in Baden-Baden. Ein Stück Deutsche Architekturgeschichte. Karlsruhe, 2002, p. 25.

10 Kabierske, Gerhard. Egon Eiermann als Lehrer. In: Jaeggi, Annemarie (org.). Egon Eiermann (1904-1970): die Kontinuität der Moderne. op. cit, p. 42.

11 Idem, ibidem.

12 Idem, p. 42. Broos afirma ter sido assistente de Eiermann durante o período que trabalhou em seu escritório em Karlsruhe. Não há, no entanto, nenhum registro oficial no Arquivo da Universidade de Karlsruhe sobre este possível trabalho, que poderia ter ocorrido entre 1949 e 1952. Entretanto, em um documento para a Municipalidade de Karlsruhe, Eiermann afirma que Broos é seu colaborador no escritório e também seu assistente. Esta intensa ocupação de Eiermann com seus projetos e a transferência das atividades docentes para assistentes, a que se refere Kabierske, pode ter dado margem à colaborações informais. Nenhum dos ex-colaboradores de Eiermann, entretanto, confirmou a versão de Broos.

13 Idem, p. 43.

14 Eiermann, Egon. Justificativa de projeto para o concurso da Kaiser-WilhelmGedächtniskirche. Karlsruhe, 28.2.1957. Grifo nosso.

15 Exemplo que será analisado posteriormente.

16 Eiermann, Egon. Architekten auf Abwegen. Eiermann und sein Kompromiß. Die Bauwirtschaft. Heft 8, 22.2.1958, p.154.

17 "Desejo, que (as gerações futuras) tenham entendimento por aqueles, que viveram o terror, cujo sofrimento as ruínas são testemunhas, e de que ela mesmo padeceu". Eiermann, Egon. Kaiser-Wilhelm-Gedächtniskirche. In: Das neue Berlin. Sonderpostwerzeichen der Landespostdirektion Berlin. Berlin, 1970, s/p., apud: Pehnt, Wolfgang. Sechs Gründe, Eiermanns Werk zu lieben. Und einer, es nicht zu tun. op. cit. p. 23.

18 Schnitzler, Georg von. Segundo Lilly Schnitzler. In: Querschnitt, Heft 9, 1929, p. 583, apud: Durth, Werner; Sigel, Paul. Baukultur. Spiegel gesellschaftlichen Wandels. Berlim: Jovis, 2009, p. 262.

19 „Haltung der Zurückhaultung” (Atitude da moderação). Johann, Ernst. Die Haltung der Zurückhaltung. Deutschland in Brüssel. Werk und Zeit. n.6, ano 7, 1958, p. 3-6.

20 Pehnt, Wolfgang. Deutsche Architektur seit 1900.2a ed. Ludwigsburg/ München: Wüstenrot Stiftung/ Deutsche Verlags-Anstalt, 2006, p.303.

21 Entretanto, estas características não se aplicam à arquitetura residencial. A maior parte das casas ainda fazia questão de ter características bastante convencionais, exibindo qualidades de solidez, proteção e segurança. É possível encontrar facilmente exemplos mais tradicionais em revistas como a Baumeister. 
22 Entrevista do arquiteto em 1967. In: Boyken, Immo; Büchener, Rudolf (et.al).op. cit., p. 203.

23 "A construção metálica exige melhores conhecimentos, exige clareza lógica até nos mínimos detalhes [...] que não por último, se manifesta da utilização do ângulo reto como optima ratio. É de se constatar que, hoje, a Arquitetura Moderna utilize amplamente o concreto com uma veia formal francamente perdulária, barroca, que mais lembra uma plástica (escultura) a uma construção.” Eiermann, Egon. Discurso no Primeiro Congresso do Aço em Luxemburgo, 1964. In: Boyken, Immo; Büchener, Rudolf (et.al).op. cit., p. 146. A despeito de todo este amor declarado ao aço e sua qualidade de uso renovável, o arquiteto não foi imune aos novos tempos, e algumas de suas últimas obras ostentam o concreto armado e sua expressão de peso, como mostram os edifícios da Neckermann e, principalmente, da Olivetti.

24 Jaeggi, Annemarie. Kanzleigebäude der Deutschen Botschaft. Washington, 1958-1964. In: Jaeggi, Annemarie (org.). op. cit., 187.

25 Idem, ibidem.

26 Cf. Eiermann, Egon. Hans Poelzig, unserem Lehrer. Bauwelt, Heft 11, 1959, p. 332. Publicado originalmente em Bauwelt, 2.7.1936.

27 Projeto vencedor de concurso, que leva em conta não somente seu programa, mas também reage ao sítio e ao entorno. Acabou desprezado, e em seu lugar construído um "tradicional" projeto moderno de segunda linha do arquiteto Paul Bodes.

28 Neste Siedlung emergencial de dois pavimentos, a solução assume um aspecto fundamentalmente estrutural - o arquiteto lança apoios externos e cria uma generosa cobertura, que mantém as paredes de alvenaria longe da umidade - além de servir como acesso às moradias do pavimento superior; difere, portanto, da concepção funcional com que é justificada posteriormente.

29 Eiermann, Egon. Carta a Hermann Eckelmann, 7.8.1959. SAAI Karlsruhe.

30 Que depois passou a ser Helmut Horten.

31 Pehnt, Wolfgang. Sechs Gründe, Eiermanns Werk zu lieben. Und einer, es nicht zu tun. op. cit., p. 24.

32 Que não parece, entretanto, ter abalado o arquiteto, já que disputou com o Grupo Horten, a patente sobre a invenção do revestimento. Eiermann não ganhou a disputa e, assim, este revestimento pode ser usado em outros edifícios do Grupo.

33 Refiro-me aqui às passarelas como algo aposto ao edifício, e não sua continuidade espacial como no Pavilhão de Bruxelas. 


\section{A obra de Friedrich WiLhelm Kraemer}

Se Eiermann não é conhecido, tampouco reconhecido no Brasil, podese esperar muito menos reconhecimento no que tange a obra de Friedrich Wilhelm Kraemer. Autor de trabalhos exemplares do pós-guerra, elogiado por críticos, o arquiteto não parece obter reconhecimento nem mesmo de seus pares, críticos e historiadores em seu país. Nota-se apenas muito recentemente o esforço, em especial de um grupo de pesquisadores de Braunschweig ${ }^{1}$ em resgatar a obra completa deste arquiteto por meio de exposições e publicações. ${ }^{2}$ Independentemente da existência ou não de reconhecimento e da qualidade arquitetônica de seu trabalho, através de mais de quatro décadas de atuação, sua obra ajudou a moldar a face da nova Braunschweig e ajudaram a compor o cenário da "grande cidade" no pós-guerra.

Kraemer conta entre os principais e mais bem sucedidos arquitetos da Alemanha pós-guerra, ${ }^{3}$ um dos mais jovens da chamada segunda geração de modernos daquele país. Sua obra não possui, entretanto, a genialidade de um Scharoun ou Eiermann, e se desloca, entre um início claramente filiado à arquitetura tradicional do Terceiro Reich, quando inicia sua carreira, a uma decidida adesão ao moderno internacional, que mescla influências da arquitetura escandinava, bem como do Estilo Internacional, a partir dos anos 1950. Sua importância devese também ao renome conquistado em sala de aula.

\section{O INÍCIO DA CARREIRA NOS ANOS 1930}

Talvez como muito poucos arquitetos, Friedrich Wilhelm Kraemer desfrutou de uma rápida ascensão, iniciada já nos tempos do Nacional Socialismo. A profícua carreira se liga diretamente ao momento político vivido no país, onde o arquiteto soube aproveitar as oportunidades de trabalho a ele confiadas, que o lançaram como um arquiteto de precoce renome no ambiente pós-guerra.

Como Arquiteto de Confiança do DAF e Kreisreferent do Departamento Schönheit der Arbeit, ${ }^{4}$ cargo que desempenhou a partir de 1939 até o fim da guerra, Kraemer desfrutou de uma posição privilegiada perante seus colegas, com uma ativa atuação. ${ }^{5}$ Seu trabalho para o governo contou-o como "politicamente incorrompido", e o autorizou a assumir, em fins de 1945, com apenas 38 anos, a direção do Curso de Arquitetura da então Escola Técnica de Braunschweig, logo depois de ter dirigido, por pouco tempo (maio-dezembro de 1945) a Secretaria de Obras (Oberbaurat) da cidade. 
Sua carreira serve de bom exemplo para demonstrar o quão próspero os anos 1930-1940 representaram para alguns arquitetos. Quando em fins de 1945 Kraemer é nomeado Diretor do curso de arquitetura, já contava em seu currículo mais de 50 obras entre residências, edifícios comerciais e indústrias. Nada mal para quem se formou em 1929 e abriu escritório próprio apenas em 1934.

Kraemer iniciou, portanto sua carreira durante o Terceiro Reich e, como muitos outros colegas, foi deste tempo que começa a desfrutar de significativa fama. O arquiteto soube aproveitar a onda de construção durante o Nazismo, que tivera lugar privilegiado em Braunschweig. Cidade industrial, ali foram construídas inúmeras indústrias dentro do Plano de armamento do Governo a partir de 1936. São diversos projetos industriais que datam desta época, assim como o projeto de edifícios administrativos, centros sociais e alojamento para funcionários.

Entretanto, a exemplo de outros arquitetos que trabalhavam nestes anos, também em seu currículo ficariam algumas obras sem a devida menção. Entre elas, o abrigo para operários submetidos ao trabalho escravo para indústria de motores de avião Büssing em Braunschweig, firma para a qual já havia construído alojamento para funcionários e o galpão de produção em $1941 .^{6}$

Tornada a guerra realidade e a consequente proibição de novas edificações, mesmo assim seu posto de arquiteto do DAF não seria afetado, dado a importância da construção da indústria bélica, e o privilegiado posto de "indispensabilidade" dos arquitetos a ela ligados, e que garantia nestes anos não somente segurança financeira como o não destacamento para os campos de batalha. ${ }^{7}$

Além dos postos de trabalho privilegiados junto à estrutura governamental, ao longo dos anos 1930 Kraemer vinha consolidando uma bem sucedida carreira como arquiteto autônomo. Suas obras iniciais mostram afinidade com uma arquitetura de linhas tradicionais típicas para a época; influência que se estenderá pelo menos até suas primeiras obras já "modernas" do pós-guerra até início dos anos 1950. Embora Kraemer não tivesse, aparentemente, contato com a Escola de Stuttgart ao sul do país, suas primeiras obras residenciais e industriais mostram uma inegável influência do Heimatstil professada por Schmitthenner: corpos simples

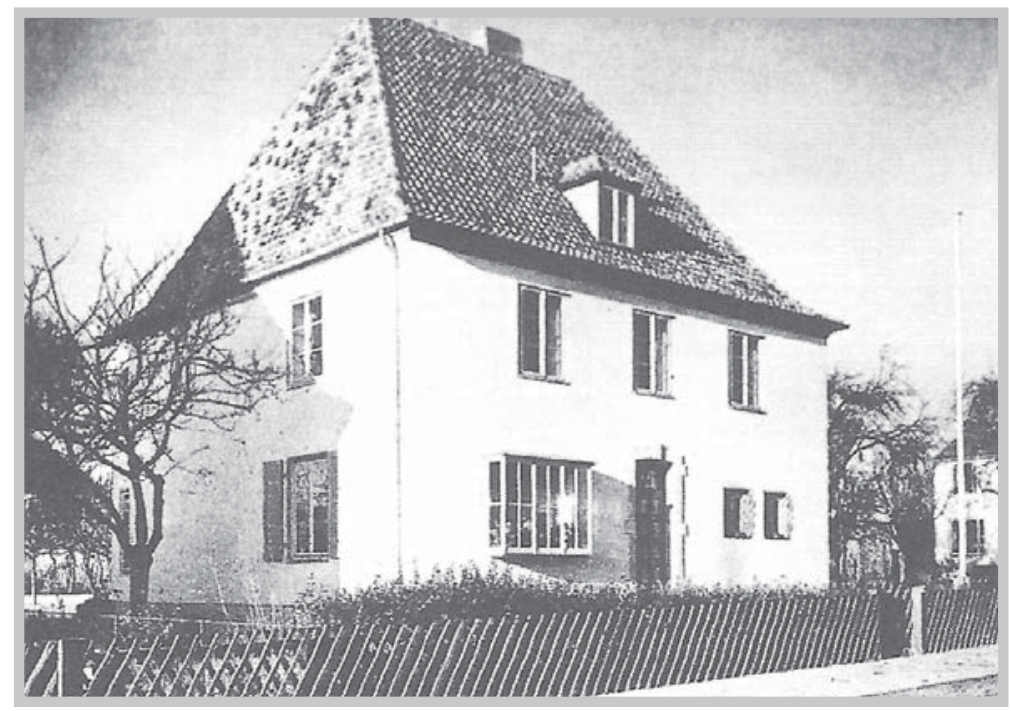

Fig. 1 - Friedrich Wilhelm Kraemer. Residência Albrecht. Braunschweig. 1935-1936. 


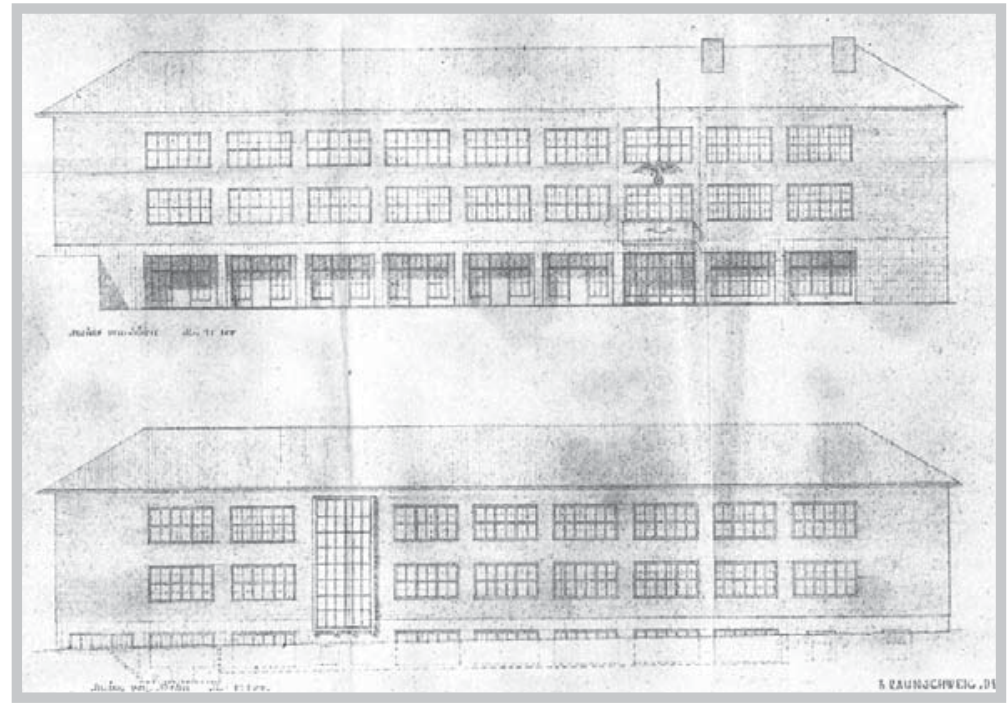

Fig. 2 - Friedrich Wilhelm Kraemer. Alojamento para a indústria Franke \& Heidecke. Braunschweig. 1937-1938.

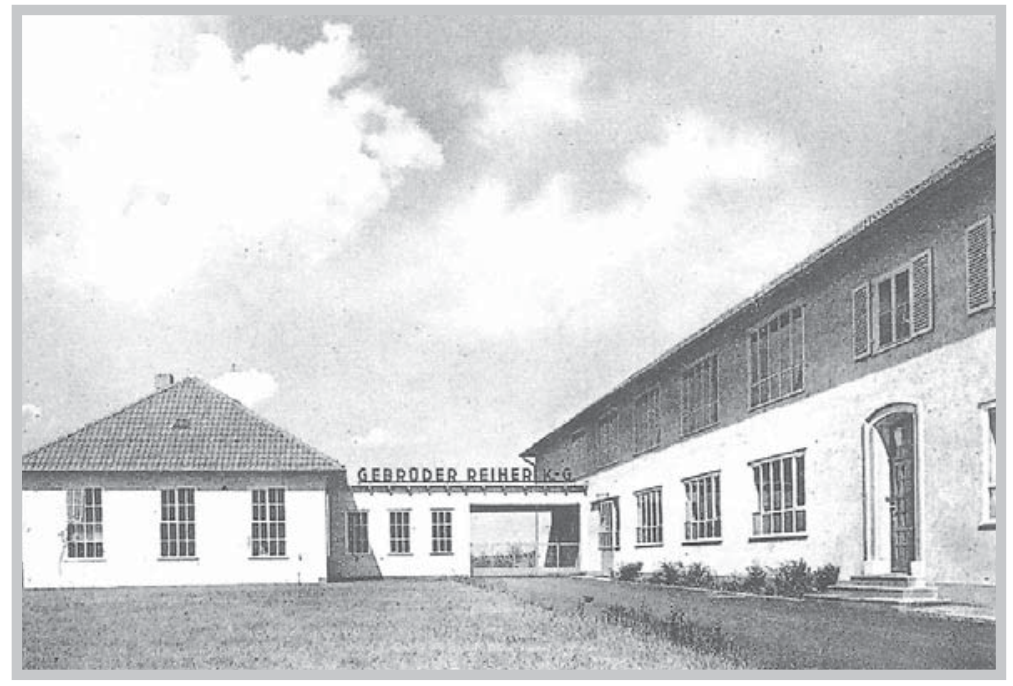

Fig. 3 - Friedrich Wilhelm Kraemer. Indústria Gebrüder Reiher. Braunschweig. 1938-1939.

e entroncados, quase na mesma proporção dos telhados altamente inclinados, com pouco ou nenhuma sobressaliência (beiral), aberturas pequenas e isoladas na fachada, lucernas, e o sentido de calma e serenidade da concepção. Também a planta baixa remetia à concepção da "casa burguesa": separação dos ambientes, sem uma ligação mais direta entre eles, com excesso de circulações, e a presença da "formalidade" espacial.

Até mesmo na construção industrial, onde, como já visto, havia permissão oficial para a construção moderna, Kraemer oferece uma arquitetura que pode ser caracterizada como típica dentro da arquitetura tradicional daqueles anos, com a volumetria definida dentro dos termos semelhantes de suas primeiras casas. Como exemplo, tem-se a construção do alojamento para

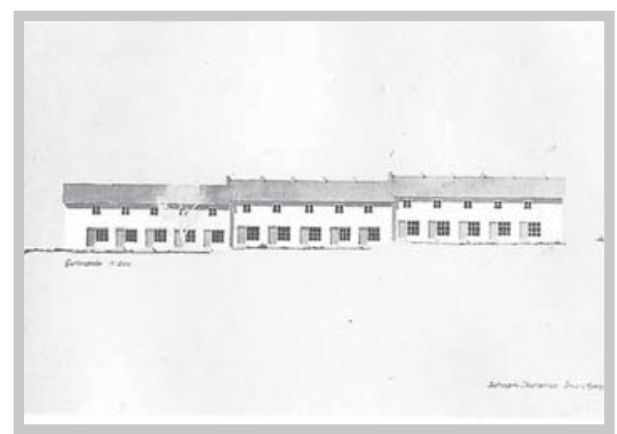

Fig. 4 - Justus Herrenberger. Casas em fita. Projeto estudantil. 1946-1947 a indústria Franke \& Heidecke (1937-1938) que apesar de lançar mão de elementos e propostas modernas, como o uso de pilotis no andar térreo e o pano de vidro como fechamento às escadarias, mostra uma volumetria extremamente convencional e dentro dos parâmetros da "boa" arquitetura, como entendida na época.

A arquitetura tradicional seguida por Kraemer nos anos 1930 e 1940, e verificada nos primeiros anos após a guerra, sobretudo no programa residencial, se reflete também na obra de seus alunos, ao menos quando ainda estavam sob sua proteção. No projeto para uma casa em fita de $45 \mathrm{~m}^{2}$ de Justus Herrenberger ${ }^{8}$ a linha tradicional - presença do telhado, formato e desenho das aberturas - evocando um Heimatstil simplificado e em escala reduzida, ainda é verificado. Também no trabalho 
de Walter Höltje para uma vidraçaria a estética moderna não é sentida - um trabalho que se confunde com o do mestre, como o exemplo da Conti Gästehaus - casa de hóspedes para a Firma Continental, um dos primeiros projetos de Kraemer do pós-guerra, com a colaboração de Broos, que se assemelha a outras casas projetadas pelo arquiteto nesta época.

Em seus trabalhos de estudante, Broos preconiza, ao contrário, uma arquitetura mais contemporânea, como revela seu projeto para o concurso para remodelação da Rua Steinweg em Braunschweig, em parceria com Justus Herrenberger. Na perspectiva aérea o projeto toma aspecto radical, composto prioritariamente por prismas, que lembra o projeto do Reichsbank de Mies van der Rohe. Entretanto, uma das elevações nos mostra algumas diferenciações em relação àquele, como a existência de cobertura de quatro abas e a diferenciação de escalas. Em uma rua comercial como esta, o projeto prevê, além dos edifícios de cinco pavimentos, outro de um pavimento para comércio, concebido ao longo da rua.

\section{ARQUITETURA DO PÓS-GUERRA}

A arquitetura tradicional, claramente compromissada com a estética professada pela política cultural do Estado Nazista, persistiu ainda por alguns anos na linguagem da arquitetura pós-guerra de Kraemer. Entretanto, a "coação"

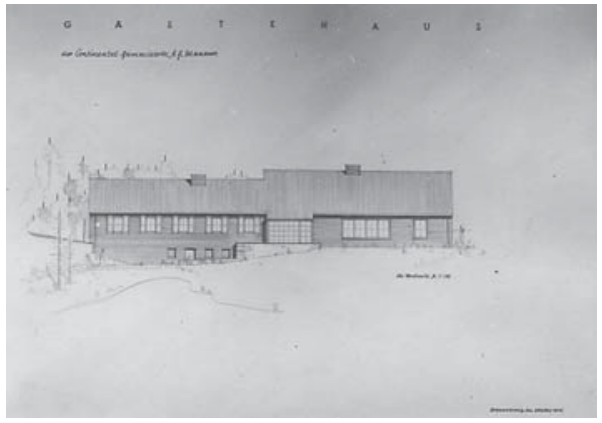

Fig. 5-Friedrich Wilhelm Kraemer. Conti Gästehaus. Hanover. 1945-1947.

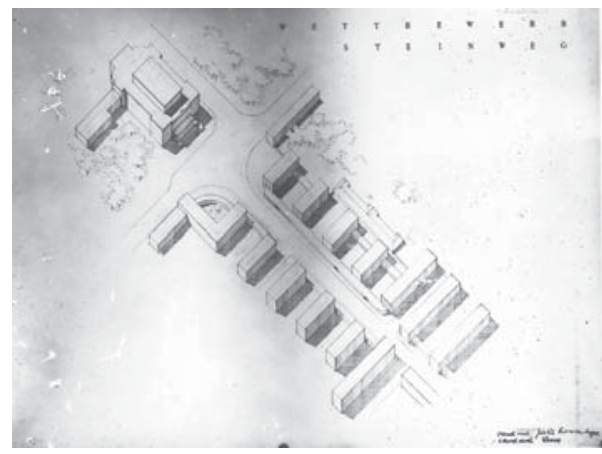

Fig. 6 - Justus Herrenberger, Hans Broos. Remodelação da Rua Steinweg. Projeto estudantil. Braunschweig. 1946.

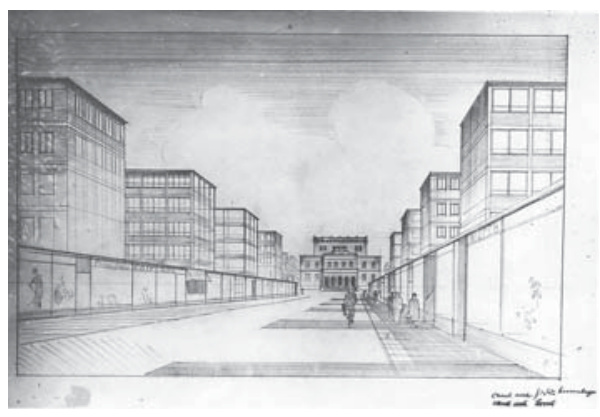

Fig. 7 - Justus Herrenberger, Hans Broos Remodelação da Rua Steinweg. Projeto estudantil. Braunschweig. 1946. ao moderno ou, sua adequação a esta linguagem, se fez sentir rapidamente, nítido e conscientemente voltada para uma linguagem internacional, de viés norteamericano e escandinavo. Destes países viria o impulso inicial de suas obras do imediato pós-guerra, capaz de transformar em pouco tempo, a linguagem convencional, com forte acento do Heimatstil em uma arquitetura de acordo com o que os novos tempos pediam (não mais o professado e idealizado "espírito da época"). Mesmo assim, sua nova e "moderna" arquitetura ainda parece ser realizada sobre velhas bases, mudada apenas a roupagem e colocados alguns elementos tipicamente modernos e de fácil aprendizagem. "Bauen, als wenn Du schwebst" (construa como se você flutuasse), mote professada por Kraemer em suas aulas, sintomático para os anos 1950, parece não ter sido seguido rigorosamente pelo próprio arquiteto, ao menos até meados dos anos $1950 .{ }^{9}$ 
Na Sede Social da Büssing (1953-1954), ainda podem ser sentidos o tom "atarracado" das obras dos anos 1930. Apesar do recurso, constantemente usado pelo arquiteto, de prover o terraço com delgadas coberturas com leve movimento ascendente em "V", o prédio continua com aspecto massivo em uma composição, no geral, convencional com sua regularidade e estabilidade quebrada apenas pelo uso de cobertura. Volumetria, aliás - edifício prismático regular com jogo de cobertura, uso de pilotis e beirais no térreo - que também Eiermann muito construiu, e que pertence à arquitetura cotidiana dos anos 1950 para lojas e centros comerciais, edifícios administrativos e sociais, símbolo do momento próspero que vivia o país.

Este "moderado" moderno, além de ser um indício do enredo que o cingia ao passado, também sinaliza a abertura de Kraemer às influências externas, notadamente a arquitetura escandinava, que preza por uma arquitetura de traços modernos sem

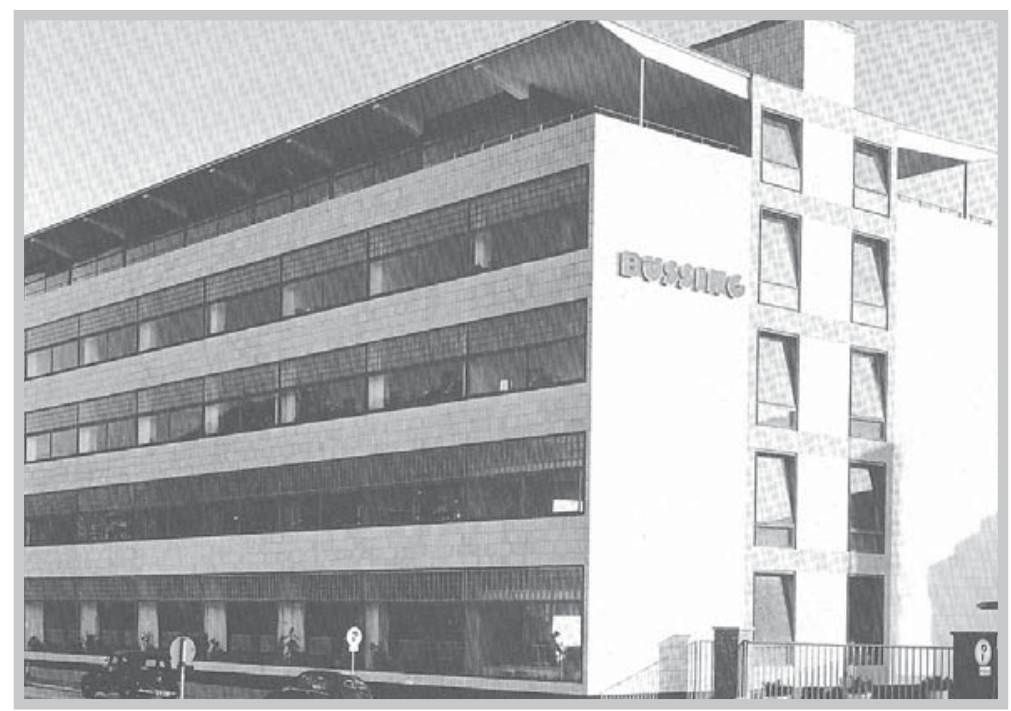

Fig. 8 - Friedrich Wilhelm Kraemer. Sede Social da Büssing. Braunschweig. 1953-1954.

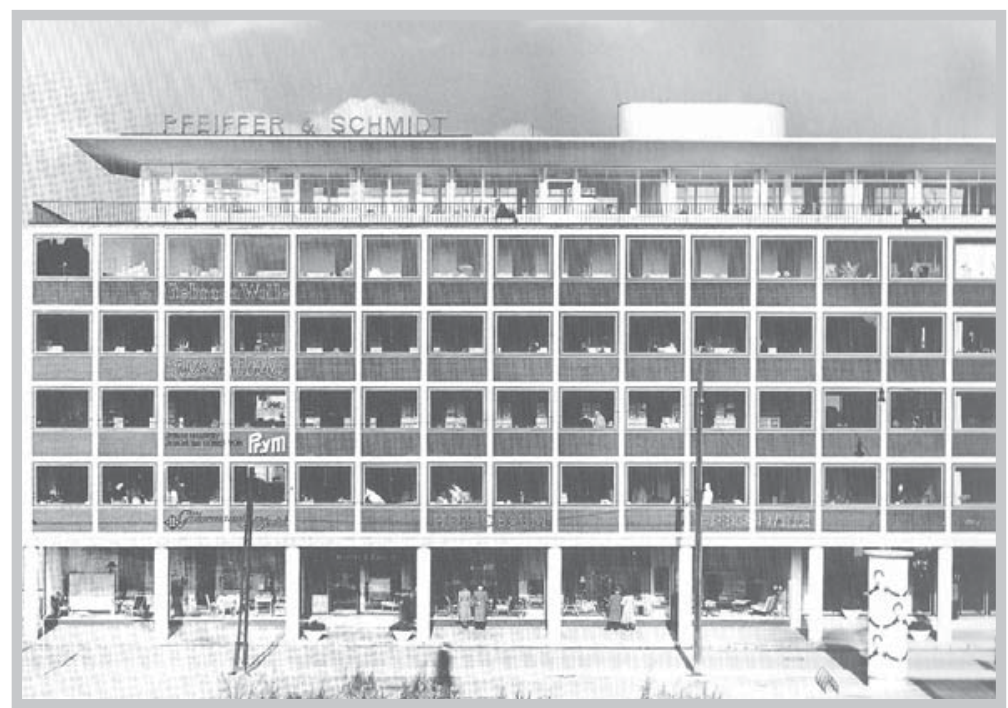

Fig. 9 - Friedrich Wilhelm Kraemer. Casa Comercial Pfeiffer \& Schmidt. Braunschweig. 1951-1954. o tom radical e universalizante da equivalente norte-americana. Volumes simples e bem definidos, uso de materiais variados e em sua maioria empregados ao natural (por vezes combinando aqueles mais finos com os mais rudimentares, ou então materiais simples como a madeiracomdetalheseacabamentos perfeitos que confere à obra um toque requintado) e a exploração de um apurado acabamento são algumas das características desta arquitetura.

O edifício da Rádio Emissora NWDR de Hannover (1948-1951), concebido em parceria com Gerd Lichtenhahn e Dieter Oesterlen, é uma mostra deste moderno simples e austero, porém não dogmático, onde predomina a regularidade compositiva e a integridade formal, com forte ascendência da arquitetura escandinava. Ou então a segunda Casa do Arquiteto (1955), 
onde predomina a simplicidade volumétrica, quase convencional, muito embora, a planta difira totalmente das casas dos anos 1930. Aqui Kraemer concebe ambientes interligados, com salas de estar e jantar e escritórios diretamente conectados (apenas o desenho da planta baixa confere diferenciação entre eles e certa privacidade aos ambientes) e também o acesso direto à casa, sem o recurso do ambiente "representativo" burguês como transição, além da ligação mais direta entre interior e exterior nos diversos ambientes.

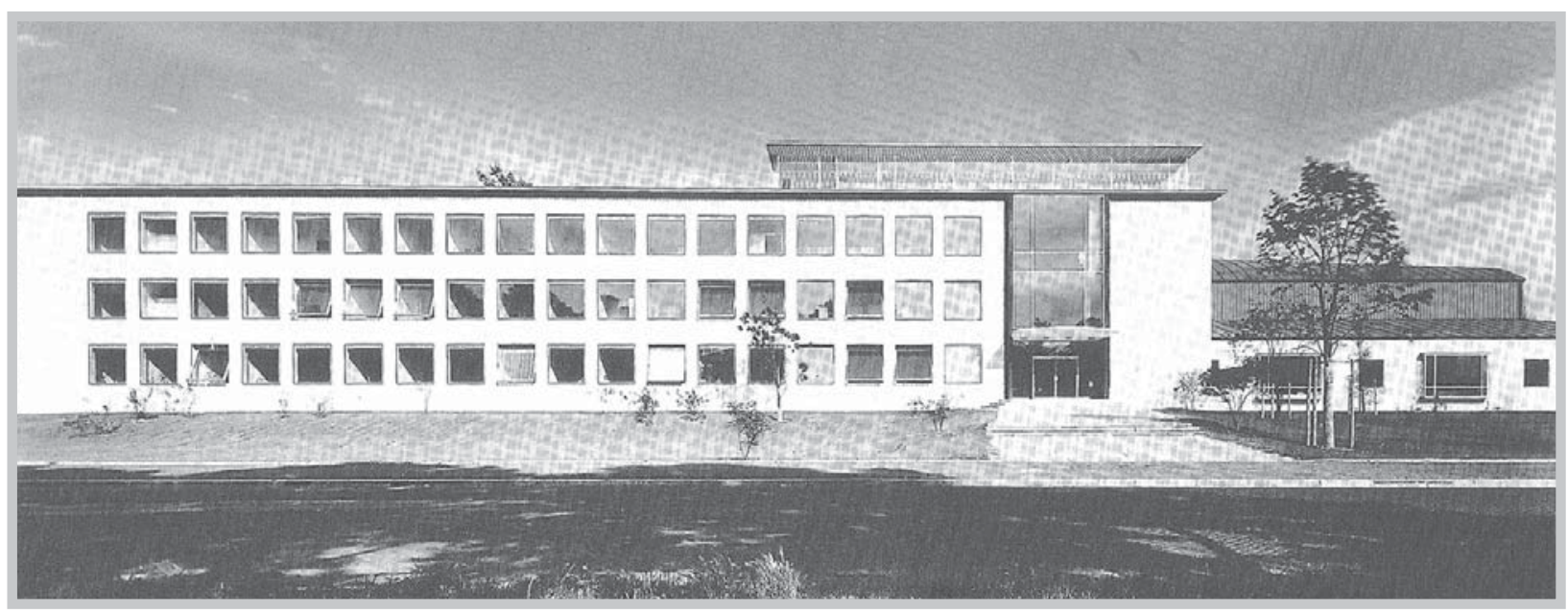

Fig. 10 - Friedrich Wilhelm Kraemer, Gerd Lichtenhahn, Dieter Oesterlen. Rádio Emissora NWDR. Hannover. 1948-1951.

Outro bom exemplo da linha projetual seguida nestes primeiros anos pós-guerra é o projeto da pequena Escola de Ensino Fundamental de Peine (1952-1954) que contou com a participação de Broos na elaboração do projeto, ${ }^{10}$ laureado com o primeiro lugar em concurso. Da planta baixa e da volumetria extremamente simples, surge um projeto claro e conciso baseado em uma linguagem moderna que é sentida em seu

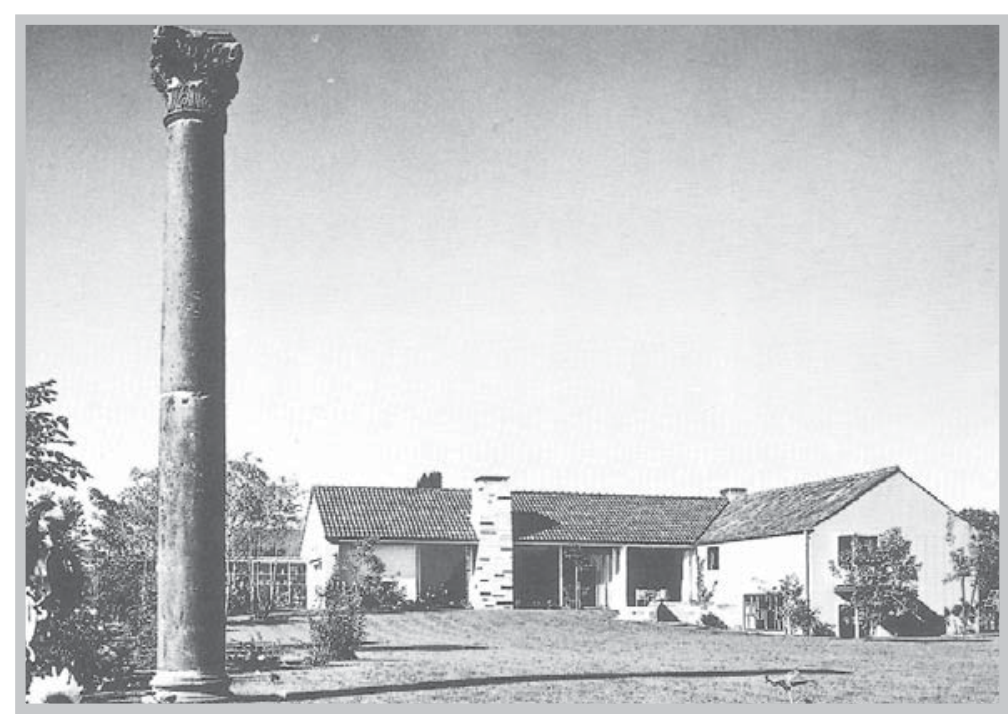

Fig. 11 - Friedrich Wilhelm Kraemer. Segunda Casa do Arquiteto. Braunschweig. 1955. pragmatismo. O programa, bastante restrito, distribui-se nos três volumes de que se compõe a escola: duas alas para as salas de aula e o edifício principal para administração e auditório, além de serviços de apoio, interligados por passarelas cobertas e envidraçadas. O volume principal é concebido na forma pavilhonar como um grande espaço de pé-direito duplo, também pensado como espaço de lazer, com cobertura levemente inclinada, erigido em alvenaria estrutural, com estrutura da cobertura em concreto armado pré-fabricado que suporta, 
por sua vez, os balcões internos também em concreto. O projeto mescla, de uma forma despretensiosa, tecnologias novas e tradicionais, combinando diversos materiais na sua construção e nos acabamentos: madeira no forro, concreto, vidro com perfis metálicos, tijolo vermelho escuro deixado aparente, uma variedade cromática e sensorial, cujo resultado, é a noção de aconchego, próprio da arquitetura escandinava. As superfícies envidraçadas fazem o contato com o exterior e contrastam com os blocos fechados, os volumes introspectivos e o caráter reservado do edifício.

Os anos imediatamente posteriores à guerra, especialmente entre 1946 e 1948, foram caracterizados para o escritório de Kraemer como anos de muitos concursos, entre eles de novas construções, como a Escola de Peine, mas também para projetos de reconstrução, de edifícios e setores urbanos devastados. ${ }^{11}$ Enquanto o tenso debate entre "reconstrução" versus "nova construção" polarizava opiniões, na prática muitos arquitetos decidiam seu próprio caminho caso a caso. Em sua primeira encomenda do pós-guerra, o arquiteto começa a consolidar uma postura bastante

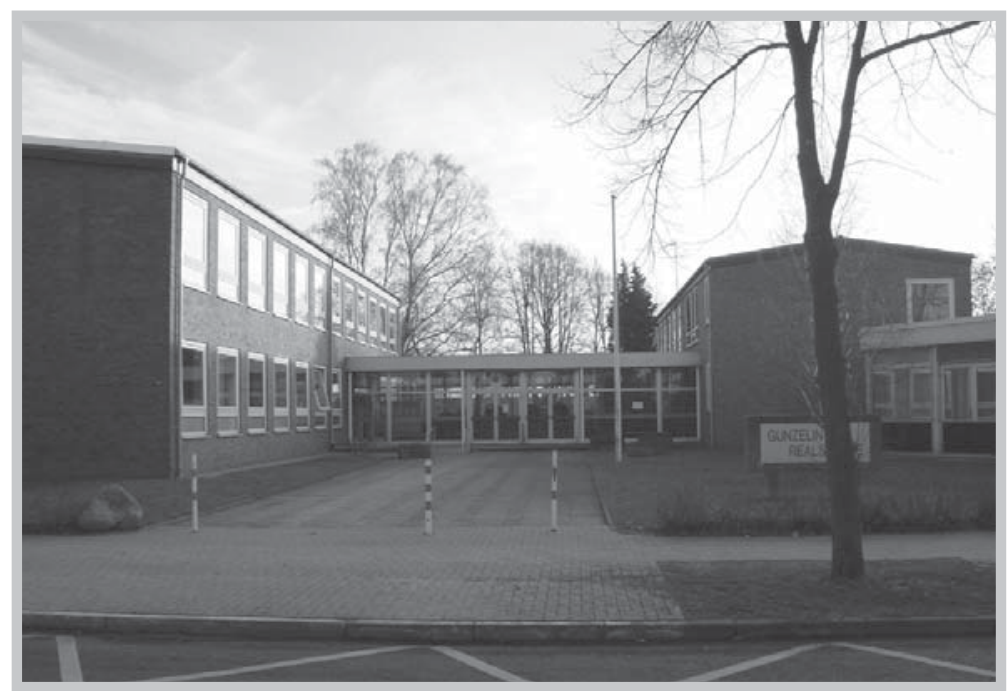

Fig. 12 - Friedrich Wilhelm Kraemer. Escola de Ensino Fundamental. Peine. 1952-1954.

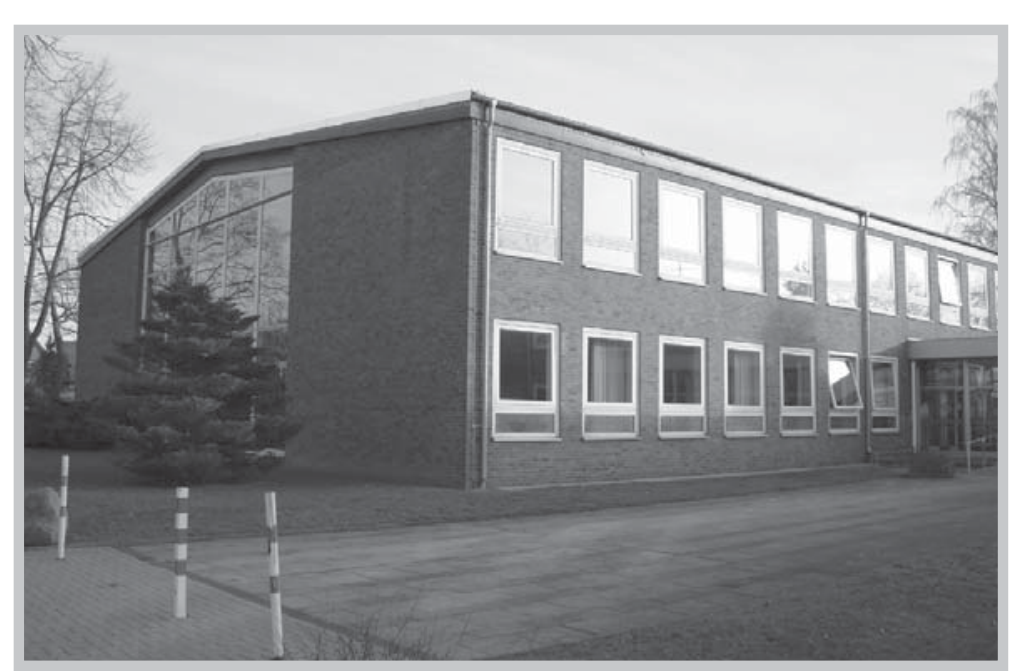

Fig. 13 - Friedrich Wilhelm Kraemer. Escola de Ensino Fundamental. Peine. 1952-1954. segura em relação ao patrimônio construído, já iniciada em sua curta experiência como Diretor de Planejamento da cidade, ${ }^{12}$ que contribuiria ao futuro renome da Escola de Braunschweig.

No Concurso "Alte WaageWollmarkt"13 - o primeiro de muitos conquistados por Kraemer ao longo da carreira - é colocado três tarefas essenciais, que requeriam soluções tanto ao nível arquitetônico, quanto ao nível urbano: reconstrução do antigo edifício da Escola Profissional do Comércio, parcialmente destruído na guerra; construção de um novo edifício em lugar do destruído "Alte Waage" e finalmente a remodelação do casario da praça adjacente "Alte Waage-Wollmarkt", com liberdade para agir sobre os limites dos terrenos. 


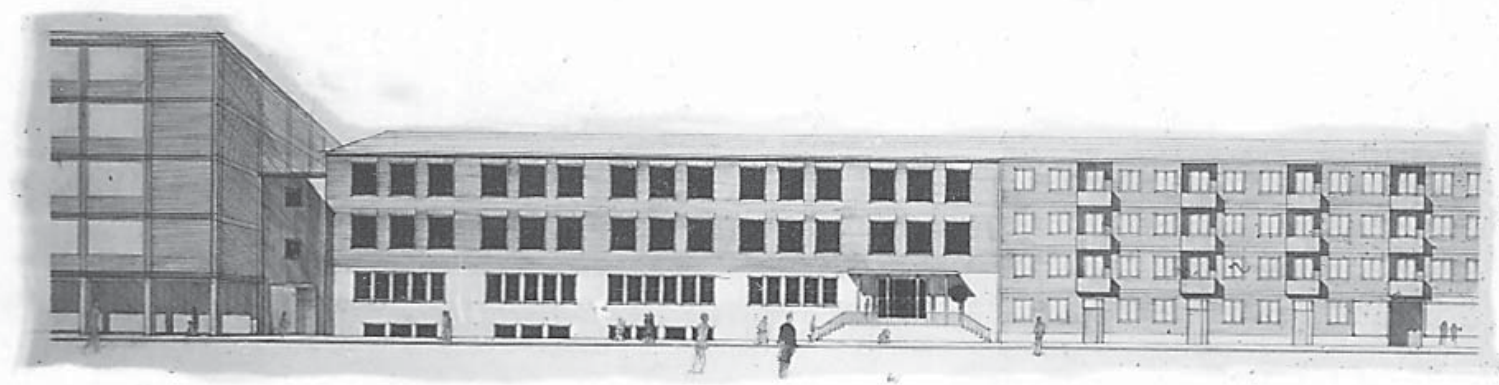

Fig. 14 - Friedrich Wilhelm Kraemer. Concurso "Alte Waage-Wollmarkt”. Braunschweig.1946.

Junto ao projeto encaminhado para o concurso, Kraemer formula uma explicação de maneira persuasiva e enfática sobre sua proposição para os novos edifícios junto à praça, concebidos segundo o "espírito da época". Segundo o arquiteto, o edifício original do ano de 1550 adequa-se às necessidades econômicas e sociais de seu tempo. A ele contrapõe um exemplo de 1650: "cada época teria construído o novo de acordo com seu espírito", e perfaz exemplos até 1850. “Uma reconstrução do passado iria de encontro ao desenvolvimento histórico e natural," e completa: "ainda que disponhamos dos materiais e do potencial artesanal daquele tempo."14 Diz, por fim, que "não deve surgir uma 'antiga Braunschweig', medieval, neoclássica ou, como sempre banalizada (pois é o produto de toda imitação), em falso Heimatstil."15 Sobre uma das pranchas lê-se o seguinte: "Nós reconhecemos a música de Hindemith, uma escultura de Kolbe ou uma tela de Nolde como testemunhas válidas de nosso tempo, as sentimos encantados como revelação do novo, o que todos nós procuramos. Somente na arte de construir tornouse comum, fazer assim como fossem ainda os dias de Beethoven, Thorwaldsen ou Caspar David Friedrich.” Desta forma o arquiteto justifica sua proposição com uma solução contemporânea, com edifícios de quatro pavimentos como "sugerido no exemplo (original) de 1550", mas em menor altura e partindo de um novo parcelamento do solo.

Apesar de sua postura teórica tipicamente moderna, o projeto revela não ser dos mais radicais; ao contrário, e talvez por isso mesmo tenha conquistado o primeiro lugar, pois apesar da linguagem moderna, com cobertura levemente inclinada, não desvirtua o espaço original, se adapta a ele e tenta restituir, através de uma nova linguagem, a antiga praça. A proposta tentou, assim, encontrar um meio termo; sem fazer uso de recursos históricos, manteve a velha estrutura urbana. Moderação que não foi suficiente para acalmar os ânimos da sociedade e da imprensa local, 


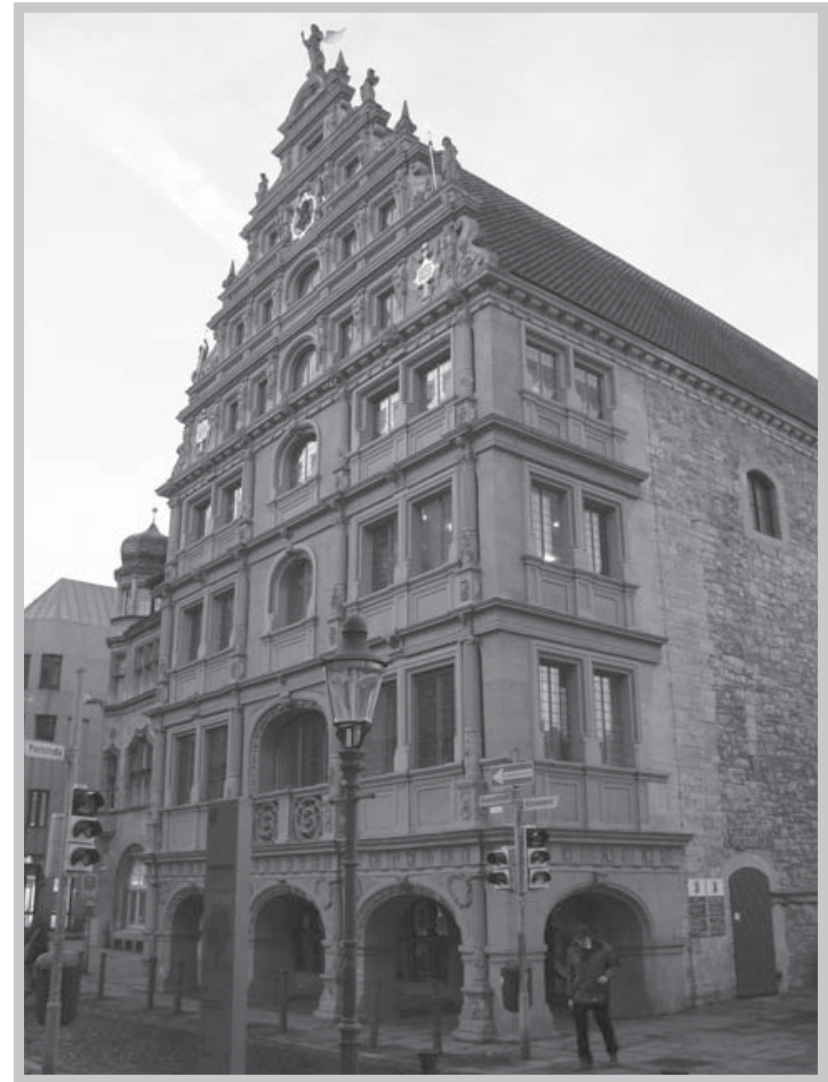

Fig. 15 - Friedrich Wilhelm Kraemer. Gewandhaus. Reconstrução. Braunschweig. 1946-1961.

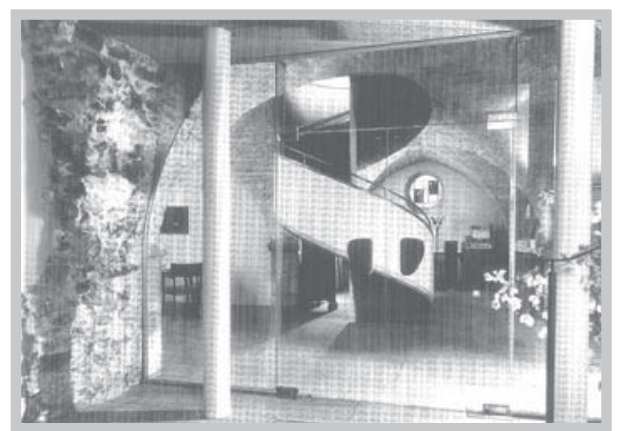

Fig. 16 - Friedrich Wilhelm Kraemer. Gewandhaus. Reconstrução. Braunschweig. 1946-1961. que viam nos dois primeiros colocados, projetos "modernos demais", certamente, por não respeitarem as antigas parcelas do terreno. ${ }^{16}$

Data da mesma época outro grande projeto de reconstrução, a Gewandhaus, ${ }^{17}$ prédio renascentista do século XIII também localizado no centro antigo da cidade, objeto de um meticuloso e extenso trabalho de Kraemer e sua equipe. Também aqui se nota a preocupação com o contexto urbano: para preservar o caráter do prédio - parcialmente destruído - e a unidade do contexto junto à praça do mercado, que conta com outros edifícios significativos, o arquiteto reconstrói externamente o edifício em sua forma original, utilizando-se do próprio material que cedera aos ataques aéreos. No seu interior, prima por uma remodelação contemporânea, em que é marcante o apuro dos detalhes e a harmoniosa convivência entre o antigo e o novo.

Parte do frontão de fins do século XVI conservou-se, enquanto que todas as casas enxaimel do século XV que o ladeavam na fachada voltada à praça não resistiram ao fogo. A análise criteriosa do material que restou da destruição e a meticulosa identificação da localização de cada elemento compositivo - facilitada pela identificação de um rigoroso esquema de proporção a que estava submetida a fachada (quadrados e triângulos) - possibilitou a reconstrução do frontão em seu aspecto original. Já a fachada voltada à praça ganhou nova concepção, na renúncia do arquiteto em reconstruir as antigas casas enxaimel. Ao contrário, foi deixada a fachada lisa voltada para a praça, e construída apenas nos fundos desta fachada uma casa enxaimel, pensada para fechar o "vazio" que ficara na praça, que antes possuía um caráter fechado, como as praças medievais. $\mathrm{O}$ interior do edifício foi totalmente reconstruído segundo novas necessidades, com a concepção de salas de reunião, para congressos e administração. Colunas metálicas, escadas helicoidais e o uso de concreto e vidro, com acabamentos primorosos, são contrapostas à estrutura massiva do antigo prédio, deixada à vista em seu caráter bruto. 
A partir destes dois projetos, que envolviam a possibilidade ou não da reconstrução (em seu caráter histórico) ou sua solução com propostas contemporâneas, fica clara a posição do arquiteto: para Kraemer, vale a pena reconstruir segundo o caráter original da obra quando esta possui significativo valor histórico - como era o caso da Gewandhaus; o que não possui valor, é eliminado - como nas casas enxaimel - ou substituído por formas contemporâneas, a exemplo do casario da praça "Alte Waage". Em todas as propostas, fica clara a atenção com a estrutura urbana existente que, sendo constituída por novas ou velhas formas, deve ser mantida, segundo o arquiteto, em seu caráter original.

Apesar da consolidada visão sobre o patrimônio construído, revelado em concursos e praticado em sala de aula com seus estudantes, Kraemer também se firmou um arquiteto contemporâneo, através de uma arquitetura cristalina de traços cada vez mais claros, consolidada principalmente em

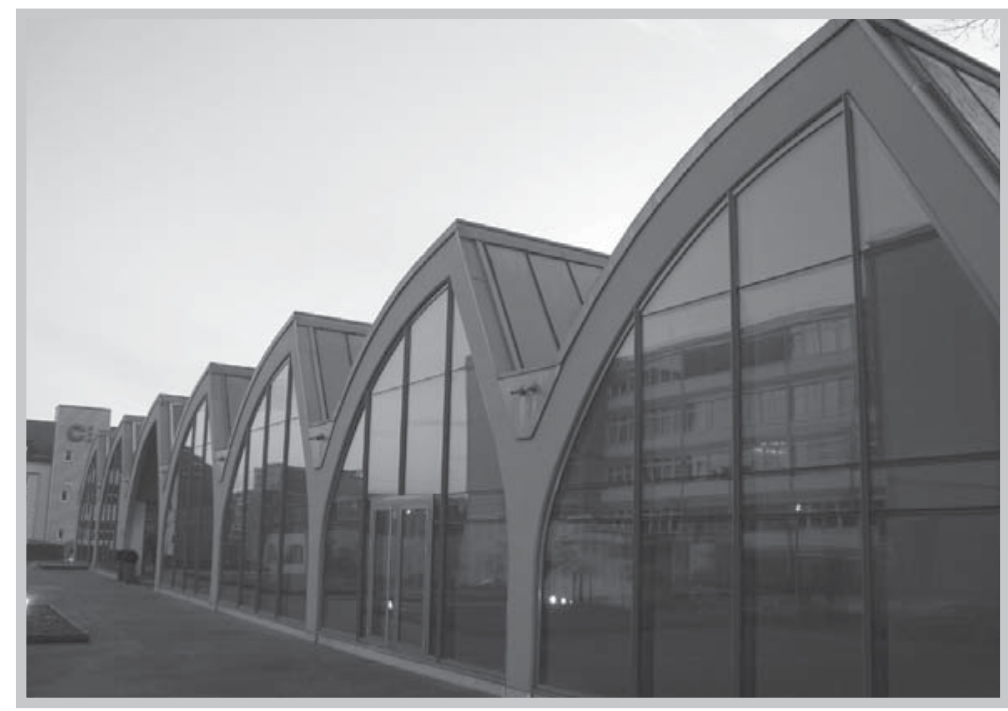

Fig. 17 - Friedrich Wilhelm Kraemer. Oficina VIII Franke \& Heidecke. Braunschweig 1955-1957. suas construções industriais. Gradualmente a arquitetura mais "quente" e simples dos primeiros anos, que persiste, entretanto, em alguns projetos residenciais, cede lugar a uma arquitetura que prima pela leveza, concisão e redução de materiais. São principalmente os edifícios industriais que demonstram esta guinada para uma arquitetura de face cada vez mais internacional, como sugerem os bons exemplos da Oficina de Conserto e Edifício Administrativo da VW Max Voegts (19511956) e das Oficinas VIII e IX da Firma Franke \& Heidecke (1955-1957). ${ }^{18}$ Neste exemplo, o edifício prismático e cristalino de cinco pavimentos em concreto armado convive com a oficina de um pavimento, que faz de seus sheds de estrutura metálica e perfil sinuoso o motivo de sua concepção estética.

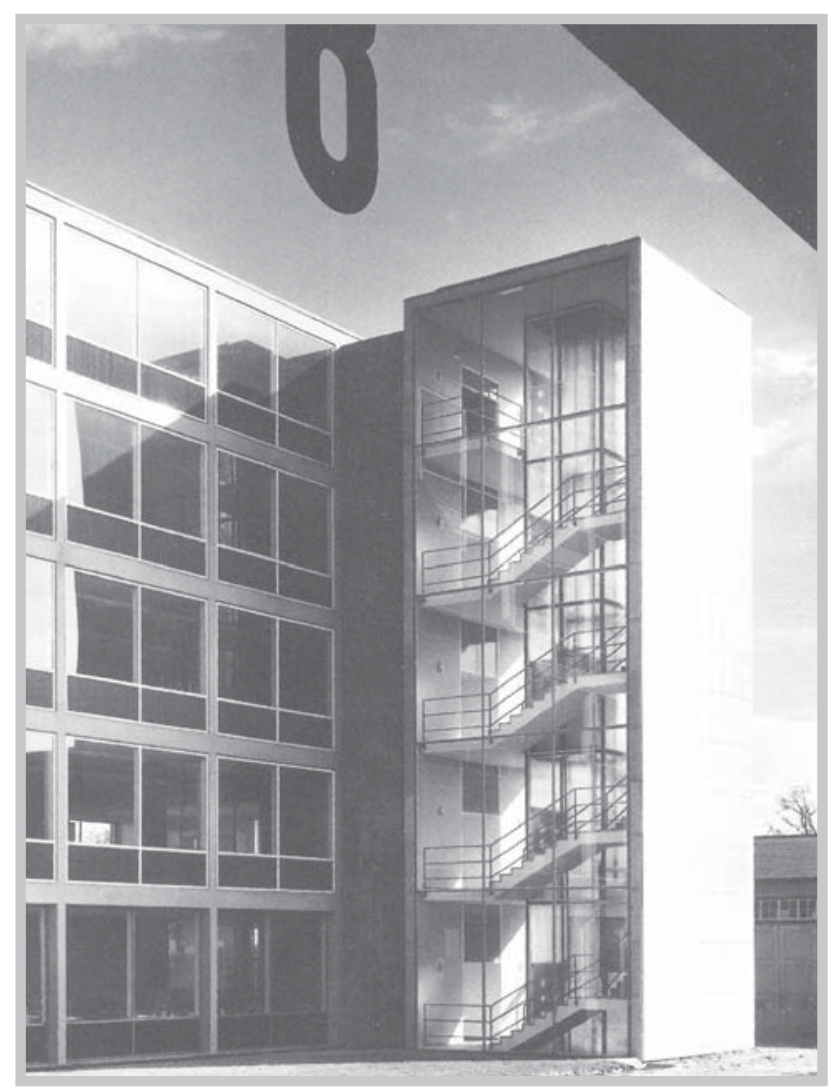

Fig. 18 - Friedrich Wilhelm Kraemer. Oficina IX Franke \& Heidecke. Braunschweig. 1955-1957. 


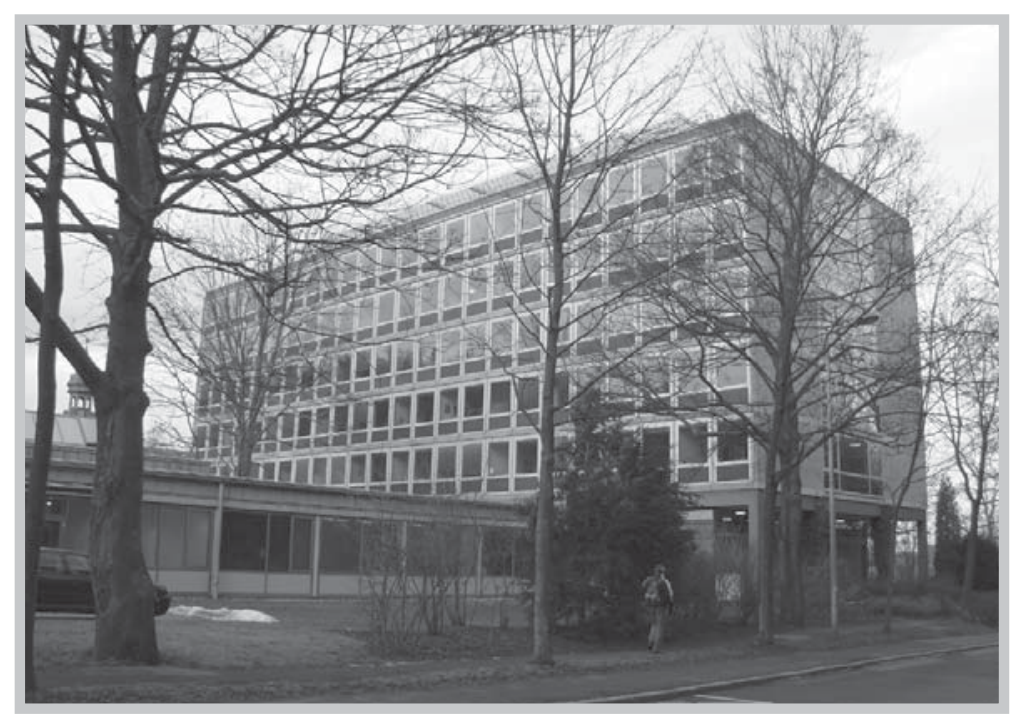

Fig. 19 - Friedrich Wilhelm Kraemer. Edifício Administrativo da Unterharzer Berg- und Hüttenwerke. Goslar. 1950-1958.

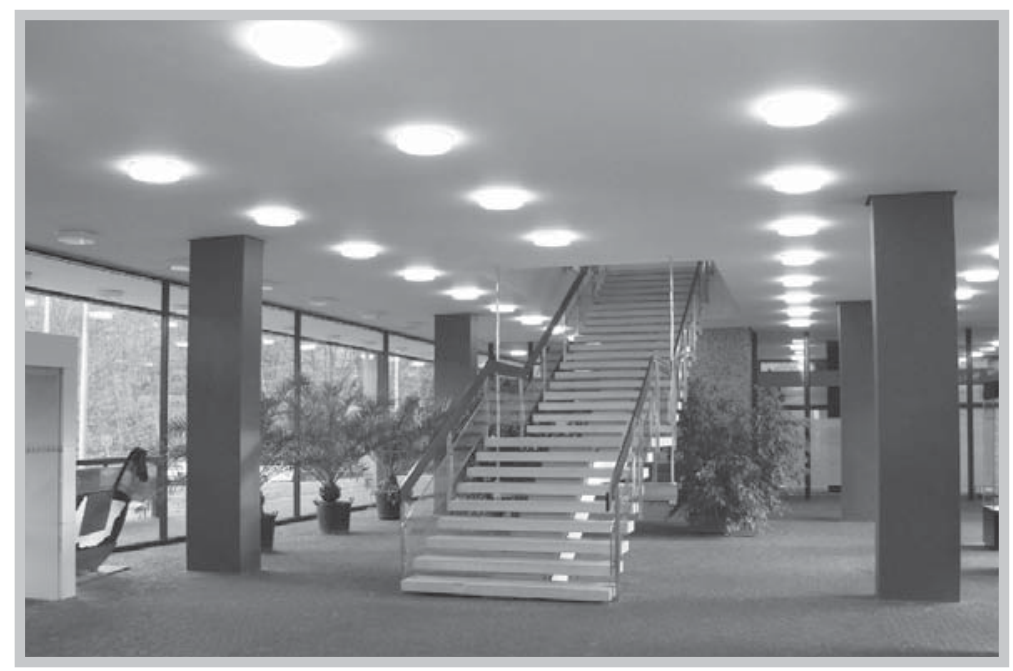

Fig. 20 - Friedrich Wilhelm Kraemer. Edifício Administrativo da Unterharzer Berg- und Hüttenwerke. Goslar. 1950-1958.

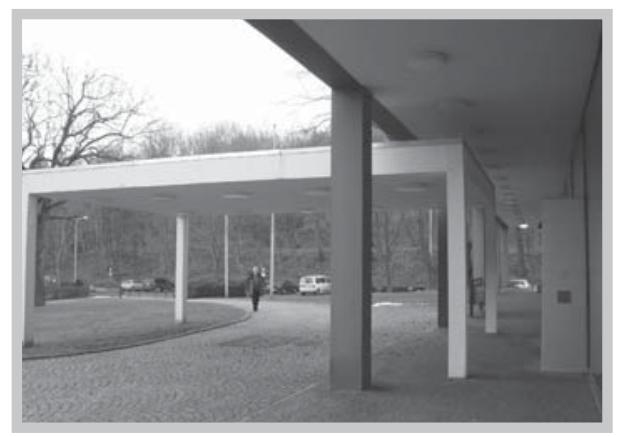

Fig. 21 - Friedrich Wilhelm Kraemer. Edifício Administrativo da Unterharzer Berg- und Hüttenwerke. Goslar. 1950-1958.
Tambémosmuitosedifíciosadministrativos e comerciais dos anos 1950 revelam aproximação a esta estética voltada aos exemplos internacionais, notadamente o norte-americano. Uma das melhores mostras é o Edifício Administrativo da Unterharzer Berg- und Hüttenwerke (1950-1958) fruto de concurso restrito que deixou para trás entre outros, Paul Bonatz, e contou com a participação de Hans Broos na elaboração do projeto. Localizado na periferia da bela Goslar, uma cidade medieval intocada pela guerra, este edifício guarda semelhanças com outros já construídos pelo arquiteto, mas de elegância sem igual.

Considerado um dos mais belos edifícios administrativos dos muitos já construídos por Kraemer, ${ }^{19}$ e louvado pela renúncia do arquiteto em fazer "falsas considerações" à cidade antiga, ${ }^{20}$ o prédio é concebido como um prisma em concreto armado de cinco pavimentos sobre pilotis, e revela na pureza de sua concepção, nos detalhes e no contraste de materiais uma estética apurada. Sob o prisma encontra-se a cobertura de acesso que não toca o prédio; justaposto a este está o bloco de escritórios e auditório de um pavimento em forma de átrio, cuja cobertura está abaixo da linha do primeiro pavimento e adentra o edifício, também sem o tocar. Ou seja, são volumes tratados como independentes, num ideal de leveza, elegância e transparência que marcou a época de sua construção. Aqui o arquiteto utiliza recursos e elementos presentes em vários de seus projetos - a atenção que confere às escadas, concebidas quase sempre como elementos soltos e vazados com certa imponência, onde são marcantes os requintados 
materiais de acabamento, como o aço inox; ou então o contraste deste material com a parede ao fundo, placas de concreto revestidas com pedregulhos, que também reveste parcialmente as fachadas laterais do prédio, em contraste com o vidro que domina nas outras duas; e por fim, o terraço coberto que confere o fechamento superior do prédio. No interior do pavimento térreo, sua limpeza construtiva, baseada na redução formal e da paleta de materiais, bem como o refinamento de seus detalhes e materiais requintados sugere a aproximação com a arquitetura miesiana, ${ }^{21}$ que a este tempo, se refletia fartamente nas obras do arquiteto, notável também nos projetos das casas Sandforth (1956-1957) e na Roedenbeck (1963-1965). Nestas, a estética límpida e elementar sugerem uma leveza incomum em

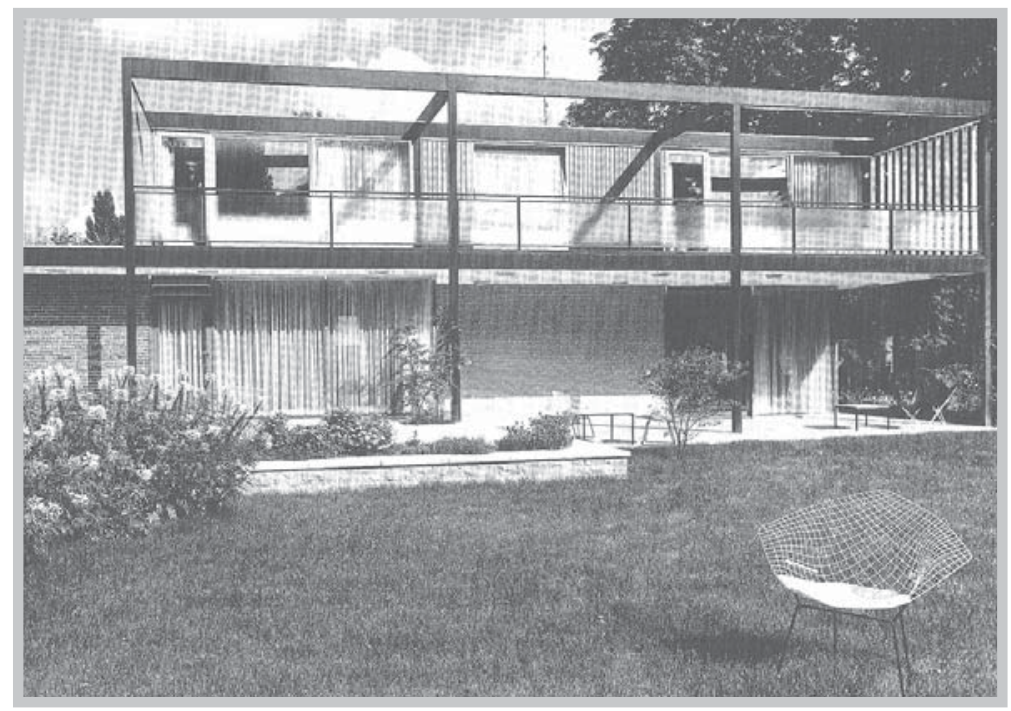

Fig. 22 - Friedrich Wilhelm Kraemer. Residência Sandforth. Braunschweig. 1956-1957. seu trabalho. Na primeira também a planta baixa revela uma concepção por planos paralelos e transversais que quase não se interceptam para conformar os diferentes ambientes da casa.

Afora sua estética apurada e a elegância das soluções, o edifício em Goslar mostrou-se uma boa solução ao nível urbano ao dividir-se o programa em dois volumes. Sem se tornar um edifício maciçamente construído, sua leveza e redução na escala adequa-se ao terreno levemente montanhoso de seu entorno e ao casario predominante na paisagem da cidade. Mas também outro fator chama a atenção nesta obra: o imenso desejo pela ordem e disciplina formal, revelado por meticuloso estudo e total amarração da obra através de proporções numéricas. Três quadrados (proporção 1:1) somados perfazem a fachada principal; a fachada lateral é 1:1. Todo edifício, até o desenho das aberturas, segue um rigoroso sistema. Interessante notar que o mesmo artigo que enaltece as "falsas referências" à cidade medieval e a proposição de uma obra moderna como

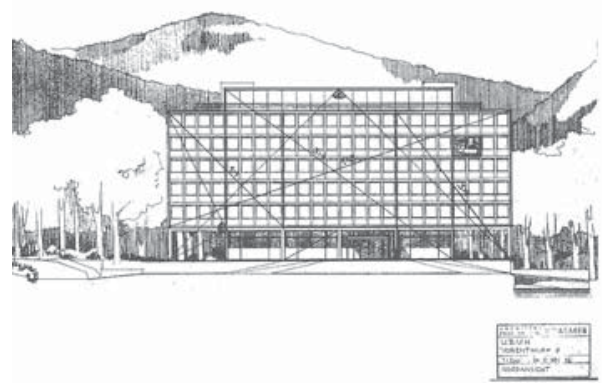

Fig. 23 - Friedrich Wilhelm Kraemer. Edifício Administrativo da Unterharzer Berg- und Hüttenwerke. Estudos de proporção.
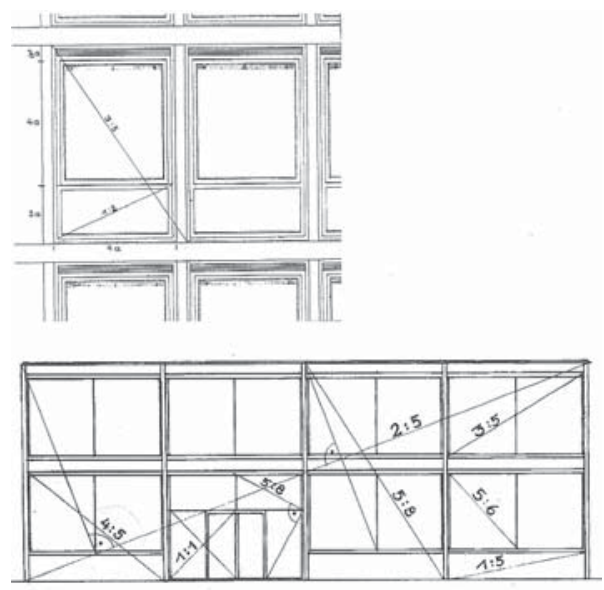

Fig. 24 - Friedrich Wilhelm Kraemer. Edifício Administrativo da Unterharzer Berg- und Hüttenwerke (acima) e Oficina Voegts (abaixo). Estudos de proporção. 


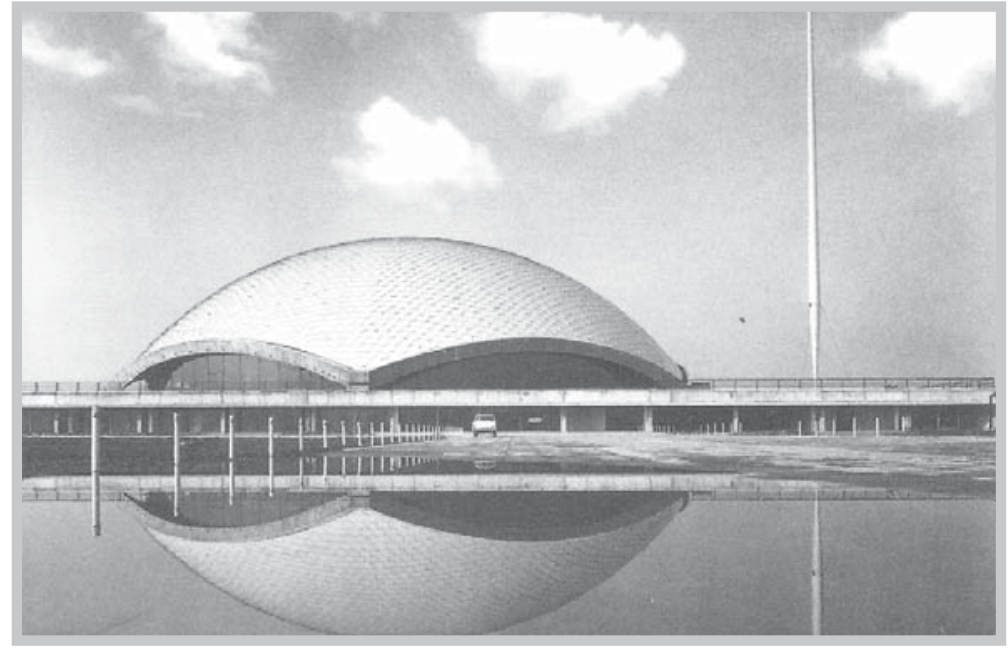

Fig. 25 - Friedrich Wilhelm Kraemer. Jahrhunderthalle. Frankfurt. 1960-1962. única solução sensata, sublima o comparecimento destas proporções, mostrando os desenhos do arquiteto, e sua incondicional procura pelas "leis eternas" de composição.

Tal pensamento, herdeiro da ideia clássica de beleza, encontra seu exemplo mais impressionante no projeto do Pavilhão "Jahrhunderthalle" (1960-1962)

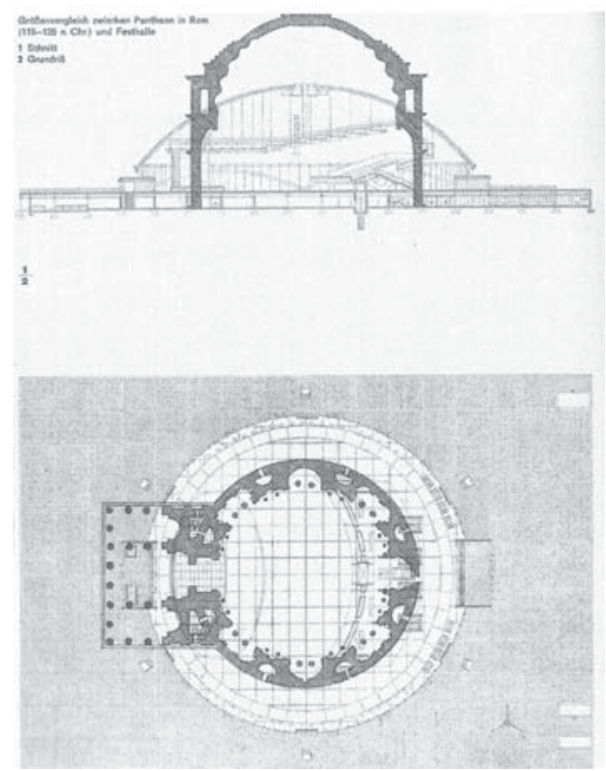

Fig. 26 - Friedrich Wilhelm Kraemer. Desenho do Jahrhunderthalle sobreposto ao do Panteão. em Frankfurt. Através de uma planta-baixa e um corte do projeto, o arquiteto revela sua intenção de fazer do Panteão romano seu exemplo ideal de geometria e proporção. Sobre a base do Panteão, o arquiteto sobrepõe o projeto do novo pavilhão, uma casca estrutural de concreto armado, e mostra o quão ligados ainda estão a nova arquitetura, técnica e funcional, e a velha tradição. Da tradição clássica, entretanto, não se servia Kraemer de uma forma mimética ou por citações literais; ao contrário, ela lhe servia de suporte para uma outra arquitetura, baseada nesta ordenação maior que lhe permitia extrair "do transitório, algo eterno." 22

\section{ESCOLA DE BRAUNSCHWEIG}

Da mesma forma que Egon Eiermann em Karlsruhe, Kraemer foi a principal figura dentro da Escola Técnica de Braunschweig. Primeira escola a abrir as portas da zona britânica, incrivelmente ainda em fins de 1945, a "Braunschweiger Schule", como viria a se chamar, foi igualmente um dos principais centros de formação de arquitetos na Alemanha pós-guerra. Sua principal característica, se não exprime uma unidade estética em suas proposições, apesar da clara filiação de seus professores ao moderno, foi a intensiva pesquisa em tentar adequar uma linguagem moderna às heranças do passado. Tanto no plano urbano quanto no arquitetônico, o confronto entre o novo e o antigo, e a procura por um sensato caminho entre novas construções e reconstrução foi, sem dúvida, uma das características mais fortes e particulares desta escola. Estudo que não 
ficava apenas no plano teórico; no imediato pós-guerra, a escola propiciava uma união bastante próxima entre teoria e prática - alunos trabalhavam no escritório particular dos professores, participavam de concursos e tomavam parte, na prática, dos projetos de reconstrução da devastada Braunschweig, ${ }^{23}$ como melhor demonstra o projeto de reconstrução da Gewandhaus, iniciado em 1946 com a participação de alunos e a sua frente, o arquiteto Kraemer.

Através da escola de Braunschweig podemos ver a importância da arquitetura escandinava sobre a local. Ao lado das aulas que se ocupavam da arquitetura moderna internacional, com especial atenção aos exemplos norte-americanos de Mies, SOM e Walter Gropius, a arquitetura escandinava, com Alvar Aalto, Gunnar Asplund e Arne Jacoben desempenhava um importante papel. Para os vizinhos do norte seguiram inúmeras excursões, a primeira delas em 1951 com quase sessenta estudantes, com destino à Dinamarca e Suécia. Neste país, parece ter causado enorme sensação o projeto de ampliação da Prefeitura de Göteborg (1913, 1934-1937) de Gunnar Asplund, como relata um dos integrantes da viagem. ${ }^{24}$ Neste projeto, o antigo prédio de 1913 em estilo neoclássico ganha como prolongamento o novo prédio de Asplund que segue os padrões do antigo em escala, ritmo das aberturas, fechamento da cobertura e, principalmente, o arquiteto continua com a característica do cheio sobre o vazio. Uma linguagem bastante moderada, com concessões à monumentalidade, como é típico da obra do arquiteto sueco, e típico também em muitas obras escandinavas, que operavam uma linguagem moderna dentro da tradição local.

Esta concepção vem ao encontro do que era proposto por parte dos professores da "Braunschweiger Schule", que procurava um caminho alternativo entre a reconstrução (no sentido histórico) e a linguagem moderna: "a forma de acordo com o sentido" 25 como colocaria Dieter Oesterlen, que em 1953, assim como Walter Henn, foi nomeado professor daquela universidade, e ao lado de Kraemer formariam o núcleo central da "Braunschweiger Schule".

Com Kraemer, as aulas de história da arquitetura eram retratadas como "Schule des Sehens" (escola do olhar) cujas regras formais deveriam ser apreendidas pelos estudantes e utilizadas nos novos edifícios. ${ }^{26}$ No centro de sua concepção está seu convencimento de que "haveria leis da forma (gestaltung) de validade atemporal, de que o arquiteto deveria conscientemente se servir, para através da arquitetura, conseguir criar 'beleza"” ${ }^{27} \mathrm{Da}$ observação, deveria se passar aos exercícios práticos: exercícios de

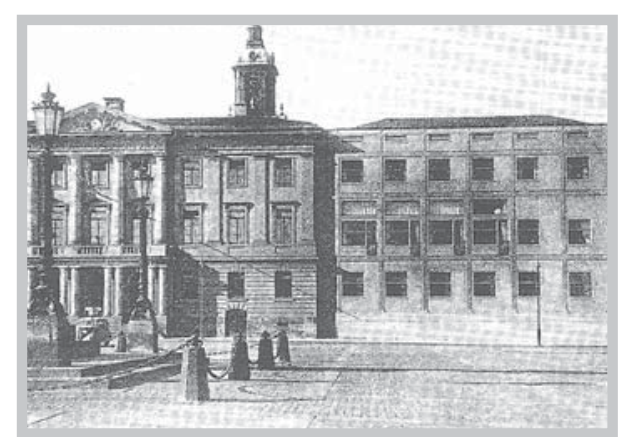

Fig. 27 - Erick Gunnar Asplund (ampliação). Prefeitura de Göteborg. 1913, 1934-1937. 
projetos já eram solicitados nas primeiras fases, complementados com estudo das possibilidades técnicas. ${ }^{28}$

Kraemer defende que muitos aspectos que determinam a arquitetura deviam ser aprendidos e ensinados, como funcionalidade, construção e planejamento orçamentário da obra. Entretanto vê um setor que não se deixa compreender apenas pelo pensamento investigativo e reflexivo: a forma arquitetônica. ${ }^{29} \mathrm{~A}$ beleza seria conseguida através de leis imutáveis de proporção, ordem e clareza. Para ele, a forma é conseguida através da aplicação destas leis, e a beleza seria o resultado destes elementos subjetivos que não podem ser racionalmente explicados.

A lição de Karlsruhe se coloca nas antípodas deste pensamento: "Construir em nosso tempo significa, com auxílio de análise tecno-científica, estabelecer uma ordem e, com estes novos princípios ordenadores, constituir uma nova Forma. [...] Nós reconheceremos que nesta ordenação, a lógica, a limpeza, a clareza, com outras palavras, o conceito ético da Verdade, tem papel fundamental. Verdade é um componente da Beleza, pressuposto do fazer artístico. Assim, por esta razão, a nova arquitetura, assente sobre uma ordem econômica, será elevada à Arte." ${ }^{30}$ Para Eiermann, a forma e a beleza dali resultante deveriam ser, ao contrário, explicadas e compreendidas racionalmente; a forma resultante não poderia ser mais que o resultado de leis racionais aplicadas ao projeto.

Certamente sua noção de beleza estava ligada à noção de proporção e harmonia como suas obras revelam. Antes de uma estética inovadora, a maior parte das obras de Eiermann chamam a atenção pelo senso de equilíbrio e proporção das partes, mas também é certo que para Eiermann a forma surgia da própria funcionalidade, da estrutura e da construção, e a verdadeira beleza surgia da perfeita harmonia entre estes três componentes. Para a fábrica de Blumberg, Eiermann dizia: "não me parece necessário, que se ache a Tecelagem de Blumberg bonita; me alegraria caso a considerasse correta. Pois que muitas coisas, que conduzem à forma, surgem de reflexões de natureza técnica. Mas segura é a tentativa, em todas as coisas, de ser correto, isto é, coerente, o ponto de partida de uma concordância, que podemos então e, em último caso, qualificar como harmonia, como um conceito de Beleza". ${ }^{31}$

Para Kraemer, "um classicista dentro do moderno", 32 a simples colocação da estrutura em verticais e horizontais em relação seria gratuidade; uma ordem maior deve uni-las numa relação harmoniosa, que ultrapasse a simples posição fortuita dos elementos: "Partes ditadas pelo uso (aberturas nas paredes) ou pela estatística estrutural (suportes verticais e horizontais com suas superfícies de 
preenchimento) não devem ser simplesmente aceitas, senão trabalhadas em sua composição e lapidadas em suas relações, até que se tornem mais que arbitrárias relações de superfície, mais que uma rede arbitrária de verticais e horizontais, a saber, proporções, isto é, não mais casualmente, mas relações conscientemente ordenadas. $^{33}$

Broos, portanto, durante seus anos de estudo e experiência profissional, em Braunschweig e em Karlsruhe, bebeu de fontes totalmente distintas, ainda que estas fontes, grosso modo, tenham conduzido a resultados arquitetônicos muitas vezes bastante semelhantes. ${ }^{34}$

Educado entre um tradicionalismo formal ligado aos anos 1930 (seja no ensino tradicional recebido em Praga ${ }^{35}$ com Dietz Brandi como diretor, ${ }^{36}$ ou ainda com Kraemer em Braunschweig) e o impulso à arquitetura moderna no pósguerra (tanto com Kraemer quanto, principalmente, com Egon Eiermann e os anos imediatamente posteriores), Broos consolidou uma formação teórica e prática complexa e variada, que mescla diversos elementos e posturas até mesmo contrárias. Além destes fatores, junta-se a ideia de proporção e harmonia advinda da arquitetura clássica de seu mestre Kraemer e, não por último, o forte apelo à tradição e a procura de um caminho sensato entre a nova arquitetura e as construções históricas em Braunschweig.

Diferentemente do que geralmente se considera, a geração de Broos - formada no imediato pós-guerra - formou-se muito ainda sob os auspícios da tradição nos moldes do Estado Nazista, posto que nos anos imediatos o que se via era uma continuidade de soluções tradicionais com leves tons reformulados, algo visível na linguagem dos professores, que os exercícios projetuais de seus pupilos espelhavam. Ao contrário do que se supõe, a modernidade para ele e sua geração não foi algo natural ou de natureza contínua, mas aprendida e conquistada, antes de tudo, almejada.

Apesar da comprovada e insistente sobrevivência da arquitetura tradicional nos anos pós-guerra ${ }^{37}$ (obliterada pela crítica e de proporções maiores que se achava ou se desejava), a tradição (no sentido formal), para a maioria destes jovens arquitetos, não era visto como uma atitude sensata, que antes, esperavam pela irrupção de uma nova e democrática sociedade. Por este motivo, a terceira geração vai procurar espelhar sua obra, de modo geral, na primeira geração os "pais" do moderno - e não na segunda, que, ao seu ver, estava comprometida com os ideais nacional-socialistas. ${ }^{38}$ E quando da "redescoberta" da Bauhaus e da arquitetura moderna por estes jovens, seria o decantar de um novo e promissor destino; e qualquer dito em contrário, ou crítica à Bauhaus - como o 
fez Rudolf Schwarz em polêmico artigo na imprensa local ${ }^{39}$ - era encarado como uma traição, uma dissensão à causa moderna. Daí que, embora um moderno menos radical e com entendimentos muito mais profundos da complexidade humana - motivado, entre outras coisas, pela reconstrução do pós-guerra e até mesmo pelas tradições repassadas nos anos 1930-1940 - arquitetos como Broos entenderam a arquitetura através dos valores da modernidade dos anos 1920: “[...] não se trata de se prender a este ou àquele estilo. Arquitetura para mim é desafio, invenção, futuro." ${ }^{30} \mathrm{Ou}$ seja, idéia de progresso, novidade, pesquisas formais e tecnológicas que acompanham o espírito dos tempos; um constante renovar-se e reinventar-se.

Estas experiências estarão presentes, naturalmente, na obra de Broos, de modo amplo e dosado, como veremos mais adiante. Mas, surpreendentemente, muito deste "resgate" das referências iniciais de sua formação se dará (ou não serão tão claramente visíveis) nem tanto em sua obra imediatamente posterior, nem nas obras dos primeiros anos brasileiros; e sim, a partir de fins dos anos 1960, quando sua obra se aproxima do Brutalismo Paulista, talvez, justamente quando sua experiência, o volume de projetos e as oportunidades que lhe chegam, lhe permitem expor, de forma madura e reflexiva, este copioso universo. 


\section{Notas}

1 Dirigido pela professora Karin Wilhelm, do curso de Arquitetura da Universidade de Braunschweig.

2 É de autoria deste grupo o único livro editado sobre a obra de Kraemer: Wilhelm, Karin; Gisbert, Olav (et. al.). Gesetz und Freiheit. Der Architekt Friedrich Wilhelm Kraemer (19071990). Berlin: Jovis, 2007, que também deu origem a uma edição da Revista Der Architekt dedicada à obra do arquiteto: Kraemerlust. Schlüsselreize der Nachkriegsmoderne. Der Architekt. n. 4, 2007. A despeito deste reconhecido esforço de pesquisa e divulgação, a não inventariação do material referente à obra do arquiteto, presente em parte nesta universidade, sob a responsabilidade deste mesmo grupo de pesquisa, impossibilitou uma análise mais pormenorizada de plantas e outras questões relativas ao trabalho de Broos com Kraemer para a presente tese.

3 Entre 1960 e 1974 seu escritório passou a se chamar "Prof. Kraemer, Pfennig, Sieberts" (KPS) e chegou a totalizar 170 colaboradores entre Braunschweig e Colônia.

4 Como maior e uma das mais importantes organizações dentro do governo nazista, o DAF - Deutsche Arbeitsfront possuía sob seu manto vários departamentos, entre eles o Schönheit der Arbeit, instituída em janeiro 1934, e dirigida por Speer até este se tornar ministro do armamento. Este departamento era responsável pela construção dos equipamentos industriais dentro do Terceiro Reich. Kreisreferent seria uma espécie de consultor regional.

5 As duas atividades estavam diretamente ligadas. Como Kreisreferent, o arquiteto ficava responsável pela construção de alojamentos e centros sociais para indústrias, bem como dos próprios edifícios industriais, além de atuar como consultor sobre questões como higiene, luz natural e artificial e ventilação nestes edifícios. Já como arquiteto de confiança do DAF (espécie de colaborador externo ao DAF) as atividades se dirigiam aos diversos setores desta organização, desde construção de habitações, indústrias, alojamentos, locais de lazer, entre outros.

6 Wilhelm, Karin. Gesetz und Freiheit. In: Wilhelm, Karin; Gisbert, Olav (et. al.). Gesetz und Freiheit. Der Architekt Friedrich Wilhelm Kraemer (1907-1990). op. cit., p. 16.

7 Entretanto isso não impediu que Kraemer fosse designado aos campos de batalha. Em 1939 passou três meses como desenhista junto a um batalhão. Em 1943 retornaria ao front, agora como soldado, onde seria gravemente ferido. Em virtude deste ferimento Kraemer não voltaria a ter as habilidades para desenhar.

8 Colega e amigo de Hans Broos, já mencionado em outras oportunidades.

9 Talvez seja justamente esta a arquitetura de "transição" do imediato pós-guerra, que mescla ainda elementos tradicionais com forte desejo de uma renovação formal voltada ao moderno (além dos inúmeros projetos de reconstrução, como será aqui apresentado), que motivou Broos a sair do escritório de Kraemer em 1949, pois comparado a ele, as obras que Eiermann constrói no mesmo período são incomparavelmente mais modernas.

10 Porém não em sua construção.

11 Entre os mais importantes, o "Alte Waage-Wollmarkt", relativo a reconstrução de um setor urbano; Escola Secundária de Peine (1952-1954) e Edifício Administrativo em Goslar (1950-58), com a participação de Broos; além da Exposição Constructa (1950-1951) planejamento e projeto de algumas edificações - em conjunto com Konstanty Gutschow.

12 Onde propõe a noção de "Ilha Histórica" para o centro histórico da cidade.

13 Broos utilizou o tema da reconstrução deste setor urbano como tema de seu trabalho final da graduação, feito em conjunto com Justus Herrenberger. Mas ao que tudo indica Broos não participou deste concurso. Justus Herrenberger em entrevista à autora.

14 Wettbewerb “Alte Waage” in Braunschweig. Baumeister Heft 5-7, 1948, p. 214.

15 Idem, ibidem. 
16 Ainda que em um projeto alternativo, o grupo tenha respeitado os lotes e sugerido fachadas individuais ao invés de uma única fachada para todo o setor. Por falta de espaço esta sugestão não teria sido apresentada ao júri.

17 Apesar do nome de Broos não constar oficialmente neste projeto, admite-se como certa sua participação, tendo em vista que foi um extenso trabalho que ocupou vários colaboradores de Kraemer desde 1946, fato que é reforçado pelo trabalho próximo entre mestres (no caso, Kraemer) e alunos dos primeiros anos pós-guerra. A participação de Broos é confirmada por Justus Herrenberger. A omissão de seu nome deve-se ao fato da primeira publicação sobre a obra datar de 1953, quando havia tempo, Broos não estava mais no escritório. Cf. Baumeister, Heft 10, 1953.

18 Esta última chegou a ser noticiada pela Revista Habitat, numa matéria sobre a arquitetura alemã do pós-guerra, assinada pelo colaborador constante da revista (e de outras internacionais) Udo Kultermann. Cf. Revista Habitat, n.48 mai/jun.58, p. 14-15).

19 DBZ - Deutsche Bauzeitschrift, Heft 8, 1961, p. 1053.

20 Bauen und Wohnen, Heft 6, 1960, p. 226.

21 Fica difícil precisar o quão fiel o projeto executivo foi ao projeto vencedor do concurso, nem o peso de Broos no projeto, já que não foi possível o acesso aos projetos originais. Sabe-se que passou por várias revisões e que a proposta de número 8 foi a executada. - Cf. Bauen und Wohnen, Heft 6, 1960, p. 223. Além disso, o fato desta aproximação com a obra de Mies, algo que pode ser verificado em outras obras destes anos, sugere a reformulação e "atualização" do projeto, segundo as pesquisas de Kraemer desta época.

22 Kraemer, Friedrich Wilhelm. Bauten der Wirtschaft und Verwaltung. In: Handbuch moderner Architektur. Berlin, 1957, p. 324, apud: Fendt, Martina. Architektur und Musik. In: Wilhelm, Karin; Gisbert, Olav (et. al.).op. cit., p. 72.

23 Prática esta que, no entanto, não se manteve por muito tempo, devido ao crescente número de estudantes ingressos; por exemplo, no semestre de inverno 1946/1947 havia apenas 14 estudantes para cada professor, o que permitia esta ligação bastante próxima; já em 1952 este número era mais que o dobro. Cf. Schmedding, Anne. op.cit. p. 106.

24 Justus Herrenberger, a este tempo assistente de Kraemer na TH Braunschweig. Schmedding, Anne. op. cit., p. 104.

25 “Gestaltung dem Sinne nach”. Schmedding, Anne. op. cit.,p. 106.

26 Segundo Herrenberger, os alunos faziam estudos de proporção nas fachadas dos projetos, e no escritório de Kraemer, a Broos era solicitada esta atividade pelo apreço que demonstrava. Em entrevista à autora.

27 Fendt, Martina. op. cit. p. 65.

28 Idem, p. 104

29 Idem, p. 66.

30 Eiermann, Egon. Carta a Josef Neckermann. 19/03/1960. In: Institut für Baugeschichte der Universität Karlsruhe. Egon Eiermann: Briefe des Architekten 1946-1970. Stuttgart: Deutsche Verlags-Anstalt, 1994, p. 166-168.

31 Egon Eiermann. Die Arbeitende Mensch und die Technik. Baukunst und Werkform, Heft 10, 1951, p. 28.

32 Dietmer Brandenburger. Architektenpoträt: Friedrich Wilhelm Kraemer. Der Architekt, 12, 1987, p. 595

33 Fendt, Martina. op. cit., p. 69.

34 Em especial nos projetos de edifícios comerciais e administrativos dos anos 1950.

35 Entre 1940 e 1942. À época a cidade estava ocupada pelos Nazistas.

36 Dietz Brandi, arquiteto ex-aluno de Schmitthenner na escola de Stuttgart. Após 1930 iniciase a "penetração" de ex-alunos da Escola de Stuttgart nas instituições de ensino alemãs e nos territórios ocupados. Paul-Schultze-Naumburg que havia sido nomeado diretor da antiga 
Bauhaus de Weimar em 1928, a partir daí dá início ao processo de "limpeza" que tira os modernos de seus postos de comando, e leva ex-alunos de Schmitthenner como diretores de museus e de instituições de ensino. Em Praga, durante a guerra, outros ex-alunos de Schmitthenner, além de Brandi, assumem postos como professores. Cf. Voigt, Wolfgang. Die Stuttgarter Schule und die Alltagsarchitektur des Dritten Reiches. In: Hartmut, Frank (org.) Faschistische Architekturen. Planen und Bauen in Europa 1930 bis 1945. Hamburg: Christians, 1985, p. 248-249.

37 Cf. Frank, Hartmut. Trümmer. Traditionelle und moderne Architekturen im Nachkriegsdeutschland. In: Schulz, Bernhard (org.). Grauzonen. Farbwelten. Kunst und Zeitbilder 1945-1955. Berlin/ Wien: Medusa, 1983.

38 Durth, Werner. Deutsche Architekten. Eine Biographische Verflechtungen 1900-1970. Stuttgart/ Zurique: Karl Krämer Verlag, 2001, p. 291.

39 Schwarz, Rudolf. Bilde Künstler, rede nicht. Baukunst und Werkform, n. 6, 1953, p. 9. Schwarz, entre outras várias colocações, afirma que o materialismo, o funcionalismo e o tecnicismo acabaram por quebrar a tradição cultural do ocidente (e não o Nazismo) e, de um modo oblíquo, acaba ligando a isso, os nomes de Gropius e da Bauhaus. Para ele, Gropius continuaria sendo um artista descompromissado.

40 Depoimento de Hans Broos em matéria assinada por José Wolf. Escritório Hans Broos. AU n. 50, out./nov. 1993, p. 96. 



\section{Capítulo 4 0 brutalismo em Hans Broos}





\section{O BRUTALismo}

A mudança de Broos de Blumenau para São Paulo, em 1962, coincide com o período de renovação na arquitetura nacional, que em São Paulo adquire notável vigor. Mais importante que seu estabelecimento naquela cidade, é o fato de sua arquitetura compartilhar, de modo lento e progressivo, desta mesma transformação que se processava no cenário arquitetônico nacional.

Os anos de 1961 e 1962 configuram-se em anos de transição para Broos. É exatamente em 1961 que surgem projetos em São Paulo, que se ampliam gradativamente em número, mas não resultam em um sucesso inicial. Destes primeiros trabalhos em São Paulo quase nada é construído, e o arquiteto sobrevive dos projetos e obras - em número razoável - em andamento no sul do Brasil, como Prefeitura e Residência Helmuth Baumgarten em Rio do Sul, Residência Zadrozny, Grande Hotel e Edifício Visconde de Mauá em Blumenau.

Em São Paulo o arquiteto almeja participar do ímpeto de crescimento que tivera lugar no país, ${ }^{1}$ e abraçar projetos de maior alcance; seus projetos iniciais refletem isso: se em Blumenau o arquiteto projeta prioritariamente residências unifamiliares, em São Paulo inicia seus trabalhos com projetos de grande vulto - indústrias e hospitais. Broos ousa dar um redirecionamento na carreira, aos moldes do que vinha fazendo na Alemanha. $\mathrm{O}$ arquiteto, que lá elaborava projetos industriais e se louvava da parceria com o arquiteto "industrial" Egon Eiermann (como ele se autodenominava) ainda não havia projetado indústrias ou projetos semelhantes no Brasil. Talvez seja esta a razão mais plausível para o "encerramento" da bem sucedida carreira em Blumenau, ${ }^{2}$ que já contava cerca de cinquenta projetos no Estado de Santa Catarina na curta experiência brasileira dos anos 1953 até 1961 (afora a revalidação do diploma, que lhe custou um ano de dedicação). Não foi, portanto, o insucesso que lhe impeliu a mudança a São Paulo: foi antes, o credo e a necessidade de alçar vôos maiores através de seus projetos.

Apesar do curto período passado no Rio de Janeiro entre 1956 e 1957 e da influência da Escola Carioca admitida em seus primeiros anos no Brasil, Broos, no início dos anos 1960, dirige-se à capital paulista como, aliás, muitos arquitetos imigrantes haviam feito antes dele. ${ }^{3}$ Sua formação prática, que se distinguiu no ensino universitário e completou-se em Karlsruhe sob o comando de Egon Eiermann, relaciona-se intimamente com o teor pragmático e engenheiril da formação dos arquitetos de São Paulo, cujo ensino politécnico esteve na origem. 
A preocupação social, aos moldes da retórica socializante e politicamente ideológica que marcou os debates da arquitetura brasileira nos anos 1950, não foi o que marcou seu pensamento e fazer arquitetônico. Mas certamente sua experiência pós-guerra o impelia à formulação de projetos, segundo sua visão, de maior influência, com maior peso coletivo, ${ }^{4}$ de maior amplitude e interferência social. Muito aos moldes do pensamento de vanguarda da década de 1920, mas já relativizados e menos idealizados, Broos acredita no poder de transformação da arquitetura; não a transformação social e reformista típica daqueles anos, mas uma transformação em escala local, naquele tempo e espaço, entre arquitetura e seu meio, que se completam e agem reciprocamente, perfazendo um novo ambiente, mais humano e adequado aos usos. O arquiteto nunca desconsiderou, no entanto, o valor do projeto da casa individual que, aliás, o acompanhou durante toda sua carreira; ao contrário. O poder de transformação e comunhão entre meio e arquitetura era visto para uma fábrica, uma igreja, qualquer local coletivo, o que afinal a casa também o é - um lugar de convivência por natureza.

Ao tomar esta postura mais concreta e realista Broos afasta-se dos discursos político-ideológicos da esquerda e dos meios acadêmicos que os alimentaram, e isto ajuda a explicar o quase total desconhecimento de suas obras junto ao meio especializado e sua rarefeita presença na historiografia da arquitetura moderna brasileira. Uma intricada gama de fatores pode explicar tal fato: uma personalidade introspectiva e de tradição bastante formal; o isolamento inicial da carreira brasileira numa cidade afastada dos principais centros, e seu igual distanciamento, mesmo já em São Paulo, dos meios acadêmicos e das organizações de classe, e das grandes polêmicas teóricas que marcaram o contexto profissional nos anos 1950 e 1960.

\section{A MUDANÇA DE UM DISCURSO}

A partir da metade dos anos 1950 nota-se uma crescente modificação do discurso teórico da arquitetura brasileira e a consequente desvinculação com a retórica que a legitimou nos anos 1930-1950. Do "projeto moderno" que tinha como proposta a construção de uma identidade nacional, focalizado na Escola Carioca, passa-se gradativamente a um discurso de cunho fortemente ideológico, voltado para a valorização da estrutura como definidora da expressão plástica do edifício.

João Vilanova Artigas, com uma série de artigos e discursos proferidos principalmente a partir de meados dos anos 1950, vai "construindo" o arcabouço teórico e se transforma no principal porta-voz e definidor da via teórica desta arquitetura. Mesmo sem ter, com isso, definido parâmetros ou uma base teórica que fundamenta a ação prática, sua construção teórica agiu como tal. Ademais, 
para os outros arquitetos, sua produção arquitetônica desempenhava o papel de discurso prático e contraprova à eloquência teórica.

Os textos de Artigas dos anos 1950/1960 espelham a construção de um novo projeto moderno, centrado no que justamente era considerado - nem tanto pelos brasileiros, mais pelos estrangeiros ${ }^{5}$ - o calcanhar de Aquiles da nova arquitetura brasileira: o cunho social de suas obras ou, a visão social de seu "projeto". Artigas concebe a visão de uma arquitetura centrada em sua função social, com uma forte carga político-ideológica na defesa da técnica e da tecnologia nacional como elementos da defesa da soberania nacional ${ }^{6}$ e da luta anti-imperialista, reforçado mais tardiamente pela defesa da idéia do "desenho" (projeto) como possível forma de emancipação política. ${ }^{7}$

Em seus discursos a partir de meados dos anos 1950 Artigas elabora uma proposta teórica de uma arquitetura politicamente engajada, expressão da realidade técnica e tecnológica do país: "a realidade é que a exuberância de formal e a audácia técnica de nossa arquitetura esforçam-se para superar uma realidade social caracterizada pelo atraso de sua infra-estrutura", ${ }^{8}$ ou seja, alia arquitetura nacional e desenvolvimento tecnológico e consequente emancipação política, um intricado e persuasivo discurso que influenciou a arquitetura brasileira e gerações de arquitetos por anos, quando não mais pela veia teórica, sua atuação perdurou pelo modelo arquitetônico legitimado por este discurso.

Através do discurso, elaborado e coerente, principalmente através do texto "O Desenho", Artigas coloca que o projeto poderia sugerir novas bases de convívio social e a ele era outorgado o poder de influir na sociedade e no modo de viver. Já em 1950 Lina Bo contribui através de sua crítica, com o simbolismo formado acerca da produção de Artigas: "uma casa construída por Artigas, não segue as leis ditadas pela vida de rotina do homem, mas lhe impõe uma lei vital, uma moral que é sempre severa, quase puritana”, que assim conclui: "A casa de Artigas [...] é a mensagem paciente e corajosa de quem vê os primeiros clarões de uma nova época: a época da solidariedade humana."

Em face da elaboração teórica, sua prática profissional adquiriu um significado simbólico que extrapolou o simples fazer arquitetônico. Suas formulações, projetos, adquiriram um sentido de integração social: a cobertura, geralmente ampla, que abarca e integra os diferentes ambientes internos, unificados, por sua vez aos externos, num esforço de eliminação de barreiras entre o interno e externo, entre público e privado; e também de militância política: na Casa Baeta (1956, com Carlos Cascaldi), o arquiteto dispõe a casa lateralmente à rua e propõe como fachada principal a empena lateral cega, atitude vista pela 
crítica como transgressora e denunciatória da realidade contraditória que se vivia: "uma atitude crítica em face da realidade" ${ }^{10}$ A partir deste mesmo ideário, tenta exprimir a realidade nacional em termos do conhecimento tecnológico e a expressar a partir da estrutura, as possibilidades plásticas da arquitetura. Por um lado, cabe ao projeto espelhar a realidade tecnológica da nação "sem máscaras", e por outro, forjar uma nova realidade no plano social.

No dizer de Maria Alice Junqueira Bastos: deste ideário, “é possível pinçar algumas indicações disciplinares - uso de tecnologia avançada; valorização dos espaços de uso coletivo, ausência do 'supérfluo', ou seja, uma arquitetura expressa pela estrutura; expressão contemporânea - tornou-se medida de valor na arquitetura paulista, juntamente com a valorização dos encargos públicos [...]"11 que dão a referência "social" a esta arquitetura.

Também a obra de Niemeyer é marcada por uma inflexão claramente voltada nos termos deste novo ideário nacional, exposta no texto "Depoimento" de 1958. Nele, o mestre faz a tão famosa auto-crítica, valorizada pelos pupilos, em que reconhece o excessivo apreço pela originalidade, e estabelece uma nova conduta em sua prática projetual, balizada pela simplificação formal, em que a expressão do edifício seria dada pela própria estrutura, e não mais por seus elementos secundários. ${ }^{12}$ Já em sua obra, a partir de meados dos anos 1950 era possível reconhecer uma significativa mudança de paradigma: o arquiteto, reconhecido pela liberdade de suas curvas em que se fazia reconhecer a primazia dada à criatividade (que culminou na infeliz concepção do gênio criador) passa a reconhecer o primado da estrutura em suas soluções, e a buscar na "síntese" dos volumes puros a nova expressão formal de sua arquitetura, que tem no projeto do Museu de Caracas (1954) o início desta nova "fase".

De modo geral, a mesma mudança de paradigmas é passível de reconhecimento no campo teórico e prático da arquitetura brasileira a partir de meados dos anos 1950, quando a predominância arquitetônico-cultural passa do Rio de Janeiro a São Paulo. As obras paulistas passam a contribuir com novas pesquisas no campo arquitetônico, "quando o discurso crítico-teórico da arquitetura moderna brasileira estava se voltando para a valorização da ideia de uma expressão plástica definida a partir da própria estrutura [...], ${ }^{13}$ tentando inculcar uma continuidade da especificidade da arquitetura moderna brasileira desde os anos 1930 (na exploração plástica do concreto armado), na montagem de um quadro evolutivo único, que se antes, valorizava o vínculo com a tradição construtiva local, a mescla de materiais tradicionais e modernos, adequação climática, entre outros, agora passa a salientar a exploração plástica da solução estrutural. ${ }^{14}$ 


\section{Brutalismo Paulista}

$\mathrm{Na}$ virada dos anos 1950 e 1960, a arquitetura brasileira vivia um momento de grande euforia, inspirada ainda na construção de Brasília e no mote desenvolvimentista do Governo Jucelino Kubitschek. Na arquitetura passam a ser valorizadas, "as estruturas bem urdidas e engenhosas. A capacidade da engenharia para domar e ocupar o território nacional tornou-se inspiração da arquitetura brasileira."15

Estruturas suspensas, os balanços, os grandes vãos, a sensação do edifício estar "pousando" desafiando as leis da gravidade e o senso comum no campo da estática, viraram mote desta arquitetura que notabilizou-se pela proeza estrutural, e passou a constituir constantes desafios às leis da engenharia.

O projeto de Lina Bo para o MASP (1957-1968) talvez tenha se constituído num dos projetos mais surpreendentes neste sentido. O terreno, que antes abrigava uma Casa de Baile e um belvedere que proporciona bela vista para o centro da cidade, foi doado à Prefeitura com o compromisso de manter os visuais para a cidade. Do compromisso que liga o projeto à cidade dos anos 1930/ 1940 surge o mote para o grande vão, a ostentação da capacidade tecnológica do país e grande premissa do projeto. Aqui a solução estrutural é o grande feito do projeto e ponto de maior interesse.

Uma significativa mudança na linguagem formal da arquitetura nacional tornouse evidente a partir de meados dos anos 1950 nas obras de uma jovem geração de arquitetos que começa de forma muito prolífica suas carreiras. Nomes como Joaquim Guedes, Millan, Paulo Mendes da Rocha, Fábio Penteado, Pedro Paulo de Mello Saraiva, Décio Tozzi, João Walter Toscano, despontam no cenário arquitetônico nacional no fim dos anos 1950 com obras que inovaram pelo teor mais austero e até agressivo que assumiam com forte apelo à racionalização dos processos construtivos e tendência à serialização dos componentes.

Entre as polêmicas de ser ou não um movimento de vanguarda à parte da linha carioca, ${ }^{16}$ o Brutalismo Paulista é inegavelmente produto de seu tempo, com equivalentes nos Estados Unidos, Japão, Europa, e não privilégio inventivo brasileiro. Se teve aqui nuances próprias, como realmente teve - aliás, somente a designação comum parece unir produções tão díspares quanto o movimento britânico e o brasileiro, por exemplo, além de uma série de valores que se fizeram mais ou menos absorvidas e presentes internacionalmente, como a "verdade construtiva" e opção pelo uso de materiais ao natural - o Brutalismo Paulista parece ser fruto de uma renovação da arquitetura nacional nutrida pelas discussões e transformações que se processavam no panorama internacional, e a partir do já desgastado modelo da Escola Carioca. 
É inegável que o Brutalismo Paulista tem origens, motivações e feições que a diferem da Escola Carioca e seu projeto de modernidade, mas caracterizá-la como um movimento autônomo seria ignorar todo o desenvolvimento porque passou a arquitetura brasileira na primeira metade do século passado, e conceber o Brasil em "ilhas" o que, de fato, em meados do século XX não pode mais ser o tom do discurso. Seria igualmente desconhecer a transformação porque passava a arquitetura no Brasil, com o tom das críticas internacionais, as críticas internas que se faziam presentes e a acolhida que esta crítica teve no Brasil - não de maneira direta ou franca, pois regia o tom inflamado de discursos ufanistas em defesa da nossa arquitetura - mas que surge velado, como na autocrítica de Niemeyer, que não passou indiferente às mudanças da arquitetura moderna no plano internacional.

Uma "revolução" nunca é certeira; uma renovação é sempre resultado de um processo; processo complexo e constituídos por várias iniciativas - Reidy, Niemeyer, Artigas, e uma nova geração de arquitetos, reunidos em São Paulo (com talento e crítica suficientes para demonstrar seu descontentamento em relação aos caminhos da Arquitetura Brasileira, e contestar cânones estabelecidos e aparentemente inamovíveis) que não ficaram imunes às discussões internacionais. Tampouco a mudança nos rumos da arquitetura brasileira pode ser outorgada a relação simplista de causa e efeito entre a autocrítica de Niemeyer e sua "aceitação" pelos paulistas, principalmente Artigas. ${ }^{17} \mathrm{~A}$ autocrítica é, ela mesma, também produto de seu tempo, consequência de um novo pensamento que se formava na arquitetura brasileira e internacional, um novo "espírito" de época.

O Brutalismo se configura num processo de revisão do Movimento Moderno no plano internacional, uma reformulação que tem lugar no seio da arquitetura moderna, que se abre a novos debates, tendo em vista novas possibilidades construtivas e tecnológicas, novas explorações formais, e mostra o esgotamento de um receituário, que por seus ares de hegemonia, mostra brechas, fraquezas e a necessidade de revisões. Ao mesmo tempo que se diferencia da arquitetura moderna e a critica em muitos aspectos, o Brutalismo bebe ainda da mesma fonte, e deixa antever laivos até mesmo vanguardistas em seu bojo.

$\mathrm{Na}$ produção de alguns críticos percebe-se tentativas de "nacionalização" do Brutalismo, como em Marlene Acayaba: "Nessa época, os arquitetos paulistas liderados por João Vilanova Artigas, combatiam o dogmatismo racionalista de Le Corbusier e da arquitetura oficial carioca. Criticando-a como uma adaptação da arquitetura corbusiana aos trópicos, sem o caráter brasileiro que terá mais tarde, defendiam a contribuição de São Paulo na expressão da cultura brasileira", ${ }^{18}$ onde 
pretende outorgar à arquitetura brutalista paulista a noção de "caráter brasileiro". Como lembra Maria Alice Junqueira Bastos, as obras desta corrente não perseguiram, ao menos inicialmente, "o tom nacional, a diferenciação por clima ou cultura, mas ao contrário, perseguiram uma linguagem universal, tecnológica, a implantação genericamente correta." ${ }^{19}$ Ademais, percebe-se no dizer de Acayaba, a sugestão de que o Brutalismo seria uma "insurgência” brasileira, desconectada de sua "conexão internacional" nos dizeres de Banham, e surpreendentemente, que se volta contra Le Corbusier, cuja obra tardia foi, justamente, uma das influências principais do Brutalismo Paulista e internacional.

À parte a denominação genérica e a inclusão ao rol Brutalista de obras tão díspares quanto o Edifício da FAUUSP de Artigas, ou o Centro de Pesquisas da IBM de Marcel Breuer (1960-1961) e a Escola de Hunstaton (1950) do casal Smithson (o que faz com que Ruth Verde Zein a refute como obra brutalista, ainda mais como obra inaugural desta corrente, como defende Banham), a origem e influência comum indiscutível ao amplo espectro desta corrente são as obras corbusianas do pós-guerra. A Unidade de Habitação de Marselha (1946-1952) e as obras subsequentes, elevam o concreto armado em seu estado natural, rude e tosco, a material-símbolo desta corrente.

De forma bastante significativa e contribuidora para a cristalização de um possível estilo brutalista, foi a divulgação em 1956 das Maisons Jaoul em Neuilly (1951-1954) de Corbusier. Realizada em estrutura de concreto à vista com tijolos aparentes, além da recorrência a técnicas tradicionais como as abóbadas, esta obra sinalizava desde já certa amplitude do movimento. Do mesmo modo, colocava que o Brutalismo não seria partidário apenas do béton brut, mas de materiais utilizados em seu estado natural; e ainda, utilizados em uma edificação de escala e programa diversificado e que admitia técnicas convencionais, o que outorgou à tendência também certa característica vernacular.

$\mathrm{Na}$ ausência de um cânon teórico da corrente a embasar a produção dos arquitetos, cuja exceção se faz ao livro de Banham, ${ }^{20}$ que tentou colocar as bases da tendência quando do já total estabelecimento desta - em 1966, bastante posterior, portanto, ao surgimento das obras - estas servem, elas mesmas, de postulado para as criações. Também por esta razão, o Brutalismo aceitou as mais diversas influências - Corbusier, Mies, Wright - e disparou as mais diferentes obras, tanto que, internacionalmente, seja quase impossível arrolá-las sob um único postulado comum. Como o próprio Banham afirma, o Brutalismo passa a se manifestar a partir de um dado momento, em diversas partes do globo, que não comungam necessariamente da mesma essência, excetuando-se os ensinamentos da obra de 
Le Corbusier, com adições eventuais de outras influências, analisadas caso a caso. O que as une, portanto, seria um vago sentido estético já esquecido o discurso ético, um abarcar vago e difuso, amplo, que mais que sua rede internacional, exige particularizações locais.

\section{BRUTALISMO E NEOEXPRESSIONISMO ALEMÃO}

Com os pressupostos modernos desmantelados, já que a arquitetura do período não mais compartilhava da mesma base filosófica e doutrinária, os anos 1950 assistem a um rico e complexo descortino de proposições no panorama arquitetônico mundial, cujas manifestações não se resumem apenas ao chamado Estilo Internacional. Bastante diversa, porém, é a narrativa crítica referente a este período. Em meio às solinhadas bases modernas e à emergência de uma variada gama de arquiteturas impossível de ser "etiquetada" sob uma denominação comum, ${ }^{21}$ a arquitetura compreendida entre os anos pós-guerra e os anos 1970 tem sido tratada de maneira simplista, desde uma visão canônica e parcial pela revisão crítica da modernidade, que não privilegia as próprias características do período, mas o vê amarrado a concepções que lhe precedem ou são ulteriores, (neste caso, entre modernismo e pós-modernismo). Exemplo disto é o desconhecimento quase total no Brasil, de boa parte dos arquitetos e obras citados e analisados nesta tese.

Somente o caso alemão já nos dá boas e irrevogáveis demonstrações do variado contexto da época. Nele há a convivência (nem sempre pacífica) de arquiteturas de cunho historicista, nos moldes tradicionais, com fortes influências da arquitetura escandinava, a chamada corrente "neoexpressionista", arquitetura orgânica, sobretudo nas mãos de Scharoun e seus discípulos (que também passa a ser confundida com a arquitetura neoexpressionista), além, é claro, do Estilo Internacional, baseado nos edifícios norte-americanos.

Enfim, elencar o conjunto destas propostas e suas imensas variações (maior peso da tecnologia em alguns, maior peso do vernáculo em outros) seria tarefa impossível, tampouco nos interessa, além das obras já aqui indicadas. Importa demonstrar, ainda que parcialmente, o quão rica e complexa se mostra a realidade do período e o quão pobre e distorcido tem sido seu retrato junto à crítica que lhe é posterior.

Interessante notar que, mesmo após a reconstrução alemã nos anos 1950 e 1960, os arquitetos alemães conhecidos e divulgados, continuam sendo os mestres da vanguarda, agora em suas carreiras norte-americanas. Dos arquitetos alemães que continuaram no país neste tempo e que se tem maior conhecimento, ao 
menos no Brasil, continuam sendo Hans Scharoun, Frei Otto e, posteriormente e com menos ênfase, Oswald Matthias Ungers; ao demais, lhes foi reservado tão simplesmente função anódina ou quase quimérica. Muito mais se comenta as obras do pós-guerra de mestres da arquitetura realizadas na Alemanha, como Mies e Gropius (que pouco construíram em sua terra natal) e Corbusier (Unidade de Habitação de Berlim); ou paradoxalmente, a obra de eminentes visitantes como Alvar Aalto (com diversos edifícios construídos) e arquitetos das novas gerações, igualmente ilustres como van den Broek, Bakema, o escritório SOM, entre outros.

Por este motivo, não é surpreendente que a obra de Egon Eiermann não seja sequer mencionada no Brasil, ou ainda obras de Scharoun (excetuando-se a alardeada Filarmônica de Berlim), ou Gottfried Böhm, ou - extrapolando os limites alemães - até mesmo a obra tardia de Marcel Breuer - que difere substancialmente do Breuer da Bauhaus ou das residências nos Estados Unidos dos anos 1940, a que sempre sua obra é aludida - sejam praticamente ignoradas ou não recebem a devida atenção.

No caso de Eiermann, que interessa a este estudo, parece ser mais paradoxal ainda, o fato de que autores alemães sequer mencionem a existência de elementos brutalistas em seus projetos, ou de obras que, de forma indubitável, se aproximam desta tendência. Sempre analisada a coerência formal de sua obra - o que de fato existe - ela não fica imune à mudança dos tempos. Os elementos formais e estruturais individualizados e exteriorizados de que faz uso como meio compositivo, forte característica de sua arquitetura desde os anos 1940, a partir de fins dos anos 1950 e anos 1960 tornam-se mais expressivos e com alusão a um peso visual e massa corpórea dantes não buscada pelo arquiteto. No Edifício da Neckermann (1958-1961) esta linguagem mais agressiva ganha especial interesse, quando o arquiteto potencializa estas características de sua arquitetura, e recorre agora, ao concreto armado.

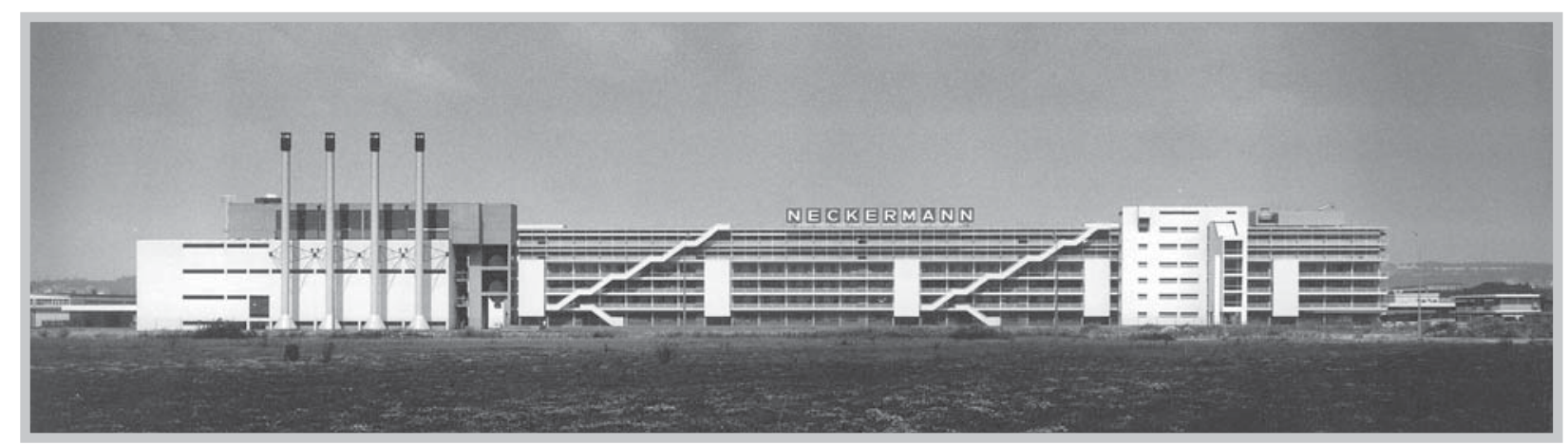

Fig. 1 - Egon Eiermann. Edifício Neckermann. Frankfurt. 1958-1961. 
Sua última obra, o Edifício da Olivetti, o qual não viu concluído, talvez seja aquela que mais ostensivamente apresenta características brutalistas - mais uma vez, não aventadas pela crítica local, que justifica a escolha estrutural do edifício com pilar central ladeando duas construções mais baixas - influenciados pelo discurso do próprio arquiteto - como, mais que uma opção funcional, uma "imposição" funcional, tendo em vista o vasto programa, o exíguo terreno e suas inúmeras limitações legais. Uma "injunção" que, aliás, toma como modelo o projeto para o novo Centro Administrativo da cidade de Marl na Alemanha (1958, 1962-1967) de Bakema e van den Broek, principalmente, ao compararmos um desenho do arquiteto que precede a solução final. Ambos os projetos se baseiam na concepção do pilar central, de matriz wrightiana, (ícones do Brutalismo Paulista), solução que o arquiteto vinha demonstrando em projetos anteriores não realizados, como para o Edifício da IBM em Böblingen (1965-1966), além de um projeto posterior para a Embaixada Alemã em Moscou (1969). Entretanto, o forte teor estrutural da proposta de Egon Eiermann para a Olivetti, é diluído pela presença das passarelas externas, notórias em sua arquitetura pela leveza e movimentação que sugerem. A proposta que tanto animou as fachadas dos mais importantes prédios do arquiteto, acabaram agora por desfazer a força sugestiva que tal proposição encerra. Ademais, as edificações de um pavimento da Olivetti, já demonstram ser vitimários do mal que abatia o Brutalismo em escala internacional - ostentam certo exagero estrutural, que já ganha ares de ornamentação em aço e negam a limpidez e concisão de obras anteriores. Outro projeto parece incorrer nesta questão, como o Edifício Administrativo da Fischtel \& Sachs (projeto, 1964-1966). Além disso, em muitos projetos, a partir dos anos 1960, o arquiteto propõe o edifício escalonado. Solução muito utilizada no Brutalismo, por um lado esteve sempre muito viva na memória do arquiteto, ${ }^{22}$ mas por outro, revela proximidade à tendência brutalista, principalmente com o projeto de Habitação para a cidade de Wulfen (1963-1964), onde, ao invés da solução leve da Prefeitura de Essen (1963) ganha formas mais densas e compactas em concreto armado.

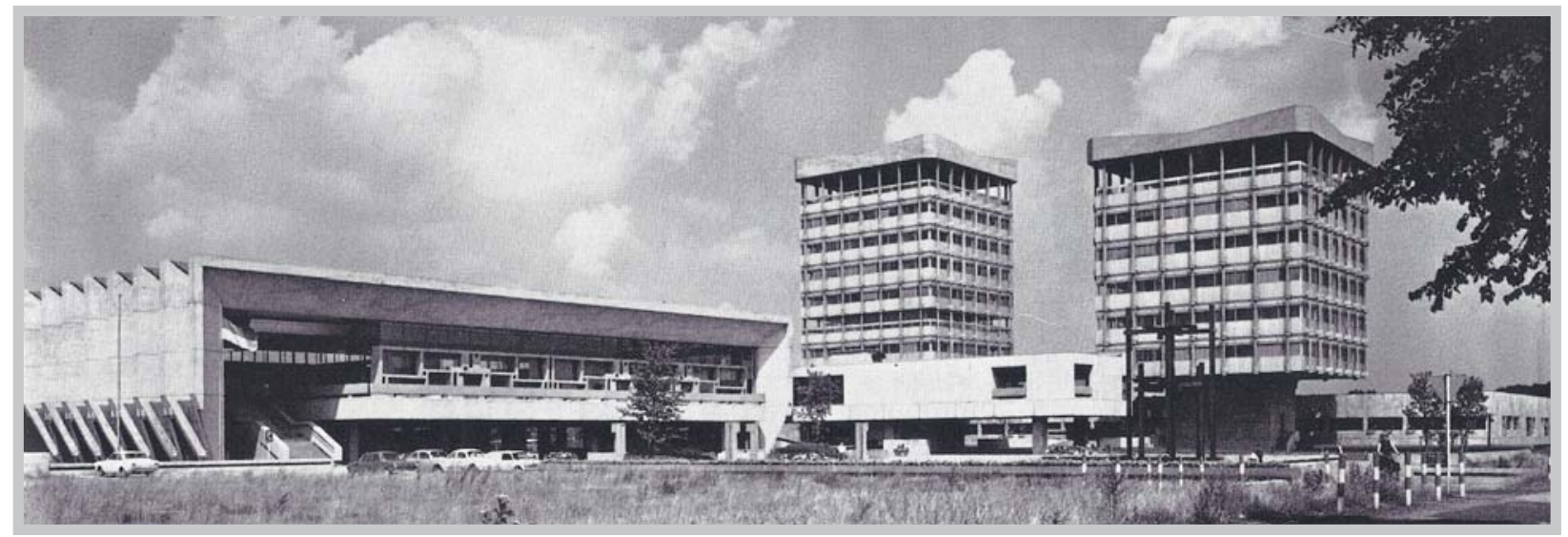

Fig. 2 - J. H. Bakema, J. B. van den Broek. Centro Administrativo. Marl. 1958, 1962-1967. 


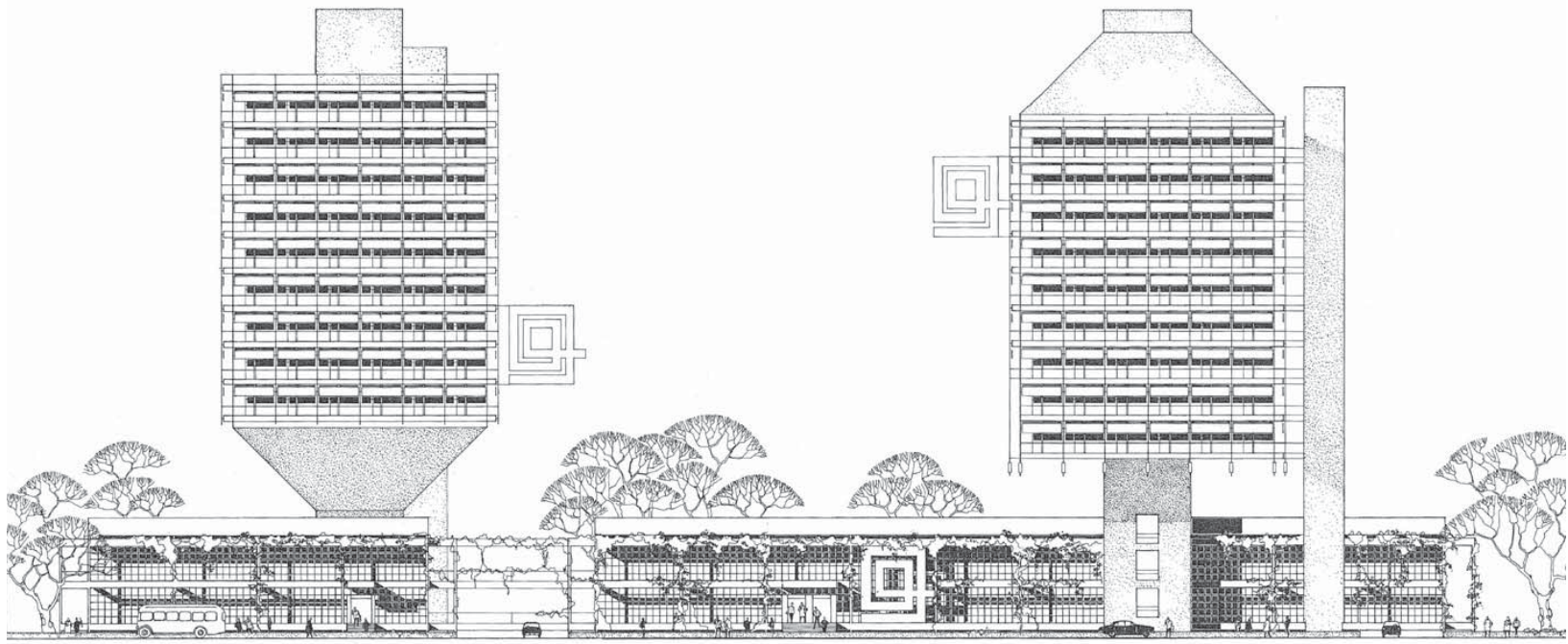

Fig. 3 - Egon Eiermann. Edifícios da Olivetti. Alternativa de projeto.

Entretanto, é difícil falar apenas em Brutalismo alemão; ele esteve muito ligado ao Neoexpressionismo, com figuras como Gottfried Böhm, Walter Förderer e Ungers (que, posteriormente, será uma das principais figuras dos pós-moderno no país). Segundo Wolfgang Pehnt, o retardamento do Brutalismo ou seu não alinhamento à tendência mundial, teve como principalorigem o chamado Neoexpressionismo, que tem justamente seu ponto alto em meados dos anos 1950 com a Filarmônica de Berlim (1956, 19601963), auge da carreira de Scharoun e da arquitetura alemã pós-guerra. ${ }^{23}$

Além disso, a não total aceitação do Brutalismo(ousuaprontaaceitação) com suas superfícies rugosas e seu

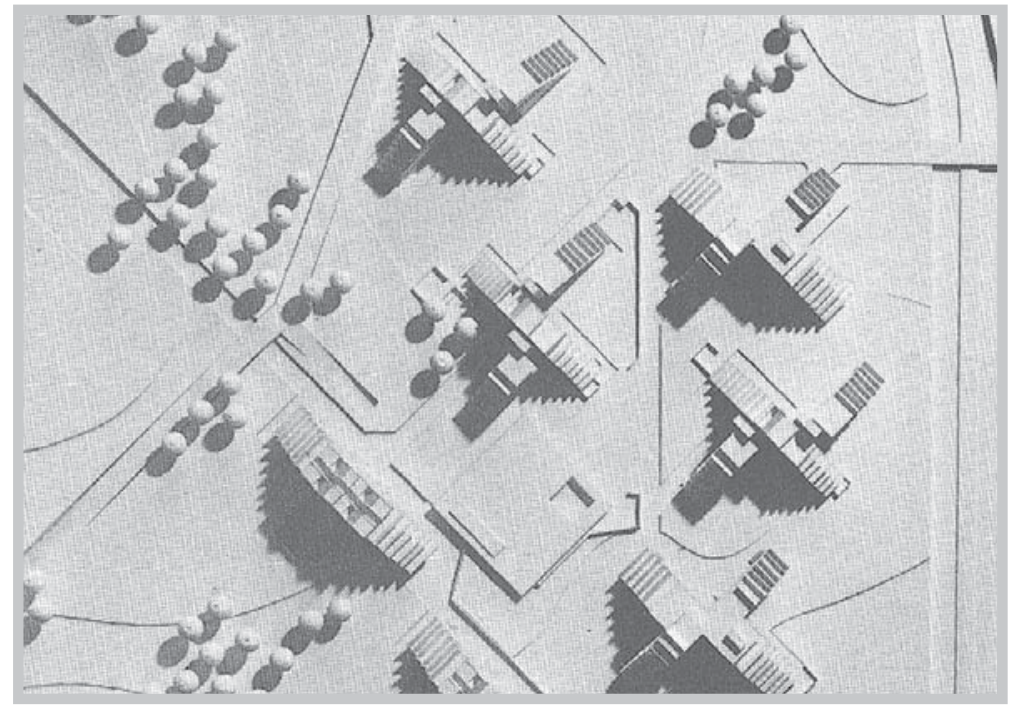

Fig. 4 - Egon Eiermann. Habitação para a cidade de Wulfen. 1963-1964.

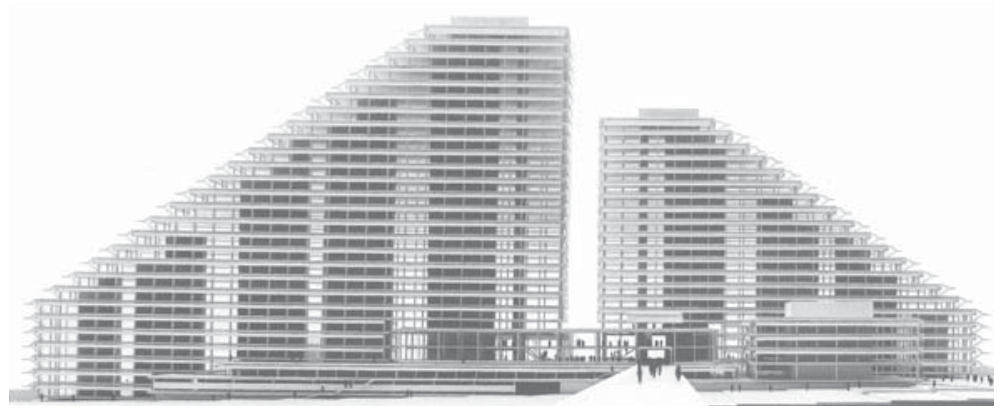

Fig. 5 - Egon Eiermann. Prefeitura de Essen. 1963. aspecto massivo nos anos 1950/1960 tinha a ver com uma questão tecnológica e ideológica: a prosperidade econômica prematura de fins da década 1940 e década de 1950 coloca plenamente a possibilidade do uso do aço nas construções, amparado nos exemplos norte-americanos dos arranha-céus, tomados como exemplos de progresso; ideológico, porque a arquitetura em aço nutria um sentimento de progresso e desenvolvimento futuro, e ostentava conforto e bem- 
estar que a apartava dos tempos de escassez do imediato pós-guerra. Também esta arquitetura, com suas características de leveza e transparência, servia como um exemplo de um novo mundo e contraponto a um passado cuja arquitetura também deveria ser substituída.

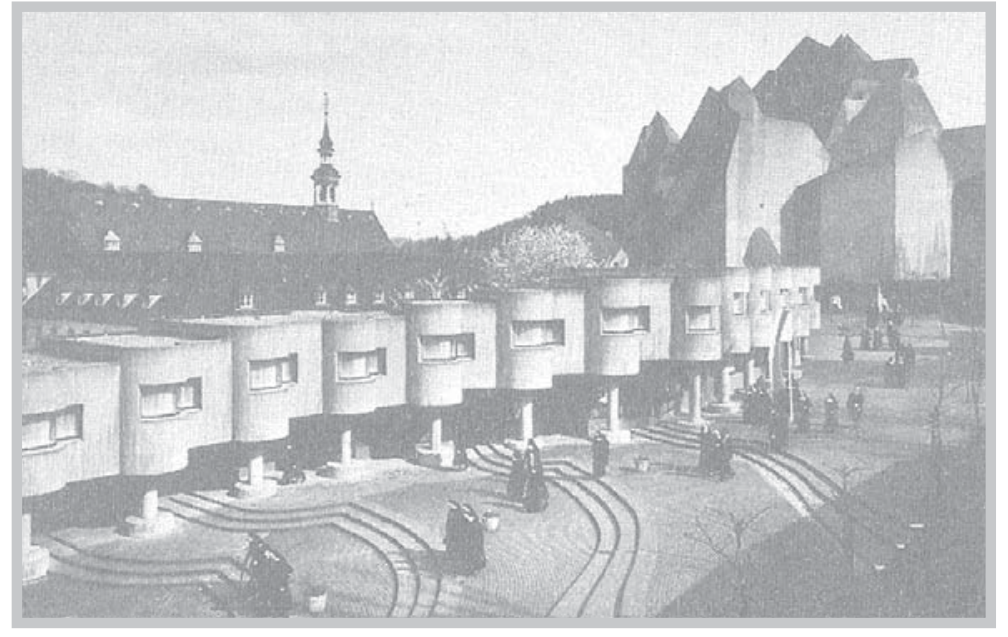

Fig. 6 - Gottfried Böhm. Capela de Neviges. 1968.
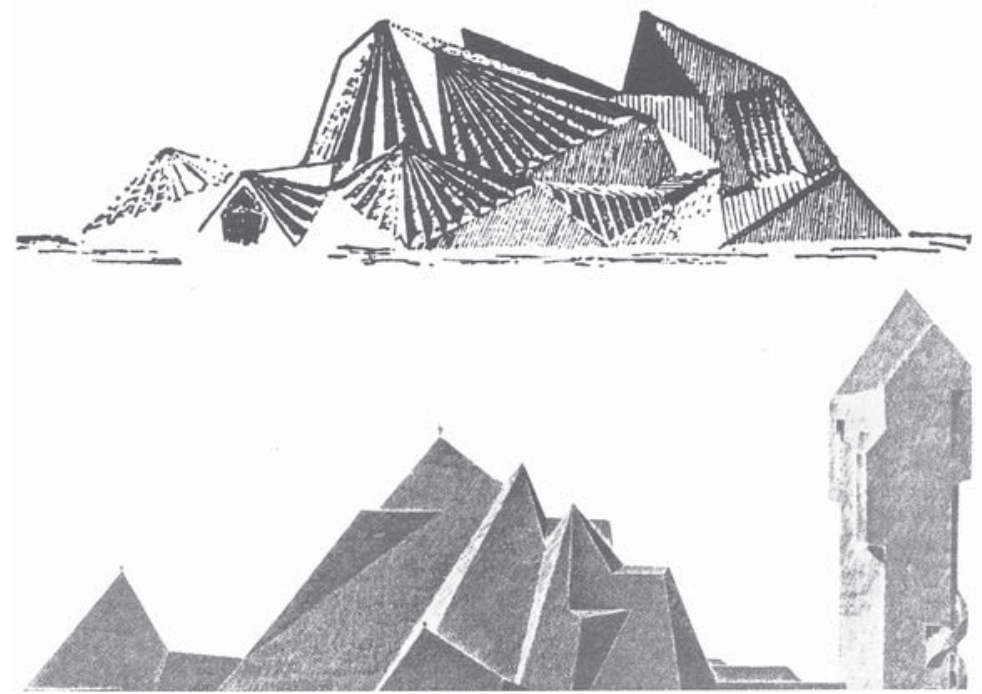

Fig. 7 - Wassili Luckhardt. Projeto para cinema. 1920 (acima). Gottfried Böhm. Capela de Neviges. 1968 (abaixo).

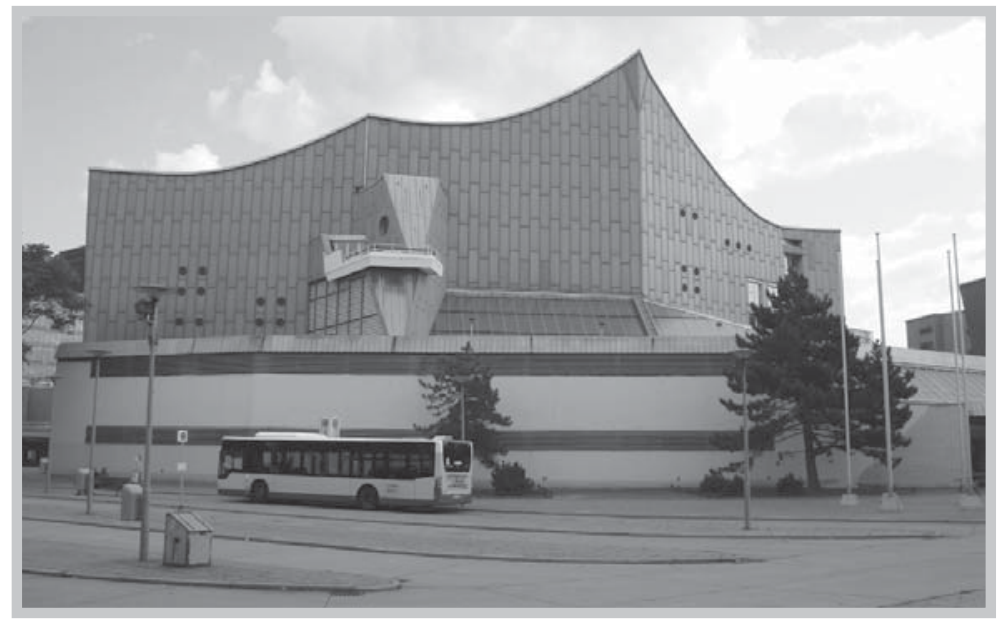

Fig. 8 - Hans Scharoun. Filarmônica de Berlim. 1956, 1960-1963.
O Neoexpressionismo revisita os buliçosos dias de 1918, e mostra que a Arquitetura do Expressionismo continuava sendo fonte inesgotável de criação para os arquitetos alemães no fim dos anos 1950 e os anos 1960. Hans Scharoun é o caso mais conhecido da personificação desta aura arquitetônica. Gottfried Böhm constrói visões místicas em concreto aparente que remete diretamente aos férteis anos 1920. A igreja em Neviges (1968), com o arranjamento geometrizante de seu interior evoca o misticismo próprio das catedrais góticas, com seu duro contraste de luz, e assemelhase aos delírios juvenis de Wassili Luckhardt, em seu projeto para um cinema em 1920.

A Filarmônica de Scharoun, e a alguns metros dali, a Neue Nationalgalerie de Mies van der Rohe (1962, 1965-1968) assinalam a diversidade de proposições que um mesmo período pode gerar. O espaço fantasioso de Scharoun transformase em espaço lacônico nas mãos de Mies; a opulência quase folclórica, multifária e de muitas miragens tem em Mies a versão contemporânea do templo clássico sobre pódio. Aqui "o espaço surge não como volume, que seria definido através 
de seu arranjamento, mas como um lugar, que é definido através de sua idéia de ordenação." ${ }^{24}$ Essa não deixa de ser também a ideia contida no Brutalismo Paulista - fundar um lugar; ser um lugar e não tão somente uma arquitetura; aqui é manifestado o desejo de se diferenciar do entorno, querer ser um mundo a parte, que se basta em si mesmo, uma nova organização diversa do mundo externo, mas ao mesmo tempo em constante contato com ele.

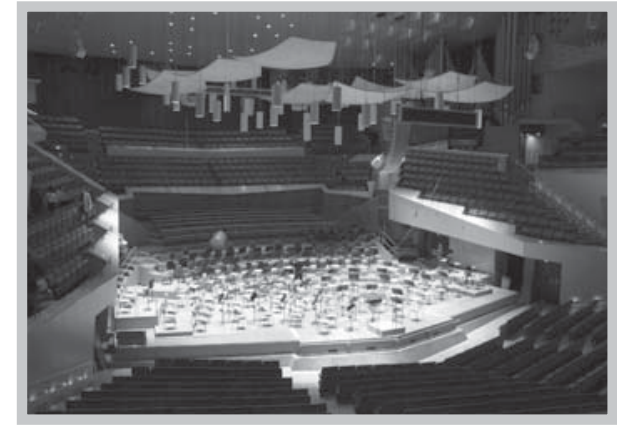

Fig. 9 - Hans Scharoun. Filarmônica de Berlim. 1956, 1960-1963.

Pehnt trata o tema Brutalismo com relativa superficialidade; o vê como a solução formal natural para a produção em massa, "brutal", dos anos 1960 - onde as finas, leves e transparentes estruturas dos anos 1950 não encontrariam mais lugar. As obras "mostram e exageram a forma e a maneira, como uma construção é feita, exibem as ligações construtivas, deixam as instalações visíveis. O grosseiro vale como o desejo de estampar a

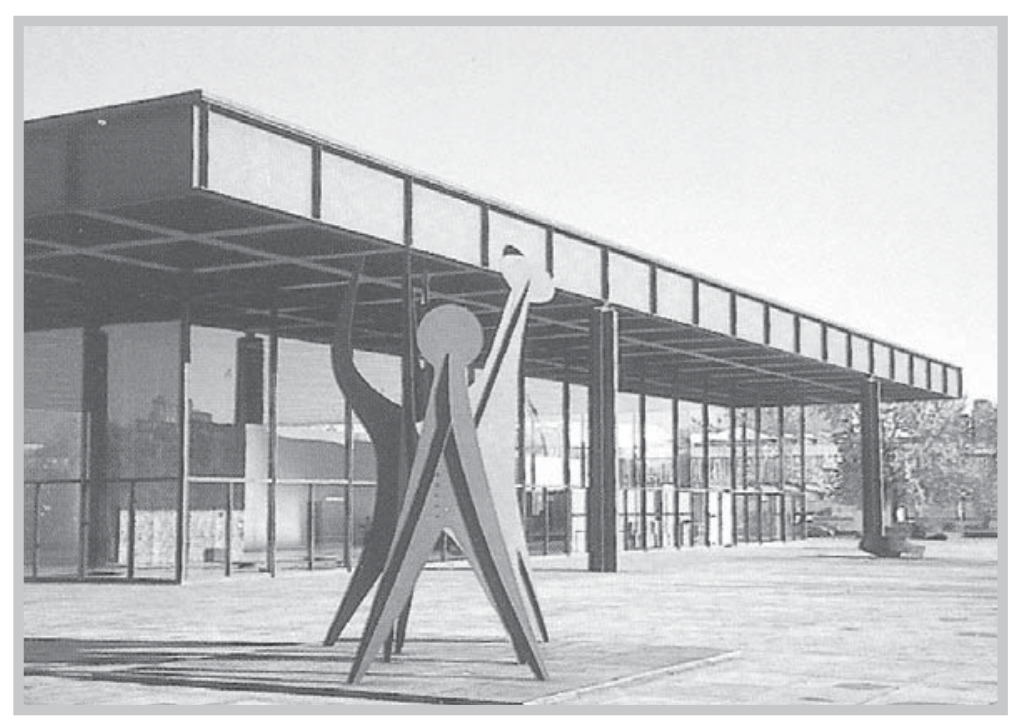

Fig. 10 - Mies van der Rohe. Neue Nationalgalerie. 1962, 1965-1968. tabernária realidade do dia-a-dia e colocar junto à necessidade da produção de massa a exclusividade da invenção" ${ }^{25}$ Como assinala Pehnt, os anos 1960, tanto para planejamento urbano quanto para as edificações, representaram construções para as grandes massas. Não somente novas cidades ou novos bairros alcançavam cifras recordes; o edifício mesmo chegou a dimensões desconhecidas. ${ }^{26}$

Jürgen Joedicke talvez seja o crítico que se debruça mais demoradamente sobre o tema, analisando, porém, mais seus limites e restrições que tende a reduzir esta manifestação a poucas obras, e parece querer achar somente obras brutalistas originais, sem assumir o caráter inclusivo desta corrente, ${ }^{27}$ algo que a proximidade temporal talvez limitasse a visão ou, ainda, faz parte do mal de grande parte dos historiadores e críticos - tudo querer demarcar, classificar, estabelecer limites quando estes são na maioria das vezes escorregadios.

Como princípio formal genérico do Brutalismo, Joedicke faz uma interessante comparação com a obra de Mies: enquanto este parte do grande espaço que é dividido em pequenas partes, o Brutalismo parte do individual, do espaço dividido e proporcionado segundo sua função e conectado entre si, ou seja, da autonomia dos espaços que formam o conjunto; o espaço composto por unidades 


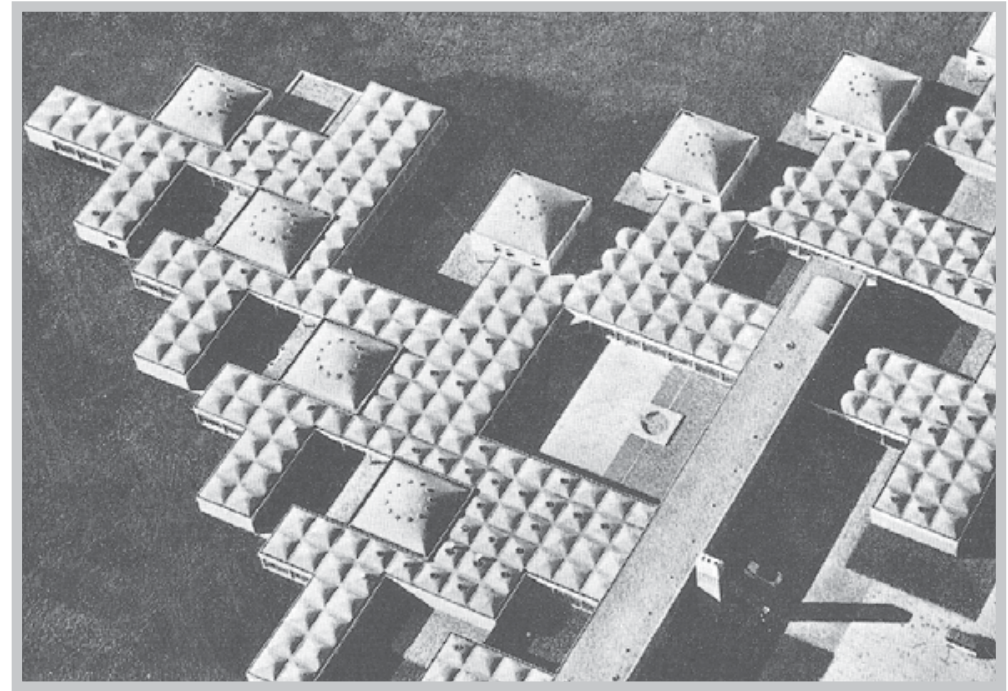

Fig. 11 - Aldo van Eyck. Casa de órfãos. Amsterdã.1958-1960.

em contradição ao espaço único e genérico de Mies. "O ponto de partida não é, portanto a grande forma, e sim, a forma unitária". 28

Enquanto em Mies a forma resultante é o paralelepípedo puro, no Brutalismo é a forma multifária, com corpos e elementos individualizados e realçados externamente, frisando a independência formal das funções do edifício. Por trás deste princípio formal estaria, portanto, o conceito da função; Joedicke o denomina princípio "urbano" pois aqui, como no Brutalismo, trata-se de funções específicas e diversas que concorrem para um todo. ${ }^{29}$ Um exemplo seria a casa de órfãos de Aldo van Eyck (1958-1960); segundo o arquiteto, "uma casa como uma cidade, uma cidade como uma casa", onde as diversas funções são separadas em unidades formais unitárias, como é exemplo também a Prefeitura de Marl van den Broek e Bakema (1958, 1962-1967). A tendência em separar diferentes funções em unidades formais diversas mostrou-se particularmente ativa em relação a elementos considerados secundários de uma edificação. Mais comumente são separados: torres de circulações e serviços, circulações horizontais, e também elementos como dutos, canalizações e gárgulas, estas, verdadeiro fetiche dos arquitetos ditos brutalistas. Um exemplo clássico e cabível é o Richards Medical Research Center da Universidade da Pensilvânia (1957-1961) de Louis Kahn, onde são diferenciadas as torres de laboratórios das torres de ventilação e exaustão. Esta composição traz vantagens funcionais - os espaços internos dos laboratórios não são subdivididos; construtivas - diferenciação construtiva entre as diferentes partes: estrutura metálica para torre de laboratórios, e concreto armado para as torres de ventilação; e compositivas - possibilidade de diferenciação formal a partir da diversidade funcional, com a visível predominância das torres de serviço na composição do edifício, ou seja, uma inversão na hierarquia das funções.

Assim como Joedicke sugere, Pehnt coloca que, para Mies van der Rohe a única função que um edifício admite é a flexibilidade; quando espaços com funções específicas são necessários, mesmo assim são relegados a um papel secundário. ${ }^{30}$ Como no Crown Hall em Chicago, na Neue Nationalgalerie de Berlim as salas e espaços menores do museu são dispostos na base e, o edifício, localizado acima desta, permanece um espaço amplo e generoso, intocado, que admite os mais diversos usos. 
Assim visto, a arquitetura ideal de Mies contraria as premissas que vigiam nos anos 1960 - quando sua arquitetura admite uma forma para múltiplas funções e, nisso, de um modo paradoxal, antecede a críticaitaliana de que a forma precederia à função ${ }^{31}$ (e não seu contrário: “form follows function”), ela seria soberana, prevaleceria sobre o tempo e as mudanças de demanda. O Brutalismo, como será encarado em alguns países, será o oposto disto, ou seja, procurará, para cada função, uma forma específica, individualizando volumes,

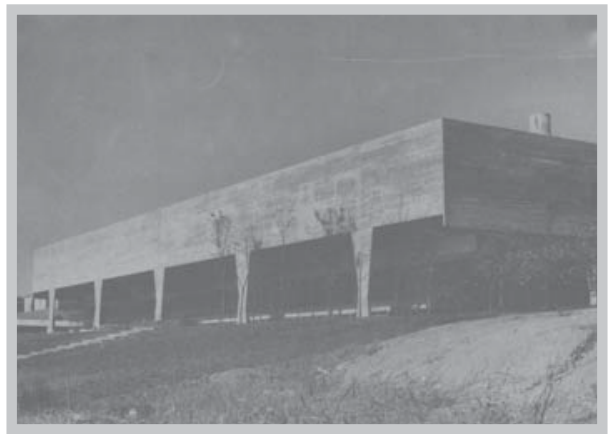

Fig. 12 - Vilanova Artigas. Faculdade de Arquitetura e Urbanismo-USP. São Paulo. 1961-1969. espaços e também elementos secundários do edifício.

Mas para o Brutalismo Paulista, além de outras premissas formais, ${ }^{32}$ também este amplo espaço genérico, invólucro neutro, destinado a múltiplos usos servirá de inspiração. Desta concepção se aproxima, além de muitos outros exemplos, o edifício da FAUUSP, seu envoltório também neutro (porém em concreto) e o espaço central destinado a vários usos.

Ao contrário do Brutalismo europeu, e a exemplo da obra miesiana, o Brutalismo Paulista preza pela solução genérica, que antes de revelar o caráter funcional dos espaços que abriga, os oculta, em soluções geralmente cerradas, embora permeáveis, num envoltório genérico; visualmente alheios ao entorno, mas pragmaticamente abertos, em franca conexão com o exterior. Esse talvez seja um dos aspectos (que nem todas as obras brutalistas compartilham, é claro) mais interessantes e particulares do Brutalismo Paulista. Estar no edifício sem precisar bater à porta (porque ela simplesmente inexiste) como na FAUUSP, ou o espaço pérvio sob o edifício do MASP.

O Brutalismo europeu, alimentado pela característica da arquitetura em geral dos anos 1960, verá na topografia uma aliada para seu significado, uma arquitetura topológica, que quer ser, simultaneamente, arquitetura e paisagem. As construções em terraço destes anos são estímulos criativos aos arquitetos. Esta inspiração a partir da paisagem tem na Prefeitura de Bergisch Gladbach-Bensberg de Gottfried Böhm um de seus mais paradigmáticos exemplos, através do edifício massivo e monumental amoldado à topografia local, cuja

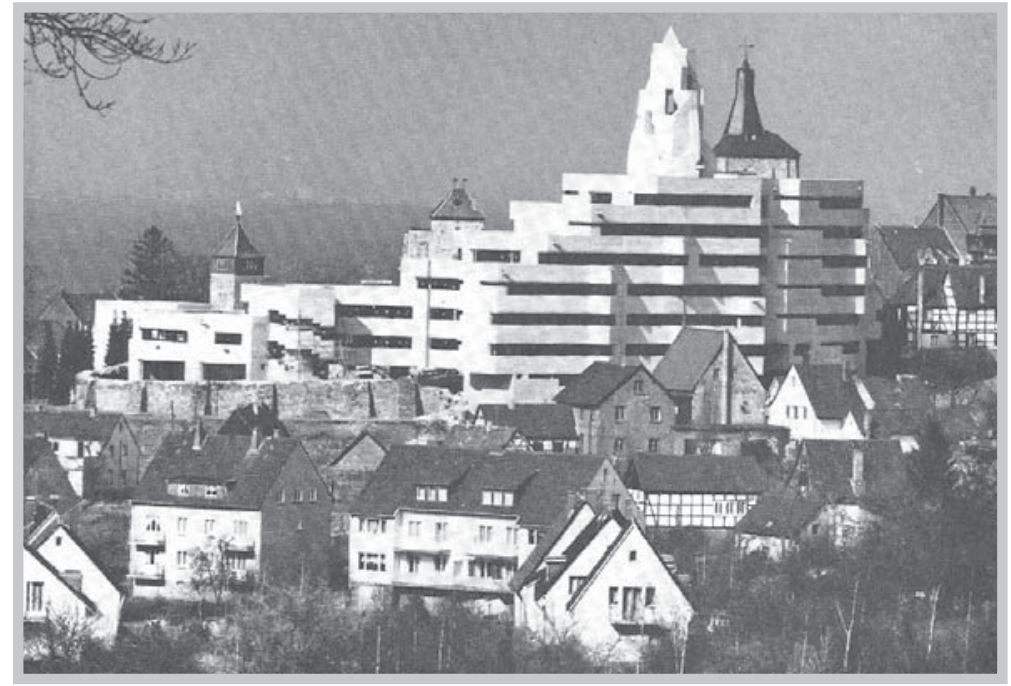

Fig. 13 - Gottfried Böhm. Prefeitura. Bergisch Gladbach-Bensberg. 1963-1969. 
torre escultórica serve como complemento picaresco, em concreto armado, aos edifícios vizinhos.

O Brutalismo Paulista tinha, ao contrário, a exemplo da arquitetura moderna dos anos 1920, a pretensão de ser exemplar, representar um mundo diferente; sua relação com o mundo é de contraste (e foi assim que entre seus pares, a arquitetura moderna, já sob o signo do "Estilo Internacional" se tornou banal, porque corrente). O Brutalismo Paulista não quis se confundir com a paisagem, mas quis, ele mesmo, através da solução projetual única e à maneira da Unidade de Habitação de Corbusier, ser edifício-cidade que se basta em si.

Interessante que, mesmo a arquitetura internacional dos anos 1960 e também o Brutalismo teve este caráter ou pretensão de ser arquitetura e paisagem, ou arquitetura e cidade - mas quase sempre com limites bem precisos - em nenhum momento isso se confirma, pra além da visualidade ou princípio compositivo de um modo tão pragmático como no Brutalismo Paulista. 


\section{Notas}

1 Que a esta época ainda vivia sob a bonança dos anos 1950, antes de ser deflagrada a crise econômica e política que antecedem o golpe militar.

2 Ainda que um encerramento não seja o caso, ao contrário. Hans Broos, mesmo em São Paulo deu continuidade ao trabalho iniciado no sul do Brasil, e realizava seguidamente obras em Blumenau e nos arredores. Paradoxalmente, quando já estava no sudeste do país, é de Blumenau que o arquiteto recebe suas maiores encomendas fabris, advindas da Companhia Hering, também sua maior cliente desde fins dos anos 1960 até anos 1980. Sua ligação com Blumenau não seria, portanto, jamais rompida.

3 Como Lukjan Korngold (1940), Adolf Franz Heep (1947), Lina Bo (1947) Victor Reif (1950), Eugênio Szilágyi (1951), Delfim Amorim (1951), entre outros.

4 Faz-se exceção, porém, em relação aos edifícios residenciais em altura. Broos, a exemplo de Eiermann, era contra a idéia de construir em alturas; via nisso algo de desumano e prejudicial à cidade. Teve poucos exemplos construídos e nas obras identificamos sua contrariedade - nenhuma solução criativa, tampouco inovadora; suas obras de edifícios em nada se comparam ao restante de sua obra.

5 Como Max Bill, Bruno Zevi, Ernesto Nathan Rogers. De fato, Lúcio Costa admitiu, em sua resposta às críticas de Max Bill, em 1953, que "a arquitetura brasileira [...] anda muito necessitada de ducha fria de quando em quando" ou ainda Mindlin, já em 1945 dizia: “[...] falta-nos ainda muita coisa. Falta-nos a visão concreta, realizada na prática, dos grandes problemas sociais da coletividade. Faltam-nos habitações populares, faltam-nos escolas, hospitais [...], sobretudo, um urbanismo de sentido social [...]." Cf. Lucio Costa: Sobre Arquitetura. Porto Alegre. Centro de Estudantes Universitários de Arquitetura, 1962, p.159 e Mindlin, 1979, p.172, apud: Segawa, Hugo. Arquiteturas no Brasil 1900-1990. São Paulo: Edusp, 1997, p. 206, respectivamente.

6 Cf. Artigas, João Batista Vilanova. Le Corbusier e o Imperialismo, 1951; Os caminhos da Arquitetura Moderna, 1952. In: Artigas, João Batista Vilanova (org. José Tavares Correia de Lira, Rosa Artigas). Caminhos da Arquitetura. 4. ed. São Paulo: Cosac \& Naify, 2004.

7 Cf. Artigas, João Batista Vilanova. O Desenho, 1967. In: Artigas, João Batista Vilanova. Op. cit.p. 108-118.

8 Artigas, João Batista Vilanova. Discurso aos formandos FAUUSP, 1955. In: Artigas, João Batista Vilanova. Op. cit., p.61-62.

9 Lina Bo Bardi. Casas de Vilanova Artigas. Habitat n.1, out.-dez. 1950, p.2.

10 Artigas, João Batista Vilanova. Os caminhos da Arquitetura Moderna, 1952. In: Artigas, João Batista Vilanova. Op. cit. p. 50. Cf. Buzzar, Miguel Antônio. João Batista Vilanova Artigas: Elementos para a compreensão de um caminho da arquitetura brasileira 1938-1967. Dissertação de Mestrado. São Paulo: FAU-USP, 1996.

11 Bastos, Maria Alice Junqueira. Dos anos 50 aos 70: como se completou o projeto moderno na Arquitetura Brasileira. Tese de Doutorado. São Paulo: FAU-USP, 2004, p. 28.

12 Niemeyer, Oscar. Depoimento. In: Xavier...p. 239. Publicado originalmente na Revista Módulo, n. 9, fev. 1958.

13 Bastos, Maria Alice Junqueira. op. cit., p. 36.

14 Idem, p. 32.

15 Idem, p.140.

16 Hugo Segawa aceita a arquitetura paulista como continuidade da Escola Carioca, tendo como principal fato a auto-crítica de Niemeyer, em que o arquiteto coloca sua mudança de postura e a preferência pelas "soluções compactas, simples e geométricas" e que se exprimem "pela própria estrutura" e sua compreensão por Artigas. Assim, depreende que "o caráter mais marcante da arquitetura paulista - a estrutura como arquitetura é tributário das conclusões de Niemeyer de 1958-1960"; e que Niemeyer, em São Paulo, "foi cultuado pelos ideais e pelas realizações construídas que, passadas por uma releitura, se transformaram noutra arquitetura nas mãos dos arquitetos paulistas - sem perda da essência que a originou." Cf. Segawa, Hugo. Arquiteturas no Brasil. Op. cit. p.147-148. Grifo 
no original. Já Bruand parece compactuar com a outra idéia, ao classificar o Brutalismo como um movimento autônomo dentro do cenário arquitetônico nacional.

Ruth Verde Zein afirma que em nome de uma identidade que não se queria romper as duas formulações não são vistas como distintas, "mas como faces de uma continuidade, mesmo quando venham a diferir totalmente - coisa que só vai começar as ser reconhecida a partir dos anos 1970, [...] apenas quando o volume de obras afiliadas às novas tendências torna impossível qualquer teimosia em seguir afirmando uma continuidade que já havia sido, desde há muito, estilhaçada.” (p. 51). Entretanto, algumas páginas a seguir, Zein irá relativizar a própria afirmação, quando coloca que a arquitetura Paulista Brutalista "tanto dá continuidade quanto rompe com a tradição imediatamente anterior, parcial, mas significativamente.”. Cf. Zein, Ruth Verde. A arquitetura da Escola Paulista Brutalista: 1953-197, op. cit., p.186.

17 Como o faz Segawa. Cf. nota n.16.

18 Acayaba, Marlene. Residências em São Paulo 1950-1970. São Paulo: Projeto, 1986, p.19.

19 Bastos, Maria Alice Junqueira. op. cit., p. 159.

20 Banham, Reyner. El Brutalismo em Arquitectura: Etica o Estética? Barcelona: Ed. Gustavo Gili, 1966.

21 Não que isso ocorresse no período entre-guerras; seria incorrer no mesmo erro e ver aquelas manifestações de forma igualmente simplista e desvalorizar diferenças ou posturas diversas, entretanto, parece este o olhar consolidado pela historiografia daquela época, surpreendentemente, até hoje. Cf. Capítulo 2.

22 Como já nos referimos ao Projeto "Casa da Amizade" de seu professor Hans Poelzig. Ver Capítulo 3.

23 Pehnt, Wolfgang. German Architecture 1960-1970. Praeger Publishers: New York, Washington, 1970.

24 Pehnt, Wolfgang. Deutsche Architektur seit 1900. 2a ed. Ludwigsburg/ München: Wüstenrot Stiftung/ Deutsche Verlags-Anstalt, 2006, p.324.

25 Idem, p.356.

26 Idem, p.342.

27 Apesar da apresentação que Banham faz do tema e, de fato, válida até hoje como marco teórico, e apesar da importância do casal Smithson na divulgação teórica e nas obras desta corrente, afiliar o Brutalismo estritamente ao que propunham teoricamente ou tendo como exemplo a obra do casal, parece ser fato descartado, embora ainda presente na historiografia recente, e merece ser tratado de forma ampla e contemporânea. Cf. Zein, Ruth Verde. A arquitetura da Escola Paulista Brutalista: 1953-1973. op. cit.

28 Joedicke, Jürgen. Moderne Architektur. Strömungen und Tendenzen.. Stuttgart/ Bern: Karl Krämer Verlag, 1969, p. 124.

29 Idem, ibidem.

30 Pehnt, Wolfgang. German Architecture 1960-1970. op. cit., p. 25.

31 Rossi, Aldo. A arquitetura da cidade. São Paulo: Martins Fontes, 1995.

32 Entre elas, o edifício porticado, a laje em grelha uni- ou bidirecional, os apoios perimetrais (à exemplo da Neue Nationalgalerie), ou por vezes recuados. Sobre a influência da obra miesiana no Brutalismo Paulista, cf.: Zein, Ruth Verde. A arquitetura da Escola Paulista Brutalista: 1953-1973. op. cit. e: Mahfuz, Edson da Cunha. Ordem, estrutura e perfeição no trópico. Mies van der Rohe e a arquitetura paulistana na segunda metade do século XX. Arquitextos, São Paulo, 05.057, Vitruvius, fev $2005<$ http://vitruvius.es/revistas/read/ arquitextos/05.057/498>. 


\section{UM BRUTALISMO E MUITAS REFERÊNCIAS}

A aproximação de Broos ao Brutalismo deu-se gradativamente; mais que uma procura por novas tipologias ou novos elementos formais, ela se deu, inicialmente, pela mudança nos materiais: no uso do concreto aparente e por uma nova pesquisa junto aos materiais, deixados naturais. Pode-se inferir igualmente que sua linguagem, principalmente no programa residencial, já possuía muitos elementos, desde a Casa Abel, que depois viriam a configurar a linguagem da tendência Brutalista. A principal delas, a concepção formal da "caixa", quase sempre sobre pilotis, o caráter introspectivo da composição, e a importância dada à racionalidade da estrutura e seu papel como ordenadora da composição e da estrutura interna, mas que, naturalmente, não configuram nenhuma tendência de per si.

Broos chega ao Brasil com uma linguagem aparentemente definida - difícil de confirmar, entretanto, apenas a partir de uma obra, mas que pode ser aceita, tendo em vista sua condição de tipo formal para futuras proposições, da qual Broos explorará novas pesquisas formais e espaciais, e que segue aberta às novas contribuições do debate artístico e arquitetônico de sua época, tendo admitido influências locais e internacionais.

A arquitetura que Broos realizou na Alemanha - seja em colaboração com Kraemer ou Eiermann ou como autônomo - tinha muito mais da austeridade e pragmatismo paulista do que a liberdade formal carioca. Ainda que Broos conscientemente tenta incorporar parte desta "fantasia" brasileira (nos dizeres do arquiteto) em suas obras - como coberturas borboleta, movimentação da planta, jardim interno, além, é claro, da inelutável necessidade de adequação local, seja em relação ao clima ou aos materiais disponíveis - suas obras, de modo geral, e principalmente aquelas construídas, continuam mais densas e fechadas, sem a característica leveza e transparência da Escola Carioca.

Broos somente se ocupará de forma significativa com o Brutalismo, ou elementos deles, a partir de meados dos anos 1960, quando a corrente sai de seu caráter excepcional e passa a se firmar em São Paulo e no mundo, e contava com o endosso de profissionais locais de peso como Artigas, Joaquim Guedes, Carlos Millan, entre outros. Até então, Broos parecia ainda querer fazer uso de ou adequar do modo que lhe aprouvesse, elementos da Arquitetura Moderna Brasileira, versão carioca. $\mathrm{O}$ arquiteto segue experimentando, como que para saciar um desejo, ou sentir-se de fato no novo ambiente ou, mais provavelmente (não excluindo as demais), para encontrar seu posicionamento e o modo pelo qual conduziria seu fazer projetual no ambiente brasileiro. 


\section{A CASA: CAMPO EXPERIMENTAL DE PROJETO}

A primeira obra do arquiteto que demonstra uma sensível alteração estética é justamente no programa residencial, que se configurou ao longo dos anos de trabalho num constante e profícuo campo de pesquisa. Talvez pela liberdade que o programa permite, ou por se tratar na maioria das vezes de projetos não realizados - o que talvez se fosse levado a cabo acarretaria modificações várias - foi no programa residencial que o arquiteto permitiu-se as maiores experimentações, acompanhando tendências e correntes arquitetônicas, admitindo influências em seu trabalho. Ao analisarmos seus primeiros projetos residenciais, vemos que Broos nunca deixou de utilizar materiais e técnicas convencionais - pedra, madeira, alvenaria. Em todas as casas construídas, a estrutura da cobertura era de madeira, mas ocultada por uma alva platibanda, que garantia o desenho límpido e homogêneo, o contorno nítido e a linearidade dos projetos, como na casa de Zadrozny. A partir de 1962, data de sua mudança para São Paulo, seus projetos passam a refletir uma nova postura, já esboçada nos projetos mais "puristas" dos anos 1957-1959: a tão propagada "verdade construtiva" e a honestidade em relação ao uso dos materiais, que são acompanhadas, não como resultado, senão como desejo exploratório, de inúmeras variações e especulações formais e espaciais nos anos seguintes.

Na Residência Werner Arnold de 1962, Broos parte da tipologia que motivou a maior parte de seus edifícios residenciais: paredes laterais vedadas, parede frontal recuada com a "marcação" das divisões internas na fachada. Neste projeto, já podemos falar de uma empena (e não mais uma parede) lateral; a cobertura, em cimento amianto, tem a estrutura de madeira deixada visível. Várias residências destes anos 1960 e 1970 espelham esta mudança de atitude em relação ao projeto.

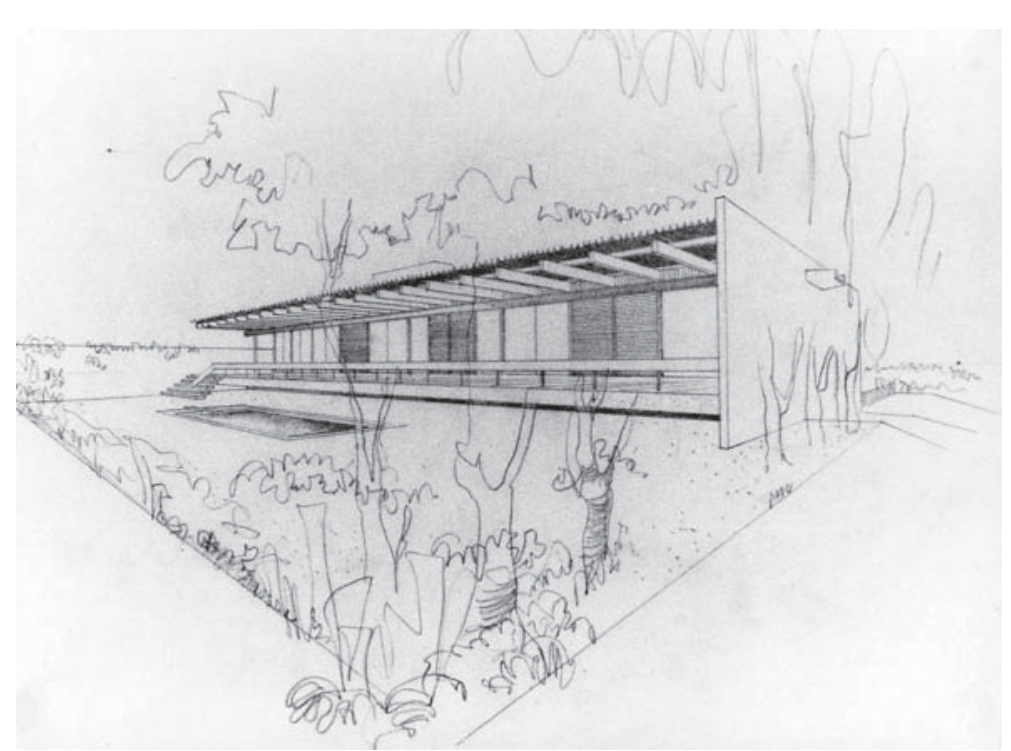

Fig. 1 - Hans Broos. Residência Werner Arnold. Projeto. São Paulo. 1962.
Nestes anos suas casas voltam-se também, muitas vezes, a um tema caro aos brutalistas: o grande espaço de convivência, quase sem barreiras visuais internas e a permeabilidade entre interior e exterior. Entretanto, Broos trabalha este tema de maneiras muito diversas. Na maioria dos exemplos, o que se pretende é a interiorização da casa, um "voltar-se" para dentro, para a vida familiar, exacerbando o que já era esboçado com a inversão 
funcional - setor de serviços voltado para a rua, e setores íntimo e social recuados do domínio público, atingindo, assim, maior grau de privacidade junto aos "fundos" do terreno. Agora Broos projeta um "voltar-se" para dentro total, nem sempre partindo da grande cobertura que abarca todos os ambientes, mas criando pátios internos, recriando um espaço natural dentro da casa para onde se voltam todos os ambientes internos. Um espaço ao mesmo tempo intimista, que parece alheio ao mundo externo, mas que providencia uma relação cada vez mais direta com o exterior.

\section{$\mathrm{Na}$ Residência Mario Lambert}

(1969) a planta-baixa é concebida a partir de blocos funcionais - três blocos separados e aparentemente sem conexões entre si - mas abrigados sob a ampla cobertura, que garante a aparência unitária à casa e sua conexão interna. $\mathrm{O}$ arquiteto lança uma grelha de colunas com espaçamento irregular e estrutura ali espaços abertos e fechados. Não podemosfalar em pátios, ou em uma casa com varandas; espaços abertos e fechados mesclam-se quase na mesma proporção; não podemos falar em corredores; estes projetamse como espaços abertos entre os blocos estanques, e não mais como espaços de conexão dentro de um objeto fechado.

Aqui a grande cobertura que abriga, não congrega um espaço central único de convivência, e sim, múltiplosespaços, abertosefechados, "centrais" (não necessariamente ao centro) e perimetrais. Embora mantenha franca conexão com o exterior, o que se pretende não é a fusão entre espaço interno e externo, entre natural e construído;

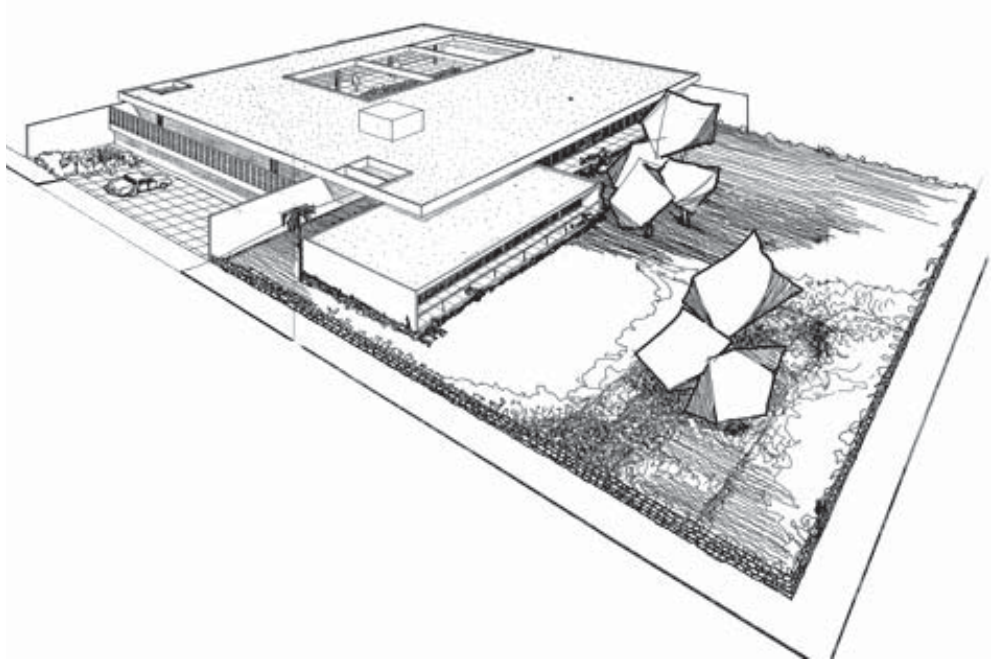

Fig. 2 - Hans Broos. Residência Mario Lambert. Projeto. São Paulo. 1969.

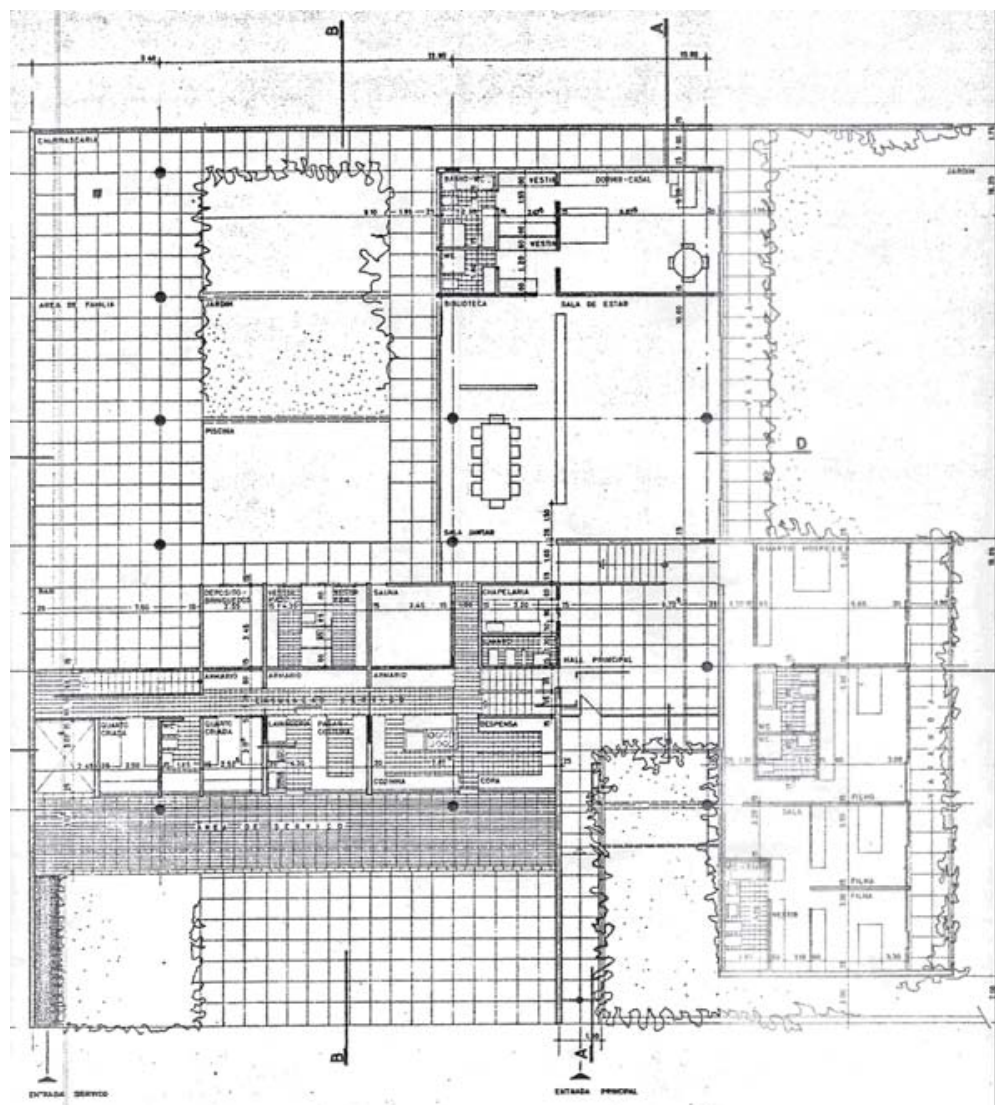

Fig. 3 - Residência Mario Lambert. Planta Baixa. 
a casa recria o espaço natural em seu interior, e a permeabilidade procurada é aquela interna, entre o espaço "natural" e construído do interior da casa. O que não deixa de ser um contra-senso, pois o tamanho generoso do terreno, que permanece boa parte vazio, para onde voltam-se os dormitórios e parte do setor social, não induz necessariamente a esta solução, que parece ser adequada a um terreno mais exíguo.

Esta residência, apesar de evocar o recorrente tema da casa como abrigo, não remete aos exemplos formais que possuem nesta questão a premissa maior (como as casas de Artigas, por exemplo). Apesar do mesmo conceito que lhe dá origem, a concepção formal é totalmente distinta. A casa não ostenta uma fachada propriamente dita. No que seria a fachada principal, os ambientes internos são recuados e voltados para o interior. O que se vê é a horizontalidade das linhas da cobertura e do pavimento sobre pilotis, que conformam vazios, uma mescla entre cheios e vazios.

Em uma atitude teoricamente paradoxal, ao conceito espacial intimista e da cobertura que abarca - conceito presente no Brutalismo - corresponde a destruição formal da "caixa" que da origem àquela concepção. A arquitetura parece se estruturar numa sucessão de planos superpostos que se afastam do solo e recriam jardins e o espaço externo em seu interior. Sua arquitetura perde o caráter de objeto acabado e cerrado que motivara a concepção das casas anteriores, mas conserva sua aura intimista. Como consequência da cobertura que se projeta de maneira extensiva e dos ambientes dispostos recuados dos limites da fachada, a luz também é trazida pela cobertura, através de recortes na cobertura que privilegiam determinados espaços.

Algumas destas concepções também podem ser notadas no projeto da Residência Endlein (1969). Mas se antes a planta baixa assumia a concepção em blocos funcionais estanques, que guardavam espaços abertos e passagens entre eles, aqui a planta assume novamente uma forma única, “dentada”, envolta

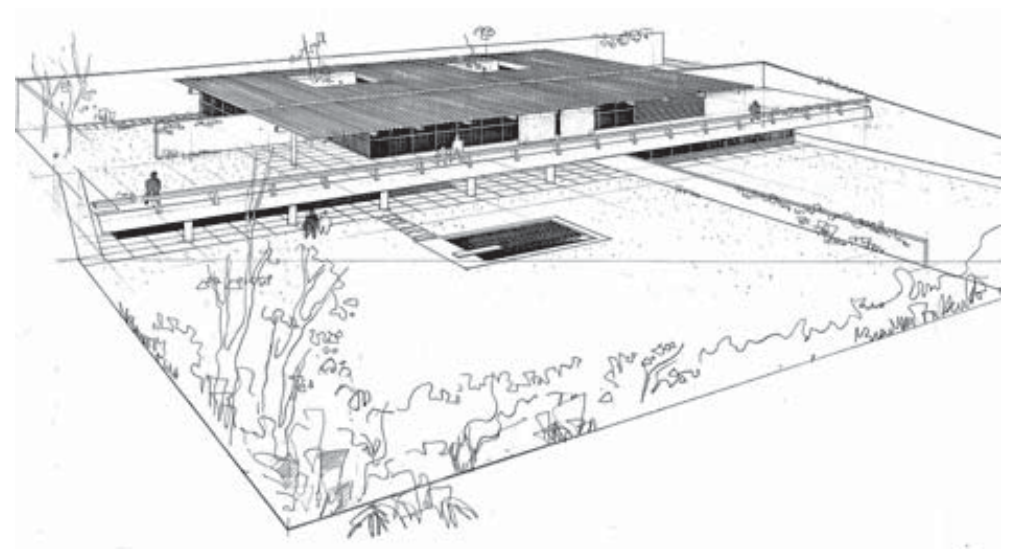

Fig. 4 - Hans Broos. Residência Endlein. Projeto. São Paulo. 1969. pelos jardins. Aproxima-se da concepção da Residência Castor Delgado Perez (1958-1959) de Rino Levi, cuja planta, apesar de ser permeada pelos amplos jardins internos e perimetrais, não perde a concepção unitária. Ao contrário, na casa Lambert os ambientes são "diluídos" em meio ao espaço 
vazio, cabendo somente à laje do pavimento e à cobertura uni-los em uma concepção única e identificálos como um objeto coeso. Aqui não vamos falar na cobertura que abriga, nem de espaços centrais, mas da procura por uma intensa troca entre espaço interno e externo, entre espaço natural e construído. Pesquisas espaciais e formais a que se propõe o arquiteto para resolver dois temas principais - a convivência e a privacidade, que vê na casa um espaço coletivo por natureza.

Ambas residências podem ser consideradas variações da casapátio: casas sobre pilotis, com o programa distribuído em um único pavimento, em que o térreo é mantido livre, com funções de

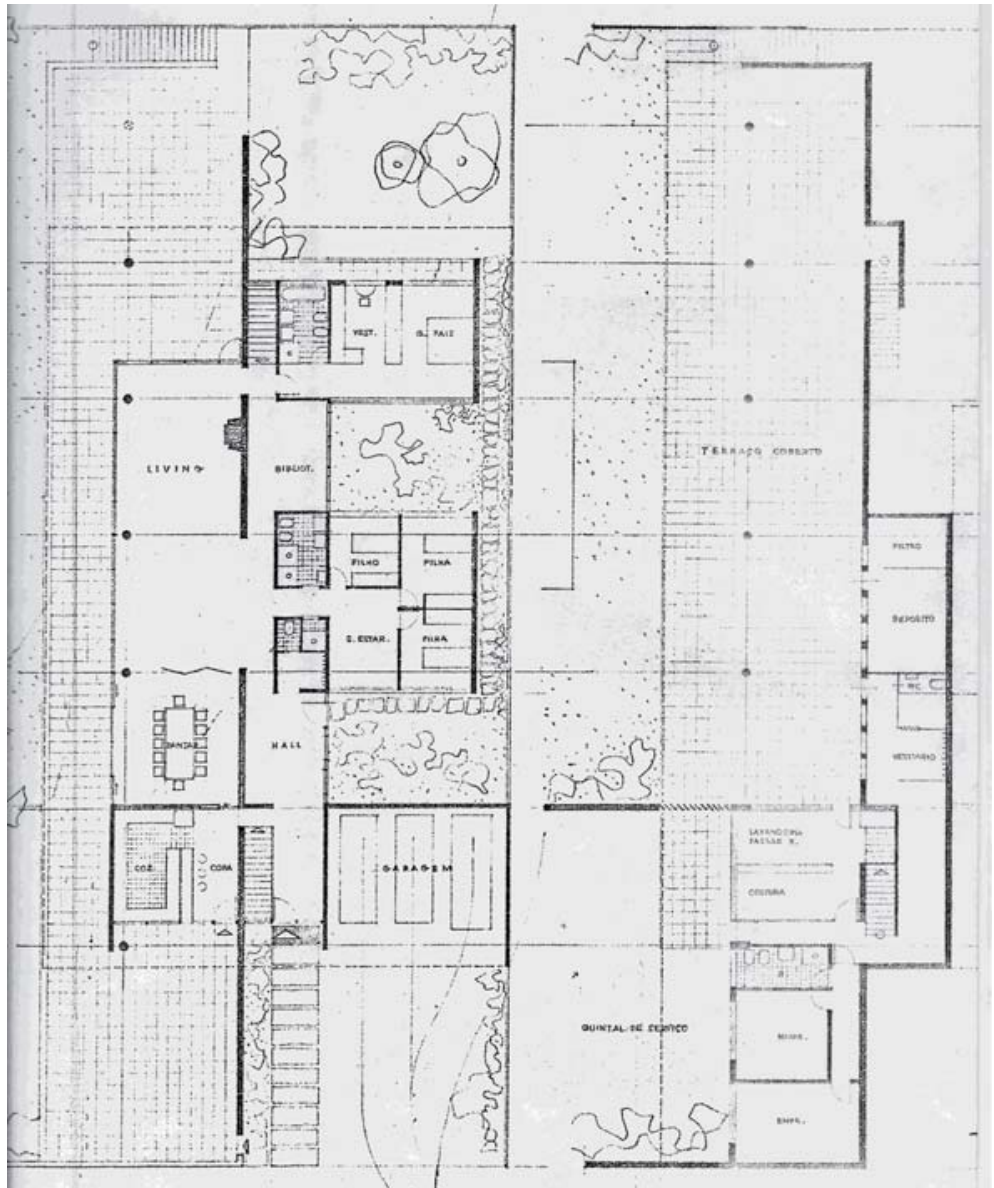

Fig. 5 - Residência Endlein. Planta baixa. serviço e apoio, garagens e/ou espaços de lazer abertos embora na casa Endlein esta solução é propiciada, em parte, pelo declive do terreno, mas, naturalmente, uma opção do partido também. Soluções que encontram eco em algumas formulações da tendência brutalista, como nas casas de Paulo Mendes da Rocha e João de Gennaro (Casa Bento Odilon Ferreira, 1963, Casa do Arquiteto, 1964), e de Artigas (Casa Mendes André, 1966).

As intensas pesquisas espaciais cedem cada vez mais lugar a variações na linguagem formal, com resultados formais bastante distintos entre si, em que o arquiteto procura e aceita diversas influências em seu trabalho. Talvez em nenhuma outra obra isso seja mais notável do que na Residência Jan Rabe (1968), projeto não construído de 1968. Concebida aparentemente como uma caixa porticada, com apoios que

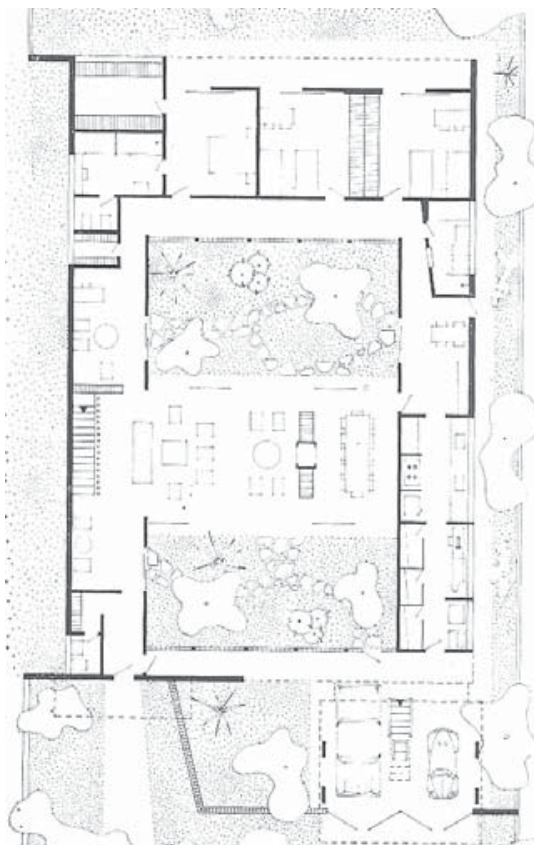

Fig. 6 - Rino Levi. Residência Castor Delgado Perez.1958-1959. Planta baixa. afunilam à medida que tocam o solo em formato triangular, Broos chega a formulações bastante próximas a algumas propostas de Artigas, como a Taques Bittencourt (1959) e Ivo Viterito (1962). O projeto faz menção à grande estrutura, 
envolvente que abraça um determinado espaço, tornando-o permeável, visual e espacialmente, onde procura aumentar a interação entre o homem, a casa e o espaço natural. Entretanto, ao contrário das casas de Artigas, a caixa não é senão apenas aparente; as empenas laterais porticadas, dispostas nas fachadas longitudinais, suportam a uma altura mediana a laje que sustenta a casa propriamente dita.

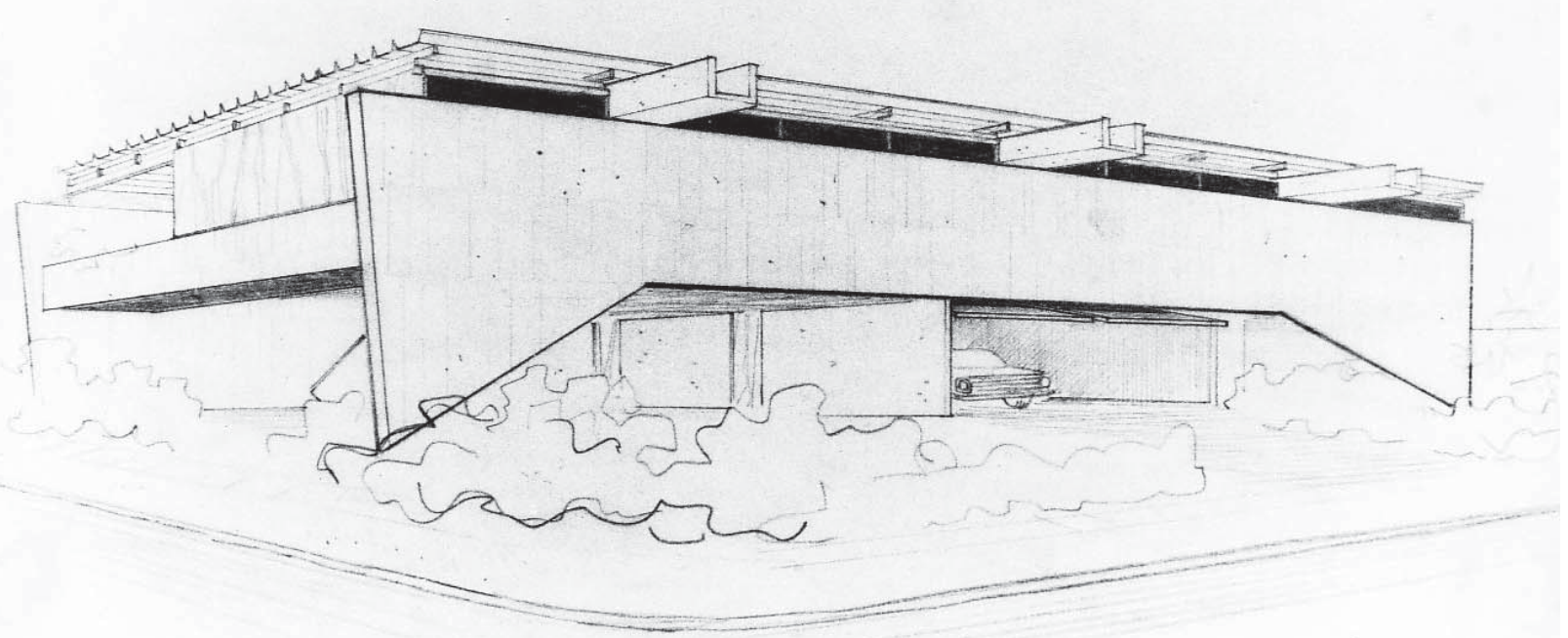

Fig. 7 - Hans Broos. Residência Jan Rabe. Projeto. Blumenau. 1968.
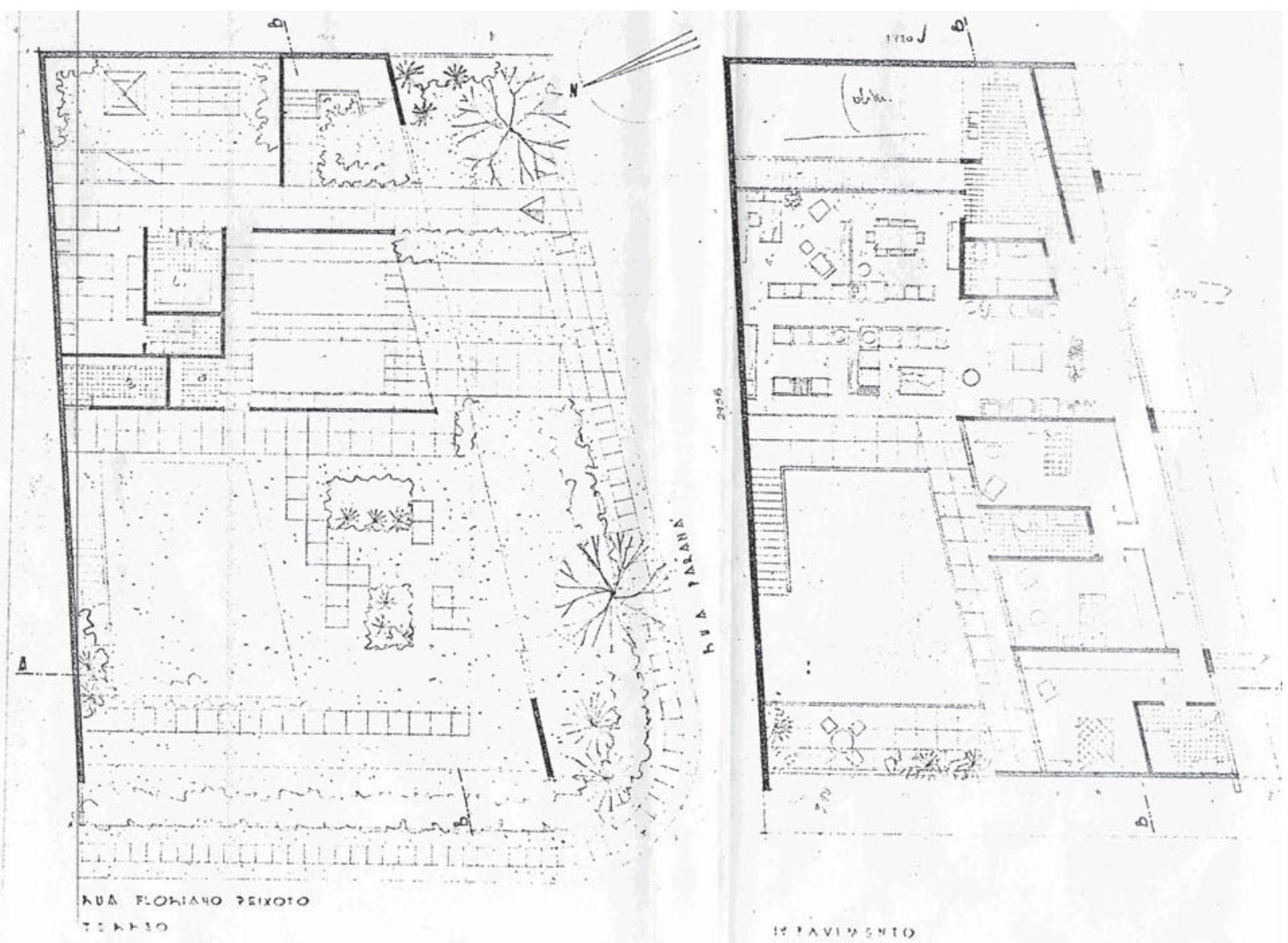

Fig. 8 - Residência Jan Rabe. Planta baixa. 
O fato mais surpreendente nesta casa é sua relação com o exterior. É projetada ao redor de um átrio, como um motivo gerador, local aberto, em franca ligação com o exterior - união no sentido vertical, e não uma ligação no sentido de expansão lateral como mais geralmente se verifica para onde os ambientes da casa se voltam. Há uma mescla surpreendente entre espaço interno e externo, entre público e privado. O átrio é o espaço de transição, "semi-público", por onde se sai do ambiente público e urbano e se adentra o interior intimista e privado. Se na solução formal, o arquiteto sugere uma forte aproximação com o Brutalismo Paulista, muito embora ainda renuncie aos padrões formalizados, prova que no campo conceitual esta aproximação se faz muito maior. Aqui, a cobertura que abarca, é pensada em primeiro lugar como laje do pavimento - a exemplo das casas-pátio anteriores, Lambert e Endlein. Entretanto, sua concepção formal, baseada no átrio e na "envolvente" que abraça os espaços internos, revela o desejo não somente de integração interna, mas de transformar espaço externo em interno, transformar em espaço central da casa, um espaço que é semi-público, aberto, permeável, em continuidade à calçada, numa fluidez espacial surpreendente.

\section{Tambéma Casa do Arquiteto (1971-} 1978) manifesta a centralidade e o poder sugestivo que o átrio encontra em suas proposições. Mas aqui também a cobertura surge como elemento definidor da composição, tanto formal quanto espacialmente. A grande cobertura que abarca o espaço interno, tornando-o "fluido", permeável, à

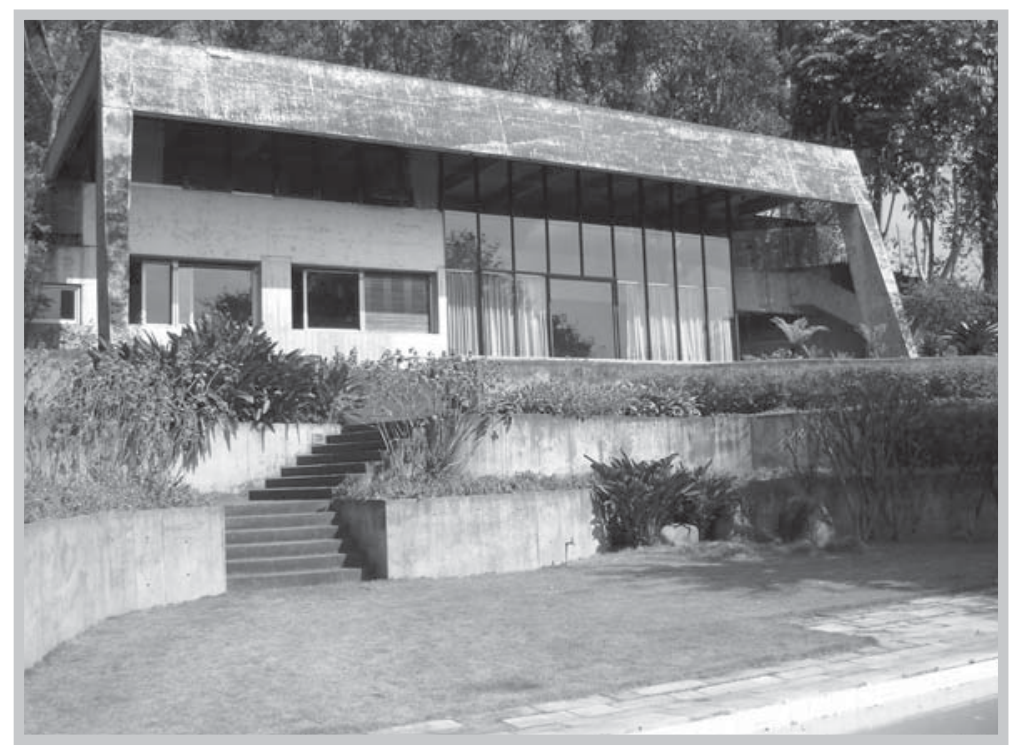

Fig. 11 - Hans Broos. Residência do Arquiteto. São Paulo. 1971-1978.

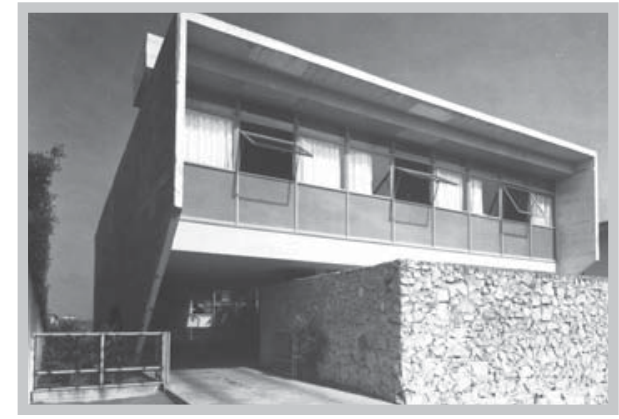

Fig. 9 - Vilanova Artigas. Residência Taques Bittencourt. São Paulo. 1959.

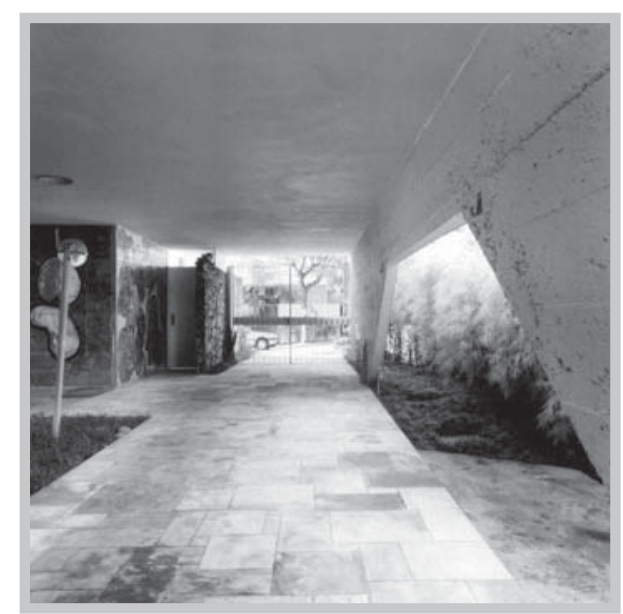

Fig. 10 - Vilanova Artigas. Residência Taques Bittencourt. São Paulo. 1959. maneira do fazer de muitos "brutalistas" surge evidente, com nítidos contornos. Se na Residência Rabe a cobertura era reconhecida de maneira ambígua, aqui não há dúvida quanto seu papel como definidora da volumetria e como envolvente do espaço interno. As casas tem no átrio seu espaço essencial. Se antes ele fazia o intermédio entre espaço público e privado, entre exterior e interior e entre o natural e o construído, agora ele se restringe ao espaço interno e também faz a conexão 
visual entre os ambientes sociais da casa e entre estes com o exterior através do fechamento de vidro. Todo ele com aberturas translúcidas, seu fechamento não impõe limites reais e seu espaço prolonga-se pelas varandas externas e ganha o espaço natural outra vez.

Ambas as casas tem no átrio e na cobertura seus elementos fundamentais e "fundacionais"; a cobertura delimita o território, parece querer demarcar um lugar e sob ela propiciar intensa troca de relações, seja interna - a casa como um "ninho", abrigo, espaço comum de convivência - seja com uma franca relação com o exterior. Entretanto, se ambos partem das mesmas premissas projetuais, orientados para um mesmo fim, buscam a relação com o exterior de maneira oposta. Enquanto a Casa Rabe busca a introspecção, cuja ligação com o exterior se faz somente através do átrio - a casa envolve o espaço natural trazendo-o para dentro da vivência diária, transforma o espaço externo em interno -, na casa do Arquiteto, apesar

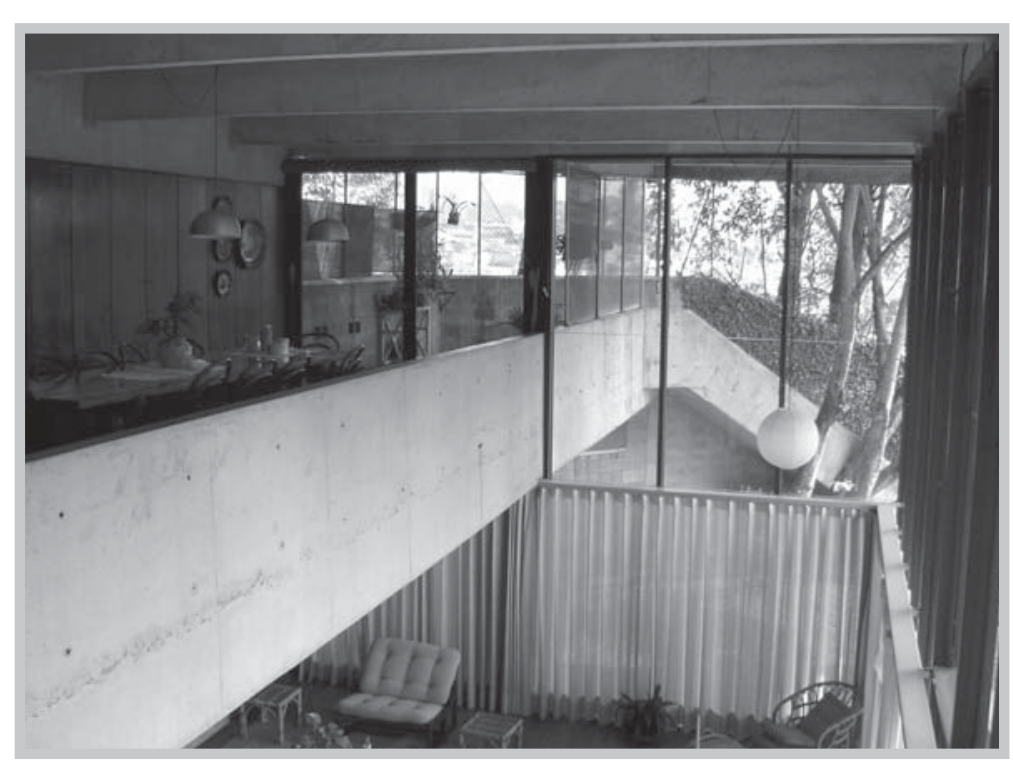

Fig. 12 - Hans Broos. Residência do Arquiteto. São Paulo. 1971-1978.

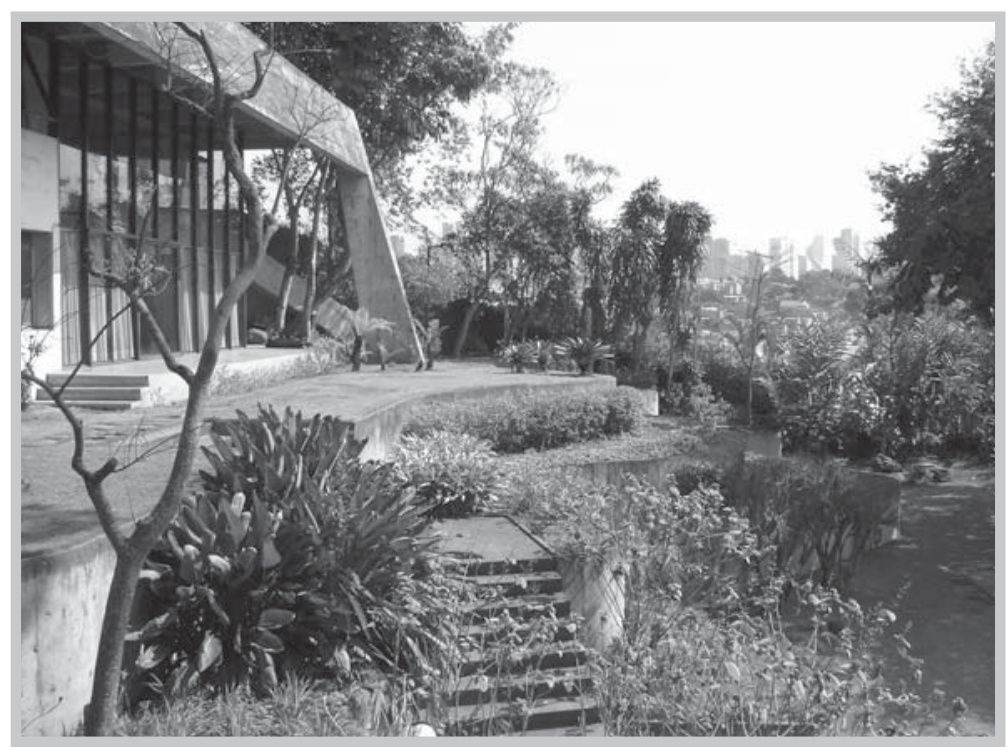

Fig. 13 - Hans Broos. Residência do Arquiteto. São Paulo. 1971-1978. do aparente recolhimento cuja cobertura dá ideia, a noção é de expansão. $\mathrm{O}$ ambiente interno ligase surpreendentemente ao externo, amplia seu próprio espaço, através da continuidade espacial efetuada através do guarda-corpo do mezanino-átrio. $\mathrm{O}$ mesmo guardacorpo de concreto que perfaz o contorno do mezanino prossegue para a varanda adjacente à sala de jantar e daí para a escada até a varanda térrea. Na outra direção, o guarda-corpo também extrapola os limites da casa e prossegue à maneira de um muro sobre o andar térreo/ parcialmente subsolo, e faz a ligação entre o escritório e o terraçojardim. Através de um desenho único e contínuo o arquiteto pretende unir interior e exterior, um elemento que num movimento de expansão extrapola o espaço interno e não reconhece limites, apenas fechamentos de vidro que permitem uma continuidade visual e espacial. 


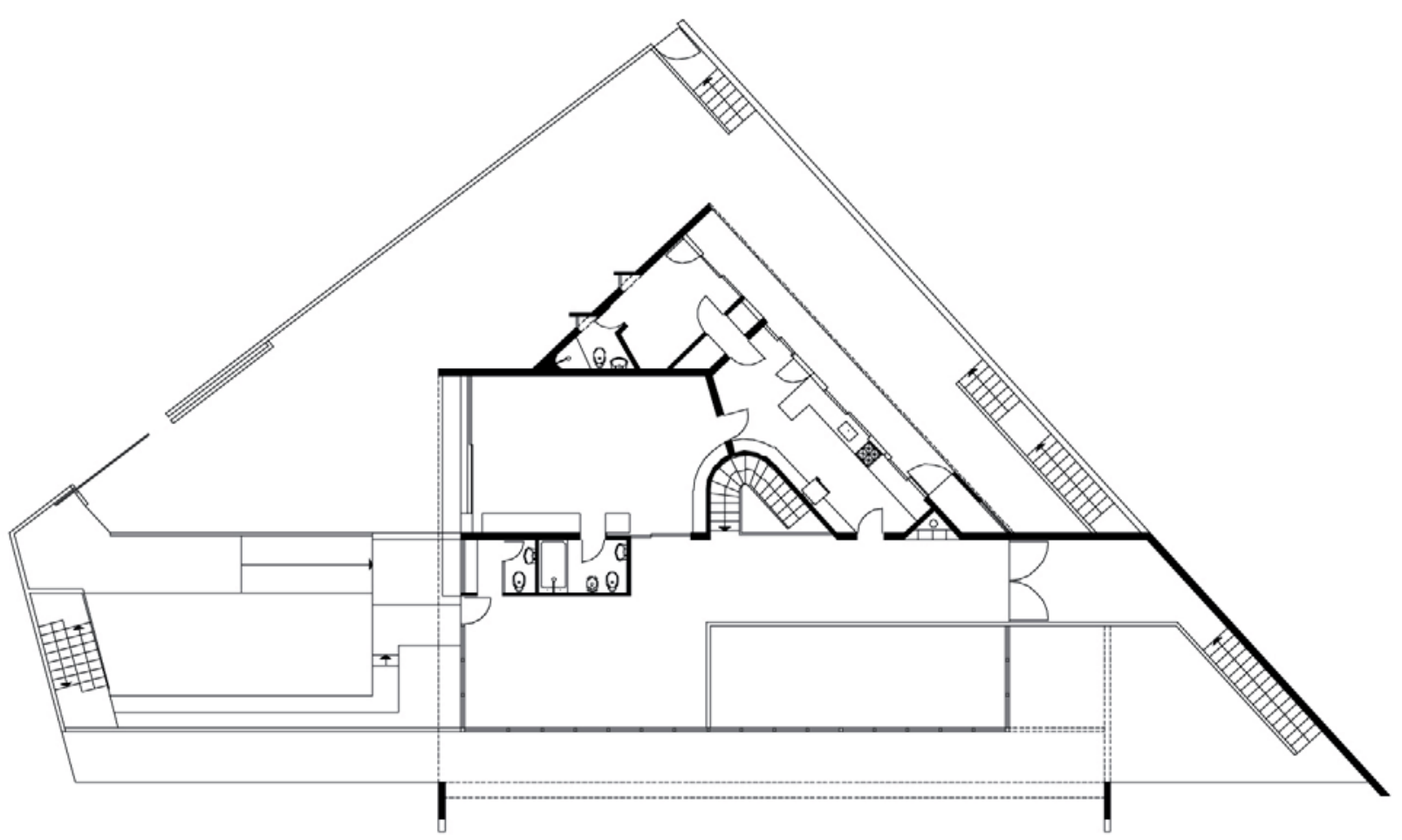

Fig. 14 - Residência do Arquiteto. Planta baixa.

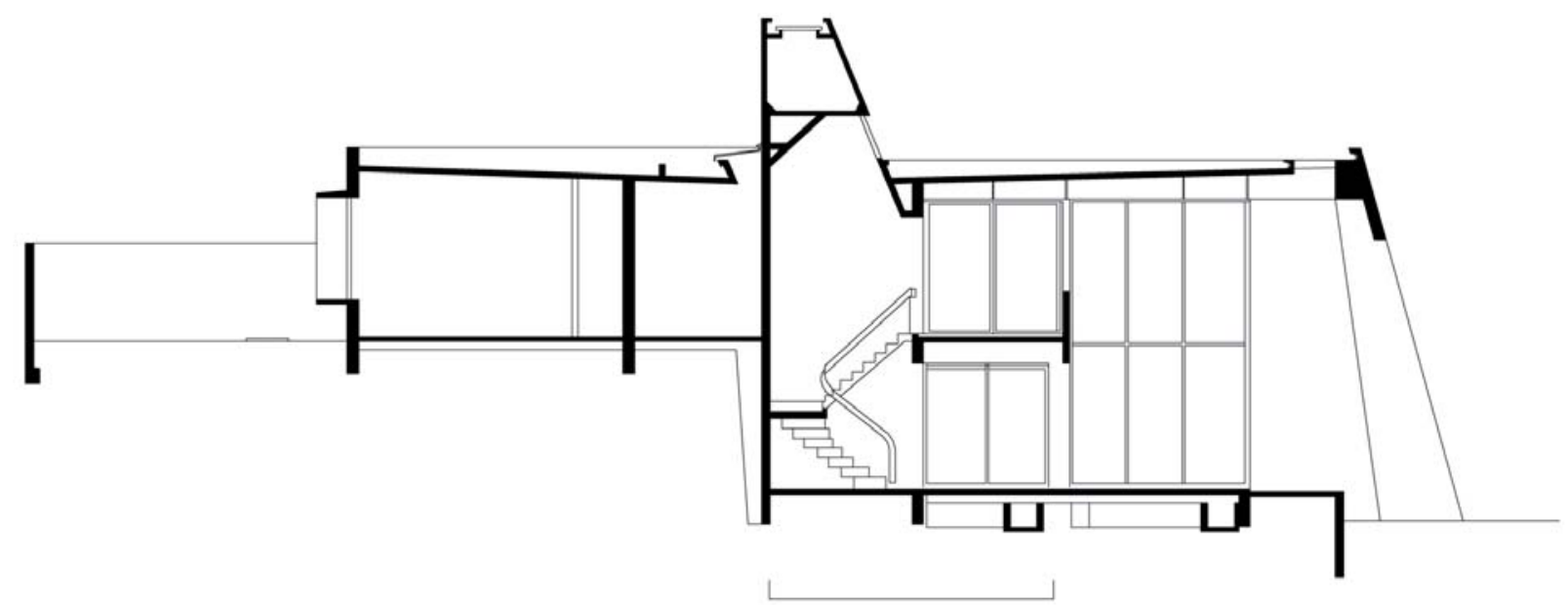

Fig. 15 - Residência do Arquiteto. Corte transversal.

Ao mesmo tempo em que o arquiteto faz de cada projeto motivo de novas investigações, busca novas soluções espaciais a partir de modelos formais já experimentados. No projeto da Residência Rivadávia Wollstein (1974-1976) Broos busca exemplo na Casa Zipser e sua matriz miesiana - projeto concebido em extensão, do tipo pavilhonar, situada em uma plataforma acima da rua, onde temse realçada a cobertura plana em toda a extensão do terreno. Também aqui Broos faz uso do pergolado sobre o acesso principal, dando continuidade e ampliando a já generosa cobertura. $\mathrm{O}$ arquiteto utiliza-se das mesmas premissas formais da casa Zipser, mas agora trocados os materiais. Ao invés da alva platibanda que ocultava 


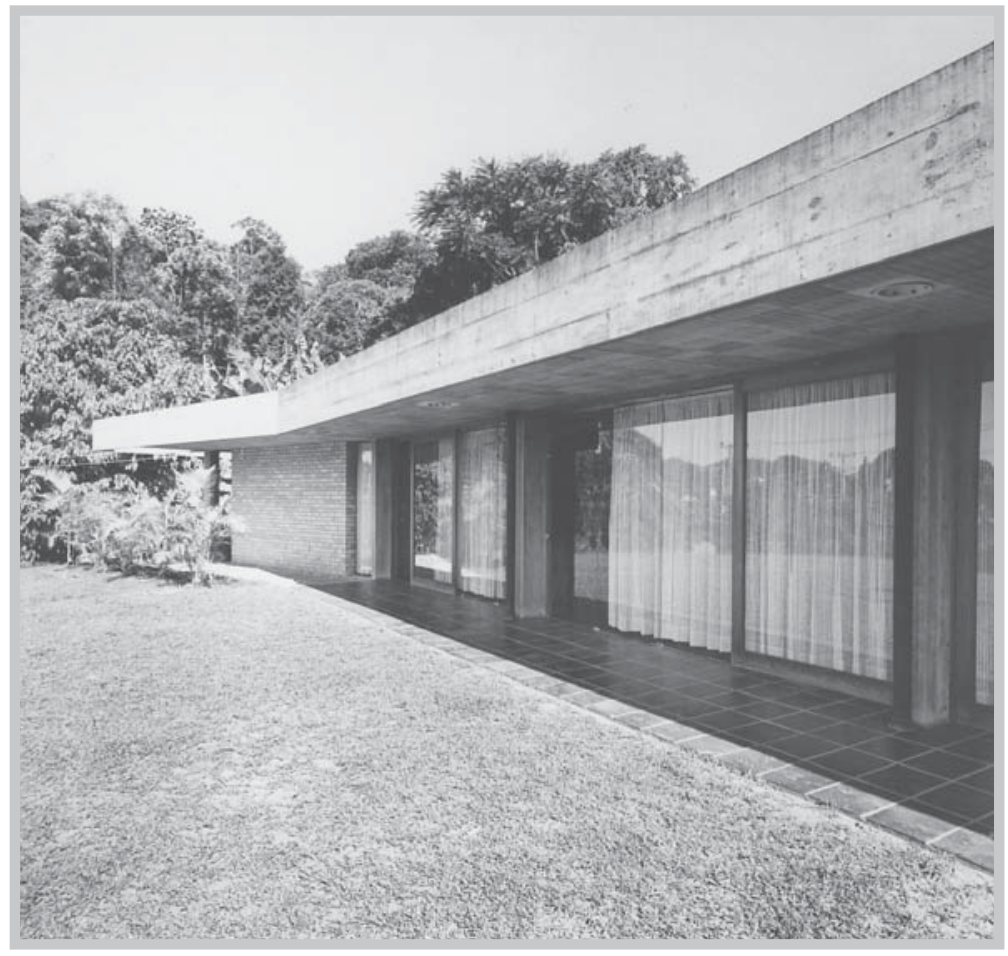

Fig. 16 - Hans Broos. Residência Rivadávia Wollstein. Blumenau. 1974-1976.

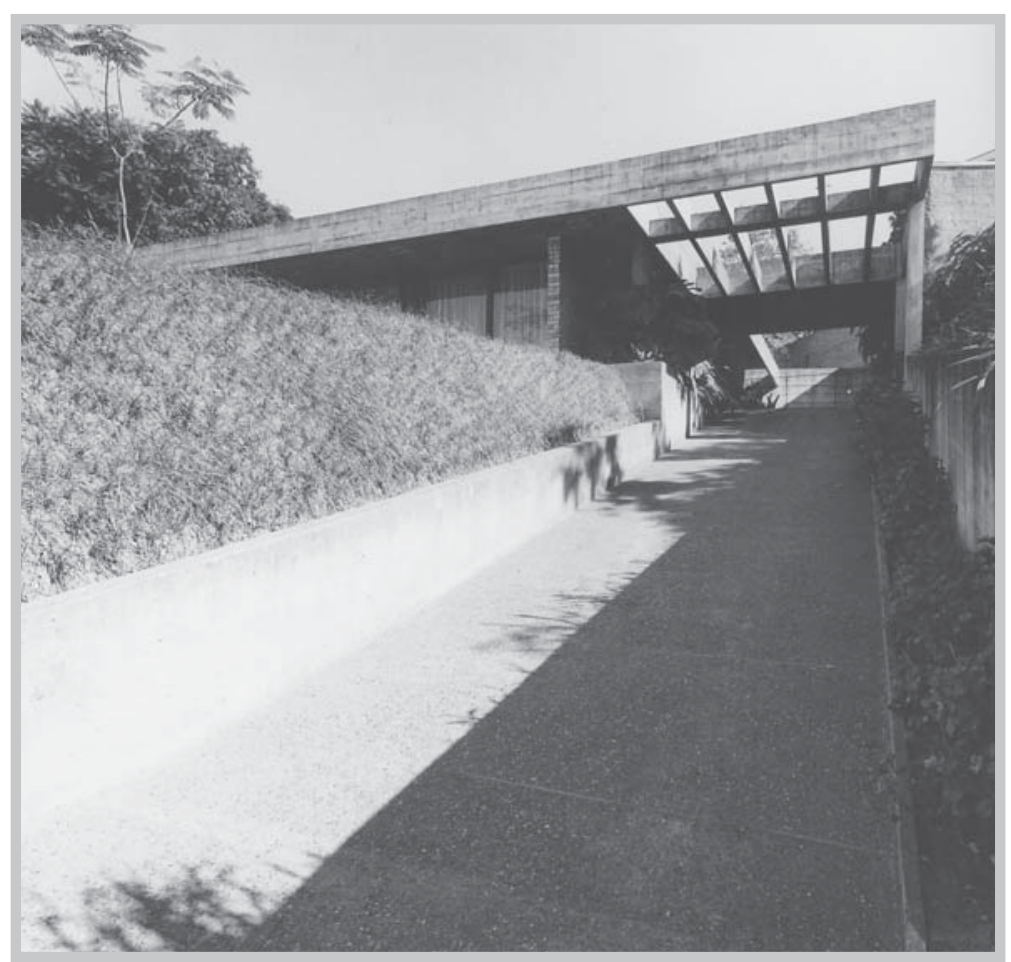

Fig. 17 - Hans Broos. Residência Rivadávia Wollstein. Blumenau. 1974-1976. a tradicional cobertura, tem-se o concreto aparente, utilizado também na estrutura portante - em parte apoios pontuais em concreto, em parte paredes de alvenaria portante com tijolo à vista. Assim como naquela casa, aqui também as amplas aberturas em vidro tendem a incorporar o jardim, tornando fluido o limite entre espaços internos e externos. À maneira da casa Zipser, a casa Wollstein ocupa a metade posterior do lote (de modo irregular, tendo em vista o formato do terreno), mas dispõe, em contrapartida, de um pequeno pátio no cruzamento dos setores social, íntimo e de serviço. Aqui, o átrio das casas anteriores dá lugar ao pátio fechado, numa solução que une planta térrea, mais compacta e horizontalidade dominante.

De modo geral, nas casas de meados dos anos 1970 em diante, das pesquisas com átrios e coberturas em suas pesquisas próximas ao Brutalismo Paulista, o arquiteto volta à concepção do pátio, em basicamente duas soluções: o pátio interno, em plantas que, após articulação e "diluição" da planta baixa dos anos 1960 voltam a ser compactas (ou seja, não o pátio aberto destas casas, mas pátios fechados); e plantas com formatos em "L", "U", ou " $T$ ", que dispõem de jardins externos para os quais os ambientes são voltados, como um resultado do espaço cada vez mais intimista que a proximidade com o Brutalismo proporcionou.

São nestas pesquisas espaciais do arquiteto, que encontramos referências, citações não apenas formais, mas principalmente conceituais do Brutalismo, 
onde Broos pretende desenvolver novas experiências e aprofundar investigações sobre a interação homem e espaço construído, que já pressupõe o espaço natural. Voltando ao exemplo da Casa do Arquiteto, extrai-se outro importante aspecto de sua arquitetura.

Importante parte do substrato brutalista prioriza a noção da arquitetura como fato isolado, autônomo, em aparente desvio e ruptura com o meio que o cerca, típico do caráter "exemplar"1 desta arquitetura, que embora não seja insensível ao meio, renuncia deliberadamente a um enlear-se com a paisagem (também aqui pode ser em parte explicado o gosto pelas estruturas suspensas, como em São Bonifácio, ${ }^{2}$ em que o edifício ganha notabilidade, desprende-se visualmente do contexto, e demonstra certo apreço pela monumentalidade).

Entretanto, na Casa do Arquiteto, como em muitas obras, a arquitetura busca uma relação mais próxima com a paisagem, de extensão e conexão física, não apenas visual. Vemos isso também na Fábrica da Hering Matriz, ${ }^{3}$ ou até mesmo na Casa Zadrozny, em como Broos aproveita o desnível do terreno para dar aparência única e linear à construção. Na Casa do Arquiteto, o mezanino e a cobertura são gerados em função do grande caimento do terreno; e a partir da casa formamse platôs, em concreto aparente que seguem as curvas de nível do terreno, com paisagismo de Roberto Burle Marx. Aqui toda paisagem é construída, dominada e adequada às necessidades do homem. Na parte mais baixa encontra-se o escritório, e acima dele, um terraço-jardim em continuidade com o lote.

Seja neste exemplo, nas Casas Zadrozny, Zipser, na Fábrica da Hering, ou em São Bonifácio, a arquitetura modifica a realidade em que se insere, e impressões de leveza, deslocamento e, também

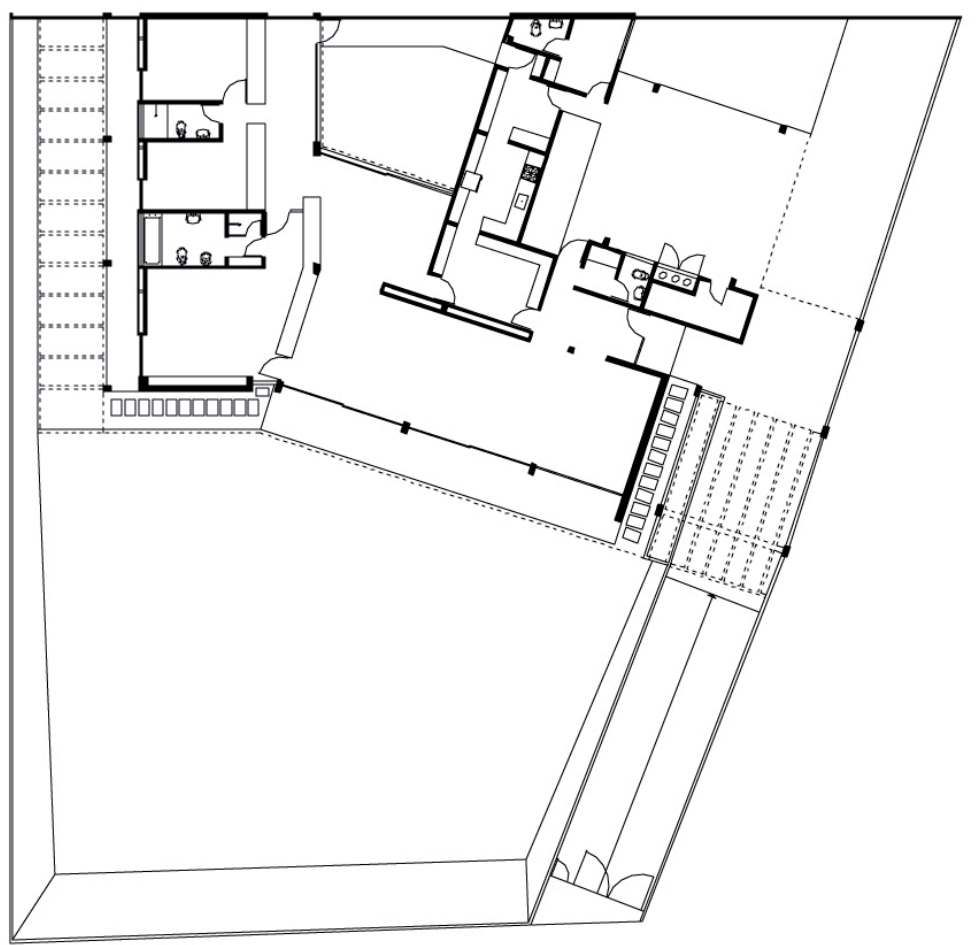
tensões e oposições ao ambiente, são atribuições feitas em conjunto

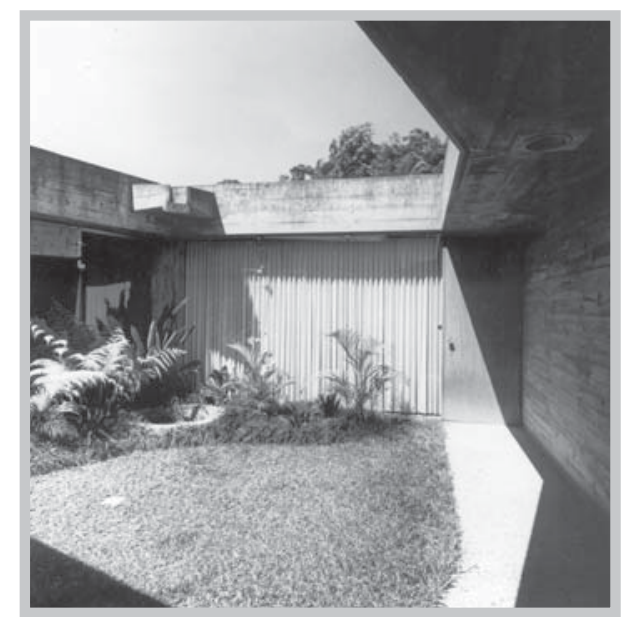

Fig. 18 - Hans Broos. Residência Rivadávia Wollstein. Pátio interno. Blumenau. 1974-1976. 
com o espaço externo, numa concepção formal que tenta ser única, em perfeita relação com o espaço circundante.

\section{Igreja e Centro Paroquial São Bonifácio}

O projeto da Igreja e Centro Paroquial São Bonifácio (1964-1966) ${ }^{4}$ revela, de forma indubitável e surpreendente, a aproximação do arquiteto com o Brutalismo Paulista, através da radicalidade da proposta da igreja vedada e suspensa sobre pilotis. Sua primeira obra construída em concreto aparente revela forte substrato corbusiano, entretanto, referente muito mais ao primeiro Corbusier do que aquele pós-guerra, com que nitidamente o Brutalismo se filia; muito mais ao Corbusier da Villa Savoye que prima pela elegância e pureza formal, mas com a cor e a textura que deram vida à Unité, que tanto influenciou o Brutalismo em escala mundial e, paulista. A corpulência que São Bonifácio inadvertidamente remete, é devido, claro, ao uso do concreto aparente, de modo rude, com o rastro de seu feitio e, também ao quase total fechamento do volume. E apesar das referências possíveis, nenhuma delas é direta e emulativa; parece ser muito mais fruto de proposições advindas de referências múltiplas, até mesmo da própria obra, catalisada pelo meio paulista, onde o Brutalismo já se encontrava arraigado como tendência. Se por um lado chama a atenção a massa corpulenta da caixa suspensa, por outro, é inegável a surpresa que causa a esbeltez e elegância dos seus apoios.

O tom radical da proposta é, em parte, explicado pela situação do terreno; em parte pelo vasto programa proposto, mas também, e talvez principalmente, pela motivação com que a particularidade do programa parece tocar o arquiteto.

Broos tinha uma situação contrastante a resolver: construir uma igreja em um

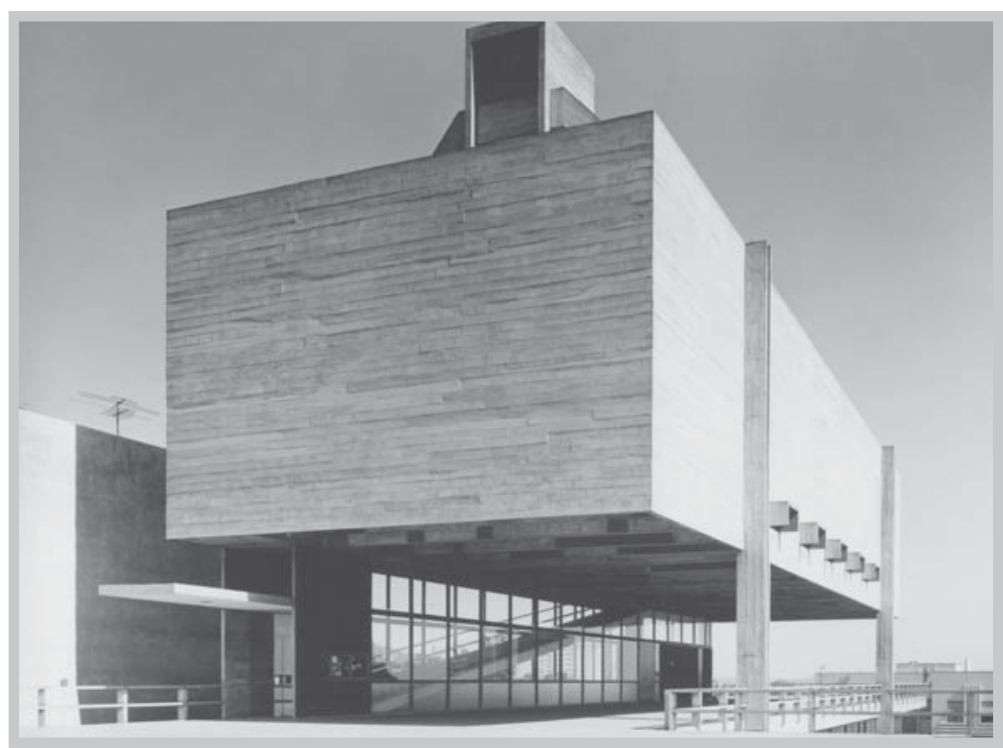

Fig. 20 - Hans Broos. Igreja e Centro Paroquial São Bonifácio. São Paulo. 1964-1966. contexto urbano já formado, com a necessidade de sua inserção num lote estreito em uma rua predominantementeresidencial, eao mesmo tempo, propiciar à igreja um espaço de reclusão sem interferência externa. O programa, vasto e diverso, propiciava a diferenciação em dois blocos distintos: além da igreja, previa toda uma estrutura de moradia para os padres e hóspedes, com a possibilidade de encontros e conferências. Assim, o arquiteto aproveitou o desnível do terreno de 
pouco mais de quatorze metros para colocar a partir do nível da rua, três andares subsolo, com dormitórios para hóspedes, biblioteca, moradia para padres, asilo, ambulatório, enfermaria, consultório, sala de reuniões, ambientes auxiliares e salão de conferências, localizado junto à rua com pé-direito duplo. No terceiro subsolo ficam as garagens e serviços de apoio.

Deste modo, todos estes ambientes localizamse abaixo do nível da rua, permanecem ocultos aos olhos do visitante. Acima da rua, avistase tão somente o volume suspenso da igreja, recuado do passeio, que lhe garante certo tom monumental. Abaixo dele, tem-se o pátio criado em continuidade com a rua, a partir do qual temse a visão para o Parque Ibirapuera. De qualquer modo, parece ter sido a solução ideal, que priorizava acomodar de forma independente os dois programas diferentes; e dar à igreja volume

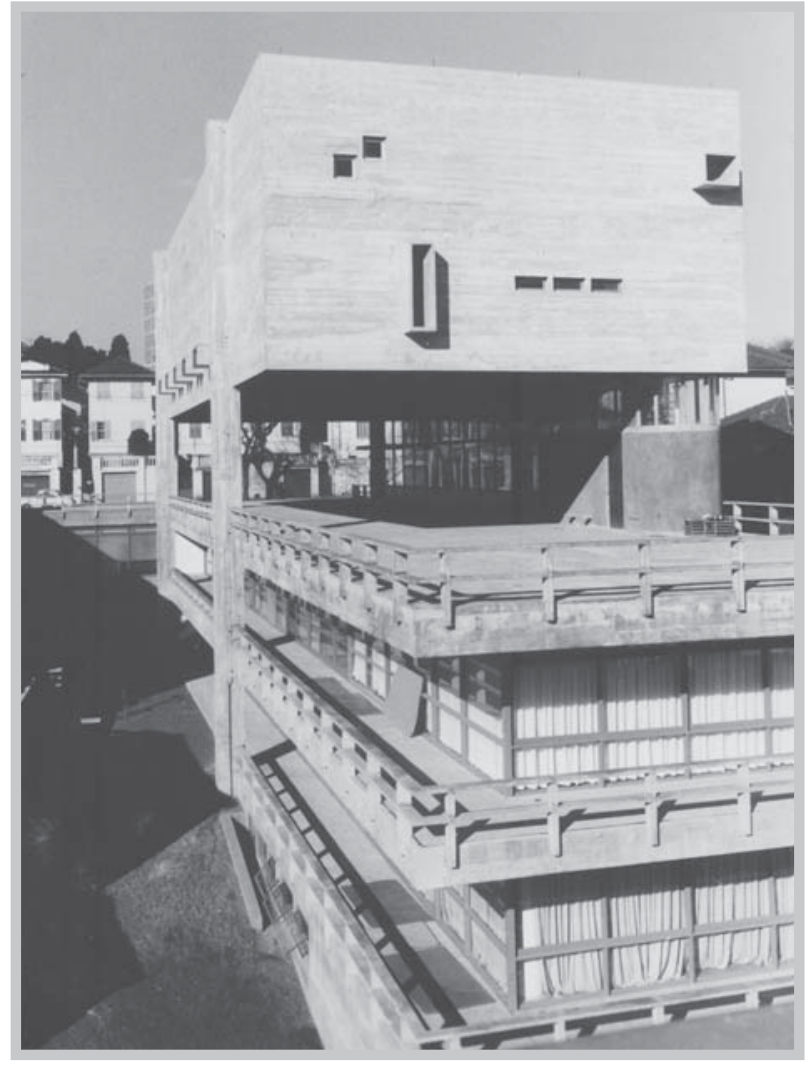

Fig. 21 - Hans Broos. Igreja e Centro Paroquial São Bonifácio. São Paulo. 1964-1966. próprio e ressaltado do entorno, ou seja, uma solução formal condizente com um programa que parece exigir soluções especiais, até dos mais cépticos arquitetos. ${ }^{5}$ Três degraus diferenciam a "praça" semi-pública da rua, e assim o arquiteto distingue sutilmente aquela arquitetura do entorno e o novo espaço formado, assim como fizera Eiermann na Gedächtniskirche, ou faz Mies em várias de suas propostas.

Broos no memorial do projeto assinala a situação urbana como "desfavorável" rua residencial, estreita, "monótona", com espírito comercial; terrenos semelhantes nas dimensões e o alinhamento estrito das construções. "Não existe praça, nem alargamentos, nem área de descanso para o transeunte [...]". ${ }^{6}$ Broos parece querer recriar, através deste projeto, a tradicional visão da igreja localizada em um largo, e seu posicionamento distante da rua possibilita a distância indispensável para apreciá-la em sua "majestosidade necessária". Broos soube equilibrar o recinto fechado e pesado da igreja com a liberação do solo, de modo que continuamos avistando a cidade através do pátio, formado em continuidade ao passeio. O volume da igreja, recuado em aproximadamente treze metros da rua, não rompe com a escala do entorno, e contribui com a noção de "respiro" urbano, na rua estreita e então composta por casas alinhadas aos limites frontais e laterais dos terrenos.

A solução remete irremediavelmente ao anteriormente construído MASP de Lina Bo Bardi, tanto em sua fachada voltada para a Avenida Paulista quanto a 
posterior. É inegável a aproximação entre os dois prédios e a solução de caixa suspensa por apenas quatro pilares (com soluções estruturais bastante diferentes

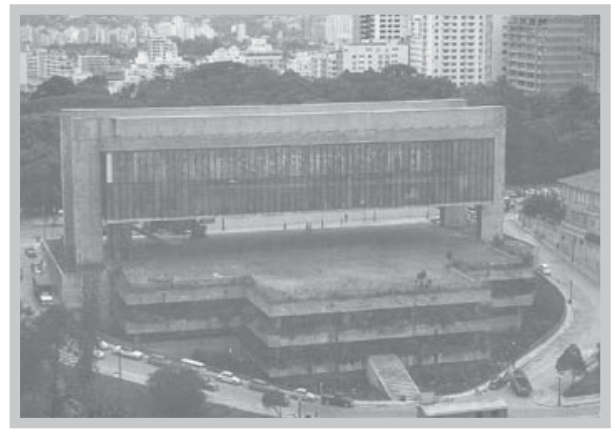

Fig. 22 - Lina Bo Bardi. Museu de Arte de São Paulo. São Paulo. 1957-1968. num caso e noutro), ainda mais se compararmos com os primeiros desenhos do projeto de Lina, quando em sua proposta, a arquiteta sugeria a caixa totalmente opaca (e, portanto, mais adequada à função museológica).

O projeto de São Bonifácio é concebido em volume e traços essenciais; ao volume corpulento da igreja é contraposto a esbeltez dos apoios, a delicadeza da rampa e sua cobertura; à dureza, rusticidade e opacidade do concreto aparente, o vidro que envolve a rampa e a torna um convite à entrar. Mesmo sem a procura de uma linguagem ostensivamente estrutural, esta arquitetura é toda ela, estrutura. Com paredes laterais pensadas como vigas de meros $20 \mathrm{~cm}$ de largura, a caixa suspensa da igreja é sustentada por quatro esbeltos pilares que se sobressaem exteriormente em $50 \mathrm{~cm}$ da parede-viga. Ainda assim os pilares recebem uma cavidade central (formato $U$ ) para abrigar os dutos de água pluvial. O campanário, apoiado nos dois pilares fronteiros, eleva-se igualmente em traços estruturais essenciais; ao invés da massa, um esqueleto estrutural como contraponto ao fechamento do corpo da igreja.

E embora o radicalismo que a proposta encerra, neste projeto, mais que em qualquer outro, o arquiteto faz uso de um complexo sistema de relações proporcionais que remetem à tradição clássica. A exemplo de Kraemer, Broos parece buscar nas leis “imutáveis" de proporção, ordem e clareza o sentido de beleza que o programa lhe parece reclamar. Mesmo sem fazer uso de elementos simbólicos que anunciem alguma aproximação à tradição da arquitetura religiosa, Broos submete todo o projeto a um rigoroso esquema de relações, como que para lhe conferir uma ordenação maior, ou uma validade atemporal. Na fachada principal, o vão do pátio,

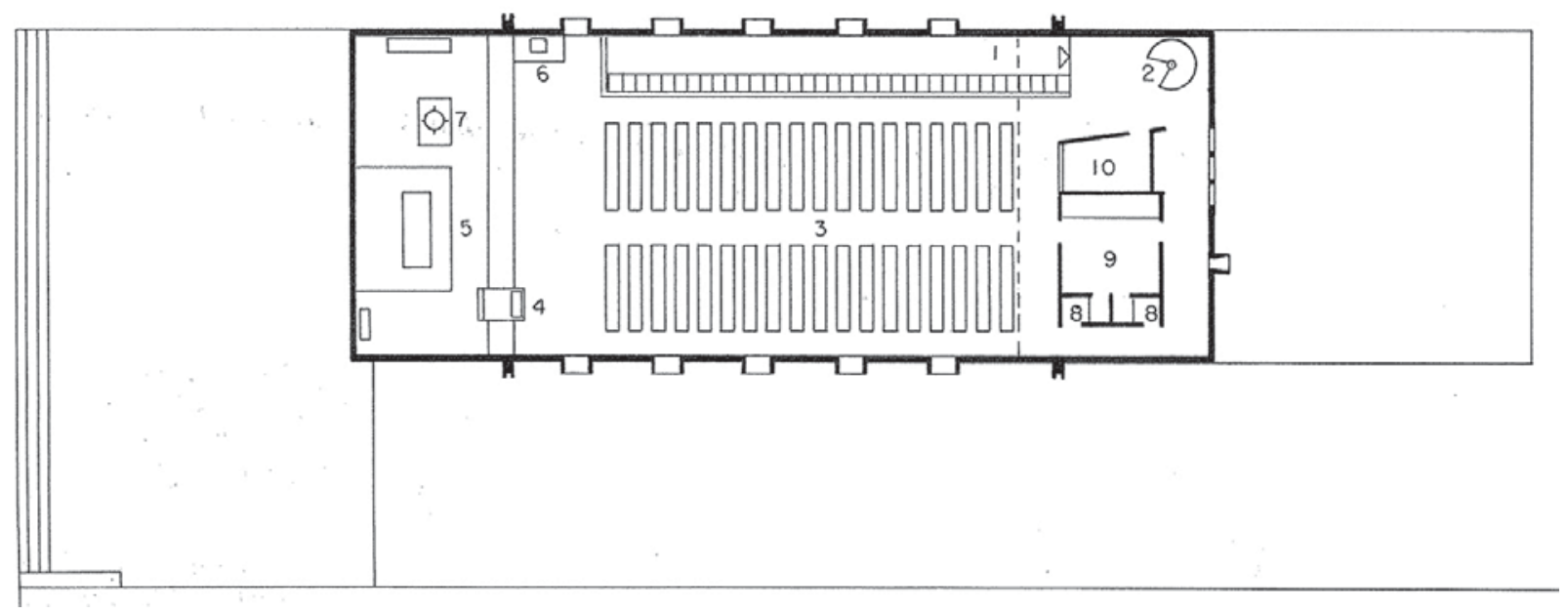

Fig. 23 - Igreja e Centro Paroquial São Bonifácio. Planta baixa. 
o volume da igreja e deste até a altura superior do campanário configuram proporção em ritmo vertical de 1:2:1, enquanto na fachada lateral, os apoios perfazem um ritmo longitudinal de proporção 1:3:1 a partir dos balanços e vão central. Também o campanário, uma "caixa” sineira retangular, é concebida na proporção 1:1:2.

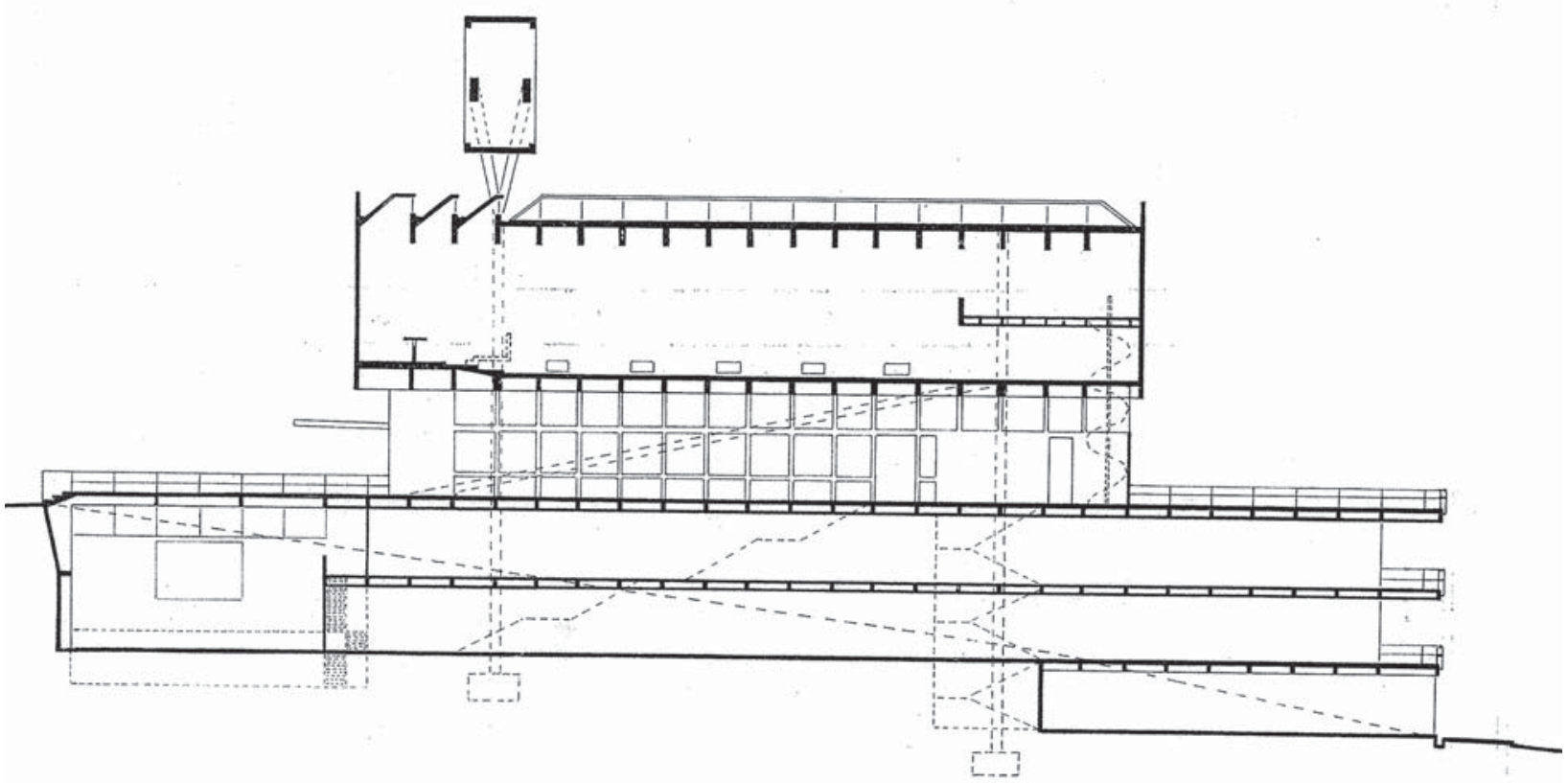

Fig. 24 - Igreja e Centro Paroquial São Bonifácio. Corte Iongitudinal.

Do volume opaco e fechado da igreja sobressaem-se apenas pequenas aberturas laterais e nos fundos do prédio. Aberturas precisamente demarcadas que não permitem desfazer a ideia de bloco cerrado. No interior, o volume único da igreja, com uma linguagem reduzida ao essencial, remete ao aspecto rude e tosco do exterior. O concreto aparente se faz presente em quase todos os acabamentos internos, segundo Broos, para "transparecer a expressão de veracidade do pensamento religioso". De um lado tem-se o vazio da rampa e a luminosidade que avança para o espaço interno; de outro, os belos desenhos em alto-relevo das Estações da Via Sacra, do escultor Kurt Bielecki, encravados no concreto. Todos os elementos internos são de autoria do arquiteto. Para o desenho da pia batismal Broos inspirase no elegante desenho de Egon Eiermann para a Matthäuskirche, reelaborada e redimensionada para a Gedächtniskirche.

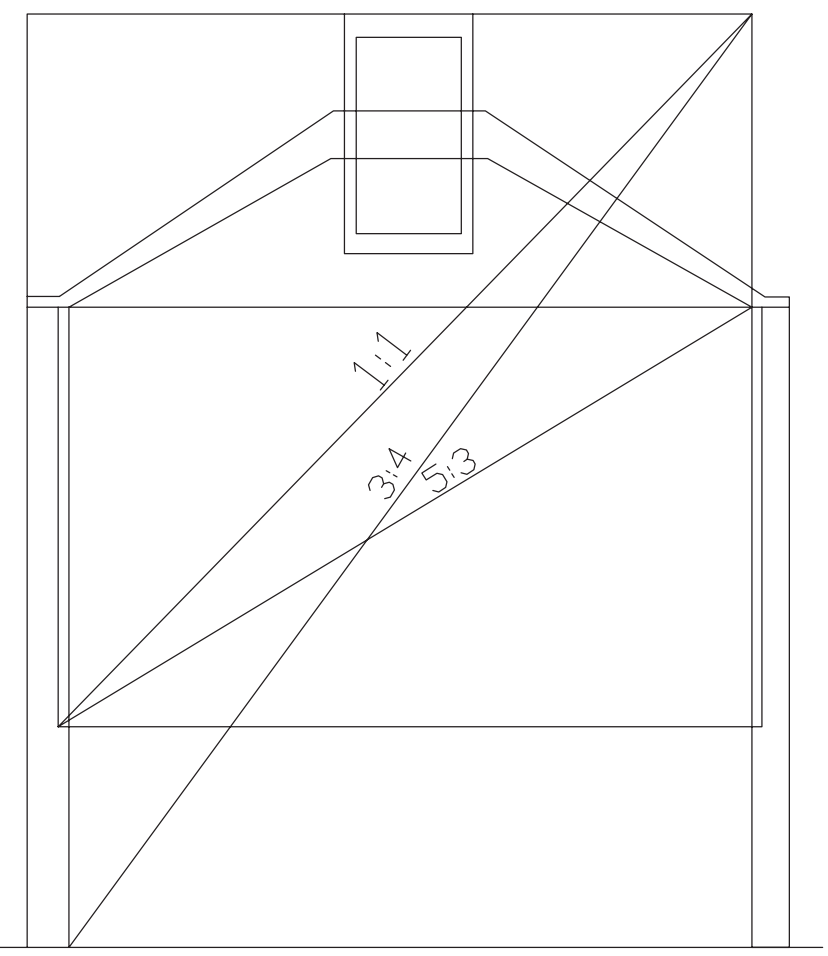

Fig. 25 - Igreja e Centro Paroquial São Bonifácio. Relações de proporção. 


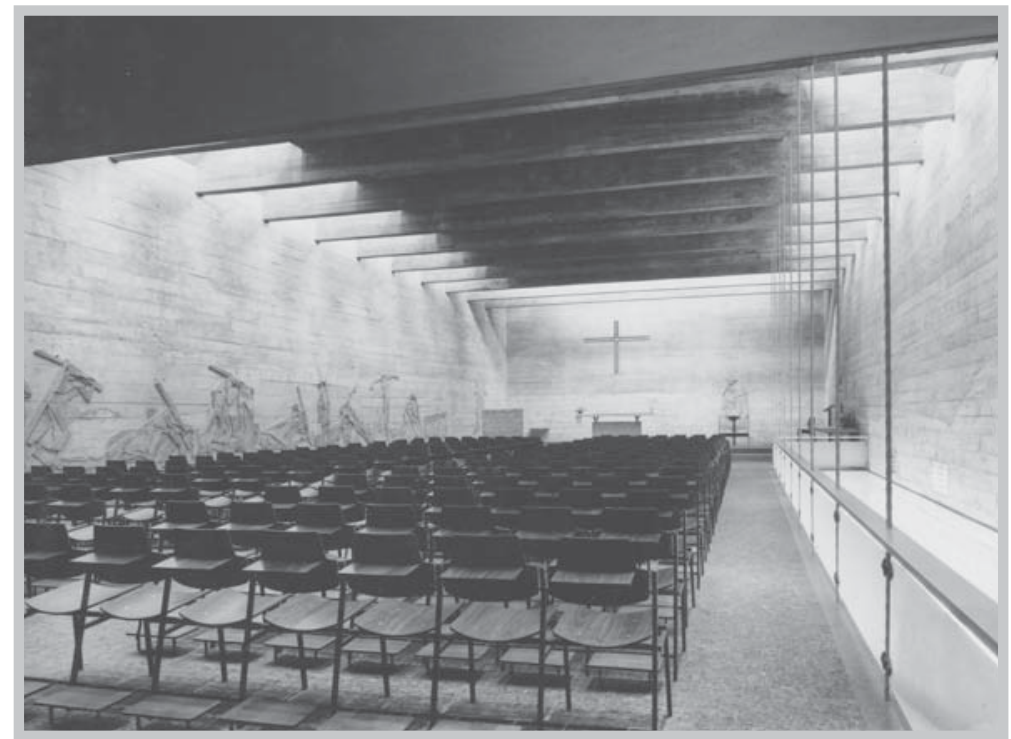

Fig. 26 - Hans Broos. Igreja e Centro Paroquial São Bonifácio. São Paulo. 1964-1966.

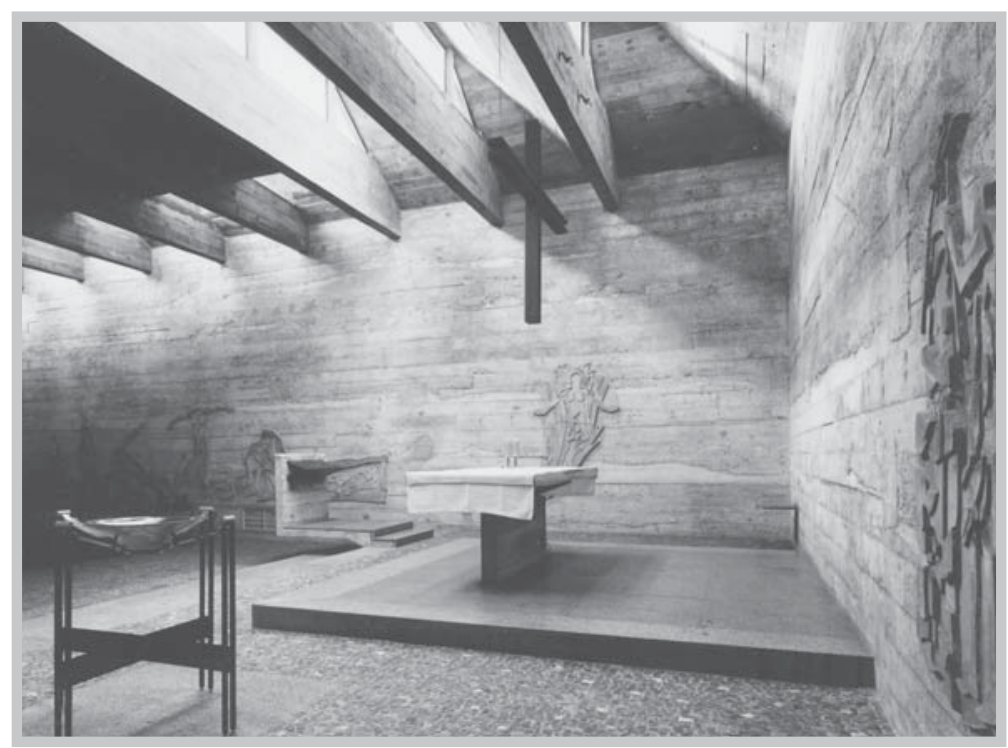

Fig. 27 - Hans Broos. Igreja e Centro Paroquial São Bonifácio. São Paulo. 1964-1966.
No ambiente simples de seu interior, a luz recebe especial atenção, e parece preencher $o$ espaço num efeito cênico de áreas iluminadas e sombreadas. As vigas transversais, dispostas a cada $1,80 \mathrm{~m}$, escondem em seu entremeio aberturas zenitais que conferem iluminação sabiamente administrada: ao longo das paredes laterais, apenas tangenciando o espaço; difusa e suave ao longo da "nave", e intensificada sobre o altar. Esta dureza e presença unívoca do concreto aparente e sua textura grosseira, tem como contrapeso a suavidade da luz, que pretende evocar a espiritualidade e propiciar o lugar de reclusão ideal.

Assim como São Bonifácio pretende criar o espaço de intimismo e reclusão, também outros projetos vêem no desenho da caixa fechada, alheia ao mundo externo, a solução ideal para o espaço sacral. É recorrente o desejo de diferenciação e proteção da igreja em relação ao exterior; protegê-la sem deixar de realçá-la, demarcando o lugar sagrado do profano: "Ao redor deste outro espaço, como eu vejo o espaço da igreja, necessita-se da parede fechada, que simultaneamente delimita e protege esse outro espaço contra o resto do mundo." A A "caixa" como lugar sagrado, que protege e diferencia o lugar sagrado do profano é usado por Düttermann em St. Agnes em Berlim (1964-1967).

Entretanto, esta diferenciação com o exterior nem sempre vem através da concepção da caixa. A Pfarrkirche Christi Auferstehung (1964-1970) projeto de Gottfried Böhm em Colônia, remete a uma fortaleza deífica, que guarda um mundo à parte. Mais uma vez sua obra assume um ar escultórico, construída em concreto aparente e tijolo à vista. Ao contrário da simplicidade e concisão de São Bonifácio, Böhm sugere o gesto expressionista e a profusão de elementos; 
ao contrário do espaço único, o espaço multifário e de múltiplas miradas. Passados mais de dez anos dos projetos das igrejas de Böhm no Brasil e de Itoupava Seca, a profunda diferença que as sinalizava também é aqui percebida; aqueles projetos, singelos se comparados às realizações de agora, já anunciavam e continham os encaminhamentos das obras de seus autores. Também através destas obras se faz notar a diferença com que o Brutalismo se projetou num e noutro país, se aceitarmos que ambos os projetos, de Böhm em Colônia e de Broos em São Paulo, são formulações que refletem as feições, grosso modo, com que a tendência se cristalizou na Alemanha e no Brasil.

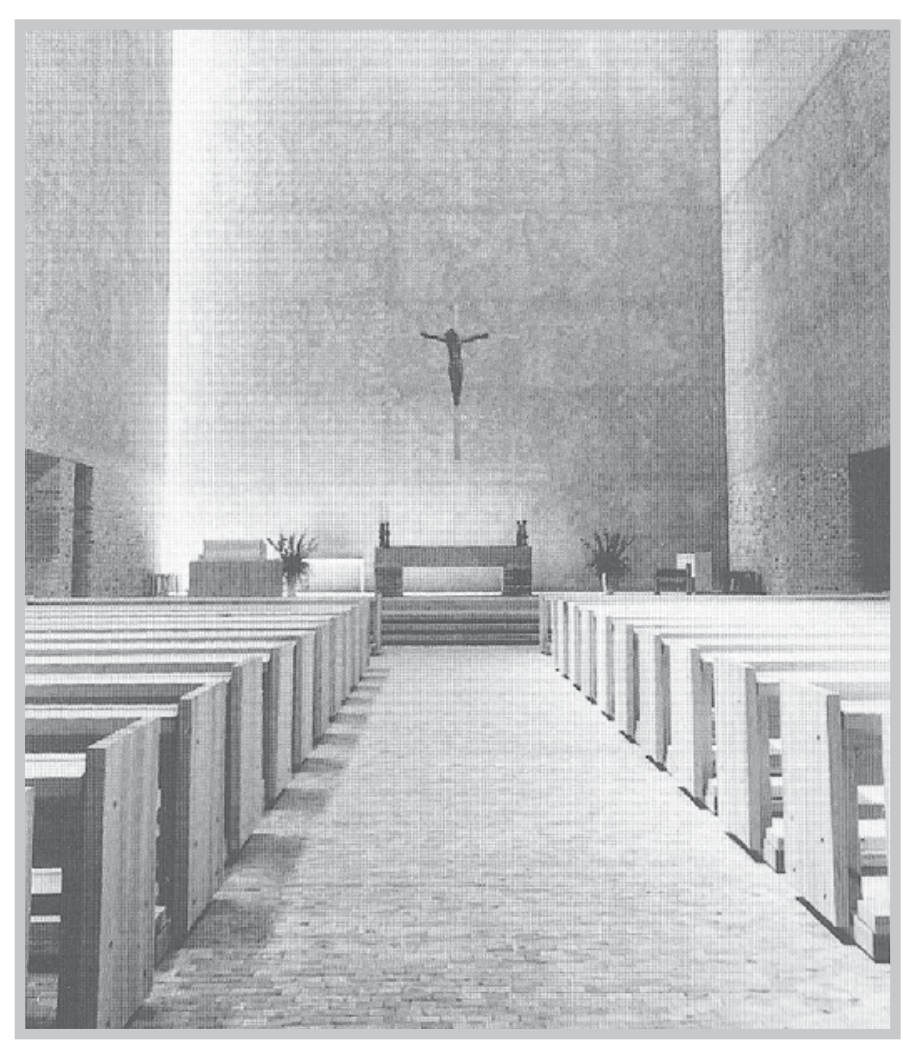

Fig. 28 - Werner Düttmann. St. Agnes. Berlim.1964-1967.

Entretanto, mesmo após esta inegável aproximação com o Brutalismo Paulista, o fato de Broos sempre repensar sua arquitetura sobre bases firmes e sua inquietação criativa constante, asseguram sua autonomia em relação à Escola Brutalista, mesmo quando aceita seus pressupostos formais e conceituais. Isso também, porque o faz de maneira bastante particular, através de referências várias, e sem o desejo de virtuosismo estrutural e o exagero formal que marcam algumas obras, principalmente a partir dos anos 1970, primando mais pela limpeza formal e desenho estrutural bastante simples.

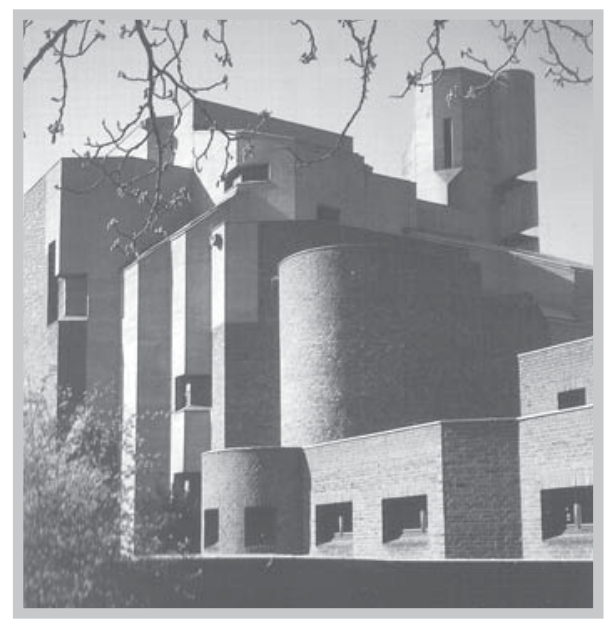

Fig. 29 - Gottfried Böhm. Pfarrkirche Christi Auferstehung. Colônia. 1964-1970.

A partir dos anos 1970, a obra do arquiteto demonstra maior sintonia com o Brutalismo Paulista, agora tendência plenamente difundida, em um misto que envolve sua base arquitetônica, referências alemãs e afinamento às matizes locais. Sua obra surge como mais um exemplo do grau de heterogeneidade e hibridização que a arquitetura Brutalista brasileira assumiu, que demonstra que teve praticantes diversos, e mais do que concorrer para uma mesma direção ou linguagem unívoca, convida à complexidade e à dispersão. Os últimos estudos acerca do tema tem colaborado para endossar esta ideia, mais que estreitar, ampliar o leque. ${ }^{9}$ Quando muitos se apoderam de uma determinada linguagem 


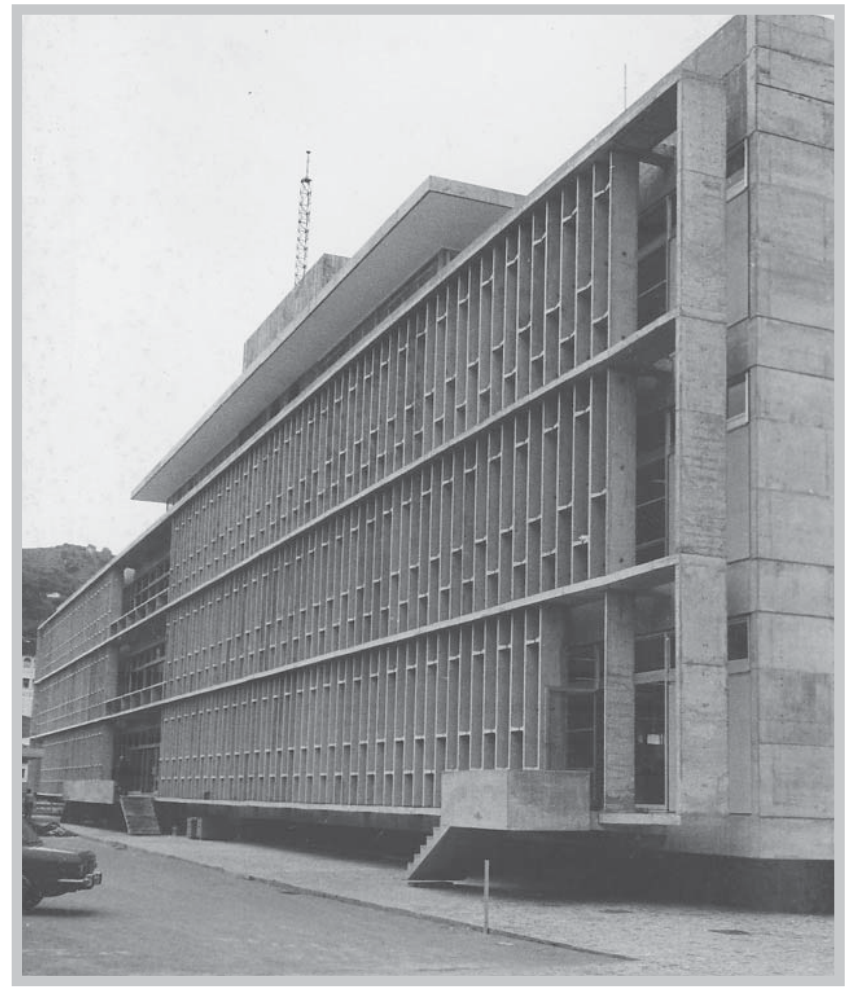

Fig. 30 - Hans Broos. Centrais Elétricas de Santa Catarina (CELESC). Florianópolis. 1966-1968. (como ocorreu em meados dos anos 1960 no Brasil) isso concorre para que ela seja particularizada, absorvida de diversas maneiras, ainda mais em se tratando de uma corrente que careceu de teoria e manifestos.

Tal é a liberdade projetual que advoga para si que, apesar da construção de São Bonifácio, claramente dentro da tendência Brutalista, este fato não acarreta uma incondicional "adesão" do arquiteto a esta tendência. Tanto é que, após aquele projeto, Broos concebe outros edifícios, quase todos em concreto aparente, não necessariamente brutalistas, como o caso de algumas residências, já mencionadas neste trabalho. Este também é o caso do Edifício das Centrais Elétricas de Santa Catarina (CELESC) ${ }^{10}$ (1966-1968).

Projetado para o novo Aterro da Baía Sul de Florianópolis, o Edifício da CELESC apresenta-se como um paralelepípedo ligeiramente acima do solo, não traz necessariamente novidades formais, ao contrário. Liga-se à sua arquitetura anterior, ou melhor, à sua "fase" de aproximação à Escola Carioca, através da estrutura colunar interna (Dom-ino), utilizada raras vezes pelo arquiteto, que propicia a planta livre e a fachada livre, arrematada com os belos brises verticais. Este também parece ser o caso do Parque Fabril da Cia Hering de Blumenau, cujo planejamento, iniciado em 1968, estendeu-se até meados dos anos 1970 com o projeto dos edifícios. Embora concebido todo ele em concreto aparente (mesclando tijolos à vista em menor proporção) e apresentar muitos elementos da tendência brutalista, não pode ser assim classificado; e embora a importância particular dos edifícios, também o planejamento físico da fábrica desperta enorme interesse, pela convivência que propõe entre os novos prédios e o entorno natural e construído.

\section{A Fábrica Hering Matriz de Blumenau}

O desenvolvimento daindústria têxtilconfunde-secom o próprio desenvolvimento econômico, urbano, social e cultural de Blumenau. A cidade, que passou por um impressionante processo de industrialização desde finais do século XIX, ${ }^{11}$ viu nascer, por entre os vales de seus arredores, uma bela paisagem fabril, que marca até hoje de forma única e surpreendente sua paisagem urbana. ${ }^{12}$ 
A Cia Hering se constitui em um dos mais surpreendentes exemplos de planejamento industrial do país, ${ }^{13}$ através de um processo contínuo de desenvolvimento e apropriação do espaço, onde Hans Broos também toma parte da história da formação da empresa. O projeto da Hering Matriz de Blumenau foi o primeiro edifício fabril de grande porte realizado por Broos no Brasil, e com ele deu início a uma parceria de mais de vinte anos de colaboração com a empresa, na função de arquiteto e consultor, que lhe rendeu inúmeros projetos industriais e também o renome de "arquiteto industrial", uma experiência que tivera seus passos iniciais em sua curta carreira alemã. Pode-se dizer que, destes projetos industriais surgem suas obras mais profícuas e que demonstram, de uma forma mais cabal, o pensamento do arquiteto, pelas inúmeras leituras e conexões que propõem. Neles o arquiteto mescla referências várias, de sua própria obra, do Brutalismo Paulista e, de forma bastante notável, do mestre Eiermann. É através da arquitetura fabril, pois (além da arquitetura residencial), que se faz bastante presente uma conexão com sua obra alemã, que sugere a presença de uma sutil ligação desde os tempos das primeiras indústrias de Eiermann do pós-guerra, até os anos 1970, com elementos retomados e renovados nas mãos de Broos.

Nos anos 1960, beneficiando-se da melhoria de infra-estrutura nos setores de transportes e comunicações e dos planos de retomada do crescimento e desenvolvimento da indústria nacional pelo Governo Militar, as indústrias têxteis, que já haviam saído do contexto pós-guerra em condições favoráveis, avançam pelos anos 1970 em ritmo bastante acelerado. ${ }^{14}$ É do contexto dos anos do "milagre econômico" e da prosperidade que atingiu o setor industrial entre fins dos anos 1960 e meados dos 1970 que devem-se os planos de expansão da Cia. Hering; primeiro com o projeto da unidade matriz e o sistema de satélites, depois unidades em outras regiões do país, como Nordeste e Centro-Oeste. ${ }^{15}$

A premissa fundamental relacionada aos projetos de ampliação relaciona-se ao desejo da empresa de permanecer no sítio original - o Vale do Bom Retiro preservando a história e a arquitetura da época de fundação da empresa. Desta forma, para a expansão de seu núcleo foi adotado o sistema de unidades satélites, que são edifícios localizados nas proximidades de Blumenau, responsáveis somente pela costura das peças dentro do processo de produção. Ao todo, são seis unidades: Água Verde e Itororó em Blumenau, e as unidades nas cidades de Rodeio, Indaial, Ibirama e Gaspar.

No projeto do Complexo da Indústria Têxtil Hering-Matriz de Blumenau (19681975) foi encomendado ao arquiteto a construção de vários edifícios fabris a serem construídos junto ao vale estreito e cercado por morros, ladeando alguns edifícios 


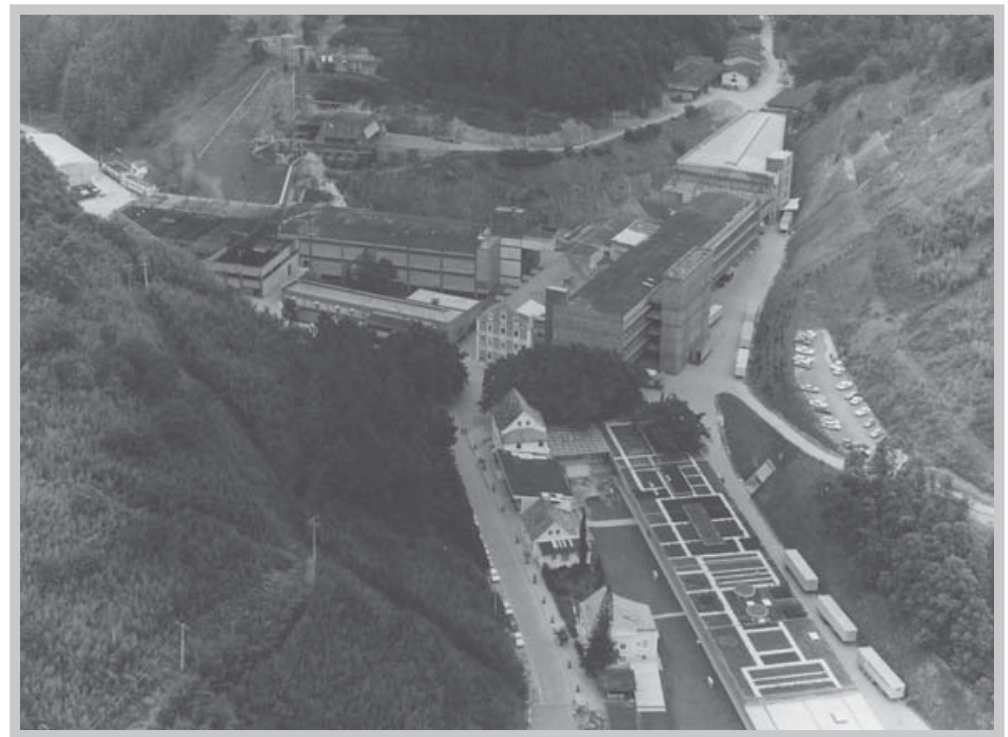

Fig. 31 - Hans Broos. Hering Matriz. Blumenau. 1968-1975.

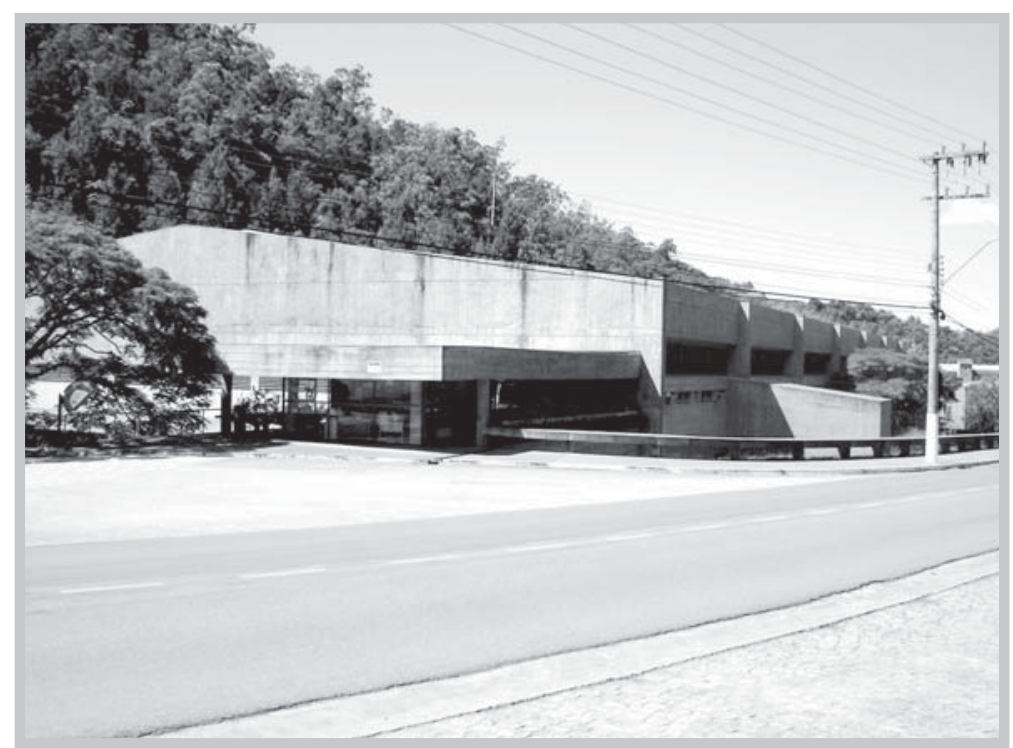

Fig. 32 - Hans Broos. Hering Matriz. Edifício da Malharia. Blumenau. 1968-1975. remanescentes com características tradicionais da imigração alemã que datavam da época de fundação da empresa. Estas eram apenas algumas das especificidades que envolveram o projeto que, além disso, deveria ser previsto em etapas, onde apenas alguns edifícios antigos permaneceriam no local, enquanto outros teriam apenas uma sobrevida, até que fossem substituídos pelos novos prédios.

Quando Broos dá início ao planejamento e ao projeto dos edifícios do parque fabril da Cia Hering já havia concluído sua mais recente e então conhecida obra, a Igreja de São Bonifácio. Se esta pode ser incluída no rol de obras Brutalistas, como vimos anteriormente, o mesmo não ocorre com a Hering Matriz; tendo em vista algumas obras posteriores, dir-se-ia tratar-se de uma obra "transitória", ${ }^{16}$ não fosse, como veremos, tratar-se de uma

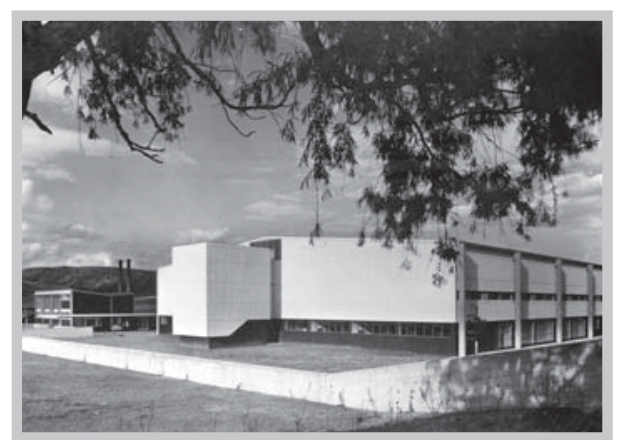

Fig. 33 - Egon Eiemann. Indústria Têxtil Blumberg. Blumberg. 1949-1951. demonstração da liberdade criativa reivindicada por seu autor, que não se filia facilmente a padrões estabelecidos; mas, mais que isso, trata-se de propor para cada caso, com suas particularidades e características, soluções que lhe parecem as mais adequadas.

No edifício da Malharia (1972-1974) podemos notar uma sutil ligação formal com São Bonifácio. A procura pela fachada lisa (aqui exceto pelas aberturas), o mesmo desenho do pilar (inspirado nos apoios externos da Fábrica Blumberg), que se prolonga até o solo como pilotis (pois o térreo, recuado, favorece a noção de bloco suspenso), a mesma limpeza construtiva e simplicidade na composição. Além destas notáveis aproximações com a obra que lhe é imediatamente anterior, a referência máxima 
nesta obra de Broos é, sem dúvida, a Indústria Têxtil de Blumberg de Egon Eiermann, realizada cerca de vinte anos antes, com a colaboração de Broos. ${ }^{17}$

Ao dizer que aprendera a projetar indústria com o mestre alemão, certamente com o exemplo de Blumberg, Broos trouxe dele mais que a experiência do projeto industrial; trouxe referências diretas. Os rasgos horizontais, a marcação externa dos pilares, os volumes das escadas e a concepção geral do volume não deixam dúvida quanto sua filiação, ainda que reformulado e elaborado com novos materiais, neste caso, concreto armado aparente. Assim como no pavilhão principal da Fábrica de Blumberg, o Edifício da Malharia apresenta grande simplicidade volumétrica - planta retangular, com cobertura em cimento amianto em duas águas sobre estrutura metálica, a linearidade e horizontalidade dos volumes. Assim como Egon Eiermann procurava lançar a estrutura e elementos secundários (principalmente circulação vertical, mas também a horizontal) para fora do prédio, também o faz Broos, com o intuito de deixar o espaço interno livre para maquinários, circulação e remanejamento interno. Estrutura e volumes das escadas e corredores externos são assim lançados para fora do prédio, e contribuem para uma exata leitura da funcionalidade do edifício, com circulações bem demarcadas, ao gosto brutalista. Em ambos os casos, os pilares são exteriorizados, conferem alinhamento vertical ao volume horizontalizante e marcam a racionalidade estrutural que dá origem à planta.

O desenho da caixa da escadaria externa também é semelhante ao de Blumberg, e revela o desejo de conferir leveza formal: no caso da Fábrica Hering - em concreto armado - através do menor contato possível com o solo; no caso de Blumberg, através do contraste de material e cor, mesmo tocando totalmente o solo. Ainda que a proposta formal seja bastante semelhante, a solução de articulação daquele elemento com o prédio, um recurso projetual típico do arquiteto alemão, foi mais feliz que a encontrada por Broos.

Broos parte da mesma solução compositiva encontrada em Blumberg - linearidade do conjunto realçada pela estreita faixa de abertura ao longo do prédio; e o contraste dado entre o térreo revestido de pastilhas na cor preta e o pavimento superior - em telhas de cimento amianto ondulada

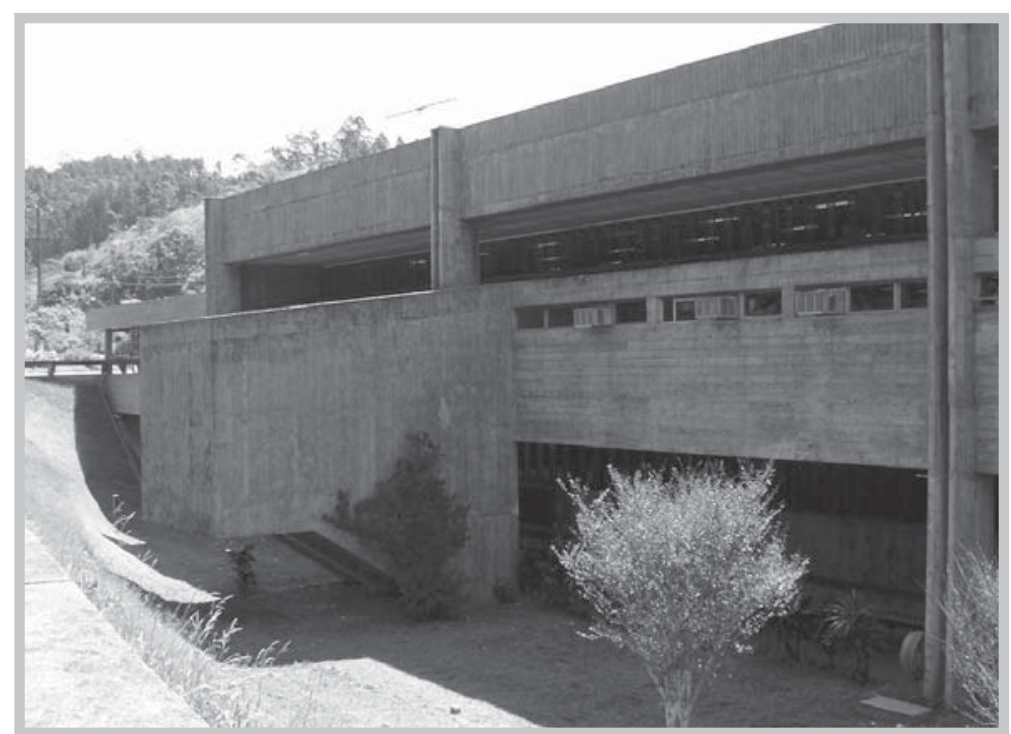

Fig. 34 - Hans Broos. Hering Matriz. Edifício da Malharia. Blumenau. 1968-1975. 


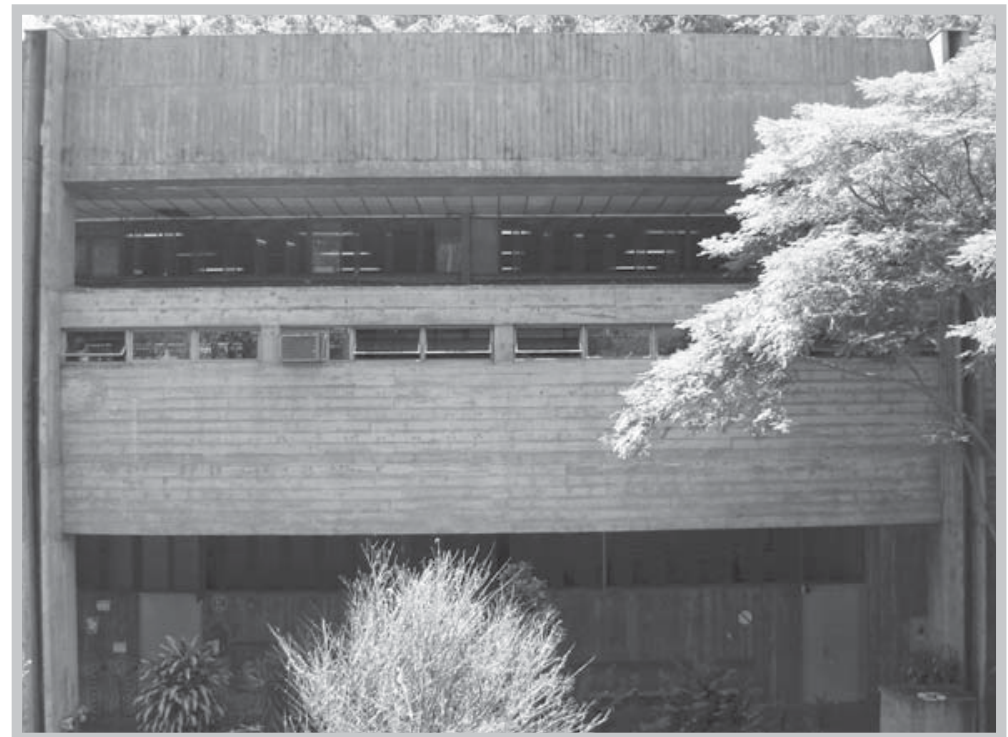

Fig. 35 - Hans Broos. Hering Matriz. Edifício da Malharia. Blumenau. 1968-1975.

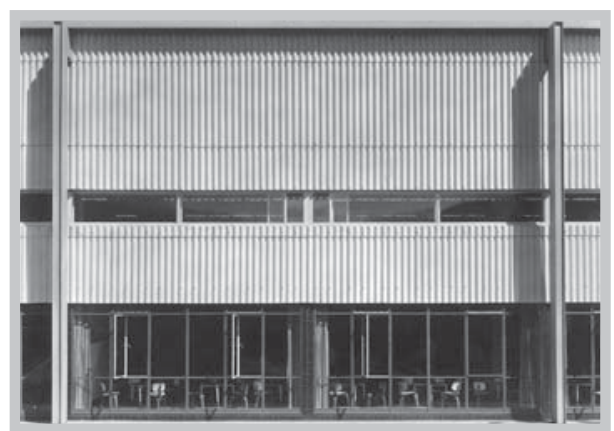

Fig. 36 - Egon Eiemann. Indústria Têxtil Blumberg. Blumberg. 1949-1951.

na cor natural - que faz com que somente este último se ressalte, e a distância não registramos o andar térreo. Em Blumenau, a longa abertura horizontal de Blumberg, justificada por Egon Eiermann como necessária aos operários para manterem contato visual com o exterior, foi trocada por um rasgo de semelhante proporção, mas que é aberta, servindo de circulação externa e certamente, ponderando quanto à diversidade climática. O jogo formal com os materiais em Egon Eiermann é substituído por pilotis, com subsolo recuado. ${ }^{18}$ Ambos os prédios mantém, assim, a faixa horizontal referente ao andar superior realçada, com proporções bastante similares, somente invertidas a proporção das faixas superior e inferior da abertura.

Egon Eiermann possui em sua obra mesma, vários dos elementos que se tornariam presentes na linguagem de Broos, e se tornariam marca do Brutalismo Paulista, como as estruturas externalizadas, circulações demarcadas e contribuindo na definição plástica do edifício, volumes de escadas bem definidos e articulados ao bloco principal. Claro que tais elementos por si só não configuram determinada corrente, mas sua especificidade está no modo como Broos retoma estes elementos, sublimando a construtividade, o peso e a massa construída, e não por último, o uso do concreto aparente.

Para Egon Eiermann, o uso do concreto aparente desvirtuaria a linguagem elegante e a leveza que sempre preconizou em seu trabalho; mesmo quando o usou, procurava prosseguir com os preceitos que balizaram sua arquitetura; apesar dela ostentar sensivelmente estes novos tempos, é marcada por uma surpreendente linearidade e evolução de conceitos que sua obra prematura já anunciava.

De fato, não podemos falar em um Egon Eiermann brutalista; é claro que é inegável que suas obras - Neckermann, Olivetti, entre outras menos conhecidas - se aproximam desta tendência. Mas também é certo que muito desta linguagem é característica de sua obra mesma, e que não foi explorada pelo arquiteto dentro 
das premissas brutalistas, exceto em alguns casos. Na maior parte das vezes, o sentido de peso visual não é buscado. Nos termos que o Brutalismo assumiu na Alemanha, sua arquitetura se distancia ainda mais; não surpreende que em nenhum momento seja aventada pela crítica local uma aproximação de Egon Eiermann com o Brutalismo em algumas obras de finais dos anos 1950 em diante. Seria, provavelmente, um sacrilégio contra o arquiteto que sempre procurou exprimir a noção de elegância, leveza, proporção e equilíbrio em seu trabalho. Neste sentido, que sua arquitetura também serviu de base à arquitetura Brutalista de Broos, não parece sem fundamento; ao contrário, a arquitetura de Egon Eiermann, não somente sua obra mais tardia, sugere e estimula, ganha força e corpo em uma linguagem totalmente nova em Broos.

É o que nos sugere a análise de outro importante bloco do conjunto fabril, o Edifício da Costura (19691974), atual Administração. Este edifício traz referências múltiplas, tanto projetuais e conceituais quanto relacionadas ao seu contexto imediato. Em sua fachada norte, longitudinal, Broos também parece remeter, em concreto aparente e linguagem mais pesada e opaca, ao exemplo de Egon Eiermann, desta vez ao Edifício da Neckermann.

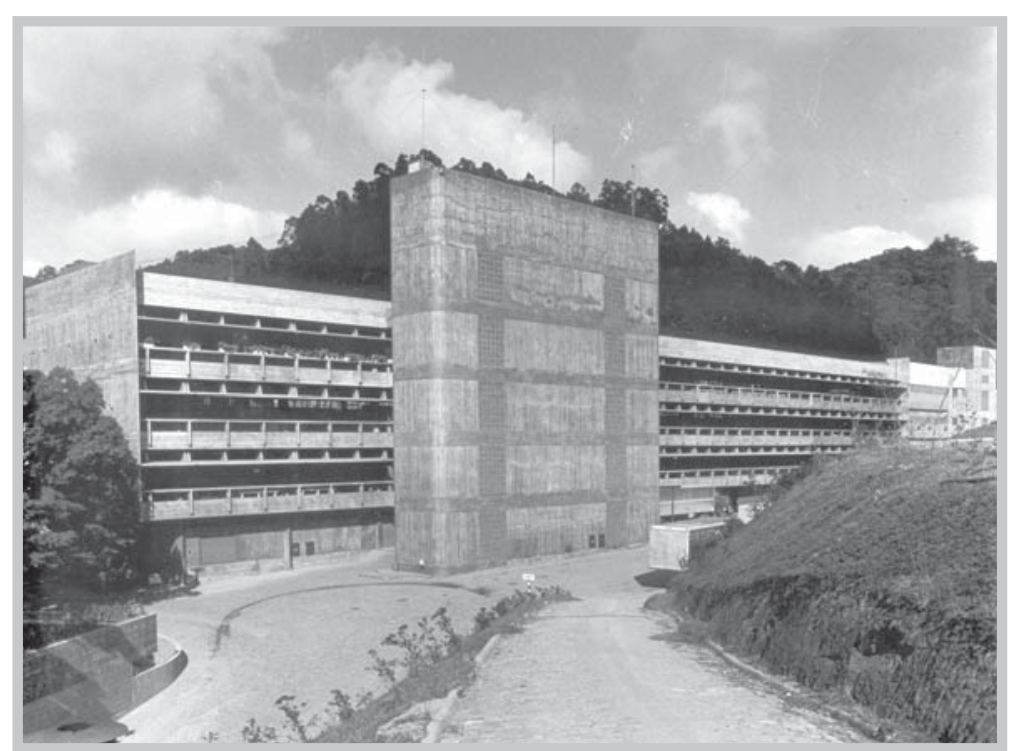

Fig. 37 - Hans Broos. Hering Matriz. Edifício da Costura. Blumenau. 1968-1975. Separados por quase vinte anos, dois exemplos dos mais interessantes da arquitetura industrial de Eiermann - Blumberg e Neckermann - mostram a continuidade e evolução de uma ideia. A estrutura que é lançada para fora do prédio em Blumberg (necessidade estrutural e também funcional) ganha máxima expressão na Neckermann, com áreas de apoio e escadarias também externalizadas (por motivos funcionais) e dramatizadas, atuando fortemente na composição do edifício.

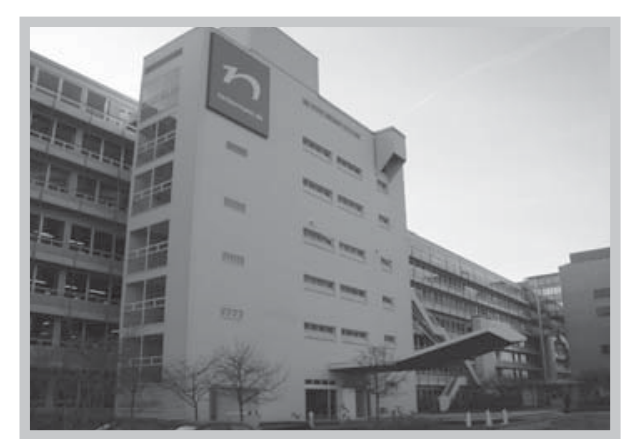

Fig. 38 - Egon Eiermann. Versandhaus Neckermann AG. Frankfurt. 1958-1961.

Tradicionalmente não vinculado ao Brutalismo ${ }^{19}$ pela crítica local, este edifício de finais dos anos 1950 ostenta, inegavelmente, uma linguagem muito mais agressiva e massiva que a habitual praticada por Egon Eiermann. Indubitavelmente ela se coloca dentro da marcha evolutiva da obra do arquiteto - elementos secundários, ambientes de apoio e circulações todos externalizados e individualizados - que 


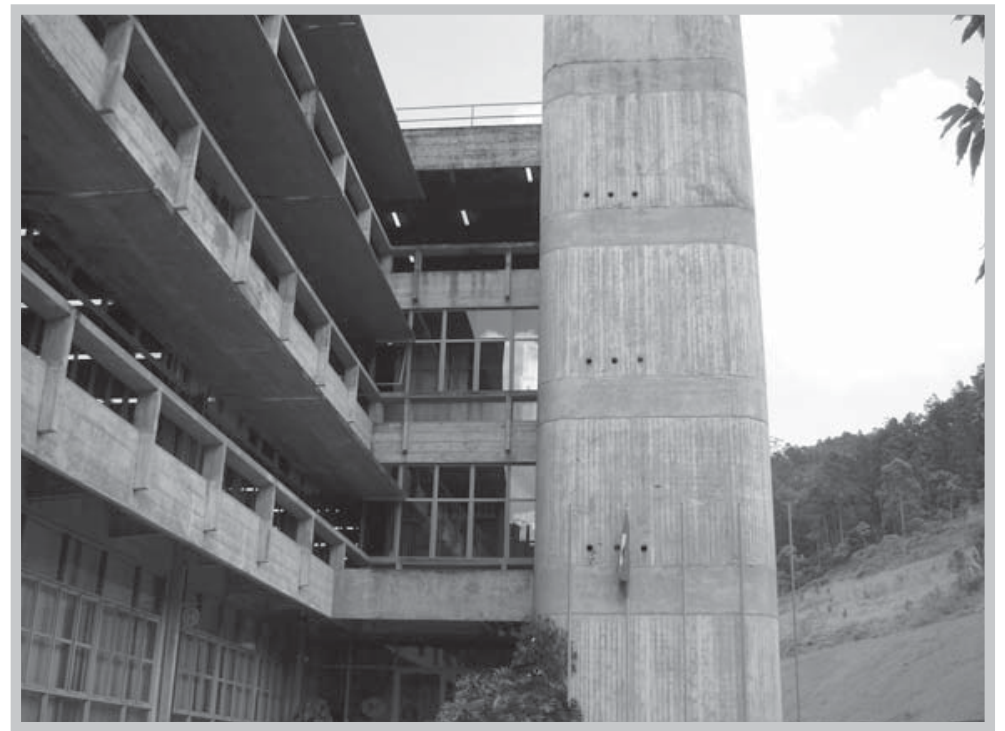

Fig. 39 - Hans Broos. Hering Matriz. Edifício da Costura. Blumenau. 1968-1975.

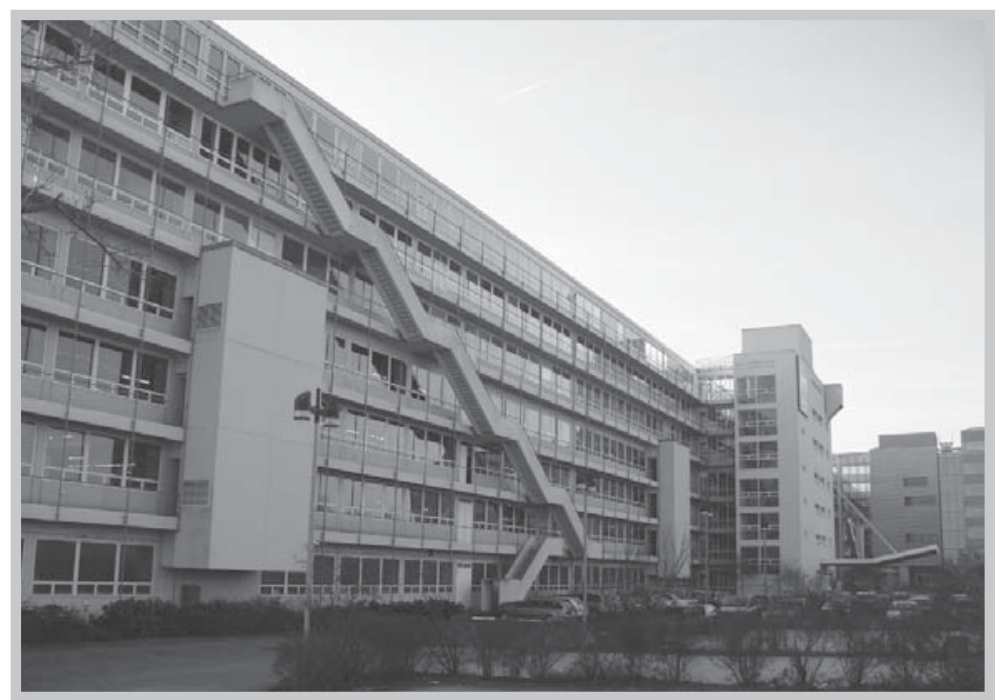

Fig. 40 - Egon Eiermann. Versandhaus Neckermann AG. Frankfurt. 1958-1961. geram escadarias e volumes corpulentos em concreto, em diagonais e verticais que se sobrepõe e opõe ao volume horizontalizante com o predomínio do vidro. Aqui estão presentes também as passarelas externas e, parcialmente, também os elementos de proteção solar.

O que chama a atenção neste edifício são a expressão e o peso dados a determinados elementos, que ganham aqui dramaticidade dantes nunca vista. As escadarias surgem como raios sobrepostos à fachada, emprestando sua alusão dinâmica ao volume; volumes externos retangulares menores (unidades de climatização) fazem uma marcação vertical ao prédio, enquanto volumes verticais maiores (com escadarias, elevadores e serviços de apoio) fazem contraponto e conferem equilíbrio ao volume horizontal de grande extensão. Grande mesmo: $257 \mathrm{~m}$ de comprimento, que nas mãos de Egon Eiermann, diluem-se sabiamente em articulações e sobreposições de elementos menores. É com este imenso edifício, que o arquiteto prova da melhor maneira o que sabe fazer como poucos: articular elementos sejam eles estruturais, funcionais, e relacioná-los dentro de uma composição harmônica. Através deste exemplo, de uma dimensão sobre-humana, tem-se à distância, a agradável visão de um edifício com elementos articulados e bem distribuídos longe de qualquer monotonia; e próximo a ele, a riqueza de detalhes e uma variedade formal adequada à escala humana.

Algumas obras tardias de Eiermann revelam a força sugestiva de determinados elementos presentes em sua obra, que ganham força expressiva como nunca, operados em concreto (e revestido de branco, material reiteradamente desvalorizado pelo arquiteto). Estes exemplos revelam, de forma consciente ou não, uma aproximação ao novo espírito dos tempos, que se na Alemanha não foi 
denominado Brutalismo, nem ganhou ares semelhantes ao que se convencionou assim chamar, revela que certas características permearam a arquitetura mundial, até arquitetos como Egon Eiermann e sua sugestiva e intocada "linearidade", como insistem em colocar alguns críticos.

Talvez como em nenhuma outra fábrica o arquiteto explore de tal maneira os elementos funcionais e técnicos como recurso estético. Apesar de já ser típico em sua obra expor caldeiras e explorar a visualidade de chaminés, na Neckermann, esta linguagem funcional é exacerbada. Através da externalização dramática de muitos elementos funcionais e técnicos, e pela multiplicidade de dados em sua fachada - que além de torres, escadas, chaminés numa escala maior, ainda conjuga guarda-corpos e guias metálicos verticais ao longo de todos pavimentos - se propõe como precedente formal do Centro_Pompidou de Paris (1972-1977) de Richard Rogers e Renzo Piano.

O Edifício da Costura da Hering Matriz demonstra a tomada de algumas consagradas soluções projetuais de Eiermann. Na fachada norte do prédio Broos refaz, a seu modo e em concreto aparente, as consagradas "passarelas" externas do arquiteto alemão, que sugestivamente são colocadas como que sobrepostas ao prédio, que tem sua fachada de vidro recuada, mas com ele se confundem pela similaridade do material e seu caráter de peso visual. Broos também recria, timidamente, os quebra-sóis, também em concreto, que remetem ao modelo de Egon Eiermann: inclinado e concebidos em lona. O conjunto passarela mais quebra-sol perfaz elemento leve e gracioso que confere movimento e escala nos edifícios de Eiermann. ${ }^{20}$ Aqui Broos reproduz o conjunto em concreto aparente, portanto, visualmente pesado e rígido, que

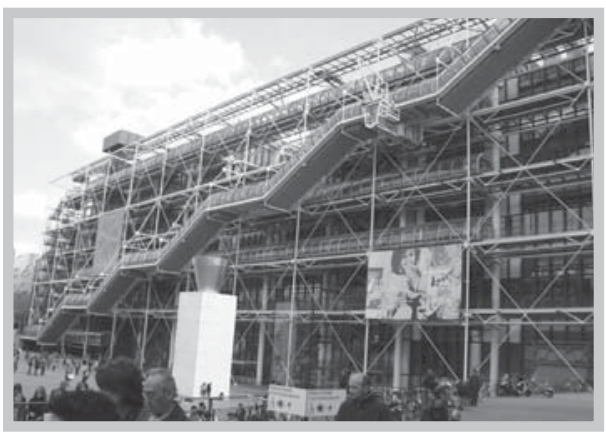

Fig. 41 - Richard Rogers, Renzo Piano. Centro Pompidou. Paris. 1972-1977. contraria as noções e objetivos que lhe são outorgados. Entretanto, cumprem com quase todas as funções que possuem nos edifícios de Eiermann ${ }^{21}$ - ao invés de servir como rota de fuga, aqui cumpre o papel de circulação externa e mais rápida, com ligação direta ao bloco das escadarias; facilita a limpeza e manutenção da fachada de vidro, e também serve como bloqueio ao sol, já que recua a fachada propriamente

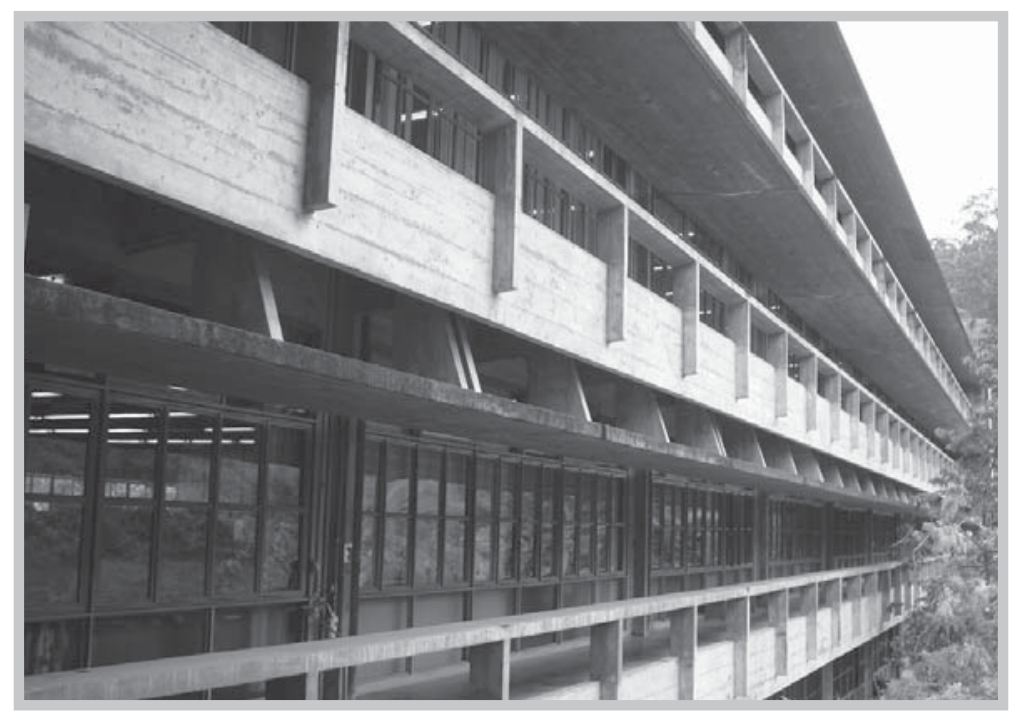

Fig. 42 - Hans Broos. Hering Matriz. Edifício da Costura. Blumenau. 1968-1975. 
dita e utiliza o quebra-sol de concreto suspenso na laje da passarela. Claro que, a um olhar esta aproximação não é reconhecível, já que Broos troca os elementos leves, diferenciados e destacados dos prédios de Eiermann por estruturas densas e pesadas que se incorporam ao prédio e não são percebidas como elementos sobrepostos. Mas um exame mais apurado revela esta "sobreposição" de fachadas à Eiermann, com a fachada de vidro recuada e sombreada e as passarelas e brises à frente. Também no edifício da Costura, Broos parte dos mesmos pressupostos da arquitetura de Eiermann: lançar estrutura, espaços de apoio e circulações para o exterior do edifico, ou seja, todo e qualquer elemento que impeça a concepção de um ambiente interno amplo e livre de barreiras. Deste modo, escadas, sanitários e ambientes de apoio são abrigados em uma torre deslocada do prédio principal, que a ele se liga por corredores de vidro, em continuidade às circulações externas, ou "passarelas" externas, como o exemplo da Neckermann.

Os quebra-sóis, utilizados timidamente no edifício da Costura, serão retomados na Unidade Satélite de Água Verde (1973-1976) de uma forma muito mais erudita e com maior apropriação. A Unidade de Água Verde pode ser considerada edifício-síntese entre referências alemãs de Broos e do Brutalismo Paulista, que resulta num edifício peculiar e de singular beleza. Também aqui a estrutura é lançada para fora do prédio; mas não se trata de elementos isolados como passarelas ou brises. Neste exemplo, os apoios e os brises externalizados tornam-se mote para uma casca estrutural que, como em nenhum outro caso, é totalmente independente, solta da "fachada" recuada de vidro. Este envoltório em concreto aparente, possui função estrutural e funcional - com a finalidade de proteger a fachada oeste da incidência solar, garantindo iluminação adequada para o interior do edifício, sem privar as operárias da vista para o jardim. Aqui, os brises ganham dimensões generosas, são projetados como bandejas levemente inclinadas, apoiadas nos pilares e suspensas por elementos verticais no paramento superior. A fachada é, toda ela, estrutura; uma casca vazada superposta à fachada interna. Como nenhum outro exemplo, este envoltório estrutural se destaca do fechamento interno de vidro e propõe sua total independência como elemento plástico.

Em ambos os exemplos, no prédio da Costura da Hering Matriz e na Hering Água Verde, as referências externas são trabalhadas por Broos de um modo muito próprio, e que chegam até mesmo a contrariar certos preceitos de Egon Eiermann. A torre da escadaria do bloco da Costura, por exemplo, contrariando a relativa rigidez do bloco principal recebe cantos arredondados; todo seu tratamento externo remete a uma feitura de cunho artesanal (aliás, como todos 
os edifícios do conjunto, uma forte característica do Brutalismo Paulista); entre as vigas avistam-se o desenho das formas do concreto, intercaladas por faixas verticais de blocos de concreto vazados para ventilação da torre.

Apesar de ser um bloco único e homogêneo, o edifício da Costura possibilita múltiplas leituras. Se na fachada norte a referência é a longínqua Neckermann (ou então, as referências são elementos cristalizados de Egon Eiermann, revelados precisamentenoexemplodaNeckermann), na fachada leste, a referência está ao lado, inspirada numa atitude madura e segura de seu autor.

Nesta fachada, ladeando o prédio antigo da costura de 1890, Broos admite como fechamento uma simples empena de concreto suspensa do chão, realçada em sua ínfima espessura, que ao mesmo tempo, faz a vedação à fachada voltada a leste e assume uma neutralidade em favor da arquitetura antiga. Esta empena funciona como um plano sobreposto ao edifício, à maneira das "passarelas externas" sobreposta à face norte, em cujo interior há uma espécie de segunda fachada, recuada, com aberturas de vidro que permitem iluminação e ventilação naturais em seu interior. E através dos pequenos orifícios presentes na empena avistase o terraço-jardim de Burle-Marx localizado à frente.

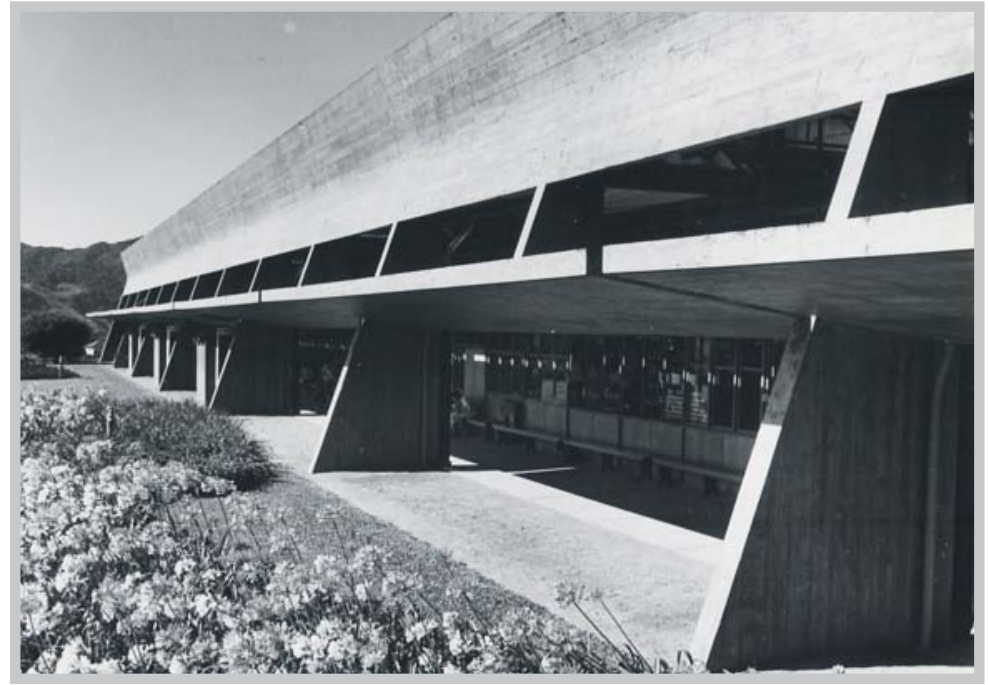

Fig. 43 - Hans Broos. Unidade Satélite de Água Verde. Blumenau. 1973-1976.

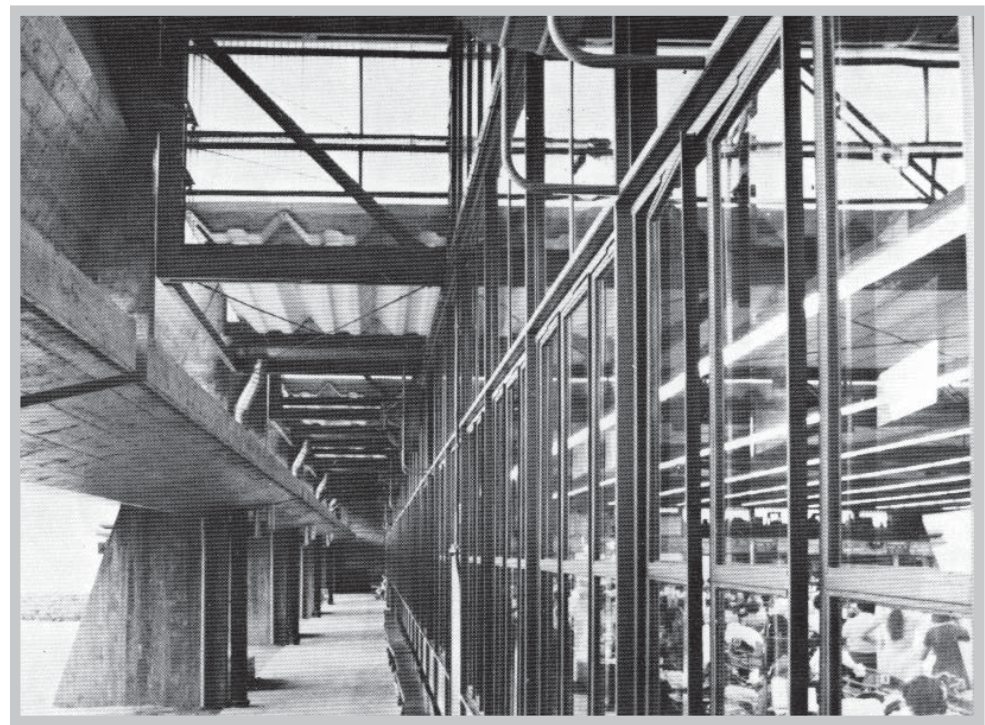

Fig. 44 - Hans Broos. Unidade Satélite de Água Verde. Blumenau. 1973-1976.

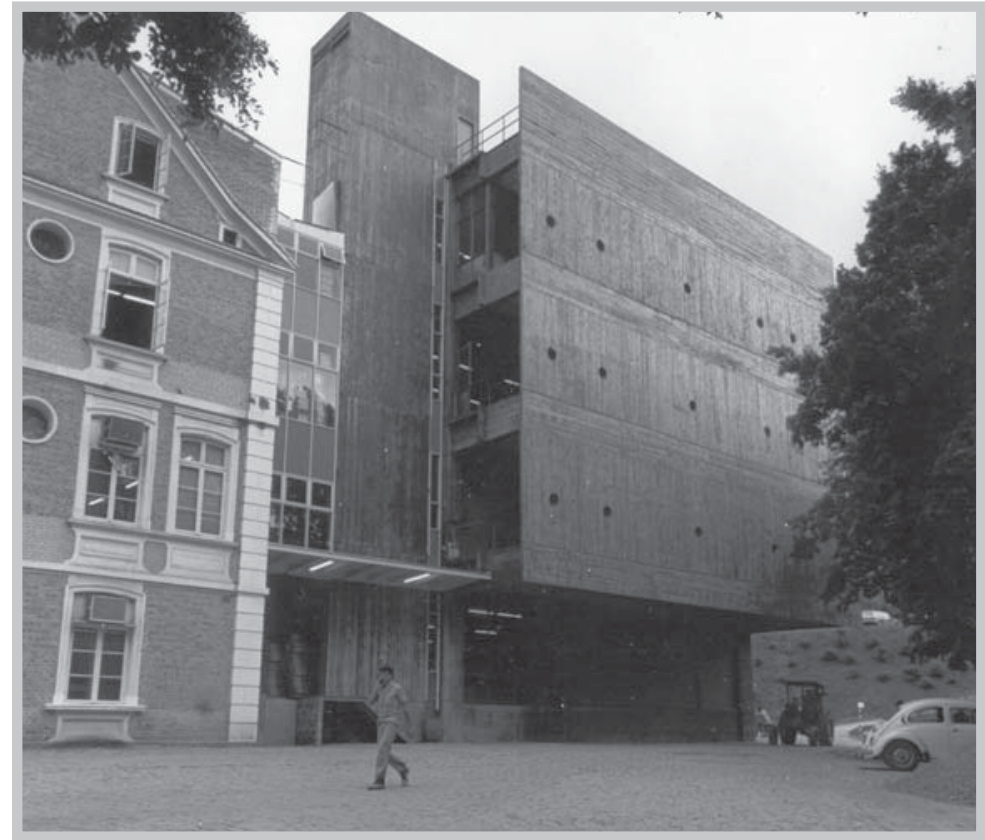

Fig. 45 - Hans Broos. Hering Matriz. Edifício da Costura. Blumenau. 1968-1975. 


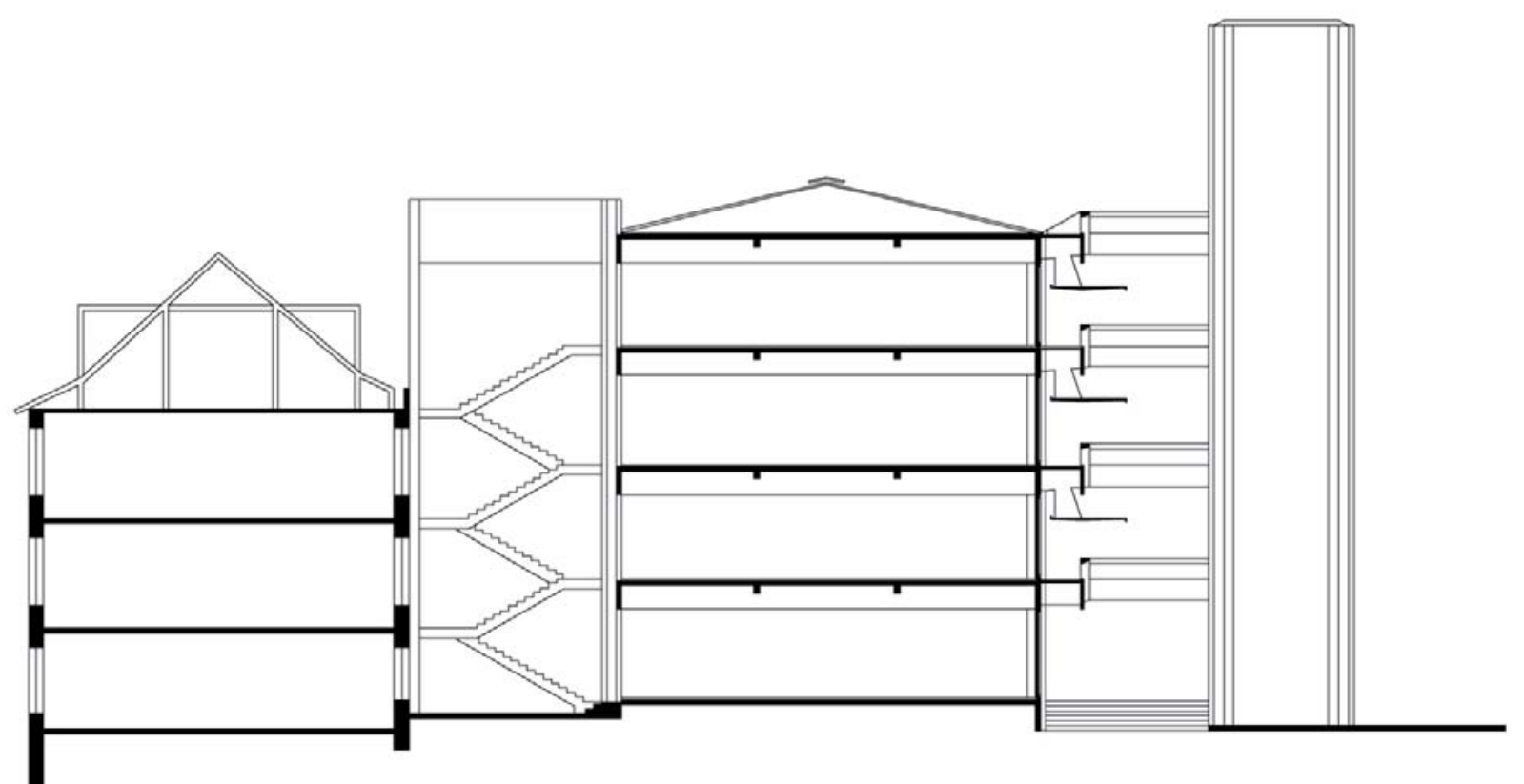

Fig. 46 - Hering Matriz. Edifício antigo e novo da Costura. Corte Transversal.

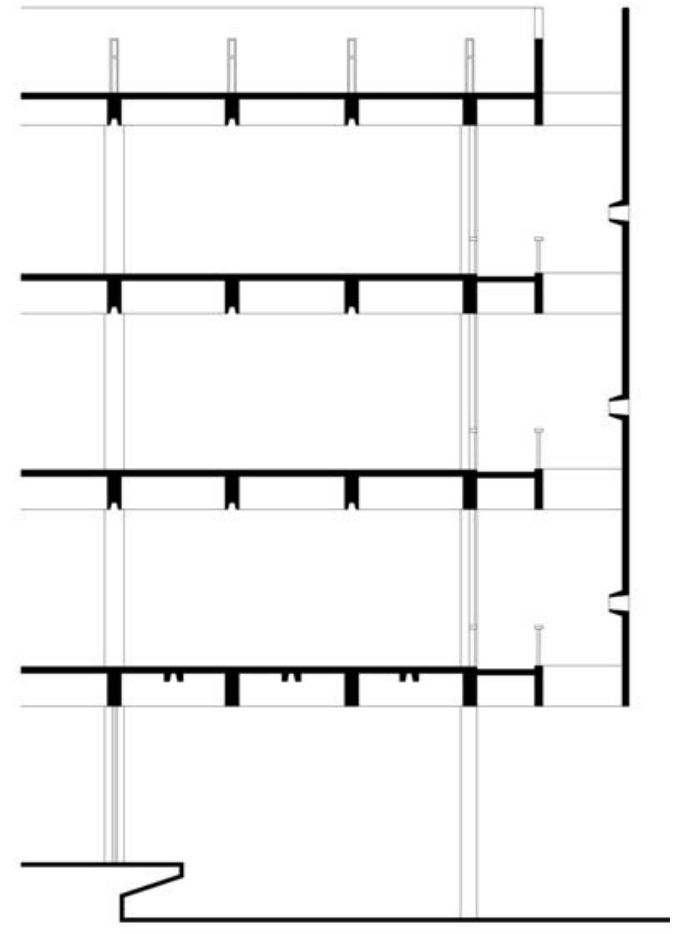

Fig. 47 - Hering Matriz. Edifício da Costura. Corte Longitudinal.
Interessante notar que para uma situação que seria apenas provisória - como mostrada na maquete do conjunto, em que o prédio histórico seria substituído por outro igual ao novo edifício - o arquiteto propõe uma solução de, mais que adequação, ${ }^{22}$ respeito às características da obra, como escala e o ritmo, para formular um nova arquitetura, que se remeta tão somente a seu tempo, numa atitude de sublimar os tempos atuais sem desvalorizar o passado. Broos pretende, assim, criar uma arquitetura contemporânea, boa arquitetura que responda de maneira adequada aos pressupostos funcionais e formais que são colocados, que respeite a arquitetura antiga, sem a ela subjugar-se ou procurar reproduzir, de uma maneira falsa (como só poderia ser) as formas que retratam sua essência - afinal, toda arquitetura é o retrato de uma essência que lhe deu origem; por isso, para Broos, lhe parece impossível imitar uma arquitetura, o que seria sempre falso e gratuito, pois a essência é jamais reproduzível. Não deve ser confundida como uma atitude de negação ao passado. Ao contrário; é o respeito e o credo de que somente respostas verdadeiras - adequadas a sua época - podem valorizar o passado, garantir "a continuidade da evolução, que se chama também de 'tradição"', ${ }^{23}$ como toda boa 
arquitetura o fez em sua respectiva época. É uma postura diferente das vanguardas dos anos 1920 que negavam o passado numa atitude de auto-afirmação, e também, uma noção oposta ao firmado no pós-guerra, como novamente a obra de Eiermann nos serve de exemplo.

Alguns anos antes do projeto da Hering Matriz, Eiermann havia realizado um de seus projetos mais conhecidos, a Kaiser-Wilhelm-Gedächtniskirche(1957-1963) ${ }^{24}$ localizada no coração de Berlim, igreja que acolhe em sua proposta as ruínas da velha catedral que resistiram aos bombardeios da Segunda Guerra. Diferentemente das duas etapas anteriores do concurso - em que o arquiteto previa a eliminação da torre, e por pressão da população e da imprensa ela foi

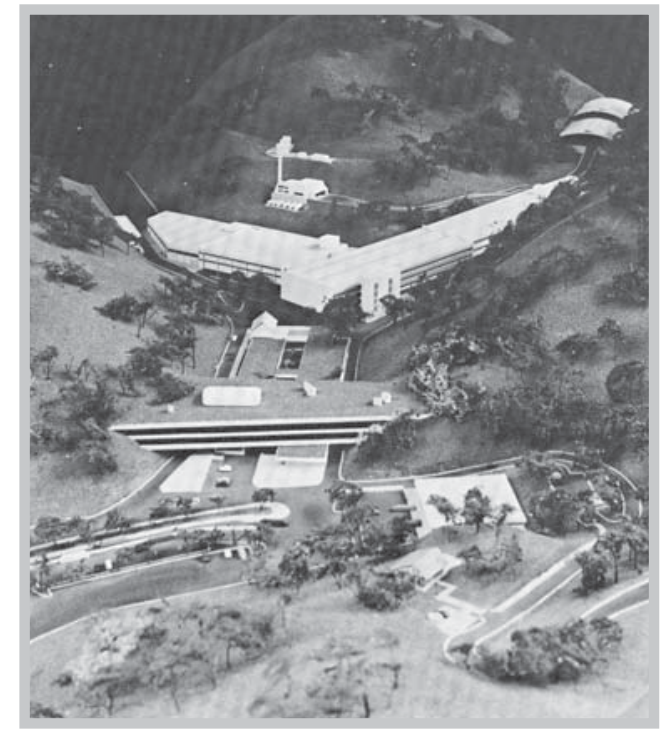

Fig. 48 - Hans Broos. Hering Matriz. Maquete do conjunto. Blumenau. finalmente admitida - o arquiteto deve lidar agora com a torre que restou da igreja de 1891 e conciliar sua proposta às reminiscências do passado.

Sua relação com a história é a de um arquiteto decididamente contemporâneo, que não pretende, tampouco sente necessidade de estabelecer relações com o passado. Afinal, do peso da história haviam se libertado as gerações anteriores do Movimento Moderno; para Eiermann e sua geração, não havia motivo algum para contemporizar com a volta dos estilos, já que libertar-se da história era, ao mesmo tempo, renunciar ao passado nazista, ${ }^{25} \mathrm{com}$ sua arquitetura monumental de colunas e frontões clássicos e de caráter "regionalista" nas pequenas obras.

Tal comportamento é sintomático para a época, demonstrado também no documento que marca a nova fundação do Deutscher Werkbund em 1947: “o patrimônio destruído não deve ser historicamente reconstruído, novas tarefas somente podem surgir em novas formas", ${ }^{26}$ e que tenta definir alguns pontos a serem considerados nos esforços de reconstrução do país.

Nas situações em que Eiermann deparou-se com resquícios do passado, sua posição foi a de afirmar-se moderno. No projeto da Gedächtniskirche é através do incisivo contraste que o arquiteto concebe sua proposta, e como em alguns de seus projetos com semelhantes questões, a arquitetura histórica é utilizada como citação com a qual são confrontados os novos edifícios.

Ao lado de Kraemer, e a partir de suas experiências no pós-guerra, Broos aprendeu a lidar com a arquitetura histórica de uma maneira mais profunda que a sua geração anterior: "Nós consideramos toda a história, toda a cultura, como ato de passagem. A cultura não é feita somente hoje, somente pelas pessoas em ação. A cultura é feita também da herança, da tradição, com seus sistemas e valores que 
se aceitam da geração passada, se corrige, e adapta à situação atual e que se aplica e desenvolve para responder as necessidades de hoje para o futuro." ${ }^{27}$

Os trabalhos realizados por Broos desta época evidenciam o esforço em conciliar uma arquitetura atual sem deixar de lado o valor do patrimônio construído. Um de seus primeiros trabalhos junto a Kraemer foi a reconstrução do edifício renascentista "Gewandhaus" 28 de 1590 na Praça do Mercado da cidade, que foi mantido em suas características exteriores, com alguns elementos do seu interior remodelados a partir de uma visão contemporânea. Além disso, vários outros projetos, como estudante ou após, ilustram reconstruções de praças e pequenos conjuntos históricos, que tentam aliar o novo e o antigo desde uma visão urbanística. Postura pela qual a Universidade de Braunschweig tornou-se conhecida, ao buscar uma proposta conciliadora tanto no plano urbano quanto do edifício, entre uma linguagem moderna e as construções históricas. ${ }^{29}$ Tendo a sua frente Kraemer, e mais tarde Walter Henn e Dieter Oesterlen, este enfoque era ampliado através de um exercício prático intensivo oferecido aos alunos aliado ao aprendizado teórico, o que pode ser caracterizado como uma particularidade desta Universidade nos anos imediatamente posteriores à guerra. ${ }^{30}$

Antes de uma emulação desnecessária, ou uma arquitetura insípida, a empena de concreto armado deixado aparente, lhe parece em forma e cor o elemento ideal que garante a harmonia do conjunto, mas realçando tempos e técnicas distintos, o passado e o futuro da empresa unidos em equilíbrio.

$\mathrm{Na}$ empena Broos conserva tão somente pequeninas aberturas para garantir a vista do belo terraço-jardim; aberturas que como em outros edifícios construídos pelo arquiteto, não comprometem a noção de bloco fechado (neste caso de uma empena "cega"), até mesmo em relação à fachada norte, cujos corredores externos não desfazem a ideia de fechamento homogêneo. A exemplo de São Bonifácio, Broos refaz nos edifícios da Hering os mesmos pequenos elementos de abertura e/ou ventilação, sempre bem demarcados, que se projetam externamente e ganham formatos diversos; elementos pontuais que rompem com a rigidez e não contrariam a massa e a volumetria densa dos edifícios. Tubos pré-fabricados de concreto animam a volumetria simples do Edifício do Beneficiamento e brincam com os efeitos da luz. Também no Depósito de algodão, pequenas aberturas diferenciam o bloco homogêneo e pesado, que tem ainda na leveza e simplicidade da escada externa um ponto de contraste. Na tinturaria, são elementos estruturais e "secundários" que estimulam a fachada - a marcação externa da estrutura (como no Edifício da Malharia), as gárgulas e a escada helicoidal fazem a composição de um edifício que não tem sua composição marcada senão por sua funcionalidade. 
Neste momento, entre fim dos anos 1960 e início dos anos 1970 ocupava a prancheta do arquiteto projetos bastante distintos entre si: Cia. Hering, algumas Unidades Satélites, Mosteiro de São Bento ${ }^{31}$ e tinha início o projeto da própria residência no Morumbi. Mostramos que nas residências o arquiteto ocupava-se intensamente com pesquisas de pátio interno, átrio, cobertura, ou seja, um lugar de convivência comum e com maior relação com o espaço externo. $\mathrm{Na}$ Hering Matriz o tema é trazido para o espaço urbano; não mais em uma residência ou bloco único, mas como elemento amalgamador de um conjunto, de um espaço urbano e coletivo, como se pode entender os espaços da fábrica.

A Praça Histórica traduz esta pesquisa do espaço privado para o urbano. Localizada junto ao Centro Social e junto às antigas residências preservadas da família Hering, a Praça Histórica recebe um tratamento arquitetônico e paisagístico especial. Seu desenho, com escadas, recortes, ângulos, que tem na fonte o elemento centralizador, ${ }^{32}$ recebe o pergolado de concreto aparente com domos que a demarca como coração da fábrica, espaço de convivência por excelência, acentuado pela cobertura que a define e distingue. $\mathrm{Na}$ Hering Matriz o grande espaço de convivência e encontro se espacializa na Praça Histórica que promove também um intenso diálogo com a natureza e o entorno construído.

Com efeito, a proposta de Hans Broos de convivência com o entorno construído - não apenas com a arquitetura histórica - abre-nos caminhos para outras discussões. A este propósito, interessantes aproximações unem os arquitetos Lina Bo e Hans Broos. Afora o projeto do MASP, que claramente serviu de inspiração para a solução adotada pelo arquiteto em São Bonifácio, mesmo partindo de condições bastante díspares, também podemos verificar proximidades entre a Fábrica

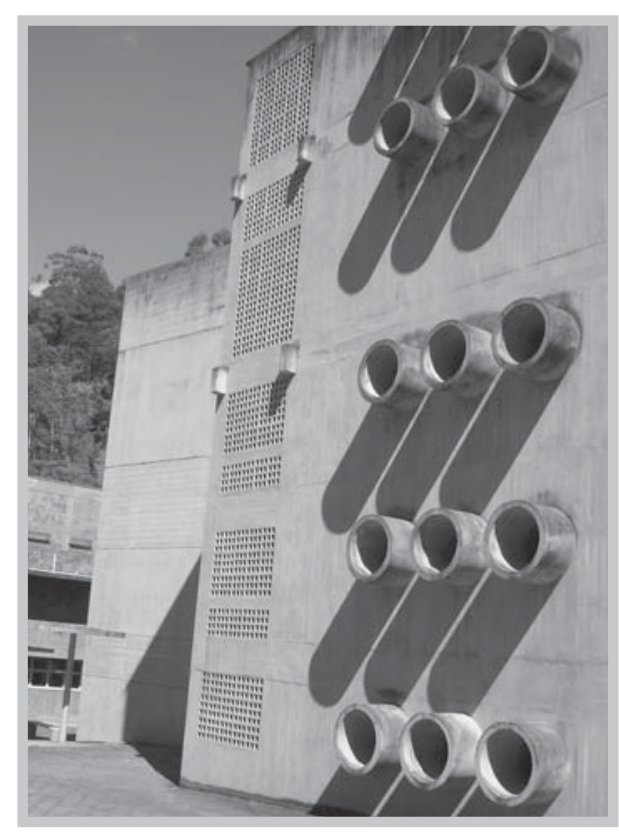

Fig. 49 - Hans Broos. Hering Matriz. Edifício de Beneficiamento. Blumenau. 1968-1975.

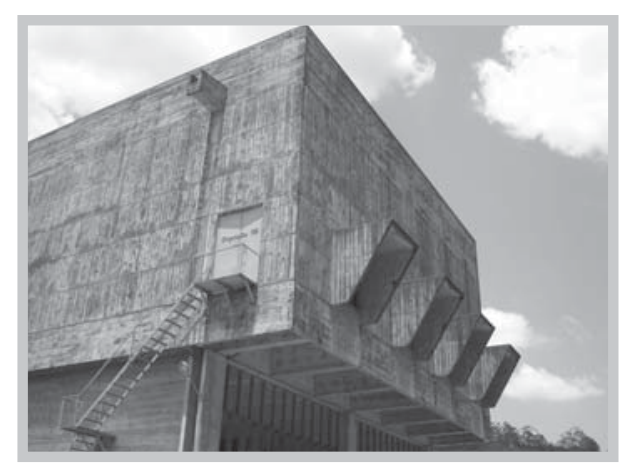

Fig. 50 - Hans Broos. Hering Matriz. Depósito de algodão. Blumenau. 1968-1975.

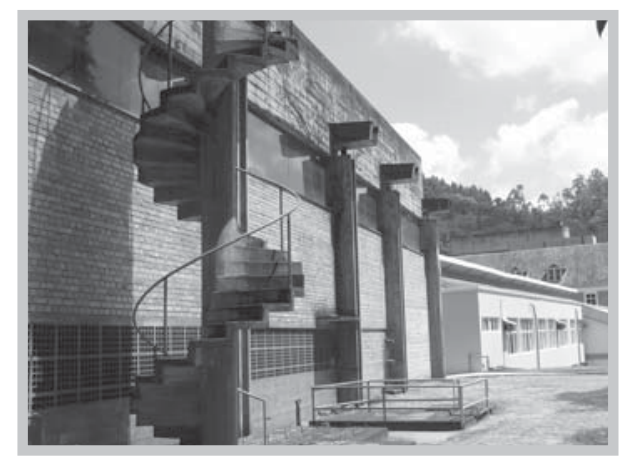

Fig. 51 - Hans Broos. Hering Matriz. Edifício da Tinturaria. Blumenau. 1968-1975. Hering Matriz e o SESC Fábrica da Pompéia (1977) da arquiteta italiana. Segundo Maria Alice Junqueira Bastos, este projeto representa o marco oposto ao de Brasília, pelo fato "de que seu projeto representou, na arquitetura brasileira de então, a aceitação da cidade, o convívio do moderno com o existente." ${ }^{33}$ Neste sentido, Broos antecipa esta postura com seu projeto para o conjunto fabril da Hering Matriz, tanto no que diz respeito ao convívio com a arquitetura histórica, quanto ao convívio com o existente, 


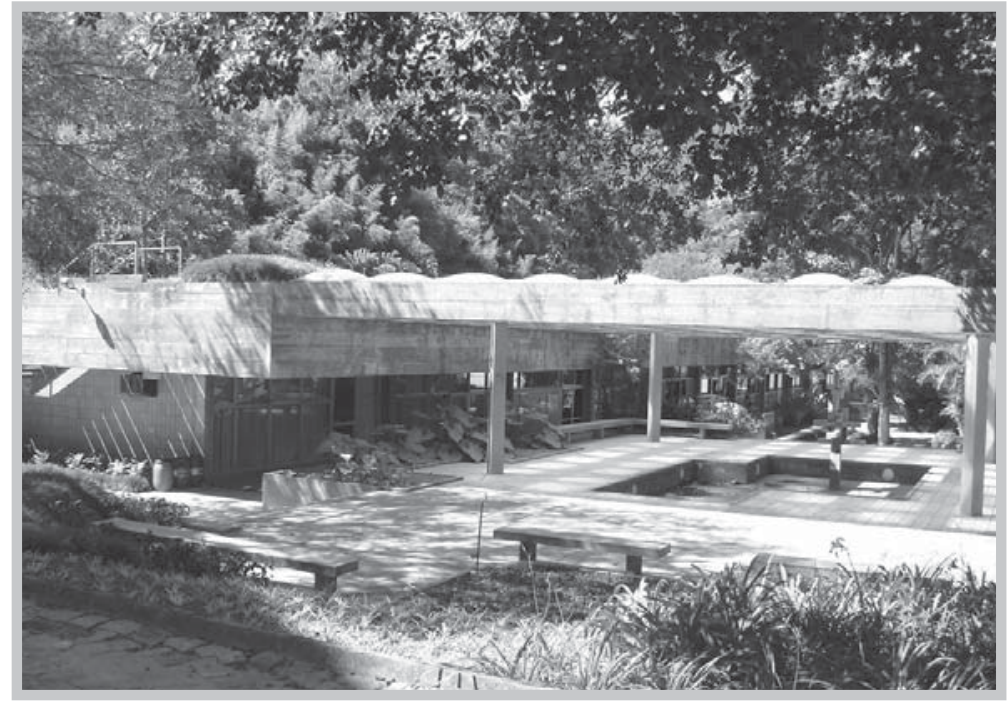

Fig. 52 - Hans Broos. Hering Matriz. Praça histórica. Blumenau. 1968-1975.

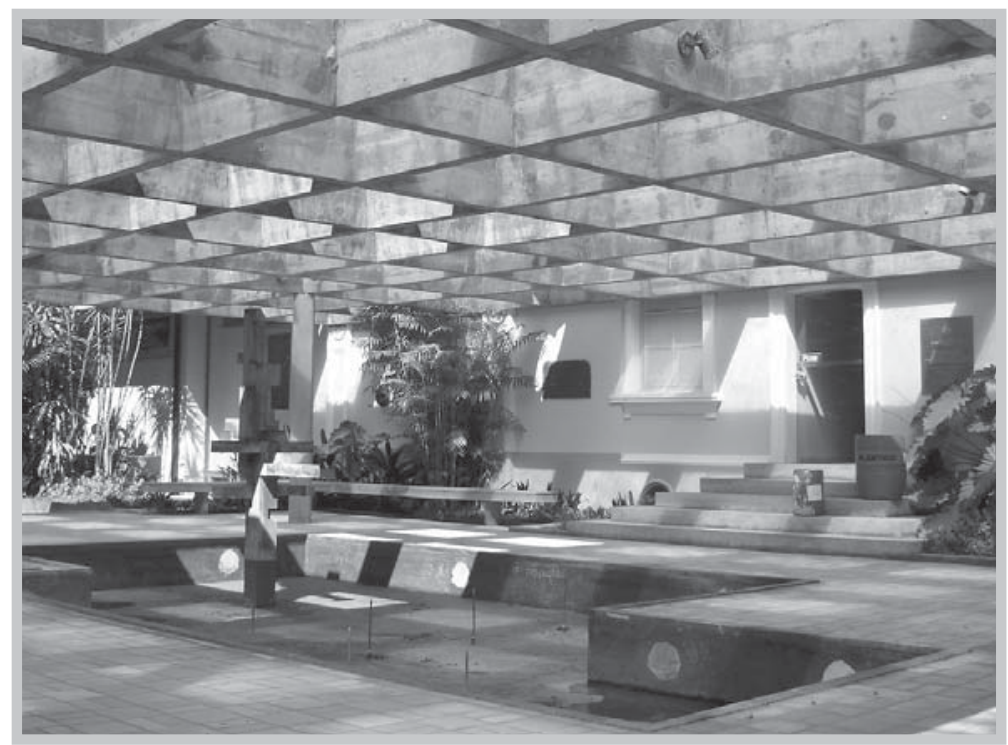

Fig. 53 - Hans Broos. Hering Matriz. Praça histórica. Blumenau. 1968-1975. amplo senso. Muito embora na época de sua construção ao complexo da Hering não cabia o entendimento de espaço "urbano", e diferia do contexto urbano denso do projeto de Lina, a Fábrica Hering também encontrou uma situação já formada, onde o arquiteto teve de lidar com os prédios históricos da fábrica e principalmente, casas em estilo enxaimel na inserção dos novos prédios. Ademais, os espaços da Hering são pensados como um espaço urbano: estradas, caminhos e passeios são projetados por entre o conjunto fabril, que se coloca como uma unidade funcional integrada e em perfeita continuidade com a cidade.

Mas são também as soluções formais e compositivas que chamam a atenção nestes dois projetos. Em ambos há a interessante mescla de materiais e volumetrias, e a saudável diversidade entre o velho e o novo, e entre edifícios baixos contrapostos a torres, nestas, vemos a predileção por orifícios - irregulares e quadrados em Lina, circulares e tubos externos em Broos; ao invés de longas aberturas, a predominância do cheio sobre o vazio, de superfície fechadas e rugosas. O bloco das quadras esportivas do SESC (com orifícios irregulares), assim como no Edifício do Beneficiamento da Hering Matriz (com tubos externos), sugerem um tímido expressionismo arquitetônico típico do trabalho de alguns colegas europeus nesta época, que se difere do comportamento nacional e mostram o não alinhamento restrito de ambos os arquitetos ao Brutalismo Paulista.

Se por um lado muitas obras de Broos aproximam-se da tendência brutalista paulista e em muitas delas é notável a assimilação de proposições dos colegas 
paulistas, por outro lado não se depreende de sua obra o "projeto moderno" ligado àquela (tampouco nos interessa analisar aqui sua obra apenas pela veia teórica); não se vincula às suas formulações crítico-teóricas e revela noções que permeariam os debates do meio arquitetônico da década de 1970, como revela o projeto da Hering Matriz. A significativa influência do projeto moderno dos anos 1950-1970 como coloca Maria Alice Junqueira Bastos corroborou na legitimação de uma dada corrente arquitetônica dentro do panorama nacional ${ }^{34}$ (leia-se Brutalismo Paulista) que valorizava esta postura e, de certa forma, impunha aos "dissidentes", ou aos arquitetos que a ela não se alinhavam de forma irrestrita, papel secundário dentro do panorama arquitetônico nacional, o que foi legitimado pela historiografia da Arquitetura Moderna Brasileira. Com efeito, a obra da arquiteta Lina Bo Bardi passou a ser valorizada somente a partir dos anos $1990,{ }^{35}$ igualmente a obra de Broos, que passou a ter certa valorização muito recentemente. ${ }^{36}$

\section{ASSIMILAÇÕES LOCAIS}

O tema da grande cobertura se faz presente em obras simultâneas de Hans Broos, em programas e soluções tão diferentes quanto as propostas para a Casa do Arquiteto, o Mosteiro São Bento e como vimos, para o espaço "urbano" da Hering Matriz. Sua recorrente preocupação - propiciar um espaço de convívio e troca entre os homens e destes com a natureza - encontra na cobertura a solução espacial e plástica ideal. Se antes buscava-se diferenciar com exatidão os setores da casa, trazendo para dentro dela o pátio (muitas vezes aberto, para convívio com o exterior), agora se pretender amalgamar funções sob a cobertura única que abarca e congrega. A casa do arquiteto, como vimos, faz parte desta pesquisa, que encontra novas soluções formais, que se distingue de seus precedentes, assim como a Casa Jan Rabe.

No final dos anos 1960, como vimos, Broos admite novas soluções formais em seu trabalho. O desenho dos pilares - bastante discretos em São Bonifácio (como o desenho de Egon Eiermann), que marcavam a estrutura da planta - ganha desenhos mais elaborados, num primeiro momento na experimentação da Casa Rabe, depois na Casa do Arquiteto e no Mosteiro de São Bento (1971-1974). Aqui, o desenho da cobertura, a exemplo da Casa do Arquiteto, recebe contornos nítidos e define volumetricamente o edifício, com a fachada frontal recuada, as empenas laterais e a cobertura visualizadas em sua espessura, formam uma "caixa" de marcante horizontalidade. Se esta obra guarda aproximações com sua arquitetura anterior, principalmente residencial, que tinha como proposta formal e estrutural prioritária a concepção da "caixa" - uma solução estrutural 


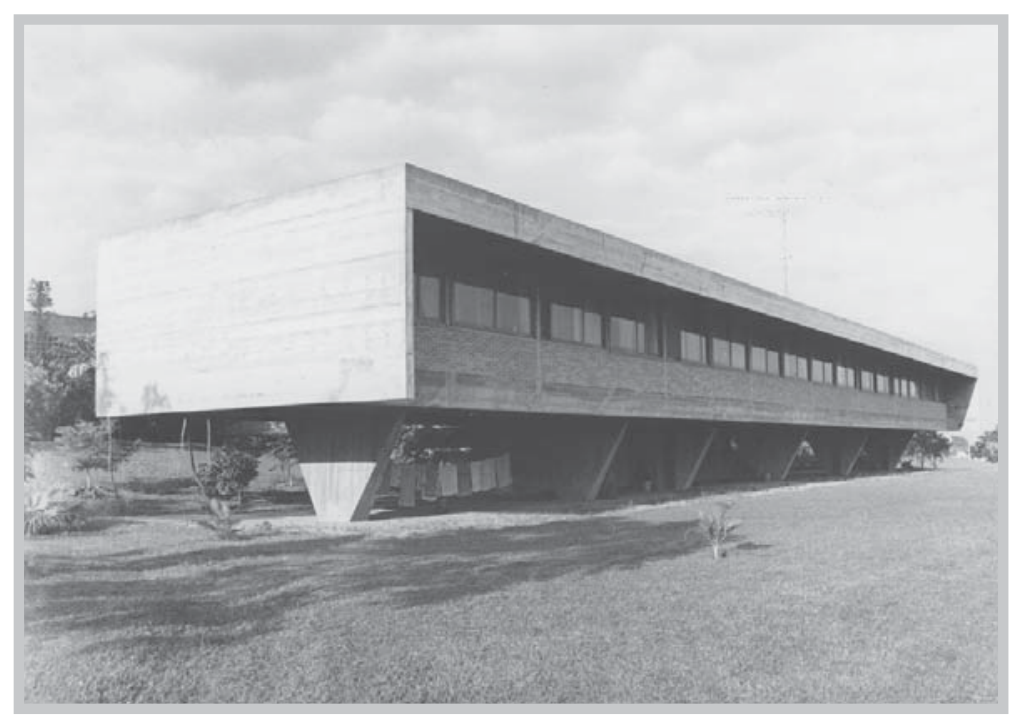

Fig. 55 - Hans Broos. Mosteiro de São Bento. Vinhedo. 1971-1974.

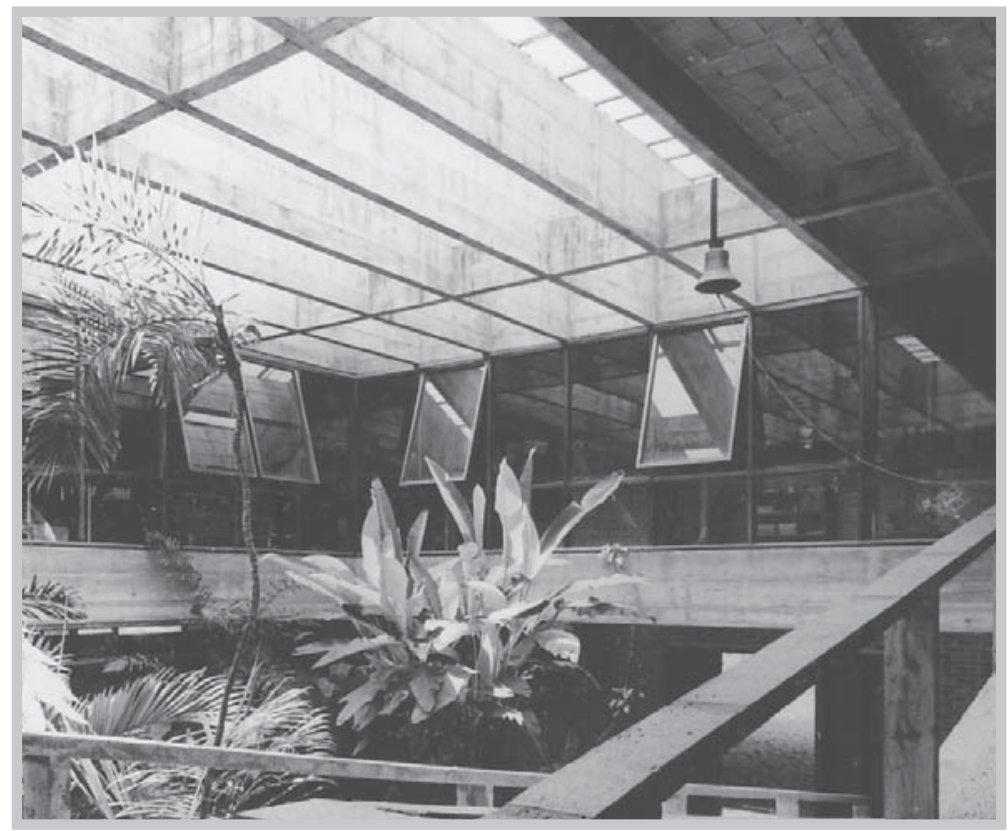

Fig. 56 - Hans Broos. Mosteiro de São Bento. Vinhedo. 1971-1974.

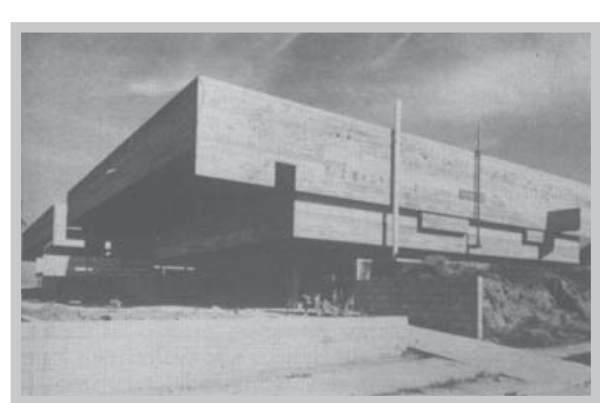

Fig. 57 - Paulo Mendes da Rocha e João de Gennaro. Casa do Butantã. São Paulo. 1964. quase sempre perimetral, em forma de paredes laterais portantes - é certo também, que o arquiteto tenta uma aproximação formal com o Brutalismo Paulista, mais precisamente como as casas de Artigas, resolvidas com os mesmos pressupostos formais, e também de Paulo Mendes da Rocha e João de Gennaro, como a Casa do Butantã (1964).

Entretanto, no Mosteiro São Bento, a cobertura que dá os contornos volumétricos ao prédio é utilizada como pressuposto formal, e diferencia-se do seu uso anterior, em que predominava uma nova concepção espacial. Difere-se, pois da grande cobertura, como espaço volumétrico que tudo "abarca". O tema da cobertura define o edifício formalmente, mas não se coloca como elemento "extensivo" e quase "onipresente", como a ideia da cobertura como uma envolvente para espaços internos visíveis e permeáveis, sugere. O prédio, com planta em $\mathrm{H}$ - com duas alas centrais que conectam as alas longitudinais, e posteriormente recebeu o volume da igreja, articulado ao volume - possui ao centro um pátio com pérgulas, mas tendo em vista o vasto programa e a necessidade de reclusão de parte dele, a cobertura não teve o mesmo uso que na casa do arquiteto, por exemplo. 


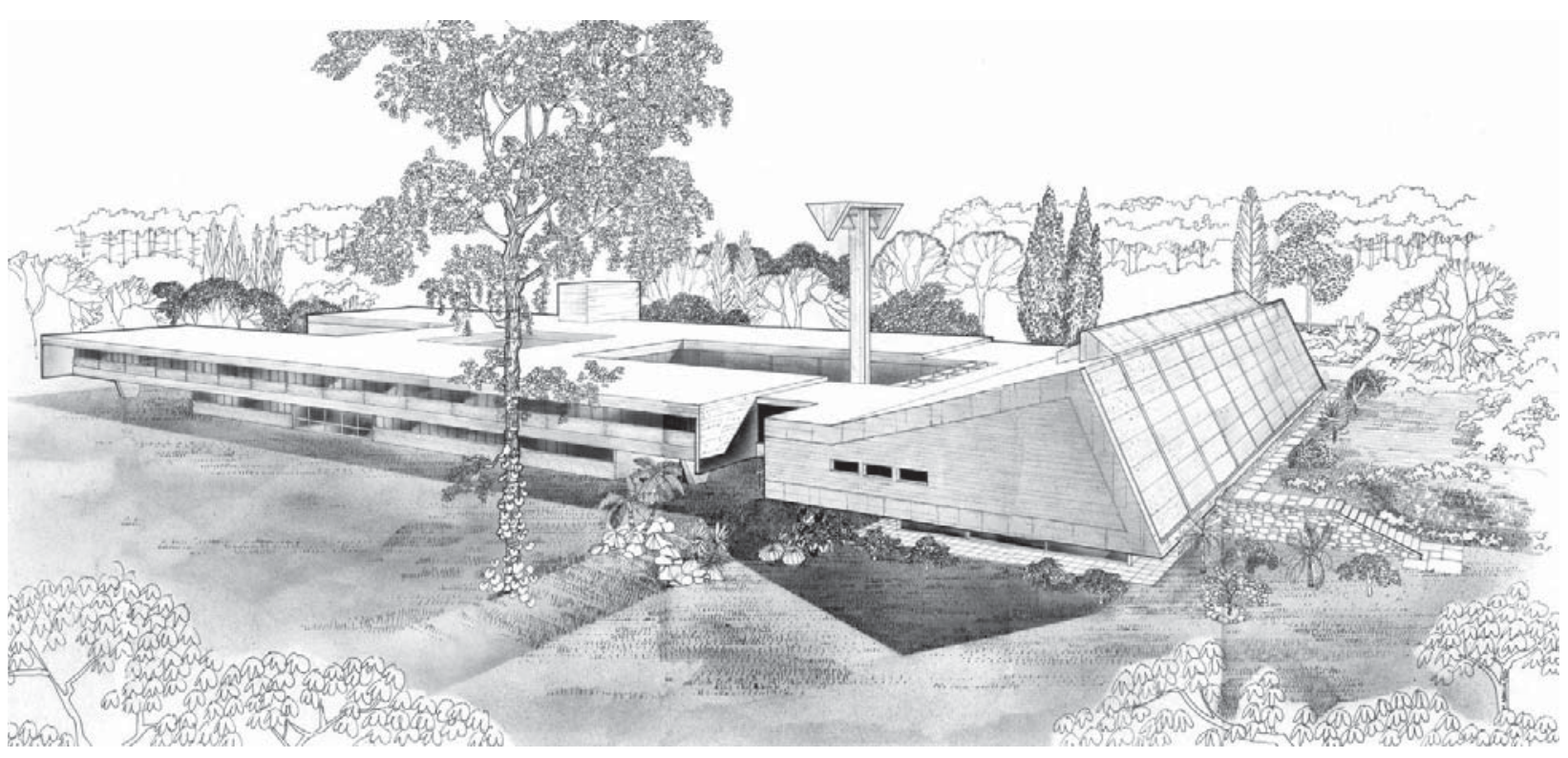

Fig. 58 - Hans Broos. Mosteiro de São Bento. Vinhedo. 1971-1974.

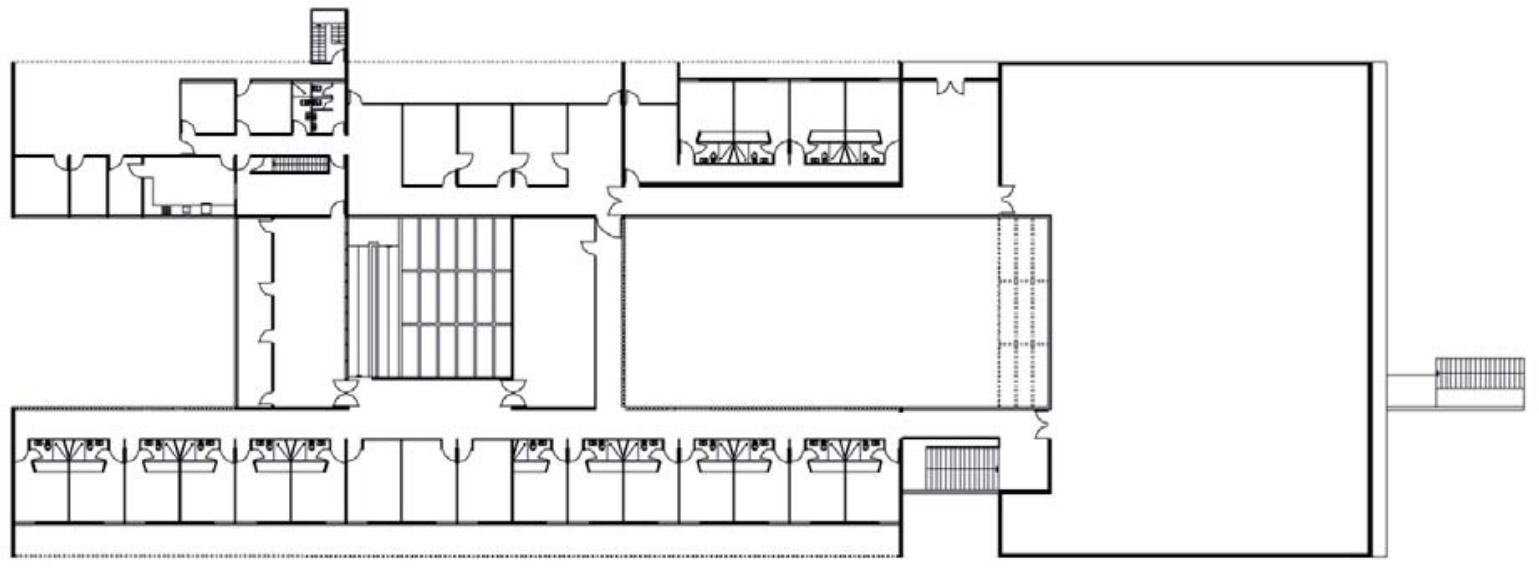

Fig. 59 - Mosteiro de São Bento. Planta baixa.

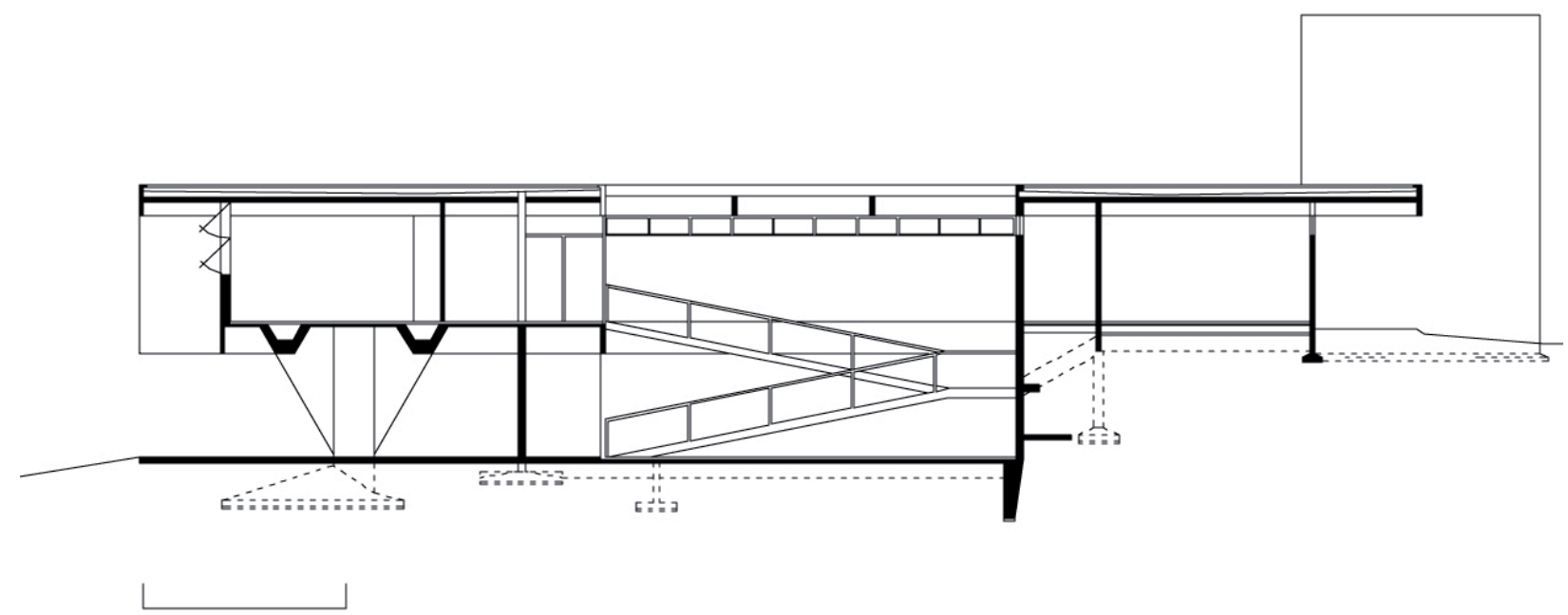

Fig. 60 - Mosteiro de São Bento. Corte transversal. 
No Mosteiro, a cobertura identifica apenas novas pesquisas formais, desta vez, mais direcionadas ao ambiente paulista. A escolha do partido e o tema do pátio interno favorecem, naturalmente um convívio bastante interiorizado, com setores bem definidos - a ala de acesso público, com apartamento para hóspedes, escritórios, recepção e acesso à igreja, refeitório e setor de serviços, e a ala privativa, com apartamentos, ambos ladeando a área de reclusão dos monges, com o pátio interno. No Mosteiro, outras características bastante particulares do Brutalismo Paulista são aqui referenciadas - o bloco único (apesar do vasto programa e da grande planta, Broos dá à solução características de bloco único, que pode ser visto no setor dos dormitórios, destacado dos demais, onde a cobertura teve papel especial nesta noção) destacado do chão, características horizontais predominantes, realçados pelos pilotis recuados e sem ligação aparente com o bloco, em área sombreada, tornados quase imperceptíveis.

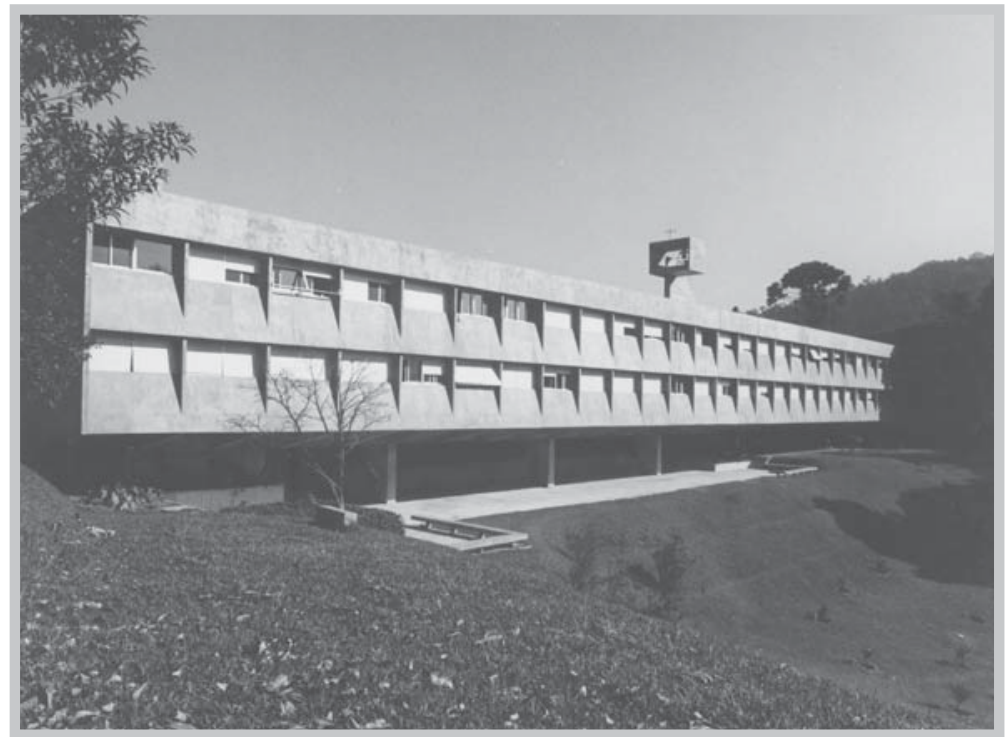

Fig. 61 - Hans Broos. Abadia de Santa Maria. São Paulo. 1974-1977.

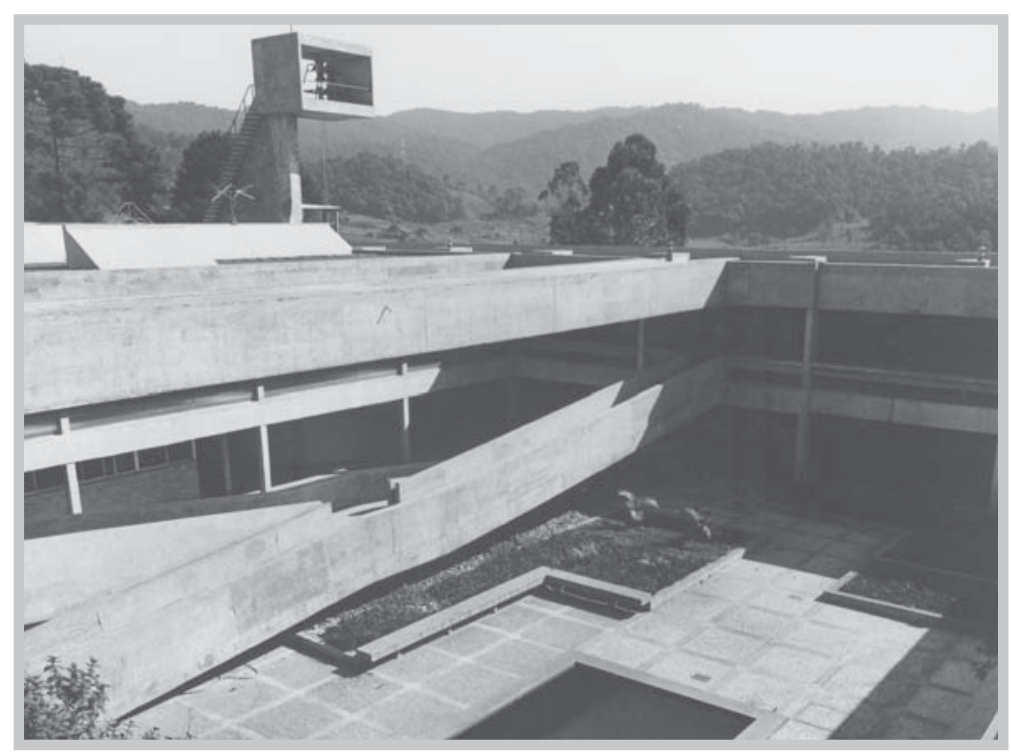

Fig. 62 - Hans Broos. Abadia de Santa Maria. São Paulo. 1974-1977.
Segundo Broos, a obra de São Bento foi um "ensaio" para o que seria sua grande realização, a obra da Abadia de Santa Maria (19741977). Para o projeto o arquiteto busca inspiraçãolongínqua, na obra pós-guerra corbusiana, ao mesmo tempo em que assimila influências locais, como já vinha trabalhando em projetos anteriores. À parte a grande dimensão e complexidade do programa, também na Abadia o arquiteto resolve o programa com a solução do bloco único, neste caso, com uma planta retangular com pátio central, onde a noção da cobertura é formalmente retirada. $\mathrm{O}$ arquiteto se desfaz da noção da caixa e do desenho perfilado do bloco - presente em trabalhos simultâneos - para dar vazão a uma idéia de maior consistência e peso visual do volume. Como no Mosteiro de São Bento, Broos recua os pilares, e gera uma tensão entre o volume e os apoios (ou 
a aparente falta deles), que aqui é exacerbado pelo maior volume do bloco e a menor proporção dos apoios em relação àquele. Tem-se a noção do edifício estar "pousando", em franca contradição à sua corpulência.

Para a fachada principal Broos busca referências numa das obras mais conhecidas da obra tardia de Corbusier: o Convento de La Tourette (1956-1960). Se antes as obras brutalistas de Broos estavam muito mais marcadas pelo Corbusier préguerra, ou as estruturas límpidas e regulares de seu mestre Eiermann, ou até referências miesianas, Broos troca este aspecto mais "preciso" e conciso pela Corbusier pós-guerra. Se não se liga à ele precisamente pela expressividade e virtuosismo estrutural das obras, pelo desenho dos pilotis da Unité, liga-se pela corpulência conferida ao bloco; nem tanto pela rugosidade das texturas, mais pelas citações e demarcação do ritmo das celas da monjas, sem deixar de salientar o caráter de volume único da Abadia, que contraria os vários elementos aparentemente sobrepostos e autônomos que surgem em La Tourette. Entre citações mais diretas como o campanário ou os brises verticais da igreja num ritmo irregular - que remetem aos brises, presentes nos corredores internos e em alguns ambientes como o refeitório de La Tourette - tem referências mais diluídas como a marcação das celas individuais na fachada.

A planta do bloco, um retângulo na proporção 3:2, reserva em seu interior um pátio central, restrito às monjas. O programa é bastante diverso; abrange desde os dormitórios e a igreja com os ambientes de apoio, até serviços médicos, dependências administrativas e uma pequena oficina tipográfica. No interior do prédio, o arquiteto dá ênfase às circulações e acessos, através de grandes rampas, que dão acesso ao edifício e cortam o pátio de um lado a outro. Mesmo numa edificação de relativa complexidade como esta e de amplas dimensões, como nas outras obras do arquiteto, é a estrutura elemento organizador do espaço. Uma grelha uniforme de 5,70m é lançada, organiza e dá origem a todos os espaços, desde as celas individuais até o pátio e a igreja. Também aqui, a exemplo de São Bonifácio, o arquiteto lança mão de relações proporcionais que remetem à tradição clássica, nem tão presentes e complexas, porém, como naquela igreja.

Já foi ressaltada a alusão à obra corbusiana que o edifício da Abadia perfaz em sua plasticidade externa; porém, sua composição assume também aspectos a esta altura já balizados pela corrente paulista. Além dos aspectos já citados, a igreja nos dá outra demonstração disso.

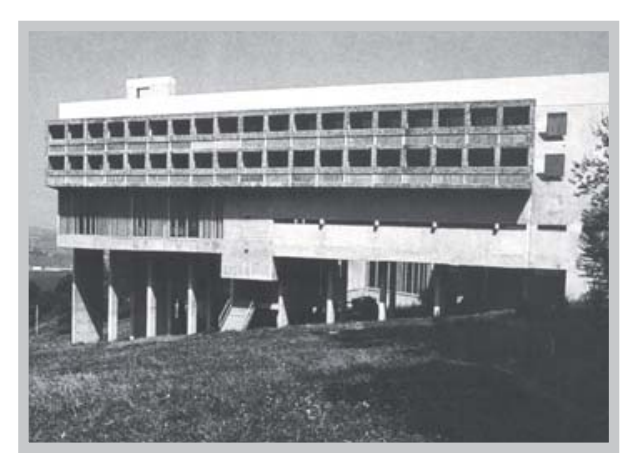

Fig. 63 - Le Corbusier. Convento de La Tourette. 1956-1960. 


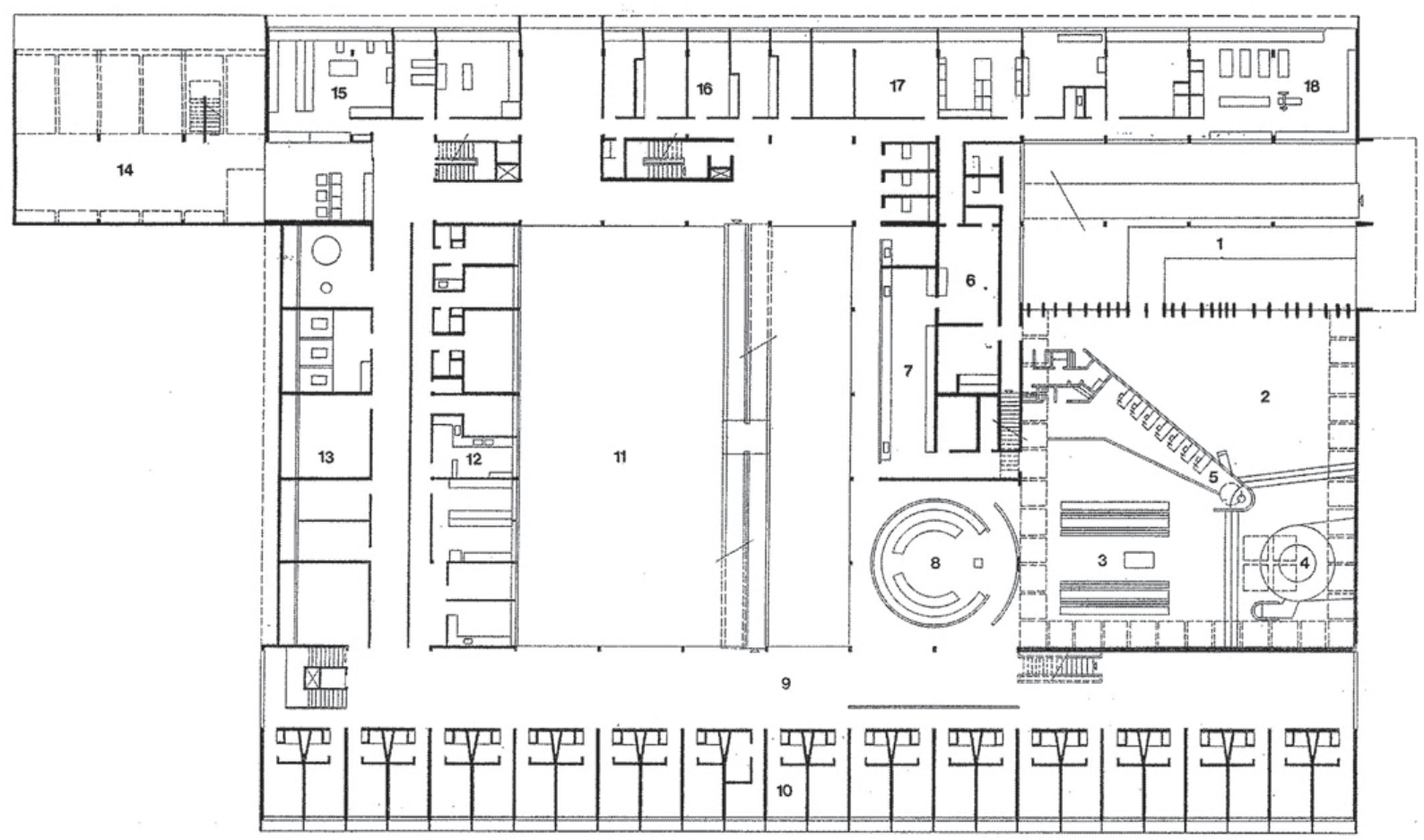

Fig. 64 - Abadia de Santa Maria. Planta baixa.

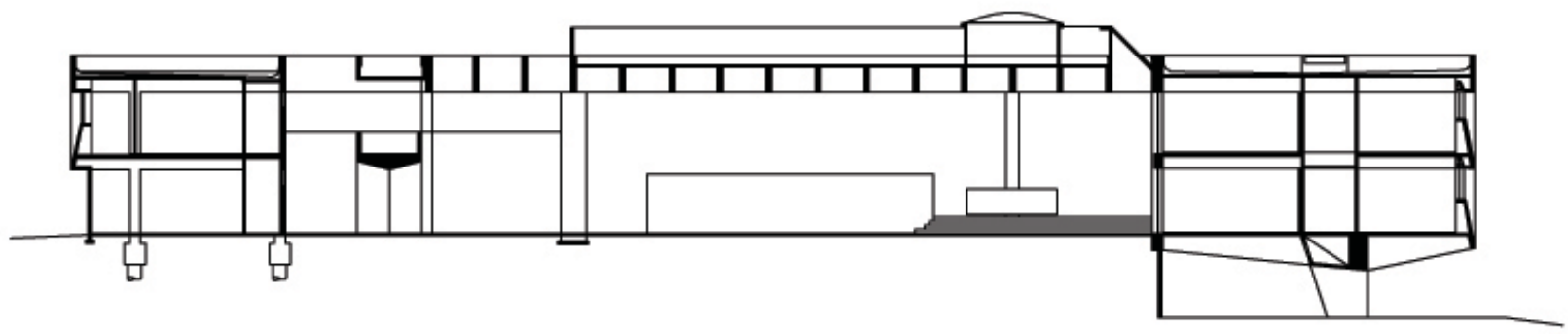

Fig. 65 - Abadia de Santa Maria. Corte Transversal.

Diferentemente da capela junto ao Mosteiro de São Bento (e assim também em La Tourette), cujo volume se distingue do edifício como objeto autônomo e articulado ao bloco principal, com interior de grande simplicidade e espaço único para monges e público em geral, a capela da Abadia de Santa Maria, se insere no edifício, como parte dele, e não desfaz, assim, a noção de bloco unitário do conjunto. Entretanto, seu interior, a despeito de não distinguir-se volumetricamente, revisita a noção presente em São Bonifácio de um "mundo a parte".

O volume interno da igreja revela forte influência miesiana: o espaço único e flexível, a cobertura em grelha bidirecional, o grande vão, a economia de meios e notável austeridade. De maneira interessante, a aparente rigidez da planta retangular é imediatamente quebrada por um painel a meia altura disposto na diagonal, que confere direcionamento ao espaço, divide e marca o espaço público 
daquele restrito às monjas e ainda abriga o confessionário em seu interior. Mesmo assim, a presença do painel não significa a fragmentação do espaço; este é apreendido em seu todo, como um volume único e homogêneo. $\mathrm{O}$ posicionamento do altar, aliado ao painel,permitequeacelebraçãoreligiosa seja efetuada para os dois públicos distintos, não ocultando a visão do altar a nenhum deles. O belo painel de Burle Marx, em concreto aparente, encontra equivalentes na Casa do Arquiteto e na Indústria da Hering de Rodeio $^{37}$ (que, por sua vez teve solução similar à encontrada no Edifício Plavinil-Elclor de Rino Levi, também com painéis e paisagismo de Burle Marx criado no recuo obrigatório do edifício, recurso bastante utilizado pelo arquiteto), e troca as tradicionais estações da Via Sacra por figuras abstratas e geométricas. Como em São Bonifácio, a luz é administrada em pontos determinados: perimetralmente e de forma abundante sobre o altar. Todos

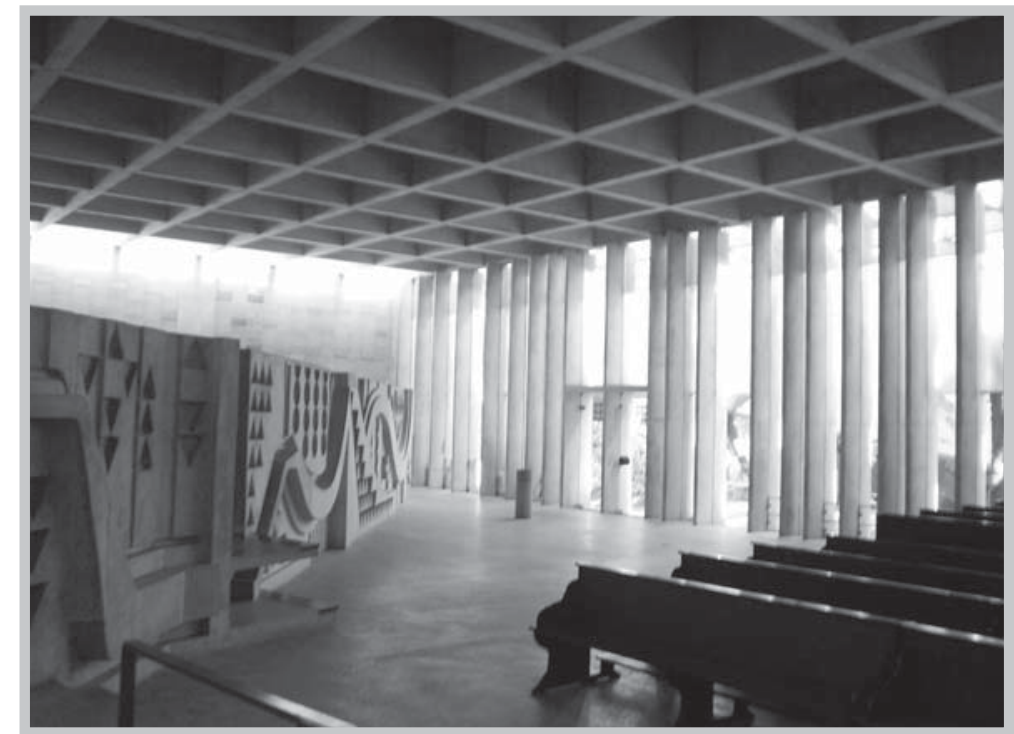

Fig. 66 - Hans Broos. Abadia de Santa Maria. São Paulo. 1974-1977.

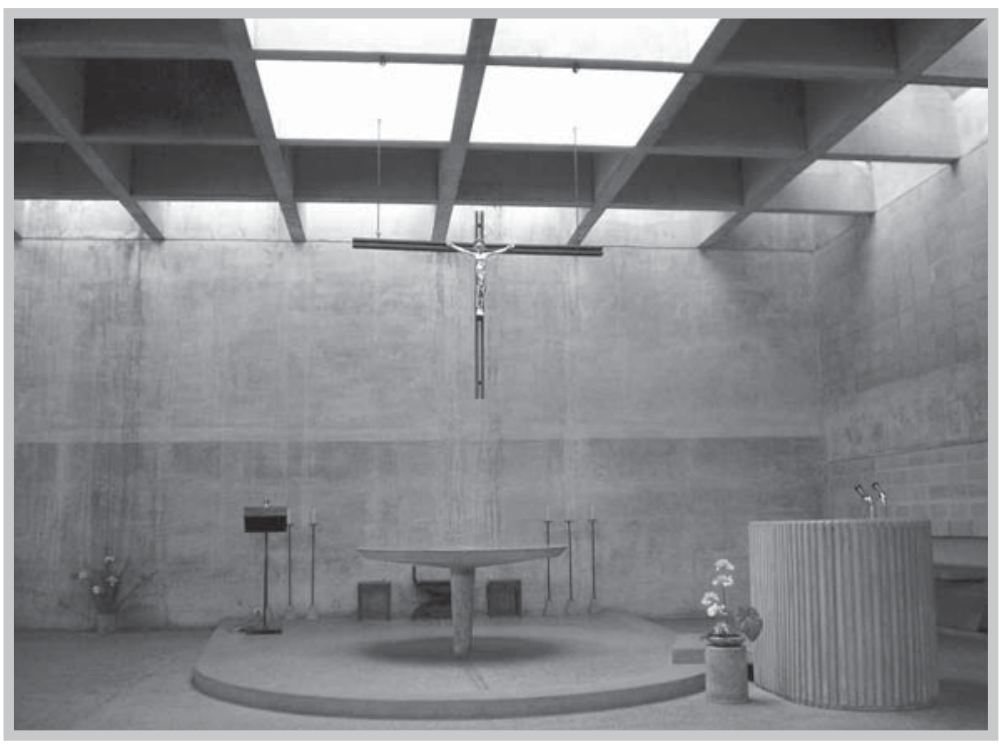

Fig. 67 - Hans Broos. Abadia de Santa Maria. São Paulo. 1974-1977. os acabamentos e elementos litúrgicos são em concreto aparente. A simplicidade volumétrica, a austeridade interna e a redução compositiva a elementos essenciais, tem sua contraposição na iluminação zenital que revela detalhes, texturas de um material utilizado de diversas maneiras e para diversos fins.

\section{O ARQUITETO INDUSTRIAL BROOS}

Apesar do grande número de residências projetadas pelo arquiteto - e de muitas delas não terem sido construídas - elas foram mais importantes à medida que proporcionaram um campo experimental como nenhum outro, em que muitas vezes não estava atrelada a responsabilidade da efetiva execução da obra. Entretanto, nenhum outro campo gerou exemplos mais profícuos que o programa industrial, que passa a rivalizar em números com o programa residencial a partir 
dos anos 1970. Estes anos representam um período muito fértil na produção industrial do arquiteto, atrelada à construção do complexo da Hering e suas filiais - ou satélites - e a expansão da empresa para outras regiões do país. Depois de iniciada a Hering Matriz e as unidades de Água Verde e Indaial, Broos dá início a mais dois projetos de forma simultânea: Hering Satélite de Rodeio e a grande unidade do Nordeste.

Em que pesem as diferenças programáticas, e consequentemente de escala - a Hering Rodeio é mais uma das unidades satélites, que abriga, portanto, somente o setor da costura, enquanto a Unidade do Nordeste responde por todo o processo de produção têxtil - ambas em muito se diferenciam também formalmente e explicitam em sua volumetria e materiais as diferentes motivações que lhes deram origem.

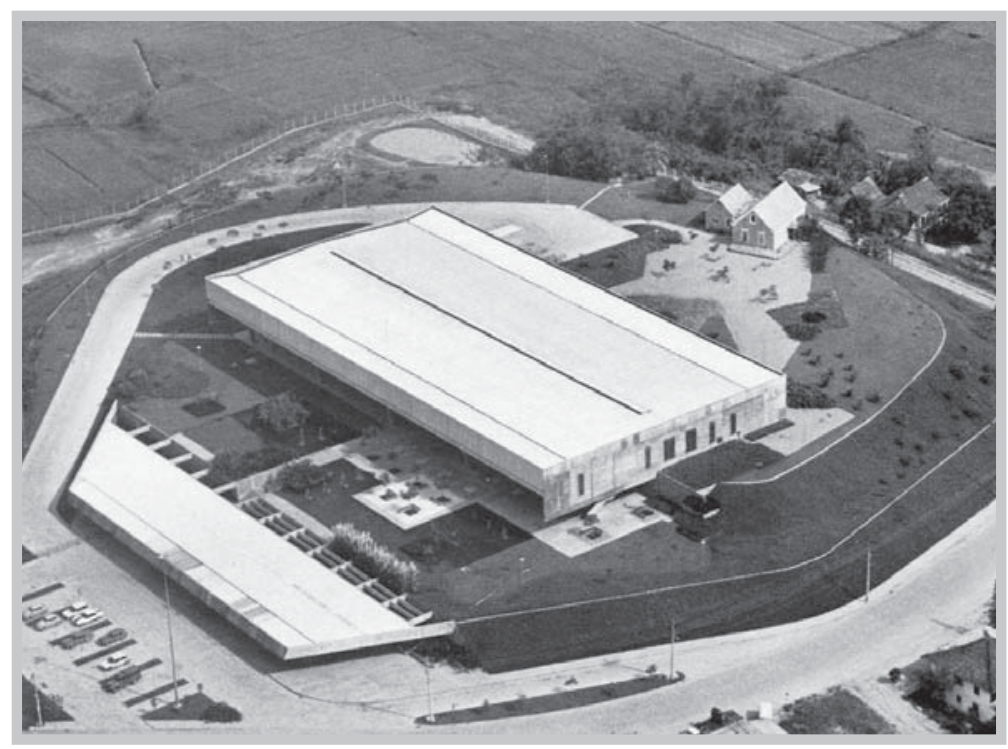

Fig. 68 - Hans Broos. Unidade satélite de Rodeio. Rodeio. 1977-1978.

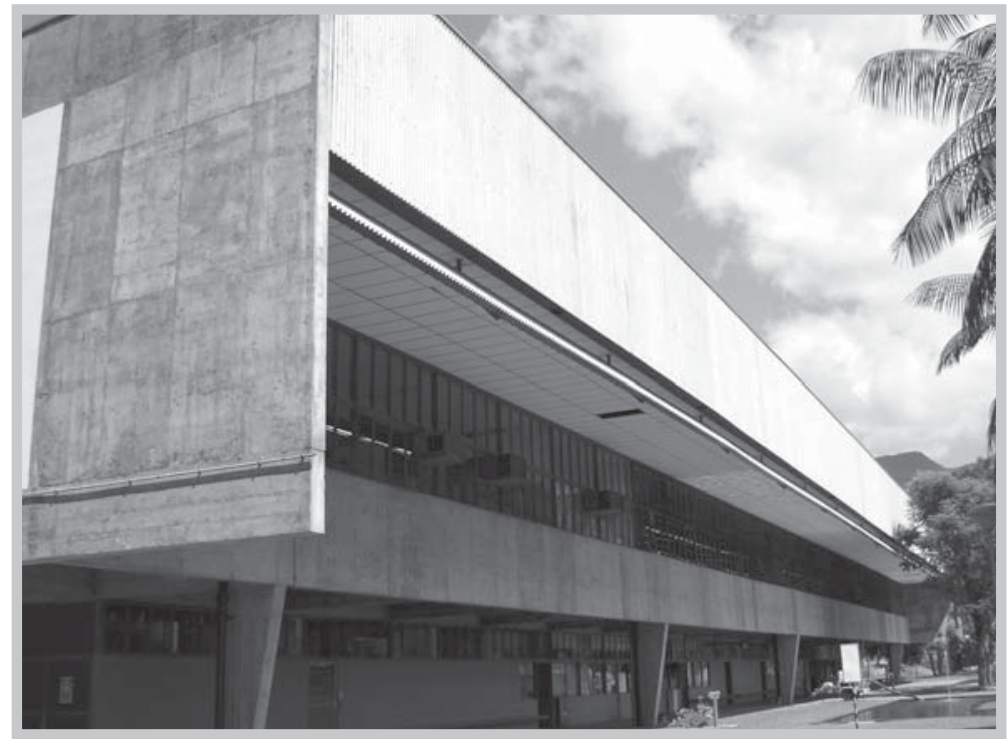

Fig. 69 - Hans Broos. Unidade satélite de Rodeio. Rodeio. 1977-1978.
A Hering de Rodeio (1977-1978) ainda se liga essencialmente à Hering Matriz e Hering Água Verde. Como esta, o que chama atenção de imediato é a unidade formada entre a obra e seu entorno, uma simbiose entre obra construída e natural. O edifício, como em Água Verde, localiza-se no topo de uma pequena elevação e é projetado em extensão, uma volumetria retangular e baixa, cuja horizontalidade é marcante, que se adequa e aproveita o desnível do terreno. Já a portaria - uma ampla laje de concreto disposta no ponto mais baixo do morro - funciona como um fechamento àquele, como sua extensão natural, seguido com seus contornos as curvas de nível do solo. A portaria "desloca-se" do terreno através de um pergolado em toda a extensão, com belo tratamento paisagístico de Burle Marx, ${ }^{38}$ que inclui painéis em concreto aparente, vegetação e espelhos d'água, além do jardim defronte à fábrica. 
Pela primeira vez nas fábricas, o arquiteto trabalha com o tema da "caixa" que define volumetricamente o edifício - formada pelas empenas laterais e pela cobertura - esta porém, reformulada, não mais em concreto, mas com uma grande platibanda metálica e a adição de um brise também metálico, disposto diagonalmente, que oculta a estrutura metálica da cobertura. Em termos gerais, porém, as referências ao Brutalismo Paulista continuam - a grande cobertura, com fachada frontal recuada e o bloco sobre pilotis. O maior interesse aqui recai na cobertura, que domina visualmente o bloco e lhe confere horizontalidade marcante. Nas empenas laterais o arquiteto remete às soluções de aberturas que havia feito em São Bonifácio e na Hering Matriz: estreitas e longilíneas aberturas com brises verticais, dispostas perpendicularmente ao edifício de um modo irregular. As aberturas são rasgos verticais de uma delicadeza que se contrapõe à dimensão e ao peso do bloco; sua saliência faz uma marcação vertical contrária à característica horizontalizante do volume, reagem à luz, sem descaracterizar a aparente consistência e a noção de bloco fechado.

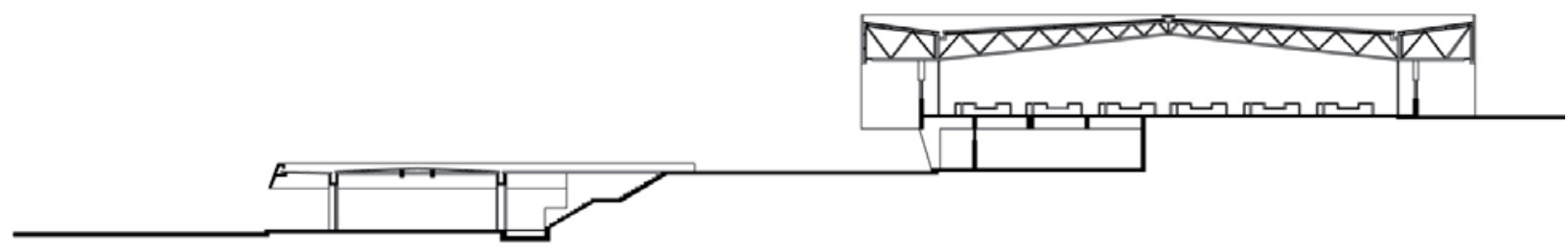

Fig. 70 - Unidade satélite de Rodeio. Corte Transversal.

A certa distância, ambos os edifícios - a portaria e o bloco da costura - são duas estruturas que desejam "levitar", em que unem soluções formais e o aproveitamento das características do terreno para criar um interessante projeto, em perfeita comunhão com o entorno. Em ambos, com suas fachadas recuadas - a portaria com fechamento de vidro - são exaltadas as coberturas, em sua linearidade e horizontalidade, fazem o contraste entre uma pretendida leveza, em que parece faltar-lhes os apoios, e as pesadas estruturas em concreto armado. Dentreas unidades satélites, todas elas pequenas unidades com projetos de grande interesse, a Hering Rodeio corporifica a mais perfeita harmonia entre edifício e seu entorno.

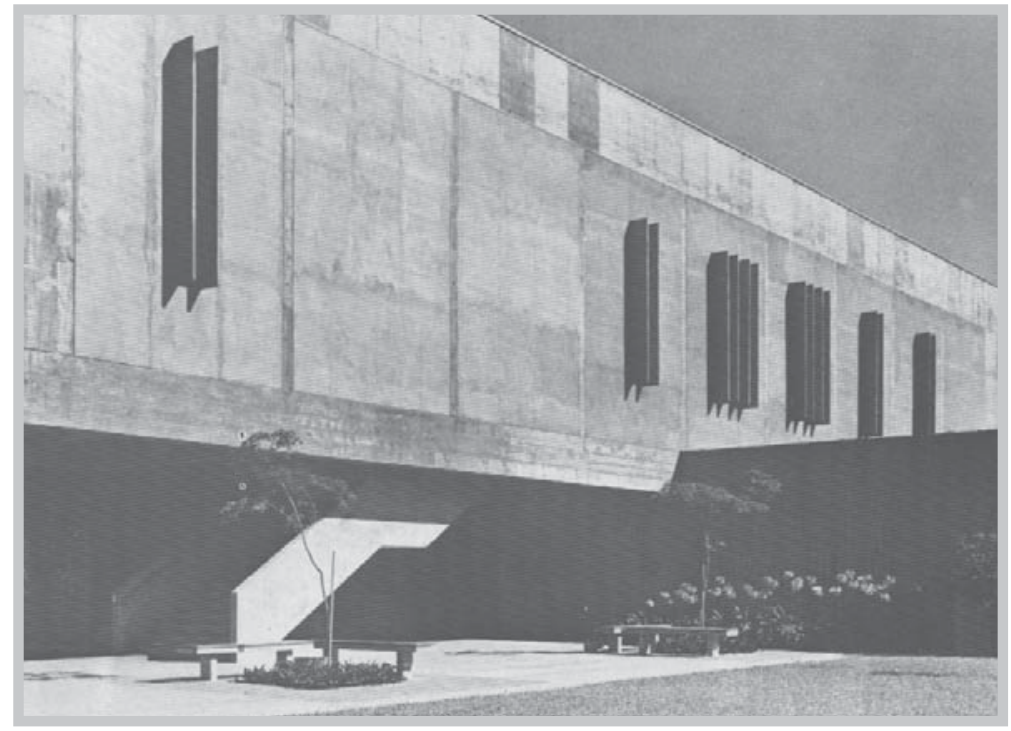

Fig. 71 - Hans Broos. Unidade satélite de Rodeio. Rodeio. 1977-1978. 


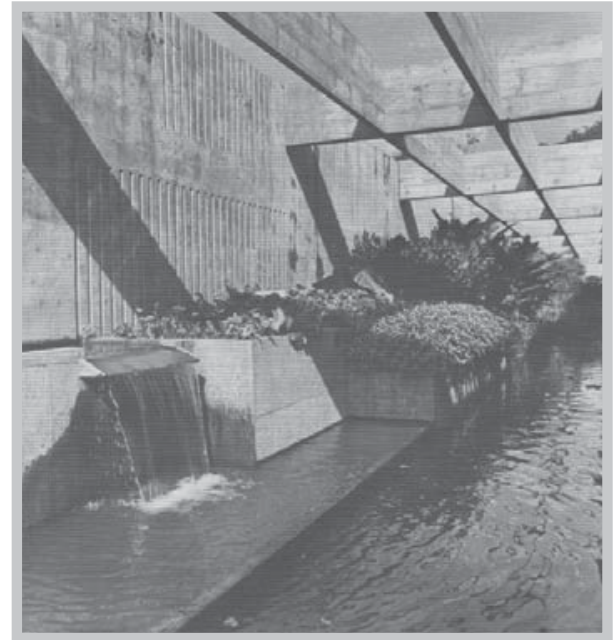

Fig. 72 - Hans Broos. Unidade satélite de Rodeio. Rodeio. 1977-1978.

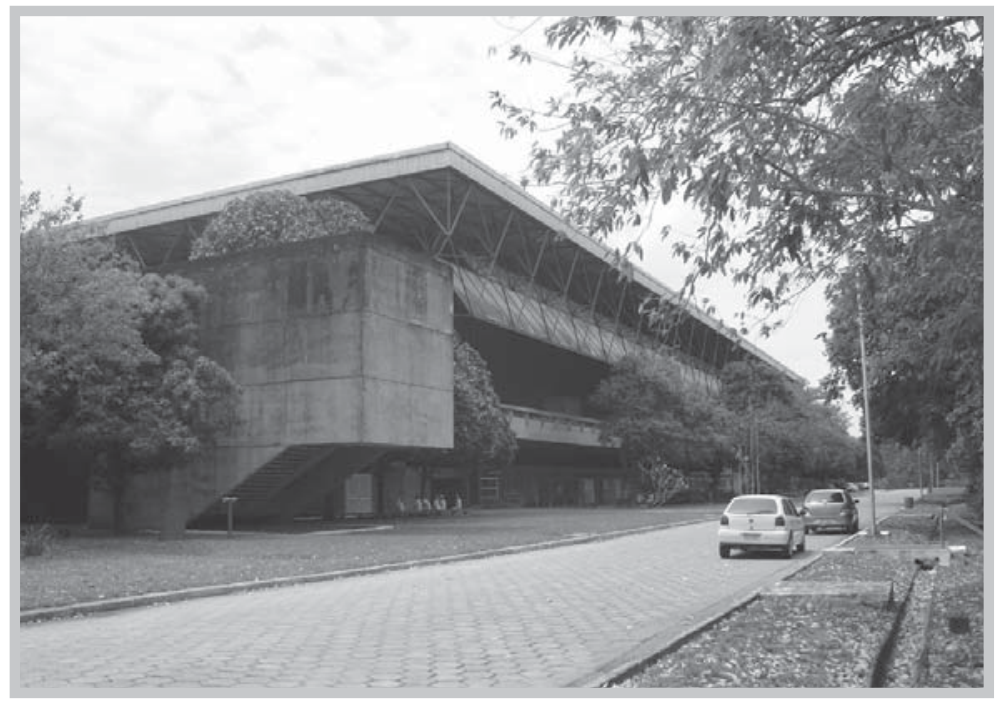

Fig. 73 - Hans Broos. Hering do Nordeste. Paulista, PE. 1975-1978.

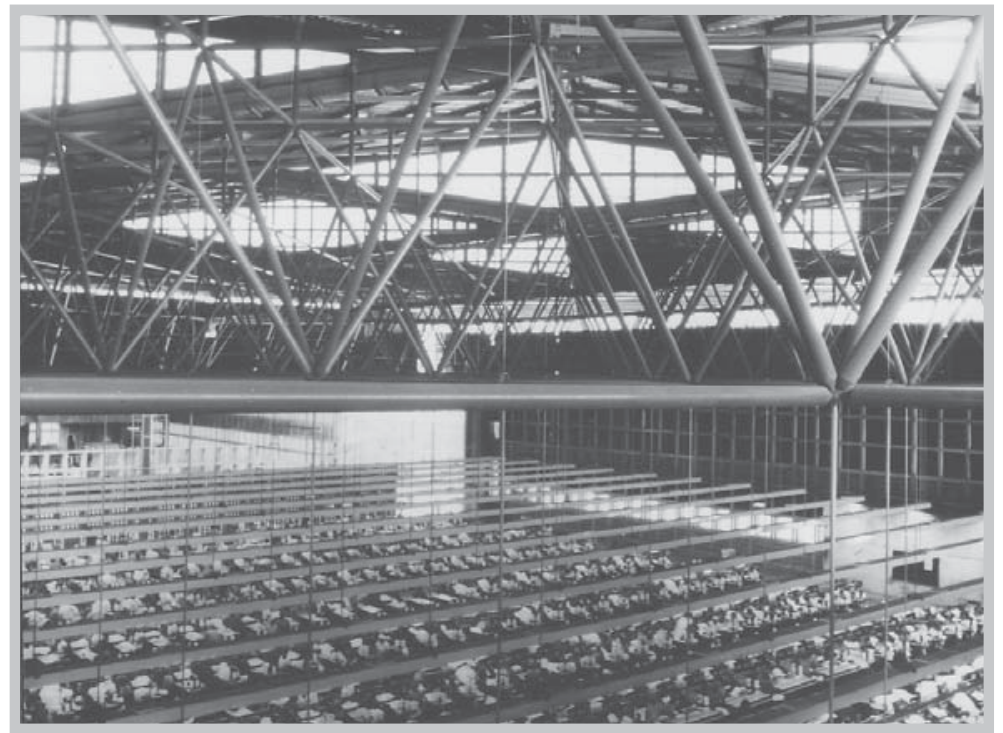

Fig. 74 - Hans Broos. Hering do Nordeste. Paulista, PE. 1975-1978.
Apesar de ter sido construída no mesmo período, e revelar algumas ligeiras semelhanças com o projeto de Rodeio, a Hering do Nordeste $(1975-1978)^{39}$ parece surgir de inspiração outra. Com programa e escala muito maiores, foi justamente algumas condicionantes do programa e, principalmente, o clima e o ambiente do Nordeste os fatores de maior peso para a assumida mudança compositiva da obra em relação às edifícios industriais anteriores.

$\mathrm{Na}$ Hering do Nordeste predomina a grande escala e as grandes dimensões que abrigam em apenas um edifício, todos os setores produtivos de uma indústria têxtil. Em sua cobertura recai a maior atenção do projeto: tanto como fator climático, quanto estrutural. $\mathrm{O}$ arquiteto justificouseuprojetoapoiadonaidéia de que novos tempos solicitavam a adesão a novos materiais; e o material do momento, de que grande parte dos arquitetos lançava mão como solução compositiva, era a construção em aço. $\mathrm{O}$ arquiteto escreve que desde os anos de 1970 optou pela tecnologia do aço na arquitetura por suas qualidades na economia de área construída, transparência e continuidade dos espaços de produção, reduzindo o uso do concreto armado; e justifica que "a ambientação brasileira pedia uma solução espiritual e filosófica adequada às condições climáticas e sociais do país." ${ }^{\prime 0}$

Entretanto, o concreto armado, material símbolo da arquitetura moderna brasileira, nunca havia sido abandonado, ao contrário; o 
que predominava era uma continuidade formal com a Escola Paulista, muito embora seus ideais e seu "projeto" já haviam sido abandonados há tempos. Nos anos de 1970 e 1980 parte da arquitetura brasileira expressa as possibilidades tecnológicas como expressão formal da arquitetura, não mais em forma do arrojo estrutural permitido pelo concreto armado, mas as novas possibilidades de materiais, em especial o aço, que agora poderia concorrer com o concreto devido ao desenvolvimento da indústria siderúrgica nacional.

Com esta justificativa, não parece que os novos tempos pediam esta solução, mas sim o local do projeto, com suas altas temperaturas e a necessidade de aproveitamento climático. A Hering Rodeio construída simultaneamente, não ostenta tal composição, muito embora a estrutura metálica já houvesse sido usada pelo arquiteto em quase todas as unidades satélites e alguns edifícios da Matriz, porém não tirando partido plástico do material e da estrutura. $\mathrm{O}$ clima do Nordeste pedia uma nova solução; na cobertura (mais uma vez) recai não somente a plasticidade do edifício como o grande interesse do projeto.

Sua estrutura treliçada com sheds é direcionada aos ventos predominantes da região, fazendo com que todo o espaço interno - único e indiviso - usufrua da constante brisa marítima.

O edifício da Hering Nordeste também revelao papelpreponderante que se deu às exigências funcionais. A treliça metálica, além de proporcionar o aproveitamento climático, é justificada pelos grandes vãos que possibilita, apoiada em apenas oito pilaresinternos: "Os grandes espaços, que facilitam eventuais remanejamentos do layout e a supervisão dos conjuntos de trabalho, foram vencidos por uma estrutura espacial cujos apoios estão localizados nos limites do edifício". ${ }^{41}$

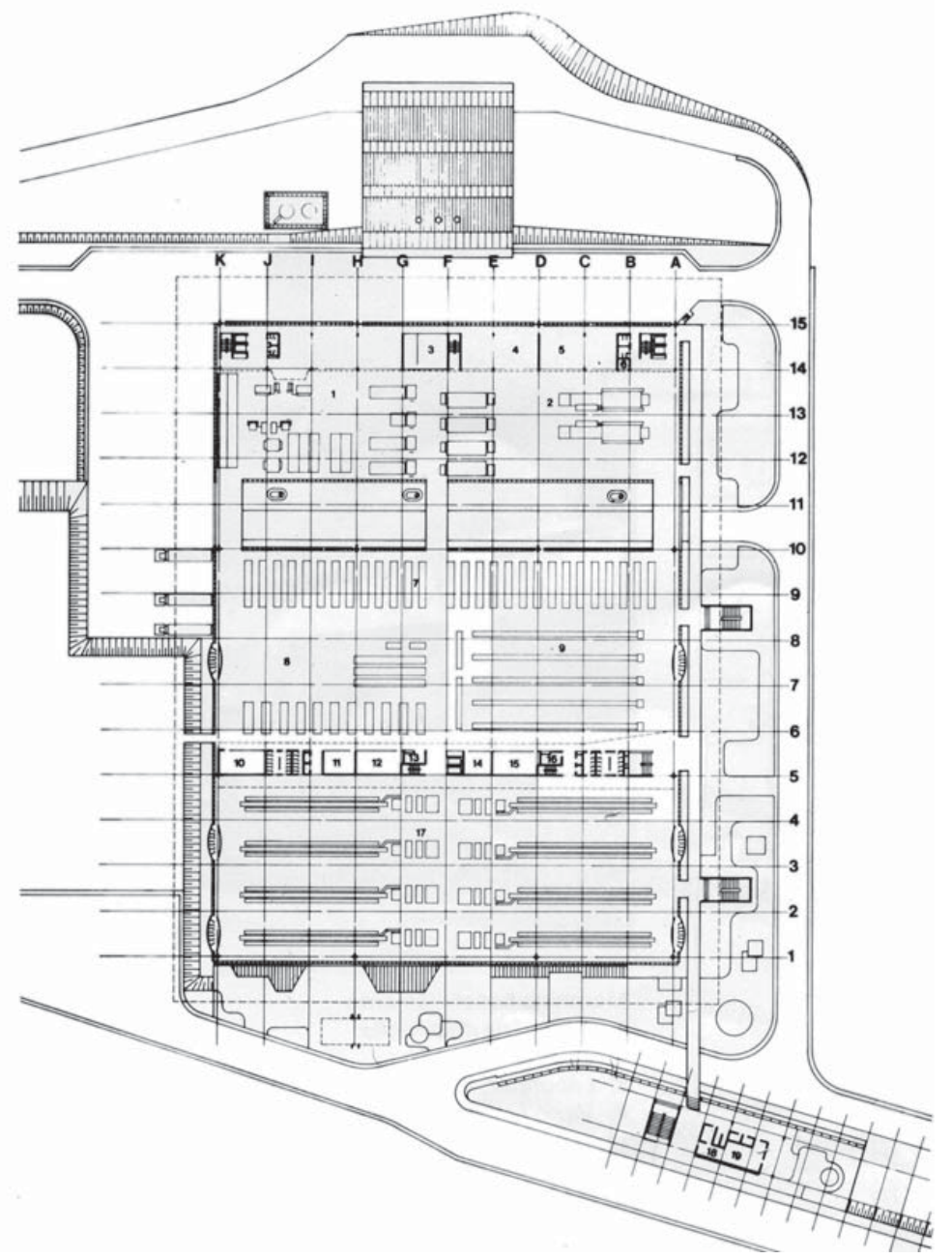

Fig. 75 - Hering do Nordeste. Planta baixa. 


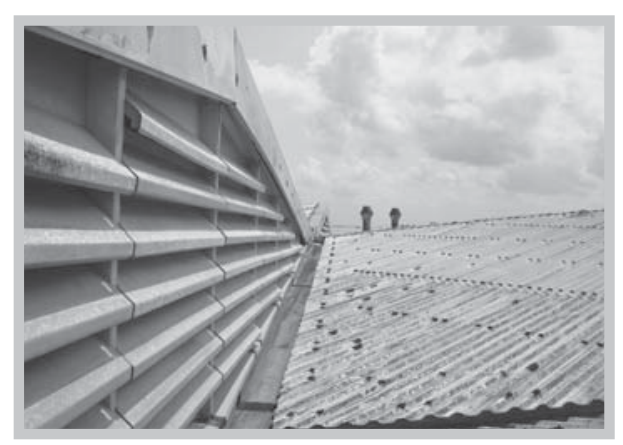

Fig. 76 - Hans Broos. Hering do Nordeste. Paulista, PE. 1975-1978.

Através de incentivos governamentais ${ }^{42}$ a unidade do Nordeste, instalada no distrito industrial de Paulista, município da grande Recife, parece comungar do ímpeto desenvolvimentista que se manifestou no Brasil e fazer parte das grandes construções que grassavam no país dos anos 1970. Diferentemente da Hering Matriz, onde muitos edifícios compõem o sistema produtivo, aqui optou-se por colocar em um mesmo edifício todas as funções da fábrica, gerando um edifício de grandes dimensões: $216 \mathrm{~m}$ x 192m, uma realidade bastante diversa daquela no sul do país. O grande desafio deste projeto, além das ações climáticas e funcionais era, sem dúvida, amenizar tanto externo quanto internamente a escala arquitetônica, e buscar soluções que priorizassem a devolução de uma escala humana não priorizada como premissa inicial e fundamental.

$\mathrm{O}$ arquiteto tomou partido então, dos fechamentos, seus desenhos, cores, formatos e texturas, blocos de concreto vazados em sua maioria, que servem como fechamento e permite a entrada dos ventos por todos os lados, que contribuem na boa climatização interna. Também foram tomadas medidas para amenizar a escala do bloco. Assim como havia feito no Edifício da Malharia da Hering Matriz, Broos tirou partido do desnível do terreno, localizado numa baixada às margens da Rodovia PE-18. À distância, avista-se tão somente a cobertura que sobressai em sua estrutura leve e vazada em meio ao verde; apesar de suas grandes dimensões, sua implantação contribui para a continuidade visual na ampla planície. $\mathrm{O}$ arquiteto soube equilibrar com magistral talento, a grande escala do bloco e sua implantação que o oculta na paisagem. Fato este que, internamente, apesar dos esforços com a variedade de fechamentos, não foi capaz de contribuir efetivamente para uma relação mais humana dentro das funções do edifício. Internamente, tudo foi pensado para facilitar as relações entre as diferentes funções e o possível remanejamento dos equipamentos: grandes vãos e pé-direito generoso.

Alguns detalhes interessantes do projeto, que remetem a obras anteriores: a passarela de ligação entre a portaria e a fábrica, o volume externo da escadaria que revisita o exemplo da Malharia da Hering, escadas internas em balanço, ou até mesmo a bela e (relativamente) pequena casa de Caldeiras - belo exemplo do que pode ser considerado ainda uma continuidade com a Escola Paulista acabam diluídos em meio ao gigante fabril que chama a si todas as atenções. 
Construída poucos anos antes da Hering do Nordeste e contemporânea a algumas das Unidades da Hering Matriz, para o projeto da Tecanor (19731977) ${ }^{43}$ localizada ao lado da primeira, Broos possui as mesmas preocupações em conciliar com harmonia, edifícios e o entorno, e lança mão de soluções de projeto semelhantes àquelas dos exemplos catarinenses. Embora se depare com situações díspares - na Hering Matriz a fábrica é inserida num fundo de vale e, aqui, uma vasta planície junto ao mar - o objetivo é tornar o conjunto fabril o mais harmônico possível, conjugando os prédios entre si e com a paisagem circundante.

OTecanorcongrega váriosedifícios, a exemplo da Hering Matriz. Ao avançar-se pela PE-18 avistam-se os edifícios com a cobertura ao

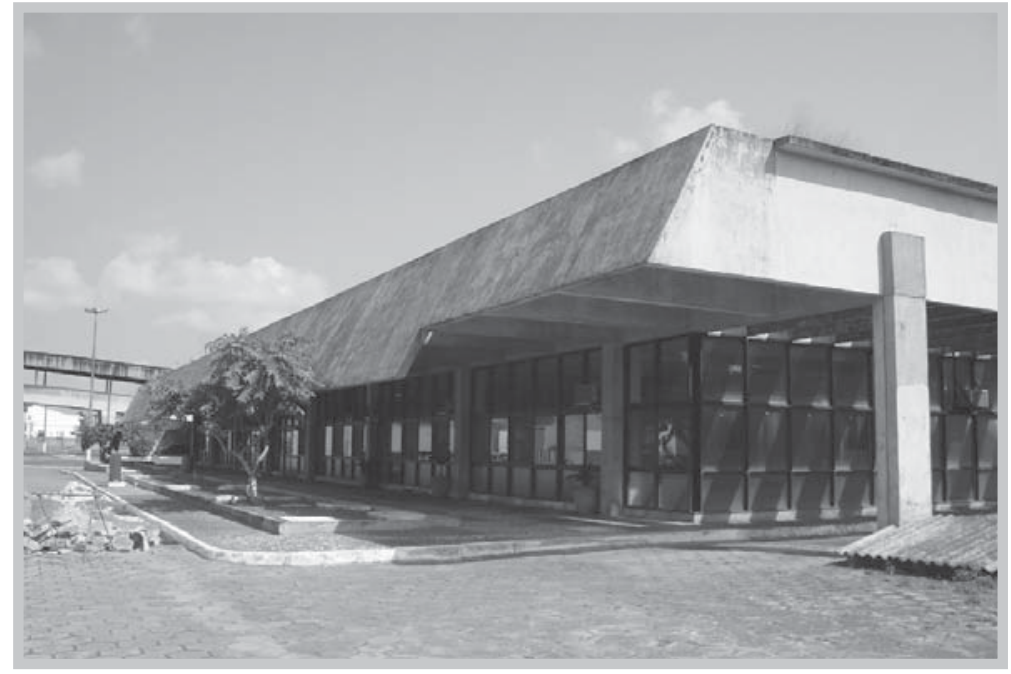

Fig. 77 - Hans Broos. Tecanor. Paulista, PE. 1973-1977.

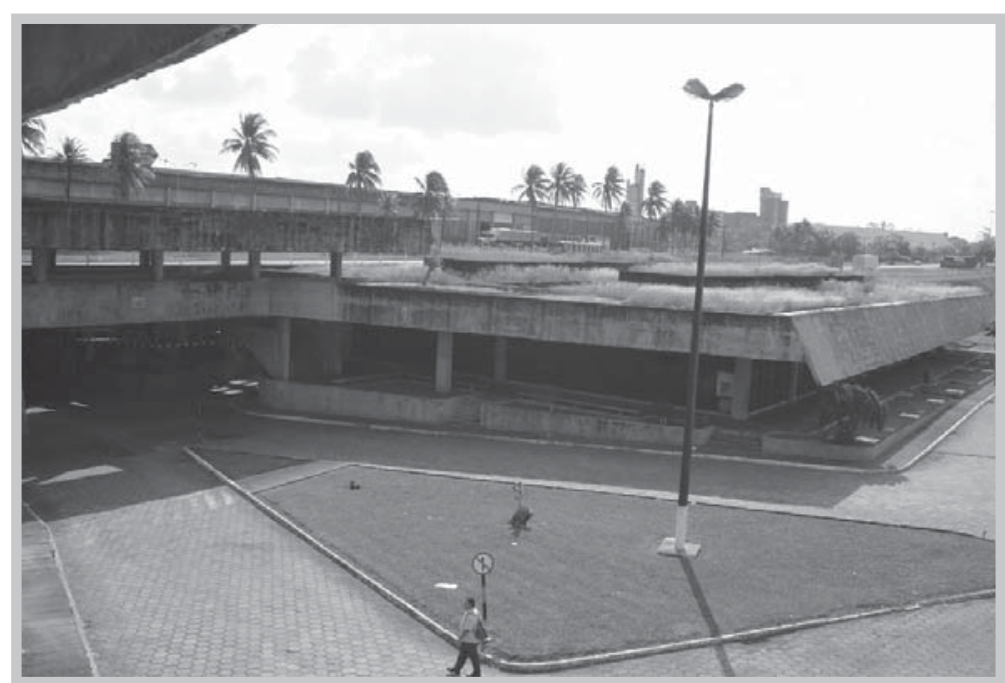

Fig. 78 - Hans Broos. Tecanor. Paulista, PE. 1973-1977. nível da rua ou de um pavimento acima, em continuidade visual com a planície, e que terá como fundo a Hering Nordeste. Mais uma vez Broos aproveita o desnível do terreno para colocar edifícios de uma maneira quase "natural", em continuidade com a rua. Edifícios vazados e baixos "diluem-se" na paisagem, e da mesma forma que na Hering Matriz, os edifícios mais altos são dispostos nos "fundos" do terreno. Na portaria, Hans Broos reproduz um feliz modelo: edifício baixo, com ampla cobertura de concreto e fachada de vidro recuada, edifício "incrustado" no terreno, e acima dele, um terraço-jardim em continuidade com a rua. Ao lado deste, uma passagem subterrânea para veículos e pedestres faz a ligação com as demais unidades localizadas do outro lado da via.

Os maiores edifícios não despertam o mesmo interesse que os da Hering Matriz, não deixam dúvidas, porém, quanto às influências que continuam a animar as 


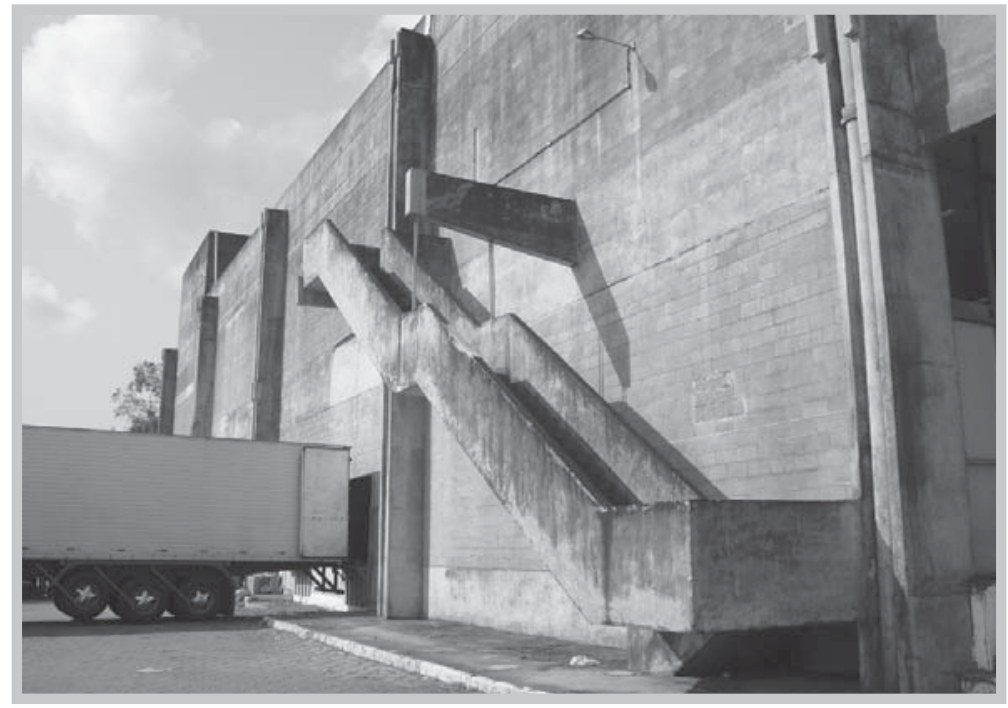

Fig. 79 - Hans Broos. Tecanor. Paulista, PE. 1973-1977.

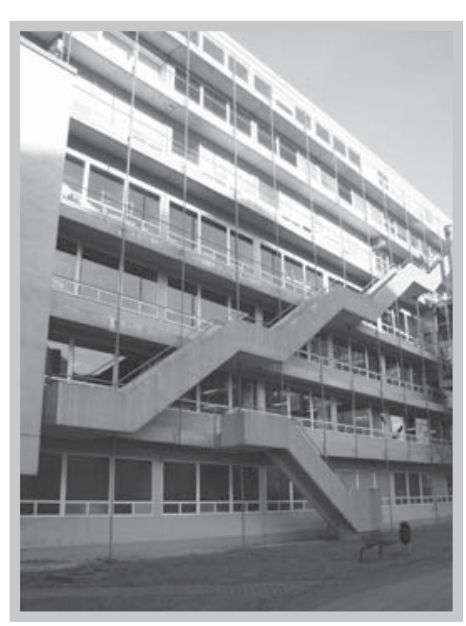

Fig. 80 - Egon Eiermann. Versandhaus Neckermann AG. Frankfurt. 1958-1961. dinamismo ao bloco inerte. soluções do arquiteto: no Edifício de Despachos, a escada externa remete diretamente à Neckermann de Eiermann, já utilizada como exemplo por Broos para outras soluções. Construída na mesma época que a Hering Matriz, a obra revela que também no Nordeste a influência eiermanniana se faz marcante - as escadas externas que dinamizam o volume extensivo da Neckermann são citadas na fachada lisa do bloco da Tecanor, que possui apenas na escada e na demarcação externa de sua estrutura (como na Malharia da Hering) o diferencial compositivo, que impõe

Volumes horizontalizantes, marcados pelas coberturas e estruturas de concreto armado aparente, brises, passarelas e rampas, remetem a premissas formais brutalistas, e marcam a interessante ambientação desta fábrica que, no entanto, carece da "urbanidade" e do espaço central que tanto dão vida à Hering Matriz.

\section{CONSIDERAÇÕES}

Hans Broos traz em sua arquitetura brutalista uma série de referências e aproximações formais e conceituais que, excetuando-se alguns poucos exemplos, nunca são diretas, miméticas ou gratuitas, e sempre conduzem a certa complexidade formal e espacial, e nunca a um entendimento simplista.

Broos já possui em sua arquitetura algumas premissas que posteriormente nortearão a arquitetura Brutalista Paulista, e revela a afinidade que sua linguagem encontra no novo meio; em especial a preferência pela contenção da caixa e suas variantes, que perfaz o bloco único e autônomo, e a racionalidade estrutural que dá origem à sua concepção formal.

Estas afinidades nem sempre gerarão arquiteturas formalmente e conceitualmente semelhantes ao Brutalismo. Disso resulta que, num primeiro momento, o impulso inicial de suas primeiras obras brutalistas, encontram-se em sua própria obra, tomadas também algumas referências eiermannianas, quando o arquiteto parte 
para o uso do concreto armado. O meio local, veio a catalisar estas afinidades e Broos passa a adotar, com maior nitidez, certas soluções peculiares ao Brutalismo Paulista a partir dos anos 1970; que não são verificáveis, porém, em todas as obras. Podemos afirmar não existir uma linguagem brutalista definida em Broos, tampouco que se apresenta como um Brutalismo estrutural como veio a se definir na corrente paulista, a não ser aquela colocada nos próprios termos de sua arquitetura, em suas características mais gerais, como citado anteriormente. Pois as fronteiras desta tendência eram tão largas e a liberdade projetual que reivindicou para si tão ampla que não lhe cabe nenhuma taxação. Entretanto, é justamente esta noção inclusiva e não restritiva, que caracteriza o Brutalismo Paulista. Como coloca Zein: "a tendência (brutalista paulista) vai se fixando e ampliando seu atrativo e interesse, seja pelo exemplo (de profissionais experientes), seja por mostrar-se capaz de assimilar distintas contribuições segundo variados focos conceituais, mostrandose como 'estilo" rico e passível de ser vivificado de muitas maneiras" ${ }^{44}$

E muito embora a influência de Eiermann seja inegável, como referência diluída ou citação direta, as obras de Broos não podem ser compreendidas a partir da noção que a obra eiermanniana encerra. Apesar de apresentar elementos brutalistas e do fato de algumas obras se aproximarem inegavelmente desta tendência - como o Edifício da Olivetti - não falaremos em um Eiermann brutalista; que flertou, sim, com esta tendência, contudo se manteve muito mais atrelado a sua arquitetura anterior, onde a leveza e a precisão construtiva eram suas premissas. ${ }^{45}$ Broos se afasta desta noção já em suas primeiras obras brasileiras. Apesar de conceber a arquitetura como algo racional e não se permitir desvios formalistas, Broos assimilou muito mais a criação e as possibilidades plásticas do concreto armado, mais ao gosto brasileiro. Broos sai da frieza das obras alemãs (mais condizentes com a obra de Eiermann, contudo, do que sua Residência Abel) sem, no entanto, renunciar aos princípios gerais de sua arquitetura. ${ }^{46}$

Em sua arquitetura brasileira dos anos 1960 e 1970, embora influências locais sejam inegáveis em seu trabalho, mais que em filiações, falaremos em aproximações e paralelismos. Também sua obra se insere e ajuda a compor o cenário multifário de nosso Brutalismo e a revelar o quão vasto é o rol de referências e citações dentro desta corrente, num panorama muito mais rico e complexo, menos unívoco e unidirecional do que tem noticiado nossa recente historiografia. ${ }^{47}$ Do mesmo modo, seu exemplo vem a contradizer a tendência à "nacionalização" do Brutalismo Paulista, ou seja, a recusa de seu atrelamento ao equivalente internacional e na aceitação da existência de influências internacionais em sua linguagem, devido, entre outros motivos, à visão político-ideológico que o ligava ainda à suposta construção de um "projeto moderno" e nacional, em consonância ao projeto moderno dos anos 1940-1950. 


\section{Notas}

1 Cf. Zein, Ruth Verde. As Tendências e as discussões do pós-Brasília. Projeto, n. 53, julho 1983.

2 Que será analisado a seguir.

3 Projeto que será analisado neste capítulo.

4 Obra laureada com o Prêmio Rino Levi do IAB-SP em 1967.

5 Que não é o caso de Broos, ao contrário. Por isso mesmo, o arquiteto encara o programa religioso com imenso fascínio.

6 Broos, Hans. Memorial do Projeto. 1966.

7 Idem.

8 Werner Düttmann. apud: Pehnt, Wolfgang. Deutsche Architektur seit 1900. 2a ed. Ludwigsburg/ München: Wüstenrot Stiftung/ Deutsche Verlags-Anstalt, 2006, p. 361.

9 Como os trabalhos de Zein, Ruth Verde. A arquitetura da Escola Paulista Brutalista: 19531973. Tese de doutoramento. São Paulo e Porto Alegre: PROPAR-UFRGS, 2005, e Gimenez, Luis Espallargas, Arquitetura paulistana da década de 1960: técnica e forma. Tese de doutoramento. São Paulo: FAU-USP, 2004.

10 Mais tarde se tornaria o Palácio do Governo.

11 Muitas empresas têxteis foram fundadas no fim do século XIX: Hering, a primeira delas (1880), Karsten (1882), Roeder (1885) que passa a se chamar Empresa Industrial Garcia, e mais tardiamente Altemburg (1922) e Artex (1936).

12 A formação da zona urbana de Blumenau procedeu-se de forma bastante peculiar. A implantação das primeiras empresas seguiu os pequenos núcleos rurais implantados desde os tempos de fundação da colônia, situados junto aos fundos de vales, dispersos um dos outros. Assim, as empresas ali implantadas geraram núcleos urbanos dispersos que compactuaram com uma formação urbana descentralizada; ou seja, as aglomerações industriais precederam os núcleos urbanos em Blumenau. Cf. Bernardo p.29

13 Nunca recebeu formalmente algum prêmio, mas é considerada por Hugo Segawa como um entre os projetos industriais mais interessantes dos anos 1960, e qualificada como "o mais interessante parque industrial criado no país nos últimos 30 anos" pela revista Projeto na edição comemorativa de número 300. Cf. Segawa, Hugo. Arquiteturas no Brasil 1900-1990. São Paulo: Edusp, 1997, p. 161; e Projeto n. 300 março, 2005, respectivamente.

14 Bielschowsky, Bernardo Brasil. Patrimônio Industrial e Memória Urbana em Blumenau/ SC. Dissertação de Mestrado. Florianópolis: PGAU-UFSC, 2009, p. 37.

15 Hering do Nordeste na cidade de Paulista-PE e a outra em Anápolis-GO, esta não executada, ambas também projetadas por Broos.

16 Denominação que revela, em determinados momentos, com legitimidade, uma evolução, uma mudança de postura; entretanto, tem sido empregada na maior parte das vezes como algo sem valor ou característica própria que somente se afirma em função do que lhe precede ou lhe é ulterior; apenas intermédio entre "fases" distintas de seu autor; refutamos aqui esta idéia.

17 Ver Capítulo 3.

18 Broos utiliza o desnível do terreno para conceber o edifício da Malharia com um subsolo aberto, de modo que o edifício não ultrapassasse as edificações vizinhas - edifícios típicos da arquitetura alemã da imigração, com três pavimentos e telhados bem inclinados, com lanternim, construídas como moradias para os operários, mas ao longo dos anos tomadas para a expansão da empresa. Deste modo, já à entrada da fábrica tende para uma mescla natural entre o novo e antigo. Deste modo, Broos manteve o alinhamento e altura dos novos edifícios com os demais, salvaguardando a integridade visual da rua.

19 Ou ao Neoexpressionismo, como parece atender, em muitos casos, também o Brutalismo, para o caso alemão.

20 Sobre as críticas ao uso deste elemento, ver Capítulo 2. 
21 As funções, a que se destinam as passarelas externas seriam, segundo o arquiteto, servir de rota de fuga, proteção à incidência solar, facilitar a limpeza e manutenção das aberturas, sem a necessidade de andaimes (no caso de edifícios em altura), e ainda, como contraventamento.

22 Já que a adequação remete a um "ajustar-se”, “amoldar-se” a outro (exemplar) edifício; não é este o caso pois, apesar do respeito à escala do edifício vizinho e o objetivo expresso de valorizá-lo, o edifício de Hans Broos impõe-se como obra autônoma, ciente de sua importância, porque expressão de novos paradigmas que novos tempos pressupõem.

23 Broos, Hans. O homem e a cidade: Reflexos mútuos. Texto da palestra em 16/06/89. São Paulo.

24 Ver Capítulo 3.

25 Pehnt, Wolfgang. Sechs Gründe, Eiermanns Werk zu lieben. Und einer, es nicht zu tun. In: Jaeggi, Annemarie (org.). Egon Eiermann (1904-1970): die Kontinuität der Moderne. Ostfildern-Ruit: Hatje Cantz Verlag, p. 22.

26 Ein Aufruf: Grundsätzliche Forderungen. Publicado em diversas revistas, entre elas: Baukunst und Werkform n.1, 1947, p. 29.

27 Broos, Hans. Texto da Palestra na Associação de Arquitetos e Engenheiros de Brusque. Brusque, 11/07/89.

28 Ver Capítulo 3.

29 Schmedding, Anne. Lehre in Braunschweig. In: Wilhelm, Karin; Gisbertz, Olaf; Klingenberg-Jessen, Detlef (et. al.). Gesetz und Freiheit: der Architekt Friedrich Wilhelm Kraemer (1907-1990). Berlin: Jovis, 2007, p. 107.

30 Idem. p. 108.

31 Obra que será analisada neste capítulo.

32 A fonte representa o ribeirão ali existente, fator decisivo para a instalação da empresa naquele local em fins do século XIX.

33 Bastos, Maria Alice Junqueira. Dos anos 50 aos 70: como se completou o projeto moderno na Arquitetura Brasileira. Tese de Doutorado. São Paulo: FAU-USP, 2004, p.14.

34 Idem, p.30.

35 Além do livro: Ferraz, Marcelo Carvalho (Coord.) Lina Bo Bardi. São Paulo, Instituto Lina Bo e P. M. Bardi, 1993, os trabalhos acadêmicos de Maria Cristina Nascentes Cabral. Racionalismo arquitetônico de Lina Bo Bardi. Dissertação de Mestrado. Rio de Janeiro: Pontifícia Universidade Católica, 1996; Olívia F. de Oliveira. Hacia Lina Bo Bardi Tese de Doutorado. Universidade Politécnica da Catalunha, ETSAB, 1994; e alguns livros mais recentes.

36 Já falamos das modestas citações de Broos na historiografia nacional. A dissertação de mestrado da autora (2006) é o primeiro trabalho que visa uma compreensão mais profunda e completa de seu trabalho. Cf. Segawa, Hugo. Arquiteturas no Brasil 1900-1990. São Paulo: Edusp, 1997, e Bastos, Maria Alice Junqueira. Pós-Brasília: rumos da arquitetura brasileira. São Paulo: Perspectiva, 2003, e os artigos: Zein, Ruth Verde. Cia. Hering: a Matriz de Blumenau e o Satélite de Rodeio. Projeto n. 60, fev. 1984, p. 33-66, e: Zein, Ruth Verde. Prêmio IAB/SP para a Hering Nordeste. Projeto n. 60, fev. 1984, p. 30-32.

37 Que veremos adiante.

38 Como já foi indicado, o paisagismo de Burle Marx nesta obra remete diretamente a outro trabalho seu, no Edifício Plavinil-Elclor (1961) de Rino Levi.

39 Recebeu o Prêmio para Edifícios industriais do IAB-SP em 1983.

40 Texto particular do arquiteto. São Paulo, 21/07/2005.

41 Apresentação do projeto. “O Complexo Têxtil da Hering do Nordeste S/A Malhas”. Projeto. n. 46, dez. 1982, p. 61.

42 Através de recursos da SUDENE - Superintendência do Desenvolvimento do Nordeste.

43 Empresa têxtil pertencente ao grupo Hering.

44 Zein, Ruth Verde. A arquitetura da Escola Paulista Brutalista: 1953-1973. op. cit,, p.117. 
45 Tanto é que, mesmo no Edifício da Olivetti, o arquiteto não deixa de propor elementos leves e com noção de movimento como suas passarelas externas. Sua relutância em relação à noção de peso e vigor da massa construída também pode ser verificada no projeto para a Embaixada Alemã em Washington. Em anos em que o Brutalismo ganhava força como tendência e a arquitetura em geral propunha soluções de adequação à paisagem, Eiermann assinala com este projeto quase uma "resistência" e, demonstra que mesmo com o aço pode-se construir "tectonicamente", e as possibilidades construtivas e inventivas que este material ainda reserva.

46 Em conversa com a autora, Klaus Zimmermann, que trabalhou ao lado de Broos no projeto da Fábrica de Blumberg, ao referir-se a um artigo na revista alemã Bauwelt sobre a obra de Broos, em que eram mostrados trabalhos dos anos 1960/ 1970 como São Bonifácio, a Hering Matriz e a casa do Arquiteto, se disse "decepcionado" com o caminho que a obra do ex-colega tomou, no sentido que se desviou dos preceitos do mestre em comum Eiermann. O que lhe chamava a atenção era o aspecto rude, massivo das construções em concreto armado, que de fato, notabiliza em um primeiro momento a diferença em relação a obra de Eiermann. Mas ao mesmo tempo, sua opinião espelha a noção com que a obra de Eiermann ainda é lembrada - o arquiteto da precisão formal e apreciador inconteste do aço, olvidando-se das obras tardias, como já mencionado neste trabalho. Cf. WeinstockMontag, Judith. Hans Broos: Ein deutsch-brasilianischer Architekt in São Paulo. Bauwelt, n. 19, mai. 2007, p. 24-45.

47 Apesar de esforços recentes notáveis como os trabalhos acadêmicos já mencionados, notase ainda uma tendência homogeneizante, no sentido de tratar as obras "em bloco" no que se refere ao tema. 


\section{CONSIDERAÇ̃̃ES FINAIS}

Compreender a modernidade em Hans Broos, de que ela se compõe e como se relacionou entre seus pares foi o que motivou o presente trabalho, tendo em vista sua produção arquitetônica dos anos 1960 e 1970.

A busca por elementos conceituais e as relações que estabeleceu com vertentes do pensamento projetou-nos a cenários distantes, complexos e polêmicos como toda boa história a ser desvendada, ainda que não de todo presumida. No juntar dos fatos e ao fim do itinerário, tem-se o encontro com uma obra que mescla influências múltiplas e nos revela ampla perspectiva.

Mais do que o exame da obra de Hans Broos, esta pesquisa permitiu ampliar o olhar sobre dois momentos distintos da arquitetura alemã: os anos 1930 e o pós-guerra. De maneira aparentemente difusa, estes momentos - tratados como períodos absolutamente estanques pela historiografia do Movimento Moderno mostram-se de tal forma entrelaçados, que se tornou inviável a análise do contexto pós-guerra sem retroceder o olhar. Pois também o contexto dos anos 1930 marcaria esta nova geração moderna, seja pelo repasse de elementos tradicionais, que perduraria alguns anos no pós-guerra, seja pelo repúdio que alimentariam em relação ao período. Com base nesta aversão - não sem uma visão distorcida dos fatos, moldada pelos próprios arquitetos ditos modernos e pela historiografia que lhe deu suporte - a nova geração se lança destemidamente ao moderno, para se desvencilhar de um passado amargo e se projetar num esperançoso porvir. Fadados ao moderno - assim podem ser descritos estes jovens recém-saídos dos bancos universitários no pós-guerra, não sem porém, um entendimento mais profundo da realidade e uma aproximação mais pragmática com o mundo do que as vanguardas o fizeram.

De modo amplo, mas significativo, também a obra de Broos é parte deste contexto, se não pela relação direta e intricada como um de seus personagens, de modo indireto pela situação conformada e pelos exemplos dos mestres, estes sim, agentes diretos.

Este recomeço pós-1945, de todos aqueles presentes na trajetória de Broos a pequena e distante, porém familiar Blumenau, e a metrópole pulsante, São 
Paulo - foi, sem dúvida, o mais difícil deles, e o que deixou sólidas marcas em sua obra também.

Entretanto, os laços com o país de origem nunca seriam desfeitos, ao contrário. Da experiência alemã, Broos trouxe mais do que uma sólida formação prática e teórica; trouxe referências diretas, que de modo surpreendente, se fazem sentir não nos primeiros anos de sua atuação em solo brasileiro, mas quando o arquiteto contava 20 anos de experiência projetual. Sua arquitetura revela, assim, a validade daqueles ensinamentos, que se mostraram atuais e até mesmo na dianteira do pensamento urbano no Brasil, como demonstra seu projeto para a Hering Matriz. De fato, este projeto transforma-se em condensador de muitas destas experiências, e se mostra, ainda, em franca aproximação com a arquitetura brasileira do período.

Longe de tratar a arquitetura de modo frívolo, Broos mostra que sua obra acompanhou as modificações e respondeu ao "espírito da época", sem ser, contudo, um seguidor inconteste de determinadas tendências. Através de sua obra, o arquiteto reivindicou certa autonomia, e se mostrava aberto a diferentes influências. Neste aspecto sua postura se aproxima ao do mestre Eiermann. Apesar da notável influência da obra miesiana, o risco de cair em um dogmatismo esteve muito menos presente nele do que se fez notar em outros "seguidores" de Mies. Tanto que Eiermann foi capaz de gerar propostas tão díspares quanto o Edifício da IBM e a Casa Merkur, ambos em Stuttgart. Também assim pode ser entendida sua aproximação ao Brutalismo, dentro de um campo de atuação que permite certa movimentação. A não adesão incondicional a determinadas tendências parece ser também o que une a obra destes arquitetos. Mesmo quando as propostas de Broos dos anos 1960 e 1970 mostram-se afinadas àquela tendência, como a Igreja de São Bonifácio tão bem anuncia, isto não se reflete numa adesão incondicional ao Brutalismo - entendido não enquanto proposta, mas como possibilidade, que lhe permite manter certo distanciamento judicioso, e ao mesmo tempo se nutrir de referências supostamente irreconciliáveis, como a obra de Eiermann dos anos 1940 e 1950.

De todos os temas e personagens aqui tratados, Broos segue sendo o principal, porém não o único. O presente trabalho também se prestou a ser uma porta aberta a autores e obras pouco conhecidos e valorizados dos anos pós-guerra, como os exemplos de Kraemer e Eiermann. Ao lançar olhar sobre estas manifestações que permearam a discussão aqui proposta, este estudo procurou contribuir para uma visão mais ampla sobre aqueles anos e abrir possibilidades para novos debates e investigações. 


\section{REFERÊNCIAS}

\section{Livros}

ACAYABA, Marlene. Residências em São Paulo 1950-1970. São Paulo: Projeto Editores, 1986.

ARGAN, Giulio Carlo. Arte Moderna. São Paulo: Companhia das Letras, 1992.

ARGAN, Giulio Carlo. Projeto e Destino. São Paulo: Ática, 2001.

ARGAN, Giulio Carlo. Walter Gropius e a Bauhaus. Lisboa: Editorial Presença, 1951.

ARRUDA, Maria Arminda do Nascimento. Metrópole e Cultura: São Paulo no meio do século XX. Bauru, SP: EDUSC, 2001.

ARTIGAS, João Batista Vilanova (org. José Tavares Correia de Lira, Rosa Artigas). Caminhos da Arquitetura. Inclui "A função social do arquiteto". 4. ed. São Paulo: Cosac \& Naify, 2004.

ARTIGAS, Vilanova. Caminhos da Arquitetura. São Paulo: Cosac \& Naify, 1999.

BANHAM, Reyner. El Brutalimo en Arquitectura: Etica o Estética? Barcelona: Ed. Gustavo Gili, 1966.

BANHAM, Reyner. Teoria e projeto na primeira era da máquina. 3. ed. São Paulo: Perspectiva, 2003.

BASTOS, Maria Alice Junqueira. Pós-Brasília: rumos da arquitetura brasileira. São Paulo: Perspectiva, 2003.

BONDUKI, Nabil Georges. Affonso Eduardo Reidy: arquitetos brasileiros. Lisboa, São Paulo: Editorial Blau, Instituto Lina Bo e Pietro Bardi, 2000.

BOYKEN, Imo; BÜCHENER, Rudolf (et al.). Egon Eiermann 1904-1970: Bauten und Projekte. Stuttgart: Deutsche Verlags-Anstalt, 1984.

BREUER, Marcel. Buildings and projects: 1921-1961. London: Thames and Hudson, 1962.

BROOS, Hans. Construções Antigas em Santa Catarina. Blumenau: Cultura em Movimento; Florianópolis: Ed. da UFSC, 2002.

BRUAND, Yves. Arquitetura Contemporânea no Brasil. 4. ed. São Paulo: Perspectiva, 2002.

CAMARGO, Mônica Junqueira de. Joaquim Guedes. São Paulo: Cosac \& Naify, 2000. 
CAVALCANTI, Lauro. Moderno e Brasileiro. A história de uma nova linguagem na arquitetura (1930-1960). Rio de Janeiro: Jorge Zahar Ed., 2006.

CHOAY, Françoise. O Urbanismo. São Paulo: Perspectiva, 1979.

COLLINS, Peter. Changing Ideals in modern architecture 1750-1950. London: Faber and Faber, 1965.

COLQUHOUN, Alan. Modernidade e Tradição Clássica: ensaios sobre arquitetura 1980-87. São Paulo: Cosac \& Naify, 2004.

CURTIS, William. Modern Architecture since 1900. New Jersey: Prentice-Hall, 1982.

Die Neue Sammlung, Staaliches Museum für angewandte Kunst (Org.). Zwischen Kunst und Industrie. Der Deutsche Werkbund. München, 1975.

DUPEUX. Louis. Historia cultural da Alemanha 1919-1960. Rio de Janeiro: Civilização Brasileira, 1992.

DURTH, Werner. Deutsche Architekten. Biografische Verflechtungen 1900-1970. Stuttgart/ Zurique: Karl Krämer Verlag, 2001.

DURTH, Werner; GUTSCHOW, Niels (Org.). Architektur und Städtebau der Fünziger Jahre. Ergebnisse der Fachtagung in Hannover 1990. Köln/ Bühl-Baden. Deutsches Nationalkomitee für Denkmalschutz, 1990.

DURTH, Werner; SIGEL, Paul. Baukultur. Spiegel gesellschaftlichen Wandels. Berlim: Jovis, 2009.

EIERMANN, Egon. Bauten in Baden-Württemberg: 1946-1972. Stuttgar: Universität Stuttgart, 2001.

EIERMANN, Egon. Die Möbel. Karlsruhe: INFO Verl., 1999.

EIERMANN, Egon. Planungsstudie verwaltungsgebaude: am beispiel fur die IBM - Deutschland. Stuttgart: Kramer, 1970.

EIERMANN, Egon. Über das Möbel. In: Die Landpost (Konstanz), 1945.

FERRAZ, Marcelo Carvalho (Coord.). Lina Bo Bardi. 3. ed. São Paulo: Instituto Lina Bo e P. M. Bardi, Imprensa Oficial do Estado de São Paulo, 2008.

FRANK, Hartmut (Org.). Faschistische Architekturen: Planen und Bauten in Europa 1930 bis 1945. Hamburg: Christians, 1985.

FRAMPTON, Kenneth. História Crítica da Arquitetura Moderna. São Paulo: Martins Fontes, 2000.

GIEDION, Sigfried. Espaço, Tempo e Arquitetura: o desenvolvimento de uma nova tradição. São Paulo: Martins Fontes, 2004.

GOODWIN, Philip L.; Smith, G. E. Kidder. Brazil Builds: Architecture new and old 1652-1942. Nova Iorque: MoMA, 1943.

GROPIUS, Walter. Bauhaus: Novarquitetura. 6. ed. São Paulo: Perspectiva: 2001. 
HARTMANN, Kristiana. Trotzdem modern. Die wichtigsten Texte zur Architektur in Deutschland 1919-1933. Braunschweig/ Wiesbaden: Vieweg, 1994.

HERZOGENRATH, Wulf(Org.). Bauhaus Utopien: Arbeiten aufPapier. Stuttgart: Edition Cantz, 1988.

HOFFMANN, Hubert. Neue Deutsche Architektur. Stuttgart: Verlag Gerd Hatje, 1956.

HUSE, Norbert. "Neues Bauen" 1918-1933. Moderne Architektur in der Weimarer Republik. 2. ed. Berlim: Ernst \& Sohn Verlag, 1985.

INSTITUT FÜR BAUGESCHICHTE DER UNIVERSITÄT KARLSRUHE. Egon Eiermann: Briefe des Architekten 1946-1970. Stuttgart: Deutsche VerlagsAnstalt, 1994.

IRIGOYEN, Adriana. Wright e Artigas: Duas viagens. São Paulo: Ateliê/Fapesp, 2002 .

JAEGGI, Annemarie (Org.). Egon Eiermann (1904-1970): die Kontinuität der Moderne. Ostfildern-Ruit: Hatje Cantz Verlag, 2004.

JOEDICKE, Jürgen. Geschichte der modernen Architektur. Synthese aus Form, Funktion und Konstruktion. Stuttgart: Verlag Gerd Hatje, 1958.

JOEDICKE, Jürgen. Moderne Architektur. Strömungen und Tendenzen.. Stuttgart/ Bern: Karl Krämer Verlag, 1969.

JOEDICKE, Jürgen. Treinta años de arquitectura 1930-1960. Buenos Aires: Ediciones 3, 1962.

KOPP, Anatole. Quando o moderno não era um estilo e sim uma causa. São Paulo: Nobel/ Edusp, 1990.

KORMANN, Edith. Blumenau: arte, cultura e as histórias de sua gente (18501985). (Edição da Autora) Vol. IV, 1996.

KOURY, Ana Paula. Grupo Arquitetura Nova: Flávio Império, Rodrigo Lefèvre e Sérgio Ferro. São Paulo: Romano Guerra Editora; Edusp; Fapesp, 2003.

KREBS, Peter. Böhm, Ungers, Poelzig. Vorlesungen. Karlsruhe: Universität Karlsruhe, 2002.

LAMPUGNANI, Vittorio M.; SCHNEIDER, Romana (Org.). Moderne Architektur in Deutschland 1900 bis 1950: Expressionismus und Neue Sachlichkeit. Stuttgart: Verlag Gerd Hatje, 1994.

LE CORBUSIER. Obras Completas 1952-1957. Zurique: Girsberger Zurich, 1957.

LE CORBUSIER. Por uma arquitetura. 6. ed. São Paulo: Perspectiva: 2002.

LOURENÇO, Maria Cecília França. Operários da Modernidade. São Paulo: Hucitec/ EDUSP, 1995

MARSCHALL, Werner. Contemporary Architecture in Germany. New York: Prager, 1962. 
Matriz de São Paulo Apóstolo: Blumenau, Santa Catarina, Brasil. Blumenau: [s. n.], 1963.

MILLER-LANE, Barbara. Architecture and Politics in Germany 1918-1945. Cambridge: Harvard University Press, 1968.

MONTANER, Josep Maria. A modernidade superada: Arquitetura, arte e pensamento do século XX. Barcelona: Gustavo Gili, 1997.

MONTANER, Josep Maria. Arquitectura y crítica. Barcelona: Gustavo Gili, 1999.

MONTANER, Josep Maria. As Formas do século XX. Barcelona: Gustavo Gili, 2002.

MONTANER, Josep Maria. Depois do Movimento Moderno: arquitetura da segunda metade do século XX. Barcelona: Ed. Gustavo Gili, 2001.

NAGEL, S.; LINKE, S. Industriebauten. Gütersloh: Beterlsmann Fachverlag, 1969.

NERDINGER, Winfried (Org.). Bauhaus-Moderne im Nationalsozialismus. München: Prestel, 1993.

NOELLE, Elisabeth; NEUMANN, Erich Peter. The Germans: Public Opinion Polls 1947-1966. Wesport: Greenwood Press, 1981.

PEHNT, Wolfgang. Deutsche Architektur seit 1900. 2. ed. Ludwigsburg/ München: Wüstenrot Stiftung/ Deutsche Verlags-Anstalt, 2006.

PEHNT, Wolfgang. Die Erfindung der Geschichte. Aufsätze und Gespräche zur Architektur unseres Jahrhunderts. München: Prestel, 1989.

PEHNT, Wolfgang. German Architecture 1960-1970. Praeger Publishers: New York, Washington, 1970.

PEHNT, Wolfgang; HAUPT, Peter; GUNTER, Horst. Egon Eiermann: Die KaiserWilhelm-Gedächtnis-Kirche. Berlin: Ernst \& Sohn, 1994.

PEHNT, Wolfgang; SCHIRREN; Matthias (Org.). Hans Poelzig 1869 bis 1936: Architekt, Lehrer, Künstler. München: Deutsche Verlags-Anstalt, 2007.

PEVSNER, Nikolaus. Panorama da arquitetura ocidental. São Paulo: Martins Fontes, 1982.

PORTOGHESI, Paolo. Depois da Arquitetura Moderna. São Paulo: Martins Fontes, 2002.

PUNTONI, Álvaro (Ed.). Vilanova Artigas: arquitetos brasileiros. São Paulo: Instituto Lina Bo e P.M.Bardi: Fundação Vilanova Artigas, 1997.

REIS FILHO, Nestor Goulart dos (Intr.). Rino Levi. Milão: Edizioni di Comunitá, 1974.

RICHARDS, J. M. Introducción a la Arquitectura Moderna (1940-1944). Buenos Aires: Ediciones Infinito, 1957. 
ROWE, Colin. Manierismo, Arquitectura Moderna y Otros Ensayos. Barcelona: Gustavo Gili, 1978.

SCHREIBER, Mathias. Deutsche Architektur nach 1945. 40 Jahre Moderne in der Bundesrepublik. Stuttgart: DVA, 1986.

SCULLY Jr., Vincent. Arquitetura Moderna. São Paulo: Cosac \& Naify, 2002.

SEGAWA, Hugo. Arquiteturas no Brasil 1900-1990. São Paulo: Edusp, 1997.

SEGAWA, Hugo; SANTOS, Cecília Rodrigues dos; ZEIN, Ruth Verde (Orgs.). et al. Arquiteturas no Brasil: Anos 80. São Paulo, Projeto, 1988.

SCHULZ, Bernhard (Org.). Grauzonen. Farbwelten. Kunst und Zeitbilder 19451955. Berlin/ Wien: Medusa, 1983.

TAFURI, Manfredo. Teorias e História da Arquitetura. Lisboa: Editorial Presença, 1979.

TEUT, Anna. Architektur im Dritten Reich 1933-1945. Frankfurt/ Berlin: Verlag Ullstein, 1967.

TROOST, Gerdy. Das Bauen im neuen Reich. Bayreuth: Gauverlag Bayerische Ostmark, 1938.

Vilanova Artigas. Arquitetos Brasileiros. São Paulo: Instituto Lina Bo e P. M. Bardi, Fundação Vilanova Artigas, 1997.

VOGT, Adolf Max. Architektur 1940-1980. Ludwigsburg: Verlag Ullstein, 1980.

WERNER, Bruno E. La Nueva Arquitectura en Alemania. Munique: F. Buckmann, 1952.

WILHELM, Karin; GISBERT, Olav (et al.). Gesetz und Freiheit. Der Architekt Friedrich Wilhelm Kraemer (1907-1990). Berlin: Jovis, 2007.

WINGLER, Hans M. (Org.). 100 Jahre Walter Gropius. Schließung des Bauhauses 1933. Simpósio. Berlim, 28.03.1983.

WINGLER, Hans M. La Bauhaus: Weimar, Dessau, Berlin. 1919-1933. Barcelona: Gustavo Gili, 1962.

XAVIER, Alberto (Org.). Depoimento de uma Geração. Arquitetura Moderna Brasileira. São Paulo: Cosac \& Naify, 2003.

XAVIER, Alberto; LEMOS, Carlos; CORONA Eduardo. Arquitetura Moderna Paulistana. São Paulo: Pini, 1983.

ZANINI, Walter (Org.). História Geral da Arte no Brasil. Vol. II. São Paulo: Instituto Walther Moreira Salles/ Fundação Djalma Guimarães, 1983.

\section{Trabalhos ACAdÊMicos}

BASTOS, Maria Alice Junqueira. Dos anos 50 aos 70: como se completou o projeto moderno na Arquitetura Brasileira. Tese de Doutorado. São Paulo: FAU-USP, 2004 . 
BIELSCHOWSKY, Bernardo Brasil. Patrimônio Industrial e Memória Urbana em Blumenau/ SC. Dissertação de Mestrado. Florianópolis: PGAU-UFSC, 2009. BUZZAR, Miguel Antônio. João Batista Vilanova Artigas: Elementos para a compreensão de um caminho da arquitetura brasileira 1938-1967. Dissertação de Mestrado. São Paulo: FAU-USP, 1996.

CABRAL, Maria Cristina Nascentes. Racionalismo arquitetônico de Lina Bo Bardi. Dissertação de Mestrado. Rio de Janeiro: Pontifícia Universidade Católica, 1996.

CAMARGO, Mônica Junqueira de. Princípios de Arquitetura Moderna na obra de Oswaldo Arthur Bratke. Tese de Doutorado. São Paulo: FAU-USP, 2000, p. 52.

DAUFENBACH, Karine. Hans Broos: a expressividade da forma. Dissertação de Mestrado. Rio de Janeiro: FAU-UFRJ, 2006.

GIMENEZ, Luis Espallargas, Arquitetura paulistana da década de 1960: técnica e forma. Tese de Doutorado. São Paulo: FAU-USP, 2004.

IRIGOYEN DE TOUCEDA, Adriana Marta. Da Califórnia a São Paulo: referências norte-americanas na casa moderna paulista 1945-1960. Tese de Doutorado. São Paulo: FAU-USP, 2005.

ZEIN, Ruth Verde. A arquitetura da Escola Paulista Brutalista: 1953-1973. Tese de Doutorado. São Paulo e Porto Alegre: PROPAR-UFRGS, 2005.

\section{Artigos (De/ Sobre Hans Broos)}

Apresentação do projeto. "Abadia de Santa Maria." Projeto no 137, 1991, p. 4548.

Apresentação do projeto. “Centro Paroquial.” Acrópole, n 344, 1967, p. 25-31.

Apresentação do projeto. "Fórum de Blumenau". Habitat nº 64, 1961, p. 14-16

Apresentação do projeto. "Hospital Oswaldo Cruz, São Paulo." Habitat, n 77, 1964, p. 23-30.

Apresentação do projeto. "Igreja em Santa Catarina." Acrópole, no 313, 1965, p. 26-28.

Apresentação do projeto. "Residência em Blumenau." Acrópole no 297, 1963, p. 259-263.

Apresentação do projeto. "Sociedade Beneficência Portuguesa de Santos." Módulo, no 38, 1964, p. 52-56.

Apresentação do projeto. Grande Hotel Blumenau, Santa Catarina. Habitat, n. 63, mar. 1961, p. 31-34.

Apresentação do projeto. O Complexo Têxtil da Hering do Nordeste S/A Malhas. Projeto n. 46, dez. 1982 p. 51-68.

BROOS, Hans. "A Construção Industrial: Sua posição na atual sociedade". Projeto, no 121, 1989, p. 89-93. 
BROOS, Hans. "A evolução cultural na Europa”. Texto da Palestra, São Paulo, 28/04/93., p. 6.

BROOS, Hans. "A imagem do homem na cultura ocidental". Texto da Palestra, São Paulo, 14/09/93.

BROOS, Hans. "A relação entre a vida do homem e o ambiente natural". Texto da Palestra, Florianópolis, 20/11/2002.

BROOS, Hans. "Escolha da profissão de arquiteto". Texto da Palestra, São Paulo, 03/11/1994.

BROOS, Hans. “O homem e a cidade: Reflexos mútuos”. Texto da Palestra, São Paulo, 16/06/1989.

BROOS, Hans. “O indivíduo nos desafios da época”. Texto da Palestra, Blumenau, 04/11/1993., p. 6.

BROOS, Hans. "Pensar e Decidir: o espírito da atualidade". Texto do arquiteto, 02/08/1988.

BROOS, Hans. Palestra na Associação de Arquitetos e Engenheiros de Brusque. Texto da palestra, Brusque, 11/07/1989.

SANTOS, Cecília Rodrigues dos. “...Porque as catedrais não eram brancas." Projeto, no 128, dez/ 1989, p. 40-49.

Sede da Hering 1977-1984. Projeto n. 300 março, 2005.

WOLF, José. “Escritório Hans Broos”. AU, n. 50 out./nov. 1993, p. 93-100.

WOLF, José. “Uma pedra no caminho”. Depoimento de críticos e arquitetos sobre arquitetura paulista. $A U$, n. 17, abr/maio 1988, p. 49-60.

ZEIN, Ruth Verde. “As Tendências e as discussões do pós-Brasília”. Projeto, n.53 julho 1983, p. 81.

ZEIN, Ruth Verde. Cia. Hering: a Matriz de Blumenau e o Satélite de Rodeio. Projeto n. 60, fev. 1984, p. 33-66.

ZEIN, Ruth Verde. Prêmio IAB/SP para a Hering Nordeste. Projeto n. 60, fev. 1984, p. 30-32.

\section{PERIÓDICOS}

$\mathrm{ARCH}+$

Bauen und Wohnen

Baukunst und Werkform

Baumeister

Bauwelt

Bauen und Wohnen

Der Architekt. 
Die Neue Stadt

L'Architecture d'aujourd'hui

Acrópole

AU

Habitat

Módulo

Projeto

\section{ENTREVISTAS}

Peter Dresel (Arquiteto ex-colaborador no Escritório Egon Eiermann). Karlsruhe. 03/11/2008.

Jenny Abel (moradora da Residência Gustav Abel e filha deste). Gernsbach. $11 / 11 / 2008$ e 25/01/2009.

Klaus Zimmermann. (Arquiteto ex-colaborador no Escritório Egon Eiermann). Karlsruhe. 29/12/2008 e 23/01/2009.

Justus Herrenberger (Arquiteto ex-colaborador no Escritório F. W. Kraemer). Braunschweig. 22/01/2009.

Wolfgang Bley (Arquiteto ex-colaborador no Escritório Egon Eiermann). Karlsruhe. 24/01/2009.

\section{ARQUIVOS CONSULTADOS}

Arquivo particular do arquiteto Hans Broos. São Paulo e Blumenau.

Arquivo Histórico da cidade de Olinda.

Arquivo Histórico das cidades de Bad Oldesloe, Braunschweig, Gernsbach, Lübeck, Goslar, Hannover, Karlsruhe, Rastatt e Stuttgart. (Alemanha)

Arquivo Histórico das Universidades de Braunschweig, Karlsruhe e Praga.

SAAI (Südwestdeutschland Archiv für Architektur und Ingenieurbau). Karlsruhe. 


\section{FONTE DAS ILUSTRAÇ̃̃ES}

\section{CApítulo 1}

\section{UM OUTRo Recomeço: A “GERMÂNicA” BlumenaU}

Figuras 1-4, 8, 10, 11, 20, 21, 33, 46-51: Acervo Karine Daufenbach Figuras 5-7, 9, 14, 17-19, 24-26, 28-32, 36-45: Acervo Hans Broos

Figura 12: PEHNT, Wolfgang; HAUPT, Peter; GUNTER, Horst. Egon Eiermann: Die Kaiser-WilhelmGedächtnis-Kirche. Berlin: Ernst \& Sohn, 1994.

Figura 13: EIERMANN, Egon. Bauten in Baden-Württemberg: 1946-1972. Stuttgar: Universität Stuttgart, 2001.

Figuras 15, 16, 27: BRUAND, Yves. Arquitetura Contemporânea no Brasil. 4. ed. São Paulo: Perspectiva, 2002. Figuras 22, 23: HOFFMANN, Hubert. Neue Deutsche Architektur. Stuttgart: Verlag Gerd Hatje, 1956.

Figura 34: GIEDION, Sigfried. Espaço, Tempo e Arquitetura: o desenvolvimento de uma nova tradição. São Paulo: Martins Fontes, 2004.

Figura 35: FRAMPTON, Kenneth. História Crítica da Arquitetura Moderna. São Paulo: Martins Fontes, 2000.

\section{CAPÍtulo 2}

\section{ARQuitetura ALEMÃ nos ANOS 1930}

Figuras 1, 2, 18, 20: PEHNT, Wolfgang. Deutsche Architektur seit 1900. 2. ed. Ludwigsburg/ München: Wüstenrot Stiftung/ Deutsche Verlags-Anstalt, 2006.

Figuras 3-17: SAAI Karlsruhe

Figura 19: TROOST, Gerdy. Das Bauen im neuen Reich. Bayreuth: Gauverlag Bayerische Ostmark, 1938. Arquitetura em crise

Figuras 1, 2, 7 e 15: DURTH, Werner; SIGEL, Paul. Baukultur. Spiegel gesellschaftlichen Wandels. Berlim: Jovis, 2009.

Figuras 4, 5, 6, 8, 11, 12 e 13: PEHNT, Wolfgang. Deutsche Architektur seit 1900. 2. ed. Ludwigsburg/ München: Wüstenrot Stiftung/ Deutsche Verlags-Anstalt, 2006.

Figura 10: PEHNT, Wolfgang; SCHIRREN; Matthias (org). Hans Poelzig 1869 bis 1936: Architekt, Lehrer, Künstler. München: Deutsche Verlags-Anstalt, 2007.

Figuras 3, 9 e 14: Acervo Karine Daufenbach

\section{Capítulo 3}

\section{RECOMEÇO OU CONTINUIDADE?}

Figura 1: Acervo Karine Daufenbach

Figuras 2, 4, 6, 7, 12, 13 e 15: PEHNT, Wolfgang. Deutsche Architektur seit 1900. 2. ed. Ludwigsburg/ München: Wüstenrot Stiftung/ Deutsche Verlags-Anstalt, 2006.

Figuras 3, 5, 10, 11 e 14: DURTH, Werner; SIGEL, Paul. Baukultur. Spiegel gesellschaftlichen Wandels. Berlim: Jovis, 2009.

Figuras 8 e 9: SAAI Karlsruhe. 


\section{UM RECOMEÇO POSSÍvEL}

Figuras 1, 4, 13, 14: PEHNT, Wolfgang. Deutsche Architektur seit 1900. 2. ed. Ludwigsburg/ München: Wüstenrot Stiftung/ Deutsche Verlags-Anstalt, 2006.

Figuras 2, 3: Acervo Karine Daufenbach

Figuras 5-12, 15-17: SAAI Karlsruhe

\section{REFERÊNCIAS ALEMÃS}

\section{A obra de Egon Eiermann}

Figuras 1-5, 7, 9, 11, 14, 16-20, 25, 25, 27-29, 31-35: SAAI Karlsruhe

Figuras 6, 10, 26: PEHNT, Wolfgang. Deutsche Architektur seit 1900. 2. ed. Ludwigsburg/ München: Wüstenrot Stiftung/ Deutsche Verlags-Anstalt, 2006.

Figura 8: CURTIS, William. Modern Architecture since 1900. New Jersey: Prentice-Hall, 1982.

Figura 12: JOEDICKE, Jürgen. Moderne Architektur. Strömungen und Tendenzen.. Stuttgart/ Bern: Karl Krämer Verlag, 1969.

Figuras 13, 21: JAEGGI, Annemarie (org.). Egon Eiermann (1904-1970): die Kontinuität der Moderne. Ostfildern-Ruit: Hatje Cantz Verlag, 2004.

Figura 15: Acervo Karine Daufenbach

Figuras 22,23: BOYKEN, Imo; BÜCHENER, Rudolf (et.al). Egon Eiermann 1904-1970: Bauten und Projekte. Stuttgart: Deutsche Verlags-Anstalt, 1984.

Figura 30: LAMPUGNANI, Vittorio M.; SCHNEIDER, Romana (org.). Moderne Architektur in Deutschland 1900 bis 1950: Expressionismus und Neue Sachlichkeit. Stuttgart: Verlag Gerd Hatje, 1994.

\section{A obra de Friedrich Wilhelm Kraemer}

Figuras 1-3, 8-11, 16, 18, 22-27: WILHELM, Karin; GISBERT, Olav (et. al.). Gesetz und Freiheit. Der Architekt Friedrich Wilhelm Kraemer (1907-1990). Berlin: Jovis, 2007.

Figuras 4-7, 14: Acervo Hans Broos

Figuras 12, 13, 15, 17, 19-21: Acervo Karine Daufenbach

\section{CAPÍtulo 4}

\section{O BRUTALISMO}

Figuras 1, 3, 4: SAAI Karlsruhe

Figuras 2, 11, 13: JOEDICKE, Jürgen. Moderne Architektur. Strömungen und Tendenzen.. Stuttgart/ Bern: Karl Krämer Verlag, 1969.

Figura 5: BOYKEN, Imo; BÜCHENER, Rudolf (et.al). Egon Eiermann 1904-1970: Bauten und Projekte. Stuttgart: Deutsche Verlags-Anstalt, 1984.

Figura 6: KREBS, Peter. Böhm, Ungers, Poelzig. Vorlesungen. Karlsruhe: Universität Karlsruhe, 2002.

Figura 7: PEHNT, Wolfgang. German Architecture 1960-1970. Praeger Publishers: New York, Washington, 1970.

Figura 8, 9: Acervo Karine Daufenbach

Figura 10: PEHNT, Wolfgang. Deutsche Architektur seit 1900. 2. ed. Ludwigsburg/ München: Wüstenrot Stiftung/ Deutsche Verlags-Anstalt, 2006.

Figura 12: BRUAND, Yves. Arquitetura Contemporânea no Brasil. 4. ed. São Paulo: Perspectiva, 2002.

\section{UM BRUTALISMO E MUITAS REFERÊNCIAS}

Figuras 1-5, 7, 8, 16-18, 20, 21, 26, 27, 30, 31, 33, 37, 43-45, 48, 55, 56, 58, 61, 62, 68, 69, 71, 72, 74, 75: Acervo Hans Broos

Figura 6: REIS FILHO, Nestor Goulart dos (intr). Rino Levi. Milão: Edizioni di Comunitá, 1974. 
Figuras 9, 10: Vilanova Artigas. Arquitetos Brasileiros. São Paulo: Instituto Lina Bo e P. M. Bardi, Fundação Vilanova Artigas, 1997.

Figuras 11-15, 19, 23-25, 32, 34, 35, 38-42, 46, 47, 49-53, 59, 60, 64-67, 70, 73, 76-80: Acervo Karine Daufenbach

Figuras 22, 54: FERRAZ, Marcelo Carvalho (coord.). Lina Bo Bardi. 3a ed. São Paulo: Instituto Lina Bo e P. M. Bardi, Imprensa Oficial do Estado de São Paulo, 2008.

Figura 28: PEHNT, Wolfgang. Deutsche Architektur seit 1900. 2. ed. Ludwigsburg/ München: Wüstenrot Stiftung/ Deutsche Verlags-Anstalt, 2006.

Figura 29: PEHNT, Wolfgang. German Architecture 1960-1970. Praeger Publishers: New York, Washington, 1970 .

Figura 36: SAAI Karlsruhe

Figura 57: BRUAND, Yves. Arquitetura Contemporânea no Brasil. 4. ed. São Paulo: Perspectiva, 2002.

Figura 63: SCULLY Jr., Vincent. Arquitetura Moderna. São Paulo: Cosac \& Naify, 2002. 